\author{
UNIVERSIDADE DE SÃO PAULO
}

FACULDADE DE FILOSOFIA, LETRAS E CIÊNCIAS HUMANAS

DEPARTAMENTO DE LETRAS MODERNAS

PROGRAMA DE PÓS-GRADUAÇÃO EM LÍNGUA E LITERATURA ITALIANA

\title{
O AMBIENTE INTERGERACIONAL NO ENSINO DE ITALIANO LE: O CASO DO ITALIANO NO CAMPUS
}




\author{
UNIVERSIDADE DE SÃO PAULO
}

FACULDADE DE FILOSOFIA, LETRAS E CIÊNCIAS HUMANAS

DEPARTAMENTO DE LETRAS MODERNAS

PROGRAMA DE PÓS-GRADUAÇÃO EM LÍNGUA E LITERATURA ITALIANA

\title{
O AMBIENTE INTERGERACIONAL NO ENSINO DE ITALIANO LE: O CASO DO ITALIANO NO CAMPUS
}

Alessandra Harumi Bonito Fukumoto

Dissertação apresentada ao Programa de PósGraduação em Língua e Literatura Italiana do Departamento de Letras Modernas da Faculdade de Filosofia, Letras e Ciências Humanas da Universidade de São Paulo, para obtenção do título de Mestre em Letras.

Orientadora:

Profa. Dra. Paola Giustina Baccin 
Autorizo a reprodução e divulgação total ou parcial deste trabalho, por qualquer meio convencional ou eletrônico, para fins de estudo e pesquisa, desde que citada a fonte.

FICHA CATALOGRÁFICA ELABORADA PELA

BIBLIOTECA DA ÁREA DE ENGENHARIA E ARQUITETURA BAE - UNICAMP

Fukumoto, Alessandra Harumi Bonito

F955a O ambiente intergeracional no ensino de italiano LE: o caso do Italiano no Campus / Alessandra Harumi Bonito Fukumoto. - São Paulo, SP: [s.n.], 2010.

Orientador: Paola Giustina Baccin.

Dissertação de Mestrado - Universidade de São Paulo, Faculdade de Filosofia, Letras e Ciências Humanas.

1. Língua estrangeira - Estudo e ensino. 2. Terceira idade. 3. Língua italiana. I. Baccin, Paola Giustina. II. Universidade de São Paulo. Faculdade de Filosofia, Letras e Ciências Humanas. III. Título. 


\section{O AMBIENTE INTERGERACIONAL NO ENSINO DE ITALIANO LE: O CASO DO ITALIANO NO CAMPUS}

Dissertação apresentada ao Programa de PósGraduação em Língua e Literatura Italiana do Departamento de Letras Modernas da Faculdade de Filosofia, Letras e Ciências Humanas da Universidade de São Paulo, para obtenção do título de Mestre em Letras.

BANCA EXAMINADORA

Profa. Dra. Paola Giustina Baccin (orientadora)

Profa. Dra. Fernanda Landucci Ortale

Prof. Dr. José Carlos Ferrigno

Dissertação defendida e aprovada em: 
Ao meu marido, pela cor e sabor que o mundo tem desde que ele entrou na minha vida... Meu porto seguro.

Aos meus pais, pelo contínuo e incondicional apoio em todas as minhas escolhas... Meus alicerces. 


\section{Agradecimentos}

Agradeço à CAPES pela bolsa DS concedida em abril de 2009.

A minha orientadora, Prof.a. Dra. Paola G. Baccin, por ter sempre me trazido de volta para a realidade nas muitas vezes em que "viajei" demais e por, nos momentos de desespero, sempre me mostrar que as coisas não são tão complicadas quanto parecem.

À Prof.a. Dra. Vera Lúcia Marinelli, por me mostrar na Licenciatura um belo caminho a ser percorrido e ter incentivado esta pesquisa, bem como pelos conselhos dados para sua realização, tanto antes como na qualificação.

À Prof.a. Dra. Fernanda Landucci Ortale pelos comentários e conselhos preciosos dados na qualificação e que nortearam a conclusão do trabalho.

Às professoras Dras. Giliola Maggio e Angela Zucchi pelos conselhos sempre incentivadores.

À Prof.a. Dra. Elisabetta Santoro pela disponibilidade sempre, seriedade e pelo muito que aprendi com ela no período de monitoria no Italiano no Campus.

Aos monitores do Italiano no Campus, que sempre se dispuseram a me ajudar na pesquisa com a aplicação incansável de questionários e por concederem informações valiosas para a realização desse trabalho. Mais que monitores e colegas, meus companheiros e amigos, com quem sempre tive trocas fantásticas e tanto aprendi.

Aos alunos do Italiano no Campus que se dispuseram a participar anonimamente dessa pesquisa.

Ao pessoal da Secretaria do DLM-Pós, em especial à Edite e ao Júnior pelo atendimento sempre atencioso.

Ao Júlio Fuji por sempre me auxiliar (e aturar!) nas muitas dúvidas sobre a pós.

Aos funcionários da SCE-FFLCH, em especial, Lina, Ângela e André, pela ajuda e disponibilidade com o levantamento da história do Italiano no Campus.

À Paula, pois sua ajuda e disposição em me trazer peso e mais peso em livros foram imprescindíveis para este trabalho.

A minha sogra, D. Ana, exemplo de mulher. E em memória do meu sogro S. Antônio, exemplo de amor à vida!

Aos meus irmãos, Matheus e Pâmela, pela paciência nas minhas muitas ausências.

A Gláucia, Dani, Alice, Elena e Clóvis pela amizade e incentivo.

Agradeço a todos os meus ex-alunos do Italiano no Campus que me fizeram crescer, aprender e amar ainda mais minha profissão. São eles a razão deste trabalho existir. 
A velhice surge aos olhos da sociedade como uma espécie de segredo vergonhoso do qual é indecente falar.

Simone de Beauvoir, 1976, A velhice. 


\section{Resumo}

O mundo passa por um envelhecimento populacional e, segundo estimativas do IBGE, o Brasil será o sexto país no mundo com a maior população idosa em 2025. Com o aumento da expectativa de vida, aumenta também o tempo livre, de aposentadoria, dando espaço para atividades esportivas, recreativas, educativas, dentre outras. A busca pela realização pessoal tem levado os idosos a procurarem atividades que haviam "adiado" devido ao trabalho, à família e a outros fatores. Dentre essas atividades, há grande interesse pelos cursos de língua estrangeira. Surgem, então, oportunidades de contato intergeracional nas aulas de língua, que trazem benefícios para todos os participantes. Para o desenvolvimento desta pesquisa, partimos da discussão sobre identidade, abordada pelos Estudos Culturais (em especial, Stuart Hall e Tomaz Tadeu da Silva), estudos da Psicologia Social sobre estereótipos e preconceito e pesquisas na área de Gerontologia. O Italiano no Campus (IC), apesar de não ter sido criado especificamente com o intuito de ser um Programa Intergeracional, possui grupos etariamente heterogêneos, com alunos de 16 até 78 anos, podendo, assim, ser considerado um ambiente intergeracional em que os participantes possuem um objetivo em comum: aprender a língua italiana. Dessa forma, o IC constitui um espaço de grandes trocas e de ampla possibilidade para a quebra de estereótipos e preconceitos sobre os idosos e o próprio processo de envelhecimento. O ambiente propicia, também, aumento do respeito ao outro e maior conhecimento de uma geração sobre a outra, bem como a quebra de estereótipos negativos que envolvem os idosos e o processo de aquisição/aprendizagem de uma língua estrangeira. O papel do professor torna-se, então, fundamental nesse contexto, já que pode determinar o sucesso ou o fracasso desses ambientes intergeracionais e das relações que neles ocorrem. Nossa pesquisa envolveu alunos e monitores do IC, com um levantamento de dados realizado em três etapas, com questionários aplicados a alunos e monitores e entrevistas feitas com monitores. Com os dados, conseguimos traçar o perfil dos alunos do Italiano no Campus - que hoje conta com um quarto do seu público dentro da chamada terceira idade - e colher depoimentos sobre as relações intergeracionais tanto na visão dos monitores quanto na visão dos alunos. Os resultados nos mostraram que a maioria dos alunos prefere os grupos intergeracionais e que tanto alunos quanto monitores acreditam que a heterogeneidade etária enriquece o curso. Mesmo que não tenha sido concebido com essa finalidade, o IC tem potencial para ser um Programa Intergeracional, auxiliando, inclusive, na reinclusão social do idoso.

\section{Palavras-chave:}

intergeracional - terceira idade - ensino de língua estrangeira - italiano LE - estereótipos 


\section{Abstract}

Overall, the global population is aging and, according to IBGE estimates, Brazil will have the sixth largest elderly population by 2025 . The increase in life expectancy, together with the amount of free time available in retirement, has meant more time for sporting, recreational and educational activities, among other things, for this segment of the population. The quest for personal fulfillment has led many elderly to finally participate in activities that they had previously "postponed", largely due to more pressing work and family commitments. Included among these activities, there is now great interest in foreign language courses. Thus, opportunities for intergenerational contact among participants of language courses arise, which in turn bring benefits for all those involved. Our starting point for the development of this study was the discussion around identity covered by various Cultural Studies (particularly, those by Stuart Hall and Tomaz Tadeu da Silva), as well as studies about stereotypes and prejudice in the realm of Social Psychology and general research into the area of Gerontology. Despite not being created specifically for the purpose of being an Intergenerational Program, the Italian on Campus (IC) course has groups that span considerable age ranges, from 16 to 78 years. These groups can thus be considered intergenerational environments in which participants have a common objective: learning the Italian language. Accordingly, the IC has constructed a space for important exchanges and with great potential for breaking down stereotypes and prejudices about the elderly and the aging process itself. This type of environment also promotes increased respect for others and greater opportunities for the generations to find out more about each other, as well as getting rid of the negative stereotypes pertaining to the elderly, with regards to the process of acquiring and learning a foreign language. Therefore, the role of the teacher becomes fundamental in this context, because it can determine the success or failure of these intergenerational environments and the relationships that occur within them. Our study involved IC students and monitors and comprised of a fact-finding mission in three stages, with questionnaires applied to students and monitors, as well as interviews with the monitors themselves. With this data, we were able to define the profile of the students participating in the Italian on Campus course, where a quarter of participants are now defined as seniors, and to record experiences about intergenerational relationships, both from the standpoint of the monitors as well as from that of the students themselves. The results show us that most of the students prefer the intergenerational groups and both students and monitors believe that broad age range enriches the course. Even though it was not conceived for this purpose, the IC course has the potential of becoming a true Intergenerational Program, further aiding in the social re-inclusion of the elderly.

\section{Keywords:}

intergenerational - old age - foreign language teaching - Italian as a foreign language- stereotypes 


\section{Riassunto}

La popolazione mondiale sta invecchiando e, secondo le prospettive dell'Istituto Brasiliano di Geografia Statistica, il Brasile sarà, nel 2025, il sesto Paese al mondo con il maggior numero di cittadini anziani. Con l'aumento della speranza di vita, aumenta anche il tempo libero, di pensione, dando luogo ad attività sportive, educative, di svago, tra le altre. La ricerca per la realizzazione personale fa crescere il numero di anziani che cercano, tramite questo tipo di attività, di realizzare quello a cui avevano rinunciato a causa del lavoro, della famiglia o di altri motivi. Tra queste attività, c'è grande interesse per i corsi di lingue straniere. Sorgono, dunque, le opportunità di contatto intergenerazionale durante le lezioni di lingue, che sono benefiche per tutti i partecipanti. Per lo sviluppo della nostra ricerca, siamo partiti dalla discussione sullidentità dal punto di vista adottato dagli Studi Culturali (specialmente Stuart Hall e Tomaz Tadeu da Silva), studi di Psicologia Sociale sugli stereotipi e il pregiudizio, e ricerche dalla Gerontologia. L'Italiano no Campus (corso di lingua italiana offerto dalla Facoltà di Lettere dall'Università di San Paolo e aperto alla comunità, detto IC), anche se non è stato ideato con lo scopo di essere un Programma Intergenerazionale, possiede studenti di età eterogenea, dai 16 ai 78 anni; è possibile, pertanto, considerarlo un ambiente intergenerazionale nel quale i partecipanti hanno un obiettivo unico: imparare la lingua italiana. In questo modo, l'IC rappresenta uno spazio di grande scambi con ampia possibilità di eliminare stereotipi e pregiudizi sugli anziani e il proprio processo di invecchiamento, di allargare il rispetto verso l'altro e la maggior conoscenza di una generazione rispetto all'altra, e anche di vincere quegli stereotipi che vedono coinvolti gli anziani e il processo di acquisizione/apprendimento di una lingua straniera. Il ruolo dell'insegnante diventa, in questo modo, fondamentale all'interno di questo contesto perché può determinare il successo o l'insuccesso di questi spazi intergenerazionali e delle relazioni che si instaurano al loro interno. La nostra ricerca ha coinvolto studenti e insegnanti dell'IC, che hanno risposto a questionari e interviste divise in tre tappe. Con i dati ottenuti, abbiamo tracciato il profilo degli studenti dei corsi di lingua dell'Italiano no Campus - che oggigiorno ha circa il 25\% di studenti appartenenti alla terza età (sopra i 60 anni) - e abbiamo anche raccolto testimonianze sui rapporti intergenerazionali sia dal punto di vista degli insegnanti che degli studenti. I risultati mostrano che la maggioranza degli studenti preferisce i gruppi intergenerazionali e che, sia studenti che insegnati, credono che l'eterogeneità di età arricchisca il corso. Anche se non è stato pensato per questa finalità, l'IC ha il potenziale per essere un Programma Intergenerazionale, ponendosi come supporto alle questione suddette e anche alla re-inclusione sociale degli anziani.

\section{Parole chiavi:}

intergenerazionale - terza età - insegnamento di lingua straniera - italiano LS - stereotipi. 


\section{Lista de ilustrações}

Figura 1 - Magritte, La condition humaine ....................................... 45

Figura 2 - Esquema da representação ......................................... 47

Gráfico 1 - $\quad$ Ascensão da expectativa de vida dos brasileiros ..................... 13

Gráfico 2 - Estimativa de vida ao nascer ....................................... 14

Gráfico 3 - Pirâmide populacional brasileira em 1980 ........................... 15

Gráfico 4 - Pirâmide populacional brasileira em 2005 .......................... 15

Gráfico 5 - $\quad$ Pirâmide populacional brasileira: projeção para 2050 ............. 16

Gráfico 6 - Público geral por faixa etária ........................................... 119

Gráfico 7 - Público geral por nível …........................................ 144

Gráfico 8 - Público principiante por faixa etária .............................. 158

Gráfico 9 - Público principiante por sexo …................................. 160

Gráfico 10 - Público geral por sexo …....................................... 161

Gráfico 11 - Público geral por faixa etária: participação de cada sexo ....... 161

Gráfico 12 - Público geral por grau de escolaridade ............................... 163

Gráfico 13 - Justificativas apontadas pelo público principiante para a escolha do curso ........................................... 169

Gráfico 14 - Assuntos de maior interesse citados pelo público geral ......... 173

Gráfico 15 - Público geral por faixa etária: grau de satisfação ................. 179

Gráfico 16 - Avaliação do relacionamento com colegas: público geral ....... 187

Gráfico 17 - Público geral que gostaria de separação por faixa etária ....... 206

Gráfico 18 - Público geral: ritmo das aulas ...................................... 213

Gráfico 19 - Público geral: ritmo das aulas por faixa etária .................. 213

Gráfico 20 - Público geral que gostaria de um grupo só com sua faixa etária 


\section{Lista de tabelas}

Tabela 1 - Instrumentos utilizados no levantamento de dados 6

Tabela 1B - Instrumentos da pesquisa 134

Tabela 2 - Modelos de Programas Intergeracionais: idosos servindo jovens e crianças 100

Tabela 3 - Modelos de Programas Intergeracionais: crianças e jovens servindo idosos 101

Tabela 4 - Modelos de Programas Intergeracionais: crianças, jovens e idosos servindo juntos 102

Tabela 5 - Participantes da pesquisa com principiantes 137

Tabela 6 - Objetivos das perguntas do questionário para principiantes 138

Tabela 7 - Objetivos das perguntas do questionário geral para monitores

Tabela 8 - Objetivos das perguntas do questionário para todos os níveis . 145

Tabela 9 - Fatores que influenciaram a escolha em ser professor(a) de italiano 154

Tabela 10 - Grau de satisfação profissional 155

Tabela 11 - Fatores de insatisfação profissional 156

Tabela 12 - Decisão em estudar italiano 171

Tabela 13 - Materiais extra mais utilizados pelos monitores entrevistados . 173

Tabela 14 - Quais habilidades se sentem mais à vontade para trabalhar em sala

Tabela 15 - Se a divisão dos conteúdos nos módulos é adequada 181

Tabela 16 - A opinião dos monitores em relação aos grupos intergeracionais

Tabela 17 - Qual faixa etária consideram não poder ser "misturada" 194

Tabela 18 - Se os monitores preferem dar aula para alguma faixa etária ... 197

Tabela 19 - Qual é, geralmente, a faixa etária de seus alunos 201

Tabela 20- Para qual faixa etária fariam um curso específico 203

Tabela 21- Se acham que os grupos deveriam ser divididos por faixa etária 


\section{Normas de transcrição das entrevistas}

Normas adotadas para a transcrição das entrevistas, conforme Preti (2001)

\begin{tabular}{|c|c|c|}
\hline Sinal & Ocorrência & Exemplo \\
\hline ( ) & Incompreensão de palavras ou segmentos & Cada vez que eu ( ) tinha uma surpresa. \\
\hline (hipótese) & $\begin{array}{l}\text { Complemento incluído pelo } \\
\text { transcritor/entrevistador para maior clareza do leitor }\end{array}$ & $\begin{array}{l}\text { A maioria deles (dos alunos) são muito } \\
\text { interessados. }\end{array}$ \\
\hline$::$ & Prolongamento de vogal ou consoante & É::: não que eu saiba, mas::: pode ter ocorrido. \\
\hline Maiúscula & Indica entonação enfática & Eu acho que TODOS devem participar. \\
\hline$?$ & Interrogação & Por que ele fez isso? \\
\hline " " & Citações da fala de outra pessoa & Ah, ele disse "esse exercício é muito difícil". \\
\hline$\ldots$ & Pausas prolongadas* & Se eu sabia? ... Acho que não... \\
\hline ((minúscula)) & Comentários descritivos do transcritor & Eu achava que seria fácil ((riu)). \\
\hline / & Frase reformulada & Eu estava.../na verdade, quando aconteceu [...] \\
\hline- & Mudança de assunto & $\begin{array}{l}\text { Estava chovendo aquele dia. - Você viu que ontem } \\
\text { passou na TV um documentário [...]. }\end{array}$ \\
\hline$\left[{ }^{*}\right]$ & Supressão de trecho a fim de preservar a identidade & $\begin{array}{l}\text { Eu comecei a dar aula no Italiano no Campus em } \\
{\left[{ }^{*}\right] .}\end{array}$ \\
\hline$[\ldots]$ & $\begin{array}{l}\text { Para as transcrições utilizadas no meio dos } \\
\text { capítulos, esse sinal mostra trecho da fala } \\
\text { suprimido. }\end{array}$ & $\begin{array}{l}\text { Eu trabalhava em escolas de idiomas [...] Só agora } \\
\text { consegui me satisfazer profissionalmente. }\end{array}$ \\
\hline
\end{tabular}

* Em Preti, é usado para indicar qualquer pausa, pois não são utilizados sinais da língua escrita como vírgula, ponto final etc.

a Optamos por não adotar todas as normas apresentadas na obra pois não tínhamos o intuito de uma análise da conversação nos moldes dos estudos dos fenômenos da oralidade. 


\section{Sumário}

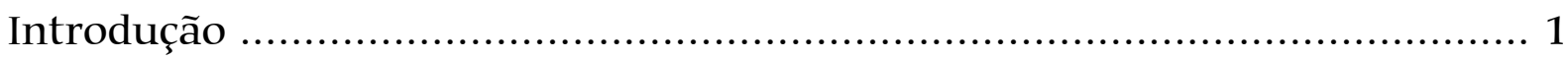

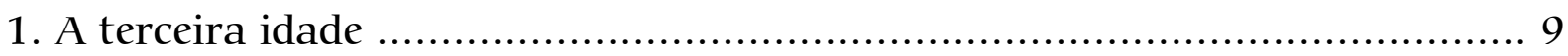

1.1. A denominação terceira idade ........................................................ 11

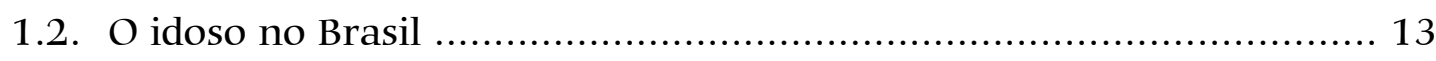

1.3. O idoso e a legislação brasileira ........................................................... 17

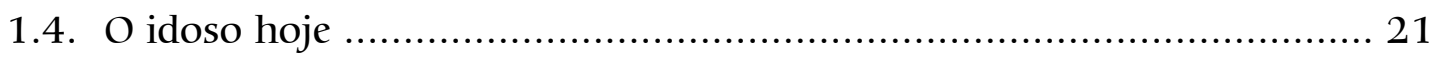

1.5. A importância das atividades sociais para a terceira idade ................. 27

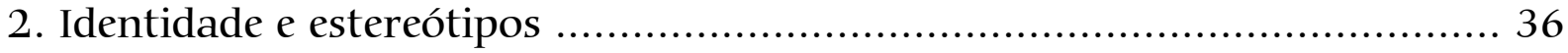

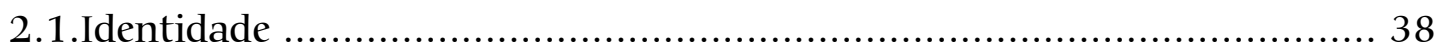

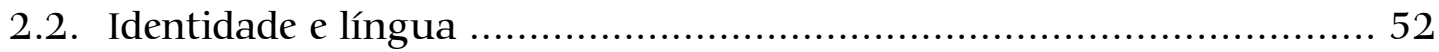

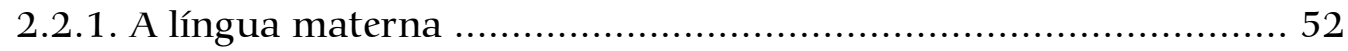

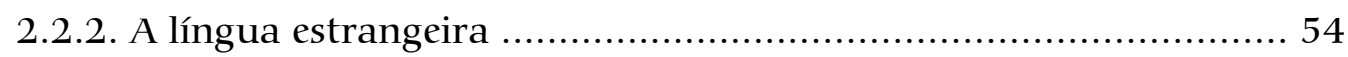

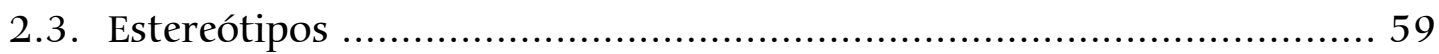

2.3.1. Os estereótipos nas aulas de língua italiana ................................ 64

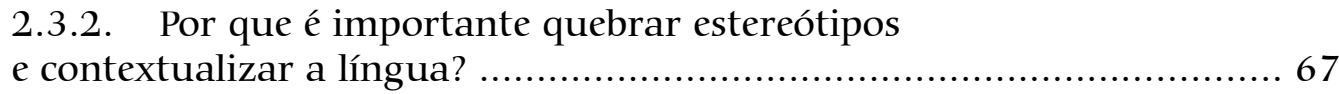

2.4. Os estereótipos contra os idosos: influências na sala de aula .............. 69

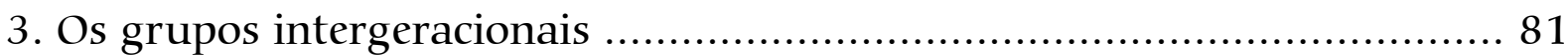

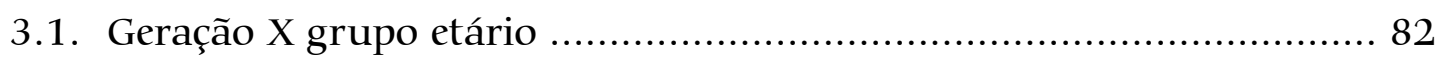

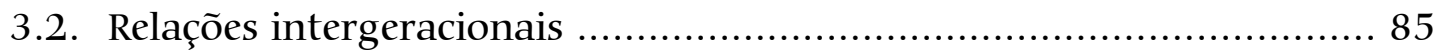

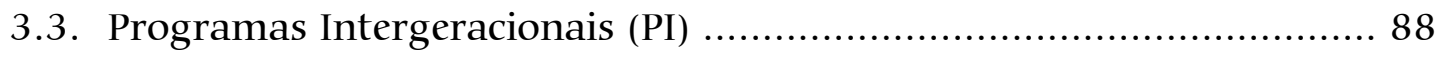

3.3.1. O contexto dos Programas Intergeracionais .............................. 90

3.3.2. As bases teóricas dos Programas Intergeracionais ..................... 95

3.3.3. Tipos e modelos de Programas Intergeracionais ....................... 98

3.3.4. Objetivos e resultados dos Programas Intergeracionais ........... 103

3.3.5. Programas Intergeracionais no Brasil .................................... 108

3.3.6. O estudo em colaboração com a UNESCO ………………….... 109

3.4. O que consideramos intergeracional e o Italiano no Campus ............ 112

3.4.1. Histórico do Italiano no Campus ........................................... 113

3.4.2. O Italiano no Campus como um ambiente intergeracional ...... 118 
3.5. Por uma pedagogia da diferença .......................................... 120

3.5.1. A aprendizagem ao longo de toda a vida .......................... 120

3.5.2. A Pedagogia da Diferença .............................................. 123

4. Levantamento de dados ........................................................ 131

4.1. Os instrumentos para levantamento dos dados ....................... 134

4.1.1. Os questionários .................................................... 134

4.1.2. As entrevistas ......................................................... 135

4.2. Primeira etapa: os grupos principiantes ............................... 136

4.3. Segunda etapa: monitores e alunos dos cursos de língua do Italiano no Campus ........................................... 139

4.3.1. O questionário geral aos monitores ................................ 140

4.3.2. O questionário geral dos alunos .................................. 143

4.3.3. O questionário específico para os monitores ...................... 146

4.4. Terceira etapa: as entrevistas ........................................ 147

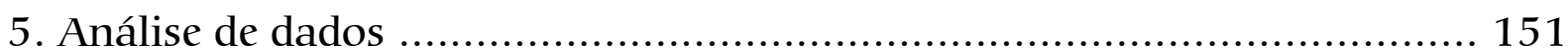

5.1. O perfil dos participantes do Italiano no Campus ...................... 154

5.1.1. Os monitores ........................................................... 154

5.1.2. Os alunos .......................................................... 156

5.2. A escolha pelo curso de italiano .............................................. 169

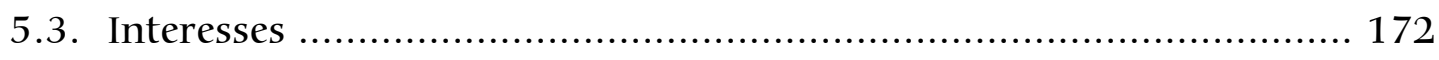

5.4. A estrutura do Italiano no Campus ................................... 177

5.5. A heterogeneidade dos grupos ......................................... 184

5.5.1. Principiantes ......................................................... 184

5.5.2. Alunos de todos os níveis ....................................... 186

5.5.3. Os monitores ............................................................... 192

5.6. A intergeracionalidade do Italiano no Campus ......................... 196

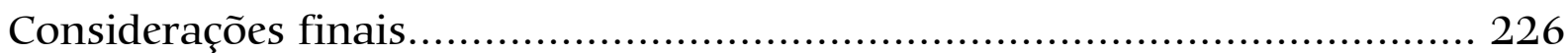

Referências bibliográficas.................................................. 234

Bibliografia consultada.................................................... 245

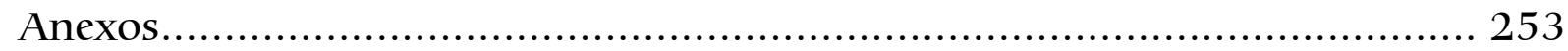


Introdução 
Com o aumento da população idosa no Brasil e no mundo, começa-se a prestar mais atenção a essa fase da vida que muitos esperam viver e que, ao mesmo tempo, tentam evitar ou retardar: a velhice.

O idoso sofre hoje, na nossa sociedade, uma situação de exclusão social devido à imagem de improdutividade que está ligada à aposentadoria. Em uma sociedade em que o valor é dado ao que é produtivo e novo, o que é velho é visto de forma pejorativa, e isso inclui as pessoas mais velhas. O fato de os idosos estarem assumindo hoje um papel de maior destaque se deve não só ao envelhecimento populacional, mas também, em grande parte, por estarem cada vez mais em busca de um envelhecimento ativo e bem-sucedido, fornecendo modelos positivos de velhice. Além disso, os idosos começam a surgir como mercado de consumo promissor.

Apesar do aumento da visibilidade dos idosos na sociedade brasileira atual, persistem os estereótipos negativos em relação a eles, ao processo de envelhecimento e à velhice. Muito do preconceito que existe contra o idoso ainda está arraigado a crenças estereotipadas sobre essa fase da vida, vista prioritariamente como fase de declínio e perdas. Nas áreas que discutem os processos de aquisição/aprendizagem de línguas estrangeiras isso não é diferente.

Quando se elege como "ideal" para a aquisição/aprendizagem de língua estrangeira um processo igual ou equivalente àquele que ocorreu na aquisição da 
língua materna, os idosos passam a ser considerados imediatamente os menos bem-sucedidos nas aulas de língua estrangeira. No entanto, estudos mostraram que idosos podem compensar as perdas de memória, quando existirem, bem como encontrar estratégias de aprendizagem baseados em suas experiências de aprendizagem (algo que não acontece com as crianças, por exemplo). Os estudos mostram, também, que quanto mais ativa mantemos nossa mente, mais "intacta" ela permanece.

O interesse nos idosos como alunos de língua estrangeira começou quando, ainda na graduação, frequentei o curso de extensão de língua italiana da Faculdade de Filosofia, Letras e Ciências Humanas da USP, o Italiano no Campus, e pude verificar um alto número de alunos aposentados que participavam dos cursos. Em seguida, durante o estágio de observação para a disciplina de Licenciatura em Italiano, realizado em dois ambientes distintos: um instituto de língua italiana e os cursos de extensão do Italiano no Campus, despertou-se uma curiosidade pelo número de alunos aposentados presentes nos grupos. Em alguns destes, esses alunos chegavam a representar mais de 50\% da turma. Concomitantemente com essa observação, durante as aulas de Metodologia do Ensino de Italiano, vimos que não existia material didático de língua italiana específico para esse público, e ouvi, também, como observadora das aulas, os comentários de alguns professores e alunos dos cursos em relação aos alunos idosos.

A maioria desses comentários costumava generalizar os idosos como uma categoria única e de ações e pensamentos uniformes, colocando em relevo características pessoais e tornando-as grupais. As observações, tanto das aulas quanto dos comentários, nos fizeram focar esse público de aposentados, muitos já na chamada "terceira idade", e nosso primeiro intuito era o de investigar a necessidade ou não de materiais didáticos especialmente elaborados para eles. Mas à medida que nos aprofundávamos nos estudos sobre os idosos, sua re-inserção na 
sociedade hoje, suas necessidades, percebemos algo que nos fez mudar o rumo da pesquisa. Muitos depoimentos de idosos revelavam que o convívio com pessoas de outras gerações tinha trazido benefícios para a vida deles. E alguns estudiosos da área gerontológica relatam como esse convívio poderia ser benéfico também para os não idosos, propiciando a quebra de estereótipos tanto do não idoso em relação ao idoso quanto o contrário.

Mas a maior contribuição para a mudança de rumo foi notar, tanto durante a observação feita no estágio da licenciatura quanto com o olhar agora de professora desses mesmos cursos de extensão e de escolas de idiomas, que as características ditas "de idosos" quando vindas dos jovens não eram atribuídas à idade, mas a uma questão de personalidade, como se os idosos, portanto, possuíssem somente uma característica grupal. Passamos, então, a questionar o papel do professor em um ambiente intergeracional, pois seu posicionamento em relação aos alunos poderia influenciar toda a postura do grupo em relação a algum aluno específico ou, no nosso caso, a um grupo de alunos.

A partir de então, focamos a questão dos grupos intergeracionais do curso Italiano no Campus e vimos ali um fértil campo de estudos. Como um ambiente intergeracional, o Italiano no Campus pode possibilitar a quebra de estereótipos e preconceitos em relação aos idosos e ao próprio processo de envelhecimento, bem como aqueles estereótipos relacionados à aquisição/aprendizagem (a/a) de uma língua estrangeira (LE) na terceira idade.

As nossas reflexões sobre o tema tiveram início, portanto, nas declarações feitas informalmente por estudantes e professores que colocam os idosos em uma categoria diferente dos alunos de outras idades. As declarações envolvendo os estereótipos negativos relacionados à velhice abrangem frases do tipo: “Os idosos são muito lentos"; ou mesmo: "Eles atrapalham a aula". Essas declarações têm qual fundamento? Todos os idosos são lentos? Não idosos nunca são lentos? 
Sentimos nessas declarações um preconceito arraigado que, muitas vezes, carregamos sem que nos demos conta de o estarmos fazendo.

Estudos na área dos Programas Intergeracionais comprovam os benefícios desses contatos para todos os envolvidos, sendo que os mais comentados deles são o aumento do respeito de uma geração com a outra, a quebra de estereótipos e diminuição do preconceito de uma geração sobre a outra. Os mais jovens participantes desse tipo de programa também passam a encarar o próprio processo de envelhecimento de forma mais positiva.

O objetivo principal de nossa pesquisa foi o de levantar a visão de alunos e monitores sobre os relacionamentos intergeracionais na sala de aula e sobre o que achavam de grupos com essa formação no ensino da língua estrangeira. A nossa pesquisa envolvia os monitores por serem eles os mediadores na sala de aula, tanto dos alunos com a outra cultura e língua quanto dos alunos com os próprios alunos. Além disso, a visão que os monitores possuem dessas relações intergeracionais pode influenciar a forma como as conduz em sala de aula, podendo ter resultados positivos ou negativos.

Para atingirmos esse objetivo, era necessário passarmos antes por quatro discussões que formam os alicerces deste trabalho:

1. o papel do idoso na sociedade ocidental atual - para isso utilizamos textos da Gerontologia, principalmente aqueles com viés social e educacional, como os de Anita Liberalesso Neri, José Carlos Ferrigno, Meire Cachioni;

2. a questão da identidade e da língua - para tanto nos fundamentamos em textos dos Estudos Culturais (Stuart Hall, Kathryn Woodward, Tomaz Tadeu da Silva) e da Linguística Aplicada (Christine Revuz, Eni P. Orlandi, Kanavillil Rajagopalan, Luiz Paulo da Moita Lopes ); 
3. estereótipos e preconceito e suas influências nas pessoas estereotipadas - discussão na qual utilizamos prioritariamente os textos de Psicologia Social, dos quais destacamos as obras sob organização de Todd D. Nelson;

4. os Programas Intergeracionais e a educação - para essa discussão tomamos como base os textos sobre Programas Intergeracionais e de educação para idosos, como os de Cristina Lima, Meire Cachioni, José Carlos Ferrigno, e obra organizada por Sally Newman.

Após essas quatro discussões, passamos para a parte de levantamento de dados, no qual aplicamos questionários e entrevistas em alunos e monitores do Italiano no Campus, a fim de verificar a opinião deles em relação aos grupos intergeracionais. A Tabela 1 indica cada um dos instrumentos de levantamento de dados utilizados, em qual etapa e com qual público:

\section{Tabela 1 - Instrumentos utilizados no levantamento dos dados}

\begin{tabular}{c|l|l|l}
\hline Etapa & Instrumento & \multicolumn{1}{|c}{ Sujeitos } & \multicolumn{1}{c}{ Objetivo } \\
\hline 1 & Questionário 1 & $\begin{array}{l}\text { Estudantes dos níveis 1 do } \\
\text { Italiano no Campus } \\
\text { (total de participantes: } \\
138)\end{array}$ & $\begin{array}{l}\text { Levantar estereótipos e expectativas dos alunos em } \\
\text { relação ao povo italiano, à Itália, à língua italiana e ao } \\
\text { curso de língua italiana. Fazendo, posteriormente, a } \\
\text { divisão por faixa etária. }\end{array}$ \\
\hline 2 & Questionário 2 & $\begin{array}{l}\text { Estudantes de todos } \\
\text { os níveis do Italiano } \\
\text { no Campus (total de } \\
\text { participantes: 237) }\end{array}$ & $\begin{array}{l}\text { Verificar a satisfação com o curso, as críticas, a } \\
\text { convivência com os colegas de classe e a visão dos } \\
\text { alunos na convivência com os alunos da terceira } \\
\text { idade, bem como a vontade de manter ou não as } \\
\text { classes intergeracionais. }\end{array}$ \\
\hline 2 & Questionário 3 & $\begin{array}{l}\text { Monitores do } \\
\text { Italiano no Campus } \\
\text { (total de participantes: 6) }\end{array}$ & $\begin{array}{l}\text { Verificar a satisfação profissional e a visão } \\
\text { geral da profissão. }\end{array}$ \\
\hline 3 & Euestionário 3.1 & $\begin{array}{l}\text { Monitores do } \\
\text { Italiano no Campus }\end{array}$ & $\begin{array}{l}\text { Um questionário para cada grupo, visando confrontar } \\
\text { suas respostas com as dadas pelos alunos, com o } \\
\text { objetivo de verificar o sincronismo aluno-monitor, bem } \\
\text { como se a visão do ritmo e entrosamento do grupo é } \\
\text { igual para ambos. }\end{array}$ \\
\hline
\end{tabular}


A dissertação está dividida em cinco capítulos. No primeiro, introduzimos a questão do idoso na sociedade brasileira atual. Abordamos as questões sociais que o envolvem, como a exclusão social e a valorização do jovem pela sociedade; a invenção da denominação "terceira idade"; a legislação, principalmente a parte que trata da educação ao idoso; e finalizamos com uma introdução sobre a importância das atividades sociais para os idosos.

O segundo capítulo, intitulado "Estereótipos e identidade", inicia com uma discussão sobre identidade, sob a ótica dos Estudos Culturais, abordando a questão do idoso como uma minoria estigmatizada da sociedade. Em seguida, discutimos a relação identidade e língua materna, para, na sequência, expor a relação da língua estrangeira com a identidade formada da, pela e na língua materna e como a língua estrangeira pode servir de espaço para outra identidade que questione, por exemplo, os estereótipos sobre a terceira idade. Finalizamos o capítulo com uma introdução teórica sobre os estereótipos e o preconceito, tratando dos estereótipos culturais presentes na relação aluno-língua estrangeira, e finalizamos dando ênfase à questão do preconceito etário e quais suas influências na sala de aula intergeracional.

O terceiro capítulo discute as relações intergeracionais para, na sequência, expor a criação dos Programas Intergeracionais (seus fundamentos teóricos, modelos existentes, objetivos dos programas, resultados já obtidos etc.). Em seguida, fazemos um breve histórico do Italiano no Campus, para depois explicar por que o consideramos um ambiente intergeracional. O capítulo se encerra com uma discussão sobre a Pedagogia da Diferença, proposta por Tomaz Tadeu da Silva, e como podemos relacioná-la ao Italiano no Campus.

O quarto capítulo traz a explicação de cada etapa do nosso levantamento de dados, esclarecendo a escolha dos instrumentos utilizados em cada uma delas e quais os objetivos que pretendíamos alcançar com os dados levantados. 
O quinto capítulo é o de análise dos dados levantados, na qual traçamos o perfil do Italiano no Campus e discutimos os resultados obtidos nas repostas de alunos e monitores em relação à intergeracionalidade dos grupos do IC.

Assim, pretendemos, com o nosso trabalho:

- colaborar com a área de ensino de língua estrangeira, mais especificamente a italiana, ao estudar a relação intergeracional na sala de aula e o posicionamento do professor perante grupos intergeracionais, bem como seu papel de mediador entre uma e outra cultura, que pode possibilitar trabalhar com imagens estereotipadas, quebrando-as e diminuindo o preconceito;

- colaborar para os estudos de educação que envolvam relações intergeracionais;

- colaborar para os estudos de gerontologia educacional, visando principalmente às atividades educativas informais que possam envolver o contato intergeracional.

Frisamos que o ineditismo do nosso trabalho está no fato de abordarmos o ensino de língua estrangeira com idosos em grupos intergeracionais e não em grupos específicos para a terceira idade. No Italiano no Campus, todos os alunos, independente de suas idades, são colocados na mesma posição, a de estudantes. A intergeracionalidade está não apenas na relação aluno-professor, mas também na relação aluno-aluno. 


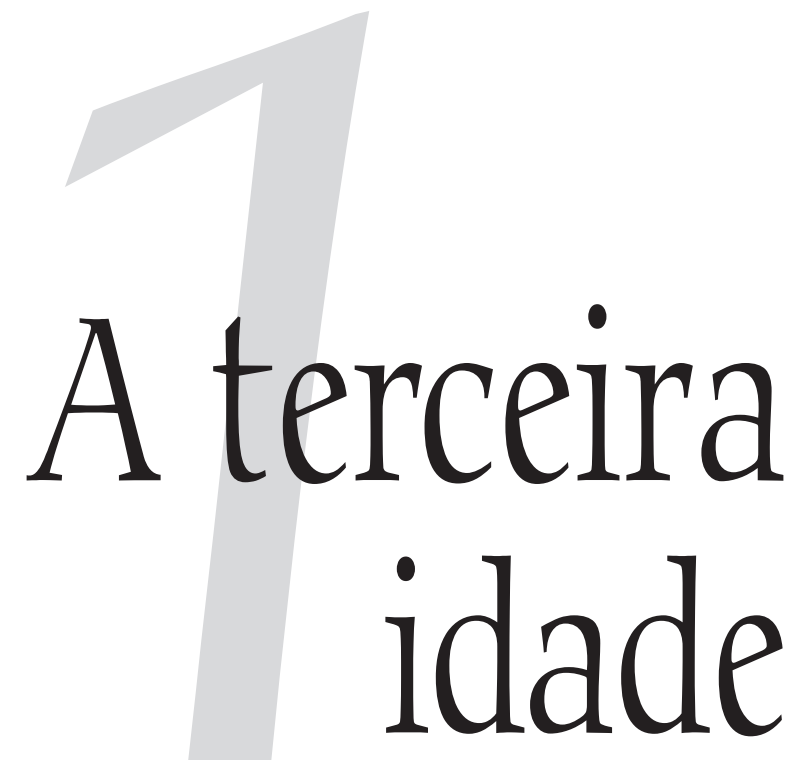


No Brasil, a partir da década de 1960, o número de idosos passou a receber a atenção de diversos setores da sociedade brasileira (Neri, 2007a). Não só aumenta progressivamente nossa expectativa de vida como, consequentemente, passamos a nos preocupar mais com essa fase pela qual todos esperam passar. Não pelo desejo de envelhecer, pois o que notamos na sociedade atual é justamente o oposto: a busca constante pelo rejuvenescimento, pela "fonte da juventude". O que se espera é viver mais e, principalmente, de forma mais saudável.

As pesquisas sobre essa fase da vida têm aumentado, sobretudo, nas áreas da Saúde e da Educação Física, com numerosos trabalhos de pós-graduação desenvolvidos. Há algum tempo outros campos (como a Educação, Serviço Social dentre outros) começaram a se voltar também para esse assunto, e a Gerontologia vem ganhando cada vez mais espaço no Brasil.

Neste capítulo, discutiremos a visibilidade que a velhice tem adquirido na sociedade brasileira e traçaremos um panorama sobre importantes estudos realizados sobre o tema. No primeiro item, 1.1., discutiremos o surgimento do termo "terceira idade". No segundo, 1.2., trataremos do envelhecimento da população brasileira, do crescimento do número de idosos com o aumento da expectativa de vida e as projeções para o futuro, características que indicam uma significativa alteração na distribuição etária da pirâmide demográfica. No item 1.3., consideramos o que diz a legislação brasileira em relação à terceira idade. No quarto item, 1.4., voltamos a atenção para o modo como os idosos são vistos na 
sociedade brasileira atual, as ideias associadas a eles e como o contexto histórico e econômico em que vivemos influencia a construção de estereótipos. Por fim, em 1.5., apresentaremos, de forma geral, o que será tratado nos capítulos seguintes: os idosos e a língua estrangeira.

\subsection{A denominação terceira idade}

Philippe Ariès (1981) relata a ausência de um "sentimento de infância" na Idade Média. Beauvoir (1976a) afirma que, até o surgimento da burguesia, somente a categoria "adulto" existia. Antes de serem reconhecidas como tal, as crianças eram tratadas como pequenos adultos, desde o modo de se vestir até o fato de aprenderem desde muito cedo a trabalhar e de se casarem e se separarem ainda jovens de suas famílias. O reconhecimento de que as crianças deveriam ser tratadas como pessoas que precisavam de cuidados diferentes deu-se gradativamente. Foi então que as crianças passaram a frequentar a escola, ao invés de aprender empiricamente uma profissão desde cedo, e passaram a ter roupas e jogos diferentes daqueles dos adultos, sendo percebidas como uma categoria social diferente da dos adultos. Dirceu Magalhães (1987:13) afirma que "em uma perspectiva histórica, podemos compreender que o idoso é uma invenção social, da mesma forma que a criança é um produto da revolução burguesa e industrial".

A classificação em faixas etárias é moderna. Viviane Magro (2003) argumenta sobre a padronização das etapas da vida na sociedade ocidental moderna, a qual "determina" o que fazemos em cada idade ${ }^{1}$. Segundo Anita L. Neri (2007b), foi na década de 1960 que o francês Pierre Vellas estabeleceu o termo "terceira idade", com o intuito de amenizar a carga negativa que "velho" carrega. A própria palavra "idoso" é usada como uma alternativa mais "elegante" ao termo "velho". Clarice Peixoto (1997:45) diz que para Cribier², a terceira idade "se inscreve numa organização da vida em 3 etapas":

1 Discutiremos mais essa questão no terceiro capítulo, no ponto 3.2

2 CRIBIER, F. (1990). Les mots pour le dire. La vieillesse, le troisiéme âge et l'âge de nos nations. Gérontologie 76: 1-8. 
- primeira idade: dependência, imaturidade, educação e socialização;

- segunda idade: independência, maturidade, responsabilidades familiares e profissionais, produção econômica e familiar;

- terceira idade: independência e maturidade, mas cujas funções sociais não são mais as mesmas: momento de usufruir e de usar o tempo à realização de si.

Segundo o Estatuto do Idoso, é considerada idosa - ou pertencente à chamada terceira idade - a pessoa que tem 60 anos ou mais. Atualmente, com o aumento da expectativa de vida, alguns autores como Giuliano Urbani (1991) e Danilo Miranda (2006) começam a falar em uma quarta idade, referindo-se às pessoas com mais de 80 anos.

Na nossa sociedade, que tanto valoriza o novo, o que é velho é visto com características negativas, e a própria palavra assume, por vezes, um sentido pejorativo. O mesmo acontece com as pessoas idosas, que, em muitas situações, têm suas imagens associadas à doença, à incapacidade, à decadência, à dependência, ao que é ultrapassado. ${ }^{3}$

Alguns autores, como Anita L. Neri (2007b), consideram a denominação "terceira idade" como um eufemismo. A autora afirma que a criatividade brasileira continua tentando encontrar formas de "amenizar" a ideia da velhice, usando expressões como "melhor idade", "maior idade", entre outras. A busca por palavras mais suaves apenas confirma que o uso de "velho" está carregado de sentidos negativos. Em especial em uma sociedade de consumo, em que muitos produtos e serviços são voltados para esse público (idosos), em vários contextos como o das estratégias de marketing e da publicidade, há uma procura frequente para encontrar modos "adequados" ou "corretos" de tratar o idoso. Não se costuma procurar eufemismos quando é necessário chamar alguém de "jovem". 


\subsection{O idoso no Brasil}

O Brasil tem passado pelo chamado "envelhecimento populacional". Segundo Roberto Belisário (2002), a faixa etária considerada idosa aumentou 70\% de 1950/55 para 2000. As estimativas apontam que em 2025 o Brasil será o sexto país com a maior população de idosos do mundo. Na década de 1910, a expectativa de vida média do brasileiro era de 33,4 anos. Em 2008, a expectativa chegou aos 76,66 anos para as mulheres e 69,06 para os homens, uma média de 72,78 anos para ambos os sexos. Em 2025, em projeção feita pelo IBGE, a expectativa de vida no Brasil será de 73,69 anos para homens e 80,86 anos para as mulheres, representando uma média de 77,2 anos. ${ }^{4}$

O Gráfico 1, elaborado a partir de dados da ONU, mostra a rápida ascensão da expectativa de vida dos brasileiros em comparação com a de países considerados mais desenvolvidos, cujo crescimento foi mais desacelerado.

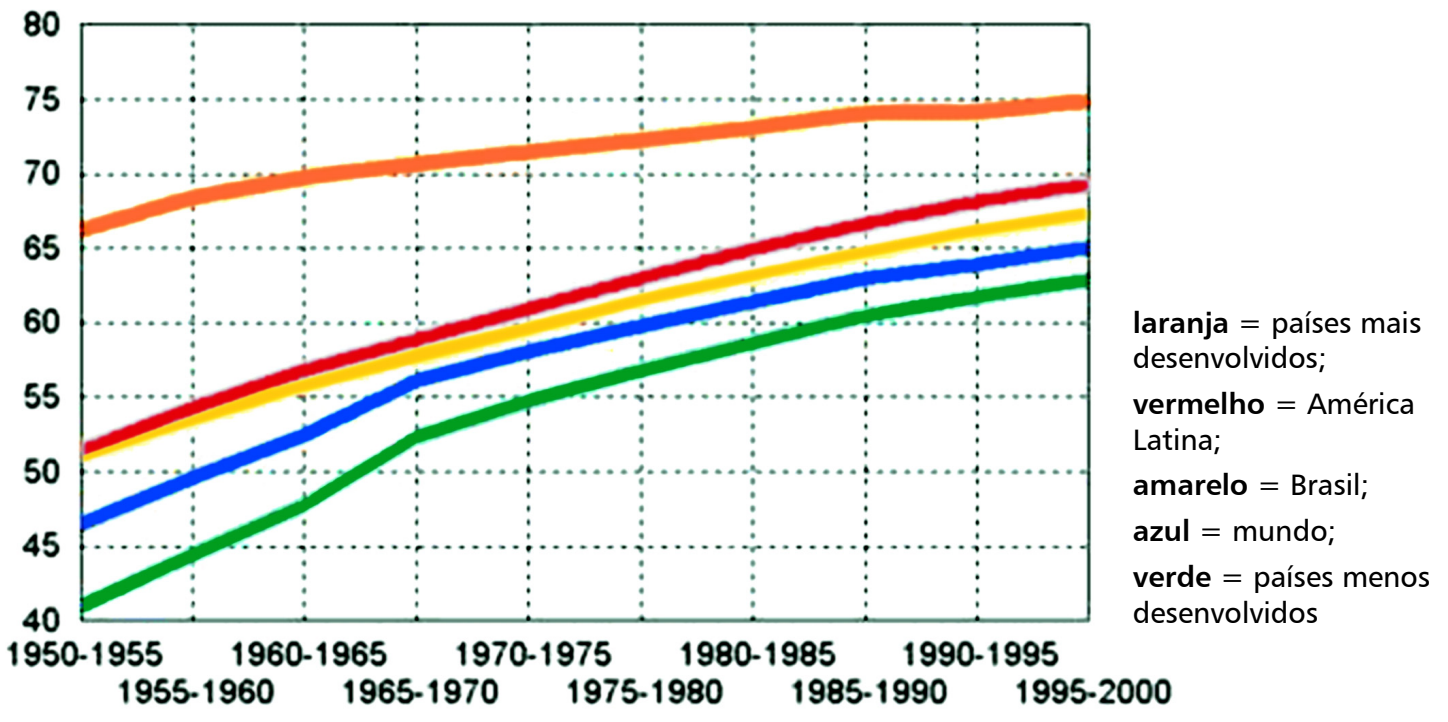

Gráfico 1 - Ascensão da expectativa de vida dos brasileiros ${ }^{5}$ 


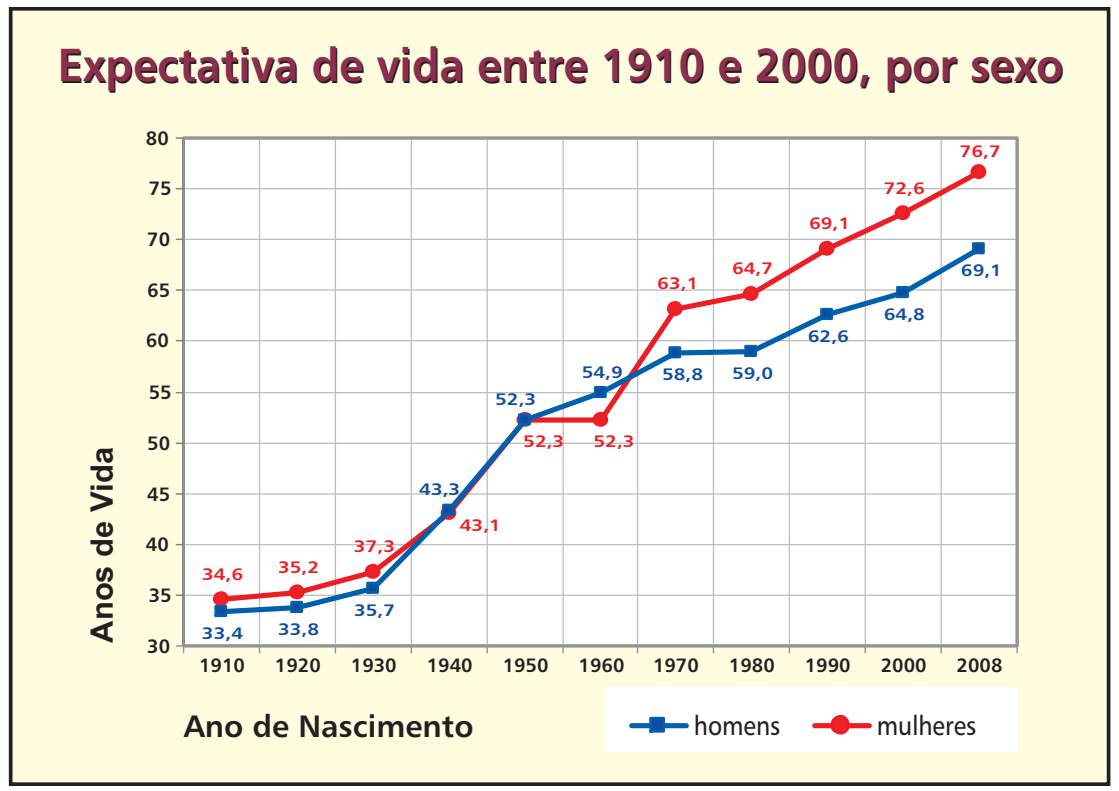

Gráfico 2 - Estimativa de vida ao nascer ${ }^{6}$

O Gráfico 2 demonstra o crescimento progressivo da "estimativa de vida ao nascer" desde o início do século XX no Brasil.

Os gráficos populacionais do IBGE (Gráficos 3, 4 e 5) mostram que ocorrerá uma mudança na pirâmide populacional, na qual a base indica a população de menos idade e o topo indica os cidadãos mais velhos do país. No Gráfico 3, é possível ver como era a distribuição da população por faixas etárias em 1980. A pirâmide indica o predomínio de jovens na base, com um topo afunilado que aponta para uma proporção bem menor da população idosa.

Em 2005 (Gráfico 4), as pesquisas do IBGE começaram a mostrar mudanças no topo, indicando aumentos significativos na população de mais idade e na parte intermediária da pirâmide, que representa os cidadãos com idade entre 20 e 60 anos.

6 Gráfico elaborado a partir de dados das Séries Históricas do IBGE, disponíveis em:

$<$ http://www.ibge.gov.br/series_estatisticas/subtema.php?idsubtema=108>. E informações divulgadas pela mesma instituição em IBGE. (2008). Projeção da População do Brasil - IBGE: população brasileira envelhece em ritmo acelerado. Instituto Brasileiro de Geografia e Estatística, Notícias, 27/11/2008. Disponível em $<$ http://www.ibge.gov.br/home/presidencia/noticias/noticia_visualiza.php?id_noticia $=1272$ \&id_pagina $=1>$. Acesso em 12/04/2009. 


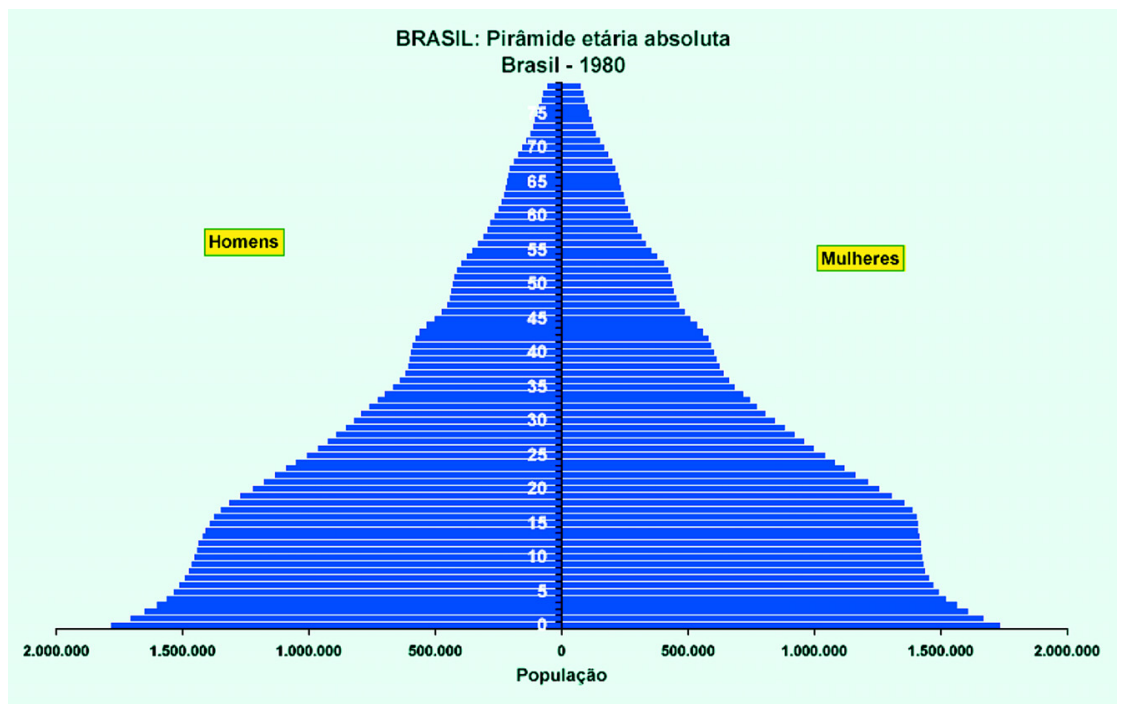

\section{Gráfico 3 - Pirâmide populacional brasileira em 19807}

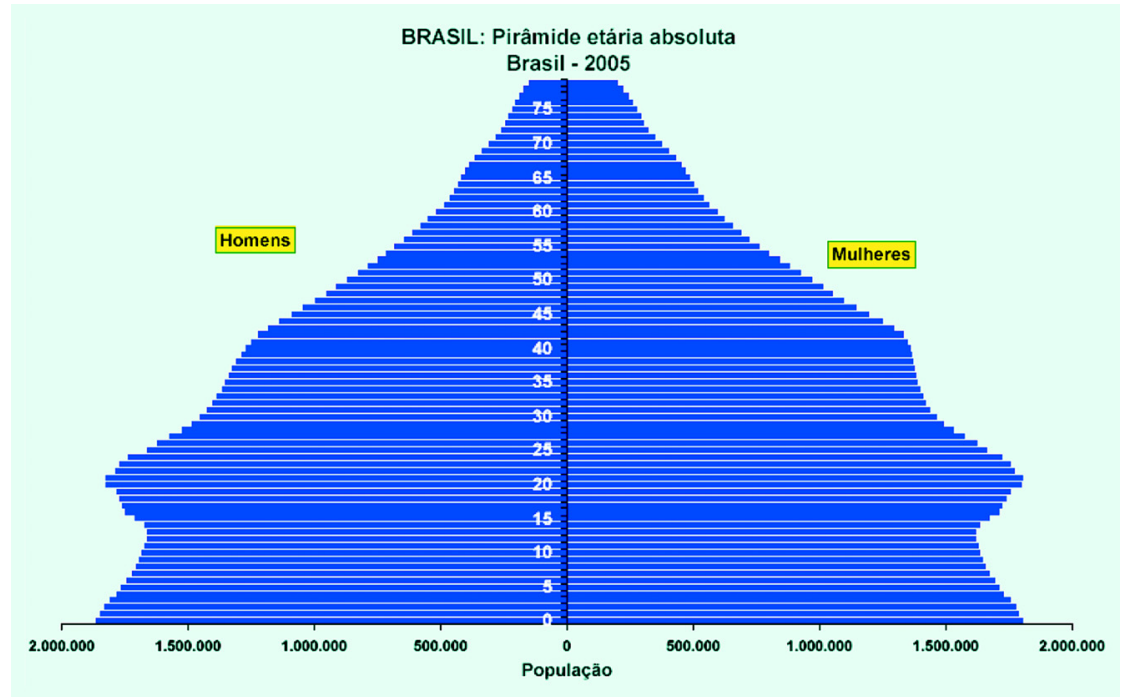

Gráfico 4 - Pirâmide populacional brasileira em $2005^{8}$

7 Retirado de: IBGE. 2004. Projeção da população do Brasil por sexo e idade para o período 1980-2050 - Revisão 2004. Instituto Brasileiro de Geografia e Estatística, Diretoria de Pesquisas, Coordenação de População e Indicadores Sociais. URL: $<$ http://www.ibge.gov.br/home/estatistica/populacao/estimativa2005/metodologia.pdf > . Acesso em 09/2006.

8 Retirado de: IBGE. 2004. Projeção da população do Brasil por sexo e idade para o período 1980-2050 - Revisão 2004. Instituto Brasileiro de Geografia e Estatística, Diretoria de Pesquisas, Coordenação de População e Indicadores Sociais. URL:

$<$ http://www.ibge.gov.br/home/estatistica/populacao/estimativa2005/metodologia.pdf> . Acesso em 09/2006. 


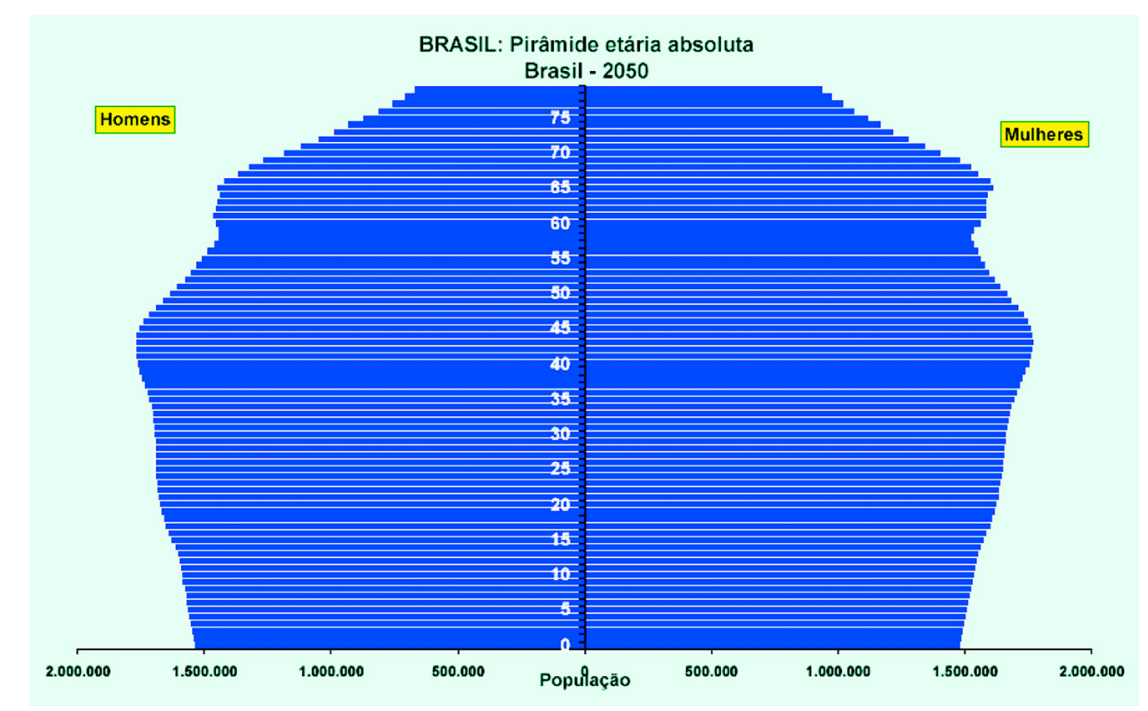

Gráfico 5 - Pirâmide populacional brasileira: projeção para $2050^{9}$

As projeções que o IBGE faz para 2050 (Gráfico 5) indicam que a Pirâmide Etária populacional tenderá a ter a base e o topo mais uniformes. A população brasileira caminha para um número mais equilibrado de jovens e velhos, e a distribuição geral fará com que o que era antes uma pirâmide perca inclusive a semelhança com a forma geométrica que inspirou o nome da representação gráfica.

Dados do $\mathrm{IBGE}^{10}$ apontam que "em 2008, para cada grupo de 100 crianças de 0 a 14 anos existem 24,7 idosos de 65 anos ou mais. Em 2050, o quadro muda e para cada 100 crianças de 0 a 14 anos existirão 172,7 idosos".

Diante de tal crescimento, o Estado, a sociedade civil e o mercado de produtos e serviços começam a voltar a sua atenção para a terceira idade. Seja pelos itens que devem ser aprimorados - como a saúde com atendimento especializado aos idosos - como aqueles com os quais o governo precisa lidar -,

9 Retirado de: IBGE. 2004. Projeção da população do Brasil por sexo e idade para o período 1980-2050 - Revisão 2004. Instituto Brasileiro de Geografia e Estatística, Diretoria de Pesquisas, Coordenação de População e Indicadores Sociais. URL: <http://www.ibge.gov.br/home/estatistica/populacao/estimativa2005/metodologia.pdf>. Acesso em 09/2006.

10 Retirado de: IBGE. (2008). Projeção da População do Brasil - IBGE: população brasileira envelhece em ritmo acelerado. Instituto Brasileiro de Geografia e Estatística, Notícias, 27/11/2008. Disponível em:

$<$ http://www.ibge.gov.br/home/presidencia/noticias/noticia_visualiza.php?id_noticia=1272\&id_pagina=1 >. Acesso em: 12/04/2009. 
como o aumento de número de aposentados e do tempo que eles receberão a aposentadoria (o que, dependendo da linha de pensamento político e econômico, constitui uma questão de maior ou menor relevância para o Estado e para os cofres públicos), bem como a diminuição do número de pessoas nas chamadas faixas "economicamente ativas". ${ }^{11}$

\subsection{O idoso e a legislação brasileira}

Segundo Vicente Faleiros (2007), as seguintes constituições são importantes, no que diz respeito à legislação referente a idosos: a de 1934, 1937, 1946, 1967 e a de 1988. É no artigo 121 da Constituição de 1934 que aparecem os direitos trabalhistas da pessoa idosa, do qual destacamos:

Art. 121 - A lei promoverá o amparo da produção e estabelecerá as condições do trabalho, na cidade e nos campos, tendo em vista a proteção social do trabalhador e os interesses econômicos do País.

$\S 1^{o}$ - A legislação do trabalho observará os seguintes preceitos, além de outros que colimem melhorar as condições do trabalhador:

a) proibição de diferença de salário para um mesmo trabalho, por motivo de idade, sexo, nacionalidade ou estado civil;

$[\ldots]$

h) assistência médica e sanitária ao trabalhador e à gestante, assegurando a esta descanso antes e depois do parto, sem prejuízo do salário e do emprego, e instituição de previdência, mediante contribuição igual da União, do empregador e do empregado, a favor da velhice, da invalidez, da maternidade e nos casos de acidentes de trabalho ou de morte; $^{12}$

Depois disso, a “Constituição de 1937 (artigo 137) estabeleceu o seguro de velhice para o trabalhador, a de 1946 (artigo 1957), a Previdência 'contra as

11 Discutiremos um pouco mais esse assunto no capítulo 3, tópico 3.3.1.

12 BRASIL. (2007). Constituição da República dos Estados Unidos do Brasil (de 16 de julho de 1934). Presidência da República, Casa Civil, Subchefia para Assuntos Jurídicos.Disponível em

< http://www.planalto.gov.br/ccivil_03/Constituicao/Constituiçao34.htm>. Versão da página/última modificação do arquivo: 28 de setembro de 2007, às 09h07.Acesso em 16/04/2009. 
conseqüências da velhice' e a de 1967, a Previdência Social 'nos casos de velhice' (artigo 158)". (Faleiros, 2007:155)

A Constituição de 1988 é importante por ter configurado um Estado de direito "com um sistema de garantias da cidadania" (Faleiros, 2007:155). Dessa Constituição, Faleiros destaca o estabelecimento da Seguridade Social (assistência, Previdência e saúde) na qual a Previdência "passa a ter caráter contributivo".

Em 1994, a Política Nacional do Idoso (PNI - lei 8.842) foi predecessora do que podemos considerar uma conquista para os idosos, sancionada em 2003: o Estatuto do $\operatorname{Idoso}^{13}$. Ele complementou as leis já existentes na PNI e assegurou mais direitos sociais, autonomia, integração e participação na sociedade. Não se pode deixar de notar, entretanto, que até mesmo o Estatuto do Idoso contém uma visão da velhice que esbarra em alguns estereótipos: "O próprio Estatuto do Idoso é implicitamente preconceituoso à medida que foi calcado numa visão da velhice incapacitada, doente e economicamente dependente, que deve ser tutelada pelas instituições sociais". (Neri, 2007a:42)

A pesquisa sobre os idosos brasileiros, realizada pela Fundação Perseu Abramo (FPA) em parceria com o Serviço Social do Comério (SESC) ${ }^{14}$, mostra um quadro bastante distinto do que se poderia associar com dependência econômica ou incapacidade. Seus resultados foram analisados por especialistas de várias áreas e publicados em obra coletiva pela editora da Fundação e do SESC ${ }^{15}$. Entre os diversos trabalhos, Gustavo Venturi e Vilma Bokany (2007), por exemplo, apontam que 92\% dos idosos têm renda própria. Marcelo Neri (2007) revela que $71 \%$ dos idosos têm controle total de suas despesas e, além disso, 88\% disseram contribuir para a renda familiar, enquanto 71\% dos entrevistados acima de 60 anos são chefes de família.

13 BRASIL. Lei $n^{\circ}$ 10.741, de $1^{\circ}$ de outubro de 2003. Dispõe sobre o Estatuto do idoso. Presidência da República Federativa do Brasil, Casa Civil, Legislação. Disponível em <https://www.planalto.gov.br/ccivil_03/Leis/2003/L10.741.htm>. Acesso em 04/2006.

14 Administração Nacional.

15 NERI, Anita Liberelesso (org.). (2007). 


\section{Educação}

Já na PNI se falava de educação para a terceira idade, incentivando a criação de programas como as Universidades Abertas para a Terceira Idade (UATIs).

Em 1998, o relatório para a Unesco da Comissão Internacional sobre Educação para o Século $\mathrm{XXI}^{16}$, coordenada por Jacques Delors, trata do conceito de "educação ao longo de toda a vida" (cf. 3.5.1.). Johannes Doll (2007) ressalta que o relatório chama a atenção para processos formativos que não são voltados para as atividades produtivas que o sujeito desenvolve ou desenvolverá em sua vida, destacando a educação direcionada a adultos e idosos. O relatório frisa que a denominada "educação ao longo de toda a vida" é a "chave" para abrir as portas do século XXI. Baseando-se nesse relatório, o Estatuto do Idoso trata do tema em seu Capítulo 5, do qual ressaltamos dois artigos:

Art. 21. O Poder Público criará oportunidades de acesso do idoso à educação, adequando currículos, metodologias e material didático aos programas educacionais a ele destinados.

$\S 1^{\circ}$ Os cursos especiais para idosos incluirão conteúdo relativo às técnicas de comunicação, computação e demais avanços tecnológicos, para sua integração à vida moderna.

$\S 2^{\circ}$ Os idosos participarão das comemorações de caráter cívico ou cultural, para transmissão de conhecimentos e vivências às demais gerações, no sentido da preservação da memória e da identidade culturais.

Art. 25. O Poder Público apoiará a criação de universidade aberta para as pessoas idosas e incentivará a publicação de livros e periódicos, de conteúdo e padrão editorial adequados ao idoso, que facilitem a leitura, considerada a natural redução da capacidade visual ${ }^{17}$.

16 DELORS, Jacques et al.(1998).

17 BRASIL. Lei no 10.741, de $1^{\circ}$ de outubro de 2003. Dispõe sobre o Estatuto do idoso. Presidência da República Federativa do Brasil, Casa Civil, Legislação. Disponível em <https://www.planalto.gov.br/ccivil_03/Leis/2003/L10.741.htm>. Acesso em $04 / 2006$. 
É farta a produção bibliográfica na área da Saúde e da Educação Física envolvendo idosos, sendo que boa parte da pesquisa científica relacionada à terceira idade se situa nessas duas áreas. ${ }^{18}$ Atualmente, estudos e projetos começam a ser ampliados e vários deles passam a se preocupar não somente com a saúde dos idosos como também com a sua reinclusão social, participação em atividades culturais etc. O próprio SESC é um exemplo disso, oferecendo atividades específicas para idosos (esportes, cursos de artesanato, cursos de língua estrangeira, dentre outros) e atividades de integração entre gerações. (Ferrigno, 2003; Lima, 2008).

Cilene Canôas (1985), em um levantamento dos programas voltados para a terceira idade no Brasil, mostra que o SESC-SP foi pioneiro ao criar, em 1963, o "Grupo de Convivência dos Idosos" e, mais tarde, em 1977, a primeira "Escola Aberta da Terceira Idade".

As Universidades Abertas para a Terceira Idade (UATIs) existem na Europa, Canadá e Estados Unidos desde a década de 1970. Segundo Faleiros (2007), no Brasil foi em 1982 que surgiu a primeira UATI, e esse tipo de projeto entrou em grande expansão na década de 1990. O projeto de UATI na USP é anterior ao Estatuto do Idoso, tendo início em 1993. Em 1994, eram 847 matriculados ${ }^{19}$ e, em 2008, segundo informações da Secretaria do Programa UATI ${ }^{20}$, o número chegou a 9.065, um crescimento de 1070,25\% num intervalo de 14 anos. A maioria das UATIs abre disciplinas e cursos específicos para os idosos. A UATI na USP se diferencia dos outros projetos por permitir ao aluno idoso que se matricule em cursos da graduação e assista às aulas junto com os alunos da própria faculdade, promovendo uma experiência intergeracional enriquecedora para os participantes. ${ }^{21}$ Segundo Peixoto (1997), esse modelo de Universidade para a Terceira Idade foi inserido no Brasil pela Pontifícia Universidade Católica de Campinas (Puccamp), em

18 Constatação feita ao realizar busca bibliográfica com alguma das palavras-chave a seguir: idoso, terceira idade, velhice.

19 BOSI, Ecléa. Um projeto feliz. In: Apresentação do Programa Universidade Aberta para a Terceira Idade da Universidade de São Paulo. <http://www.usp.br/prc/3idade/apresentacao.php>. Acesso em 07/2006.

20 Informações fornecidas pela Secretaria da Universidade Aberta à Terceira Idade da USP, em mensagem de 13 de abril de 2009, por intermédio do endereço eletrônico <usp3idad@usp.br>.

21 Falaremos um pouco mais de grupos intergeracionais no tópico 1.5. ainda deste capítulo, e aprofundaremos mais o assunto, dedicando a ele todo o capítulo 3. 
1990, ao elaborar um currículo que privilegiava as relações intergeracionais. O curso, dividido em três níveis e com direito a certificado de conclusão de curso, reunia idosos e jovens universitários nas disciplinas que frequentavam.

\subsection{O idoso hoje}

Simone de Beauvoir (1976a) afirma que o velho perde seu valor em comunidades que conhecem a escrita, pois deixam de ser vistos no papel de disseminadores da cultura e o de detentores das tradições da comunidade. Ao longo dos anos, algumas civilizações veneraram a velhice como fase de sabedoria. Um exemplo disso é a tradição de se admirar os idosos na cultura oriental, como relata a autora: Buda, o salvador dos homens, atinge o seu ápice aos 80 anos, a idade que tinha quando morreu; enquanto no Ocidente, Cristo atinge a perfeição entre os 30 e 33 anos.

Ainda segundo Beauvoir, é no Renascimento que se passa a exaltar a beleza do corpo e, no século XX, deixa-se de pensar o saber como algo cumulativo quanto mais velho mais sábio - e passa-se a acreditar que o saber torna-se desqualificado, ultrapassado. Isso desvaloriza o velho e supervaloriza o jovem, o novo. Com as sociedades industriais surgem as famílias nucleares, formadas por pais e filhos, e a figura dos avós começa a perder espaço.

A mutação constante da sociedade faz com que o idoso se sinta estrangeiro em seu próprio mundo. Beauvoir relata que, no século XIX, a Europa passou por um aumento demográfico no qual o número de idosos foi grande demais para ser ignorado. Foi então que se começou a conhecer a velhice. Três são os fenômenos importantes relacionados a essa progressão demográfica: a Revolução Industrial, o êxodo rural (devido ao desenvolvimento urbano) e o surgimento de uma nova classe, o proletariado.

Tomemos como base os textos de Richard Sennett (2003) e Walter Benjamin (1994). No mundo em que estamos inseridos, movido pelo capital, o 
passado e a tradição são deixados de lado, pois temos uma supervalorização do novo, do imediato, do a curto prazo. O que não é produtivo é abandonado. Nós somos e valemos o que produzimos. Se não produzimos, ou deixamos de produzir, passamos a não ter mais valor. O passado e a tradição estão representados na figura dos idosos, já o novo é projetado na figura dos jovens. Quando nos aposentamos paramos de produzir e, portanto, deixamos de ter valor dentro dessa sociedade. E essa aposentadoria geralmente chega quando estamos na chamada terceira idade.

Gonçalvez, Passos e Camargo (2007) afirmam que nossa identidade é construída dentro dos "campos sociais" que frequentamos, estabelecendo papéis representativos do eu. Como grande parte de nossa vida é passada trabalhando, boa parte da nossa identidade é construída com esse trabalho, ou seja, um dos nossos papéis representativos do eu mais importantes é aquele feito no campo social do trabalho. Quando nos aposentamos, deixando de trabalhar, não nos reconhecemos, pois perdemos parte da nossa identidade. Pensemos, por exemplo, em uma situação social, quando nos indagam "Você é o quê?" - e aqui, usamos a frase com o verbo "ser" justamente para mostrar como isso nos define - a resposta imediata é a nossa profissão: "Eu sou professora". Provavelmente, ao ouvir uma pergunta desse tipo não se pensa em responder: eu sou mulher, alta etc. Justamente porque nossa profissão acaba determinando grande parte de nossa identidade, e ao nos aposentarmos a sensação é de perda. A partir de então, saímos em busca de uma nova representação do eu, a ser construída com outros parâmetros que não mais aqueles do trabalho. Os mesmos autores tratam do chamado "mito da tríade": envelhecimento, aposentadoria e morte; esses elementos parecem estar intrinsecamente ligados. Nesse contexto, a aposentadoria chega a ser temida, porque ela representa a aproximação da morte, indica o quanto envelhecemos.

Na pesquisa da FPA/SESC, 95\% dos idosos aposentados declararam não ter recebido nenhum tipo de preparação para a aposentadoria e acabaram sem saber o 
que fazer ao se aposentarem. A adaptação à rotina de aposentado é difícil e delicada, pois a mudança ocorre de forma muito brusca. Um dia estamos trabalhando e, no outro, não estamos mais, estaremos em casa, com o tempo livre, sem saber muito bem o que fazer dele.

Para a atual geração de terceira idade, o fator aposentadoria é mais pesado para os homens do que para as mulheres. Para esses homens, aposentar-se significa perder os atributos que definem a sua masculinidade. Muitos homens não participam de grupos de terceira idade por preconceito (Mascarelo, Miorando e Portella, 2007).

As mulheres idosas, por terem atuado na família como cuidadoras (dos filhos, da casa, dos netos etc.), são socialmente mais ativas, e isso traz vantagens psicossociais. Um exemplo disso é o fato de elas não sentirem tanta dificuldade em buscar novos grupos sociais nos quais se inserirem. Quando não possuem mais a família para cuidar, geralmente encontram outros meios de manter contato com a comunidade, com a sociedade, seja conversando com velhas amigas, vizinhas, ou mesmo buscando grupos, cursos etc.

Atualmente vivemos algumas contradições, como nos demonstra Andréa M. Alves (2007). Uma delas é o fato de vivermos em uma sociedade que valoriza o corpo (jovem) e a juventude. E que, ao mesmo tempo, faz publicidades sobre a terceira idade mostrando uma imagem prazerosa e feliz da velhice $e$, aparentemente, livre de preconceitos. Outra contradição é a imagem de uma velhice que é sábia e experiente em uma sociedade que dá cada vez menos voz aos idosos e suas palavras parecem ter perdido valor.

Somente o que é jovem tem valor. Um idoso só é considerado interessante se possuir hábitos ditos "jovens", como pular de paraquedas ou praticar esportes radicais. Quando queremos relacionar um atributo que valorize a figura do idoso, geralmente o adjetivo escolhido é "jovem" ("Minha avó tem um espírito jovem!"). Ruth Lopes (2007) afirma que não entendemos a singularidade do idoso por 
colocá-lo em contraposição ao jovem. Por que é o velho quem tem que se adaptar ao jovem?

Reconhecemo-nos através do outro, portanto, segundo Beauvoir (1976a), nos reconhecemos velhos quando os outros nos fazem notar que envelhecemos. É, muitas vezes, na contraposição com o jovem que nos deparamos com nossa velhice. $\mathrm{O}$ adolescente percebe que está mudando porque as transformações estão no seu corpo, mas, quando envelhecemos, essa revelação da nossa idade geralmente vem dos outros, do contrário, continuaríamos a "adiar" nossa velhice. $\mathrm{Na}$ pesquisa da FPA/SESC, podemos verificar nas respostas dos entrevistados, idosos e não idosos, que cada grupo indicou a chegada da velhice em idades diferentes. As pessoas de 16 a 24 anos em média indicaram os 66 anos e três meses como a chegada da velhice; as pessoas de 25 a 59 anos indicaram os 68 anos e 11 meses; enquanto que as de 60 anos ou mais indicaram os 70 anos e 7 meses. Neri (2007a) levanta a questão: essa visão de que a velhice chega cada vez mais tarde é o reflexo de uma velhice mais saudável ou significaria uma negação da velhice?

Lopes (2007), analisando dados da pesquisa realizada pela FPA/SESC, revela que a imagem da velhice ainda é muito associada a adjetivos negativos por todos os entrevistados (idosos e não idosos), adjetivos como: "declinante, feio, impotente, improdutivo, ranzinza, gagá". Esses estereótipos acabam construindo barreiras que dificultam a comunicação e vivência com os idosos. Venturi e Bokany (2007) mostram que, na mesma pesquisa, 88\% dos idosos e 90\% dos não idosos associam a chegada da velhice a aspectos negativos, sendo que apenas um quinto dos entrevistados cita algo de positivo na imagem do idoso.

Um dado muito importante apresentado por Neri (2007a) a respeito da mesma pesquisa é o resultado das perguntas sobre preconceito contra idosos. Quando questionados (idosos e não idosos) se existe preconceito contra o idoso no Brasil, 84\% deles afirmaram que sim. Mas quando a pergunta foi sobre se o entrevistado tinha preconceitos em relação aos idosos, 95\% disseram não os ter. 
Portanto surge a pergunta: "então quem seriam os preconceituosos a que se referem?" (Neri, 2007a: 36).

Em algumas sociedades o preconceito contra os idosos é tão forte quanto o preconceito racial, e a discriminação é uma consequência do preconceito. Como podemos constatar na pesquisa da FDA/SESC, 17\% dos idosos declararam já terem sido ofendidos, tratados com ironia ou gozação, ou foram humilhados/menosprezados. Venturi e Bokany (2007) frisam que, quando perguntados sobre qual o pior ponto em ser idoso, o mais citado foi o da discriminação social (citado por 18\% dos entrevistados idosos e $24 \%$ dos não idosos). Como veremos mais detalhadamente no capítulo dois, em inglês existe uma palavra específica para o preconceito etário: ageism.

Anita L. Neri (2007a) fala da "naturalização do preconceito", ela ocorre quando uma pessoa é objeto de preconceito sem que o perceba. Isso acontece com os idosos, por exemplo, nas formas de tratamento aparentemente coloquiais e carinhosas (por exemplo: "vovozinha", "velhinho", "maior idade", "melhor idade" etc.).

Eufemismos como "terceira idade", "melhor idade", "maior idade", "idade legal" são subterfúgios semânticos, termos aparentemente bem soantes que no fundo servem para mascarar a rejeição da velhice. Se não, qual o sentido em denominá-la de outra forma? Por que precisamos buscar cognomes se o léxico dispõe de palavras consagradas pelo uso para designar certos objetos? (Neri, 2007a:41)

Venturi e Bokany afirmam que a terceira idade passou a ter maior visibilidade a partir da década de 1960, com o crescimento acelerado do número de idosos (que hoje representam cerca de $10 \%$ da população brasileira, aproximadamente 18 milhões de cidadãos). Em 1961 é fundada a primeira sociedade de geriatria no Brasil, que é aberta também a gerontólogos, em 1978. E é fundada em 1982 a primeira Associação de Gerontólogos do país. 
Outro fator importante para o aumento da visibilidade dos idosos é o fato de começarem a ser vistos como um mercado de consumo emergente. Como dissemos, na pesquisa da FPA/ SESC, vemos que 85\% dos idosos têm controle sobre o gasto do dinheiro que recebem. Os principais gastos são com comida, contas e remédios, e somente 7\% dos idosos entrevistados dispõem da aposentadoria com lazer (cursos, viagens etc.). Sendo que são as mulheres que mais gastam com lazer. Mesmo assim, Maria Santellano (2009) afirma que o público idoso em cruzeiros marítimos, por exemplo, hoje chega a representar 60\% do público total nesse tipo de turismo.

Bobbio (1991 e 1997b) afirma que em uma sociedade na qual tudo é mercado, até mesmo a velhice pode se transformar em mercadoria como todas as outras.

O mercado tem tentado atrair cada vez mais os aposentados que buscam preencher seu tempo livre com atividades que lhes proporcionem prazer e a possibilidade de continuarem socialmente ativos. $\mathrm{Na}$ mesma pesquisa da FPA/SESC, os idosos apontam como um dos pontos positivos da velhice o tempo livre. Uma das formas de preencher o tempo livre gerado pela aposentadoria é a busca por cursos "livres", sem pretensão de aprimoramento profissional, nos quais os idosos buscam certa realização pessoal. (Continuaremos essa discussão mais adiante.)

Nos cursos de extensão oferecidos pela Secretaria de Cultura e Extensão da Faculdade de Filosofia, Letras e Ciências Humanas, da Universidade de São Paulo, há uma grande procura pelo curso de língua italiana pelo público da terceira idade. Em alguns grupos chega-se a ter quase 90\% dos alunos pertencentes a essa faixa etária. Muitos deles estudam a língua italiana por serem descendentes de italianos (cf. resultados finais de nossas pesquisas comentados no capítulo cinco). Na pesquisa da FDA/SESC, a segunda maior ascendência apontada pelos entrevistados é a italiana. 


\subsection{A importância das atividades sociais para a terceira idade}

Quando se aposentam, os idosos se deparam, abruptamente, com uma vida com a qual não estão habituados. Um dia estão na sua rotina, de tantos anos, indo ao trabalho, no outro, têm o dia inteiro livre e sem tarefas obrigatórias a cumprir. Diante desse quadro, muitos aposentados se sentem perdidos, sem saber como lidar com a nova rotina, e a adaptação é demorada e difícil.

Esse processo é particularmente mais complicado para os homens, que construíram sua identidade no trabalho e, quando se aposentam, sentem-se improdutivos e entram, muitas vezes, em depressão. Deve-se considerar que a faixa etária que hoje se encontra na chamada terceira idade vem de uma época em que os homens trabalhavam fora de casa $e$ as mulheres trabalhavam, prioritariamente, na casa e cuidavam dos filhos. Por isso, a identificação com seu trabalho é mais frequente e presente entre os homens do que entre as mulheres. (Mascarelo, Miorando e Portella, 2007). Quanto às mulheres, segundo os dados trazidos por Neri (2007b:56-57):

[...] nas zonas urbanas, além de estar aumentando o número de famílias chefiadas por mulheres, elas são as que mais freqüentam grupos de convivência, movimentos sociais, viagens e oportunidades de lazer, e as que mais se dedicam a trabalhos remunerados temporários e a trabalhos voluntários. De modo geral, as mulheres são mais conectadas socialmente, tanto no âmbito da família quanto fora dela, em boa parte por influência de variáveis culturais. Essa característica lhes confere vantagens em relação ao funcionamento psicossocial e também em relação à disponibilidade de proteção e cuidado quando se tornam incapacitadas.

Além da questão da identidade que "se perde" com a aposentadoria, os idosos precisam lidar com muitas outras perdas que podem acentuar o sentimento de exclusão social: o afastamento da família, com filhos que saíram de casa, por exemplo; a morte de conhecidos e amigos e o afastamento do ambiente social do 
trabalho. Na contramão das perdas, vem o tempo livre para realizarem o que não puderam quando trabalhavam. Portanto, alguns aposentados buscam fazer os cursos que gostariam de ter frequentado, as viagens que deixaram de fazer por causa do trabalho, da família ou por outras razões. Como podemos ver nos depoimentos reproduzidos na obra de Ferrigno $(2003)^{22}$, os idosos, quando se aposentam e não sabem o que fazer com o tempo livre, podem tornar-se depressivos e solitários e acabar tendo, como consequência, problemas de saúde. Os grupos intergeracionais, ou mesmo os voltados somente para a terceira idade, promovem uma melhora na autoestima dos idosos. Ferrigno relata o caso de um idoso que tomava nove tipos de remédios e que, em algumas semanas no grupo do SESC, diminui para dois, parando justamente com aqueles que combatiam transtornos emocionais. Cristina Lima $(2008)^{23}$, que fez a pesquisa em grupos intergeracionais no SESC-Campinas, também apontou que os idosos participantes de Programas Intergeracionais e que se medicavam tiveram maior redução da depressão. Meire Cachioni e Anita L. Neri (2004) citam como Pierre Vellas ${ }^{24}$ ficou convencido de que muitos processos patológicos dos idosos tinham origem no problema da exclusão social. Também Lima (2008) afirma que "a depressão é uma das causas mais frequentes de problemas de memória nessa faixa etária”, portanto, os programas intergeracionais também podem trazer efeitos significativos na questão cognitiva.

As autoras Meire Cachioni e Anita L. Neri (2004) consideram a visão de Moody $^{25}$ para discutir os modelos existentes para abordar a educação à velhice. $\mathrm{O}$ primeiro modelo é o da Rejeição, cujo fundamento é uma visão negativa da velhice, considerando os idosos dependentes e improdutivos e, portanto, desnecessário o investimento na educação destinada a eles. O segundo é o de Serviços Sociais, esse modelo também possui uma visão negativa da velhice, acredita que o idoso não se

22 O estudo de Ferrigno, considerado intergeracional, envolve professores de 25 a 45 anos e suas relações com os alunos da terceira idade de diversos cursos oferecidos pelo SESC.

23 Na pesquisa de Lima, os grupos intergeracionais envolviam especificamente crianças e idosos.

24 Foi quem, de certa forma, "criou" as Universidades Abertas à Terceira Idade na França, em 1973, baseando-se nas que existiam anteriormente, chamadas de Universidades do Tempo Livre.

25 MOODY, R. H. (1976). Philosophical pressuppositions of education for old age. Educational Gerontology, nº 1, p. 1-16. 
desenvolve mais, mas o vê como público injustiçado que teria na educação um "remédio" para esse problema. O terceiro é chamado de Participação e Atividade, que, como o nome diz, tem uma estratégia participativa e vê na educação o meio de manutenção das habilidades e experiências dos idosos, esperando que eles possam intervir em problemas da sociedade. O quarto modelo é o da Autorrealização e Educação Permanente, que tem na educação o papel de "servir de veículo para que os sujeitos consigam manter seus níveis normais de funcionamento e desenvolvimento". Nesse modelo, a educação deixa de servir a uma função formal, na qual ela existe para que o sujeito possa cumprir certos papéis sociais. Sendo aposentado, não há mais a necessidade de estudo para melhorar na profissão que exerce ou ser "promovido" no ambiente de trabalho.

Nós concordamos com o quarto modelo citado acima, o da Autorrealização e Educação Permanente, acreditando que, a partir do momento em que não se necessita mais estudar por razões profissionais, os aposentados possam buscar a autorrealização, frequentando os cursos por prazer. Cursos que geralmente deixaram de frequentar porque antes havia outros mais importantes para os seus empregos ou mesmo porque não tinham tempo para frequentá-los. No capítulo três, discutiremos mais sobre a questão da educação envolvendo idosos, em que optamos pela adoção do conceito de "educação ao longo de toda a vida" como um conceito que vai além daquele conhecido como "educação permanente".

Precisamos ter em mente, quando falamos de programas e atividades sociais para a terceira idade, que muitos idosos podem não participar desses grupos por não se sentirem velhos ou por não quererem associar a sua imagem à de uma pessoa "velha" (Alves, 2007). Guita G. Debert (2004) afirma que o melhor modo de atrair a atenção dessa faixa etária talvez seja demonstrando os benefícios do produto, fazendo com que os idosos se identifiquem com ele, sem que seja direcionado para essa faixa etária específica. Esse é um dos pontos em que os Programas Intergeracionais se tornam mais interessantes, pois não classifica os 
idosos em faixas etárias e não os trata de forma separada, como se constituíssem um grupo diferente do restante da sociedade, perpetuando uma segregação etária que já existe na nossa sociedade.

Lembremos da questão citada anteriormente, acerca dos homens que, quando param de trabalhar, além de se sentirem improdutivos também veem a perda dos atributos que definem sua masculinidade. Johannes Doll (2007) mostra como o lazer não traz a mesma sensação que traz o trabalho, que é aquela de ser útil para a sociedade. E a atividade, para ser significativa para o idoso, tem que ter vínculo com a sua identidade. Atualmente, as atividades destinadas à terceira idade têm atraído mais mulheres do que homens. Isso se deve também ao fato de estarmos passando pela chamada "feminização da velhice", explicado por Anita L. Neri (2007b:48), que acontece em todo o mundo, não só no Brasil, a qual, segundo a autora, está associada aos seguintes fatores: "1) maior longevidade das mulheres em comparação com os homens" (basta ver a expectativa de vida de ambos, citada em 1.2.); “2) maior presença relativa de mulheres na população idosa, principalmente nos estratos mais velhos; 3) crescimento do número de mulheres idosas que integram a população economicamente ativa; e 4) crescimento do número de mulheres idosas que são chefes de família".

Os Programas Intergeracionais, além de promoverem maior integração do idoso na sociedade, permitem que alguns preconceitos e estereótipos sejam "quebrados". Tanto dos mais jovens em relação aos idosos quanto dos idosos em relação aos jovens. Ruth Lopes (2007) mostra que os não idosos (16 a 59 anos) entrevistados para a pesquisa da FPA/SESC veem os idosos como incapazes ou inúteis (37\%), ultrapassados (15\%) e desinformados (5\%); enquanto que os idosos associam à imagem dos jovens: irresponsabilidade, drogas e desrespeito. 
Um dado importante para nossa reflexão é o que nos traz Carvalho e Horiguela $(2007)^{26}$ e Lima (2008). Quando investigaram os programas intergeracionais envolvendo crianças, puderam verificar que elas estão mais livres de preconceitos e estereótipos em relação à velhice. Quando pedidos para descreverem os idosos, muitas disseram que eles são "pessoas como quaisquer outras", sem diferenciá-los por causa da idade.

Isso demonstra que nossos preconceitos e estereótipos são consequências das representações construídas social e historicamente. Por isso é importante o tratamento do tema "velhice" já nas etapas de base da vida escolar. Pois da mesma forma como construímos estereótipos e preconceitos, com o tempo podemos também destruí-los ou, pelo menos, amenizá-los. Resgatar as qualidades e positividades da velhice depende da sociedade atual. Cristina Lima (2008) deixa clara a distinção entre velhice e envelhecimento. O envelhecimento é um "processo natural de transformação do ser humano através da temporalidade" e do qual ninguém pode escapar. A velhice, por sua vez, é a "produção social e não uma categoria natural" e sobre ela nós temos influência.

Os programas intergeracionais promovem a convivência entre gerações diferentes, o que possibilita um rico compartilhamento de experiências, informações e a quebra de barreiras, estereótipos e preconceitos. Paiva e Del-Maso (2007) apontam que ambientes sociais instigam a co-construção de identidades, o que possibilita o abandono de identidades preconceituosas. A experiência de Pierre Vellas com as UATIs na França mostra que pessoas de diferentes idades e formações acadêmicas não só conviviam sem nenhum problema, como o contato levou à valorização do idoso pelo jovem (Cachioni e Neri, 2004).

No mesmo texto de Cachioni e Neri, há o relato de alguns resultados das pesquisas que elas realizaram em 1998 e em 2002. As pesquisas, feitas em UATI, contaram com a participação de 40 mulheres em 1998, e focalizou o corpo

26 A pesquisa das autoras consistia em questionários que foram respondidos por professores de ciências biológicas (que tratam do envelhecimento humano), alunos, pais e funcionários da escola com o objetivo de "identificar o significado de sua convivência com pessoas idosas e as representações sobre o sujeito idoso e o envelhecimento humano". (p.129) 
docente em 2002. As pesquisadoras investigaram quais influências afetivas e sociais do programa sobre a vida das alunas e dos docentes. ${ }^{27}$ No que se refere às alunas, um ano após seu ingresso no programa, ressaltamos os seguintes resultados:

- "o programa teve influência marcante sobre a auto-imagem das participantes $[\ldots]$ "

- "a perspectiva em relação ao curso de vida foi afetada em sua totalidade, uma vez que, na opinião dos sujeitos, melhorou o seu bem-estar subjetivo relativamente à sua capacidade de enfrentamento da morte e, também, quanto às atitudes em relação aos mais jovens"

- "a variável avaliada mais positivamente, no que diz respeito à alteração na auto-imagem como um dos benefícios percebidos de freqüentar o programa, foi a confiança na própria capacidade"

Vicente Faleiros (2007), em seu estudo, aponta que 44\% dos idosos gostariam de fazer algum curso, mas somente $2 \%$ deles estudam atualmente. É importante, para uma velhice mais saudável, que cursos para a terceira idade ou intergeracionais sejam mais difundidos e que mais cursos sejam criados (na pesquisa da FPA/SESC, 64\% dos idosos disseram não conhecer nem participar de nenhum grupo de idosos). Estudos revelam que elementos culturais podem influenciar o modo de agir e auxiliar na execução de tarefas e na construção de raciocínio (Paiva, Del-Maso, 2007). E, com o treino, a memória pode ser preservada, pois seu desempenho está relacionado a saúde física, escolaridade, relações sociais, situação socioeconômica, personalidade, nível de bem-estar emocional e autoestima (Sé, Queroz e Yassuda, 2004). O cérebro precisa de exercícios para manter sua estrutura e seu aproveitamento.

Os grupos intergeracionais, então, proporcionariam, além da "quebra de barreiras" - fazendo com que idosos e jovens pudessem rever seus preconceitos -, efeitos positivos sobre a cognição e a memória. Na USP, além da UATI, que permite

27 A pesquisa foi publicada em CACHIONI, M. (1998). Envelhecimento bem-sucedido e a participação numa universidade para a terceira idade: a experiência dos alunos da Universidade São Francisco. Dissertação de mestrado. Campinas, SP: Faculdade de Educação da Unicamp. 
aos idosos frequentarem cursos da graduação, existem ainda os cursos de extensão oferecidos pelas faculdades, que são abertos à comunidade e oferecem algumas bolsas e descontos aos alunos da terceira idade. Um desses cursos é o que nos serve de espaço de pesquisa neste trabalho: o Italiano no Campus, oferecido pela Secretaria de Cultura e Extensão da Faculdade de Filosofia, Letras e Ciências Humanas da Universidade de São Paulo.

O nosso primeiro contato com o Italiano no Campus foi da perspectiva de aluno do curso, frequentando-o durante dois semestres como forma de ter um espaço a mais para o estudo da língua italiana além daquele oferecido nas aulas da graduação; em um segundo momento, conhecemos a dinâmica de trabalho do Italiano no Campus durante o estágio de observação realizado para a disciplina da licenciatura Metodologia do Ensino de Italiano. E, em um terceiro momento, na prática como monitora nesses cursos. A partir desses contatos, pudemos notar que muitos dos grupos do Italiano no Campus (doravante IC) possuem um público significativo de estudantes aposentados, o que indica que temos ali uma grande parcela de estudantes que se encaixam na chamada terceira idade. O IC pode ser considerado um ambiente intergeracional, como discutiremos no capítulo três. E pudemos notar "informalmente" ${ }^{28}$ preconceitos em relação aos idosos oriundos de alunos e, inclusive, de alguns monitores. "Informalmente", pois quando perguntados diretamente sobre o assunto, seja pessoalmente ou em questionários, geralmente as respostas são ponderadas e dadas dentro do pensamento que podemos chamar de "politicamente correto". Diante dessa dualidade nos perguntamos se, inconscientemente, alunos e monitores tratariam o público da terceira idade de maneira diferente durante as aulas. E, muitas vezes (como veremos no segundo capítulo), os idosos acabam assumindo o estereótipo e se comportando de acordo com aquele estereótipo.

28 Utilizamos aqui o termo "informalmente" porque são observações feitas em momentos e ambientes nos quais estávamos sem a finalidade de investigarmos o assunto para nossa pesquisa e sem que os observados soubessem de nossas pesquisas. Essas observações são importantes, pois permitem vivenciar os comentários verdadeiros, sem que as pessoas se achem constrangidas a darem opiniões "politicamente corretas". 
Dentre os estereótipos estão os de que os idosos são lentos, que não lembram do que viram nas aulas anteriores e precisam que tudo seja repetido, ou mesmo que necessitam de ajuda de companheiros o tempo todo. Beauvoir (1976a) afirma que os idosos reagem mal quando os testes de inteligência aos quais são submetidos têm o tempo cronometrado. Em compensação, eles podem se equiparar ou mesmo superar pessoas mais jovens quando não há o limite de tempo. Ou ainda, em testes nos quais os idosos sabem que estão competindo com jovens, eles "fracassam" - apesar de terem sido bem-sucedidos no mesmo teste quando não sabiam que estariam "competindo" com pessoas mais jovens - por assumirem uma posição estereotipada de inferioridade em relação aos jovens. $\mathrm{O}$ nervosismo e a ansiedade provocam perdas de memória. Beauvoir mostra estudos indicativos de que a memória ligada à formação de novas associações (como aprender uma língua) é a mais alterada com a idade, mas a alteração está diretamente influenciada pelo grau de cultura dos sujeitos. E que, ao continuar a exercitar a memória e a inteligência, é possível mantê-las intactas ou mesmo encontrar mecanismos de compensação para as perdas.

Nos resultados de nossa pesquisa geral ${ }^{29}$, podemos observar que ainda é predominante nas salas de aula os alunos que escolhem o curso por sua descendência. Isso demonstra que existe uma identificação com a língua. Muitos a consideram "familiar". Quando nos aposentamos, podemos nos dedicar às atividades que gostaríamos de ter feito, mas que, por alguma razão (trabalho, família, filhos e outros) deixamos de fazer. É nessa época que a nossa representação social "dominante" - aquela que nos ligava diretamente à nossa profissão - dá espaço a uma representação do eu que pode retomar aspectos ligados às nossas origens, aspectos da vida que deixamos de lado. $\mathrm{Na}$ obra de Beauvoir (1976b:241), duas declarações recolhidas em grupos de idosos, que ela reproduz em seu texto, demonstram bem isso: "Até que enfim posso ser eu mesma! Não sou mais a esposa de fulano de tal, o empregado de sicrano de tal: eu sou eu" [...] "Posso finalmente fazer o que eu quero!". 
Neri (2007a:43-44), citando Hess ${ }^{30}$, exemplifica o que poderia auxiliar na mudança da percepção negativa da velhice:

conhecimento em relação à velhice, freqüentes exposições a interações com idosos, capacidade de colocar-se no lugar do idoso (empatia), acesso a informações que contrariam estereótipos, acesso a informações sobre as capacidades de idosos específicos (e não considerações gerais sobre a competência dos idosos), menos foco na idade e mais foco nas competências, ter idade próxima à do idoso (a presença de um profissional mais velho pode ser mais favorável ao idoso), capacidade de perceber a variabilidade existente entre os idosos e pouca ansiedade em relação ao próprio envelhecimento (os não-idosos podem ter atitudes mais negativas por causa da ansiedade em relação ao próprio envelhecimento).

O envelhecimento populacional nos traz a vantagem de possibilitar o contato entre gerações diversas, o que resulta em um compartilhamento, uma troca que enriquece todos, além de possibilitar que preconceitos e estereótipos sejam superados.

Encerramos este capítulo com uma citação de Georges Minois (1999:18) da Introdução ao seu livro História da velhice no Ocidente:

Cada sociedade tem os velhos que merece, como a história antiga e medieval amplamente demonstra. Cada tipo de organização socioeconómica e cultural é responsável pelo papel e pela imagem dos seus velhos. Cada sociedade segrega um modelo de homem ideal e é desse modelo que depende a imagem da velhice, a sua desvalorização ou valorização.

30 HESS, T. Attitudes toward aging and their effects on behavior. In BIRREN, J. E.; SCHAIE, K. Warner (eds.). (2006). Handbook of the Psycology of aging. San Diego: Academic Press. p.398-402. 
Identidade e
estereótipos 
Para darmos continuidade a nossa pesquisa, precisamos estabelecer nosso ponto de vista sobre dois conceitos fundamentais para este trabalho: identidade e estereótipo.

Devemos, para tanto, começar pelo conceito de identidade que, nesta dissertação nos servirá de duas formas: 1) para discutirmos a questão da identidade do aluno frente à língua estrangeira e como esse contato com "o estrangeiro" afeta sua relação com a língua materna, bem como de que modo a língua materna é afetada por esse contato; 2) para avaliarmos as relações entre formação dos estereótipos e de identidade. Assim, iniciaremos o segundo conceito importante deste capítulo: o de estereótipo.

Em um primeiro momento, a concepção de estereótipos nos serve de base para levantarmos, entre alunos principiantes absolutos, qual imagem eles fazem da Itália, do povo italiano e da língua italiana antes de começarem o curso. Com os resultados da pesquisa com principiantes, verificamos, fazendo uma separação por faixas etárias, se havia diferenças significativas nos estereótipos elencados em cada uma delas. Entretanto, o mais importante para nosso estudo na concepção de estereótipos é que ela nos fornece os dados e as bases teóricas necessárias para trabalhar a questão da imagem dos sujeitos estereotipados, no caso, os idosos, e como isso pode influenciar o seu desempenho na aula de língua estrangeira, nosso campo de estudos. 
Para a abordagem desses dois conceitos principais contemplaremos questões como a língua estrangeira (LE), representação, identidade e língua materna, a importância da cultura no processo de aquisição/aprendizagem da LE, os estereótipos sobre a LE, para, finalmente, abordarmos a questão dos estereótipos sobre idosos em aulas de língua e a Pedagogia da Diferença.

Para as discussões a seguir, tomamos como base textos da Psicologia Social, da Linguística Aplicada e dos Estudos Culturais.

\subsection{Identidade}

Para discutirmos a identidade, nosso ponto de partida foram os textos da área de Estudos Culturais (em especial, Stuart Hall, Kathryn Woodward, Tomaz Tadeu da Silva).

Segundo Stuart Hall (1998), são três as principais concepções de identidade:

- a do sujeito do Iluminismo: geralmente descrito como masculino. A principal característica dessa visão é a crença na existência de uma essência, de um interior, a qual se manteria inalterada. $\mathrm{O}$ indivíduo era visto como unificado, autônomo e autossuficiente;

- a do sujeito sociológico: nessa concepção ainda se acreditava em uma essência, no entanto não mais uma essência que permanecia "intacta", mas que era modificada na relação/interação com as outras pessoas, com o mundo. A identidade representa, aqui, o que Hall chama de "sutura" entre sujeito e mundo (estrutura);

- a do sujeito pós-moderno: esta é a concepção que mais nos interessa. Aqui o sujeito é visto como composto por várias identidades (sendo que elas não são fixas e muitas vezes são até contraditórias). Não se fala mais em essência. A identidade é 
uma "celebração móvel": o sujeito assume diferentes identidades em diferentes momentos e lugares.

As identidades modernas são vistas como descentradas, deslocadas, fragmentadas. O duplo deslocamento (de si mesmo e de seu lugar no mundo cultural e social) tem provocado a chamada "crise de identidade".

Woodward (2008) destaca o que chama de tensão entre as perspectivas essencialista e não essencialista. Para a primeira, a identidade é predeterminada, com uma origem. Na segunda perspectiva, a identidade é construída, portanto, mutável e moldável. A autora afirma que a identidade é relacional, construída em relação a algo externo, ao outro, ao diferente, a uma identidade que ela não é: a identidade depende de algo exterior para existir e é marcada pela diferença.

Silva (2008) argumenta que identidade e diferença são interdependentes e inseparáveis. Junto com uma afirmação sempre há uma série de negações. Por exemplo, se dissermos "Sou brasileira", estamos também dizendo "Não sou japonesa", "Não sou italiana" etc. Quando afirmamos o que somos, mostramos o que não somos e o que não podemos ser. Dessa forma, marcamos a diferença. E a diferença é sustentada pela exclusão, determinando o que "fica dentro" e o que "fica fora". ${ }^{31}$

O autor discute como a identidade e a diferença só podem ser compreendidas no âmbito dos sistemas de significação nos quais adquirem sentido. Identidade e diferença são criações sociais e culturais, estabelecidas por meio da linguagem, que é um sistema de significação (Silva, 2008). E a linguagem, como aqui entendida, é uma estrutura instável e indeterminada.

Silva (2008) e Woodward (2008) abordam o conceito de différance, de Jacques Derrida, pelo qual o significado é produzido. A relação entre significante e significado não é fixa. Derrida afirma, então, que o signo carrega

31 Esses conceitos se relacionam diretamente com a questão dos estereótipos, preconceitos e discriminação, quando tratamos de ingroup e de outgroup. Discutiremos isso mais adiante, no ponto 2.4. 
"o traço" do que é e do que não é, que só pode ser compreendido quando visto em uma sequência, uma cadeia, um contexto. O conceito de différance designa o caráter do signo de "adiamento" (da presença - pois o signo não é uma presença, mas sim um traço que ocupa o lugar de algo) e de "diferença" (relativa a outros signos).

A linguagem é o meio por excelência através do qual as coisas são "representadas" no pensamento, sendo, portanto, o meio no qual a ideologia é gerada e transformada. [...] a linguagem, por natureza, não é fixada a seus referentes em uma relação de um por um, mas é "multireferencial": pode construir diferentes significados em torno do que aparenta ser a mesma relação social ou fenômeno." (HALL, 2003a:262, grifos no original)

Se a identidade e a diferença dependem da linguagem (porque são definidas, em parte, por ela), então elas são indeterminadas e instáveis como a linguagem.

Identidade e diferença estão ligadas fortemente com as relações de poder (incluir e excluir, demarcar fronteiras, classificar, hierarquizar). A classificação é central na vida social. É a partir dela que demarcamos as fronteiras do que fica "dentro" e do que fica fora (os outros), a quais grupos nos "filiamos" e quais consideramos diferentes de nós. Para Woodward (2008), a luta para a afirmação das diferentes identidades tem causas e consequências materiais. Explicaremos a seguir.

A identidade é construída em relação ao outro, ao diferente, e a maneira mais usual de classificação (Silva, 2008) é aquela que se dá na forma de oposições binárias, nas quais um dos termos acaba sendo "favorecido", levando os outros, quando comparados a ele, a receber os valores mais negativos. Um dos termos é privilegiado. Uma identidade é, então, fixada como norma, a partir da qual as outras identidades serão comparadas e consideradas identidades "diferentes", desviantes etc. Woodward (2008) afirma que isso 
acarreta a exclusão ou marginalização das pessoas que não se encaixam na "norma" (das que são definidas como outras). É o que acontece com o idoso numa sociedade que valoriza o jovem: ele é considerado o outro que assombra a hegemonia do jovem.

Importante aqui ressaltar o que Silva (2008) afirma sobre a norma. Ao fixar uma identidade como norma, a força dessa identidade é tão ampla que parece ser invisível, pois são as outras identidades que serão marcadas. Essa norma recebe todas as características positivas e, a partir da comparação com ela, as outras só poderão ter características mais ou menos negativas.

Numa sociedade em que impera a supremacia branca, por exemplo, "ser branco" não é considerado uma identidade étnica ou racial. Num mundo governado pela hegemonia cultural estadunidense, "étnica" é a música ou a comida dos outros países. É a sexualidade homossexual que é "sexualizada", não a heterossexual. A força homogeneizadora da identidade normal é diretamente proporcional à sua invisibilidade (SILVA, 2008:83)

Para que as diferentes culturas sobrevivam, elas precisam valorizar suas tradições culturais e posições sociais, e isso pode se dar pela valorização de uma cultura em detrimento de outra. Esse processo de desvalorização do outro abre espaço para a construção de estereótipos negativos em relação a essa cultura que não é a sua.

Não podemos esquecer que as tradições culturais que nós carregamos como formadoras de nossa identidade nacional foram escolhidas por uma classe social predominante, a qual influenciou a tradição cultural que seria carregada e a que seria esquecida. É o caso, por exemplo, das colônias que sofreram um "apagamento" de suas culturas nacionais por imposição da cultura dos colonizadores. A escolha de uma língua standard é uma das formas usadas para representar uma identidade nacional (Kramsch, 1998). 
Silva (2008) afirma que a identidade é um significado atribuído social e culturalmente e que a teoria cultural contemporânea usa o conceito de "representação" para expressar essa ideia. Antes de continuarmos nossa discussão sobre identidades, vejamos o que entendemos por representação.

\section{Representação}

O conceito de representação adotado pelos Estudos Culturais não é aquele da filosofia ocidental, na qual existe uma forma adequada de representar o real e que, assim, entenderia a linguagem como representativa deste. Nessa perspectiva, a representação se apresentaria interna e externamente. Adotamos a visão pósestruturalista, que considera a linguagem como estrutura indeterminada e instável.

Na perspectiva pós-estruturalista, a representação é vista como um traço, uma marca visível, exterior, sem núcleo, sem essência, com a dimensão de significante, ou seja, que remete a um significado. A representação, então, não "reflete" o real ou o significado. E, como um sistema de significação, ela atribui sentido. Nós só podemos conhecer o real por meio da linguagem (Hall, 2003c), pois é por seu intermédio que tudo é representado no pensamento.

Importante aqui levantarmos a questão da linguagem como compreendida pelos Estudos Culturais. Na definição de Hall (1997b), a linguagem é vista como um termo geral para as práticas de representação, a linguagem constitui a realidade e não apenas a relata ou descreve. A linguagem tem, nesse sentido, o que Hall chama de "posição privilegiada na construção e circulação do significado" (Hall, 1997b:10. Grifo no original). O significado de um objeto é, portanto, socialmente construído por meio da linguagem e da representação, só adquire significado em um sistema de classificação. 
Nesse ponto, torna-se importante tratar do papel da cultura na construção da identidade. Antes, contudo, vejamos a definição que Woodward (2008:41) faz de cultura:

Cada cultura tem suas próprias e distintivas formas de classificar o mundo. É pela construção de sistemas classificatórios que a cultura nos propicia os meios pelos quais podemos dar sentido ao mundo social $e$ construir significados. Há, entre os membros de uma sociedade, um certo grau de consenso sobre como classificar as coisas a fim de manter alguma ordem social. Esses sistemas partilhados de significação são, na verdade, o que se entende por "cultura".

Hall (1997b) afirma que nossas identidades são formadas culturalmente, no interior da representação. A cultura "nos fornece" as várias identidades, dentre as quais podemos optar para assumir nossas posições-de-sujeito.

Para Hall (1997b:6), "a ênfase na linguagem e no significado, tem tido o efeito de tornar indistinta, senão de dissolver, a fronteira entre as duas esferas, do social e do psíquico". Segundo o autor, a nossa identidade emerge do diálogo entre os discursos que a cultura representa para nós e por nosso desejo de assumir posições-de-sujeito em alguns desses discursos, ou seja, de nos identificarmos.

O conceito de identificação, como explica Woodward (2008:18), aparece em Nixon ${ }^{32}$ para designar "o processo pelo qual nos identificamos com os outros, seja pela ausência de uma consciência da diferença ou da separação, seja como resultado de supostas similaridades, tem sua origem na psicanálise". Ainda segundo a autora, os Estudos Culturais retomam o conceito, com base na teoria do cinema, "para explicar a forte ativação de desejos inconscientes relativamente a pessoas ou a imagens, fazendo com que seja possível nos vermos na personagem apresentada na tela"(id. ibid., p.18).

32 NIXON, S. Exhibiting masculinity. (1997). In: HALL, Stuart (org). Representation : cultural representations and signifying practices. Londres: Sage/The Open University. 
Precisamos ter em mente, portanto, que, ao assumirmos determinadas posições-de-sujeito, há regras que devem ser "seguidas", pois se espera que cumpramos certos papéis (determinados culturalmente), que assumamos discursos. Woodward (2008:33) afirma que "todo contexto ou campo cultural tem seus controles e suas expectativas". Por exemplo, se assumimos o papel de mães, há uma série de regras e discursos que devemos "seguir" para nos encaixarmos em tal categoria. Da mesma forma que, se escolhemos ser mulheres profissionalmente bem-sucedidas, precisamos cumprir determinadas "expectativas" que definem aquele papel. Por isso, Hall (1998) afirma que na modernidade tardia as identidades, além de não serem fixas, muitas vezes são conflitantes. Segundo Woodward, há um conflito entre as exigências de uma e outra identidade (ser mãe ou ser uma mulher de negócios).

Algumas identidades prevalecem nas relações sociais porque são "visíveis". A idade, por exemplo, pode, algumas vezes, ser "disfarçada", mas dificilmente é escondida. Nesse caso, a identidade é "visível".

Silva (2008) fala da representação como um sistema de significação. Woodward (2008:17) a define como um processo cultural, que produz significados, estabelecendo identidades, pois é a partir dos significados dados pelas representações que "damos sentido à nossa experiência e àquilo que somos".

Hall (1997a) afirma que, de forma simplificada, a representação é a produção de significado por meio da linguagem.

Observemos o quadro de Magritte, La condition humaine (Figura 1): 


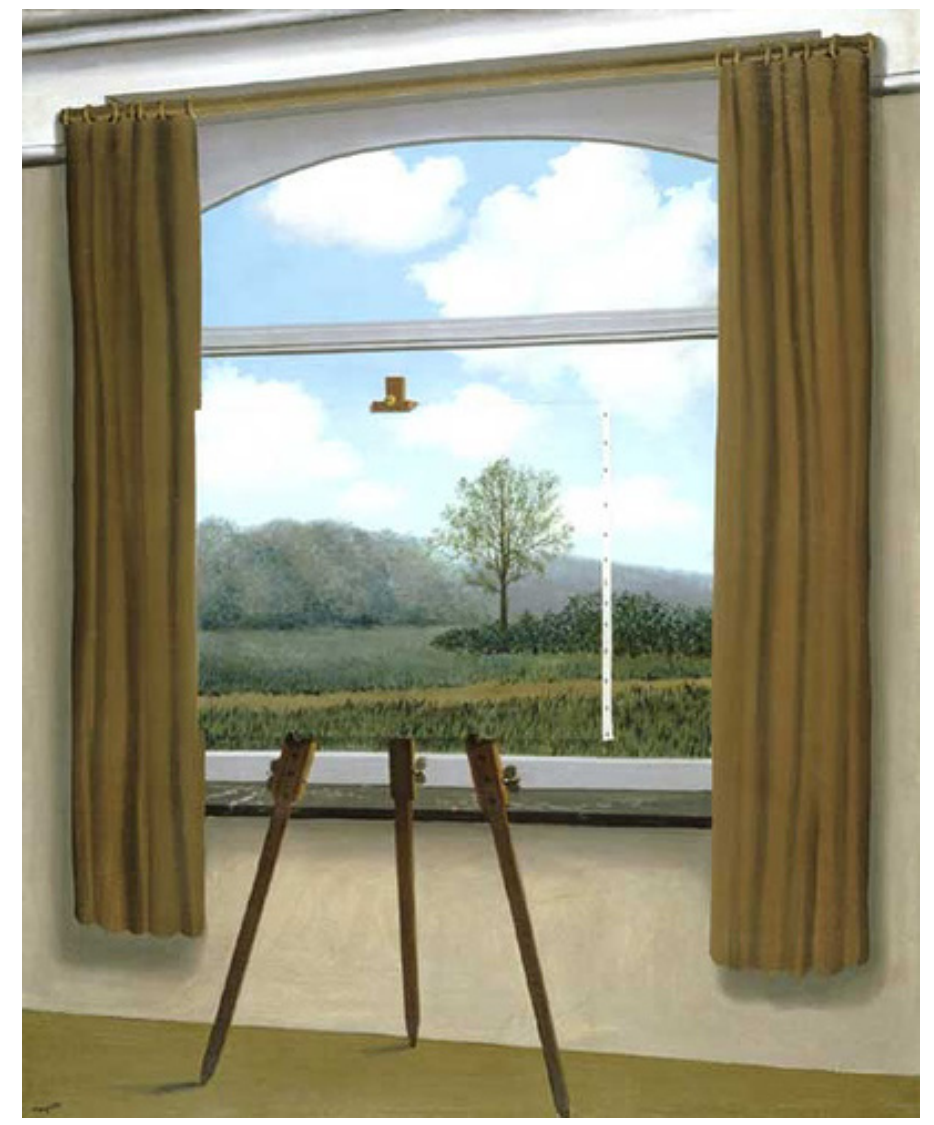

Figura 1: Magritte, La condition humaine

Seguindo o exemplo de um exercício sugerido por Hall (1997a), observemos a Figura 1. Podemos fazê-lo sob dois pontos de vista: do próprio Magritte e do "pintor" que fez o quadro diante da janela (não aparece na obra, mas está subentendido). Pensemos da seguinte forma: nós olhamos ao nosso redor e reconhecemos o que vemos porque nossos "processos mentais" decodificam nossa percepção (pessoas, objetos, coisas) em um conceito que temos daquilo que vemos, que nos diz o que é. Ao descrever o quadro a outra pessoa ("é o quadro de uma paisagem", por exemplo), o conceito do objeto passa da representação mental que fazemos dele através das palavras que usamos para designá-lo. A palavra assume o lugar ou representa, seja um objeto "real" no mundo seja um objeto imaginário. É assim que damos sentido às coisas por meio da linguagem.

Segundo Hall (1997a), nós carregamos um "mapa conceitual" na nossa mente, cada um tem o seu próprio mapa. Quando dizemos que "pertencemos a 
uma mesma cultura", estamos afirmando que, de um modo geral, compartilhamos os mesmos mapas conceituais, interpretamos o mundo de uma forma similar, permitindo que haja comunicação entre nós. No entanto, apenas o fato de partilharmos o mesmo mapa conceitual não é o suficiente para que a comunicação aconteça. Para isso, para que possamos representar e "trocar" significados e conceitos, devemos também ter acesso a uma língua que seja compartilhada, através da qual nosso mapa conceitual poderá ser "traduzido". O autor cita, como exemplo, a palavra árvore em inglês (tree). Tomaremos o seu exemplo, mas utilizando a palavra em português, ÁRVORE. Sua escolha para designar o que entendemos por árvore - uma planta - é arbitrária. Não há uma relação necessária entre o conceito e o objeto ao qual ele se refere. Uma árvore não se importaria se a chamássemos de XYZ. Da mesma forma como em italiano se usa ALBERO e em inglês se usa TREE. Isso acontece porque: "O significado não está no objeto, ou na pessoa, ou na coisa, nem está na palavra. Somos nós quem fixamos o significado tão firmemente que, após algum tempo, ele parece ser natural e inevitável. O significado é construído pelo sistema de representação". ${ }^{33}$ (Hall, 1997a: 21)

O significado é, portanto, o resultado de nossas convenções sociais, culturais e linguísticas.

Retomemos novamente a Figura 1. Esqueçamos por um momento Magritte e nos imaginemos dentro daquela cena retratada, como se estivéssemos no mesmo cômodo do quadro sobre o cavalete. Pensemos nos elementos: o todo seria o "real". A tela sobre o cavalete retrata o "real" como concebido pelo seu pintor, ou seja, como ele recortou o real e o representou. O recorte que o pintor faz do real está influenciado por suas crenças, estereótipos, por sua visão de mundo. E esse recorte é influenciado pelo recorte de mundo feito pela sociedade em que ele

33 Tradução nossa do original em inglês: "The meaning is not in the object, or person, or thing, nor is it in the word. It is we who fix the meaning so firmly that, after a while, it comes to seem natural and inevitable. The meaning is constructed by the systems of representation." 
vive e, consequentemente, pelas crenças, estereótipos e visão de mundo dessa sociedade. $^{34}$

Observemos a Figura 2:

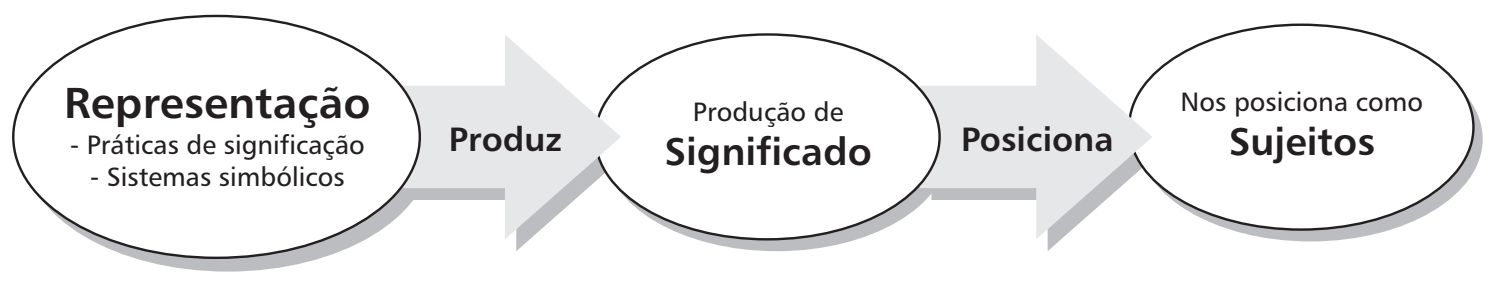

Figura 2 - Esquema da Representação

A representação, segundo Woodward (2008:17), "inclui as práticas de significação e os sistemas simbólicos, por meio dos quais os significados são produzidos, posicionando-nos como sujeito". As práticas de significação são, por exemplo, as práticas sociais que "expressam ou comunicam um significado". Hall (1997b:1) afirma que: "toda prática social tem condições culturais ou discursivas de existência. As práticas sociais, na medida em que dependam do significado para funcionarem e produzirem efeitos, se situam 'dentro do discurso', são 'discursivas'”.

A cultura pode ser entendida como um sistema simbólico, que produz sentido e discursos - que dizem, por exemplo, como devemos ocupar nossas posições-de-sujeito. Entendida como um sistema de significação, a representação produz significado, dá sentido. E é por meio desses significados produzidos que damos sentido ao que somos, à nossa experiência, e nos posicionamos como sujeitos. Por isso, a identidade e a diferença dependem e passam a existir pela representação, e é por meio dela que se ligam a sistemas de poder.

Lembrando-se do que afirmou Hall sobre as identidades serem formadas culturalmente, no interior da representação, pensemos também que a cultura "nos 
governa" (Hall, 1997b), regulando as práticas sociais. Neste ponto, colocamos três citações importantes para entender a ligação aos sistemas de poder.

Quem tem o poder de representar tem o poder de definir e determinar a identidade. (Silva 2008: 91)

Todas as práticas de significação que produzem significados envolvem relações de poder, incluindo o poder para definir quem é incluído e quem é excluído. (Woodward, 2008:18)

Se a cultura, de fato, regula nossas práticas sociais a cada passo, então, aqueles que precisam ou desejam influenciar o que ocorre no mundo ou o modo como as coisas são feitas necessitarão - a grosso modo - de alguma forma ter a "cultura" em suas mãos, para moldá-la e regulá-la de algum modo ou em certo grau. (Hall, 1997b:19)

Hall (1997b) cita três modos pelos quais há regulação (de nossas condutas) através da cultura:

- através da norma: quando agimos guiados pelas normas e conhecimentos culturais (inconscientemente) como, por exemplo, um italiano que pega um trem para ir de uma cidade a outra na Itália timbra o bilhete antes de embarcar, durante a viagem o entrega ao fiscal para que o confira, e sabe que se não estiver timbrado será multado. Hábitos como este podem parecer naturais aos italianos que os repetem frequentemente. Entretanto, para um brasileiro que vai à Itália pela primeira vez, esses atos não são parte de sua cultura e ele pode, por exemplo, não saber que deve timbrar o bilhete antes de entrar no trem. Podemos imaginar uma situação cultural parecida quando um brasileiro, morador de uma cidade pequena, vai a São Paulo pela primeira vez e precisa pegar o metrô.

- através de sistemas classificatórios: por meio de sistemas que delimitam as culturas (o que é aceitável e o que não é, o que é "normal" e o que é "anormal" etc.), nós classificamos tudo, os objetos e as pessoas, mudando nosso modo de agir com aqueles 
que não consideramos "normais". Pode-se tomar como exemplo de sistemas classificatórios culturais a comida. Os alimentos aceitáveis, adequados, valorizados, como também o seu modo de preparo (cru, cozido) e as condições de apreciação são estabelecidos culturalmente. Um brasileiro, por exemplo, poderia achar estranho comer caramujos de jardim; enquanto que para um italiano da região do Vêneto essas "especiarias" culinárias não têm nada de "anormal". Um estrangeiro pode achar estranho comer nossa famosa combinação de queijo com goiabada, o "Romeu e Julieta" ou uma buchada de bode.

- através do tipo de sujeito que nós somos: isso se dá mudando a cultura da organização, levando, por exemplo, funcionários a atingirem as novas expectativas de uma empresa através de uma autorregulação, fazendo com que se produzam novas subjetividades que atendam às novas especificações da organização (o sujeito faz isso a si mesmo para não perder o emprego, por exemplo, se adequando aos requisitos da empresa).

A mídia é, hoje, grande determinante cultural. Um exemplo de suas determinações está nos padrões de beleza que são valorizados. Por que a imagem do velho é tão discriminada? Porque o padrão de beleza em voga atualmente - a norma - é o do jovem, da pele jovem, do corpo jovem, do modo de se vestir dos jovens. O idoso, então, nessa sociedade, só é considerado se adota uma postura "jovem". Como dissemos no capítulo anterior, a indústria de cosméticos cresce a cada ano em função da busca por produtos que "retardem o envelhecimento". Aqui se pode ver uma das faces do poder de regular culturalmente uma sociedade. O idoso é excluído por não fazer parte da "norma" adotada por uma cultura (que desvaloriza o velho).

Se pensarmos a terceira idade como um "lugar" que as pessoas ocupam, uma posição-de-sujeito, devemos também pensar que há uma série de "regras" 
estabelecidas e um discurso que elas devem "incorporar", determinados culturalmente, para se encaixarem naquela "identidade".

Segundo Silva (2008:92), o conceito de performatividade coloca o foco na identidade como "tornar-se" e não como "aquilo que é". Justamente o que nos interessa no processo é a questão de as identidades não poderem ser fixáveis e de as vermos como "movimento e transformação". Segundo o autor, o conceito de performatividade foi inicialmente tratado em Austin ${ }^{35}$ para discutir as categorias de proposições que a linguagem tem. Uma delas seria o que Austin chama de proposição "descritiva" ou "constatativa", que, como os nomes revelam, simplesmente constatam ou descrevem uma ação, situação ou estado. Por exemplo: "A porta está aberta". Um segundo tipo de proposição, chamada "performativa", faz com que algo se realize, aconteça. Um exemplo desse tipo de proposição seria: "Eu vos declaro marido e mulher".

Adota-se, então, nos Estudos Culturais, a questão da performatividade como vem tratada por Judith Butler ${ }^{36}$. Segundo Silva (2008), para a autora, a identidade é uma questão de performatividade, pois "muitas sentenças descritivas acabam funcionando como performativas". Na proporção em que uma sentença descritiva é repetida, pode acabar "produzindo um 'fato'".

Em geral, ao dizer algo sobre certas características identitárias de um grupo cultural, achamos que estamos simplesmente descrevendo uma situação existente, um "fato" do mundo social. O que esquecemos é que aquilo que dizemos faz parte de uma rede mais ampla de atos linguísticos que, em seu conjunto, contribui para definir ou reforçar a identidade que supostamente estamos apenas descrevendo. (Silva, 2008:93)

35 AUSTIN, J. L. (1998). Como hacer cosas con palabras. Barcelona: Paidós.

36 BUTLER, J. (1999). Corpos que pesam: sobre os limites discursivos do "'sexo". In: LOPES LOURO, G. (org.). O corpo educado. Pedagogias da sexualidade. Belo Horizonte: Autêntica. p. 151-172. 
Discutiremos isso mais adiante, quando falaremos de estereótipos e, mais especificamente, dos estereótipos sobre a terceira idade. Com a repetição de uma sentença, uma pessoa pode acabar assumindo o discurso e ocupando aquela posição. Um exemplo disso é quando se diz que os idosos são mais lentos nas aulas de línguas; o idoso pode acabar assumindo esse discurso, essa posição, e agindo de acordo com o que "se espera" dele naquele "lugar". Os estudos sobre os estereótipos, que discutiremos mais adiante, mostram como isso se dá.

Outro elemento importante da performatividade na produção da identidade é a repetibilidade. Para um enunciado performativo ser "eficaz", ele deve ser repetido e deve poder ser repetido. Nesse ponto, Silva (2008) ressalta a noção de Derrida $^{37}$ de citacionalidade, isto é, a repetibilidade da escrita e da linguagem, baseada na ideia de que uma "característica essencial do signo é que ele seja repetível". Em um processo de "recorte e colagem": retiramos o signo de um contexto social mais amplo para o inserirmos em outro contexto no qual, aparentemente, é somente uma opinião particular.

A força da performatividade no processo de produção da identidade vem da repetibilidade. Uma única sentença não tem efeito. É a repetibilidade que faz ser "verdade". É nosso discurso retirado de outro discurso e assim por diante.

Silva (2008) ainda afirma que para Judith Butler, a repetibilidade não só permite reforçar identidades já existentes como também possibilita a interrupção das "identidades hegemônicas". Podemos relacionar essa interrupção nas identidades hegemônicas com a possibilidade de quebrar estereótipos e, consequentemente, preconceitos e discriminação.

Retomaremos essas questões em 2.5. e também no capítulo três, quando abordaremos o que Silva chama de "Pedagogia da Diferença", conceito que utilizaremos na discussão sobre os grupos intergeracionais no ensino de língua estrangeira. Silva define, portanto, a identidade da seguinte forma: 
Primeiramente, a identidade não é uma essência; não é um dado ou um fato - seja da natureza, seja da cultura. A identidade não é fixa, estável, coerente, unificada, permanente. A identidade tampouco é homogênea, definitiva, acabada, idêntica, transcendental. Por outro lado, podemos dizer que a identidade é uma construção, um efeito, um processo de produção, uma relação, um ato performativo. A identidade é instável, contraditória, fragmentada, inconsistente, inacabada. A identidade está ligada a estruturas discursivas e narrativas. A identidade está ligada a sistemas de representação. A identidade tem estreitas conexões com relações de poder. (Silva, 2008, p. 96-97)

\subsection{Identidade e língua}

A identidade de um indivíduo se constrói na língua e através dela. (Rajagopalan, 1998:41)

Se somos construídos na língua e através dela, a nossa língua materna (LM), o que acontece com nossa constituição na LM quando aprendemos uma língua estrangeira?

\subsubsection{A língua materna}

Primeiramente somos constituídos como sujeitos por meio da linguagem, somos nomeados, somos "falados". Não podemos ficar indiferentes às nomeações que as pessoas ao nosso redor dão ao mundo, principalmente aquelas advindas da figura materna. Segundo Revuz (1998), a audição é o sentido mais desenvolvido do feto. Carla Tavares (2004) diz que não aprendemos uma linguagem, somos constituídos, como sujeitos, por linguagem. Só depois de "sermos falados" é que passamos a ocupar nossos lugares de fala dentro do discurso. E nossa fala é mediada pela relação afetiva com o nosso interlocutor, o outro. Se a mãe reprova algo que a criança diz (alguma denominação que não é adequada), a mãe está criando sentidos, e a carga afetiva dessa relação é que marca a relação entre sujeito e língua materna. São esses sentidos da língua materna que constituem o sujeito. 
A linguagem estrutura o pensamento, ou seja, ela o precede. E a língua é o "veículo" pelo qual a linguagem se materializa (Tavares, op.cit.). É na língua que a fala torna o sujeito singular. Eni Orlandi (1998) afirma que, apesar de falarmos uma mesma língua, nenhum sujeito a fala da mesma forma que outro, e é isso que garante a nossa singularidade. Para Rajagopalan (1998:41): "A identidade de um indivíduo se constrói na língua e através dela. Isso significa que o indivíduo não tem uma identidade fixa anterior e fora da língua".

A língua e o discurso são construções sociais. E o uso da língua é, segundo Kramsch (1998), um ato cultural, a chave para entender o sentido das práticas culturais. A autora diz que os falantes de uma língua a veem como um símbolo de sua identidade social, pois ela expressa a realidade cultural. Essa identidade depende, segundo Moita Lopes (1998), de dois conceitos fundamentais: alteridade, porque o eu sempre enuncia para um outro; e contexto, porque nossa fala sempre é posicionada dentro de um contexto que é projetado na interação para mostrar como pretendemos construir os significados. E essa fala é "recortada" e entendida segundo o recorte desse outro (influenciado por seus estereótipos, suas crenças etc.).

Moita Lopes (op. cit.), Orlandi (op. cit.) e Angela Kleiman (1998) enfatizam o fator interatividade na construção da identidade. A nossa identidade é construída na nossa interação com o outro. Como já dissemos, não temos somente uma identidade, mas múltiplas, várias posições-de-sujeito que ocupamos de acordo com a situação social na qual estamos e também influenciados pelas relações de poder que estão envolvidas.

A sala de aula é um lugar de interação social onde o professor ocupa um lugar central por duas razões: a primeira é pelo fato de ser ele quem assume uma posição de líder na sala de aula, "mediando", de certa forma, as diferenças; em segundo lugar, pelo seu papel de autoridade no que se refere à construção de significados. Embora os autores (Moita Lopes, Kleiman e Orlandi) tratem de professores de português brasileiro em outros contextos educacionais, mais à 
frente demonstraremos como isso pode ser aplicado ao contexto educacional que tomamos como base deste estudo, o Italiano no Campus.

\subsubsection{A língua estrangeira}

Qual é, então, o papel da língua estrangeira nessa identidade do sujeitoaprendiz, constituído pela e na língua materna?

Christine Revuz (1998) afirma que aprender outra língua "vem perturbar, questionar, modificar aquilo que está inscrito em nós com as palavras dessa primeira língua". A mesma autora diz que só podemos aprender outra língua porque já tivemos acesso à linguagem através da língua materna.

A língua estrangeira não recorta o real como o faz a língua materna. Essa constatação que se impõe desde os primeiros momentos de aprendizagem provoca com freqüência surpresa e escândalo. [...] O que se estilhaça ao contato com a língua estrangeira é a ilusão de que existe um ponto de vista único sobre as coisas, é a ilusão de uma possível tradução termo a termo, de uma adequação da palavra à coisa. (Revuz, 1998:223).

Tendo outro recorte do real e tendo já uma língua materna, essa língua estrangeira aparece com "unidades de significação" sem sua carga afetiva (Revuz, op. cit.). Podemos "sentir" isso quando queremos, por exemplo, xingar alguém. Uma palavra obscena ou pejorativa na língua estrangeira não é sentida da mesma forma que na língua materna. Aprendemos na aula de língua que algumas palavras e expressões são grosseiras, pejorativas, obscenas, ofensivas etc. Mas não as "sentimos" da mesma forma como fazemos na LM. Em um momento de irritação ou raiva, é a emoção contida na palavra da língua materna que expressa esses sentimentos. Xingar, ofender na língua estrangeira parece não trazer o mesmo "efeito". 
A língua estrangeira nos causa estranhamento por nos apresentar outro recorte do real, nos tirando a ilusão de que existe um ponto de vista único (o da nossa cultura). Revuz (op. cit.) afirma que "a arbitrariedade do signo linguístico torna-se uma realidade tangível", pois possibilita novas significações, deslocando aquilo que tínhamos a sensação de ser "fixo" pela nossa língua materna.

Ainda segundo a mesma autora, esse estranhamento pode ser vivido de três formas diferentes pelos aprendizes de uma LE: como perda, como uma renovação/revitalização da língua materna ou como um espaço de liberdade. O eu da língua materna nunca é o mesmo eu da língua estrangeira. Alguns veem a LE como uma perda de identidade (fundada na LM) e a evitam, pois ela representaria um distanciamento da LM. Outros veem a LE como um espaço de liberdade no qual podem ser o que não são na LM. E outros ainda ficam divididos.

Revuz afirma que há dois momentos, logo no início do processo de aquisição/aprendizagem da LE, nos quais esse estranhamento fica nítido - porque influenciados inconscientemente pela LM -, os dois momentos colocam o sujeitoaprendiz diante de diferenças: a diferença fonética e a diferença de significação.

Quanto ao primeiro momento, o da diferença fonética, devemos pensar que nosso aparelho fonador está habituado a produzir os sons da língua materna. Quando nos deparamos com novos sons, precisamos aprender a recortar aquela "chuva de sons" aparentemente sem sentido. Mesmo na nossa própria LM, às vezes, fazemos o recorte de forma equivocada. Por exemplo, podemos entender a seguinte sequência: "ver a cidade" da forma como foi aqui registrada graficamente, ou como "veracidade", se mudarmos o recorte da palavra. Vejamos uma brincadeira de mudança de recorte fonético feita com uma frase italiana: "Mi capisci quando parlo?" (Você me compreende quando eu falo?). Ela pode ser recortada da seguinte forma: "Mica pisci quando parlo?" (Você não urina quando eu falo?). Um exemplo de diferença fonética entre português e italiano está nas chamadas consoantes duplas, que, em muitos casos, levam também a diferentes significados, podendo sofrer alterações "inocentes", por exemplo, capello (cabelo) e cappello (chapéu); e alguns até constrangedores: o plural de penna (caneta) é penne, 
enquanto a palavra grafada sem um $n$ - pene - indica o órgão sexual masculino. Se o aluno não consegue reproduzir o som das duplas consoantes pode acabar sendo mal-entendido.

O segundo momento nos coloca diante da diferença na maneira de construir novas significações. São os casos em que percebemos que o recorte de mundo daquele que fala a língua estrangeira é outro. Digamos que os alunos precisem colocar o artigo na frente do substantivo "flor", em italiano fiore. Em geral, eles não hesitam ao optar pelo artigo feminino. Quando o professor diz que "flor" em italiano é um substantivo masculino e que, portanto, é preciso usar um artigo masculino, há diversas reações dentre os alunos, geralmente antecedidas de espanto: alguns chegam a dizer que é "um absurdo", outros até mesmo duvidam que o professor esteja dizendo "a verdade". Nesse caso, eles tentaram transpor as categorias da língua materna, no caso a do gênero. Os professores, no momento em que dizem "como é" na LE - sejam as regras gramaticais, os hábitos culturais etc. - estão criando significados. Um exemplo de produção de significados ocorre quando, por exemplo, dizemos em que momento e sob quais circunstâncias uma palavra é usada na LE e quais são os seus sentidos.

Não podemos ignorar que os signos carregam um valor cultural e que nem sempre existirão tais valores em outras culturas. Como explicar para um italiano o que é "favela", por exemplo? Como encontrar um correspondente na língua italiana? O termo aparece como um empréstimo do português brasileiro (estrangeirismo) nos dicionários italianos, um deles traz a seguinte acepção: "bairro de barracos construídos nas periferias de grandes cidades brasileiras" 38 . Não podemos esquecer fatores culturais que vão além do que podemos designar com palavras. Algumas vezes, por exemplo, italianos que moram no Brasil afirmam achar estranho o nosso hábito de colocar "a comida toda junta em um mesmo prato".

38 Definição traduzida por nós, retirada do dicionário on-line <www.demauroparavia.it>: fa|ve|la: s.f. : ES portogh. quartiere di baracche costruite alla periferia delle grandi città brasiliane. 
Segundo Revuz (1998), “aprender uma língua é sempre, um pouco, tornar-se outro". Com a língua estrangeira, não há mais a fala dos outros, o sujeito é levado a uma nova identidade, na qual ele deve dar sentido às suas expressões. Carla Tavares (2004) diz que a LE serve como um espaço no qual se pode enunciar o que lhe é interditado na LM. ${ }^{39}$

Agnese Ferrara (2007) apresenta os resultados de uma pesquisa com alunos bilíngues, a partir da qual se constatou que esses alunos tendem a se comportar de maneiras diferentes dependendo da língua que estão falando. É como se eles incorporassem os costumes e hábitos da outra comunidade e se portassem como cidadãos nativos dela. Revuz (1998) discute que alguns aprendizes, quando se encontram em contextos da LE (a sala de aula, por exemplo), chegam até mesmo a parecer outra pessoa com relação à que aparentam ser quando em uso da LM. A autora cita o exemplo de pessoas que têm problemas de relacionamento, mas que no contexto de LE conseguem sustentar um relacionamento com sucesso e sem problemas. Pessoas tímidas podem ser falantes na LE. Alguns alunos mudam o tom de voz quando falam em italiano, por exemplo, como se fossem outras pessoas (essa mudança também pode ocorrer para poder acompanhar a fonética da LE).

Dentro de nossa língua materna nos portamos de maneiras diferentes, assumindo diferentes posições-de-sujeito, como afirma Hall (2008), dependendo do contexto social no qual nos encontramos. Comportamos-nos de modo diferente, por exemplo, diante de nosso chefe e em meio a um grupo de amigos. As mudanças não são apenas de postura ou de comportamento, mas, também, linguísticas: escolhem-se registros diferentes para falar em contextos diferentes.

Os alunos de uma língua estrangeira são colocados diante de novas possibilidades de posicionamento. Eles, então, se dividem entre o retorno (constante e ilusório) à segurança que lhes dá a LM e a busca da "liberdade" da LE.

39 Segundo Tavares (2004), o termo interditar, usado aqui com bases psicanalíticas, refere-se ao desejo que a criança sente em relação à mãe e que é "interditado" pela presença do pai, que impede aquele desejo de se realizar. A língua estrangeira, então, serviria de um espaço onde se pode enunciar aquilo que foi "interditado" na língua materna. 
Kramsch (1998) alega que:

Nossa percepção da identidade social de alguém é culturalmente determinada. O que percebemos da cultura e da língua de uma pessoa éo que fomos condicionados a ver pela nossa própria cultura e pelos modelos estereotipados já construídos ao nosso redor. (Kramsch, 1998:67) ${ }^{40}$

Essa é, a nosso ver, uma das razões pelas quais, nas aulas de língua estrangeira, é importante saber quais são os estereótipos carregados pelos estudantes sobre a cultura da LE, pois aprender uma língua vai além de aprender um outro código, com outras regras gramaticais. E, quando optamos por frequentar um curso de LE, possuímos muitos dos estereótipos que nos foram passados dentro de nossa cultura, de nossa sociedade.

Se na LE os estudantes assumem outra identidade, outra posição-desujeito, a forma como eles construíram a imagem desse outro, estrangeiro, influenciará o seu comportamento (como vimos em Ferrara), pois se fundamentarão na imagem que possuem dos nativos e da cultura dessa língua estrangeira. Se os estereótipos forem errôneos, eles podem, dentre outras situações, causar mal-entendidos quando os detentores desses estereótipos (que podem ser nossos alunos) forem ao país no qual a LE é falada como LM.

Acreditamos que o êxito na aquisição/aprendizagem (a/a) de uma LE dependa da sua aceitação como "estrangeira" e da constituição de uma representação de um eu nessa LE, uma posição-de-sujeito que assume um discurso na língua estrangeira, uma identidade como falante dessa LE. É o ato de "assumir uma outra identidade", permitindo que aquela da LM seja "mantida", que permitirá ao aluno experimentar a LE com êxito, pois ele não verá sua LM (e sua constituição como sujeito dessa língua) "ameaçada" por essa nova língua. Poderíamos talvez considerar que, pela proximidade linguística entre português e

40 Traduzido por nós do original em inglês: "Our perception of someone's social identity is very much culturally determined. What we perceive about a person's culture and language is what we have been conditioned by our own culture to see, and the stereotypical models already built around our group." 
italiano, e por causa da carga afetiva que o italiano carrega para alguns (pelo sentimento de familiarização com o italiano devido à descendência), os aprendizes podem (inconscientemente) acreditar que poderão se manter sempre próximos a esse eu da LM, nas suas identidades construídas na LM, vendo a LE de uma distância "segura", o que não permitiria a constituição da representação de um eu na LE, de uma identidade na LE.

\subsection{Estereótipos}

Antes de começarmos nossa explanação sobre o conceito de estereótipos, precisamos esclarecer que os Estudos Culturais não os abordam diretamente. Para tal discussão, nós recorremos à Psicologia Social.

Vale ressaltar que adotamos o conceito de identidade dos Estudos Culturais, que vê o sujeito pós-moderno como possuidor de identidades, assumindo diferentes posições-de-sujeito dependendo do contexto em que os sujeitos se encontram. Não vemos a linguagem como apenas reprodutora de uma visão de mundo, como adotado por alguns estudos da Psicologia Social, mas principalmente como produtora de uma visão de mundo.

Nosso intuito, ao utilizar a Psicologia Social, é o de abordar os estereótipos, o preconceito e a discriminação, três conceitos diretamente interligados. Entendemos que a discussão central dos Estudos Culturais hoje seja o conceito de identidade e de subjetividade, e que o enfoque dado às ditas "minorias" por esses estudos tenha uma visão política, com o objetivo de encontrar modos de mudar questões como a exclusão (social, racial etc.). Os Estudos Culturais buscam a mudança estudando o modo como a exclusão é produzida, como é construída e estudando as identidades na sociedade contemporânea, procurando, por exemplo, subverter os processos discriminatórios. O intuito dos Estudos Culturais é o de trazer contribuições sociais ao investigar as causas de tais discriminações. 
Todd D. Nelson (2009), em prefácio ao livro organizado por ele, chamado Handbook of prejudice, stereotyping and discrimination, fala sobre essa área da Psicologia Social, da pesquisa sobre o preconceito, menciona que sempre teve prioridade entre os psicólogos sociais - em estudos sobre como "nasce" o preconceito, como ele se mantém e como é difícil de eliminá-lo. Mas afirma se surpreender com o fato de que não existia ainda um "manual" sobre o assunto (como existe para tantos outros assuntos tratados pela área).

Por que é importante voltar nossa atenção para estereótipos e preconceitos?

A discriminação é uma consequência de estereótipos e preconceitos. Charles Stangor (2009) diz que a discriminação tem efeitos negativos tanto na saúde física quanto mental daqueles que a vivenciam. Pessoas que experimentam com frequência o preconceito e a discriminação ou outras formas injustas de tratamento relatam maior aflição psicológica, depressão e baixos níveis de satisfação com a vida e a felicidade.

Antes de continuarmos a discutir os efeitos da estereotipização, vejamos o que são os estereótipos.

A palavra estereótipo tem origem etimológica no grego. Segundo Marcos Emanuel Pereira (2002), a palavra estereótipo vem de stereos (rígido) e túpus (traço). Cachioni (2003) usa as seguintes definições para a origem da palavra: stereós (sólido, firme) e typos (modelo, símbolo, exemplar). Segundo Pereira, no plano histórico são dois os seus usos. Na Psiquiatria, no século XIX, a palavra estereotipia era usada para indicar uma repetição mecânica e frequente de gestos, falas e postura em pacientes que sofriam de dementia praecox. No jargão tipográfico, a palavra designa o molde metálico utilizado para produzir a mesma impressão 
milhares de vezes. Stangor (2009) afirma que em Psicologia Social geralmente se concorda em definir estereótipos como:

[...] os traços que vemos como características de grupos sociais, ou de membros individuais desses grupos, e particularmente aqueles que diferenciam os grupos uns dos outros. Em resumo, são os traços que vem à mente rapidamente quando pensamos nos grupos. (Stangor, 2009:2) ${ }^{41}$

Amy Cuddy e Susan Fiske (2004:4) definem os estereótipos como “(...) estruturas cognitivas que armazenam nossas crenças e expectativas sobre as características de membros de grupos sociais". ${ }^{42}$

As autoras afirmam que, para o funcionamento cognitivo humano, a categorização é necessária. Com a complexidade e quantidade de informações que recebemos, temos que selecionar aquelas que serão armazenadas. Distinguir cada pessoa como única requer tempo e esforço, por isso selecionamos as características mais salientes e criamos categorias nas quais "encaixamos" as pessoas. Os estereótipos são essas categorizações feitas com bases em dados superficiais, no sentido em que tendemos a estereotipar o que não conhecemos bem. São construções sociais desenvolvidas como qualquer outra representação cognitiva. Embora existam estereótipos positivos, a maioria deles é negativa. Nossa tendência é a de valorizar e favorecer o ingroup (o "nosso grupo", o grupo com o qual nos identificamos e ao qual pertencemos) e ver o outgroup (os outros grupos) como uma ameaça por ser diferente do ingroup. Há então uma supervalorização do ingroup e uma depreciação do outgroup (Stephan, Ybarra e Morrison, 2009).

Cudy e Fiske (2004), Sheri Levy e Julie Hughes (2009) adotam o modelo tripartite de atitudes ${ }^{43}$, no qual três mecanismos são os constituintes das atitudes

41 Traduzido por nós do original em inglês: "(...) stereotypes represent the traits that we view as characteristic of social groups, or of individual members of those groups, and particularly those that differentiate groups from each other. In short, they are the traits that come to mind quickly when we think about the groups."

42 Traduzido por nós do original em inglês: "(...) cognitive structures that store our beliefs and expectations about the characteristics of members of social groups (...)".

43 Assim como Cachioni (2003), adotamos a palavra "atitude" para nos referir ao termo em inglês: "attitude", no sentido de opinião sobre alguém ou alguma coisa, bem como o modo de se comportar com base nessa opinião. (Cambridge International Dictionary of English, 1995). 
intergrupais: afeto, comportamento e cognição. Essas atitudes, baseadas em categorias, são representadas como:

- Preconceito: componente afetivo, constituído por sentimentos negativos em relação a um grupo e seus membros, podendo exibir tratamento hostil;

- Discriminação: componente comportamental do preconceito, que leva a tratar com parcialidade pessoas e/ou grupos, com base no seu ingroup;

- Estereotipização: componente cognitivo das atitudes intergrupais, trata da associação de atributos a um grupo e seus membros.

Cuddy e Fiske relatam três consequências da categorização: 1) passamos a perceber as pessoas de um mesmo grupo como semelhantes; 2) temos uma ideia do outgroup como sendo mais homogêneo do que o ingroup; 3) há favorecimento do ingroup, que recebe atributos mais positivos e relevantes do que o outgroup.

No campo dos Estudos Culturais, Woodward (2008) trata dos sistemas classificatórios que têm como "componente-chave" a marcação da diferença, a exclusão ou marginalização das pessoas que são definidas como "outras". Segundo a autora, a marcação da diferença pode ocorrer por meio dos sistemas simbólicos de representação ou por meio da exclusão social.

Para Pereira (2002) e Becca Levy e Mahzarin R. Banaji (2004), os estereótipos teriam a função de manter as tradições culturais e as posições sociais, protegendo e enaltecendo o ingroup ou alguém. Como podemos ver a partir de Stangor (2009), Cuddy e Fiske (2004), a importância de se estudar os estereótipos está no fato de eles fazerem parte do nosso dia a dia, influenciando nosso julgamento e comportamento em relação aos outros. Precisos ou não, eles guiam nosso comportamento social, "administrando" quais informações procuramos, a quais prestamos atenção e de quais nos lembramos. Levy e Mahzarin dizem que usamos só um quarto de segundo, quando nos deparamos com uma pessoa ou um objeto novo, para classificar globalmente esse "desconhecido" entre bom ou 
ruim. E, segundo Patricia Devine (1989), o argumento da perspectiva da Inevitabilidade do Preconceito está no fato de que, enquanto existirem estereótipos, existirá preconceito.

Cuddy e Fiske (2004) elencam cinco motivos que ajudariam a explicar o processo de estereotipização:

1. Pertencimento: justificaria a necessidade das pessoas de pertencerem a um grupo;

2. Compreensão/entendimento: é um dos dois motivos cognitivos, serviria para manter e partilhar o conhecimento social;

3. Controle: é o segundo motivo cognitivo, teria como objetivo ter controle sobre interações socialmente afetivas;

4. Realçamento: um dos dois motivos afetivos; seria usado para enaltecer o eu;

5. Confiança: segundo motivo afetivo; possibilitaria a confiança entre os membros do ingroup.

Stangor (2009) e Joann Montepare e Leslie Zebrowitz (2004) afirmam que, uma vez adquirido o estereótipo, basta a presença de um membro do grupo estereotipado para sua ativação. Essa ativação do estereótipo geralmente se dá de forma automática e inconsciente.

A ativação automática dos estereótipos pode ser controlada desde que o sujeito que possui o estereótipo queira mudá-lo. Discordando daquele estereótipo implícito (adquirido do recorte do real de sua sociedade e cultura), o sujeito passará a tentar controlar as suas reações e a ativação e manifestação desses estereótipos (Devine, 1989). 


\subsubsection{Os estereótipos nas aulas de língua italiana}

Comecemos com três anedotas sobre os italianos:

\section{Paraíso e Inferno}

O Paraíso é o lugar onde o inglês é o policial, o alemão é o mecânico, o francês é o cozinheiro, o italiano é o amante e o suíço administra tudo. No Inferno, por sua vez, os ingleses são os cozinheiros, os alemães são os policiais, os franceses são os mecânicos, os suíços são os amantes e os italianos... administram!

\section{Nas cascatas}

Dez italianos visitam as Cascatas do Niágara. Em um determinado momento o guia diz: "E agora, se vocês fizerem um pouco de silêncio, até poderão ouvir o barulho".

\section{Como cansa trabalhar!}

Este é o diálogo entre Kurt, alemão, e Mario, italiano.

"Oi, Mario, como você está?"

"Mal, Kurt. Muito mal."

"Por quê? Problemas com sua namorada?"

"Não. Estou com problemas no trabalho. Todas as manhãs devo me levantar às cinco horas, pegar o ônibus, chegar no escritório, atender o telefone e escrever no computador oito horas por dia."

"E há quanto tempo leva essa vida?"

"Desde segunda-feira que vem."

Poderíamos dizer que essas anedotas foram escritas por brasileiros ou alguma outra nacionalidade que não a italiana, mas, nesse caso, elas foram retiradas $^{44}$ de um livro didático de italiano para estrangeiros ${ }^{45}$, como unidade didática destinada a estudantes de nível 1.

Quando decidimos fazer um curso de língua estrangeira, chegamos com ideias preconcebidas de como ele será. Não só em sua questão estrutural, se 
aprender a língua será fácil ou difícil, como também carregamos as expectativas em relação aos conteúdos culturais que nos serão apresentados: já temos uma ideia preconcebida do falante nativo daquela língua e de suas tradições culturais, hábitos etc. Os estereótipos são passados de geração para geração, são culturais. Com o tempo e com a tomada de consciência, decidimos quais estereótipos mantemos e quais vamos descartar. (No Brasil, por exemplo, são comuns piadas maldosas com nosso colonizadores portugueses, tratando-os como limitados intelectualmente, ou com nossos vizinhos argentinos. E muitas vezes nem mesmo sabemos o porquê de as fazermos. Todos os povos escolhem vítimas para as suas piadas. Na Itália, os carabinieri seriam os intelectualmente limitados, os genoveses são considerados pão-duros.)

Precisamos ter em mente, como professores de língua estrangeira, que os estereótipos podem tanto dificultar quanto auxiliar o processo de aquisição/aprendizagem da LE, dependendo de seu tipo (se positivo ou negativo) e de como ele é trabalhado.

Um estereótipo positivo que é reforçado pode favorecer a imagem do povo italiano, fazendo com que os alunos sintam uma afetividade maior em relação à Itália, aos italianos e, consequentemente, auxiliando o processo de a/a da língua. Por exemplo: "os italianos são receptivos" e o material fornecido em sala de aula leva o aluno a enfatizar essa imagem.

Se um estereótipo positivo é quebrado pode modificar a imagem que os alunos tinham, destruir o estereótipo que carregavam. Por exemplo, se o aluno tem a imagem de que a Itália é um país sem problemas sociais, econômicos e políticos e é informado, por exemplo, da questão do lixo nas ruas de Nápoles, muito comentado em 2007/8 - consequência de atos mafiosos infiltrados na política, envolvendo desvio de dinheiro - ou mesmo que alguns aposentados não recebem o suficiente para comer.

Por um lado, a quebra de um estereótipo pode ser ruim, pois o aluno pode diminuir sua afetividade e expectativas positivas em relação à Itália e aos italianos, 
influenciando o processo de a/a da língua negativamente. Por outro lado, isso possibilita uma visão mais realista do contexto cultural no qual a língua italiana é falada como materna, permitindo que o aluno comece a ver a Itália e sua população de outra perspectiva, ajudando na construção do contexto da língua estrangeira.

Um estereótipo negativo, quando quebrado, pode possibilitar uma aproximação maior do aluno com a língua e a cultura do país, permitindo uma inserção maior na cultura do lugar e, consequentemente, auxiliando o processo de a/a da LE. Por exemplo, se o aluno acredita que todos os italianos são "gordos" porque comem demais, quando informados de que há em grande parte da Itália uma tradição pela boa comida e que foi lá que surgiu o movimento contra as comidas de fast food, o movimento chamado Slow Food

Um estereótipo negativo, se reforçado, pode criar uma barreira ou aumentar um "pré-conceito" em relação ao povo italiano, generalizando ainda mais a informação, e impedindo que o aluno se sinta à vontade para criar uma "representação do eu", que falará nessa língua estrangeira, pois não se identificará com a língua nem com a cultura italianas. Um exemplo de estereótipo negativo que pode ser reforçado é: se os alunos acreditam que a Itália é uma nação machista e são informados de que mulheres italianas têm escondido a gravidez - ou mesmo a evitado - para não serem demitidas do trabalho. ${ }^{46}$

Quando falamos em ensino de LE, sabemos que o professor de idiomas se encontra (inicialmente) diante de dois desafios fundamentais para o sucesso ou o insucesso do curso. O primeiro deles é o de tentar "recriar" ${ }^{47}$ uma outra cultura,

46 Silvia Ferreri, diretora de cinema e escritora, recolheu depoimentos de mulheres para um documentário que, posteriormente, transformou em livro. Ambos se chamam Uno virgola due. Relata histórias de mulheres que perderam o emprego por causa da gravidez e até um caso em que o chefe pediu que sua funcionária abortasse caso quisesse permanecer no cargo. <http://archiviostorico.corriere.it/2007/novembre/19/Incinta_chiesero_abortire_licenziata_co_9_071119113.shtml>

47 Usamos aqui o termo recriar, pois se espera que uma aula de língua estrangeira possa fornecer ao aluno um momento de contato com essa outra língua e outra cultura, como se dentro da sala de aula fosse "um outro mundo". E essa é uma das dificuldades de trabalhar com o ensino de língua estrangeira fora do país que a fala como materna, pois fora da sala de aula o aluno está circundado de língua materna. A sala de aula, então, tem que tomar a posição de um "mundo à parte", no qual o aluno poderá entrar em contato com uma cultura diferente. 
um outro contexto (o da comunidade que fala a língua estrangeira como língua materna, geralmente distante fisicamente de onde o curso é dado), e inserir o aluno dentro dessa cultura. O segundo desafio é o de lidar com o recorte que o aluno faz dessa cultura, ou seja, como "administra" as influências de sua própria cultura recorte que ele "construiu" dentro de sua sociedade e de sua língua materna - e como encara essa diferença. Como lidar com os estereótipos, a resistência ao estrangeiro e mesmo a sua própria imagem de sujeito-falante dessa nova língua.

\subsubsection{Por que é importante quebrar estereótipos e contextualizar a língua?}

Pensemos, como um exemplo, nos alunos que chegam ao curso de língua italiana com a ideia de que a proximidade com o português ou a origem latina do italiano facilitará o processo de a/a da LE (mesmo aqueles que nunca estudaram latim fazem essa afirmação; lembremos que o francês também tem origem latina.). Ou, então, os alunos que, sendo descendentes de italianos (mesmo que não tenham tido contato com a língua), esperam que a "familiaridade" que eles sentem em relação à língua - por uma questão afetiva - facilite o processo de a/a. Quando esses alunos se deparam com alguma dificuldade ou com algo que lhes soa "estranho" - como no caso de um substantivo que em italiano é masculino enquanto que em português é feminino (fiore - flor), é o suficiente para o início do estranhamento. O estranhamento pode ocorrer, também, quando percebem que a língua com a qual se achavam familiarizados nada se parece com aquele italiano standard dado na sala de aula, provavelmente porque seus ascendentes já tivessem sua fala permeada pelas influências do português brasileiro a que qualquer imigrante está sujeito, ou mesmo porque o que falavam era um dos "dialetos" da Itália. Nesse caso, há duas reações possíveis: ou ocorre o bloqueio no processo de a/a, pois o "familiar" passa a ser "estranho"; ou o aluno encara aquele momento como uma quebra do estereótipo e passa a ver a língua efetivamente como estrangeira, como diferente da sua língua materna. E esse processo de 
estranhamento, de diferenciação fará com que o aluno esteja aberto a vivenciar plenamente a LE.

É necessário que os alunos consigam compreender que determinados comportamentos, hábitos, modos de falar são culturais e que, portanto, não basta aprender uma língua gramaticalmente, se deixamos de lado os outros fatores que influenciam as relações sociais.

Os professores de língua estrangeira possuem a dificuldade de tentar recriar em sala de aula um ambiente que faça com que o aluno se sinta "dentro" da cultura da LE. Ao mesmo tempo, possuem a vantagem de ter alunos dispostos a aprender/adquirir uma LE, e que tentarão incorporá-la e usá-la como falantes nativos. Para que esses alunos consigam obter êxito na LE, precisarão ter os dados culturais desse estrangeiro para que possam se comportar de forma adequada quando estiverem no contexto da LE. É importante que eles saibam, por exemplo, que não se deve fazer o sinal de "figa" e nem mesmo presentear um italiano com uma figa, achando que está desejando sorte a ele com esse gesto. Eles precisam estar informados de que na Itália a figa (tanto o gesto com a mão - exatamente igual ao dos pequenos pingentes, chaveiros e até mesmo esculturas vendidas no Brasil - quanto a palavra figa ou fica) designa o órgão sexual feminino. Bem como devem aprender que em italiano se deseja sorte facendo le corna e que o gesto, além de sorte, pode indicar que uma pessoa é cornuta (traída pelo cônjuge, em português, "cornuda").

Quebrar os estereótipos fornecendo dados sobre a cultura do país e inserindo os alunos dentro dessa cultura facilitam o modo como eles enxergam a língua estrangeira e auxiliam o processo de a/a, pois a língua é um conjunto de fatores sociais interligados. É importante que eles compreendam o recorte de mundo feito por essa língua diferente, estrangeira.

Quando falamos nessa quebra de estereótipos, nos referimos tanto aos positivos quanto aos negativos. As informações consideradas "negativas" também 
servem na construção da imagem da outra cultura, auxiliando na constituição do recorte de mundo daquela língua e, consequentemente, no processo de a/a da LE.

\subsection{Os estereótipos contra os idosos: influências na sala de aula}

Nelson (2004) afirma que, na percepção social, tendemos a automaticamente categorizar as pessoas em três dimensões maiores: raça ${ }^{48}$, sexo e idade.

Uma das características únicas do preconceito contra os idosos é que o considerado ingroup (os jovens) um dia fará parte, se tiver sorte, do outgroup (pessoas mais velhas). Ao contrário do que acontece com as outras formas de preconceito como o racismo e o sexismo, por exemplo; é que as pessoas não mudam de raça e, salvo alguns poucos casos, nem de sexo. Mas as pessoas mudam de idade. E o que se procura atualmente são justamente o prolongamento da vida saudável e a busca por manter-se "jovem".

Nelson (2004) afirma que o baixo interesse em se estudar o preconceito contra os idosos tem várias razões, mas que a mais óbvia delas é o fato de que o preconceito etário é um dos mais socialmente tolerados e "perdoados".

Em inglês, existe uma expressão específica para o preconceito em relação à idade da pessoa: "ageism". Segundo Meire Cachioni o termo foi cunhado pelo gerontólogo Robert Butler ${ }^{49}$, em 1969:

[...] para descrever os preconceitos que resultam de falsas crenças a respeito dos idosos, cujo efeito é a discriminação social baseada no critério de idade. Dez anos mais tarde, Kalish identificou um fenômeno que

48 Usamos o conceito de raça como estabelecido no texto de Santos, Lopes e Neri (2007), no qual esclarecem a distinção entre os conceitos de "raça" e "etnia". Sendo "raça" entendido como "o conjunto de indivíduos com determinada combinação de caracteres físicos geneticamente condicionados e transmitidos de geração para geração" (p. 67); e "etnia" como compreendendo "os fatores culturais de um grupo, entre eles a nacionalidade, a afiliação tribal, a religião, a língua, as instituições, os valores e as tradições, transmitidos de geração a geração por processos de aprendizagem social, mediados pela linguagem e pelo pensamento." (p.68).

49 BUTLER, R. N. (1969). Ageism: another form of bigotry. In: The Gerontologist, 9: 243-246. 
classificou de "new ageism", segundo ele uma forma de preconceito não baseada em estereótipos negativos, mas "compassivos", porque focalizados no velho dependente, incapaz e sem poder político. (Cachioni, 2003:131)

Usa-se também o adjetivo derivado do ageism, seguindo a lógica de adjetivos como racist: ageist. Hoje, essas expressões não são usadas para falar apenas do preconceito contra idosos, pois também existe preconceito contra jovens, vistos, muitas vezes, como irresponsáveis - como mostra a pesquisa da Fundação Perseu Abramo $/ \mathrm{Sesc}^{50}$. Entretanto, essas expressões são atualmente utilizadas quase que majoritariamente, para se referir ao preconceito contra os idosos. ${ }^{51}$ No texto de Ricardo Moragas (2004) aparece a palavra "idadismo" como tradução para palavra inglesa. Mas no nosso trabalho optamos pela palavra em inglês ou o termo "preconceito etário", por serem as expressões mais utilizada na literatura que consultamos para a pesquisa.

Importante ressaltarmos que Cachioni (2003) cita vários tipos de manifestações de ageism, que acabam por influenciar negativamente vários campos (inclusive o acadêmico). A autora cita o estudo de Rebok ${ }^{52}$ :

Rebok (1981) sugere que o "ageism" ocorre também no ambiente educacional, por intermédio de profissionais que são possuidores de pouca informação acerca do desenvolvimento adulto; eles dão crédito aos estereótipos por desconhecerem as competências intelectuais e a capacidade de trabalho dos idosos. Podem também estar fundamentados na crença de que os idosos não se beneficiam da educação [...] (Cachioni, 2003:132)

Como mencionamos no primeiro capítulo, em algumas sociedades o preconceito contra idosos chega a ser mais forte do que o preconceito racial. Erving Goffman (1982) nos mostra como as pessoas que portam um estigma sofrem com

\footnotetext{
NERI, A. L. (2007).

Alguns autores como Gilleard e Higgs (2002) utilizam especificamente o termo "Third Ageism".

2 REBOK, W. G. (1981). Aging and higher education: prospects for intervention. Educational Gerontology, 6:39-48.
} 
a exclusão social e o preconceito. O autor também trata em seu livro das maneiras encontradas por essas pessoas para lidar com seus estigmas. Ele aborda os vários tipos de estigma, dos quais destacamos os estigmas visíveis, ou seja, aqueles que o sujeito não pode esconder (geralmente física). Nós não podemos esconder a nossa idade. Mesmo com plásticas e cremes antirrugas, os sinais da idade inevitavelmente aparecem - mesmo que para alguns, e com a utilização de determinados tratamentos, demorem mais a aparecer. Somos, então, estigmatizados pela nossa idade.

Goffman dá exemplos de como as pessoas estigmatizadas encontram meios de lidar com o preconceito dos outros, e até mesmo encobrir o estigma que carregam - em casos nos quais o encobrimento é possível. Achamos importante ressaltar que, nos exemplos de pessoas estigmatizadas, o autor relata que algumas delas chegam a aceitar o tratamento - preconceituoso e estereotipado - dos outros em relação a elas (como pessoas incapacitadas, por exemplo) porque dizer que a ajuda ou o tratamento oferecidos não são necessários traz reações piores e chega a ser desgastante. Essas pessoas estigmatizadas, então, preferem aceitar a ajuda (não necessária) para evitar um desgaste "emocional".

Segundo Levy e Banaji (2004), Montepare e Zebrowitz (2004), um dos grandes problemas do ageism é que o ingroup (agora do ponto de vista dos idosos) carrega estereótipos negativos sobre o próprio grupo. Essa também é uma das características únicas do preconceito contra idosos, porque, ao contrário do que ocorre em outros casos, não há uma valorização do/favoritismo pelo ingroup para uma desvalorização do outgroup. E, nesse caso, os estereótipos não servem para proteger os idosos, mas para proteger a "imagem jovem" de uma sociedade.

Isso acontece porque, como comentam os autores, por pelo menos meio século o sujeito internaliza os estereótipos negativos sobre o envelhecimento e, quando chega à idade em que ele próprio faz parte desse grupo de idosos que ele estereotipou, não desenvolveu os mecanismos de defesa necessários para se proteger dos estereótipos negativos. Portanto, ele continua a "se ver" como parte 
do grupo "jovem", "se esquivando" da sua associação ao grupo de idosos o quanto pode. Quando finalmente não pode mais se identificar com o grupo de jovens, geralmente já é tarde demais para criar os mecanismos de defesa contra estereótipos negativos e acabam por assumi-los e perpetuá-los. Na obra de Ferrigno (2003:158-159), o depoimento de uma das professoras ilustra bem essa situação:

Enquanto a gente não vê muito de perto o que a pessoa que envelhece passa, não tem idéia da forma como elas são agredidas pelo social, pelas outras pessoas que convivem com elas, até por culpa delas próprias. Pelo conceito que elas tinham de velhice enquanto jovens, provavelmente para elas, o idoso era uma pessoa improdutiva, uma pessoa incapaz. De repente, quando se tornam velhas, elas assumem exatamente aquilo que elas acreditavam. (...) Acho que a gente tem que trabalhar para que isso não aconteça com a gente também. [...]

Pereira (2002), Stangor (2009), Cuddy e Fiske (2004), e Susan Whitbourne e Joel Sneed (2004) discutem como as pessoas, quando ameaçadas de estereotipização, ou pertencentes a grupos estereotipados, como os idosos, acabam por se comportar de acordo com o estereótipo em situações em que são colocadas "em confronto" com outros grupos (estereotipados como superior aos deles). Pereira, por exemplo, cita um estudo estadunidense feito com estudantes de matemática com ótimo desempenho quando a prova ocorreu somente entre eles mesmos. Quando colocados para fazer o teste com um grupo de estudantes asiáticos (que carregam o estereótipo de serem bons em matemática), o desempenho dos estudantes estadunidenses cai de forma notável. É como se "aceitassem" o estereótipo de que os asiáticos são inevitavelmente melhores do que eles, e seu desempenho decai em decorrência disso.

O mesmo acontece com idosos que voltam a estudar. No livro de Beauvoir (1976a), podemos verificar que o desempenho dos idosos em testes cai quando eles estão conscientes de estarem "concorrendo" com pessoas mais jovens. Ou mesmo os depoimentos colhidos por Pizzolatto (2008:249), em que os idosos incorporam 
"a imagem negativa que a sociedade possui em relação ao envelhecimento" demonstrando baixa autoestima. ${ }^{53}$

Além disso, Levy e Banaji levantaram dados que comprovam que a memória dos idosos tem o desempenho afetado quando submetidos a estereótipos negativos. Os idosos submetidos a estereótipos positivos sobre o envelhecimento tiveram maior eficácia da memória. O mesmo estudo revelou que os autoestereótipos influenciam o modo como os idosos se veem e como veem os outros idosos, tendo resultado direto no desempenho. O ageism tem impacto direto na cognição, comportamento e saúde dos idosos. Os autoestereótipos implícitos podem ser ativados de várias formas, através de manifestações que estão presentes na sociedade. E os estereótipos negativos contra idosos e a velhice ainda estão "ativos" nas esferas públicas. A mídia, por exemplo, além de quase não colocar idosos em papéis de destaque ${ }^{54}$, quando eles aparecem, geralmente o fazem de maneira "caricata" que acaba perpetuando os estereótipos sobre idosos.

Outro estudo interessante é citado no trabalho de Mary Kite e Lisa Wagner (2004), sobre a influência da cultura, ou seja, de como nossa cultura vê os idosos e o processo de envelhecimento. As autoras citam o trabalho de Levy e Langer ${ }^{55}$, que examinaram três grupos culturais nos quais as atitudes contra os idosos diferiam, do mais positivo ao menos positivo. O estudo mostra que os idosos do grupo cultural que têm uma visão mais positiva do envelhecimento (no caso, os chineses) obtiveram um desempenho melhor da memória do que os outros grupos. Isso sugere que as atitudes das pessoas contra o envelhecimento afetam o seu próprio processo de envelhecimento (como se elas devessem cumprir o que imaginam sobre os idosos e o envelhecimento). Nas culturas que possuem uma visão negativa do envelhecimento, esta constatação é preocupante.

53 O contexto analisado por Pizzolatto é de um grupo de terceira idade aprendizes de inglês LE.

54 Cuddy e Fiske (2004) relatam os dados da pesquisa de Zebrowitz e Montepare (2000), intitulada "Too young, too old: stigmatizing adolescents and elders". Na qual levantam que a televisão retrata apenas 1,5\% de seus personagens como idosos e, a maioria deles, em papéis menores.

55 LEVY, B; LANGER, E. (1996). Reversing disability in old age. In: KATO, P. M; MANN, T. (eds.). Handbook of diversity issues in health psychology. New York: Plenum Press. p. 141-159. 
Whitbourne e Sneed (2004) levantam quatro estereótipos sobre idosos que são comprovadamente mitos:

1. Idosos são solitários e depressivos: relaciona-se a esse mito a ideia de que idosos não são capazes de lidar com o declínio associado ao envelhecimento, mas estudos mostram que eles têm maiores meios de administrar o estresse de forma efetiva do que os mais jovens;

2. Idosos tornam-se "parecidos" conforme envelhecem: estudos gerontológicos mostraram que eles ficam mais diferentes uns dos outros e não menos;

3. Idosos são doentes, frágeis e dependentes: a maioria dos idosos considera sua saúde "boa" ou "muito boa", mesmo com limitações econômicas e sendo vistos como com pouca saúde;

4. Idosos são enfraquecidos cognitiva e psicologicamente: apesar de haver uma perda da atenção e da memória "ativa" com a idade, apenas uma minoria (7\%) desenvolve perda extrema.

Ao entrar em contato com modelos positivos de idosos (que não se encaixam no estereótipo), por exemplo, podemos modificar os estereótipos negativos. Entretanto, ao nos depararmos com informações que contradizem os estereótipos, tendemos a considerar essa informação como uma exceção (Levy e Banaji, 2004).

A velhice tem ainda mais um "agravante" no que diz respeito à estereotipização, é o que Jeff Greenberg, Jeff Schimels e Andy Martens (2004) tratam como "Teoria de Administração do Terror", baseada em Ernest Becker ${ }^{56}$. O outgroup se diferencia por possuir outra visão de mundo que pode "ameaçar" aquela do ingroup, pois insinuaria que a visão de mundo de alguém não é válida. Essa ameaça psicológica teria um efeito importante no preconceito e na 
discriminação. O que acontece em grupos de idosos é que eles representam a mais ameaçadora lembrança para as pessoas: a de que somos todos mortais.

Existiria, então, um paradoxo existencial: somos guiados a viver, tendo como única certeza a nossa morte. Ainda segundo os autores, essa constatação geraria um terror que carregamos sempre conosco, e que administramos usando mecanismos culturais para negar a morte. O fato de os idosos despertarem a ideia de morte pode ser uma das razões para o ageism. As defesas contra a ideia de morte são feitas através de defesas proximais ou distanciais. As primeiras protegem contra a consciência imediata da morte e resulta em distanciamento físico (evitando contato com idosos) ou distanciamento psicológico (vendo os idosos como diferentes dos outros e de si mesmos). As defesas distanciais servem para manter os pensamentos indesejados sobre a morte no nível inconsciente, e tem como efeitos o aumento da autoestima, maiores reações negativas a quem desafia a visão de mundo (no caso, nos faz lembrar a nossa mortalidade) e aumenta as reações positivas ao ingroup.

É o contato com pessoas mais velhas que possibilitaria uma proximidade social, permitindo o acesso às informações incongruentes com os estereótipos, forçando-nos a ver os mais velhos como um grupo social mais variável, modificando estereótipos, principalmente os implícitos.

Greenberg, Schimel e Martens (2004) afirmam que entrar em contato com idosos saudáveis, por exemplo, levantaria uma ideia de velhice saudável e não uma lembrança da morte, o que ajudaria a diminuir a tendência de as pessoas se distanciarem de idosos, desmistificando a velhice.

Stephan, Ybarra e Morrison (2009) afirmam que grupos minoritários (no nosso caso, os idosos) tendem a perceber mais facilmente as ameaças a seu grupo por estarem frequentemente "à mercê" dos grupos mais poderosos. Já os grupos mais poderosos (no caso, os jovens), quando se sentem ameaçados, reagem mais 
fortemente porque têm mais a perder (seu poder) e também por possuírem os recursos para responderem às ameaças.

Com base na literatura da Teoria da Administração do Terror, há três modos de melhorar as reações negativas contra a idade: encorajando normas e valores sociais que deem suporte ao respeito e o carinho pelo idoso, dar suporte à visão de mundo e sentido de valor das pessoas e fazer com que as pessoas sejam mais conscientes do próprio medo da morte e do envelhecimento. Os autores Greenberg et al. sugerem o uso do sistema escolar para tentar fazer com que as visões de mundo sejam mais favoráveis aos idosos.

Levy e Banaji (2004) afirmam que o problema do ageism é que, ao contrário do racismo, ele não provoca vergonha. É socialmente perdoado. Sugerem que a redução dos estereótipos etários negativos implícitos pode ocorrer através de reforço dos estereótipos etários positivos implícitos ou através da exposição a figuras e descrições de indivíduos mais velhos admirados e indivíduos jovens não admirados (este último estudo teve resultados comprovados). Encerram o texto afirmando que a redução da discriminação é alcançada com reconhecimento social e ação política.

Cuddy e Fiske (2004) indicam a cooperação entre grupos como construtora de confiança e diminuidora de estereotipização contra os membros do outgroup. A interdependência entre grupos etários pode acabar com mútuos estereótipos.

Os autores Whitbourne e Sneed (2004) tratam do "Paradoxo do bemestar", em que a maioria dos idosos, apesar do preconceito e dos indicadores sociais negativos contra eles na sociedade, conseguem manter um sentido positivo de subjetivo bem-estar. É considerado envelhecimento bem-sucedido aquele que é livre 
de doenças e deficiências, consegue manter um alto funcionamento cognitivo e físico e se mantém ativamente engajado com a vida. Os autores ainda tratam de quatro habilidades utilizadas para administrar os eventos negativos e manter a autoestima positiva:

1. O uso de mecanismos maduros de defesa: são aqueles como humor e altruísmo. Eles aumentam com a idade, sendo mais comuns em adultos mais velhos (um exemplo de mecanismo imaturo de defesa é a negação). Os idosos têm mais habilidade em lidar com emoções negativas do que os jovens;

2. Teoria da seletividade sócio-emocional: a fim de evitar desgastes emocionais, os idosos preferem se relacionar com pessoas conhecidas, que os julgarão individualmente, ao invés de desconhecidos que usarão estereótipos sociais para categorizá-los. Controlam as experiências emocionais ao controlar as interações sociais;

3. Acomodação dos objetivos: deixam de lado os objetivos estabelecidos na juventude, para não se depararem com as limitações físicas e psíquicas; ou mudam os objetivos para uma sensação de realização e conquista;

4. Teoria dos processos identitários: podem "moldar" os processos de envelhecimento para encaixá-los no seu próprio sentido de identidade.

\section{As aulas de língua}

Discutiremos no terceiro capítulo especificamente os grupos intergeracionais como ambiente propício à quebra de estereótipos e preconceitos contra idosos e os processos de envelhecimento. E de como o Italiano no Campus pode ser definido como um ambiente intergeracional, aprofundando a discussão sobre contatos intergeracionais e seus benefícios. 
Queremos aqui ressaltar a importância do conhecimento dos estereótipos sobre velhice por parte dos educadores, especialmente aqueles que lidam com grupos intergeracionais. O professor, na sala de aula, é um produtor de significados e mediador das diferenças, como vimos anteriormente. Na aula de língua, particularmente, esse papel é importante porque aquele ambiente vai servir aos alunos como um novo espaço de expressão no qual eles podem construir uma nova identidade, a de falante dessa nova língua. E essa é uma oportunidade de o aluno se posicionar de uma forma diferente daquela com a qual ele costuma se posicionar na língua materna.

Se construirmos, como educadores, um ambiente no qual tais estereótipos serão confrontados e, possivelmente quebrados, estaremos também afetando positivamente a postura desse sujeito dentro da própria língua materna. Lembremos do conceito de performatividade e repetibilidade discutidos no início deste capítulo. Podemos quebrar estereótipos dando novos significados às práticas sociais.

Defendemos um espaço para a Pedagogia da Diferença. Não pretendemos incluir o diferente de forma a anulá-lo ou apagá-lo, ou mesmo tentando transformá-lo em alguém que se confundirá entre as pessoas "não diferentes". A nossa ideia, mais do que aceitação da diferença - aceitar que existem pensamentos, pessoas, dentre outros aspectos, diferentes dos "meus", de "mim" etc. - é uma ideia de respeito pela diferença como ela é, sem a necessidade de "se adaptar à norma".

Os idosos, nas aulas de língua, tendem a assumir os estereótipos sociais existentes sobre os processos de aquisição/aprendizagem na terceira idade ${ }^{57}$. Se eles se consideram lentos ou mesmo dizem que "não têm mais idade para fazer tantos exercícios".

57 Como afirma Pizzolatto (2008:237) há um "senso comum de que aprender 'bem' uma língua estrangeira é tarefa para os mais jovens, aliás, para os bem jovenzinhos. 
Como podemos ver em Pizzolatto (2008), alguns idosos acabam usando os estereótipos em relação à velhice como "desculpa" para suas falhas no processo de a/a de LE, mesmo que essas falhas aconteçam com alunos de outras idades.

A pesquisa geral do Italiano no Campus, que apresentaremos no capítulo cinco, mostra que parte dos comentários negativos sobre a terceira idade foram feitos pelos próprios idosos.

Temos também que atentar para o fato de que muitos professores carregam estereótipos negativos sobre a velhice e acabam "moldando" seu comportamento com alunos idosos com base nesses estereótipos. Um exemplo disso é o tratamento infantilizado que alguns professores acabam adotando, por acreditarem na ideia socialmente difundida de que a velhice é uma "segunda infância".

Uma das questões levantadas no ensino em grupos de idosos é o fato de eles gostarem de contar experiências de vida na sala de aula. Dino Preti (1991), em um estudo sobre a linguagem dos idosos, argumenta sobre como a fala dos idosos é marcada por rememorações. Um modo de se aproveitar isso na aula de língua seria oferecendo situações em que os alunos possam contar suas experiências de vida e suas opiniões sobre o mundo atual utilizando o que sabem da língua estrangeira e fazendo daquele momento uma oportunidade de conversação em LE. A motivação está lá: compartilhar experiências, mas a tendência inicial dos alunos idosos é fazer isso utilizando a língua materna. Cabe ao professor conduzir aquele momento de forma a incorporá-lo à aula de língua estrangeira.

Da mesma forma como há estereótipos negativos em relação aos idosos em aulas de língua, não podemos deixar de mencionar os aspectos positivos constatados informalmente em conversas com professores de língua italiana. Um deles é o de que os alunos idosos são geralmente mais empenhados do que alunos mais jovens, sendo muito raro que eles deixem de fazer algum exercício, e a frequência deles nos cursos é de quase sempre 100\%. São também muito abertos às 
mais diversas atividades, sem medo de se exporem, pois, segundo Pizzolatto (2008), eles assumem uma postura de "nada a perder" e, como vimos, tendem a lidar com possíveis situações negativas com humor. E até mesmo o fato de estarem ali, muitas vezes, para se socializar, leva-os a promover uma interação intensa entre o grupo e muito proveitosa para a aula de língua. 


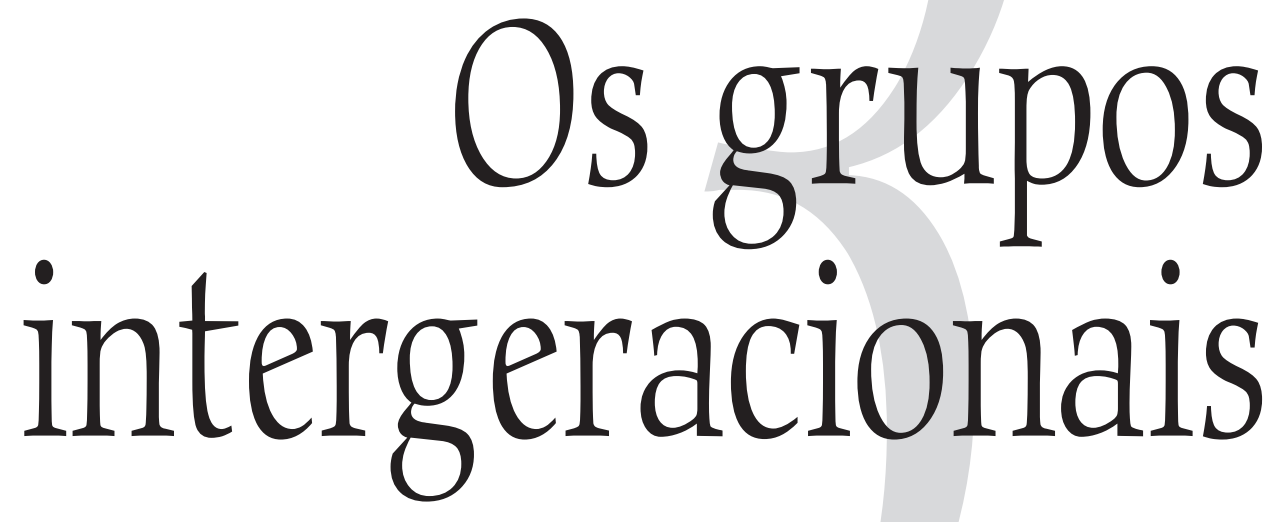


Neste capítulo discutiremos as relações intergeracionais e como as mudanças na estrutura da sociedade ocidental as afetou, levando à criação dos Programas Intergeracionais (PIs). Falaremos um pouco das bases teóricas desses programas, suas aplicações e resultados. Passaremos, em seguida, para a discussão do que compreendemos por grupos intergeracionais neste trabalho e de como podemos pensar o Italiano no Campus dentro dessa categoria intergeracional. Para finalizar, discutiremos a questão da Pedagogia da Diferença e como Programas Intergeracionais educacionais podem contribuir para a sociedade.

Para este capítulo, nos fundamentamos com textos nos campos da Gerontologia - tanto da área Social quanto Educacional -, Serviço Social, Linguística Aplicada, Sociologia e Estudos Culturais.

\subsection{Geração X grupo etário}

Primeiramente, precisamos esclarecer a diferença entre geração e faixa etária. Pessoas pertencentes a um mesmo grupo etário são aquelas que nasceram em um momento cronologicamente aproximado. É pertencer a uma mesma idade biológica (Lima, 2008; Debert, 2004). O grupo etário não é determinante, principalmente quando se trata de culturas e sociedades diferentes, como afirma Viviane Magro (2003). Por exemplo, um adolescente japonês de 15 anos provavelmente se comporta de maneira diversa da de um adolescente brasileiro da mesma idade, assim como ambos teriam reações diferentes durante um evento 
histórico, pois eles estão marcados pelas suas culturas e sociedades. Pertencem a um mesmo grupo etário, mas não possuem o mesmo contexto histórico, social etc., não pertencem a uma mesma geração.

Delimitar categorias etárias e ser um grupo etário são processos construídos socioculturalmente através da linguagem, do diálogo entre diferentes, que surge no encontro de corpos que se falam continuamente nas suas diferenças. Esse processo envolve estruturas de poder e controle, $e$ também de organização social. (Magro, 2003:36)

Para tratar de intergeracional, é necessário definir o que é "geração". O conceito de geração com o qual mais usualmente nos deparamos se refere às gerações de uma família (avós, pais, netos, bisnetos) e, atualmente, é comum encontrar o uso da palavra "geração" na apresentação de novas tecnologias (uma nova geração de celulares, por exemplo). Mas o conceito de geração que pretendemos adotar vai além dessas exemplificações.

Um dos trabalhos utilizado para tratar a questão das "gerações" é o do sociólogo Karl Mannheim (s/d), intitulado "O problema das gerações". Para ele, a questão da geração é vista como um fenômeno social e não cronológico. O autor diz que "devemos começar por compreender a geração como um particular tipo de posição social" (p.135). Ferrigno (2003) diz que assim como nós somos socialmente construídos, as gerações também o são.

Pessoas pertencentes a uma mesma geração possuem uma idade aproximada, mas isso não é um fator determinante. São as experiências partilhadas que as constituem como uma geração. São os eventos históricos que as marcam. Exemplos de eventos determinantes de gerações são: as guerras, eventos como o 11 de setembro, a invenção do anticoncepcional, a televisão, a tecnologia (Debert, 2004:52). Importante ressaltarmos, no entanto, que não basta vivenciar um mesmo momento histórico para ser considerada a mesma geração porque os eventos são experimentados por cada pessoa com base em suas experiências anteriores. Portanto, uma pessoa que já vivenciou uma guerra 
certamente se colocará de maneira diferente diante de uma segunda guerra se comparado a uma pessoa que a está vivenciando pela primeira vez. Para Ferrigno, “a geração é uma sobredeterminação de fatores históricos e culturais". (2003:41)

Além disso, segundo Mannheim, pessoas de diferentes classes também experimentam os eventos de formas diferentes. Uma crise econômica, por exemplo, tem efeitos e influências nas pessoas da classe média alta que são completamente diferentes daqueles sofridos pelas pessoas da classe baixa.

Mannheim diz que a nossa posição na sociedade determina como nos apropriamos da sua herança cultural e material intelectual. E quando assumimos uma posição, temos "tendências" que determinam como pensamos, nos comportamos e nos sentimos. Lima (2008:24) afirma que: “(..) as pessoas que compõem a mesma geração não são necessariamente do mesmo grupo etário, mas compartilham um conjunto de experiências comuns, usufruem, ao mesmo tempo, das vantagens e desvantagens de uma estrutura social vigente".

Para Ricardo Moragas (2004):

As gerações, do mesmo modo, identificam-se com outras variáveis sociais que facilitam a análise dos grupos, que podem ou não coincidir com idades próximas. A experiência compartilhada na escola, em organizações econômicas ou ideológicas, a profissão, o lazer, a história, as guerras, as revoluções, o estilo de vida, a moda, a música e qualquer denominador de conduta de grupos identifica-se também com geração, sem referência à idade $[\ldots]$ (p.8)

Chris Gilleard e Paul Higgs (2002) resumem da seguinte forma os três elementos que Mannheim usou para descrever a formação de uma geração: 1) um local temporal compartilhado (local geracional ou grupo etário); 2) um local histórico compartilhado (exposição a um período ou era comum); 3) um local sociocultural partilhado (consciência geracional).

Portanto, uma mesma geração seria formada de pessoas com idades aproximadas e contextos histórico e sociocultural aproximados. A terceira idade 
atual faria parte da geração do baby-boom, que, segundo os autores Gilleard e Higgs, abandonou o considerado "doméstico" e passou ao consumo público (por exemplo, sair para jantar, ir ao cinema). Segundo os autores, as transformações sociais do pós-guerra causaram mudanças culturais e sociais que se espalharam na segunda metade do século XX, levando a um novo entendimento da velhice. ${ }^{58}$ Isso se deve ao fato de esses adultos serem os primeiros a vivenciar o envelhecimento tendo sua entrada na vida adulta influenciada pelo ambiente da cultura juvenil dos anos 1960. Essa geração vivenciou de forma intensa as revoluções sociais, políticas e culturais dos anos 1960.

Em nossa pesquisa no Italiano no Campus (IC), fizemos uma divisão para análise por faixas etárias porque não seria possível determinar todas as gerações dos estudantes presentes. No entanto, é importante destacarmos que o fato de o IC reunir pessoas de 16 a 78 anos o coloca como um ambiente intergeracional, pois há várias gerações reunidas. Optamos por uma divisão etária, já que temos como foco investigar o preconceito etário contra o idoso e os benefícios de um ambiente intergeracional para a quebra de estereótipos e do próprio preconceito.

\subsection{Relações intergeracionais}

As relações intergeracionais são aquelas que ocorrem entre diferentes gerações. A maioria dessas relações se dá na família (Moragas, 2004), já que ela é o grupo social primário (Lima, 2008).

Com a mudança na estrutura familiar, mudaram também as relações intergeracionais. Passou-se das famílias extensas, nas quais havia a convivência de várias gerações, típica das famílias rurais, em que todos trabalhavam para a subsistência - chegando a ter até quatro gerações morando juntas - para as

58 Discutiremos mais adiante as mudanças sociais que influenciaram não só a visão da velhice hoje como a importância dos grupos intergeracionais. 
chamadas famílias nucleares, geralmente constituídas por pais e poucos filhos. Esse tipo de família surge com as sociedades industriais, em que havia a necessidade de mobilidade (devido à migração para as cidades). (Moragas, 2004; Ferrigno, 2003). Diminui-se, então, o contato intergeracional intrafamiliar.

Segundo Moragas (2004), Lima (2008) e Christopher Ward (1997), as mudanças começam a ocorrer após a Segunda Guerra Mundial, quando se adota um enfoque organizativo da sociedade, dividindo-a em grupos etários. Inicia-se uma segregação etária que propaga a ideia de que a realização das tarefas, independente de seus campos (esportivo, cultural, educacional, de lazer etc.), é mais eficiente quando ocorre entre pessoas da mesma faixa etária. Divide-se então a vida em quatro etapas principais: infância, juventude, vida adulta e velhice. Ao mesmo tempo em que essa segregação pode trazer benefícios, como leis específicas que asseguram os direitos e deveres de cada uma das etapas da vida (como o Estatuto da Criança e do Adolescente e o Estatuto do Idoso), ela ocasiona também a perda de contato entre as gerações, criando espaços sociais determinados a cada uma delas (bailes da Terceira Idade, bar exclusivamente para jovens, por exemplo). Essa ausência de diálogo entre as gerações acaba desencadeando a falta de conhecimento de uma geração sobre a outra, resultando em preconceito contra as pessoas de idade diferente, o ageism.

Os laços intergeracionais dentro da família possibilitam que jovens e idosos sejam mais conscientes das necessidades um do outro. O convívio entre gerações existente nas famílias extensas levava a um entendimento "intuitivo" entre ambos.

Newman (1997b) relata que, especificamente para os idosos, as mudanças sociais ocasionaram:

- o aumento do número de idosos;

- a ênfase na aposentadoria "precoce";

- a mudança na expectativa de vida;

- a mudança em seus papéis na família e na comunidade; 
- a separação geográfica de suas famílias;

- a falta de sistemas adequados de suporte.

Moragas (2004) afirma que as relações intergeracionais podem trazer resultados positivos (de cooperação entre gerações) ou negativos (de conflito). O autor cita ainda as deficiências na qualidade de vida dos idosos decorrentes da falta das relações sociais:

- deficiência na alimentação: como muitos idosos vivem sozinhos, não gostam de cozinhar só para eles e acabam optando por alimentos "rápidos" e geralmente pouco saudáveis;

- deficiência nos hábitos higiênicos: com o isolamento e a solidão, vem a ideia de que não precisam se arrumar, já que ninguém irá vê-los;

- deficiência na personalidade psicossocial: quando se perde a sensação de importância da/na vida social, a tendência é a de que se crie uma personalidade solitária e afastada da realidade..$^{59}$

Segundo Newman (1997a), as relações intergeracionais, além de serem importantes por fornecerem um conhecimento do outro que possibilita a quebra de estereótipos errôneos e preconceituosos que levam à discriminação, ainda trazem benefícios sociais para todos que participam de relações desse tipo. A autora afirma que o conceito de "intergeracional" surgiu em resposta à fragmentação familiar: a perda de contato intergeracional dentro das famílias leva a se pensar em "reconstruí-lo" fora das famílias.

\section{2: O Ano Europeu das Relações Intergeracionais}

As relações intergeracionais começam a ganhar destaque, uma das provas desse aumento da preocupação com o contato intergeracional foi a promoção do Ano Europeu das Relações Intergeracionais, em 1992.

59 O autor cita o exemplo da chamada "Síndrome de Diógenes", "caracterizada pelos velhos solitários, acumuladores de objetos inúteis e lixo, com saúde frágil, alimentação deficiente, os quais rechaçam toda intervenção alheia". (p.20) 
O Ano Europeu das Relações Intergeracionais foi promovido pela União Europeia (UE), que convocou os países-membros para desenvolverem iniciativas de relações intergeracionais. O Ano obteve grande êxito, superando os objetivos e as expectativas. Contou com o apoio dos meios de comunicação e consistiu não só na convocação como também na análise e premiação dos Programas Intergeracionais. Moragas (2004) diz que o sucesso do Ano Europeu das Relações Intergeracionais se deve a várias razões, dentre as quais ele destaca: o enfoque positivo dado ao envelhecimento; o embasamento científico de vários estudos sobre envelhecimento na União Europeia; e o apoio estratégico, econômico e contínuo da UE, cujo presidente na época era Jacques Delors.

Dentre os projetos apresentados, 61\% deles estavam nas áreas de cultura e educação. ${ }^{60}$

\subsection{Programas Intergeracionais (PI)}

Como mencionamos, segundo Newman (1997a), o conceito de Programa Intergeracional surge em resposta à fragmentação familiar.

Grande parte dos estudos sobre grupos intergeracionais, suas origens, aplicações e resultados é de autores estrangeiros. Um dos países mais avançados na pesquisa e implantação dos Programas Intergeracionais são os Estados Unidos. No Brasil, ainda são poucos os estudos no campo, dos quais destacamos o livro de Lima (2008), nomeadamente sobre $\mathrm{PI}^{61}$, e os trabalhos do SESC com a finalidade de unir gerações. Em novembro de 2010, o SESC Pompeia, em São Paulo, promoveu um evento sobre gerações, o qual discutia os Programas Intergeracionais aplicados no Brasil.

60 Moragas, 2004.

61 O livro de Cristina Lima é um dos poucos trabalhos publicados no Brasil que discutem diretamente os Programas Intergeracionais. 
Um estudo realizado em 2000, em colaboração com a Unesco mostra que há vários tipos de Programas Intergeracionais no mundo, sendo que alguns países possuem já um nível avançado de implantação desse tipo de programa, contando com apoio político. Esse estudo traz como editores Alan Hatton-Yeo e Toshio Ohsako e apresenta o status dos PIs nos países que participaram do trabalho, bem como seu uso como instrumento para solução de problemas sociais, suas áreas de impacto, recomendações sobre implementação de PIs e quais características são essenciais para o sucesso dos programas. Discutiremos todos esses pontos ainda neste capítulo.

Para os participantes desse estudo, a seguinte definição de Programa Intergeracional foi concordada: "Programas Intergeracionais são veículos para uma significativa e contínua troca de recursos e aprendizagem entre as gerações mais novas e mais velhas". (Bostrum et al., 2000:3) (2 $^{2}$

Já Delgado e Martínez ${ }^{63}$ apud Carvalho (2007:58) definem Programa Intergeracional "como aquele que une a mais de uma geração mediante a realização de alguma atividade planejada com o fim de alcançar determinados objetivos".

Segundo Newman e Smith (1997), os Programas Intergeracionais devem sua existência a fatores sociais, econômicos e políticos, além da sinergia única que parece haver entre jovens e idosos. Os autores relatam que os PIs têm unido, especificamente, crianças, jovens e idosos. Isso porque, no início, os programas eram voltados para suprir a ausência de contato dentro das próprias famílias (entre avós e netos), pelo fato de as famílias serem cada vez mais nucleares (e famílias monoparentais ${ }^{64}$ etc.) e os avós mais distantes (gerações que não

62 Traduzido por nós do original em inglês: "Intergenerational Programmes are vehicles for the purposeful and ongoing exchange of resources and learning among older and younger generations".

63 DELGADO, Buz; MARTíNEZ, Bueno. (2006). Las relaciones intergeracionales. Informes Portal Mayores, Lecciones de Gerontologia, Madrid, n. 66, 16 out. Disponível em:

<http://www.imsersomayores.csic.es/documentos/documentos/buzrelaciones-01.pdf>

64 Nas quais os filhos são criados por apenas um dos pais. 
coabitam, idosos mais ativos e que desejam manter sua independência após a aposentadoria).

Segundo Renato Veras (1997), os PIs costumam priorizar o relacionamento entre crianças, jovens e idosos por serem os grupos etários considerados economicamente não produtivos. Além disso, há uma afinidade entre idosos e jovens no que diz respeito às suas relações com os adultos, já que a fase adulta é atualmente vista como aquela em que o homem e a mulher atingem o seu "auge", como se nessa fase da vida eles fossem o "ser humano pleno". Essa visão coloca a criança e o jovem na posição daqueles que se preparam para ser adultos, e os idosos como aqueles que já tiverem a sua plenitude, mas que agora representam o passado. "Portanto, tanto para as crianças (que só têm futuro), quanto para os velhos (que só têm passado), não há presente. São todos marginalizados, privilegiando-se a figura do adulto". (Ferrigno, 2003:51)

\subsubsection{O contexto dos Programas Intergeracionais}

Utilizaremos aqui, na divisão interna de todo este tópico 3.3.1., o estudo de Ward (1997), realizado nos Estados Unidos, para mostrar quais mudanças sociais, culturais e políticas favoreceram o desenvolvimento de PIs. Apesar de os dados serem estadunidenses, muitos são aplicáveis à realidade brasileira. Incluiremos, em alguns momentos, o ponto de vista de outros autores.

\section{1) Mudanças sociais, demográficas e culturais}

a) Envelhecimento populacional: Ferrigno (2003:71) afirma que "o aumento da longevidade do ser humano é um fato histórico, inédito e planetário". Ocorre no mundo hoje o aumento da população idosa e da expectativa de vida. A maior longevidade implica em mais tempo de aposentadoria, que o idoso poderá utilizar com atividades voluntárias, trabalho, cursos etc. O que significa, também, maior necessidade de serviços para os idosos. Ward (1997) alega que, ao perdermos o 
formato de pirâmide etária - deixaremos de ter a base larga (jovens) e o topo estreito (idosos) -, passaremos a um número equivalente de habitantes de todas as idades, tendo maiores possibilidades de participantes de todas as faixas etárias nos grupos intergeracionais. Isso porque, com um número equivalente de cidadãos em todas as faixas etárias aumentam as chances de termos também um maior número de participante em grupos intergeracionais que representem cada uma delas.

b) Dispersão demográfica e mobilidade: nos EUA ocorre a concentração de idosos em algumas áreas devido à migração de jovens, por razões econômicas, e a migração dos próprios idosos para os novos lares de aposentados, ou mesmo em busca de estados onde o clima é mais ameno e conta com mais atrações geográficas e culturais (coincidindo com a criação de Programas Intergeracionais nas regiões para onde os migrantes idosos escolhem ir). Essa migração também é causa da separação de avós e netos. O desenvolvimento tecnológico acabou possibilitando a construção e manutenção de relações apesar das distâncias geográficas.

c) Status econômico: o autor cita três pontos: a renda diminui com a idade; mulheres idosas são mais pobres do que os homens idosos; negros e hispânicos têm renda menor do que brancos.

d) Aposentadoria: após a Segunda Guerra Mundial os padrões de aposentadoria mudaram. Junte-se a isso a maior longevidade e o fato de os idosos contarem com maior número de anos disponíveis para a realização de outras atividades, incluindo os PIs. ${ }^{65}$

e) Laços familiares: há o aumento das famílias nucleares e da separação física entre parentes. Incluímos, neste ponto, as definições encontradas, por exemplo, em Ana Maria Goldani (2004), que tratam das situações que vão além

65 Ward (1997) exemplifica a mudança no número de anos "livres" após aposentadoria da seguinte forma: um homem de 20 anos em 1950 poderia esperar ter 7,5 anos de aposentadoria. Em 1980, um homem de 20 anos já poderia esperar por 15 anos de aposentadoria. O dobro de anos de aposentadoria em um intervalo de 30 anos. 
das famílias nucleares, são os casos de pais divorciados, recasados, que formam novas redes de relações de parentesco. Além das famílias monoparentais.

f) Saúde: a maioria dos idosos se declara satisfeita com sua saúde, possibilitando uma velhice mais ativa e participativa.

g) Segregação de grupos etários: atualmente é possível encontrar revistas, clubes, bares, restaurantes etc. divididos por faixas etárias.

\section{2) Tendências políticas e ideológicas}

a) Direitos de grupo: nos Estados Unidos, de 1960 a 1990, minorias étnicas e raciais, mulheres, portadores de necessidades especiais e grupos homossexuais lutaram para um maior reconhecimento de seus direitos. A partir de 1960 e meados de 1970-80, os estadunidenses começaram a levar em consideração que idosos, crianças e adolescentes, como grupos, merecessem receber os recursos e respeito que os outros grupos recebiam. No Brasil ocorreu o mesmo, como podemos notar pela criação do Estatuto da Criança e do Adolescente e o Estatuto do Idoso.

b) Aumento no papel do governo: nos EUA houve um aumento do apoio do governo federal aos programas de bem-estar social de todos os tipos e a programas de cuidado às crianças e aos idosos. Goldani (2004) fala da "crise silenciosa" das mulheres brasileiras: existe hoje a diminuição da taxa de fecundidade, mulheres cada vez mais inseridas no mercado de trabalho e respondendo já pela chefia de 33\% dos lares. Dessa forma, as mulheres, que eram tidas como provedoras de "serviços sociais gratuitos" - por se dedicarem ao cuidado dos filhos e dos parentes idosos, em um "contrato social implícito" em que o Estado não se preocupava com o cuidado às famílias já que as mulheres se ocupavam da tarefa - passam a ser "recurso escasso" e o Estado deveria assumir uma postura de suporte à mulher, 
oferecendo o cuidado à família. ${ }^{66}$ A autora afirma que no Brasil o governo ainda parece ignorar o que está acontecendo.

c) Conflito geracional: Ferrigno (2003) afirma que os conflitos geracionais são consequência de conflitos sociais. Para Goldani (2004:232), não existem evidências de conflito geracional pela disputa por recursos escassos, interpretando que a crescente preocupação com o tema:

[...] se deve a uma visão estática da realidade e dos indicadores de desigualdade inspirados no modelo de eqüidade entre as gerações ${ }^{67}$. Segundo, diríamos que a preocupação com um viés geracional parece estar relacionada com uma percepção negativa do fenômeno de envelhecimento da população. A proporção crescente de idosos foi recebida no Brasil com pessimismo e alarme, tal como ocorreu em outros países ocidentais.

d) Mudanças culturais: 1) a procura por viver uma vida plena e significativa; 2) a valorização das experiências privadas (o pessoal passa a sobressair sobre atividades públicas e comuns, como ir à igreja, por exemplo); 3) a educação e o desenvolvimento da autoestima por toda a vida; 4) o declínio da confiança de que a vida será melhor - sentimento pós Segunda Guerra Mundial; 5) a insatisfação com a sociedade moderna.

\section{3) Problemas sociais}

a) Velhice. Ward aponta três problemas sociais maiores na velhice: 1) o isolamento social dos idosos; 2) avós que acabam assumindo o papel de pais (o autor afirma que, nos Estados Unidos, devido ao aumento do uso do crack e da

66 A autora dá como exemplo o Japão: "Preocupado com o crescimento econômico do país e diante de uma verdadeira implosão demográfica, provocada pela chamada 'crise silenciosa', que colocou o Japão como o país com os menores níveis de fecundidade do mundo, o governo desenvolveu um amplo programa de serviços voltados para famílias. Em particular para as mulheres, foram criadas novas leis de proteção ao emprego e programas sociais para facilitar a reconciliação entre o trabalho e a família e inclusive incentivos financeiros para terem mais filhos" (p.238). A autora usa o trabalho de PENG, I. (2001). Woman in the middle: welfare state expansion and devolution in Japan. Social politics. International Studies in Gender, State, and Society, Oxford, v.8, n.2, p. 191-196.

67 "O modelo de 'eqüidade intergeracional' assume que as divergências entre os grupos de idade são marcantes e que os mais jovens, os adultos e os idosos competem por recursos escassos. [...] Esse modelo assume que o setor público é uma estrutura improdutiva e que sobrecarrega o setor privado. Ao mesmo tempo, concebe os idosos como um subgrupo homogêneo, dependente e improdutivo. O entendimento de que os idosos representam, apenas, um gasto para o setor público nesses modelos econômicos ortodoxos se deve, em grande parte, à subordinação das políticas sociais à política econômica, e a importância dessa última na esfera política." (Goldani, 2004:227) 
cocaína, houve o crescimento do número de crianças pequenas que precisam de cuidados e de avós que se viram assumindo novamente o papel de pais); 3) e o preconceito contra idosos (a preocupação com a desvalorização do idoso por parte dos jovens, refletindo-se em cortes indesejados nos serviços, e jovens usando seu poder político em prol dos interesses de sua própria geração).

b) Crianças e famílias: aumento no número de divórcios e recasamentos; declínio das famílias em que os dois pais estão presentes; aumento no número de pais solteiros; aumento das mulheres no mercado de trabalho e consequente aumento da necessidade de cuidados para a criança (creches, por exemplo); educação (após a Segunda Guerra Mundial, a educação passou a ser mais universal, Ward, 1997, afirma que há uma relação direta entre o nível de escolaridade dos pais e a pobreza dos filhos).

c) Comunidade: aumento da violência, sensação de insegurança e outros fatores que diminuem a qualidade das comunidades.

Os dados expostos acima mostram quais mudanças ocorridas (social, cultural e politicamente) abriram espaço para a criação e desenvolvimento dos Programas Intergeracionais. Ward dá exemplos de como os PIs têm conseguido colaborar nas esferas acima mencionadas. Segundo McCrea e Smith (1997a), a qualidade de vida depende da interação de três níveis de estruturas sociais interdependentes: comunitário, familiar e individual. Os PIs têm impacto positivo nos três níveis, e têm como base uma evidência histórica e desenvolvimental de que os resultados das interações entre as gerações mais velhas e mais jovens são positivos e benéficos para ambas. (Newman, 1997b) 


\subsubsection{As bases teóricas dos Programas Intergeracionais}

Segundo Sally Newman e Thomas Smith (1997), ainda não há uma teoria especificamente intergeracional, portanto, as bases teóricas que tratam dos Programas Intergeracionais partem dos estudos desenvolvimentais de crianças e jovens. Os autores fazem referência aos seguintes teóricos como base para os PIs:

- Maria Montessori: criou um sistema educacional que teve grande impacto no campo da chamada "primeira infância". Sua teoria, radical para o fim do século XIX, se fundamentava no respeito à criança e na importância de um ambiente que desse suporte à aprendizagem - pois observou que a criança aprende, inicialmente, através da experiência e da experimentação. Essa ideia levou-a ao conceito de autoeducação. A importância dessa teoria para os PIs está no fato de se preocupar com o contexto do crescimento e do desenvolvimento, com a ideia de um professor compassivo, adulto, pronto e capaz de providenciar orientação sem pressionar, exigir, punir e sem fazer o trabalho pela criança. O professor seria responsável por fornecer uma estrutura de opções aceitáveis, dentre as quais a criança teria livre escolha de atividades. O idoso, então, por sua experiência de aprendizagem e características desenvolvimentais seria apropriado para esse papel.

- John Dewey: sua teoria progressista tinha como componente chave a socialização, que no contexto educacional é fornecida pelo contato criança-adulto em uma sala de aula não autoritária. Sua relevância para os PIs vem do fato de reconhecer quanto é necessário a sociedade oferecer um ambiente educacional à criança. Os idosos teriam a função de ensinar as crianças a lidarem com suas realidades e providenciar papéis-modelo para serem bemsucedidas. Os idosos, então, seriam ideais como professores críticos informais e modelos positivos de quem soube lidar com as 
realidades da vida, por serem membros mais eruditos e experientes da sociedade.

- Lev Vygotsky: entendia a interação da criança com os outros em contexto social como um fator crucial para a modelagem do pensamento da criança. A cultura assume grande importância na sua teoria, pois é ela que oferece o contexto no qual todos os membros de uma sociedade estão inseridos. Os adultos são, aqui, os responsáveis por dividir seus conhecimentos e cultura e auxiliar as crianças na Zona de Desenvolvimento Proximal ${ }^{68}$.

- Erik Erikson: em sua teoria, o ambiente e as interações são influências no curso do desenvolvimento e considerava a criança como detentora de um papel ativo na modelação de suas experiências. Apesar de ter estabelecido limites etários rígidos de estágios de desenvolvimento, sua teoria é relevante para os PIs porque vai além da infância. Os idosos com riqueza de experiência de vida, sensibilidade e compreensão podem auxiliar a resolução da "crise" de cada um dos estágios.

Ainda utilizando o estudo de Newman e Smith (1997), falemos um pouco das teorias que tratam do desenvolvimento de adultos mais velhos. Essas teorias buscam lidar com:

1. Envelhecimento fisiológico: mudanças na aparência, saúde etc. As funções fisiológicas afetadas são: os sentidos (visão, tato, olfato, audição e paladar), a memória e a capacidade em "resolver problemas". Importante aqui ressaltar que os autores citam estudos que comprovam que a capacidade de aprendizagem não diminui significativamente com o envelhecimento. Os autores citam ainda Malcolm Knowles, criador do termo Andragogia para explicar a característica particular da educação de adultos,

68 Zona de Desenvolvimento Proximal: termo que descreve tarefas que a criança não é capaz de realizar sozinha, mas que é capaz de desenvolver com a ajuda de alguém mais habilidoso (geralmente um adulto). (Newman e Smith, 1997:9) 
na qual não há limite etário para a aprendizagem se os estímulos forem adequados. Para ele, qualquer perda na velocidade ou na memória pode ser totalmente compensada por habilidades na organização e com informações dadas em contexto significativo. Adultos mais velhos aprenderiam melhor em situações sociais (trocando informações com outras pessoas, incluindo os professores). Newman e Smith afirmam ainda que os jovens que entram em contato com idosos por meio dos PIs fornecem incentivos ao exercício, pensamento e interação que retardam os processos de envelhecimento.

2. Envelhecimento social: mudanças nos papéis sociais, na renda, mudanças emocionais, nas perspectivas e prioridades, isolamento, sentimento de não ter valor na sociedade, baixo nível de adaptação, menor influência sobre seu ambiente (menor poder). Jovens participantes de PIs mudam positivamente sua concepção a respeito da velhice e dos idosos, alterando suas atitudes em relação aos idosos em geral (não só aqueles com os quais convivem). Os autores dizem que uma política social de incentivo ao crescimento dos PIs pode afetar as perspectivas sociais.

3. Envelhecimento emocional: estereótipos destrutivos com base em crenças incorretas sobre envelhecimento, baixa autoestima, sentimento de inutilidade, isolamento etc. PIs que incentivam o treinamento, a motivação e atividades significativas para os idosos afetam positivamente sua autoestima e a sensação de serem valorizados.

Ainda seguindo Newman e Smith (1997), as principais teorias que discutem os tópicos citados acima são: Teoria do Engajamento e Desengajamento (a interação social reduziria ou retardaria o impacto do envelhecimento); Teoria da Adaptação (adaptar-se à perda de papéis sociais e procurar novos e significativos papéis); e Teoria da Revisão da Vida (revisão crítica da vida - poderia ser suportada 
pelas gerações mais novas - em que os mais velhos passam suas experiências de vida, criticamente, auxiliando as gerações mais novas na modelação de seu pensamento crítico).

\subsubsection{Tipos e modelos de Programas Intergeracionais}

James McCrea e Thomas Smith (1997b) e Ann Kristin Bostrum et al. (2000) organizam os modelos de Programas Intergeracionais em 3 tipos mais usuais:

- Idosos servindo crianças e jovens;

- Crianças e jovens servindo idosos;

- Crianças, jovens e idosos trabalhando juntos pela comunidade.

Hatton-Yeo et al. (2000), no estudo colaborativo para a Unesco, identificaram um modelo a mais de PI a ser levado em consideração:

- Idosos, jovens e crianças juntos em atividades de aprendizagem informais, recreativas, lazer e eventos esportivos ou festivais e mostras de arte.

A seguir, é possível encontrar as tabelas dos modelos dos Programas Intergeracionais (separados por tipos) relatados por McCrea e Smith (1997b). Trata-se de uma adaptação que fizemos das tabelas encontradas no texto dos autores, sobre as quais fizemos algumas reformulações como a inclusão da equipe necessária, o tipo de atividade realizada e os resultados obtidos tanto com jovens quanto com idosos. Encontraremos nessas tabelas os detalhes sobre cada um dos programas, no entanto, relatamos antecipadamente quais modelos se encaixam dentro desses tipos de PIs indicados pelos autores:

1) Idosos servindo crianças e jovens. São cinco os modelos: a) mentores; b) tutores; c) cuidadores e criadores; d) amigos maduros; e) treinadores. 
2) Crianças e jovens servindo idosos. Três modelos: a) visitantes; b) companheiros e auxiliares; c) professores.

3) Crianças, jovens e idosos servindo juntos. Quatro modelos: a) embelezamento cívico; b) planejamento comunitário; c) visitantes; d) advocacia.

Como dissemos anteriormente, os PIs existentes são geralmente voltados para idosos, crianças e jovens. Mais adiante (cf. 3.4.), discutiremos as razões de considerarmos o Italiano no Campus como detentor dos elementos para se tornar um Programa Intergeracional e de poder ser inserido, de certa forma, no quarto modelo levantado no estudo de Hatton-Yeo et al. (2000). 


\begin{tabular}{|c|c|c|c|c|c|}
\hline 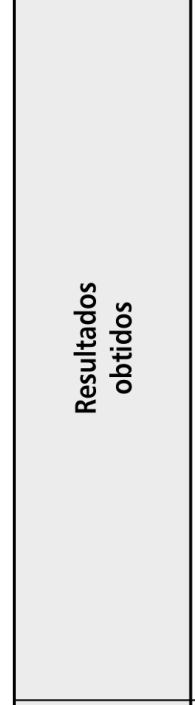 & 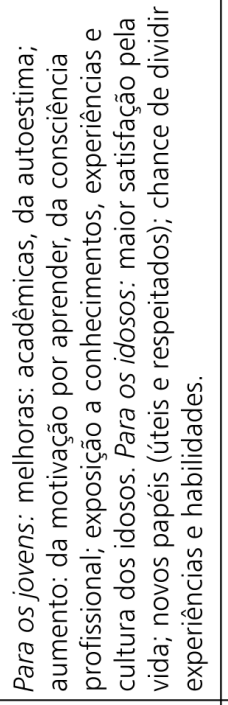 & 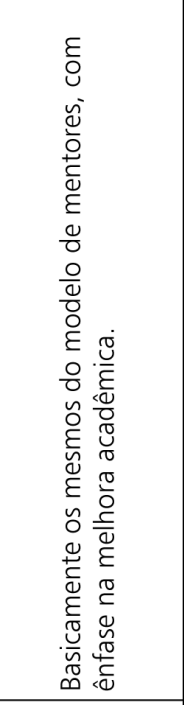 & 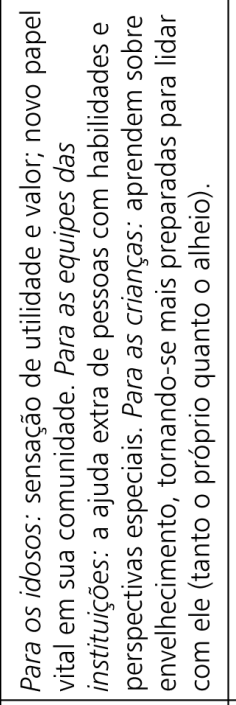 & 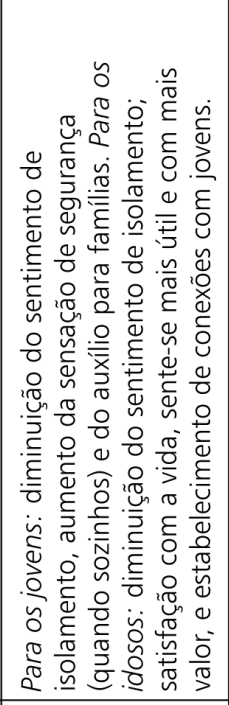 & 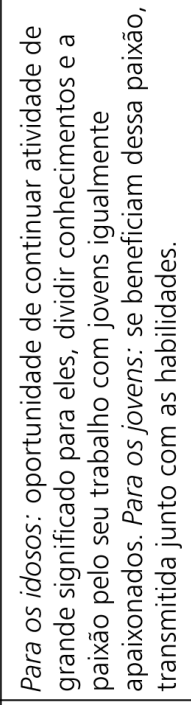 \\
\hline 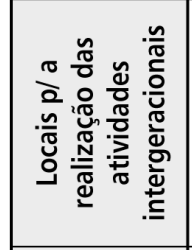 & 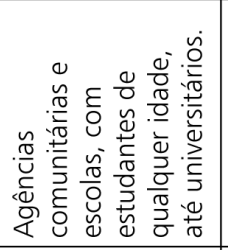 & 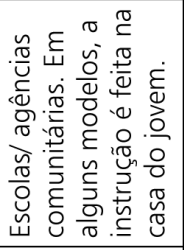 & 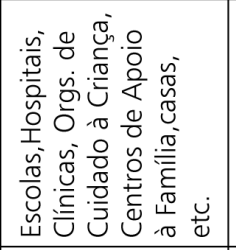 & 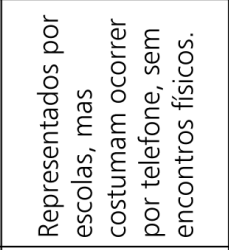 & 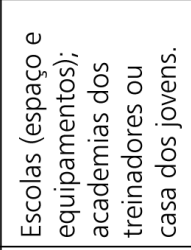 \\
\hline 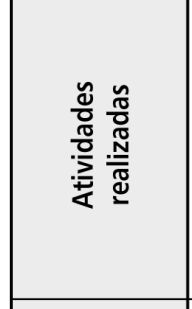 & 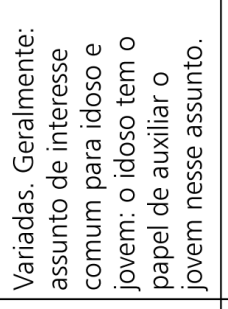 & 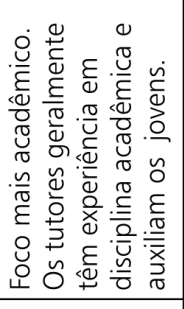 & 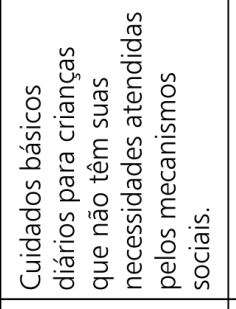 & 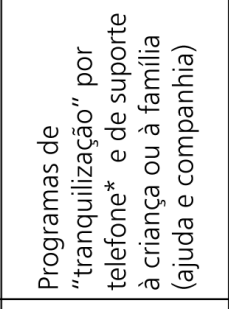 & 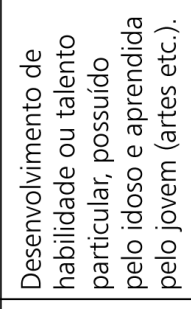 \\
\hline 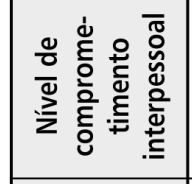 & 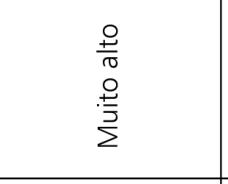 & $\frac{9}{4}$ & $\frac{\text { 운 }}{2}$ & $\begin{array}{l}\frac{9}{\pi} \\
\frac{0}{0} \\
0 \\
\frac{x}{\pi} \\
\infty\end{array}$ & $\stackrel{\circ}{\frac{1}{4}}$ \\
\hline 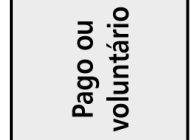 & 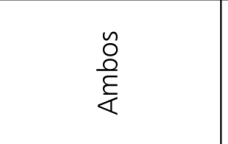 & 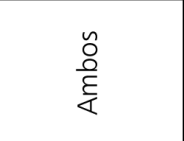 & 哭 & $\begin{array}{l}\tilde{O} \\
\frac{O}{\xi} \\
\frac{\xi}{4}\end{array}$ & 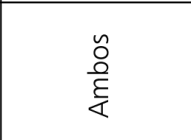 \\
\hline 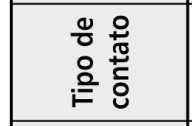 & $\underset{\sigma}{\sim}$ & 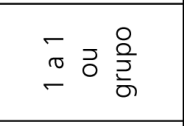 & 흥 울 & $\underset{\sigma}{-}$ & 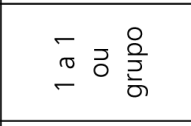 \\
\hline 胥 & 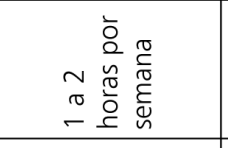 & 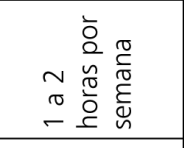 & 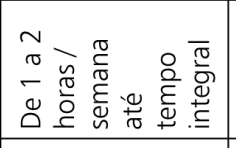 & 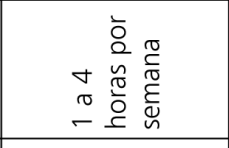 & 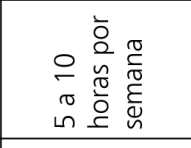 \\
\hline 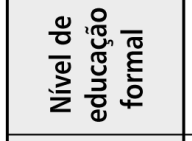 & $\begin{array}{l}\frac{0}{0} \\
\frac{0}{2}\end{array}$ & $\begin{array}{l}\frac{0}{0} \\
\frac{0}{2}\end{array}$ & 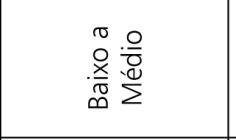 & 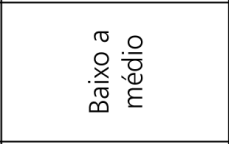 & $\frac{9}{\frac{9}{4}}$ \\
\hline 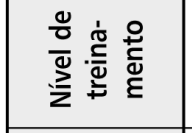 & $\frac{9}{4}$ & $\frac{.0}{\overline{0}}$ & $\begin{array}{l}\frac{0}{\overline{0}} \\
\frac{\mathrm{d}}{2}\end{array}$ & $\begin{array}{l}\frac{0}{\overline{0}} \\
\frac{\mathrm{d}}{2}\end{array}$ & $\frac{9}{\frac{1}{4}}$ \\
\hline 竞 & 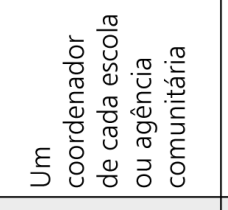 & 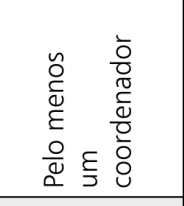 & 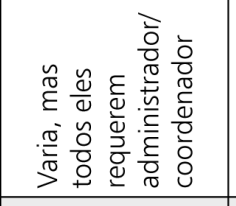 & 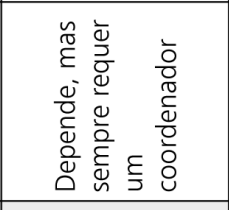 & 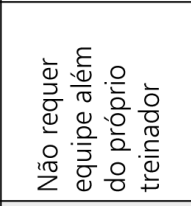 \\
\hline$\frac{\circ}{\frac{0}{0}}$ & 5ә107 & รә.0 & 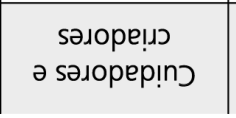 & $\begin{array}{l}\text { sodnpew } \\
\text { so6!uu }\end{array}$ & \\
\hline
\end{tabular}




\begin{tabular}{|c|c|c|c|}
\hline 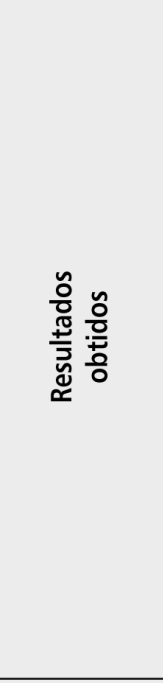 & 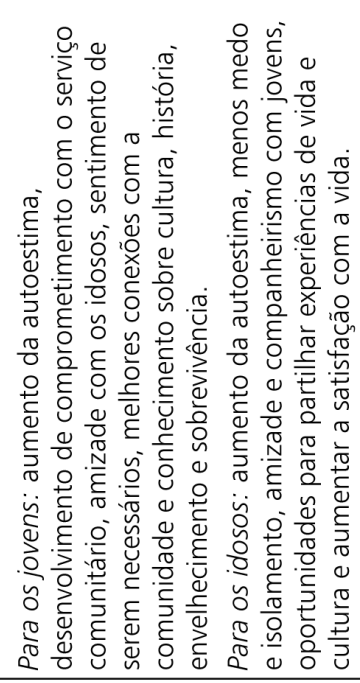 & 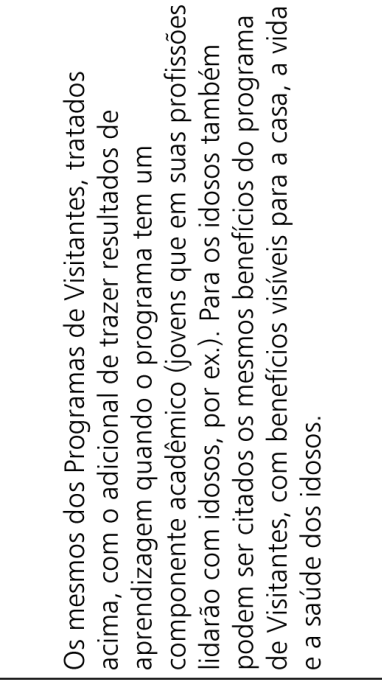 & 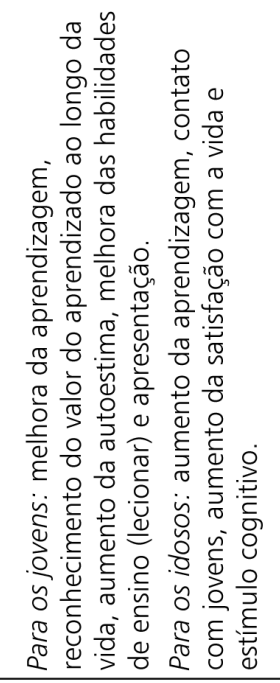 \\
\hline 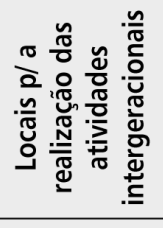 & 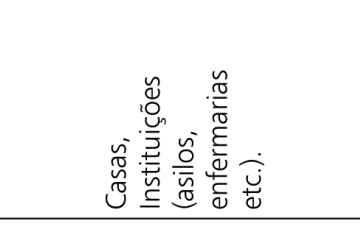 & 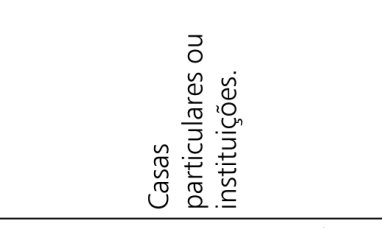 & 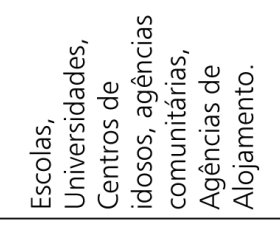 \\
\hline 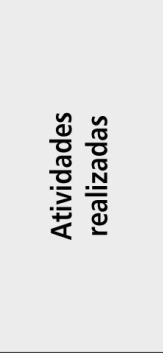 & 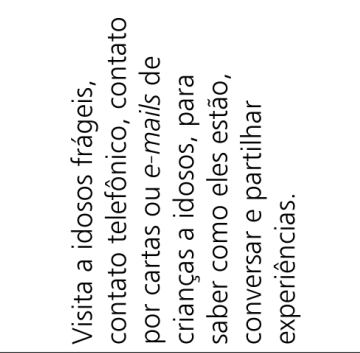 & 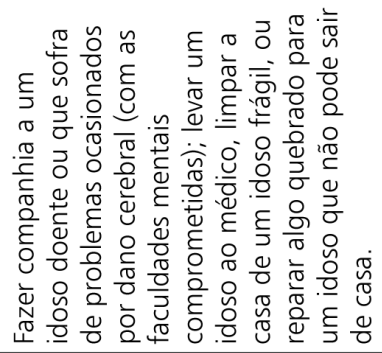 & 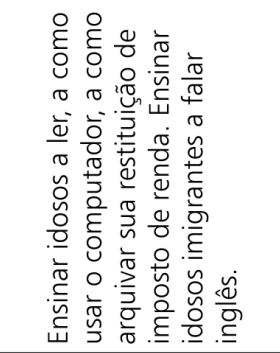 \\
\hline 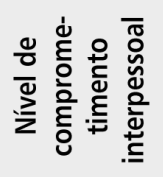 & $\begin{array}{l}\frac{0}{0} \\
\frac{\pi}{0} \frac{0}{\pi} \\
\frac{0}{0} \frac{1}{\pi} \\
\frac{0}{2}\end{array}$ & 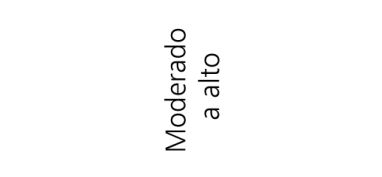 & 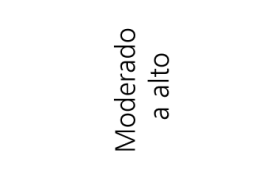 \\
\hline 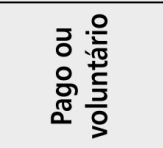 & $\begin{array}{l}\stackrel{\frac{0}{2}}{\frac{0}{50}} \\
\frac{5}{5} \\
\frac{5}{9}\end{array}$ & 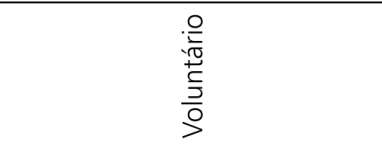 & $\begin{array}{l}\stackrel{\frac{0}{2}}{\cdot \frac{10}{2}} \\
\frac{3}{5} \\
\frac{3}{2}\end{array}$ \\
\hline 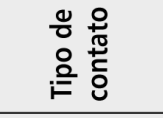 & - & 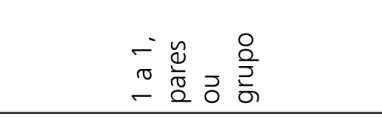 & - \\
\hline 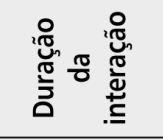 & 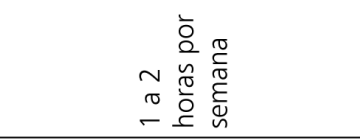 & 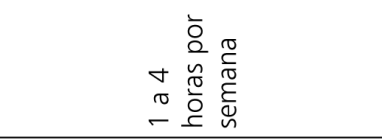 & 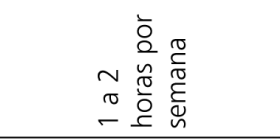 \\
\hline 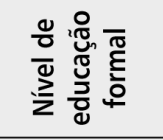 & 胥 & 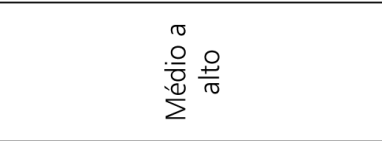 & 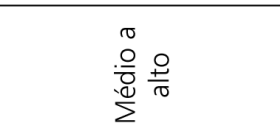 \\
\hline 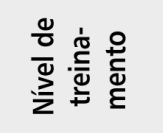 & . & $\begin{array}{l}\frac{\pi}{2} \\
\frac{\circ}{\circ} \circ \frac{0}{0} \\
\frac{0}{2}\end{array}$ & 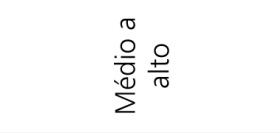 \\
\hline 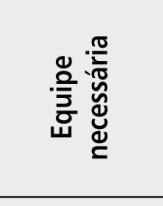 & 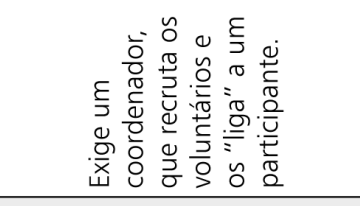 & 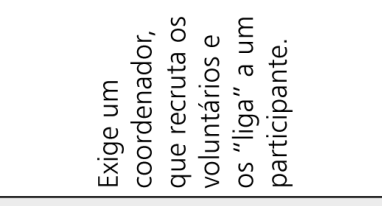 & 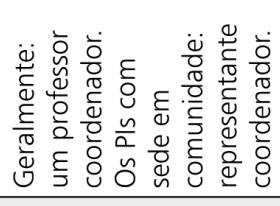 \\
\hline $\begin{array}{l}\frac{0}{0} \\
\frac{0}{2} \\
\frac{0}{\Sigma}\end{array}$ & səłueł!s!n & $\begin{array}{c}\text { səدe!!!xne ə } \\
\text { soג!्yueduoJ }\end{array}$ & səגossəfold \\
\hline
\end{tabular}




\begin{tabular}{|c|c|c|c|c|}
\hline 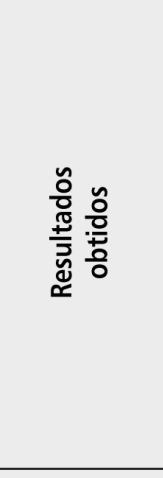 & 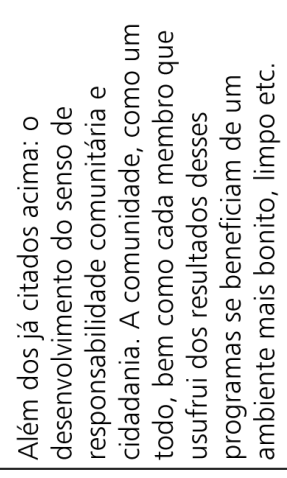 & 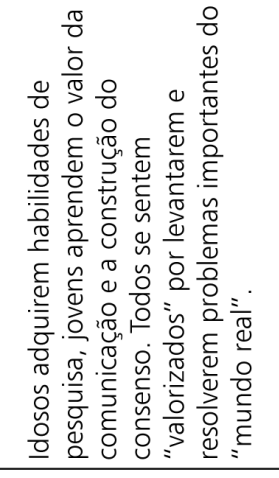 & 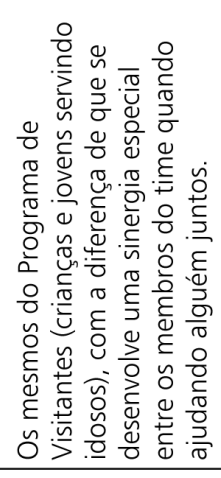 & 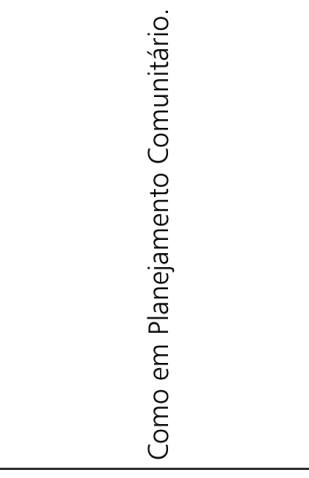 \\
\hline 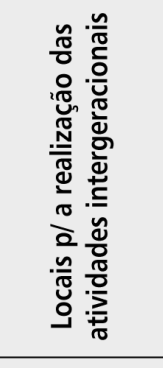 & 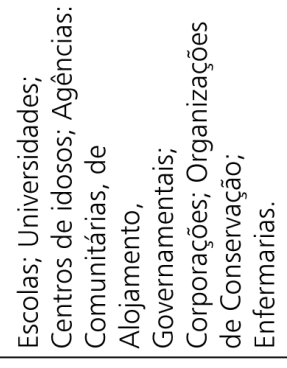 & 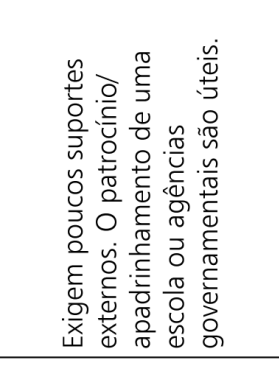 & 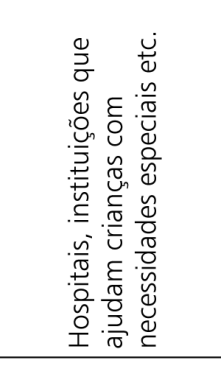 & 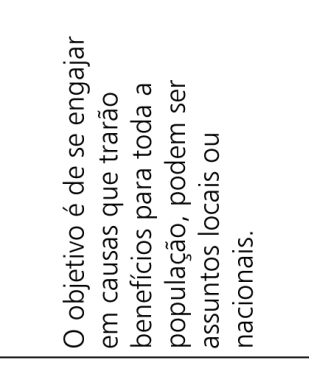 \\
\hline 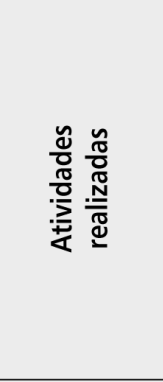 & 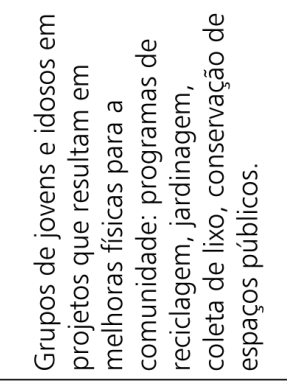 & 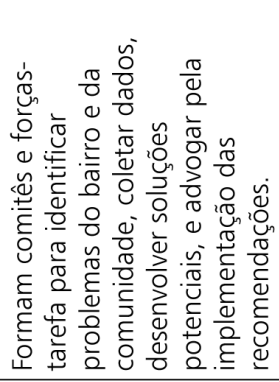 & 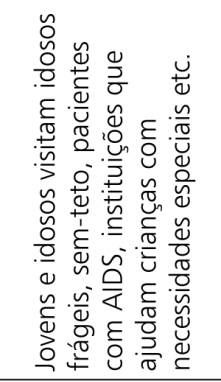 & 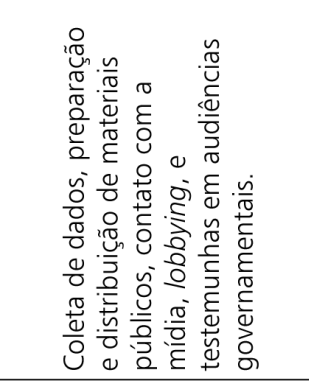 \\
\hline 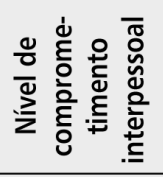 & $\begin{array}{l}\text { 胥 } \\
\text { 原 }\end{array}$ & $\frac{9}{\frac{1}{4}}$ & $\begin{array}{l}\frac{\pi}{0} \\
\frac{0}{0} \\
\frac{\pi}{\pi} \frac{9}{\pi} \\
\frac{0}{0} \\
\sum^{0}\end{array}$ & $\frac{9}{\frac{1}{4}}$ \\
\hline 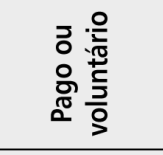 & $\begin{array}{l}\text { o } \\
\text { oे } \\
\text { है }\end{array}$ & $\begin{array}{l}\frac{.0}{50} \\
\stackrel{\frac{9}{0}}{5} \\
\frac{3}{9} \\
\end{array}$ & 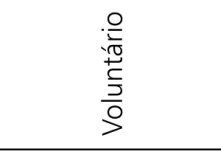 & $\begin{array}{l}\frac{.0}{50} \\
\stackrel{\frac{0}{0}}{5} \\
\frac{0}{9} \\
\end{array}$ \\
\hline 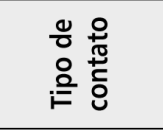 & 온 & 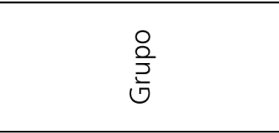 & 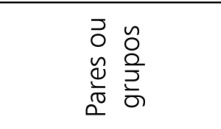 & $\sum_{0}^{\circ}$ \\
\hline 胥 & 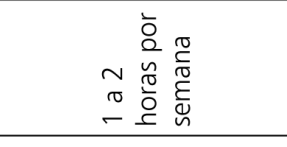 & 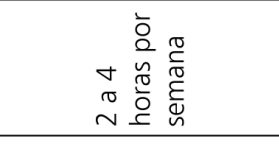 & 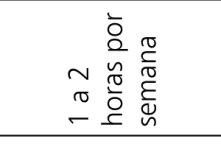 & 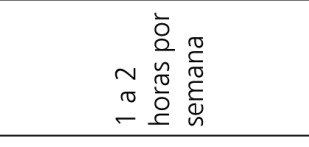 \\
\hline 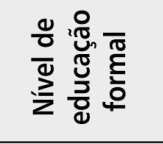 & 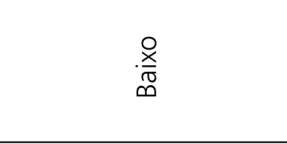 & $\begin{array}{l}\frac{\text { 음 }}{20} \\
\frac{0}{2}\end{array}$ & 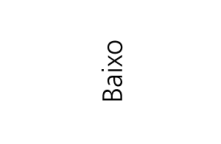 & $\begin{array}{l}\frac{0}{0} \\
\frac{0}{2}\end{array}$ \\
\hline 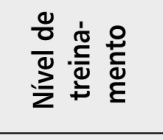 & 胥 & $\begin{array}{l}\frac{0}{0} \\
\frac{0}{2}\end{array}$ & 疍 & $\begin{array}{l}\frac{\text { 응 }}{\mathrm{v}} \\
\frac{\mathrm{g}}{2}\end{array}$ \\
\hline 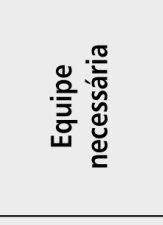 & 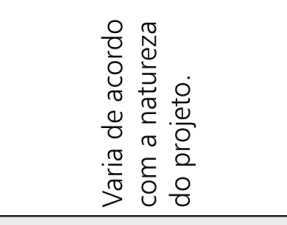 & 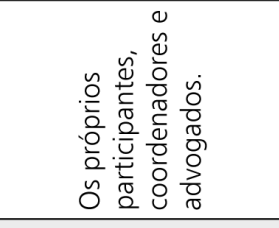 & 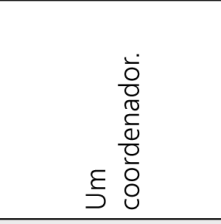 & 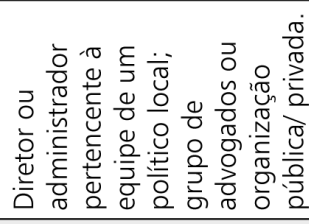 \\
\hline$\frac{0}{\frac{0}{0}}$ & 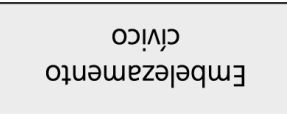 & 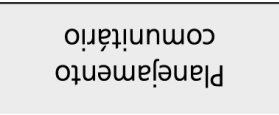 & sәңиет!!!ı & ^P $\forall$ \\
\hline
\end{tabular}




\subsubsection{Objetivos e resultados dos Programas Intergeracionais}

Newman e Smith (1997) relatam que nos EUA, os PIs têm tido êxito em lidar com problemas sociais, econômicos e políticos. O intuito da criação desses programas se deve prioritariamente à necessidade de se refazer os laços entre gerações (principalmente entre as mais velhas e mais novas), os quais anteriormente eram "naturais" (dentro das famílias extensas).

Notou-se, então, que a relação entre essas gerações traria benefícios além daqueles familiares e que os PIs poderiam lidar com questões e problemas de ambas as gerações ao mesmo tempo.

Newman (1997b) relata que nos Estados Unidos o desenvolvimento dos PIs passou por duas fases. Na primeira, nas décadas de 1960-70, os programas eram voltados para assuntos relacionados à separação geracional. Na segunda, em 1980-90, os programas passaram a se voltar para os problemas da sociedade (que começaram a aparecer em resposta às forças sociais). Essa mudança de foco foi acompanhada por um aumento da consciência nacional sobre a importância social dos Programas Intergeracionais.

Devemos lembrar que os Estados Unidos têm uma das mais avançadas redes de Programas Intergeracionais, cujos modelos são bem estabelecidos. Bostrum et al. (2000) destacam os Estados Unidos como exceção no ainda desafio de oferecer treinamento profissional para os PIs. A rede de trabalho (networking) dos PIs nos EUA tornou-se uma iniciativa nacional e formalmente estruturada em 1986, promovendo workshops, encontros e conferências a fim de oferecer suporte aos PIs já existentes e encorajar a criação de novos modelos. A profissionalização para o trabalho com os PIs emergiu em 1980. Em 1990, com o grande número de pessoas envolvidas com o trabalho intergeracional, começou-se a criar uma 
variedade de cursos universitários, institutos de treinamento e outras várias opções acadêmicas para preparar "especialistas intergeracionais".

\section{Objetivos}

No trabalho de McCrea e Smith (1997a), as áreas sociais com que os PIs buscam lidar são:

- a necessidade de segurança e proteção: o aumento da falta de segurança (real e a percepção de segurança). Os idosos podem trabalhar no cuidado à criança - necessidade crescente pelo número cada vez maior de pais que trabalham fora. Existem programas de ajuda a idosos que colaboram na diminuição da pressão de filhos que cuidam de pais idosos, e adolescentes que estudam o envelhecimento têm a possibilidade de prática no campo, trabalhando no auxílio a idosos;

- a necessidade de cuidado: neste caso o PI pode envolver simultaneamente as crianças e os idosos. Os idosos cuidando de crianças que ficam sozinhas enquanto os pais trabalham; as crianças que servem de companhia para idosos ou os auxiliam em tarefas domésticas;

- a necessidade de estabilidade: as rápidas mudanças sociais e o impacto de pais solteiros, divórcios etc. na estabilidade das famílias têm sido ligados à violência e depressão, e também à falta de autoestima entre crianças. Acredita-se que o impacto dos PIs nessas áreas poderá ser notado a longo prazo, pois eles ajudam a solidificar comunidades e fornecer estabilidade familiar e individual, além de exercer impacto nas atitudes entre os diferentes grupos etários;

- a necessidade de educação de qualidade: idosos auxiliando os mais jovens nos estudos e ensinando as "artes perdidas" (os autores citam como exemplo o ensinar a fazer pão). Enquanto os jovens ensinam os idosos a lidarem com as novas tecnologias; 
- a necessidade de ser produtivo: as altas taxas de crime juvenil nos EUA estão relacionadas à falta de oportunidades de produção educativa e recreativa fora da escola. Na área gerontológica, aponta-se a necessidade de idosos se envolverem em atividades produtivas após a aposentadoria para manter a saúde física, mental e emocional;

- a necessidade de contato entre as gerações: o aumento da segregação por faixas etárias nos ambientes sociais e a perda do contato intergeracional familiar levam à necessidade de outros tipos de contato entre as gerações a fim de promover o respeito e o entendimento entre as gerações.

Segundo Lima (2008:61), os objetivos dos PIs em relação aos idosos são:

- minimizar as perdas do processo do envelhecimento;

- promover a inclusão e valorização da pessoa idosa;

- criar oportunidades de transmissão de conhecimentos, habilidades e valores humanos a outras gerações.

Em relação às crianças e adolescentes (Lima, 2008:61):

- promover o contato diferenciado com o idoso (incentivado por meio de interação);

- criar oportunidade de trocas de experiências entre as pessoas de idades diferentes e da aprendizagem de habilidades pela educação informal;

- desenvolver um novo olhar sobre questões que envolvem o envelhecimento;

- estimular o resgate das brincadeiras tradicionais;

- desenvolver novas aptidões;

- promover a educação ao longo da vida. 


\section{Resultados obtidos}

\section{Idosos}

Dentre os resultados positivos obtidos com relação aos idosos, citado por Lima (2008:61), estão:

- "A ressignificação da sua identidade social;

- "O despertar de um novo olhar sobre as questões do envelhecimento;

- "O aumento da auto-estima e melhoria da saúde;

- $\quad$ "A possibilidade de uma nova perspectiva de vida e realização pessoal;

- "A criação de oportunidades que lhes permitam transferir a experiência de vida, valores acumulados e afetividades;

- "A promoção de novos relacionamentos positivos e estimulantes com as crianças, com profissionais e com a comunidade em geral;

- "A redução do isolamento e a promoção de um estilo de vida mais saudável e estimulante;

- "E a maior disponibilidade para aceitar e compreender o comportamento dos jovens de hoje."

Já McCrea e Smith (1997a) relatam os seguintes resultados em idosos:

- $\quad 41 \%$ das atividades intergeracionais têm impacto positivo em idosos;

- o contato com pessoas mais novas encoraja um sentido de continuidade pessoal;

- residentes de asilos que participam de PIs são mais alertas, ativos e sorriem mais;

- o contato intergeracional aumenta o funcionamento físico, cognitivo e emocional dos idosos. 


\section{Crianças e jovens}

Para as gerações mais novas, Lima (2008: 62) cita os seguintes resultados:

- "A promoção da troca afetiva entre as gerações;

- "O fortalecimento dos vínculos intergeracionais por meio da interação;

- "O aumento do interesse pela aprendizagem, pelo saber, pelo conhecimento, pelo convívio informal com os idosos;

- "A melhoria do relacionamento com os mais velhos;

- "E um melhor entendimento sobre o envelhecer e suas necessidades, com o estímulo para ajudar os mais velhos."

McCrea e Smith (1997a) relatam como resultados:

- O compartilhamento de experiências dos idosos aumenta o entendimento do funcionamento do mundo para os mais jovens.

- As crianças lidam melhor com mudanças, principalmente com aquelas relacionadas ao envelhecimento, se elas estiverem em contato com modelos positivos de envelhecimento (pessoas que gostam de sua idade e que estão envolvidas em atividades produtivas).

- Aumento da compreensão do ciclo da vida.

- As crianças em contato com idosos aprendem a vê-los como pessoas (com suas particularidades) e não como figuras estereotipadas.

- Os mais jovens aprendem mais sobre a história (nacional, geral etc.) com os relatos de quem a vivenciou.

- Jovens que entram em contato com idosos frágeis podem ser preparados para oferecer amparo a outros idosos nessas condições.

Carvalho (2007) afirma que a interação que ocorre entre os membros de um grupo é fundamental para a quebra de preconceitos e para o diálogo intergeracional. ${ }^{69}$ 


\subsubsection{Programas Intergeracionais no Brasil}

Ainda são poucos os PIs no Brasil e os estudos no campo. Muitos dos estudos que abordam a questão intergeracional se concentram no âmbito familiar ou na forma como essas relações ocorrem, mas poucos trabalhos abordam os PIs (programas feitos para unir gerações). Lima (2008) cita em seu trabalho alguns estudos intergeracionais: Novaes $^{70}$ entrevistou 452 pessoas, de 17 a 101 anos, sobre as diferentes lições de vida das gerações; Oliveira ${ }^{71}$ fez entrevistas a fim de verificar como a convivência entre avós e netos (quando os avós assumem o papel de cuidadores) de classes populares se modificava com a convivência; Ruschel e Castro $^{72}$ analisaram os discursos de 20 mulheres idosas e 10 jovens para avaliar as relações de interação e poder entre pais e filhos e avós e netos.

Ainda em Lima (2008), podemos encontrar o levantamento de alguns dos trabalhos brasileiros no campo dos PIs. São eles:

- José Carlos Ferrigno (2003): já citado no primeiro capítulo. Seu trabalho intergeracional envolvia professores de 25 a 45 anos e alunos idosos do SESC-SP. Seu livro traz depoimentos de alunos e professores e centra-se no conceito de coeducação entre gerações.

- Souza ${ }^{73}$ : projeto "Reminescências integrando gerações". Desenvolvido no Distrito Federal, os participantes eram 13 grupos de estudantes, de 8 a 13 anos, e três grupos de idosos. O estudo relata mudanças positivas em jovens e idosos, inclusive com a diminuição de preconceito contra o idoso.

70 NOVAES, M. H. (2005). As gerações e suas lições de vida: aprender em um tempo do viver. Rio de Janeiro: Puc-Rio; São Paulo: Loyola.

71 OLIVEIRA, P. S. (1999) Vidas compartilhadas. Cultura e co-educação de gerações na vida cotidiana. São Paulo: Hucitec/FAPESP.

72 RUSCHEL, A. E.; CASTRO, O. P. (1998a). O vínculo intergeracional: o velho, o jovem e o poder. Psicologia: Reflexão e Crítica, 11 (3), Porto Alegre, p.523-39.

RUSCHEL, A. E.; CASTRO, O. P. (1998b). A intergeracionalidade na dinâmica das relações de poder familiar. In: CASTRO, O. P. (org.). Velhice, que idade é essa? Uma construção psicossocial. Porto Alegre: Síntese.

73 SOUZA, E. M. (2003). Intergenerational interaction in health promotion: a qualitative study in Brazil. Revista da Saúde Pública, 37 (4), p. 463-69. 
- Brandão, Smith, Sperb e Parente ${ }^{74}$ : fizeram uma "revisão na literatura sobre a produção narrativa de crianças e adultos idosos, localizando estudos intergeracionais". (Lima, 2008:66)

- Centro de memória da Unicamp (CMU): pesquisa-ação realizada para resgatar a história de três bairros de Campinas. Os moradores mais antigos foram convidados a relatar às gerações mais novas sobre a história do bairro. "Crianças e adolescentes passaram não apenas a tomar conhecimento da história do local onde vivem, como também a compreender melhor a realidade deles e a reconhecer a própria identidade". (Lima, 2008: 67)

- Lopes ${ }^{75}$ : utilizou o "Projeto Jarinú tem Memória", da Unicamp, com o intuito de verificar as representações sociais que dois grupos de crianças tinham em relação à velhice e aos velhos, bem como a influência do projeto nessas representações.

De acordo com os autores citados, a intergeracionalidade é, por si só, um fator de promoção de igualdade entre gerações. Em uma dimensão maior, propicia a mudança de mentalidades, reforça a cidadania e envolve valores éticos, de igualdade social, democracia, justiça e dignidade, os quais dependem de conceitos culturais, econômicos e sociais. (Lima, 2008:68)

\subsubsection{O estudo em colaboração com a UNESCO}

Em 2000, pesquisadores de diferentes países se reuniram em uma coletânea com intuito de fazer uma avaliação da situação dos Programas Intergeracionais (o que já foi feito, quais os resultados obtidos etc.), propor

74 BRANDÃO, L.; SMITH, V.; SPERB, T. M.; PARENTE, M. A. M. P. (2006). Narrativas intergeracionais. Psicologia: Reflexão \& Crítica, 19 (1), p.98-105.

75 LOPES, E. S. L. (2006). Crianças e velhos no Projeto Jarinú tem Memória: representações sociais e significados. Tese de doutorado do Programa de Pós-graduação em Gerontologia da Universidade Estadual de Campinas. 
caminhos para o futuro e promover uma divulgação mais abrangente dos PIs, bem como encorajar a implementação em diversas regiões do mundo.

O documento traz recomendações para a aplicação bem-sucedida dos PIs e para a melhora desse tipo de programa. Não abordaremos aqui todos os tópicos tratados no estudo, mas ressaltaremos aqueles que interessam a essa pesquisa, principalmente os que tratam da educação ao longo de toda a vida.

\section{Para obtenção de êxito nos Programas Intergeracionais}

A definição internacional adotada em abril de $1999^{76}$ propõe as seguintes características como essenciais para o sucesso dos PIs: ${ }^{77}$

- "Que eles demonstrem benefícios mútuos para os participantes;

- "Que eles estabeleçam novos papéis sociais e/ou novas perspectivas para participantes idosos e jovens;

- "Que eles possam envolver múltiplas gerações e que incluam ao menos duas gerações não-adjacentes e não-familiares;

- "Que eles promovam o aumento da consciência e do entendimento entre as gerações mais novas e mais velhas e o crescimento da autoestima em ambas as gerações;

- "Que tratem de assuntos sociais e políticos relevantes para as gerações envolvidas;

- "Que incluam elementos de bom planejamento de programa;

- "Que relações intergeracionais sejam desenvolvidas." 


\section{Áreas de impacto dos PIs:}

O estudo comprova o êxito obtido com os Programas Intergeracionais em lidar com problemas sociais. As áreas de impacto dos PIs são as seguintes:

1) Economia e emprego. Os Programas Intergeracionais possibilitam que aposentados continuem a trabalhar (recebendo ou não para isso), assegurando a renda dos idosos e ajudando na questão da diminuição da força de trabalho (resultado da aposentadoria dos baby-boomers, da maior longevidade e da queda na taxa de fertilidade); O PIB aumenta quando todas as gerações estão envolvidas em atividades econômicas produtivas e quando dividem fontes por um benefício mútuo; etc.

2) Na sociedade. Os PIs contribuem para uma cultura de paz entre as gerações; buscam reduzir o conflito entre as gerações; etc.

3) Na aprendizagem ao longo da vida. Muito do que se fala nesse ponto trata dos PIs que envolvem as escolas, onde os idosos servem aos jovens como tutores, por exemplo (como vimos anteriormente neste mesmo capítulo). A abordagem intergeracional oferece maneiras de enriquecer o processo de aprendizagem e ensino; ao não requerer espaço, material e outros itens diferenciados para cada idade, tornase economicamente rentável para a sociedade, além de aproveitar os recursos já existentes de maneira mais eficiente; os PIs ajudam os idosos que estão em risco de serem excluídos socialmente e de terem uma vida solitária ao colocá-los em contato com outras gerações e em serviços voluntários, e os mais jovens podem ter a aquisição de habilidades da vida acelerada com o contato com os idosos; transmissão da cultura, que é um valioso papel cultural da aprendizagem ao longo da vida; os PIs promovem, tanto nos jovens como nos idosos, maior aprendizagem sobre o desenvolvimento humano e o envelhecimento, deixando os participantes mais conscientes dos assuntos sociais, políticos, econômicos e culturais que envolvem o envelhecimento; etc. 
4) Na saúde. Os PIs promovem um envelhecimento ativo e participação social, o contato com os mais jovens faz com que idosos se previnam contra problemas de saúde e facilita a recuperação de doenças ou ferimentos - consequentemente há uma redução dos custos de assistência médica e social; criação de empregos em serviços de cuidados (idosos cuidando de crianças e jovens; e jovens e pessoas de "meia-idade" servindo aos idosos); etc.

Como pudemos observar em todo o ponto 3.3., os Programas Intergeracionais trazem benefícios a todos que deles participam. Desde sua criação e elaboração, os PIs foram pensados para refazer os laços intergeracionais, estimular o respeito e o conhecimento de uma geração sobre a outra e lidar com questões sociais. Como vimos, os resultados obtidos com os PIs foram positivos.

\subsection{O que consideramos intergeracional e o Italiano no Campus}

Embora os trabalhos que tratem das relações intergeracionais, bem como de Programas Intergeracionais, tratem da necessidade de trabalhos que envolvam também outras gerações, a maior parte deles se concentra na união de crianças, jovens e idosos, saltando as gerações intermediárias.

Adotamos para este estudo uma visão de intergeracional na qual várias gerações diferentes estejam em contato por um objetivo em comum, neste caso, aprender a língua italiana. Mannhein (s/d) observa que o contato entre as gerações mais velhas e mais novas ter sempre envolvido uma geração intermediária. Da mesma forma que esse contato acontece, acreditamos que as gerações em um mesmo ambiente - mais novas, mais velhas $E$ intermediárias - seja tão benéfico quanto os outros tipos de Programas Intergeracionais aqui mencionados. 
Antes de explicarmos por que classificamos o Italiano no Campus como um grupo intergeracional, falaremos um pouco sobre sua história e constituição.

Escolhemos o Italiano no Campus para a pesquisa não apenas porque esta é uma das finalidades de sua criação (servir à pesquisa dos alunos de pósgraduação do programa), mas principalmente por termos ali um público diferente do encontrado em outros cursos de língua italiana ${ }^{78}$.

\subsubsection{Histórico do Italiano no Campus ${ }^{79}$}

Os cursos de língua começaram a ser oferecidos pela Secretaria de Cultura e Extensão da Faculdade de Filosofia, Letras e Ciências Humanas da USP em 1994, sendo o inglês o primeiro deles.

O curso de língua italiana passou a ser oferecido como curso de extensão no ano seguinte, em 1995, sob coordenação da Profa. Dra. Mariarosaria Fabris. Na época, apenas o nível um foi oferecido e teve 33 alunos inscritos. Em 1997, o curso só foi oferecido no primeiro semestre, com o nome de Italiano $I V$, e contou com 38 inscritos, com carga horária de 36 horas.

Depois de um ano e um semestre sem aparecer dentre os cursos de extensão oferecidos, o curso de língua italiana volta em 1999, com o nome Italiano para Principiantes, sob a coordenação da Profa. Dra. Paola G. Baccin - com carga horária de 36 horas. Nesse período, o curso foi ministrado em dois horários diferentes (segundas e quartas-feiras e terças e quintas-feiras, sempre no horário das 12 h15 às 13h45) e teve, durante todo o ano de 1999, 320 inscritos. Contava, então, com dois monitores. A partir desse momento o curso de italiano não parou mais de crescer. No primeiro semestre de 2006, recebeu oficialmente o nome de Italiano no Campus.

78 Veremos como, no capítulo cinco

79 As informações utilizadas para elaboração do histórico do Italiano no Campus foram fornecidas pela Secretaria de Cultura e Extensão da Faculdade de Filosofia, Letras e Ciências Humanas da USP, pelas coordenadoras, monitores e ex-monitores do IC. 
Em 2009, foram 740 alunos inscritos (sendo 374 deles só no segundo semestre).

O Italiano no Campus hoje é dividido entre os cursos de Língua, Conversação e Língua \& Cultura, totalizando, no primeiro semestre de 2010, 32 grupos ativos $^{80}$, dentre os quais, 25 são de língua. Os cursos têm carga horária de 45 horas e contavam, até o primeiro semestre de 2010, com oito monitores. Os cursos de extensão sempre foram ministrados por estudantes de pós-graduação do programa de Língua e Literatura Italiana. O Italiano no Campus também oferece cursos de férias intensivos nos meses de fevereiro e julho, com a mesma carga horária dos cursos semestrais.

O Italiano no Campus surgiu com o intuito de atender à comunidade USP, em primeiro lugar, e também para servir de laboratório aos estudantes de pós do programa. Sempre são disponibilizadas sete bolsas de estudo para cada um dos níveis, sendo que as bolsas são sorteadas entre a comunidade USP (duas para discentes, uma para docentes, uma para funcionários) e a terceira idade (três bolsas). Além das bolsas, há descontos para a terceira idade, professores ativos da rede pública, monitores bolsistas, estagiários e alunos da FFLCH. É gratuito para docentes e funcionários da FFLCH.

Importante ressaltar que a denominação "terceira idade" (e as bolsas destinadas a este público) definia pessoas com mais de cinquenta anos. Foi a partir de 2002 que se passou a considerar terceira idade aqueles com sessenta anos ou mais.

\section{A coordenação}

A coordenação do Italiano no Campus é revezada entre os professores da Área de didática de Língua e Literatura Italiana e sempre conta com um vice- 
coordenador também da Área. Não existe um tempo mínimo ou máximo de permanência estabelecido, e o trabalho de coordenação do Italiano no Campus não é remunerado.

Cabe à coordenação tratar das questões administrativas e burocráticas (abertura de turmas, adequar os cursos às instâncias necessárias para sua realização, pagamento de monitores etc.), mas seu principal papel é a questão didática e a formação docente. São realizadas reuniões mensais entre monitoria e coordenação, nas quais se visa, principalmente, à reflexão sobre a prática didática. A coordenação também elabora e oferece cursos de atualização aos monitores, abertos também a outros professores de italiano.

Outra função do coordenador é a de atender os alunos caso seja necessário.

O Italiano no Campus iniciou sua sexta coordenação no segundo semestre de 2010.

\section{A monitoria}

Os cursos de extensão de italiano sempre foram ministrados por estudantes de pós-graduação do programa, que passam por um processo seletivo para o cargo de monitoria. Para tanto, o pré-requisito é possuir uma graduação e estar matriculado em um curso de pós-graduação, cujo diploma será conferido pela Faculdade de Filosofia, Letras e Ciências Humanas da USP. O teste de seleção conta com prova escrita, análise de currículo e prova didática. Sendo que cada uma das etapas é eliminatória.

Os monitores recebem uma remuneração mediante bolsa, não consistindo em vínculo empregatício com a unidade, e o valor da remuneração depende do número de horas/aula lecionadas. A divisão do número de horas/aula dos monitores é estabelecida em reunião com todos os monitores e coordenação, de acordo com a disponibilidade de horários de cada um. 
Os monitores do Italiano no Campus geralmente possuem a licenciatura em língua italiana, mas ela não é pré-requisito.

\section{O curso de língua}

O Italiano no Campus, como dissemos, tem seus cursos divididos em Língua, Conversação e Língua \& Cultura. O nosso foco aqui são os cursos de língua, pois geralmente o público dos outros cursos são os próprios alunos dos cursos de língua.

Os cursos de língua são divididos em oito módulos de 45 horas cada um. Atualmente adota-se um livro didático, mas o planejamento das aulas e de todas as atividades-extra fica a cargo do monitor, permitindo flexibilidade na condução das atividades.

Para cada módulo há uma avaliação ao final do semestre, que consiste em um teste escrito com redação (70\% do valor da nota) mais um teste oral (valendo os 30\% restantes da nota). A avaliação escrita é unificada para cada nível, com a pontuação predeterminada e com a avaliação da redação feita com base em critérios discutidos em reuniões entre monitoria e coordenação. A avaliação oral fica a cargo do monitor, mas segue os critérios de avaliação formulados por monitores e coordenação, seguindo uma tabela de pontuação que tem como base os critérios estabelecidos pelo Quadro Comum Europeu ${ }^{81}$.

Ao final de cada módulo, os alunos recebem um certificado da Secretaria de Cultura e Extensão (SCE-FFLCH) e, ao final do curso, um certificado de conclusão.

Os horários das aulas geralmente se concentram naqueles em que o prédio da Faculdade de Letras não é usado pela graduação, sendo que, em alguns horários,

81 COUNCIL of Europe. (2001). Common European Framework of References for Languages. Cambridge: Cambridge University Press. Disponível em: <www.coe.int>. Acesso em: 22/01/2009. 
outros prédios da Faculdade de Filosofia, Letras e Ciências Humanas são utilizados por não terem aulas ${ }^{82}$.

\section{Infraestrutura}

O Italiano no Campus conta com a infraestrutura da própria FFLCH. Tanto monitores quanto coordenação falam da precariedade dessa infraestrutura disponível. São as mesmas dificuldades enfrentadas por todos os professores, inclusive dos cursos de graduação e de pós-graduação da Faculdade:

1. falta de salas adequadas ao número de alunos;

2. falta ou precariedade de equipamentos de áudio e vídeo;

3. falta de apoio aos cursos ministrados aos sábados, já que funcionários não trabalham nesse dia;

4. falta de ventiladores e aparelhos de ar condicionado que prejudicam a concentração nos meses mais quentes do ano;

5. precariedade na manutenção do prédio. Uma aluna idosa com dificuldades de locomoção, que, inclusive, abandonou o curso do IC, registrou a dificuldade de acesso aos andares devido a um elevador que permaneceu quebrado por muitos meses.

\section{O público do Italiano no Campus}

O pré-requisito para frequentar o Italiano no Campus é ter o ensino médio completo. Hoje, o curso tem como público muito mais do que só comunidade USP, havendo grande participação de moradores das redondezas.

82 O prédio de História e Geografia, por exemplo, não possui aulas matinais da graduação, e algumas salas são utilizadas pelo Italiano no Campus. Aos sábados, praticamente todos os prédios da faculdade são disponibilizados aos cursos de extensão de línguas (todas elas), além dos outros cursos. 
Como dissemos, em 2009, o Italiano no Campus contou com 740 alunos, sendo 374 no segundo semestre (incluindo os alunos dos cursos de Língua \& Cultura e Conversação). ${ }^{83}$ Nosso questionário dirigido aos alunos de todos os níveis dos cursos de língua do Italiano no Campus reuniu as respostas de 237 estudantes. Com os dados levantados, podemos dizer que o IC é um curso frequentado predominantemente por mulheres, que correspondem a $77,6 \%$ dos alunos dos cursos de língua. A idade dos alunos varia de 16 a 78 anos. $^{84}$

Um dado importante a ser notado é que, apesar de o curso visar à própria comunidade USP, quando perguntada a profissão atual dos participantes, em primeiro lugar ficaram os aposentados, correspondendo a 16\% dos respondentes, enquanto que os estudantes ficaram em terceiro lugar, com 11,8\%.

Veremos mais detalhes sobre o perfil dos frequentadores do Italiano no Campus no capítulo cinco.

\subsubsection{O Italiano no Campus como um ambiente intergeracional}

É importante ressaltarmos que o Italiano no Campus não foi pensado com o intuito de ser um Programa Intergeracional. Não há em sua formulação um embasamento conceitual nem mesmo tem seus objetivos voltados para o contato intergeracional. Mas podemos considerá-lo um ambiente intergeracional porque é marcante a mistura etária que ocorre em seus grupos, unindo alunos de 16 anos até $78 \operatorname{anos}^{85}$, sendo que todas as faixas etárias nesse entremeio participam dos cursos. E o mais importante é que essas pessoas estão reunidas por um objetivo comum, que é o de aprender a língua italiana.

\footnotetext{
83 Informações fornecidas pela Secretaria de Cultura e Extensão da Faculdade de Filosofia, Letras e Ciências Humanas da USP, em mensagens iniciadas em 08 de dezembro de 2009, por intermédio do endereço eletrônico <agenda@usp.br>

84 Os dados se referem àqueles adquiridos na nossa pesquisa. Houve uma porcentagem de alunos que não especificou a idade.

85 Esses são os dados obtidos pela nossa pesquisa. O aluno de menor idade declarada tinha 16 anos, e a maior idade declarada foi de 78 anos.
} 
Verificando os números "gerais" do Italiano no Campus, temos a seguinte divisão de alunos por faixa etária (Gráfico 6):

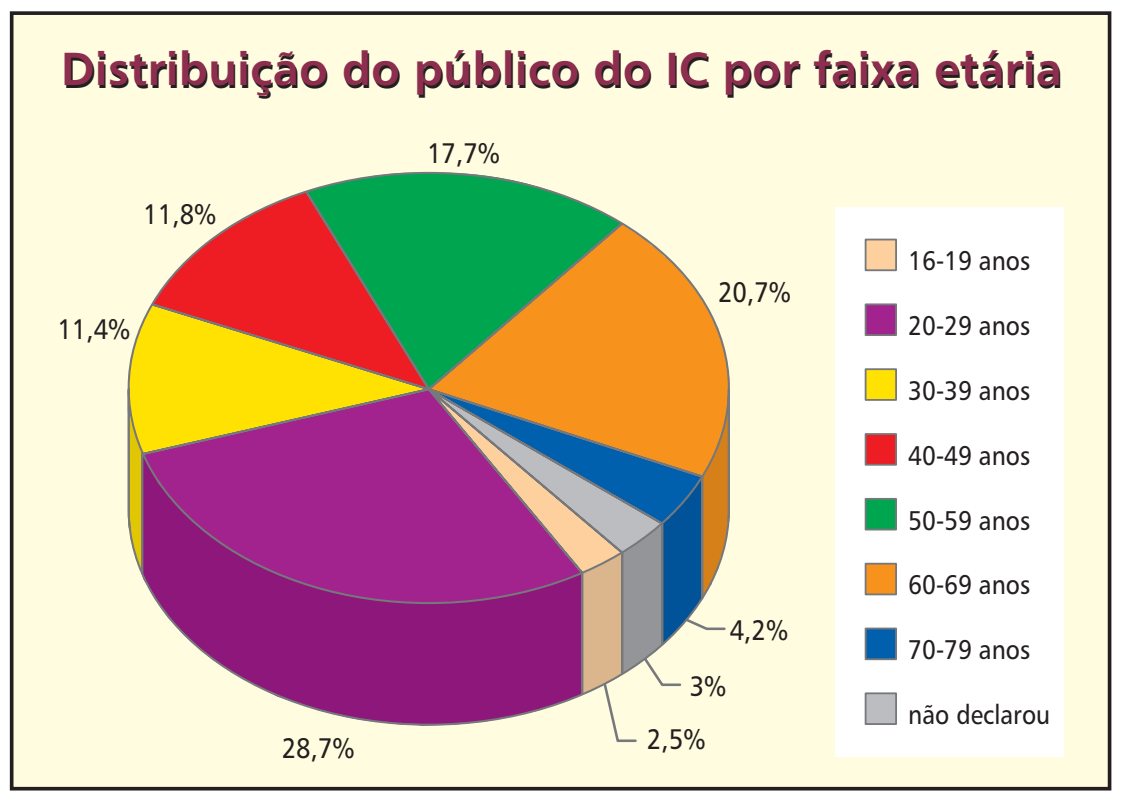

Gráfico 6 - Público geral por faixa etária

Como podemos notar no Gráfico 6, o público de 20 a 29 anos é a maioria, correspondendo a 28,7\% do público do Italiano no Campus, enquanto pessoas na faixa etária entre 60-69 anos ocupam o segundo lugar de maior público frequentador do IC, $\operatorname{com} 20,7 \%$.

Observando o Italiano no Campus, começamos a pensar em como ele, ao reunir diferentes gerações, poderia proporcionar benefícios para todos os participantes. Principalmente em relação aos idosos: em como o contato poderia ajudar a quebrar estereótipos sobre a velhice, bem como ajudar esses idosos a se manterem socialmente ativos e desempenharem novos papéis sociais. 


\subsection{Por uma pedagogia da diferença}

No capítulo dois, defendíamos o Italiano no Campus como um espaço onde seria possível pôr em prática a chamada Pedagogia da Diferença ${ }^{86}$. Vemos o IC como um espaço no qual podemos construir o respeito pelas diferenças, dada a heterogeneidade dos grupos.

Para discutirmos mais a questão, aprofundaremos o conceito de "aprendizagem ao longo de toda a vida".

\subsubsection{A aprendizagem ao longo de toda a vida}

Delors et al. (1998b), no capítulo cinco do relatório para a Unesco, destacam o fato de que a "educação ao longo da vida" é um conceito de educação que vem ultrapassar aquele de "educação permanente", pois vai além da continuidade no estudo voltado para o campo profissional (atualizações, melhora de currículo etc.) e passa a visar a um tipo de educação que é também voltada para o lazer e para a satisfação pessoal após o período profissional. A comissão da qual fazia parte o autor chama a atenção para o fato de considerarem esse conceito como a "chave que abrirá as portas para o século XXI" (p.104). Os autores declaram que, dado esse fato, a comissão passa a dar maior importância a um dos quatro pilares da educação: aprender a viver juntos, justamente o pilar que trata de aprender a respeitar as diferenças e a aceitar o outro como ele é. A comissão considera esse pilar um dos desafios da Educação no século XXI.

Os chamados "quatro pilares da educação" são:

1) Aprender a conhecer: aprender a aprender, a dominar os instrumentos do conhecimento. 
2) Aprender a fazer: indissociável de aprender a conhecer, liga-se à formação profissional, mas além da noção de qualificação profissional, enfatiza a competência pessoal.

3) Aprender a viver juntos, aprender a viver com os outros: um dos maiores desafios atuais da educação, não basta reunir membros de diferentes grupos, é necessário que haja como pano de fundo um contexto igualitário e projetos comuns. Os autores dizem que, nesse contexto, os preconceitos e a hostilidade podem desaparecer.

4) Aprender a ser: tem como princípio fundamental o fato de que "a educação deve contribuir para o desenvolvimento total da pessoa". (p.99)

Como dissemos, o pilar que a comissão passa a dar maior importância é justamente aquele que trata das diferenças e de conviver com as diferenças, em um contexto de expansão da ideia de aprendizagem ao longo da vida. É interessante ressaltar que, segundo os autores, algumas disciplinas estão mais aptas a lidar com essa finalidade, eles citam a geografia humana e as línguas e literaturas estrangeiras por trabalharem com outras culturas, costumes e hábitos, abrindo espaço para uma compreensão mais abrangente do outro, podendo modificar comportamentos. "Quando se trabalha em conjunto sobre projetos motivadores e fora do habitual, as diferenças e até os conflitos interindividuais tendem a reduzirse, chegando a desaparecer em alguns casos". (Delors et al., 1998b:98)

Trabalhando em projetos comuns, com um objetivo em comum, passa-se a valorizar mais as semelhanças do que as diferenças. Em uma aula de língua, por exemplo, pessoas com dificuldades parecidas tentam se ajudar. E, como vimos no capítulo dois, um maior conhecimento sobre o outro quebra preconceitos e estereótipos que só servem de barreiras para as relações interpessoais.

Bostrum et al. (2000) dizem que os Programas Intergeracionais contribuem para o aprendizado ao longo de toda a vida ao "trazer à tona" o potencial para a aprendizagem partilhada entre as gerações, o que é enriquecedor 
para o currículo de todos que participam desse tipo de programa. Além disso, os PIs estimulam o respeito às diferenças ao unir gerações diferentes nas mais diversas atividades, construindo respeito, questionando estereótipos estabelecidos a respeito de uma geração e de outra, consequentemente quebrando-os e diminuindo (e até acabando) com preconceitos entre as diferentes gerações.

Em Carvalho (2007) vimos que Dumazedier ${ }^{87}$ divide em três as formas de transmissão de saber entre as gerações:

- dos mais velhos aos mais jovens: imagem dos mais velhos como detentores dos saberes e tradições culturais que devem ser transmitidas;

- dos mais jovens aos mais velhos: como no caso das novas tecnologias, por exemplo, ensinar um idoso a navegar na Internet;

- coeducação entre gerações: a existência de saberes "de ontem e de hoje" convivendo de forma cooperativa ou conflituosa, mas que permite o convívio verdadeiro entre as gerações.

Lima (2008) aponta que, para ocorrer o processo de coeducação entre gerações, é necessário que três pontos essenciais se realizem:

- motivação dos integrantes do grupo;

- igualitarismo estimulado pelo profissional da atividade;

- a aprendizagem recíproca.

A autora afirma ainda que a aprendizagem cooperativa aproveita a heterogeneidade do grupo e, como podemos ver, o papel do profissional que coordena um grupo intergeracional é fundamental na construção de um ambiente igualitário que estimule o respeito, o conhecimento e a troca entre as gerações.

87 DUMAZEDIER, Joffrer. (1992) Criação e transmissão dos saberes. Tradução: Vera Ribeiro. Revista Gerontologie et societé, n. 16, jul. 


\subsubsection{A Pedagogia da Diferença}

Tomaz Tadeu da Silva (2008) afirma que por mais que seja nobre cultivar os sentimentos de tolerância e respeito, não podemos deixar de ver a diferença como uma produção social e que, como tal, envolve relações de poder. Não basta "tolerar" ou "respeitar" o diferente, o outro, é necessário que haja uma compreensão de como esse processo de "diferenciação" é produzido, como a diferença é construída.

O autor, antes de defender a ideia de uma Pedagogia da Diferença, comenta outras estratégias pedagógicas existentes:

- "liberal": cultiva o respeito e a tolerância pela diversidade cultural. O problema da abordagem é que ela deixa de questionar as relações de poder e acaba dando espaço para "novas dicotomias, como a do dominante tolerante e a do dominado tolerado ou da identidade hegemônica, mas benevolente e da identidade subalterna mas respeitada". (p.98)

- "terapêutica": a discriminação e a incapacidade de conviver com o diferente se devem a distúrbios psicológicos, derivados de imagens errôneas do outro, e que devem ser tratados.

- Uma abordagem mais comumente utilizada, que ficaria como intermediária das duas citadas acima, coloca o outro como exótico e curioso ao apresentar de forma superficial as diferentes culturas, reforçando, assim, as relações de poder.

O autor argumenta, então, a favor de uma Pedagogia da Diferença, adotando como sua base uma teoria que discuta como são produzidas a identidade e a diferença. "Uma política pedagógica e curricular da identidade e da diferença tem a obrigação de ir além das benevolentes declarações de boa vontade para com a diferença. Ela tem que colocar no seu centro uma teoria que permita não simplesmente reconhecer e celebrar a diferença e a identidade, mas questioná-las". (p.100) 
Como diz Eni P. Orlandi (1998), o reconhecimento das diferenças muitas vezes consiste em seu apagamento. Tenta-se integrar/incluir o "diferente", fazendo-o sumir em meio aos "normais" ao invés de aceitá-lo em sua diferença. Isso acontece com os idosos, que, para se "integrarem", parecem precisar assumir uma postura que seja socialmente considerada "jovem".

Nos grupos intergeracionais, podemos trabalhar com essa questão se construirmos, antes de tudo, um ambiente igualitário, e o papel do professor é fundamental para a sua construção.

O papel do professor é o de transmitir as informações, facilitar a aprendizagem e adaptá-la à capacidade de cada aluno, processo que, a partir do professor, desenvolve o respeito e a confiança; por analogia, os demais aprendem o respeito às dificuldades de aprendizagem dos colegas e isso os leva a ajudá-los quando podem. (Lima, 2008:73)

Interessante ligarmos a essa afirmação de Lima o depoimento de um dos monitores do IC:

E: E você, já teve que lidar com algum problema de relacionamento entre os alunos?

M5: [...] o que já aconteceu mais de uma vez foi eu tratar algum aluno de modo exemplar pra que os outros percebessem como tem que tratar aquele aluno, e eles começam a copiar. Desse jeito assim, implícito. Por $N$ motivos: pelo aluno ser/ geralmente é por ser mais lento, por não conseguir acompanhar a turma. Mas também pelo aluno ser cri-cri também. E começar a apresentar problemas, a fazer perguntas demais e não aceitar nada explicado pela primeira vez, tem muito isso, né? Ficar pondo à prova. Faz isso comigo e faz isso com os colegas. Então, no meu comportamento, mostro e eles passam a imitar. ${ }^{88}$ 
O papel do professor é fundamental na forma como os alunos irão se posicionar diante do "diferente". Pois, como podemos ver em Moita Lopes (1998), o professor tem um papel central na construção das identidades por assumir uma posição de líder na sala de aula e pelo seu papel de autoridade em relação à construção de significados. ${ }^{89}$ Os professores de LE também estão construindo significados na sala de aula, desde o seu posicionamento em sala de aula como figura de maior poder até o momento em que auxiliam os alunos na compreensão de um texto, de um diálogo, ao explicar o significado de uma palavra e, principalmente, ao servir de "ponte" para a compreensão de uma cultura diferente, fornecendo informações (geralmente por eles mesmos selecionadas e, portanto, influenciadas por suas crenças e preferências, por exemplo) etc. O autor afirma ainda que "pode-se argumentar que, devido ao fato de a professora estar posicionada em um papel de maior poder em relação aos alunos, ela pode estar controlando as identidades sociais possíveis de serem desempenhadas pelos alunos em aula". (p.316).

Moragas (2004) mostrou que a Itália é o país europeu onde os idosos têm mais contato com a família. O professor poderia aproveitar essa informação para incluir em seu programa a questão do idoso italiano, criando, por exemplo, uma unidade didática que aborde: 1) a ligação do idoso italiano com a família; 2) imagens de idosos ativos (que vão de um lugar a outro de bicicleta); 3) imagens de idosos detentores de velhice saudável; 4) a questão da aposentadoria ser, muitas vezes, insuficiente para as necessidades básicas dos idosos - e abordar a questão de como a adoção do Euro provocou uma crise econômica na Itália. É possível que, ao inserir o tema na sala de aula de língua, possamos fazer com que alunos, tanto jovens quanto idosos, passassem a encarar a velhice também alicerçados nessa outra imagem e quebrar estereótipos e preconceitos. A abordagem dos pontos negativos também é importante na construção da imagem desse outro, mostrando que problemas com a previdência não são apenas uma realidade brasileira.

89 O trabalho do autor trata "a relação entre a interação em sala de aula e a construção da identidade em aulas de leitura em língua materna." (p.311) 
É muito importante que em um contexto intergeracional, o professor tenha a habilidade de tratar a todos de forma igualitária, sem distinção devido à idade do participante, já que muitas vezes o nosso comportamento é guiado por crenças errôneas a respeito do outro. Tomemos como exemplo um dos estereótipos comuns nas aulas de língua: considerar o idoso um aluno mais lento no processo de a/a da LE. Tratar os idosos como lentos pode levar todo um grupo a tratá-los dessa forma, quando, na verdade, muito da velocidade com que a pessoa aprende/adquire uma LE não se relaciona à idade. Há alunos jovens que são lentos, e não ouvimos afirmações de que são lentos porque são jovens.

Lima, Simões e Tavares (1997) falam de como alguns estudos científicos "enviesados" confirmam erroneamente estereótipos culturais. Cachioni (2003) também trata do assunto, falando de preconceitos científicos, que se baseiam em estudos da ciência médica - para os quais o envelhecimento é fase de declínio e perdas - para tratar do envelhecimento cognitivo, difundindo estereótipos errôneos que dão origem a preconceito.

Mesmo que haja diferenças no processo de aquisição/aprendizagem de idosos e jovens, pois existe o declínio de algumas habilidades com o avançar da idade, alguns estudos mostram que essas diferenças não são significativas, uma vez que idosos, mesmo que não tenham mais as habilidades e capacidades da juventude, conseguem encontrar meios de compensação capazes de manter seus níveis de aprendizagem. Paiva e Del Maso (2007) e Sé, Queroz e Yassuda (2004) falam da "plasticidade do cérebro", mostrando que com exercícios pode-se manter sua estrutura e melhorar seu aproveitamento. É importante ressaltar que, como dito no texto de Sé, Queroz e Yassuda, o desempenho da memória e outras funções cognitivas são influenciados pela saúde física, escolaridade, relações sociais, situação socioeconômica, personalidade, nível de bem-estar emocional e autoestima. Indicativos de que os estereótipos negativos em relação à velhice e à discriminação social sofrida pelos idosos podem afetar os níveis de autoestima e bem-estar emocional a ponto de interferir nas suas funções cognitivas. Quanto 
mais se mantém a mente ativa, melhor seu funcionamento. Delors et al. (1998b) afirmam que estudos em diversos países mostraram que a participação de adultos em atividades educativas e culturais, após o ensino formal, está diretamente relacionada com o nível de escolaridade: quanto maior a formação, mais se quer continuar a estudar. Ou seja, muitos dos idosos que participam de cursos são idosos que costumam manter sua mente ativa. Conforme Doll (2007:117), seguindo Lehr" e Rudinger ${ }^{91}$ de, "quanto maior o nível de escolaridade, maior a probabilidade de preservação das capacidades intelectuais até idade avançada". Mary Schleppegrell (1987) afirma que não há declínio nas habilidades intelectuais se os idosos se mantém saudáveis.

Beauvoir (1976a) sustenta que quando não pressionados pelo tempo, em atividades cronometradas, o desempenho dos alunos idosos é igual ou superior ao dos alunos mais jovens.

Outro fator importante é o de muitos professores incorporarem a ideia de que a velhice é uma segunda infância e acabar por tratar alunos de forma infantilizada, com atividades que não condizem com suas expectativas e interesses. Pizzolatto (2008) nos mostra que, os próprios idosos podem assumir essa postura, mesmo que, ao mesmo tempo, exijam de si mesmos uma atitude "mais adequada à sua idade". O autor frisa que agir na aula com certo ar de indisciplina é apenas aparente. Na verdade, a maioria dos alunos está ali para se socializar e trocar experiências. Schleppegrell (1987) afirma que o contexto no qual o adulto aprende é a principal influência na sua habilidade em aprender outra língua, sendo que o maior obstáculo é a crença - tanto do idoso quanto do professor - de que "mais jovem é melhor".

Uma das questões levantadas em grupos de/com idosos é o fato de eles gostarem de contar experiências de vida na sala de aula. Dino Preti (1991), em um

\footnotetext{
90 LEHR, U. (2000). Psycologie des Alterns. Wiebelsbach, Quelle und Meyer.

91 RUDINGER, G. (1987). Intelligenzentwicklung unter unterschiedlichen sozialen Bedingungen. In: LEHR, U.; THOMAE, H. (orgs.). Formen seelischen Alterns. Stuttgart, Enke, p.57-65.
} 
estudo sobre a linguagem dos idosos, trata de como a fala deles é marcada por rememorações. Um modo de se aproveitar isso na aula de língua seria oferecendo situações em que os alunos possam contar suas experiências de vida e suas opiniões sobre o mundo atual utilizando o que sabem da língua estrangeira e fazendo daquele momento uma oportunidade de conversação na LE. A motivação está lá: compartilhar experiências, se a tendência inicial dos alunos idosos é fazer isso utilizando a língua materna, cabe ao professor conduzir aquele momento de forma a fazê-lo incorporar a aula de língua estrangeira.

Da mesma forma como há estereótipos negativos em relação aos idosos em aulas de língua, não podemos deixar de falar dos aspectos positivos constatados informalmente em conversas com professores de língua italiana. Um deles é o de que os alunos idosos são geralmente mais empenhados do que alunos mais jovens, sendo muito raro que eles deixem de fazer algum exercício, e a frequência deles nos cursos é de quase sempre 100\%. São também muito abertos às mais diversas atividades, sem medo de se exporem. ${ }^{92} \mathrm{E}$ até mesmo o fato de estarem ali, muitas vezes, para se socializarem, leva-os a promover uma interação intensa entre o grupo e muito proveitosa para a aula de língua.

O Italiano no Campus é um ambiente de heterogeneidade, e mais visivelmente: heterogeneidade etária. Se o professor souber trabalhar um ambiente igualitário, os alunos podem aprender com a cooperação e unir as gerações, quebrando estereótipos e diminuindo/acabando com preconceitos. Tanto dos jovens em relação aos idosos quanto o contrário. Há, de início, um objetivo comum, que é o de aprender a língua italiana. E a possibilidade de se "criar" uma nova identidade que falará essa língua estrangeira pode também permitir uma mudança em suas outras identidades, construindo um novo significado de velhice. Assim como quando aprendemos uma língua estrangeira ela afeta nossa relação 
com a língua materna, ao obtermos novas imagens sobre envelhecimento e velhice - e nesse ponto os idosos ativos que buscaram o curso para a manutenção da atividade intelectual, da vida social e da memória estão servindo como modelos positivos para os mais jovens, que passarão a encarar a velhice de uma forma diferente - também podemos modificar nossas crenças sobre a velhice e o próprio processo de envelhecimento, mudando nosso comportamento em relação aos idosos.

Promover debates em sala de aula que levantem as experiências de todas as gerações envolvidas auxilia na compreensão do outro, no processo de cooperação e na aceitação do diferente como ele realmente o é.

Não podemos esquecer, no entanto, que o Italiano no Campus, não tendo sido pensado como um Programa Intergeracional, se desejar passar a tal categoria precisaria de uma reelaboração teórica que envolvesse o treinamento dos professores para lidarem com tal realidade. O que temos atualmente e que podemos perceber nos depoimentos dos monitores do IC é que não há um preparo específico para ensinar no IC justamente porque ele também serve como um lugar de aprimoramento profissional para os monitores. Fica, então, a pergunta: Será que o que estudamos e praticamos na Licenciatura é o suficiente em termos de preparação de professores de língua estrangeira? Nos depoimentos, podemos ver que os monitores dizem ter aprendido a lidar com a heterogeneidade na prática, com "jogo de cintura".

Mas será que todos os monitores têm a sensibilidade de notar o seu poder como professor dentro da sala de aula? Pois não raro, em comentários informais em reuniões de monitores, houve reclamações sobre alunos idosos. Os próprios monitores muitas vezes não percebiam que estavam generalizando uma característica pessoal para todo o grupo de idosos, ignorando o fato de que pessoas de 20 anos agem da mesma forma. Por exemplo, muitas reclamações se referem ao fato de "idosos quererem traduzir tudo". E no princípio até levantamos a hipótese de que, se isso fosse verdade, poderia ser derivado de uma aprendizagem anterior 
de LE, cuja abordagem tivesse sido baseada na tradução. Mas a prática mostra que isso não se aplica a todos os idosos, e mais, muitas pessoas jovens gostam de traduzir tudo o que o professor fala. Trata-se de uma questão de personalidade, de estilo de aprendizagem.

O professor não perceber que está se apoiando em um estereótipo errôneo, ao definir todo um grupo etário dessa forma, pode levá-lo a perpetuar esse estereótipo em sala de aula, difundindo-o entre os alunos, e tratando os outros alunos idosos como se fossem todos iguais, o que acabaria gerando um conflito entre os próprios alunos na crença de que os idosos "estão atrapalhando a aula porque traduzem tudo", ignorando a tradução quando vinda de um aluno mais jovem.

É necessário que o professor compreenda o seu papel e sua importância na criação de um ambiente igualitário e na administração das diferenças na sala de aula, colaborando para ampliar a cooperação entre alunos e abrindo caminho para o respeito mútuo. 


\section{Levantamento de dados}


Para atingirmos os objetivos do nosso trabalho, dividimos o levantamento de dados em três etapas que mencionaremos aqui brevemente e nas quais nos aprofundaremos a seguir.

- $1^{a}$ Etapa: Pesquisa com alunos do nível 1 (realizada em 3 momentos diferentes);

- $2^{a}$ Etapa: Pesquisa geral do Italiano no Campus (com alunos e monitores);

- $\quad 3^{a}$ Etapa: Entrevistas.

Mais adiante, é possível ver a Tabela 1B, feita com base na Tabela 1, apresentada na introdução, acrescida de: direcionamento para o anexo no qual é reproduzido o modelo de instrumento utilizado e resultado gerais, respectivamente; e a denominação dada para cada instrumento no capítulo de análises. Os anexos incluem as tabelas de resultados dos questionários e a transcrição completa ${ }^{93}$ das entrevistas.

Este capítulo serve de introdução ao quinto capítulo deste trabalho. Optamos por redigi-lo à parte, para que no capítulo cinco possamos apenas discorrer sobre os resultados dos levantamentos de dados obtidos relevantes ao nosso trabalho. Neste capítulo, portanto, explicaremos etapa por etapa do nosso levantamento, a escolha pelos instrumentos utilizados e quais eram os objetivos. 
É importante ressaltarmos que nossa pesquisa envolveu um público muito específico, o do Italiano no Campus. No quinto capítulo, discutiremos mais sobre quais as suas peculiaridades e diferenças em relação a outros cursos de língua italiana. Portanto, as informações que levantamos não podem ser generalizadas para todos os alunos de língua italiana ou para todos os ambientes de ensino da língua. Os resultados levantados e apresentados têm como base o número de questionários e respostas obtidos.

Outro fator que achamos importante evidenciar, e que determinou boa parte da execução de nosso levantamento de dados, tanto com questionários quanto com entrevistas, é que os participantes e entrevistados não soubessem que o tema de nosso trabalho e nosso objetivo envolveriam principalmente a questão dos idosos nas aulas de língua. Era importante que eles desconhecessem nosso tema para que não ocorresse uma posição de autopreservação, na qual as respostas escolhidas fossem dadas de forma a entrar em um discurso "politicamente correto". Para esse fim, tivemos que recorrer também a questionamentos que abordassem a questão etária de forma generalizada, ou mesmo partir de um conceito geral e esperar que o próprio participante ou entrevistado falasse sobre o assunto.

Ressaltamos, também, que todas as etapas passaram por uma pesquisapiloto para aprimoramento dos questionários e da estruturação das entrevistas. As pesquisas-piloto foram descartadas. 
Tabela 1B: Instrumentos da pesquisa

\begin{tabular}{|c|c|c|c|c|c|}
\hline Etapa & Instrumento & Sujeitos & Objetivo & $\begin{array}{c}\text { Denominação } \\
\text { dada no trabalho }\end{array}$ & Anexo \\
\hline 1 & Questionário 1 & $\begin{array}{l}\text { Estudantes do } \\
\text { nível } 1 \text { do } \\
\text { Italiano no } \\
\text { Campus }\end{array}$ & $\begin{array}{l}\text { Levantar estereótipos e } \\
\text { expectativas desses alunos em } \\
\text { relação ao povo italiano, à Itália, à } \\
\text { língua italiana e ao curso de } \\
\text { língua italiana. }\end{array}$ & $\begin{array}{l}\text { Pesquisa/questionário } \\
\text { com principiantes } \\
\text { Pesquisa/questionário } \\
\text { com o nível } 1\end{array}$ & $B$ e $C$ \\
\hline 2 & Questionário 2 & $\begin{array}{l}\text { Estudantes de } \\
\text { todos os níveis } \\
\text { do Italiano no } \\
\text { Campus }\end{array}$ & $\begin{array}{l}\text { Verificar a satisfação com o curso, } \\
\text { as críticas, a convivência com os } \\
\text { colegas de classe e a visão dos } \\
\text { alunos na convivência com os } \\
\text { alunos da terceira idade, bem } \\
\text { como a vontade de manter ou } \\
\text { não as classes intergeracionais. }\end{array}$ & $\begin{array}{l}\text { Pesquisa/ } \\
\text { questionário geral }\end{array}$ & $D$ e $E$ \\
\hline 2 & Questionário 3 & $\begin{array}{l}\text { Monitores do } \\
\text { Italiano no } \\
\text { Campus }\end{array}$ & $\begin{array}{l}\text { Verificar a satisfação profissional e } \\
\text { a visão geral da profissão. }\end{array}$ & $\begin{array}{l}\text { Pesquisa/questionário } \\
\text { dos monitores }\end{array}$ & $\begin{array}{l}\text { F, G, cf. } \\
\text { cap. } 5\end{array}$ \\
\hline 2 & $\begin{array}{l}\text { Questionário } \\
3.1\end{array}$ & $\begin{array}{l}\text { Monitores do } \\
\text { Italiano no } \\
\text { Campus }\end{array}$ & $\begin{array}{l}\text { Verificar o sincronismo monitor- } \\
\text { aluno quanto ao ritmo das aulas, } \\
\text { percepção das relações na sala de } \\
\text { aula e das dificuldades dos } \\
\text { alunos. }\end{array}$ & $\begin{array}{l}\text { Questionário específico } \\
\text { (dos monitores) }\end{array}$ & $\mathrm{H}$ \\
\hline 3 & Entrevistas & $\begin{array}{l}\text { Monitores e } \\
\text { ex-monitores } \\
\text { do Italiano no } \\
\text { Campus }\end{array}$ & $\begin{array}{l}\text { Recolher experiência de monitores } \\
\text { e ex-monitores } \\
\text { em relação ao Italiano no } \\
\text { Campus, com perguntas sobre } \\
\text { o curso, a coordenação, os } \\
\text { alunos, o relacionamento } \\
\text { aluno-monitor etc. }\end{array}$ & Entrevistas & I, J e K \\
\hline
\end{tabular}

\subsection{Os instrumentos para levantamento dos dados}

\subsubsection{Os questionários}

$\mathrm{Na}$ primeira etapa com o questionário 1, e na segunda etapa com o questionário 2, por buscarmos o maior número possível de respostas, com a finalidade de obtermos dados suficientes para podermos levantar um perfil dos alunos do Italiano no Campus, bem como conseguir um número de respostas que nos permitisse um agrupamento por faixas etárias, seria inviável a realização de entrevistas. No primeiro caso, com os principiantes, obtivemos 138 questionários respondidos; no segundo, 237. 
Para obtermos esse alcance, os questionários eram nossa melhor opção. Apesar de limitar as respostas e não permitir que alunos discorressem livremente sobre os assuntos que gostaríamos de abordar, procuramos fazer com que no espaço que tínhamos, conseguíssemos obter o maior número de informações.

A entrevista com os monitores, como viável, foi pensada desde o início da aplicação da segunda etapa. Entretanto, escolhemos iniciar nosso contato com os monitores por meio de um questionário, com algumas questões envolvendo faixas etárias que eram múltipla escolha e dissertativas, esperando que a não presença de um interlocutor pudesse deixá-los mais à vontade quanto às respostas, pensando as entrevistas como um instrumento para aprofundar.

Para a elaboração dos questionários, tomamos como base o texto de Anivaldo Chagas (2000).

\subsubsection{As entrevistas}

Durante a pesquisa, pensamos em entrevistas como forma de aprofundar a questão da visão dos alunos e monitores sobre a heterogeneidade dos grupos, já que os questionários acabam sendo meios limitados de coleta de dados quando se trata de um assunto tão "delicado" quanto à heterogeneidade etária dos grupos do Italiano no Campus. Percebemos, também, que, quando a observação era feita, sem intuito de abordar o assunto dos idosos nas salas de aula, os comentários fluem de maneira completamente diferente, e com uma frequência maior. Os questionários também limitam as respostas a partir do momento em que fornecem um espaço específico para ela. Além disso, não queríamos que os questionários fossem longos demais para não tomar tempo demasiado das aulas dos monitores e nem provocar cansaço nos alunos, que responderiam às últimas questões (as mais importantes para nós) de forma impaciente. 
Primeiramente, pensamos em fazer entrevistas em profundidade ${ }^{94} \mathrm{com}$ os alunos representantes de todas as faixas etárias do IC. No entanto, para seguirmos os moldes das entrevistas em profundidade com o número de participantes que estipulamos como necessário para ter uma amostragem mais fiel à realidade do IC, seria inviável no tempo de pesquisa que tínhamos a disposição. Pensamos então nas pesquisas com os monitores, que poderiam fornecer relatos de sala de aula e manifestar sua visão do relacionamento entre os alunos.

As entrevistas eram semiestruturadas, ou seja, tínhamos um roteiro de perguntas que pretendíamos seguir, mas que de forma alguma limitavam tanto o espaço de fala dos entrevistados quanto a inclusão de perguntas conforme surgisse a oportunidade.

Para essa etapa do levantamento de dados, tomamos como base a obra de Maria Virgínia Rosa e Marlene Arnoldi (2006) e textos de Maria I. Queiroz (1991) e Antônio Carlos Gil (1991). Para a transcrição das entrevistas, utilizamos algumas das normas de transcrição encontradas em Dino Preti (2001). Optamos por uma transcrição mais simplificada para que o texto fosse mais acessível, por isso não utilizamos todas as normas adotadas em Preti.

\subsection{Primeira etapa: os grupos principiantes}

A primeira etapa de nossa pesquisa foi dirigida aos estudantes principiantes, do nível 1, do Italiano no Campus. A escolha por esse público em específico aconteceu por desejarmos, para esta etapa, alunos que ainda não tivessem tido nenhum tipo de contato formal com a língua italiana. Acreditamos que, nesse momento, os estereótipos sobre a língua e cultura estrangeiras estão mais fortes. ${ }^{95}$

\footnotetext{
94 As entrevistas ditas "em profundidade" são realizadas em vários encontros espaçados, para permitir que os entrevistados se sintam à vontade com o entrevistador e discutam temas que não discutiriam com um desconhecido, ou mesmo "deixem escapar" um comentário que não fariam, pois com um número seguido de encontros, o "policiamento" sobre o que é dito vai diminuindo, e as respostas passam a ser mais espontâneas.

95 Como pudemos ver no capítulo dois, o contato com a outra cultura, o outro, o diferente, possibilita a quebra de estereótipos por fornecer maiores informações sobre esses "outros".
} 
O questionário ${ }^{96}$ foi aplicado em três momentos, com dez turmas diferentes de nível 1, totalizando 138 alunos. A divisão dos participantes por momento de realização da pesquisa é demonstrada na Tabela 5, a seguir:

Tabela 5: Participantes da pesquisa com principiantes

\begin{tabular}{c|c|c|c}
\hline Ano & Período & Quantas turmas & Número de alunos \\
\hline 2007 & $2^{\circ}$ semestre & 4 & 58 \\
\hline 2008 & $\begin{array}{c}\text { Fevereiro - curso } \\
\text { de férias }\end{array}$ & 2 & 26 \\
\hline 2008 & $1^{\circ}$ semestre & 4 & 54 \\
\hline \multicolumn{2}{l}{ Total de alunos participantes } \\
\hline
\end{tabular}

Para que nosso objetivo fosse atingido, o questionário deveria ser dinâmico e as perguntas deveriam ser respondidas sem muita reflexão, principalmente as iniciais. Não queríamos que os alunos tivessem tempo de elaborar suas respostas a ponto de nos fornecer aquelas "politicamente corretas". Para tanto, na primeira parte do questionário, pensamos num jogo de palavras no qual eles deveriam associar de três a cinco termos que lhes viessem à mente, sem reflexão, quando indagados sobre o povo italiano (aspectos físicos e psicológicos) e a Itália. Com essa etapa da pesquisa, fizemos uma divisão por faixas etárias para verificar se a imagem dos alunos em relação ao povo italiano e à Itália variava muito conforme a idade do respondente.

Em seguida, as perguntas eram relativas ao curso de língua, com questões sobre o que esperavam conhecer no curso, quais elementos gostariam que fossem mais trabalhados, se achavam que o curso seria fácil. Essa parte do questionário envolvia questões dissertativas, para que os alunos tivessem a possibilidade de dar respostas livres, sem que houvesse influência das opções oferecidas. Um dos nossos objetivos secundários era o de fazer uma divisão etária para verificar se havia 
diferenças de interesses e expectativas em relação ao curso, o que poderia justificar uma separação etária dos grupos.

Na Tabela 6, apresentamos o objetivo de cada uma das questões.

Tabela 6: Objetivos das perguntas do questionário para principiantes

\begin{tabular}{|c|c|c|}
\hline Perguntas & Relativas a: & Objetivos \\
\hline Dados pessoais & idade e sexo & Levantar o perfil do aluno que entra no Italiano no Campus \\
\hline 1,2 e 3 & $\begin{array}{l}\text { palavras que Ihes vinham à mente } \\
\text { quando se menciona Itália, aspectos } \\
\text { físicos e psicológicos do povo } \\
\text { italiano. }\end{array}$ & $\begin{array}{l}\text { Verificar qual a imagem que os alunos, sem contato formal } \\
\text { com a língua, fazem da Itália e do povo italiano, para, } \\
\text { posteriormente, averiguar a existência de diferenças nessas } \\
\text { imagens de acordo com a faixa etária do respondente. }\end{array}$ \\
\hline 4 & $\begin{array}{l}\text { razões da escolha pelo curso de } \\
\text { língua italiana. }\end{array}$ & $\begin{array}{l}\text { Verificar a informação de professores de italiano que } \\
\text { apontam que a maioria dos alunos de língua italiana } \\
\text { procura o curso por prazer e por razões afetivas } \\
\text { (descendentes de italianos), o que facilitaria o processo de } \\
\text { a/a da LE. O intuito era verificar essa afirmação. }\end{array}$ \\
\hline 5 & $\begin{array}{l}\text { grau de dificuldade que os alunos } \\
\text { esperavam enfrentar no curso, } \\
\text { justificando as respostas }\end{array}$ & $\begin{array}{l}\text { Verificar se os alunos acham que a língua italiana será } \\
\text { facilmente adquirida/aprendida, por se sentirem } \\
\text { "familiarizados" com a língua. }\end{array}$ \\
\hline 6 e 7 & $\begin{array}{l}\text { elementos do curso que suporiam } \\
\text { mais fáceis ou mais difíceis. }\end{array}$ & $\begin{array}{l}\text { Conhecer os pontos que os alunos achavam que seriam } \\
\text { mais fáceis ou mais difíceis do curso, na expectativa de } \\
\text { auxiliá-los durante o curso. }\end{array}$ \\
\hline 8 & expectativas em relação ao curso. & $\begin{array}{l}\text { Verificar o que os alunos esperavam que o curso lhes } \\
\text { proporcionasse, para posterior divisão por faixa etária, a } \\
\text { fim de levantar se as expectativas são diferentes. }\end{array}$ \\
\hline 9 & $\begin{array}{l}\text { aos elementos da língua e da cultura } \\
\text { italiana que esperavam que fossem } \\
\text { mais trabalhados. }\end{array}$ & $\begin{array}{l}\text { Ver quais eram os pontos de interesse dos alunos, para } \\
\text { posterior separação por faixa etária, a fim de ver se os } \\
\text { interesses eram divergentes. }\end{array}$ \\
\hline
\end{tabular}

De forma geral, os resultados mostraram que, quando separados por faixas etárias, não há diferenças significativas nas respostas dadas. O que nos permite deduzir que não haja diferença de interesses e percepções de dificuldades ou facilidades com o curso baseados na faixa etária. Dessa forma, não vemos um "conflito de interesses" entre os participantes, que levaria à necessidade de divisão dos grupos por "objetivos a serem alcançados com o curso". Se tivéssemos obtido resultados que mostrassem, por exemplo, que 50\% dos alunos escolhem o curso por razões profissionais enquanto que os outros 50\% o escolhem por lazer, teríamos na sala de aula dois objetivos distintos e que demandariam ritmos 
diferentes de aula e adaptação às finalidades de cada um dos grupos - conflitantes entre si. Obtivemos, também, alguns resultados paradoxais, como o fato de a "conversação" ser considerada tanto o ponto que os alunos acham que será mais fácil nos cursos quanto o mais difícil.

No Anexo C, é possível encontrar uma tabela para cada uma das questões, na qual comparamos os três principais resultados gerais (de todos os questionários) com os três mais citados por faixa etária.

Essa foi nossa primeira pesquisa com os alunos do Italiano no Campus. No início, nosso foco era verificar os estereótipos em relação ao curso e aos italianos e à Itália para depois partir para os estereótipos em relação aos idosos nas aulas de língua. No decorrer do estudo, entretanto, e com os resultados obtidos nas outras pesquisas aplicadas, essa etapa acabou se desviando dos rumos que o trabalho tomou, pois passamos a dar maior ênfase aos contatos intergeracionais e às relações aluno-aluno e aluno-professor. Portanto, utilizaremos, no capítulo 5 nosso capítulo de análise -, somente os dados centrais para nossa pesquisa, disponibilizando os outros dados aos leitores em nossos anexos.

\subsection{Segunda etapa: monitores e alunos dos cursos de língua do Italiano no Campus}

A segunda etapa consistiu de três tipos de questionários diferentes: um questionário para os alunos do Italiano no Campus ${ }^{97}$ (com a participação de todos os níveis dos cursos de língua); um questionário geral para os monitores ${ }^{98}$, com questões sobre seu trabalho como professores de língua italiana; e um questionário

97 Modelo do questionário no Anexo D

98 Modelo do questionário no Anexo F 
para os monitores ${ }^{99}$, específico sobre cada um dos grupos, a fim de verificar o sincronismo monitor-aluno.

Para a nossa pesquisa, os questionários com os alunos do Italiano no Campus e a entrevista com os monitores (que veremos no tópico 4.3. deste capítulo) formam o material coletado mais importante.

\subsubsection{O questionário geral aos monitores}

Este questionário foi elaborado para ser confrontado, questão a questão (o máximo possível), com o questionário respondido pelos alunos. Por isso, as perguntas deste questionário e daquele destinados aos alunos foram pensadas conjuntamente. Temos, então, questionamentos sobre as razões que os fizeram estudar a língua italiana, o número ideal de alunos por sala, o que acham da divisão do curso, quais assuntos mais gostam de trabalhar em sala de aula e o que mudariam no curso. As outras questões iniciais se referiam aos motivos que os levaram a optar pela profissão de professor de língua italiana; qual o seu grau de satisfação em lecionar - pois podemos relacionar a satisfação com o trabalho como influência na forma como ele é desenvolvido.

O foco para nossa pesquisa, no entanto, era que chegássemos "pouco a pouco" no assunto das faixas etárias, sem abordar diretamente a questão dos idosos, para não despertar uma posição de "autopreservação", em que as respostas dadas seriam "politicamente corretas". As perguntas finais, portanto, abordavam com qual público (por faixa etária) os monitores mais gostavam de trabalhar, com quais faixas eles não gostariam de trabalhar e quais eles julgavam precisar ser separadas do restante. Como todas as perguntas exigiam uma resposta dissertativa, esperávamos que, se houvesse algum tipo de manifestação contra o público idoso, ela aparecesse ali. Se pudéssemos notar nas respostas algum tipo de preconceito com o grupo de idosos, isso poderia indicar diferença de tratamento do 
monitor em relação aos alunos idosos dentro da sala de aula, mesmo que ela se desse de forma inconsciente, mas que influenciaria a forma como os outros alunos percebem e recebem esses companheiros.

No período de aplicação dos questionários, o IC contava com sete monitores "ativos"100. Dentre estes, um não respondeu ao questionário (mas seus alunos participaram da pesquisa geral). As respostas foram transcritas exatamente como foram dadas pelos participantes. Firmamos com os monitores o compromisso de manter o sigilo de qualquer informação que pudesse permitir a sua identificação. Mesmo sabendo que a exclusão de informações (como o tempo em que trabalham como professores de italiano, por exemplo) poderia enfraquecer a construção do contexto, e mesmo das respostas dadas, nosso compromisso maior era com o sigilo de suas identidades.

O questionário foi composto por 14 questões, todas dissertativas. Algumas questões que tratavam de faixas etárias eram em forma de múltipla escolha (quanto à escolha das faixas etárias, em uma separação de 20 em 20 anos), mas todas as respostas pediam justificativa. Obtivemos resultados interessantes sobre a visão dos monitores dos grupos do Italiano no Campus, bem como sobre as preferências pessoais em relação às faixas etárias com as quais preferem trabalhar, com quais elementos se sentem mais à vontade em lidar na sala de aula, dentre outros aspectos. Faremos a discussão sobre as questões que trouxeram os resultados mais relevantes no capítulo cinco, utilizando a abreviação Q3:Y, na qual "Q" corresponde a questionário e "3" é o número correspondente ao questionário de acordo com a Tabela 1B. E "Y" será substituído pelo número da pergunta dentro do questionário. Portanto, uma sigla "Q3:3" deve ser lida como: questionário 3, pergunta 3.

Na Tabela 7, abaixo, podemos verificar os objetivos das questões gerais feitas aos monitores.

100 Usamos aqui a palavra "ativos" porque alguns monitores, mediante aprovação no concurso, ficam "em espera" até que surjam turmas. Esses monitores costumam participar das reuniões pedagógicas para conhecer o funcionamento do curso, mas sem que ainda tenham assumido alguma turma. 
Tabela 7: Objetivos das perguntas do questionário geral dos monitores

\begin{tabular}{|c|c|c|}
\hline Perguntas & Relativas a: & Objetivos \\
\hline $\begin{array}{l}\text { Informações } \\
\text { pessoais }\end{array}$ & $\begin{array}{l}\text { idade, sexo, há quanto tempo } \\
\text { leciona italiano. }\end{array}$ & $\begin{array}{l}\text { Traçar o perfil do monitor do IC e verificar o tempo de } \\
\text { experiência em sala de aula. }\end{array}$ \\
\hline 1 & $\begin{array}{l}\text { o motivo que os levou a estudar a } \\
\text { língua italiana. }\end{array}$ & $\begin{array}{l}\text { Verificar se as razões que levaram os profissionais de ensino } \\
\text { de italiano a escolher essa língua são as mesmas daqueles } \\
\text { que escolhem fazer um curso livre (IC). }\end{array}$ \\
\hline 2 & $\begin{array}{l}\text { fatores que influenciaram a decisão } \\
\text { de trabalhar como professores de } \\
\text { língua italiana. }\end{array}$ & $\begin{array}{l}\text { Verificar quantos optaram deliberadamente pela profissão e } \\
\text { quantos começaram a dar aula por outras razões. }\end{array}$ \\
\hline 3 e 4 & satisfação profissional. & $\begin{array}{l}\text { Saber o grau de satisfação com a profissão e o que traz } \\
\text { insatisfação como professor de italiano. }\end{array}$ \\
\hline 5 & o número ideal de alunos por grupo. & $\begin{array}{l}\text { Confrontar o resultado com o número ideal fornecido pelos } \\
\text { questionários dos alunos e com o número de alunos que o IC } \\
\text { habitualmente possui. }\end{array}$ \\
\hline 6 & conteúdo dos módulos. & $\begin{array}{l}\text { Verificar se os monitores acham que a divisão dos conteúdos } \\
\text { nos módulos é satisfatória. }\end{array}$ \\
\hline 7 & $\begin{array}{l}\text { habilidade com a qual eles se } \\
\text { sentem mais à vontade para } \\
\text { trabalhar em sala. }\end{array}$ & $\begin{array}{l}\text { Confrontar com a resposta dos alunos sobre quais } \\
\text { habilidades eles sentem maiores dificuldades. }\end{array}$ \\
\hline 8 & $\begin{array}{l}\text { o que mudariam no curso se } \\
\text { pudesse. }\end{array}$ & $\begin{array}{l}\text { Confrontar com a resposta dos alunos sobre o que mudariam } \\
\text { no IC. }\end{array}$ \\
\hline 9 & $\begin{array}{l}\text { faixas etárias com as quais preferem } \\
\text { trabalhar. }\end{array}$ & $\begin{array}{l}\text { Verificar quais as faixas etárias com as quais os monitores } \\
\text { preferem trabalhar, as respostas podem indicar um } \\
\text { tratamento diferente para aqueles que não pertencem às } \\
\text { faixas escolhidas. }\end{array}$ \\
\hline 10 & $\begin{array}{l}\text { opinião dos monitores sobre os } \\
\text { grupos intergeracionais. }\end{array}$ & $\begin{array}{l}\text { Saber o que os monitores pensam sobre a } \\
\text { intergeracionalidade na sala de aula e confrontar com o que } \\
\text { os alunos pensam. }\end{array}$ \\
\hline 11 & $\begin{array}{l}\text { qual faixa etária, na opinião dos } \\
\text { monitores, exigiria um grupo } \\
\text { específico. }\end{array}$ & $\begin{array}{l}\text { Aqui pretendíamos saber qual faixa etária os monitores } \\
\text { consideram que não poderia ser inclusa em um grupo } \\
\text { intergeracional de língua. }\end{array}$ \\
\hline 12 & $\begin{array}{l}\text { qual é, geralmente, a faixa etária dos } \\
\text { seus alunos. }\end{array}$ & $\begin{array}{l}\text { Confrontar os dados com a resposta obtida na questão } 9, \\
\text { verificando se as faixas etárias com as quais geralmente lidam } \\
\text { em sala são aquelas com as quais eles preferem trabalhar. }\end{array}$ \\
\hline 13 & $\begin{array}{l}\text { faixa etária que escolheriam para dar } \\
\text { um curso. }\end{array}$ & $\begin{array}{l}\text { Verificar se algum dos monitores escolheria a terceira idade } \\
\text { como público para um curso. }\end{array}$ \\
\hline 14 & divisão dos grupos por faixas etárias. & $\begin{array}{l}\text { Saber se os monitores acham que deveria haver divisão por } \\
\text { faixa etária, mostrando que eles não gostariam de alguma } \\
\text { delas inserida no grupo, e confrontar com a opinião dos } \\
\text { alunos. }\end{array}$ \\
\hline
\end{tabular}

Na análise das informações obtidas nos questionários, os monitores serão indicados com a letra " $\mathrm{M}$ ", seguida do número designado a ele no questionário e pela inicial do instrumento, no caso: "q". Exemplo: "M3q", no qual lê-se: "Monitor 3 em questionário". 


\subsubsection{O questionário geral dos alunos}

Eram vários os objetivos que tínhamos quando pensamos no questionário para todos os alunos de língua do Italiano no Campus. Mais uma vez, a fim de conseguir o maior número possível de respostas, o questionário nos apareceu como a melhor opção.

O nosso primeiro objetivo era o de conseguir traçar um perfil do público frequentador do Italiano no Campus, e era a esse fim que se destinavam as primeiras perguntas relativas a idade, sexo, escolaridade e profissão. As respostas a essas perguntas iniciais nos permitem verificar quantos estudantes dos cursos de língua fazem parte da chamada terceira idade, quantos são os alunos das outras faixas etárias, se há maioria de mulheres ou homens e a quantidade de estudantes e aposentados que frequentam o curso, bem como verificar se há alguma profissão que prevalece, indicando um público que precisa ou estuda o italiano por razões profissionais ou acadêmicas.

Os questionários foram aplicados a todos os níveis dos cursos de língua do Italiano no Campus (de 1 a 8), excluindo-se os cursos de cultura e conversação, pois geralmente seus frequentadores também são alunos dos cursos de língua, o que nos forneceria respostas duplicadas. Além disso, era importante que tivéssemos o perfil do aluno que escolhe especificamente o curso de língua. Dois grupos, um de nível 7 e um nível 8, não participaram da pesquisa.

No total, obtivemos a participação de 237 alunos, divididos entre os níveis da forma como mostra o Gráfico 7.

Os questionários não eram identificados, mas frisamos a importância de que o cabeçalho dos questionários - com as informações sobre idade e sexo, profissão e escolaridade - fosse preenchido. As questões eram, em sua maioria, dissertativas, oferecendo maior liberdade nas respostas e maior riqueza do material que teríamos sobre o que os alunos pensam da heterogeneidade etária dos grupos. 


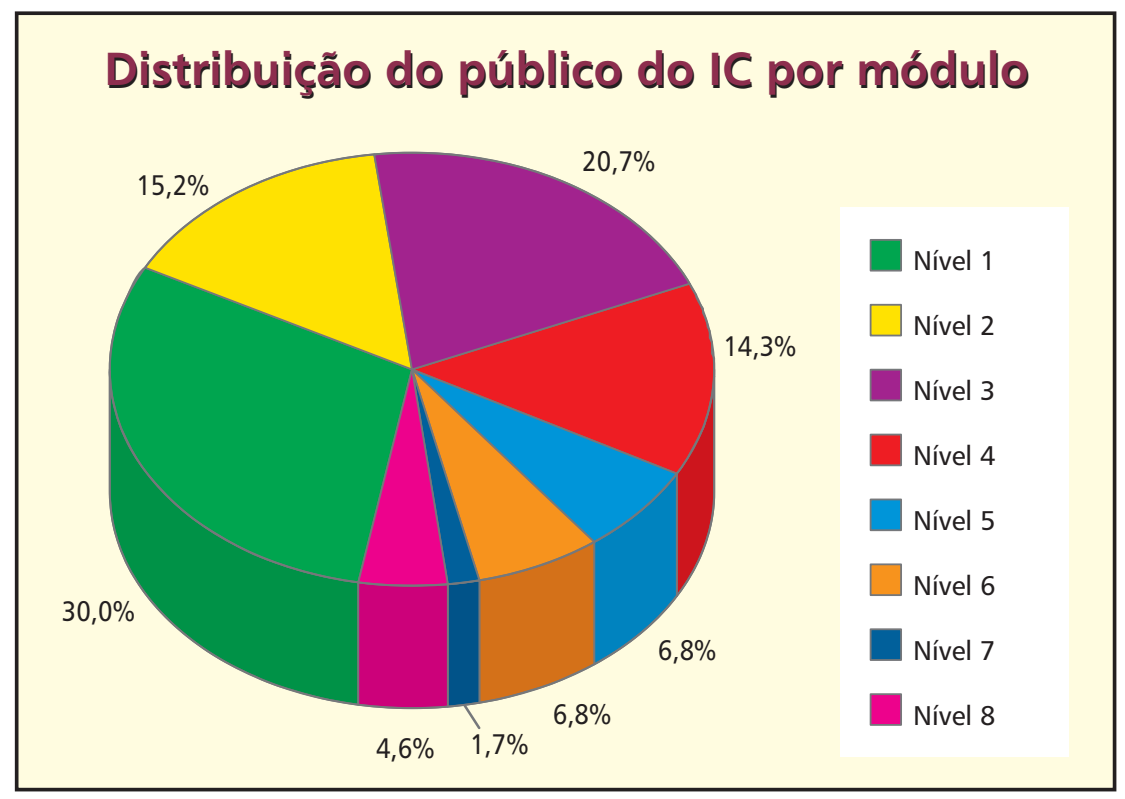

Gráfico 7 - Público geral por nível

No questionário dos alunos, assim como no dos monitores, a questão da intergeracionalidade do curso deveria ser introduzida sem que mencionássemos alguma faixa etária diretamente, no caso que nos interessa: os idosos. Dessa forma, as questões etárias apareceriam como parte das questões gerais sobre o curso. Todo final de semestre os alunos devem responder a uma pesquisa feita pela Secretaria de Cultura e Extensão, na qual avaliam o curso, os monitores e a secretaria, e podem dar sugestões para a melhoria do curso. Pedimos aos monitores que, ao aplicarem as pesquisas em seus grupos, entregassem nosso questionário juntamente com o da Secretaria (SCE), para que os alunos pensassem que se tratava de um levantamento sobre o andamento dos cursos de língua italiana. Assim, os alunos se sentiriam mais à vontade para dizer o que realmente pensavam, pois imaginariam que suas respostas poderiam influenciar a modelação dos futuros cursos - não escondendo, dessa forma, suas reais preferências.

Portanto, após as perguntas de cabeçalho, começamos com questões gerais, como: quais as razões para terem escolhido o curso, quais os pontos de maior dificuldade, o que achavam do ritmo dos módulos etc. E somente ao final do questionário, fizemos perguntas relativas à mistura de faixas etárias no curso e se gostariam que as turmas fossem divididas com base na idade, por exemplo. Não 
nos referimos, em momento algum, especificamente aos idosos, para que não despertasse a necessidade de respostas "politicamente corretas" a respeito da heterogeneidade etária dos cursos. Os alunos estavam livres para escrever o que achassem necessário.

Abaixo, podemos observar a Tabela 8 , com o objetivo de cada uma das perguntas quando o questionário foi elaborado.

Tabela 8: Objetivos das perguntas do questionário para todos os níveis

\begin{tabular}{|c|c|c|}
\hline Perguntas & Relativas a: & Objetivos \\
\hline $\begin{array}{c}\text { Informações } \\
\text { pessoais }\end{array}$ & $\begin{array}{l}\text { idade, sexo, profissão atual* e } \\
\text { escolaridade. }\end{array}$ & Traçar o perfil do estudante do IC. \\
\hline 1 & $\begin{array}{l}\text { que os levou a fazer o curso de } \\
\text { língua italiana. }\end{array}$ & $\begin{array}{l}\text { Verificar se o percentual de alunos que escolhem o curso por } \\
\text { descendência, lazer ou por razões profissionais. }\end{array}$ \\
\hline 2 & $\begin{array}{l}\text { razões de escolherem o IC e não um } \\
\text { instituto de língua. }\end{array}$ & $\begin{array}{l}\text { Levantar quais os atrativos do IC em relação aos demais } \\
\text { cursos. }\end{array}$ \\
\hline 3 & $\begin{array}{l}\text { se frequentavam ou não outros } \\
\text { cursos extracurriculares. }\end{array}$ & $\begin{array}{l}\text { Saber se os idosos frequentam mais cursos livres do que os } \\
\text { mais jovens. }\end{array}$ \\
\hline 4 & $\begin{array}{l}\text { número ideal de alunos por grupo, } \\
\text { na visão dos estudantes. }\end{array}$ & $\begin{array}{l}\text { Confrontar os resultados com o número ideal segundo os } \\
\text { monitores e com o número de alunos que o IC } \\
\text { costumeiramente possui. }\end{array}$ \\
\hline 5 e 6 & o ritmo das aulas. & $\begin{array}{l}\text { Verificar os comentários informais estereotipados de que "os } \\
\text { idosos são lentos e os jovens são mais rápidos", a partir de } \\
\text { como os próprios alunos visualizam o andamento do curso. }\end{array}$ \\
\hline 7 e 8 & $\begin{array}{l}\text { pontos com os quais sentem maiores } \\
\text { dificuldades e quais suas sugestões } \\
\text { para melhorar. }\end{array}$ & $\begin{array}{l}\text { Saber qual a maior dificuldade dos alunos nos cursos, } \\
\text { confrontar com a percepção dos monitores e com as } \\
\text { habilidades que os monitores mais gostam de trabalhar. }\end{array}$ \\
\hline 9 & assuntos de maior interesse. & $\begin{array}{l}\text { Verificar o interesse dos alunos e saber se há diferenças entre } \\
\text { os interesses principais de acordo com a faixa etária. }\end{array}$ \\
\hline 10 & $\begin{array}{l}\text { relacionamento com os colegas do } \\
\text { grupo. }\end{array}$ & $\begin{array}{l}\text { Saber se os alunos tinham alguma reclamação em relação ao } \\
\text { grupo como exclusão, preconceito, se sentir "deslocado" etc. }\end{array}$ \\
\hline 11 & $\begin{array}{l}\text { como se sentem estudando em um } \\
\text { grupo com diferentes faixas etárias. }\end{array}$ & $\begin{array}{l}\text { Averiguar o que os alunos pensam sobre a } \\
\text { intergeracionalidade na sala de aula. }\end{array}$ \\
\hline 12 & divisão dos grupos por faixas etárias. & $\begin{array}{l}\text { Verificar se algum aluno gostaria que alguma faixa-etária } \\
\text { fosse separada das demais. }\end{array}$ \\
\hline 13 & um grupo só com sua faixa etária. & $\begin{array}{l}\text { Verificar se os alunos gostariam de um grupo só com pessoas } \\
\text { de sua faixa etária. Se o aluno dissesse que os grupos } \\
\text { deveriam ser divididos por faixas etárias, mas não quisesse } \\
\text { um grupo só com a sua faixa etária, seria um indicativo de } \\
\text { preconceito etário. }\end{array}$ \\
\hline 14 & satisfação com o curso. & $\begin{array}{l}\text { Saber se os alunos estão satisfeitos com o IC e o que } \\
\text { mudariam no curso, se pudessem. }\end{array}$ \\
\hline
\end{tabular}

* Optamos por "profissão atual" ao invés de "ocupação" porque tivemos, nas pesquisas-piloto, algumas pessoas aposentadas que escreviam a profissão que desempenhavam antes. Como queríamos saber o número de aposentados que frequentavam o curso, optamos por essa expressão para que o participante não ficasse com dúvidas sobre o que lhe era questionado. 
Mais uma vez, frisamos a necessidade de não se abordar diretamente o tema, por trazer bloqueios em relação às respostas fornecidas. Portanto, inserimos quatro questões com as quais pretendíamos, indiretamente, obter comentários a respeito das diferenças etárias nos grupos de língua (as questões que vão de 10 a 13). As respostas dissertativas nos trouxeram comentários ricos para nosso trabalho, como veremos no capítulo 5.

As respostas dissertativas transcritas aparecem com uma legenda que segue este padrão: (f30n3), em que "f" mostra o sexo do participante (no caso, o feminino), "30" é a sua idade e "n3" indica o nível do curso de língua em que está (no caso, nível 3). Uma legenda como esta "m45n7", portanto, deve ser lida da seguinte forma: sexo masculino, 45 anos de idade, nível 7. Nos casos em que a pessoa não indicou sexo ou idade, a legenda será parecida com esta: (søiøn2). Sendo que "sø" corresponde a "sexo vazio" e "iø" a "idade vazio".

Como as respostas de todas as questões eram abertas e os questionários eram muitos, selecionamos os resultados mais centrais, analisados no capítulo 5. De qualquer forma, assim como as outras pesquisas, esta também pode ser encontrada no Anexo E, em uma tabela que traz a somatória das respostas de todos os níveis, divididas por faixas etárias, para consulta do leitor.

\subsubsection{O questionário específico para os monitores}

O questionário específico para os monitores se refere a seis questões específicas relativas a cada um dos grupos para os quais lecionavam, a fim de verificar o sincronismo monitor-aluno - se os monitores possuíam a mesma percepção do andamento do curso, das maiores dificuldades dos alunos e assim por diante. 
Tínhamos duas finalidades com esse questionário: a primeira era verificar se havia discrepâncias sobre como os alunos diziam ser seu relacionamento com o restante do grupo e como os monitores viam o relacionamento entre os alunos; a segunda era a de poder fornecer aos monitores uma oportunidade de confrontar sua visão do grupo e de suas próprias aulas com a visão que os alunos tinham das aulas, como uma ferramenta de auxílio para seu aperfeiçoamento profissional.

De modo geral, as respostas de monitores e alunos coincidem, principalmente quanto à questão do relacionamento entre os alunos do grupo. Uma das questões que teve mais citações diferentes entre alunos e monitores foi quanto a quais habilidades da língua os alunos tinham maior dificuldade. $\mathrm{Na}$ percepção dos alunos, a produção oral é, geralmente, apontada como a maior dificuldade, enquanto que os monitores veem em seus alunos outros pontos de maior dificuldade, como a produção escrita e a gramática. Essa percepção dos alunos pode advir do fato de que se comunicar oralmente seja o objetivo principal apontado pela maior parte deles.

Os resultados desse questionário não serão anexados, por sua especificidade e porque um dos monitores não respondeu, podendo permitir a sua identificação.

\subsection{Terceira etapa: as entrevistas}

Tínhamos a nosso favor o fato de eu também ter sido monitora do Italiano no Campus e, portanto, colega dos entrevistados. Isso possibilitou que a entrevista fosse realizada em um encontro, sem necessidade de fazê-la "em profundidade", pois os entrevistados já se sentiam à vontade com a entrevistadora - o que permite a discussão dos temas sem pensar que precisam ser "politicamente corretos". O clima informal e de bate-papo que prevaleceu durante as entrevistas gerou respostas espontâneas por parte dos participantes. 
O roteiro das entrevistas (semiestruturadas) ${ }^{101}$ foi elaborado de forma a contemplar tanto as questões relativas ao Italiano no Campus - desde coordenação, material didático e estrutura curricular - quanto questões sobre os alunos e outros monitores do IC. Pretendíamos, ao abordar os assuntos de forma indireta, pedindo que o monitor relatasse um caso de reclamação sobre aluno, por exemplo, conseguir alcançar algum comentário sobre a questão etária nas salas de aula. Abordamos diretamente a questão dos alunos idosos somente ao final da entrevista.

O roteiro contava com 44 perguntas, começando com aquelas de caráter geral sobre a profissão de professor de italiano, entrando nas especificidades do Italiano no Campus (infraestrutura, material didático, público), seguido de relatos de reclamações de alunos e monitores e finalizando com a heterogeneidade dos grupos do IC.

Dos cinco monitores e ex-monitores participantes, dois deles sabiam que a nossa pesquisa envolvia a terceira idade, mas não sabiam de que forma a temática era enfocada.

O pedido de concessão de entrevista foi feito a todos os monitores ativos e alguns ex-monitores. Cinco se voluntariaram, sendo quatro monitores ativos e um ex-monitor. Todos assinaram o Termo de Ciência, no qual esclarecíamos a finalidade da entrevista e o que nos comprometíamos a fazer em relação aos dados obtidos, bem como um Termo de Autorização da Publicação da transcrição da entrevista, com preservação de suas identidades. ${ }^{102}$

Assumimos o compromisso de não divulgar a identidade dos participantes ou qualquer outra informação que pudesse identificá-los durante a entrevista. Sabemos que a supressão de dados como o tempo de trabalho como professor de

101 O roteiro das entrevistas pode ser encontrado no Anexo J.

102 Os modelos de termos utilizados podem ser encontrados no Anexo I 
italiano e tempo em que leciona no Italiano no Campus podem comprometer a contextualização e até mesmo a valorização adequada de alguns dos dados obtidos com a pesquisa. Mas nosso compromisso primordial era aquele assumido com os monitores de preservar seus dados. Portanto, nas transcrições das entrevistas, alguns trechos foram suprimidos com esse fim. ${ }^{103}$

A legenda utilizada para indicar quando estamos tratando de dados obtidos com a entrevista dos monitores será feita da seguinte forma: "M" indica "monitor" e se seguirá de um número utilizado para "identificá-lo", finalizando com a letra "e" indicando "entrevista". Portanto, em uma legenda como esta: "M1e", leia-se: "Monitor 1 em entrevista". Quando formos citar algum trecho da entrevista, o monitor será indicado apenas com M e seu número, seguido de dois pontos e sua fala (por exemplo, "M4:" indicando "monitor 4"). E a letra "E" seguida de dois pontos corresponde à fala da "entrevistadora".

As entrevistas nos forneceram dados riquíssimos sobre o Italiano no Campus, sobre o que os monitores mudariam no curso, o papel do professor na sala de aula, a heterogeneidade dos grupos, dentre outros muitos temas que pudemos levantar nas entrevistas.

No capítulo cinco, faremos uma análise das informações coletadas que são mais significativas para o nosso trabalho, lembrando que as transcrições das entrevistas estão à disposição do leitor no Anexo K. Importante ressaltar que as abreviações não correspondem aos mesmos monitores dos questionários. Quatro dos monitores que responderam aos questionários participaram também das entrevistas. 
Realizamos algumas entrevistas com a coordenação e ex-coordenação do Italiano no Campus. Mas como o curso teve - até o momento de nossa pesquisa apenas cinco coordenadoras, seria fácil sua identificação se inseríssemos a transcrição. Apesar de algumas terem permitido a publicação com seus dados, optamos pela preservação de suas identidades. Portanto, das entrevistas com a coordenação, utilizamos os dados que nos permitem contextualizar o Italiano no Campus. 
Análise de

dados 
Optamos, neste capítulo, por não apresentar os dados obtidos com a pesquisa em sua ordem cronológica. Escolhemos a divisão por temas e, dentro desses temas, reunimos os dados de todos os levantamentos que ali cabem ser comentados. Cada tema será contemplado em um tópico (5.1., 5.2. e assim por diante). Lembramos que os dados foram obtidos por meio dos seguintes instrumentos: 1) questionário com alunos principiantes; 2) questionário geral com os monitores; 3) questionário com os monitores específico de cada grupo; 4) questionário com alunos de todos os níveis; 5 ) entrevistas. ${ }^{104}$

A escolha dos temas teve como base os questionamentos que nos colocamos quando começamos o levantamento de dados, esperando que questionários e entrevistas pudessem respondê-los. São eles:

1. Qual o perfil dos participantes do Italiano no Campus: monitores, alunos e coordenação? Qual o diferencial dos alunos do Italiano no Campus, segundo os monitores?

2. Por quais razões os alunos escolheram frequentar um curso de língua italiana? E qual o fator que os levou a escolher o Italiano no Campus especificamente? E os monitores: por que decidiram estudar a língua italiana? $\mathrm{Na}$ opinião deles, o que diferencia o Italiano no Campus dos outros lugares nos quais deram aula de italiano?

\footnotetext{
104 Lembrando que no decorrer do capítulo chamaremos o questionário 1 de "pesquisa/questionário com principiantes", o questionário 2 de "questionário dos monitores", o 4 de "pesquisa/questionário geral", o 5 de "entrevistas" e o questionário 3.1, quando aparecer, será referenciado como "questionário específico dos monitores".
} 
3. A estrutura do Italiano no Campus segundo os participantes: qual o número ideal de alunos, o que mudariam no curso se pudessem, quais as dificuldades estruturais enfrentadas (na opinião dos monitores) e a satisfação com o curso.

4. Quais os interesses dos alunos? Quais assuntos eles gostariam que fossem mais discutidos, em quais elementos da língua apresentam maior dificuldade? Com quais elementos da língua e com quais níveis do curso os monitores se sentem mais à vontade para trabalhar?

5. A heterogeneidade dos grupos na visão dos participantes: qual a opinião de monitores e alunos? Os monitores se sentem preparados para lidar com essa heterogeneidade?

6. Os participantes são a favor ou contra o aspecto intergeracional do Italiano no Campus? Com qual faixa etária os monitores preferem trabalhar e com quais não trabalhariam? Os alunos acham que deveria haver uma divisão por faixas etárias?

Nos tópicos a seguir mostraremos as respostas obtidas com nossas pesquisas, bem como aquelas para as quais não conseguimos respostas.

As perguntas de 1 a 4 servem para determinar se a heterogeneidade quanto às idades determina também as diferenças entre interesses, expectativas, posturas e resultados. As duas últimas questões buscam levantar a opinião de alunos e monitores do IC em relação à heterogeneidade, principalmente àquela etária. 


\subsection{O perfil dos participantes do Italiano no Campus}

\subsubsection{Os monitores}

Para a preservação da identidade dos monitores, omitimos neste trabalho dados como idade, sexo e tempo de trabalho tanto como professores de língua italiana quanto como monitores no Italiano no Campus.

Podemos dizer, entretanto, que a faixa etária dos monitores que participaram da pesquisa está entre 20-35 anos (número aproximativo), e que há um equilíbrio no número de monitores homens e mulheres do curso. Todos são estudantes de pós-graduação do Programa de Língua e Literatura Italiana da FFLCH-USP, não havendo distinções, para trabalhar como monitor, entre os alunos de língua e os de literatura.

Questionados sobre as razões que os levaram a escolher a profissão de professores de língua italiana, obtivemos as seguintes respostas nos questionários (Tabela 9):

Tabela 9: Fatores que influenciaram a escolha em ser professor(a) de italiano (Q3:2)*

\begin{tabular}{c|l}
\hline Monitor & \multicolumn{1}{c}{ Resposta } \\
\hline 1 & $\begin{array}{l}\text { "A demanda do mercado. Sempre fui chamado para lecionar. Não procurava trabalho como } \\
\text { professor, mas sempre surgiram oportunidades." }\end{array}$ \\
\hline 2 & $\begin{array}{l}\text { "A aptidão e o prazer em lecionar e o fascínio pela língua foram os fatores que me levaram a ser } \\
\text { professor de italiano." }\end{array}$ \\
\hline 3 & $\begin{array}{l}\text { "A oportunidade de aprender melhor a língua e rever, estudando, todos os pontos gramaticais. } \\
\text { Futuramente foram vários outros fatores que me motivaram a continuar." }\end{array}$ \\
\hline 5 & $\begin{array}{l}\text { "Ao fazer o curso de Letras, eu já tinha em mente lecionar as línguas estudadas na universidade } \\
\text { (italiano e português). Amo os dois idiomas e gosto de ensiná-los." }\end{array}$ \\
\hline 6 & $\begin{array}{l}\text { "Gosto de ensinar e apareceu a oportunidade." } \\
\text { professor de português que já tinha." }\end{array}$ \\
\hline
\end{tabular}

* A abreviação Q3:Y, como dissemos no capítulo anterior, é usada da seguinte forma: Q corresponde a questionário, 3 é o número do questionário de acordo com a Tabela 1. E Y será substituído pelo número da pergunta dentro do questionário. 
Dos seis monitores que participaram desta pesquisa, três deles destacaram especificamente o gosto em lecionar como fator que os levou a escolher a profissão de professores de língua italiana.

No mesmo questionário, indagamos sobre sua satisfação profissional, pois acreditamos que esta influencia o desempenho dos monitores e, em sala de aula, isso pode afetar - positiva ou negativamente - a forma como os alunos encaram o processo de aquisição/aprendizagem (a/a) da língua estrangeira. Quando perguntados sobre o percentual de satisfação profissional, obtivemos uma média de $82 \%$ de satisfação (Tabela 10):

Tabela 10: Numa escala de 0 a 100\%, quanto você está satisfeito(a) profissionalmente? (Q3:3)

\begin{tabular}{c|c|l}
\hline Monitor & Porcentagem & \multicolumn{1}{c}{ Justificativa (quando dada) } \\
\hline 1 & $80 \%$ & $\begin{array}{l}\text { "Porque sou completamente realizado pessoalmente, mas insatisfeito } \\
\text { com o retorno financeiro." }\end{array}$ \\
\hline 2 & $75 \%$ & - \\
\hline 3 & $90 \%$ & - \\
\hline 4 & $70 \%$ & - \\
\hline 5 & $80 \%$ & - \\
\hline 6 & $97 \%$ & - \\
\hline
\end{tabular}

Nenhum dos monitores se declarou 100\% satisfeito com a profissão. Nas entrevistas, perguntamos o que mais dava satisfação em ser professor de italiano. Na maioria das respostas foram levantadas duas razões de satisfação: gostar da língua que ensina e porque os alunos que procuram estudar a língua italiana geralmente o fazem porque gostam e são, portanto, interessados. Outras respostas se referiam ao trabalho com o processo de construção de uma LE e também a satisfação de ver o resultado do trabalho.

No questionário tínhamos uma pergunta que se referia ao que lhes trazia insatisfação (Tabela 11). 
Tabela 11: O que, na sua profissão, traz insatisfação? (Q3:4)

\begin{tabular}{|c|c|}
\hline Monitor & Resposta \\
\hline 1 & $\begin{array}{l}\text { "A enorme dificuldade em trabalhar como profissional registrado e baixíssima remuneração paga } \\
\text { pelas escolas de idiomas. Hoje entendo que a única solução é me profissionalizar como professor } \\
\text { autônomo, mas me deixa muito indisposto ter as preocupações de um profissional autônomo, } \\
\text { quando queria dedicar mais tempo à minha formação." }\end{array}$ \\
\hline 2 & "O mercado restrito e a baixa remuneração." \\
\hline 3 & $\begin{array}{l}\text { "Nada, mas vejo a oportunidade de ensinar língua como um degrau a ser superado já que meu } \\
\text { objetivo principal é ensinar literatura. Talvez não superado, mas que me dê vivência de ter alunos e } \\
\text { saber administrar uma aula." }\end{array}$ \\
\hline 4 & $\begin{array}{l}\text { "Me deixa insatisfeita o fato de ter que seguir um livro didático nas aulas; prefiro preparar meus } \\
\text { próprios materiais, embora alguns livros didáticos sejam bons. Também me dá insatisfação perceber } \\
\text { que alguns alunos querem aprender italiano, mas não se dedicam ao estudo da língua. Isso me deixa } \\
\text { desanimada, às vezes." }\end{array}$ \\
\hline 5 & $\begin{array}{l}\text { "Gostaria que houvesse maior oferta de trabalho e que eu tivesse vivido na Itália para poder ser uma } \\
\text { professora mais eficaz. Um outro fator é que os materiais de LE são muito caros." }\end{array}$ \\
\hline 6 & "Problemas burocráticos." \\
\hline
\end{tabular}

Nas entrevistas, as respostas para essa mesma pergunta envolviam também a baixa remuneração e a grande quantidade de trabalho; o não reconhecimento do trabalho por parte de alunos, coordenação ou dono de escola; e a escassez de materiais disponíveis. Uma das entrevistadas comenta que, quanto à escassez de material, a internet ajudou muito ao possibilitar o acesso a materiais autênticos e a materiais de ensino de língua divulgados em comunidades e sites de ensino de italiano LE.

Com estes dados, podemos dizer que os monitores de língua italiana estão satisfeitos com o trabalho como professores de italiano LE, apesar de reconhecer as dificuldades inerentes da profissão.

\subsubsection{Os alunos}

Para traçar o perfil dos alunos (tanto dos principiantes quanto do público geral), propusemos questões em relação à idade, sexo, profissão e escolaridade. Quanto a estes dois últimos pontos, obtivemos os resultados apenas do questionário geral. 


\section{Público por nível}

Como vimos no Gráfico 7 (cf. 4.3.2.), a maior porcentagem de público dos cursos de língua do IC é do nível 1 (30\%); a segunda maior porcentagem é do nível $3(20,7 \%)$; e a terceira é do nível 2 (15,2\%), justamente os três níveis iniciais. Podemos notar que se inicia uma diminuição significativa de alunos a partir do nível 4, sendo que a queda do nível 4 para o nível 5 chega a representar 7,5\%. ${ }^{105}$

Os monitores M1e, M2e e M4e confirmam os dados ao declararem que o público diminui conforme o nível aumenta.

M1: [...] As turmas vão se reduzindo. Às vezes o nível 1 começa com 20 e no nível 8 a mesma turma tá com, sei lá, 5, 7 alunos? E é a mesma turma. $[\ldots]$

M4: Quanto mais alto o nível, menor o número de alunos. Tenho um nível 1 com 25 e um nível 8 com 5. Acontecem algumas excę̧ões. O nível 7 com 17 pessoas. Mas o número tende a cair conforme o nível, conforme for aumentando o nível.

M2: [...] Níveis básicos chegam a ser 20 (alunos) facilmente. Nível 2 já cai pra uns 15, daí vai aumentando o nível e vai diminuindo os alunos. $[\ldots]$

\section{Idade}

Já na pesquisa com principiantes (nível 1) foi possível comprovar o ambiente intergeracional do Italiano no Campus. Entretanto, pudemos notar uma divisão de público por faixas etárias diferente daquela que encontramos quando investigado o público geral (todos os níveis). Do público que respondeu a esta pesquisa no nível 1, tivemos a seguinte divisão por faixa etária (Gráfico 8):

105 Não podemos esquecer que duas turmas dos níveis finais não participaram da pesquisa, afetando os resultados dos níveis 7 e 8. 


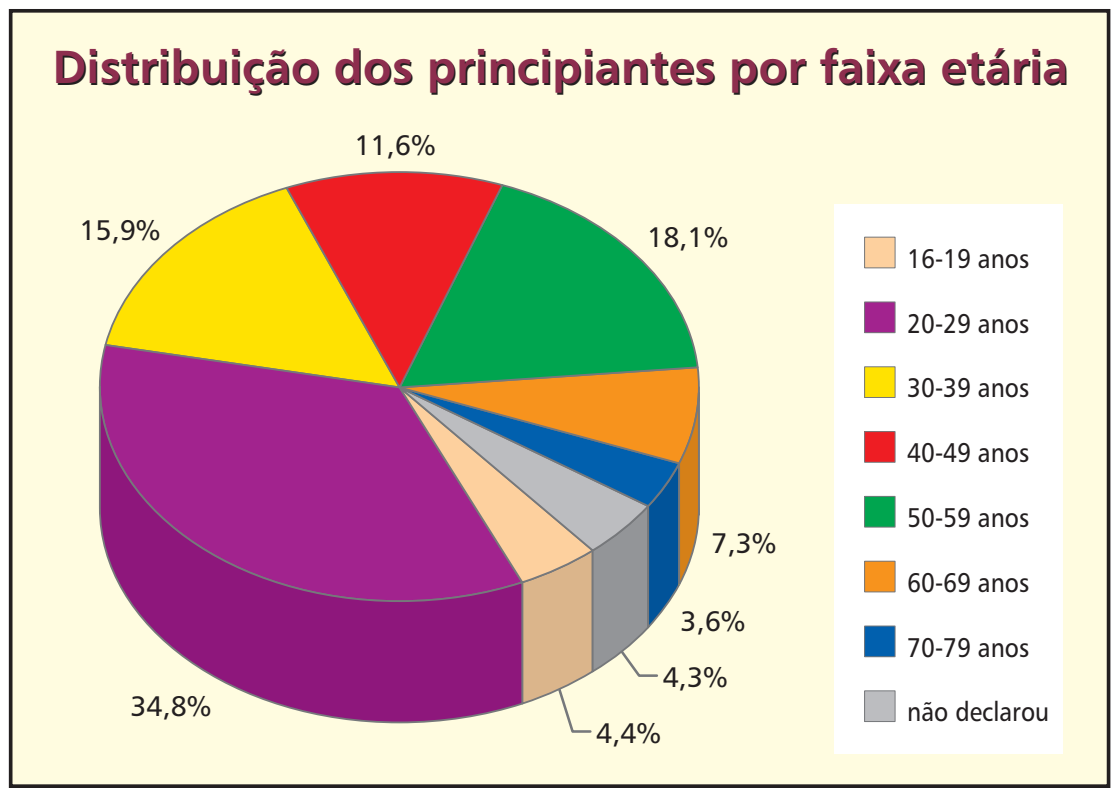

Gráfico 8 - Público principiante por faixa etária

Temos, neste caso, o primeiro maior público entre 20-29 anos, correspondendo a 34,8\% dos ingressantes no nível 1; enquanto que o segundo maior público desse nível é aquele que compreende a faixa etária entre 50-59 anos (alguns deles, se derem continuidade ao curso, pertencerão à chamada terceira idade antes de finalizá-lo). E o terceiro maior público é aquele entre 30-39 anos. O público de idosos ingressantes representa - somando-se todos aqueles acima de 60 anos - 10,9\% do nível 1 .

Já com a pesquisa geral, envolvendo 237 estudantes de todos os níveis de língua, obtivemos o perfil etário apresentado no Gráfico $6^{106}$ :

- o primeiro maior público do Italiano no Campus são os alunos de faixa etária entre 20 e 29 anos (com 28,7\%);

- o segundo maior público são os alunos com idades entre 60 e 69 anos, já considerados idosos (com 20,7\%);

- em terceiro lugar, estão os alunos de 50 a 59 anos (com 17,7\%). 
Se considerarmos o público total de terceira idade - todos com 60 anos ou mais - teríamos uma soma de $24,9 \%$ do público do Italiano no Campus pertencente à terceira idade $(20,7 \%$ de 60 a 69 anos somados ao público de 70 a 79 anos, que representam 4,2\% do público do IC). Praticamente um quarto (1/4) dos alunos dos cursos de italiano é idoso.

Podemos depreender também, ao analisar o Gráfico 6, que há equilíbrio entre as faixas etárias que frequentam o curso, com poucos representantes apenas nos dois extremos: alunos de 15 a 19 anos e alunos de 70 a 79 anos.

Se compararmos o Gráfico 6 com o Gráfico 8, podemos ver que se mantém o primeiro lugar com a faixa etária de 20 a 29 anos, mas com queda: nos níveis iniciais, esse público representa $34,8 \%$ dos frequentadores, enquanto que no público geral representa 28,7\%. Já o público de 60 a 69 anos, que nos níveis principiantes ocupa o quinto maior público, com 7,3\% - na frente apenas dos alunos de 70 a 79 anos, de 15 a 19 anos e dos que não declararam idade - passa, no gráfico do público geral, a ocupar a segunda posição, correspondendo a 20,7\% dos alunos. Poderíamos deduzir, a partir desses dados, que, ao longo do curso, o público tende a se equilibrar, havendo evasão dos alunos de faixa etária entre 20 e 29 anos, enquanto alunos idosos se mantêm nos cursos.

Podemos compreender a diminuição no número de frequentadores entre 20 e 29 anos e entre 30 e 39 anos e o aumento dos frequentadores de terceira idade pelo depoimento de M5e, no qual ele ressalta que o público universitário que estuda língua com fins acadêmicos ou profissionais não permanece nos cursos de língua do IC devido ao perfil do curso. Pode-se concluir que os alunos que procuram o curso com fins mais imediatistas tendem a abandoná-lo, enquanto aqueles que o procuram para aperfeiçoamento pessoal sentem-se mais motivados a continuar. ${ }^{107}$

107 A Faculdade de Filosofia, Letras e Ciências Humanas oferece também um curso de Italiano Instrumental por meio do Centro de Línguas. Esse curso visa a preparar o aluno para o uso do italiano instrumental para fins mais imediatos (leitura de textos, exames de proficiência etc). 
Quando perguntados sobre as razões de terem escolhido estudar italiano, os três primeiros motivos apontados são os mesmos para os alunos das faixas entre 20 e 29 anos e 60 e 69 anos. Mas no primeiro grupo, há um número maior de participantes que indica razões profissionais ou acadêmicas para frequentar o curso (para proficiência, por necessidade profissional etc.). Dentre os estudantes de 60 a 69 anos, 49\% são aposentados.

\section{Sexo}

Com as pesquisas, conseguimos também levantar o número de homens e mulheres que frequentam o IC. Nos níveis 1, as mulheres representam maioria do público (Gráfico 9):

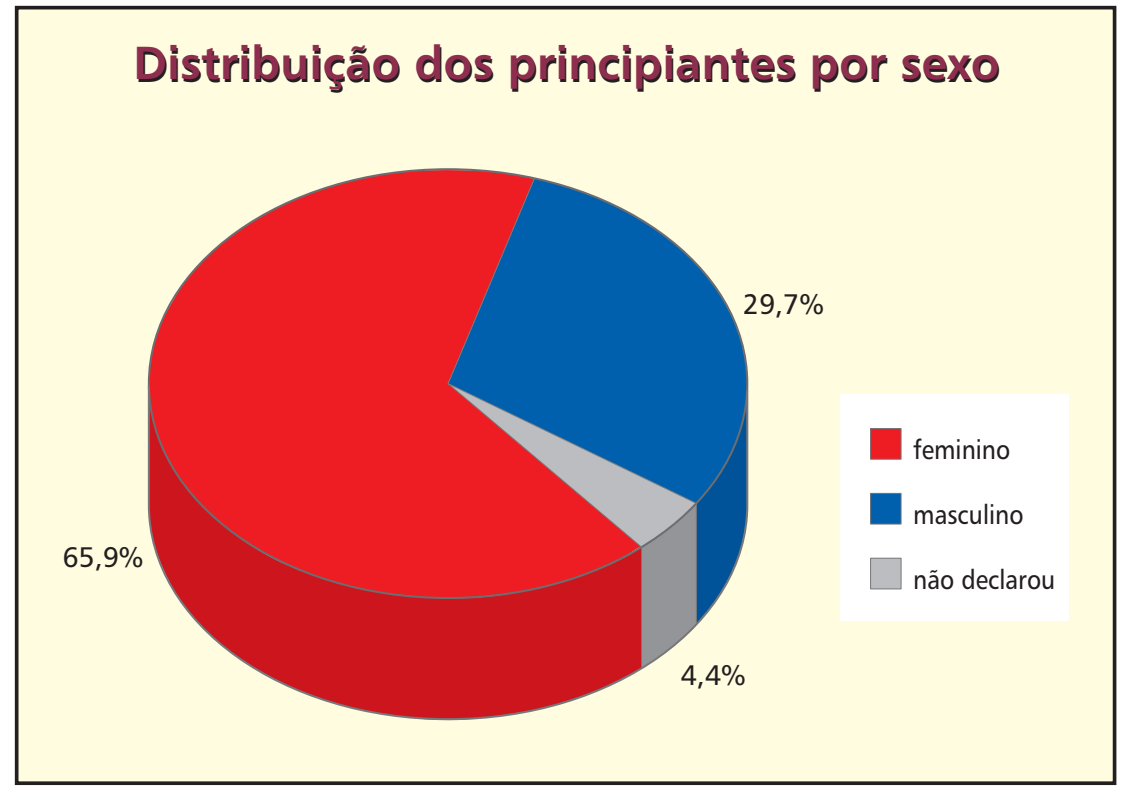

Gráfico 9 - Público principiante por sexo

Como podemos ver no Gráfico 9, as mulheres representam 65,9\% do público ingressante no Italiano no Campus. Na pesquisa realizada com o público geral do IC, pudemos traçar o seguinte gráfico (Gráfico 10): 


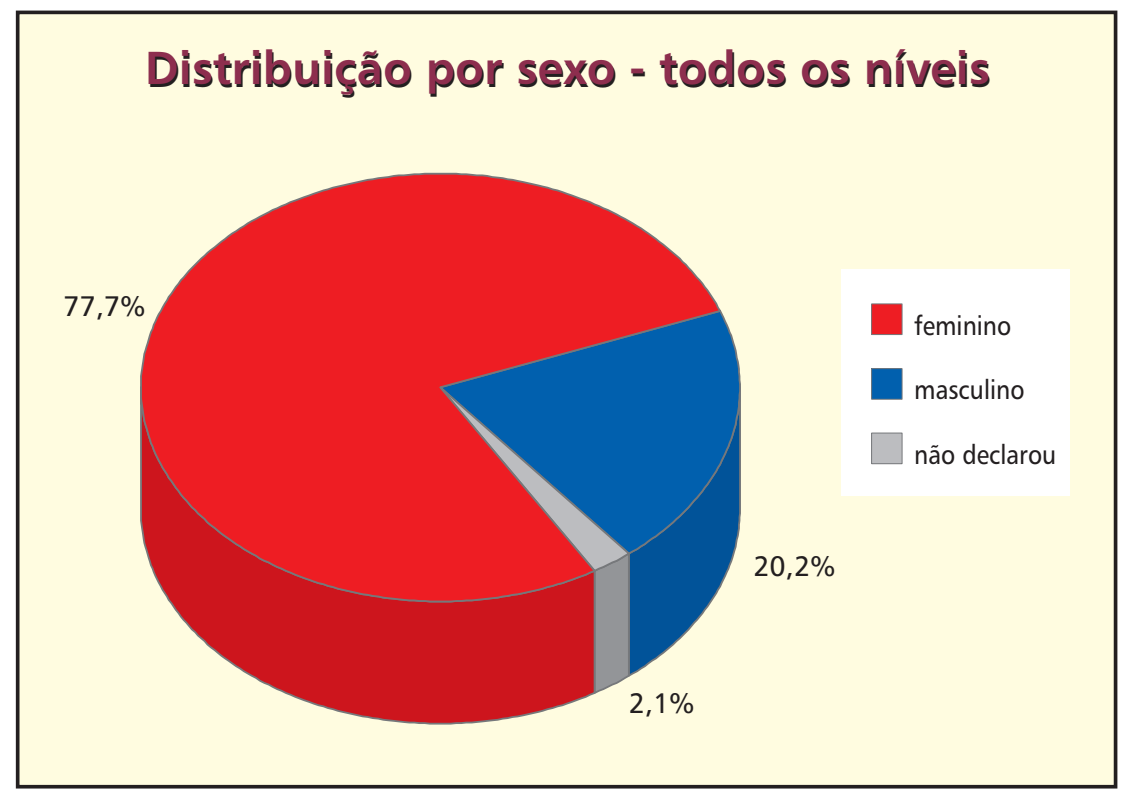

Gráfico 10 - Público geral por sexo

No Gráfico 10, as mulheres são maioria, correspondendo a 77,7\% dos alunos do IC. Se o compararmos ao Gráfico 9, veremos que as mulheres continuam sendo maioria, mas seu porcentual aumenta mais de $11 \%$, enquanto o dos homens diminui aproximadamente 9\% do nível 1 para o público geral. Se analisarmos qual a porcentagem de participação de cada sexo por faixa etária, teremos os seguintes resultados do Gráfico 11:

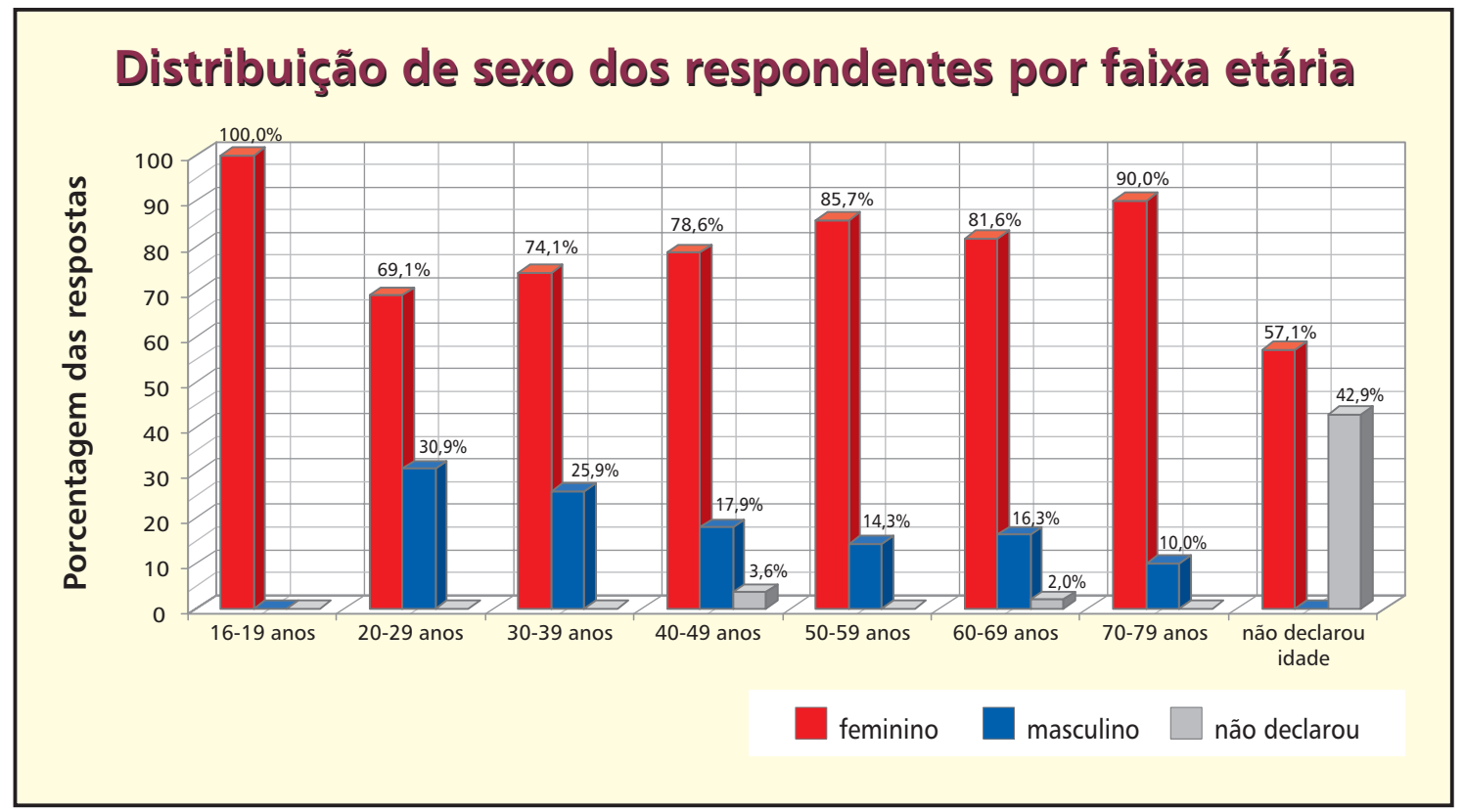

Gráfico 11 - Público geral por faixa etária: participação de cada sexo 
Segundo o Gráfico 11, em todos as faixas etárias a porcentagem de participação de mulheres está muito acima da de homens. É interessante notar que, dentre as pessoas que não declararam idade, 57,1\% eram mulheres. Isso pode ter ocorrido por um "hábito histórico" da nossa sociedade brasileira de não revelar a idade da mulher ou não questioná-la sobre o assunto, tido como descortês. As pessoas que não quiseram expor nenhum dado pessoal, deixaram de responder a todas as questões do cabeçalho (idade, sexo, profissão e escolaridade).

Como tratamos no primeiro capítulo, Neri (2007b) afirma que o Brasil assim como o resto do mundo - está vivenciando um fenômeno chamado de "feminização da velhice". Apesar de trazermos os dados de todas as faixas etárias, não podemos deixar de relacionar esse fenômeno ao fato de a maioria dos alunos do Italiano no Campus ser mulheres. Segundo Neri, a feminização da velhice se deve a fatores como: maior expectativa de vida da mulher em relação ao homem as mulheres tendem a cuidar mais da saúde -, maior facilidade de se inserir em outras atividades sociais, o crescimento das mulheres idosas que fazem parte da população economicamente ativa e o crescimento do número de mulheres idosas chefes de família.

Nas projeções sobre a expectativa de vida dos brasileiros (cf. capítulo um) vimos que as mulheres têm (e continuarão a ter) uma expectativa de vida maior do que a dos homens. Seguindo essas projeções, a tendência é de que se continue a ter uma porcentagem maior de mulheres participantes de cursos livres do que de homens, principalmente após a aposentadoria.

\section{Escolaridade}

O Italiano no Campus exige que o participante tenha concluído o Ensino Médio, o que delimita o público que terá acesso aos cursos. Entretanto, exceções podem ser abertas se o professor-coordenador autorizar. A participante mais jovem do IC declarou que ainda estava cursando o Ensino Médio, sendo o único caso de 
Ensino Médio não completo levantado. O resultado geral da escolaridade dos participantes pode ser observado no Gráfico 12, reproduzido a seguir:

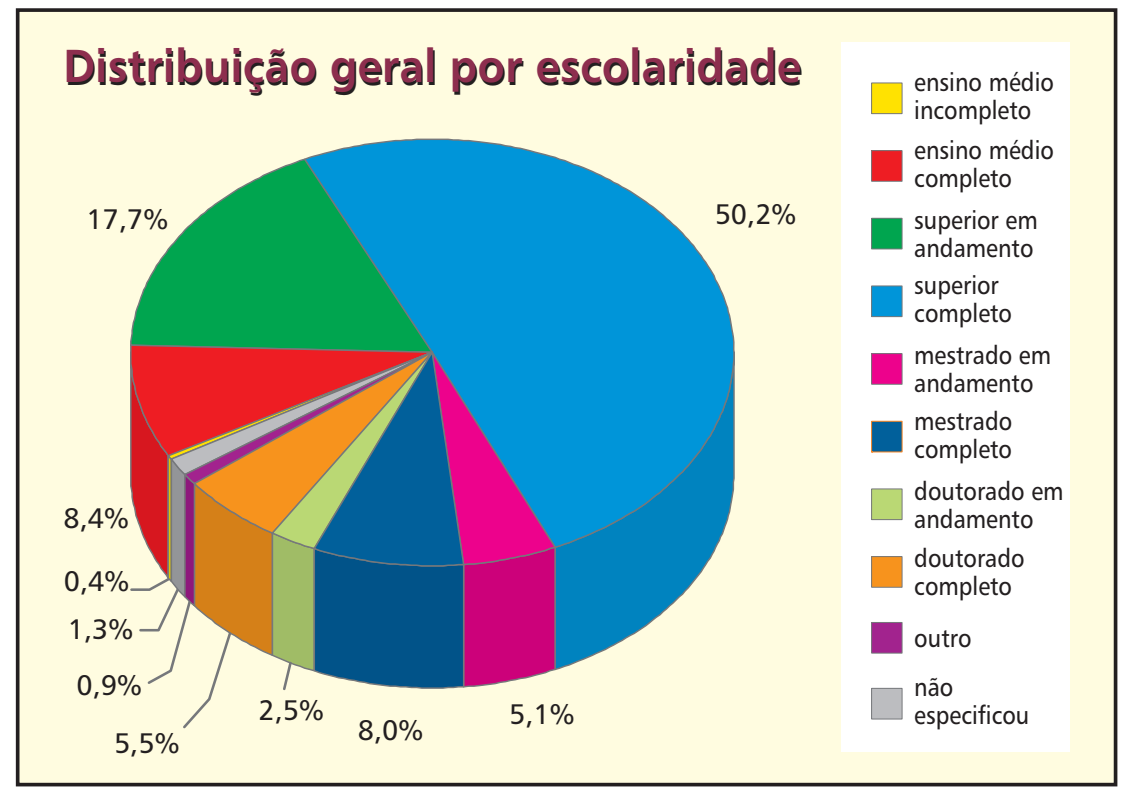

Gráfico 12 - Público geral por grau de escolaridade

Como podemos ver no Gráfico 12, mais de 50\% dos estudantes do IC possuem a graduação completa, enquanto que o segundo grau de escolaridade mais citado foi o "superior em andamento".

No primeiro capítulo, mencionamos a pesquisa feita pela Fundação Perseu Abramo em parceria com o SESC (Neri, 2007), na qual tínhamos a afirmação de que $44 \%$ dos idosos gostariam de frequentar um curso, mas que somente $2 \%$ deles de fato frequentavam algum. Outro dado trazido pela mesma pesquisa, que pode ser encontrado no texto de Santos, Lopes e Neri (2007), é o de que apenas 7\% dos idosos brasileiros possuem segundo grau completo e apenas 4\% deles têm o superior completo. Ainda, segundo as autoras, quanto maior a renda, maior a escolaridade. Lembremos aqui que Delors et al. (1998b; 1998c) declaram que quanto maior a formação, maior a vontade de se continuar estudando. Como vimos anteriormente, quanto mais se mantém a mente ativa, menores são os danos causados pelo envelhecimento e maiores são as chances de conservar as 
estruturas cognitivas intactas. Temos que considerar, portanto, o público idoso do Italiano no Campus como representantes de uma minoria no Brasil atual. Vejamos os dados obtidos sobre os frequentadores idosos do Italiano no Campus na classificação de escolaridade:

- $60 \%$ têm superior completo;

- $\quad 17,7 \%$ têm ensino médio completo;

- $\quad 15 \%$ têm mestrado completo.

Podemos concluir com esses dados que a maioria dos estudantes idosos do IC completou o ensino superior, fazendo parte dos $4 \%$ de idosos no Brasil que o concluíram. Esses idosos fazem parte dos $2 \%$ de idosos brasileiros que frequentam um curso. Porcentagens baixas em um país cuja população idosa está em contínuo aumento e já representa 10\% de seus cidadãos. Com as novas gerações adquirindo um nível maior de escolaridade podemos esperar que, futuramente, o número de idosos participantes de cursos como o Italiano no Campus seja ainda maior.

Poderíamos ainda confirmar a declaração de M5e, na qual destaca que os estudantes do Italiano no Campus possuem um nível econômico e de escolaridade "acima da média". M2e afirma que o público do IC se difere daquele das outras escolas em que deu aula pelo grau de instrução dos alunos e pelo seu poder aquisitivo. Ambos os monitores (M2e e M5e) mencionam o fato de muitos dos alunos já terem ido à Itália, o que não acontece com tanta frequência nos outros cursos em que deram aula. Por isso, segundo M5e, os alunos do IC parecem ter uma confiança maior no processo de aquisição/aprendizagem da LE.

M2: [...] Então eu diria que nós estamos trabalhando aqui com uma classe que:.... quase A, B. Então você vê (incompreensível) eles têm maior experiência. Muitos já foram à Itália e por isso querem aprender italiano, ou então porque têm que ir para a Itália e por isso querem aprender italiano. Ou o público também... acho que talvez seja maior nisso mesmo. $[\ldots]$ 
M5: [...] Acaba concentrando mais, uma concentração maior/um número maior de pessoas com maior poder aquisitivo. Eu não via e não vejo ainda nos outros cursos, nos outros lugares onde dou aula, ou dei aula, pessoas que tivessem essa/que fossem com a frequência que os alunos daqui vão pra Itália. Ou que têm contato com italianos que vêm pra cá ou pessoas na família que vão pra Itália... Isso é:..... - Eles aqui no Italiano no Campus, por ter esse repertório, parecem que se sentem mais, têm mais claro que vão conseguir se apropriar da língua e usá-la. Em outros lugares ainda é muito pitoresco o italiano, uma coisa muito distante mesmo.

No levantamento das profissões dos participantes, não houve nenhuma que se sobressaísse de forma a nos fazer supor que algum público procuraria o curso com maior frequência devido a razões profissionais.

Tivemos, então, os seguintes resultados:

- $\quad 1^{\circ}$ lugar: APOSENTADO/A - com 16,4\% do público do IC;

- $2^{\circ}$ lugar: PROFESSOR(A) - os que se declararam somente "professor(a)" correspondem a 12,2\% do público do IC, 2,1\% se declararam "professor(a) de língua estrangeira; e 1,3\% se declarou "professor(a) universitário". Unindo os resultados ${ }^{108}$, teremos o equivalente a $15,5 \% .^{109}$

- $\quad 3^{\circ}$ lugar: ESTUDANTE - com 11,8\% do público do Italiano no Campus.

Como podemos notar nos dados levantados, o maior público do Italiano no Campus é de aposentados. O que nos faz retomar a discussão do primeiro capítulo, sobre a aposentadoria ser o momento de busca por realização pessoal, e isso envolve frequentar cursos deixados de lado por outros motivos como trabalho, família etc. Como vimos no capítulo três, começa-se a dar maior

108 Pois não podemos determinar quantos dos que se declararam "professor(a)" sem especificações pertencem a um ou outro grupo, não podendo, portanto, serem divididos em "categorias"

109 Alguns, na questão de por que escolheu o IC e não um instituto de língua, declararam que professores do Estado tinham desconto no Italiano no Campus. 
destaque a esse tipo de educação informal - os cursos livres - e ao aprendizado que é voltado também ao prazer e não só ao aperfeiçoamento profissional. Como veremos adiante, uma porcentagem significativa dos alunos do IC optaram pela língua italiana por razões de ascendência italiana, o que mostra um fator afetivo com a língua. Lembro-me de uma aluna que tive no IC, com 72 anos, que declarou ter sempre desejado aprender italiano, mas que o marido não permitia que ela estudasse ou trabalhasse. Quando o marido faleceu, ela se inscreveu no curso. Ela declarou que após a morte dele, começou a fazer tudo o que sempre quis e ele nunca permitiu.

\section{Os alunos do Italiano no Campus na visão dos monitores}

Nas entrevistas, perguntamos aos monitores se o Italiano no Campus era feito para algum público específico. Três deles responderam que não, e dentre estes, um disse que de certa forma se restringe o público ao exigir o Ensino Médio completo. Um dos monitores que respondeu "de certa forma, sim" também apontou a exigência de um determinado grau de escolaridade como fator de restrição do público-alvo. E M5e diz que o curso acaba sendo voltado para os alunos que têm uma relação de vaidade com a língua.

M5: [...] Esse pessoal de diferentes faixas etárias, diferentes faixas etárias que tem um nível::... não só de escolaridade, mas também econômico, um tanto quanto alto/acima da média, digamos. E que espera ali um curso clássico... mais preocupado com o glamour de aprender italiano do que com o fato mesmo de::: assim, de educação: "Tô aqui pra verdadeiramente ampliar os horizontes, porque aprender uma outra língua enriquece." ... Isso é um discurso muito na boca de todo mundo: "Ah, tô aqui pra...", né? "enriquecer o::... o meu conhecimento", uma relação de glamour, de vaidade com a língua. Eu acho que a forma como o trabalho é feito, como é tudo conduzido, isso vai atraindo mais gente desse tipo e, as pessoas que têm esse tipo de relação com a língua permanecem. Entendem que tão no lugar certo. E pessoas, alunos que têm um outro objetivo vão embora. E, por exemplo, pensando num público que existe, que são os universitários de diferentes institutos e faculdades, não só daqui da FFLCH ou só da Letras, mas que querem aprender a língua pra ir pra 
Itália, pra fazer um exame de língua, esses não têm lugar aqui. E eu vejo que os que estão frequentando tão fora do lugar, eles não conseguem e não vão conseguir chegar no objetivo deles. Não é/É pra se ter uma relação de:... complicadíssima, complicadíssima com a universidade com esses cursos que têm por parte, com objetivo ser laboratório, mas é pra quem tem essa relação de vaidade, de grife com a língua. O curso é feito pra eles.

Alguns dos monitores entrevistados apontam o fato de o Italiano no Campus, que tem como objetivo ser laboratório, ser muito parecido com os cursos oferecidos por outros institutos e escolas de língua (tanto na divisão dos módulos quanto na adoção do material didático), o que pode acabar atraindo um público que busca o currículo que encontraria em uma escola de língua por um preço mais acessível. No questionário geral, duas alunas afirmaram ter escolhido o Italiano no Campus porque o material didático e os métodos são semelhantes aos dos Institutos.

A coordenação, ao se referir ao início do Italiano no Campus, relata que o curso foi pensado para atender à comunidade USP e que não se imaginava esse alcance externo. Confirma, também, que a heterogeneidade nos grupos sempre existiu, não se restringindo a um público específico. Hoje, a comunidade externa é maioria dos frequentadores do Italiano no Campus. M3e ressalta o fato de muitos aposentados estudarem no IC:

M3: [...] Pra comunidade (USP) eu acho positivo, e:: mas vejo que não é só - são poucos os estudantes de Letras que eu vejo nos cursos. Vejo mais a comunidade fora da USP. Muitos senhores, aposentados, que não querem ficar só em casa, preferem aprofundar mais é:: também sobre a língua, coisas que eles sempre tiveram interesse, então não ficou só na comunidade. Coisa que poderia, a comunidade USP, poderia ser mais bem aproveitado pelos alunos de italiano mesmo, da graduação, são poucos.

Dois entrevistados se referem ao baixo número de estudantes de graduação que frequentam os cursos. Durante o trabalho de monitoria no IC, pude notar que 
os cursos do Campus são em grande parte desconhecidos dos alunos da graduação de italiano, e os que o frequentam logo o abandonam por considerarem os cursos de língua do IC muito "lentos", já que a dinâmica das aulas de língua de graduação e extensão, bem como seus enfoques são completamente diferentes. Há outros cursos de língua italiana oferecidos por outras faculdades do Campus Butantã, mas destacamos que 4,2\% das citações sobre os motivos pelos quais escolheram o Italiano no Campus se referem à formação e/ou ao nível de qualidade dos monitores $^{110}$.

Nas entrevistas, retomamos a discussão sobre o fato de alunos do Italiano no Campus serem diferentes ou não dos alunos de outros lugares em que deram aula. Três deles responderam prontamente que "sim". E apontam a escolaridade e o poder aquisitivo como o diferencial do público do IC. Destacamos os comentários de dois monitores sobre a questão da diferença de público que frequenta o IC:

M4: [...] por exemplo, uma pessoa que procura uma aula particular através de um/através de uma escola, é uma pessoa que precisa de um::/de uma:.... / de uma aprendizagem meio relâmpago. [...] E no IC, não. É um público que quer aprender a língua como sistemas, com um funcionamento. Para mim, essa é a maior diferença entre os públicos.

M3: Sim. Ele é diferente. Ele é um pouco mais exigente também porque você vê que nos outros lugares às vezes a pessoa só tá fazendo porque talvez a empresa exigiu, é:: mas você vê que aqui na comunidade mesmo da USP os alunos estão interessados, quando eles fazem uma pergunta é com propriedade, então é diferente.

Nesta pergunta nenhum monitor apontou a idade como diferencial do público do IC.

\footnotetext{
110 Todos os monitores envolvidos na pesquisa eram estudantes de pós do próprio Programa de Pós-graduação de Língua e Literatura Italiana.
} 


\subsection{A escolha pelo curso de italiano}

$\mathrm{Na}$ nossa primeira pesquisa, com os grupos principiantes, perguntamos quais foram as razões que os levaram a frequentar o curso de língua italiana. As respostas mais dadas foram as seguintes:

- $25 \%$ disseram que o fizeram por serem descendentes de italianos;

- 21,4\% escolheram o curso de italiano por acharem a língua bonita;

- $11,2 \%$ disseram estar com a ida programada ou que pretendiam conhecer a Itália.

Abaixo, podemos ver o Gráfico 13, do percentual dessa questão nos grupos principiantes.

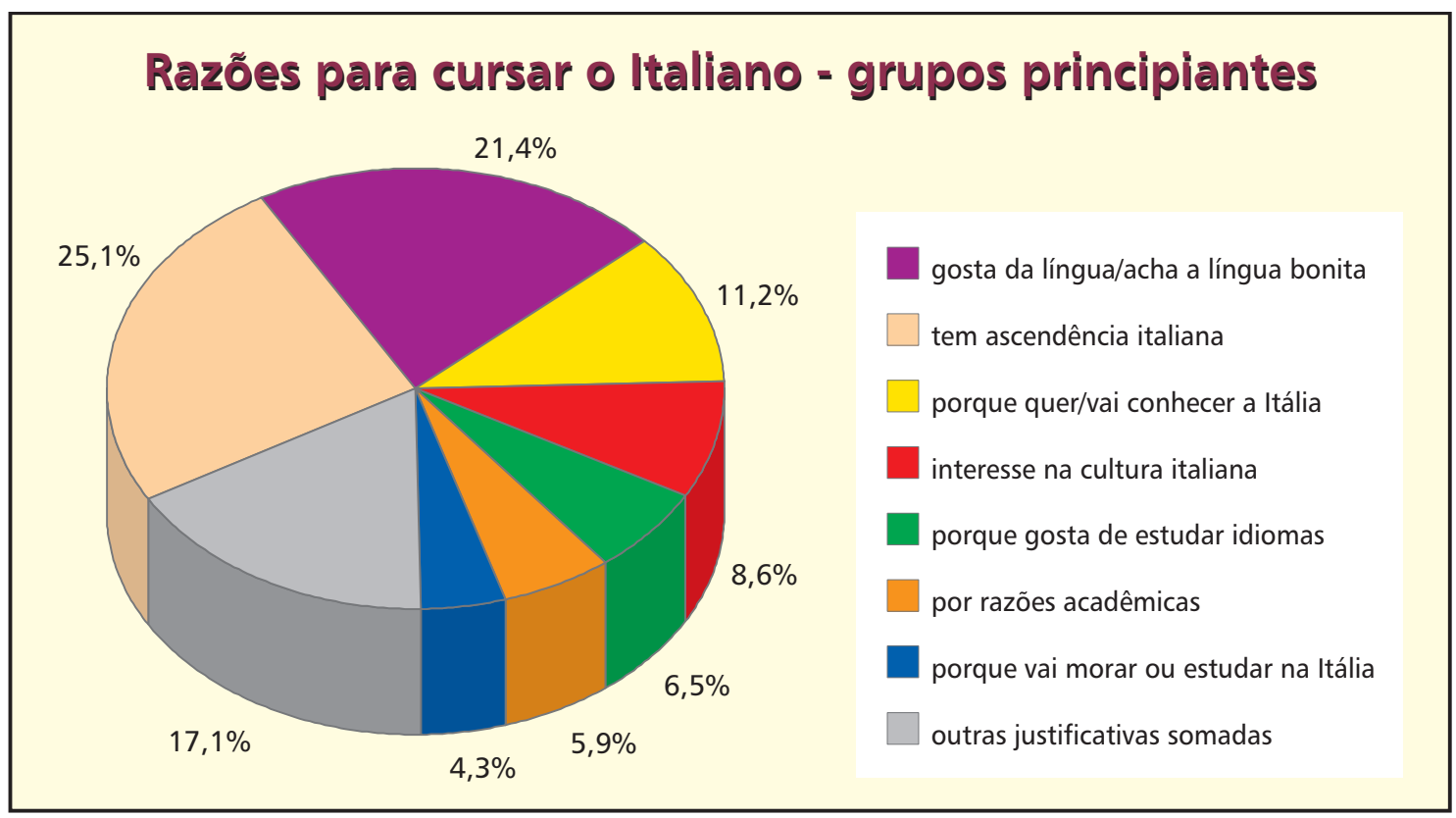

Gráfico 13 - Justificativas apontadas pelo público principiante para a escolha do curso

Podemos verificar, nos resultados apresentados no Gráfico 13, que uma porcentagem significativa dos estudantes $(25,1 \%)$ escolheu o curso de italiano por sua ascendência italiana. Essa tendência se mantém no questionário geral, a partir do qual pudemos encontrar os seguintes resultados: 
- $1^{\circ}$ lugar: Porque a família é de origem italiana./Porque tem a dupla cidadania (corresponde a 23,4\% das citações);

- $2^{\circ}$ lugar: Porque gosta da língua./Porque acha a língua bonita (14,24\% das citações);

- $\quad 3^{\circ}$ lugar: Porque gosta ou tem interesse pela Itália e pela cultura italiana ( $8,90 \%$ das citações).

Como podemos notar, os resultados gerais são compatíveis com os resultados obtidos com os grupos de nível 1. As duas primeiras posições são as mesmas. Há mudança apenas dos terceiros lugares (nos níveis 1, o terceiro lugar fica com os alunos que escolheram o curso porque vão para a Itália ou porque pretendem ir). Nos dois questionários, temos a maioria, quase um quarto $(1 / 4)$ do público do IC, que escolheu o curso de língua italiana por questões de ascendência - o que nos faz retomar a questão discutida no terceiro capítulo, de que muitos deles se sentem familiarizados com a língua.

No questionário geral, verificamos que as três primeiras colocações se mantêm nas faixas etárias estudadas, com diferença apenas no segundo lugar dos alunos de 60 a 69 anos, para os quais a segunda posição fica com o "interesse em conhecer pessoalmente a Itália/viajar para a Itália por turismo". Podemos relacionar este item ao discutido no primeiro capítulo sobre a busca, por parte dos idosos, pelo turismo como uma das opções de preenchimento do tempo livre ou realização pessoal de desejos "adiados" durante o período em que trabalhavam. Na pesquisa dos principiantes, dois estudantes da faixa etária de 70 a 79 anos declararam ter escolhido estudar italiano para "conservar a memória".

Também perguntamos aos monitores do Italiano no Campus por que decidiram estudar a língua italiana, a fim de saber se quem trabalha ensinando a língua também começou a estudá-la pelos mesmos fatores mencionados pelos alunos. Acompanhemos as respostas na Tabela 12: 
Tabela 12: Por que decidiu começar a estudar italiano? (Q3:1)

\begin{tabular}{c|l}
\hline Monitor & \multicolumn{1}{c}{ Resposta } \\
\hline 1 & "Porque queria trabalhar com línguas estrangeiras. Não pensava em me tornar professor." \\
\hline 2 & $\begin{array}{l}\text { "Foi durante o primeiro ano na faculdade, quando deveria decidir a habilitação; a ascendência e a } \\
\text { cultura geral italiana foram culminantes na escolha." }\end{array}$ \\
\hline 3 & "Identificação com a cultura e a língua." \\
\hline 5 & $\begin{array}{l}\text { "Foi uma escolha um tanto quanto casual: eu queria estudar latim e, como todos dizem que o } \\
\text { italiano é a língua mais parecida com o latim, optei por estudar a língua de Dante." }\end{array}$ \\
\hline 6 & "Como eu poderia escolher uma língua e eu já conhecia o inglês, então vi o italiano, e por instinto o \\
\hline
\end{tabular}

Nas respostas dos monitores podemos observar que, ao contrário dos alunos do Italiano no Campus (que, em sua maioria, escolheu o curso de italiano por serem descendentes de italianos), apenas um dos monitores diz ter sido influenciado por sua ascendência ao optar pela língua italiana.

O próximo passo era saber o que levava os alunos a escolherem o Italiano no Campus e não uma escola de línguas, para que pudéssemos levantar os elementos mais atraentes no IC para os alunos. Obtivemos os seguintes resultados para a pergunta "Por que o Italiano no Campus e não um Instituto de Língua?":

- $\quad 1^{\circ}$ lugar: PREÇO - 25\% das respostas;

- $2^{\circ}$ lugar: LOCALIZAÇÃO ${ }^{111}$ - com 16,6\% das respostas;

- $\quad 3^{\circ}$ lugar: PORQUE ESTUDA/TRABALHA NA USP (facilidade de já estar na USP) - corresponde a $10,8 \%$ das respostas dadas representam a comunidade USP;

- $\quad 4^{\circ}$ lugar: QUALIDADE (do curso) - com 9,8\% das respostas.

111 Por localização aqui, entende-se a proximidade geográfica com a casa do aluno ou o trabalho. As respostas "por ser na USP" foram elencadas em outra entrada, pois poderiam indicar a confiança no nome da instituição e não o espaço físico. 
O Italiano no Campus cobra uma taxa semestral para os cursos (sejam eles de língua, cultura ou conversação) considerado muito baixo em relação àqueles praticados pelos institutos e escolas de língua. Em alguns casos, a taxa que o IC cobra por semestre é praticamente equivalente à cobrada em apenas um mês de aulas em institutos. Além disso, outro atrativo do IC são as bolsas e os descontos oferecidos, que podem ser maiores ou menores para alguns alunos específicos como: graduandos, pós-graduandos, docentes e funcionários da FFLCH; graduandos em italiano da FFLCH, professores ativos da rede pública, monitores bolsistas e estagiários da FFLCH, além dos descontos para os alunos com 60 anos ou mais.

Dentre os participantes externos à comunidade USP, podemos concluir que estão, em grande parte, os moradores dos bairros próximos à Universidade, já que apontam a localização como razão de terem optado pelo IC.

Optamos por citar os quatro primeiros lugares, pois das faixas etárias de 16 até 49 anos, temos nos três primeiros lugares exatamente as três primeiras posições elencadas acima. A partir dos 50 até os 79 anos, o terceiro lugar é ocupado pela opção "qualidade do curso" e não "porque estuda/trabalha na USP".

\subsection{Interesses}

$\mathrm{Na}$ pesquisa geral, perguntamos quais os assuntos que os alunos gostariam que fossem mais abordados em sala de aula. Elencamos no Gráfico 14 os assuntos citados e qual a porcentagem das citações que eles tiveram: 


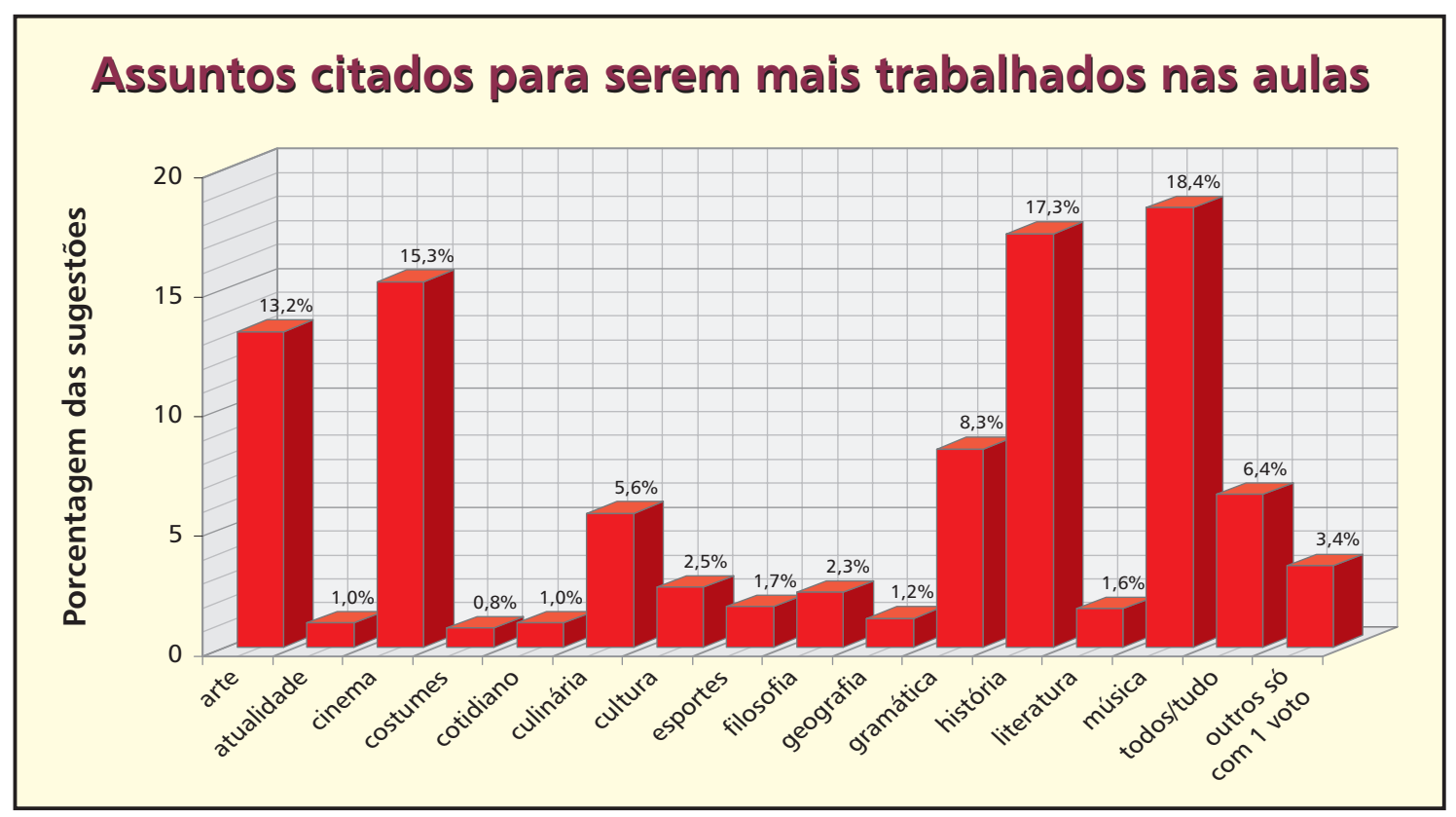

Gráfico 14 - Assuntos de maior interesse citados pelo público geral

Como podemos perceber no Gráfico 14, os assuntos de maior interesse geral são (por ordem de citação): música (18,45\% das citações), história (17,3\%), cinema $(15,3 \%)$ e arte $(13,2 \%)$. Se pensados por faixa etária, não há diferenças significativas entre os assuntos mais escolhidos. As variações existentes são: na faixa etária de 40-49 anos, o terceiro lugar fica com a "gramática". Nas faixas acima de 50 anos, "arte" empata com "história" na segunda posição.

Perguntamos aos monitores, nas entrevistas, quais materiais extra eles mais gostam de levar para a sala de aula. (Tabela 13)

Tabela 13: Materiais extra mais utilizados pelos monitores (E)

\begin{tabular}{c|l}
\hline Monitor & \multicolumn{1}{c}{ Materiais } \\
\hline 1 & Músicas, textos literários e história em quadrinhos \\
\hline 2 & Músicas e textos da Internet \\
\hline 3 & Músicas \\
\hline 4 & Artigos de jornal e contos \\
\hline 5 & Artigos de jornal on-line, músicas (porque os alunos pedem) \\
\hline
\end{tabular}


Três dos cinco monitores entrevistados declararam, espontaneamente, levar música para a sala de aula, justamente o ponto que mais interessa aos alunos segundo o Gráfico 14. Mas os resultados não permitem depreender que a escolha dos textos atenda ao desejo dos alunos de saber mais sobre arte e história, por exemplo. Entretanto, os monitores poderiam utilizar os textos literários, jornalísticos e de internet para trabalhar desde a compreensão escrita e o léxico até questões culturais. M3e e M5e disseram gostar de trabalhar com filmes, mas no IC isso fica limitado por conta da falta de recursos para aulas que exijam equipamento audiovisual e pela indisponibilidade das salas. ${ }^{112}$

Em seguida, passamos às habilidades da LE com as quais os alunos declaram sentir maiores dificuldades. Ressaltamos que, ao contrário do questionário com os níveis principiantes, o questionário geral foi aplicado ao final do semestre, portanto, os alunos de nível 1 também puderam responder com qual habilidade sentiam dificuldades.

- 54,9\% deles disseram ter mais dificuldades com a produção oral;

- 21,1\% disseram que é a gramática a parte mais difícil do curso;

- 20,3\% disseram ser a produção escrita a mais difícil.

Portanto, mais da metade dos alunos considera a produção oral o ponto mais difícil da aula de LE. Na divisão por faixas etárias, as três primeiras colocações se mantêm, com alteração entre $2^{\circ}$ e $3^{\circ}$ lugares a partir dos 50 anos. Temos, portanto, de 15 a 19 anos os seguintes três primeiros lugares (por ordem de colocação): 1) produção escrita; 2) produção oral; 3) gramática. De 20 a 49 anos as três primeiras colocações são: 1) produção oral; 2) produção escrita; 3)

112 As turmas de sábado são as mais prejudicadas, pois nesse dia da semana não há expediente, e as salas multimídias e equipamentos ficam indisponíveis. Se um aluno frequenta todo o curso de língua aos sábados, provavelmente não assistirá a nenhum vídeo, a menos que se combinem atividades extraclasse ou conte-se com a disponibilidade dos alunos em emprestarem equipamentos. Dois casos que presenciei como monitora foram de alunos que levaram para a sala de aula televisão e aparelho de DVD para que pudessem ver um filme com o professor e fazer atividades sobre eles. E um aluno que possuía um projetor e o levava em sala para que o monitor pudesse usá-lo com a mesma finalidade. 
gramática. Entre os alunos de 50 a 79 anos alternam-se os resultados de $2^{\circ}$ e $3^{\circ}$ lugar (empatando em alguns casos), ficando assim: 1) produção oral; 2) gramática; 3) produção escrita. As diferenças não são significativas, pois o número de respostas dado entre $2^{\circ}$ e $3^{\circ}$ lugar, em praticamente todas as faixas etárias, é muito próximo. Entretanto, poderíamos refletir, com esses resultados, sobre um dos estereótipos relacionados aos idosos, o de que eles gostam mais da gramática. Podemos supor que os alunos idosos possivelmente demonstrarem em aula maior interesse na gramática - pois não podemos esquecer que geralmente uma característica pessoal é generalizada a todo o grupo idoso -, possa ser derivado da dificuldade que sentem com a gramática e não de interesse (já que não aparece dentre os assuntos que gostariam que fossem mais abordados em sala de aula, como vimos no Gráfico 14).

Quando questionamos os monitores sobre quais habilidades eles mais se sentiam à vontade para trabalhar em sala, as respostas foram (Tabela 14):

Tabela 14: Quais habilidades* você se sente mais à vontade para trabalhar? (Q3:7)

\begin{tabular}{c|l|l}
\hline Monitor & Habilidade(s) & \multicolumn{1}{c}{ Justificativa } \\
\hline 1 & Produção oral & $\begin{array}{l}\text { "Organizo minhas aulas em modo que tudo 'desemboque' na produção oral dos } \\
\text { alunos, que acredito ser a maior demanda dos alunos, e, para muitos deles, a } \\
\text { maior dificuldade." }\end{array}$ \\
\hline 2 & Gramática & $\begin{array}{l}\text { "Porque tenho maior domínio e também porque, das opções acima, é a que mais } \\
\text { me agrada." }\end{array}$ \\
\hline 4 & Produção oral & $\begin{array}{l}\text { "Tive um excelente professor nos níveis básicos que dava aula fazendo perguntas. } \\
\text { Procuro seguir esse modelo reforçando bastante a oralidade." }\end{array}$ \\
\hline 5 & $\begin{array}{l}\text { Produção escrita } \\
\text { e gramática }\end{array}$ & $\begin{array}{l}\text { "Me sinto à vontade para trabalhar gramática e produção escrita, porque a minha } \\
\text { formação é mais sólida nesses âmbitos do que nos outros." }\end{array}$ \\
\hline 6 & $\begin{array}{l}\text { Produção escrita } \\
\text { e leitura }\end{array}$ & $\begin{array}{l}\text { "Pcredito que domino melhor e, em relação à produção oral ainda não me } \\
\text { aluno entenda as formas da língua e não tão subjetivas ou ambíguas como a } \\
\text { gramática." }\end{array}$ \\
\hline
\end{tabular}

* Alternativas: produção oral, produção escrita, leitura e gramática 
Como podemos ver na Tabela 14, a maioria dos monitores não declara a produção oral como a habilidade com a qual se sentem mais à vontade para trabalhar, justamente aquela na qual os alunos encontram maiores dificuldades.

Outra questão colocada aos monitores, durante as entrevistas, se referia aos níveis para os quais preferem lecionar. Os cinco participantes declararam preferir os níveis principiantes (níveis 1 e 2, sendo que um dos entrevistados declarou principiantes "até o nível 4"). Indagamos a razão da escolha:

M1: Ah, eu acho que quando eles tão começando a estudar italiano, acho que o encantamento ainda é maior. Então é como eu falei no começo, né? Trabalhar com interesse, com gente que tá a fim, faz toda a diferença, né? Acho que quando vai chegando nos níveis mais intermediário::, talvez ainda... aquele interesse ainda tá acesso. No final, tanto é que a gente vê que a turma se reduz bastante, né? [...]

Somente M1e, dos cinco monitores entrevistados, aponta que a razão de preferir dar aula aos grupos principiantes está relacionada ao interesse dos alunos ser maior no começo do curso. Os demais monitores apontam o conteúdo dos níveis ou o fato de os grupos principiantes precisarem das noções básicas como a razão que os leva a preferir esses níveis.

M3: Eu gosto muito do nível dois, porque eu acho que é um nível fundamental... é:: o aluno tem que ter uma boa base nesse nível porque ele tá aprendendo o Passato Prossimo e a estrutura desse tempo se repete mais pra frente em vários outros tempos... é:: o fato de ter um auxiliar, todo o/toda a estrutura do Passato, então, eu gosto bastante do nível dois.

M4: Aí é aquela satisfação pessoal mesmo. [...] E é o primeiro contato que eles têm realmente com a língua, então ali é o momento de explicar matematicamente o que que pode e o que não pode. [...] Então eu prefiro trabalhar com esses níveis, pra trabalhar com calma, trabalhar direitinho, dar uma base melhor, uma base mais sólida, pra evitar 
problemas maiores:: nos níveis mais altos. E:.:... e também porque eu acho muito mais difícil dar aula pra nível 1 e nível 2 do que pra nível 8, por exemplo. Obviamente os conteúdos são mais elaborados, são mais:.... são mais difíceis, mas no nível 1 e no nível 2 é:: é um nulo total, eles não têm noção das coisas, então é um trabalho mais/mais forçado, é um trabalho mais braçal no nível 1. [...]

M5: Porque essa... da introdução dos alunos à língua, eu gosto bastante disso, essas primeiras noções... E também por não me sentir preparado o suficiente pra dar aula pros níveis mais avançados. Esses dois motivos: por gostar mesmo de introduzir os alunos à língua... e por não me sentir ainda suficientemente preparado pros níveis mais avançados.

Podemos notar nestas declarações que os monitores preferem, eles mesmos, lidar com aquelas partes do curso que consideram fundamentais, para depois "deixá-los" aos outros monitores. M3e chega a brincar:

M3: [...] Mas eu gosto mais do nível dois, assim. Não porque é um nível baixo, mas devido à importância do aluno ter uma boa base pra... - pelo menos eu tive certeza de como foi passado... - não que eu não confie nos outros ((risos)) mas eu gosto do nível dois.

\subsection{A estrutura do Italiano no Campus}

Realizamos algumas perguntas com a finalidade de levantar o que os participantes do IC pensavam a respeito de sua estrutura curricular, infraestrutura e organização.

\section{Diferenciais do IC}

Perguntamos aos monitores, durante as entrevistas, se havia diferenciais entre o IC e os outros lugares nos quais deram aula de língua italiana. Todos os monitores afirmaram que o IC é diferente. As razões alegadas foram as seguintes: 
- número de alunos: muito maior do que nas escolas. O IC tem como limite oferecido por turma 25 vagas, nos níveis 1 as turmas costumam ficar cheias, tendo, inclusive, lista de espera em alguns semestres - principalmente para as turmas de sábado. Mais de um monitor declarou estar acostumado a dar aulas para grupos muito pequenos ou particulares;

- acompanhamento pedagógico da coordenação do curso: com espaço para compartilhar materiais e aprofundar assuntos com os colegas e coordenação. M1e faz a seguinte declaração: "Eu acho que a coordenação mesmo do trabalho, perché os outros lugares em que eu dei aula, se eu quisesse 'brincar' de ser professora, fingir que tava dando aula, eu podia";

- nível de escolaridade dos frequentadores: destacamos a declaração de M5e: "A maioria das pessoas que estão aqui, elas têm um nível de escolaridade maior. E isso se reflete na sala de aula:: toda a dinâmica de trabalho.";

- maturidade dos alunos: segundo M4e, os alunos "já trazem uma carga boa. Ou de outras línguas ou de experiências privadas.";

- metodologia: seguir um material didático e uma estrutura curricular baseada nele. Segundo M2e, nas escolas isso acaba sendo mais maleável.

Anteriormente, vimos que nenhum dos monitores apontou a presença de alunos idosos ou a heterogeneidade etária como fator que diferencia o público do IC daqueles dos outros para os quais deram aula. Aqui, temos o mesmo resultado em relação à idade dos alunos quando questionamos os monitores sobre os diferenciais do Italiano no Campus. Os monitores apontam características dos alunos, como a maturidade e o nível de escolaridade, mas não apontam a idade. Esse pode ser um dado positivo se indicar que os monitores não consideram a idade como fator relevante nas aulas de língua e, por isso, promovam um ambiente igualitário entre os alunos. 


\section{Infraestrutura}

A infraestrutura disponível para as aulas do Italiano no Campus são aquelas da própria FFLCH, considerada precária pelos seus utilizadores. Questionamos os monitores sobre o assunto, para saber se, na opinião deles, a infraestrutura existente é suficiente para dar aula. Todos responderam que não é suficiente, sendo que as faltas vão desde a ausência de recursos tecnológicos audiovisuais até problemas com salas de aula e falta de ventiladores. A falta de recursos para utilizar materiais didáticos que envolvam vídeo é uma das maiores reclamações dos monitores. (cf. 3.4.1.).

\section{Satisfação dos alunos}

No questionário geral perguntamos aos estudantes se o curso tem atendido às expectativas deles. A maioria, 74\%, respondeu que sim, e 23\% declararam que tem atendido "em parte". Fizemos um gráfico com a divisão por nível e uma por faixa etária para verificar se havia uma tendência quando colocados dessa forma. No primeiro caso, na divisão por nível, os resultados foram muito variados, não apresentando uma tendência. No caso da divisão por faixas etárias, temos o seguinte gráfico (Gráfico 15):

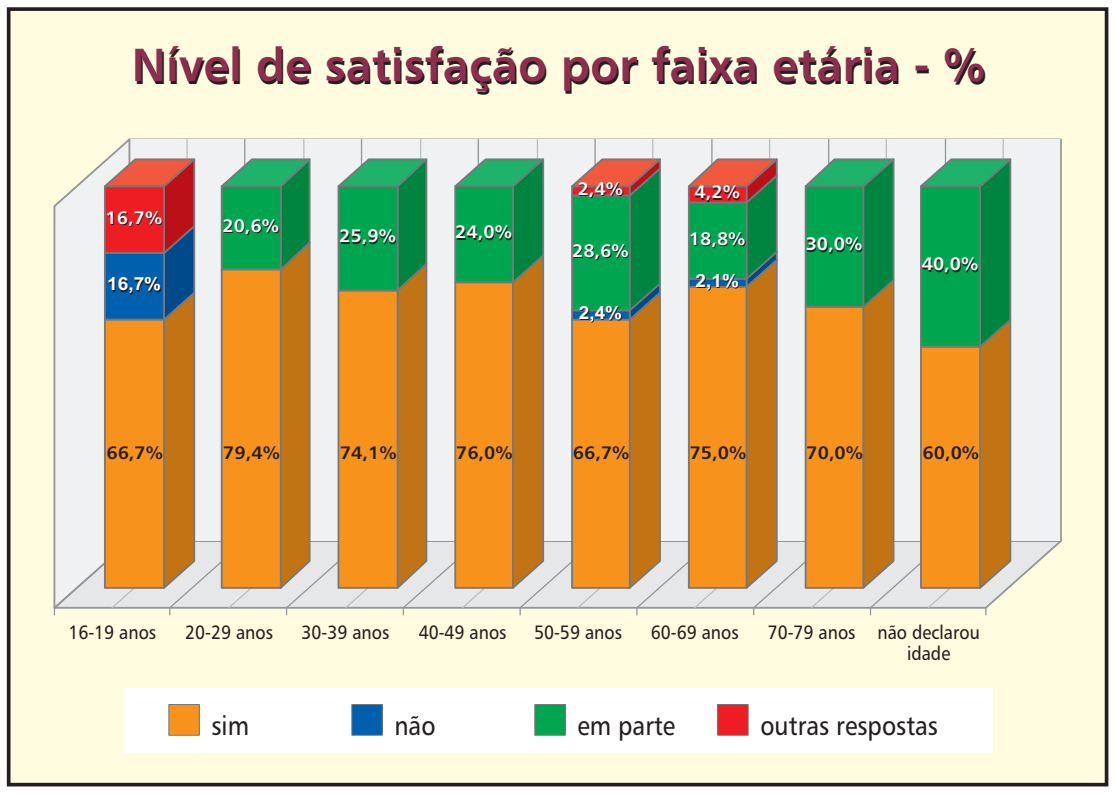

Gráfico 15 - Público geral por faixa etária: grau de satisfação 
Também aqui, no Gráfico 15, podemos dizer que não há uma tendência relativa a faixas etárias quanto ao grau de satisfação dos alunos (se ele aumenta conforme a idade dos participantes ou decai).

Em seguida, questionamos o que mudariam no curso se pudessem. Os alunos responderam:

- $\quad 1^{\circ}$ lugar: Mais conversação nas aulas (17,9\% das citações);

- 2o lugar: Maior uso de recursos multimídia, como filmes, músicas, internet etc. (8,6\% das citações);

- $3^{\circ}$ lugar: Empatam: mais atividades diferentes do livro e mais tempo para atividades extra - filmes, músicas (com 5,5\% das citações cada).

Como podemos observar, também os alunos gostariam que os recursos multimídia fossem mais utilizados durante as aulas. Mas prevalece a vontade de praticar mais conversação em sala, o que pode ser comprometido pelo número de alunos que alguns grupos possuem. As respostas obtidas tiveram citações baixas demais para que fizéssemos uma divisão por faixa etária. Entretanto, a citação sobre ter "mais conversação" sobressai em todas as faixas etárias, sendo que os outros assuntos, muitas vezes, são citados apenas uma vez dentro de cada faixa etária.

Perguntamos aos monitores se eles achavam que os alunos estavam satisfeitos com o curso (sua estrutura). A maioria respondeu afirmativamente. M5e declara que o fato de os alunos pedirem mais conversação não é novo e que foi com a finalidade de suprir essa demanda que foram criados os grupos específicos de conversação.

\section{Número ideal de alunos}

Levantamos o número ideal de alunos por turma na opinião de monitores e alunos. Obtivemos as respostas por meio do questionário dos monitores, 
entrevistas e questionário geral dos alunos. Os dados levantados foram os seguintes: 1) o número médio de alunos por turma que os monitores afirmam ter é 20 ; 2) tanto monitores quanto alunos prefeririam que os grupos tivessem, em média, 15 alunos; 3) o número de alunos tende a diminuir conforme aumenta o nível. Atualmente o Italiano no Campus estipula o número máximo de vagas oferecidas por turma em 25.

\section{Estrutura Curricular e Material Didático}

O curso de língua do Italiano no Campus é dividido em 8 níveis/módulos, que possuem seus conteúdos baseados nas unidades do livro didático adotado: Linea Diretta. Quanto à estruturação do curso, nos questionários dos monitores, obtivemos as respostas apresentadas na Tabela 15.

Tabela 15: Você acha que a divisão do conteúdo nos módulos (do IC) é adequada? (Q3:6)

\begin{tabular}{|c|c|c|}
\hline Monitor & Sim ou Não & Justificativa \\
\hline 1 & SIM & $\begin{array}{l}\text { "Sim, embora acredite que alguns níveis fiquem sobrecarregados de conteúdo } \\
\text { (níveis } 2,4,5) . "\end{array}$ \\
\hline 2 & SIM & $\begin{array}{l}\text { "O programa está bem dividido nos } 8 \text { módulos semestrais. Um aluno que nunca } \\
\text { teve contato com a língua, consegue ao final dos módulos falar bem italiano." }\end{array}$ \\
\hline 3 & SIM & $\begin{array}{l}\text { "Acredito que o material utilizado apresente os argumentos no momento certo, } \\
\text { com algumas poucas exceções." }\end{array}$ \\
\hline 4 & NÃO & $\begin{array}{l}\text { "Não gosto do modo/da sequência como os conteúdos são apresentados no } \\
\text { Linea Diretta: o "futuro semplice", por exemplo, só é apresentado no livro } 2 \text { e, } \\
\text { como no Italiano no Campus temos que seguir o Linea Diretta, certos conteúdos } \\
\text { que, a meu ver, devem ser estudados pelos alunos nos últimos níveis." }\end{array}$ \\
\hline 5 & SIM & - \\
\hline 6 & SIM & $\begin{array}{l}\text { "É bem determinado e acompanha o desenvolvimento linguístico do aluno. } \\
\text { Exceto entre os níveis } 5 \text { e } 6 \text {, que poderiam ser reformulados." }\end{array}$ \\
\hline
\end{tabular}

Apenas M4q declara não gostar da divisão de conteúdo nos módulos. Já nas entrevistas, as respostas são diferentes das apresentadas no questionário. De um modo geral, os monitores afirmam que o Italiano no Campus é muito 
parecido com as escolas de língua. E apontam a coordenação pedagógica presente como o diferencial do IC.

Alguns monitores declaram que gostariam que o material didático fosse trocado, indicando o Nuovo Progetto Italiano ${ }^{113}$ como alternativa ao Linea Diretta. Como a divisão por níveis no IC é feita com base no livro didático, eles alegam que discrepâncias decorrentes da estrutura do livro acabam sendo ruins para o curso. As provas, ao final do semestre, são unificadas ${ }^{114}$, não permitindo aos monitores muita flexibilidade dentro do cronograma. Apesar de possuírem liberdade total sobre os materiais extra que levam para a sala de aula, precisam se ater ao livro para não "prejudicar" os alunos na prova final, pois é a única que estipula oficialmente a média dos alunos. M3e declara que, de certa forma, preparava os alunos para a prova ao longo do semestre. Se isso ocorrer com frequência entre os monitores, a singularidade do grupo não será sentida e não será trabalhada em sua especificidade. Se o objetivo estipulado é o da superação do exame final, as relações sociais em sala de aula, que podem ser ricamente trabalhadas nas aulas de língua, se perderiam.

No questionário geral de monitores, alguns falaram que mudariam a única avaliação proposta no semestre e o enfoque dado ao curso (que, segundo eles, atualmente é gramatical). ${ }^{115}$

\section{Coordenação e monitoria}

Para compreender se os monitores sentiam-se motivados a discutir os problemas com a coordenação, inclusive a questão intergeracional, perguntamos se havia um bom diálogo entre monitoria e coordenação. Quatro dos cinco monitores

\footnotetext{
113 MARIN, T. MAGNELLI, S. Nuovo Progetto Italiano : corso multimediale di lingua e cultura italiana. Roma: Edilingua. (Livros 1 e 2 reestruturados em julho de 2010). Os livros contam com CD-ROM para os alunos e DVD com atividades para todas as unidades dos livros 1 e 2.

114 Lembramos que a avaliação existente hoje no IC se reduz a uma única prova ao final do semestre (iguais para todos os grupos do mesmo nível), sendo que a parte escrita vale $70 \%$ da nota (gramática e redação) e os outros $30 \%$ são compostos pela avaliação oral definida pelo monitor.

115 As tabelas com respostas dadas pelos monitores que não foram reproduzidas neste capítulo são encontradas no Anexo G.
} 
entrevistados disseram que a coordenação era acessível e disponível. Entretanto, é possível notar em seus depoimentos que existem barreiras na comunicação e na troca de ideias entre monitoria e coordenação.

Com os depoimentos ao longo da entrevista percebemos que assuntos como dificuldades de relação aluno-aluno e aluno-monitor raramente são abordados em reuniões com a coordenação. Supomos, portanto, que se algum monitor tivesse um problema em lidar com a heterogeneidade do curso, isso não seria discutido. Os próprios monitores acabam assumindo uma postura de "tem que aprender na prática", como afirma M4e, que a sala lhe é atribuída e você tem de lidar com ela, ou como declara M3e, para quem o monitor tem que ter "jogo de cintura". Lidar com a heterogeneidade, principalmente, no nosso caso, a etária, é algo que deveria ter espaço de discussão e análise nas reuniões pedagógicas.

\section{Objetivos do Italiano no Campus}

O Italiano no Campus surgiu com dois objetivos: atender à comunidade USP e servir de laboratório para os estudantes de pós do Programa de Língua e Literatura Italiana da FFLCH-USP. Perguntamos aos monitores se esses objetivos ainda permaneciam e se cumpriam.

Os monitores entrevistados declararam que, atualmente, a maioria dos alunos é comunidade externa. Uma coordenadora disse que não se esperava que a procura pelo curso por parte do público externo fosse tão grande e que, com esse dado, deveria ter ocorrido uma adaptação, já que o curso foi pensado para a Comunidade USP.

Se pensarmos nas declarações de M1e e M5e, os quais afirmam que o currículo atual do Italiano no Campus é parecido com os das outras escolas de língua, pode-se supor que o currículo atende às necessidades da comunidade externa. Mas não podemos esquecer também que os monitores declararam que os alunos do IC são diferentes dos alunos de outros cursos em que deram aula, o que 
demandaria um currículo também diferenciado, de acordo com as especificidades do público que o frequenta.

Quanto ao fato de servir como laboratório para os alunos de pós, a maioria dos monitores afirma que o IC serve de espaço para experimentarem técnicas e materiais novos, além de colocar em prática suas pesquisas, mas que há limitações tanto devido ao cronograma que deve ser seguido como quanto a equipamentos que precisariam utilizar. Alguns dos cursos de Língua \& Cultura oferecidos pelo IC são baseados em pesquisas dos monitores que querem testar suas teorias em aplicações específicas (somente produção oral, somente produção escrita, abordando apenas um aspecto cultural italiano - culinária, por exemplo -, com base em materiais diferenciados etc.).

\subsection{A heterogeneidade dos grupos}

A heterogeneidade no Italiano no Campus, segundo relatos da coordenação, sempre existiu. Nesta parte do capítulo 5, portanto, pretendemos apresentar os resultados obtidos, sobre a heterogeneidade do IC, com estes três grupos: principiantes, todos os alunos e os monitores.

\subsubsection{Principiantes}

Na nossa primeira pesquisa, com principiantes, não tínhamos a intenção de falar da heterogeneidade dos grupos, já que os alunos estavam iniciando o curso e ainda não tinham vivenciado a sala de aula heterogênea. O nosso objetivo era verificar se a heterogeneidade percebida por nós, que era tanto etária quanto profissional, também levaria os alunos a esperarem do curso resultados diferentes. Como dissemos no capítulo anterior, os resultados não mostraram diferenças significativas. Fizemos, também, perguntas que levantassem a imagem dos alunos 
em relação ao povo italiano e à Itália, a fim de verificar se a imagem (estereotipada) diferia de acordo com a faixa etária. Observemos alguns dos resultados obtidos na pesquisa.

\section{Estereótipos sobre a Itália e o povo italiano}

$\mathrm{Na}$ primeira pergunta, de caráter geral, elencamos algumas das citações em categorias. Por exemplo, muitas pessoas, quando perguntadas sobre quais palavras lhes vinham à mente quando se mencionava a Itália, citaram algum tipo de "celebridade" italiana. Ao invés de contarmos uma citação para cada uma das celebridades referidas, preferimos agrupá-las em uma categoria chamada de "personalidades italianas".

Os três maiores resultados obtidos nesta questão foram os seguintes:

1) Quando falamos "Itália" quais palavras lhes vêm à mente? (O total de palavras citadas nesta questão foi de 429):

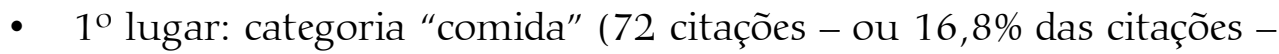
as mais citadas foram: pizza, macarrão e massas);

- $2^{\circ}$ lugar: categoria "uma cidade ou região italiana" (66 citações ou 15,4\% - as mais citadas: Roma, Veneza e Milão);

- $3^{\circ}$ lugar: categoria "uma palavra ou expressão italiana" (55 citações - ou 12,8\% das citações - de termos como ciao!, bella etc.).

Na segunda e na terceira questões, tivemos que excluir algumas respostas equivocadas, como características físicas atribuídas na pergunta sobre características psicológicas e vice-versa. Nessas perguntas, não criamos categorias, mas agrupamos características consideradas "sinônimas" pelo dicionário Houaiss.

2) Quanto ao aspecto físico do povo italiano, quais palavras lhes vêm à mente? (total de palavras citadas: 262) 
- $1^{\circ}$ lugar: bonitos (50 citações);

- 2o lugar: altos (37 citações);

- $\quad 3^{\circ}$ lugar: morenos (26 citações).

3) Quanto ao aspecto psicológico do povo italiano, quais palavras lhes vêm à mente? (total de 301 citações)

- $\quad 1^{\circ}$ lugar: alegres, felizes (39 citações);

- 2o lugar: falantes (20 citações);

- $3^{\circ}$ lugar: temperamentais (16 citações).

Como vimos no capítulo 2, os estereótipos são culturais e "passados" de geração em geração, por isso não encontramos diferenças significativas no levantamento das três primeiras questões, quando divididas por faixas etárias. No Anexo C, podem ser vistas as tabelas comparativas da pesquisa, nas quais cotejamos os três maiores resultados gerais com os três primeiros colocados por faixa etária, para fins de comparação.

\subsubsection{Alunos de todos os níveis}

No questionário geral para os estudantes do IC, perguntamos como os alunos percebiam seu relacionamento com o grupo. A questão era de múltipla escolha com espaço para justificativa e tinha o intuito de introduzir a questão da intergeracionalidade, começando nossa sondagem por como os alunos se relacionavam com os outros membros do grupo, seria uma forma de levantar comentários sobre as outras faixas etárias. As respostas dadas podem ser vistas no Gráfico 16, reproduzido abaixo: 


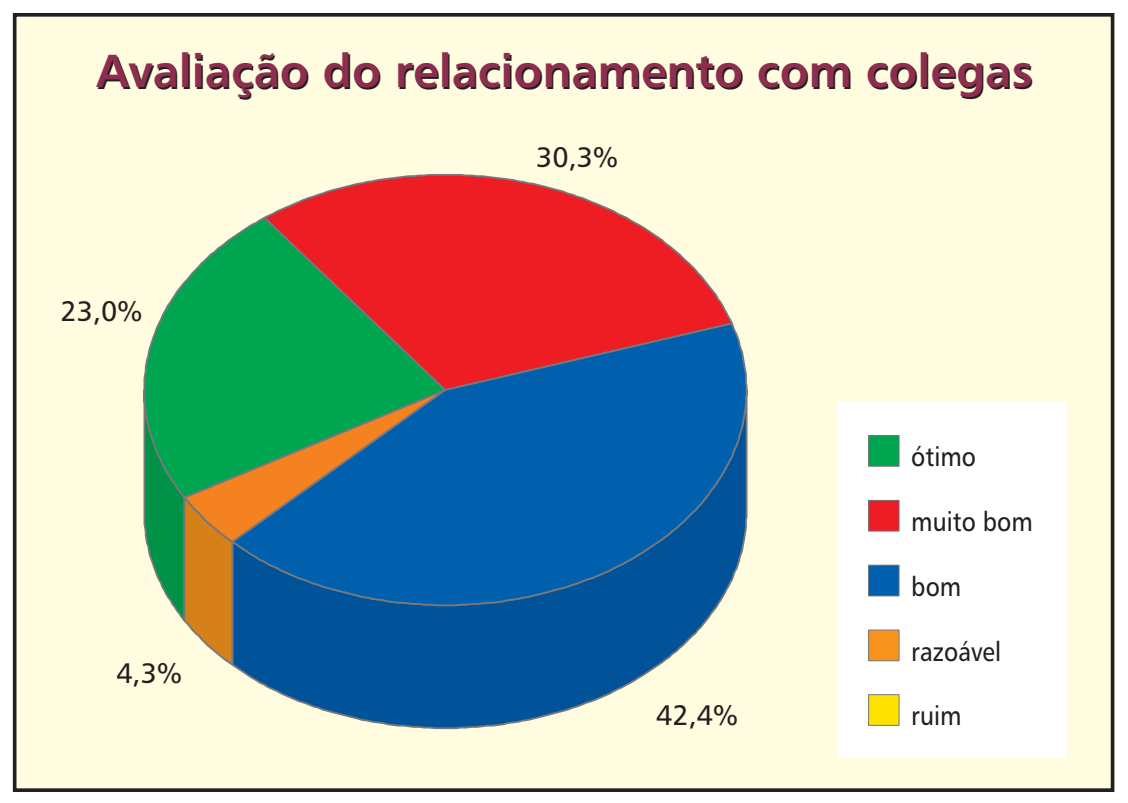

Gráfico 16 - Avaliação do relacionamento com colegas: público geral

Como podemos observar no Gráfico 16, a maioria dos estudantes afirma que seu relacionamento com os colegas do grupo é bom. De forma geral, os comentários variam de bom a ótimo, com apenas 4,3\% dos alunos declarando que o relacionamento é razoável e nenhuma declaração de que o relacionamento é ruim. Dos que responderam que o relacionamento é razoável, as alegações foram falta de interação fora da sala de aula, baixa participação na aula etc. Uma aluna, de 52 anos, declara ficar constrangida por sentir seu grupo à sua "frente em conhecimento da língua" (f52n4). Outra aluna, que não declarou a idade, se referiu a um "grupo de senhoras": "É um grupo de senhoras que já se conhecem há algum tempo, e quem chega tem difícil acesso" (fiøn3).

Nas entrevistas, os monitores declararam que, de forma geral, o relacionamento entre os alunos é bom. Segundo seus depoimentos, existem as ditas "panelinhas" e até inimizades, da mesma forma que existem grupos inteiros muito unidos e grupos em que os alunos nem sabem os nomes uns dos outros (mesmo estudando juntos há quatro semestres). M5e diz que em grupos nos quais não se manteve atento para o relacionamento dos alunos eles começaram a se hostilizar: 
M5: Acho que posso dizer, quase todas as turmas que eu peguei, né? Não foram poucas [*], havia sim um... um bom relacionamento... eu tava lá em cima, eu tava o tempo todo prestando atenção e quando eu começava a ver que desandava, eu me impunha, fazia alguma coisa pra que amenizasse. E eu vi com clareza nas turmas que eu deixei por conta própria, meio que desandava, eles vão se hostilizando, acontece isso.

M1e fala da união de seu grupo de nível 1, com pessoas de diversas faixas etárias:

M1: [...] Fico contente de ver o meu grupo de nível 1, eles são os meus xodós ((ri)). Eles ficam/assim, saem juntos, pessoal de/uma menina de vinte anos e uma de sessenta. Eu acho legal.

Uma das alunas, ao falar sobre seu relacionamento com o restante do grupo, declara: "O relacionamento entre as pessoas melhora quando o professor propõe agrupamentos diferentes nas diversas aulas." (f58n6). O que evidencia a importância do professor como mediador também das relações sociais e interações que ocorrem dentro da sala de aula.

Questionamos os alunos sobre como eles se sentiam estudando em grupos com grande variedade etária. As respostas eram dissertativas e muitas delas se limitaram a comentários como "bem", "muito bem" ou "sem problemas". Mas também tivemos respostas mais elaboradas, que explicavam por que os alunos se sentiam bem ou não com a heterogeneidade etária. Muitas delas apontavam a mistura como "interessante e enriquecedora" para o curso, e algumas declarações simplesmente diziam que era algo "normal", o que indica uma visão de convivência intergeracional como natural. De forma geral, a maioria das respostas foram positivas. Destas, os fatores que os alunos destacam de positivo na heterogeneidade são: a troca de experiências e conhecimento, conhecer diferentes pontos de vista, enriquecimento das aulas culturalmente (devido aos diferentes gostos e interesses). 
Uma das alunas fez a seguinte declaração: "Depende das pessoas, depende da faixa etária e até da forma como o professor lida com isso" (f57n6).

É interessante notar como esta declaração vai ao encontro daquela citada anteriormente, de que o relacionamento entre os alunos melhora quando o professor forma grupos diferentes entre os alunos. O papel do professor é fundamental para que o grupo se sinta em um ambiente igualitário e de respeito, onde os colegas se ajudam e entendem que estão todos ali pelo mesmo objetivo. Uma aluna, também de nível 6, diz que é só "o professor quem tem que se adaptar" (f29n6) à heterogeneidade etária.

Obtivemos com essa pergunta algumas outras declarações interessantes, das quais destacamos algumas:

\section{- Algumas das respostas positivas sobre a heterogeneidade etária}

Me sinto muito bem convivendo com jovens e pessoas mais velhas. A diversidade tem se mostrado enriquecedora e tem me ensinado muito. (f48n4)

Ótima, pois mostra que a idade não é um fator que impeça o aprendizado. O aprendizado é o esforço de cada um, a troca de experiências é ótima. ( $f 27 n 2)$

Isso é um princípio educacional depois do Ensino Fundamental. Todo curso "livre" (de livre escolha). (f64n2)

Nesse grupo, não faz diferença, porque todos são interessados e têm um bom nível de conhecimento. (f33n8)

Não vejo problemas. O que pode atrapalhar não é a diferença etária, mas pessoas de diversos níveis numa mesma turma. (f42n3)

Acho excelente; a troca de idéias entre gerações diferentes é saudável. (f64n3)

Me sinto bem, acho que o aprendizado é até melhor por isto. (f26n3)

Não sinto diferença em relação à faixa etária. (m27n3)

Bem. Pois há disciplina, respeito. (f23n4) 
Como podemos observar, alguns alunos declaram que não é a heterogeneidade etária que determina o grupo, mas sim o interesse e esforço que cada um tem, ressaltando o caráter enriquecedor das trocas geracionais. Destacamos, em negrito, duas declarações de estudantes de 26 e 27 anos. A aluna de 26 diz achar que seu aprendizado é até mesmo melhor por estar em um grupo intergeracional. Na declaração da aluna de 27 anos vemos que ela acha que a heterogeneidade etária mostra que o aprendizado depende do esforço de cada aluno e não da idade.

\section{- Algumas respostas que mostram alunos idosos assumindo a posição estereotipada}

Às vezes há alguma dificuldade porque os jovens estão mais preparados. (f66n3)

Não tenho problemas apesar da minha idade mais avançada. (f62n4)

$\mathrm{Na}$ primeira citação, a aluna associa a dificuldade que eventualmente encontra com o maior preparo dos jovens. Relacionamos essa associação que ela faz à ideia amplamente divulgada de que os mais jovens têm maior facilidade em um curso de língua estrangeira. Na segunda citação, a estudante diz não ter problemas "apesar" de sua idade, como se a idade indicasse necessariamente um fator que traria problemas na $\mathrm{a} / \mathrm{a}$ da língua estrangeira $\mathrm{e}$ mesmo de relacionamento com o restante do grupo já que a pergunta se referia a como o aluno se sente diante da variedade de faixas etárias em uma mesma turma.

\section{- Respostas dos mais jovens em que falam sobre os idosos}

É interessante ver as diferenças. Mais velhos se prendem à perfeição, gramatical sobretudo. (m24n1)

Acho normal. O fato de serem mais velhos ajuda na concentração por não haver bagunça e conversas paralelas na aula. (m33n1)

Sinto mais dificuldade pelo fato de pessoas mais velhas ter maior 
lentidão de aprendizado, o que faz com que o professor tenha que repetir a mesma coisa várias vezes, atrasando um pouco o ritmo da sala. $(f 30 n 3)^{116}$

Gosto bastante, enriquece meus relacionamentos, mas algumas vezes os mais velhos tem um pouco mais de dificuldade. (f25n3)

Ótimo! Desenvolvemos mais respeito com o próximo e ruim também às vezes os mais velhos têm mais dificuldades de acompanhar a turma. $(f 29 n 1)$

Às vezes atrapalha, quando os alunos são mais velhos (Terceira Idade) porque o ritmo de aprendizagem deles é mais lento. ( $f 25 n 4)$

Podemos ver que todas as declarações acima são de alunos de idades entre 24 e 33 anos. Das declarações transcritas, apenas a segunda não é negativa no que diz respeito ao idoso em sala de aula, pois declara que a presença de pessoas mais velhas ajuda na concentração. Uma ideia de que traz seriedade ao grupo. As outras declarações colocam os idosos no papel estereotipado de aprendizes lentos e com dificuldades, ou mesmo presos à perfeição gramatical. Importante destacarmos que perguntamos como os alunos se sentem estudando em um grupo intergeracional, o que indica que estas declarações (com exceção da segunda) mostram o incômodo dos mais jovens em relação aos idosos de seus grupos.

\section{- Outras respostas que envolvem estereótipos}

Se forem muito novos (adolescentes) creio que atrapalhe o andamento das aulas (brincadeiras, comportamento "infantil"). (m32n1)

Às vezes a teimosia dos mais jovens e a rabugice dos mais idosos me incomodam, mas nada que não seja suportável. (f48n8)

Nestas duas declarações podemos ver alguns dos estereótipos sobre os jovens: de imaturidade e teimosia. Destacamos a segunda fala, pois a estudante se coloca na posição do adulto que está no seu "auge" - como discutimos no capítulo 
$3^{117}$ - colocando-se acima da "teimosia dos jovens" e "da rabugice dos mais idosos" (duas imagens que são estereótipos sobre idosos e jovens), de como se na posição de "ser humano pleno", que não possui características negativas.

\section{- Resposta de alguns idosos}

Muito bem. Não vejo idade, mas cérebros. (f67n5)

Muito bem. Os jovens é que não sei se gostam de conviver com a terceira idade. (f62n5)

Para mim é ótimo - gostaria de saber como os colegas se sentem de estudar com pessoas mais velhas. (m57n3)

Ótima. A diversidade é importante para desenvolver melhor o aprendizado. (f60n4)

Bem. Me sinto mais jovem. (f6n8)

Não tenho problema, os jovens são ótimos. (f69n3)

Muito bem. Aprendo muito com eles e também evoluo. (f62n3)

Duas declarações, uma de uma aluna de 62 anos e outra que incluímos aqui - apesar de aluno ainda não ser considerado oficialmente idoso, por ter menos de 60 anos, mas que em sua fala "se inclui" entre os mais velhos -, mostram uma preocupação deles, na posição de mais velhos, em questionar se os mais jovens gostam de estar com os mais velhos ou não. A maioria dos idosos vê a mistura de faixas etárias como muito boa. (cf. 5.6.)

\subsubsection{Os monitores}

Perguntamos nos questionários e nas entrevistas aos monitores como eles, da posição de professores, viam a heterogeneidade dos grupos, dando enfoque à heterogeneidade etária. Nos questionários as respostas foram as seguintes (Tabela 16):

117 A criança e o jovem são vistos como os que se preparam para ser adultos, e os idosos como os que já tiveram o auge de sua vida. 
Tabela 16: 0 que você acha dos grupos que misturam diversas faixas etárias, os ditos grupos intergeracionais? (Q3:10)

\begin{tabular}{|c|c|}
\hline Monitor & Resposta \\
\hline 1 & $\begin{array}{l}\text { "Desde que não haja diferença grande demais de idade, acho ótimo. Muito produtivo. A separação } \\
\text { seria: crianças/adolescentes/adultos de } 20 \text { a } 60 \text { anos (ou de } 20 \text { a 80)/terceira e quarta idade." }\end{array}$ \\
\hline 2 & $\begin{array}{l}\text { "Até certo ponto é interessante e positivo, porém quando há em um mesmo grupo um senhor de } \\
70 \text { anos e uma criança de } 4 \text {, o professor fica sem muitos recursos para ensinar." }\end{array}$ \\
\hline 3 & $\begin{array}{l}\text { "Enriquecedor. Os mais jovens com a maior capacidade de absorver os conteúdos e os mais velhos } \\
\text { com a sua experiência nos argumentos tratados." }\end{array}$ \\
\hline 4 & $\begin{array}{l}\text { "Desde que não se misturem crianças com adultos, os grupos intergeracionais são interessantes, } \\
\text { pois favorecem a troca de experiências entre as diferentes faixas etárias." }\end{array}$ \\
\hline 5 & "É interessante para promover discussões, interação e dinamizar a aula." \\
\hline 6 & $\begin{array}{l}\text { "Ajudam aos alunos e ao professor. Pessoas que têm mais dificuldades podem juntar-se com } \\
\text { pessoas que têm mais facilidade." }\end{array}$ \\
\hline
\end{tabular}

A Tabela 16 nos mostra que no caso do Italiano no Campus, que trata de ensino de língua estrangeira, os monitores mostram restrições à junção de crianças com as outras faixas etárias. Como dissemos no terceiro capítulo, a maioria dos Programas Intergeracionais existentes envolve prioritariamente crianças, jovens e idosos. O IC se difere como ambiente intergeracional justamente por incluir outras gerações intermediárias - diferente da maioria dos PIs existentes - e, ainda assim, possibilita um ambiente de quebra de estereótipos e de estímulo do respeito ao outro.

Notemos que M3q traz a imagem estereotipada de que os mais jovens têm "a maior capacidade de absorver os conteúdos" e os mais velhos têm "experiência". Esse tipo de imagem, da juventude como momento propício à aquisição e aprendizagem de uma LE e da velhice como a fase da experiência, pode influenciar o comportamento do monitor na sala de aula, tratando os idosos de forma diferenciada, como se fossem mais lentos por não serem mais jovens e como se a única contribuição que pudessem dar em sala de aula fosse em relação às suas experiências nos assuntos abordados em aula.

Perguntamos em seguida se havia alguma faixa etária que os monitores considerassem não passível de mistura em aulas de língua italiana (Tabela 17): 
Tabela 17: Na sua opinião, alguma faixa etária* não poderia ser "misturada"? (Q3:11)

\begin{tabular}{|c|c|c|}
\hline Monitor & Faixa(s) etária(s) & Justificativa \\
\hline 1 & $\begin{array}{l}\text { 1. crianças não alfabetizadas; } \\
\text { 2. crianças alfabetizadas; } \\
\text { 3. adolescentes; } \\
\text { 7. quarta idade (acima de } 80 \\
\text { anos). }\end{array}$ & $\begin{array}{l}\text { "Retomando as respostas que dei nas duas questões anteriores, } \\
\text { acredito que crianças, adolescentes e a quarta idade apresentem } \\
\text { demandas próprias (atividades lúdicas diferentes, atividades mais } \\
\text { oralizadas ou mais escritas, etc.). Para o professor dar conta das } \\
\text { diferentes demandas em classes muito 'misturadas' é preciso ter } \\
\text { uma formação muito ampla e variada (ter muito repertório)." }\end{array}$ \\
\hline 2 & $\begin{array}{l}\text { 1. crianças não alfabetizadas; } \\
\text { 2. crianças alfabetizadas; }\end{array}$ & $\begin{array}{l}\text { "As crianças possuem outra forma de raciocínio e concentração que } \\
\text { diferem de um adolescente e/ou adulto." }\end{array}$ \\
\hline 3 & $\begin{array}{l}\text { 1. crianças não alfabetizadas; } \\
\text { 2. crianças alfabetizadas; } \\
\text { 7. quarta idade (acima de } 80 \\
\text { anos). }\end{array}$ & "Requerem um tipo especial de atenção." \\
\hline 4 & $\begin{array}{l}\text { 1. crianças não alfabetizadas; } \\
\text { 2. crianças alfabetizadas; }\end{array}$ & $\begin{array}{l}\text { "Porque como também sou professora de educação infantil (**) sei } \\
\text { perfeitamente que as crianças têm interesses e necessidades de } \\
\text { aprendizagem muito diversos dos das outras faixas etárias." }\end{array}$ \\
\hline 5 & 1. crianças não alfabetizadas; & $\begin{array}{l}\text { "Acredito que a forma de conduzir a aula e promover as atividades } \\
\text { sejam muito diferentes para grupo de adultos/terceira idade e o } \\
\text { grupo infantil." }\end{array}$ \\
\hline 6 & $\begin{array}{l}\text { 1. crianças não alfabetizadas; } \\
\text { 2. crianças alfabetizadas; }\end{array}$ & $\begin{array}{l}\text { "Depende da mistura. Crianças alfabetizadas necessitam de mais } \\
\text { atenção, mas se fosse um grupo composto de crianças, não } \\
\text { teríamos problema algum, sendo composto por uma mistura de } \\
\text { crianças alfabetizadas e não alfabetizadas." }\end{array}$ \\
\hline
\end{tabular}

* Faixas etárias apresentadas: 1. crianças não alfabetizadas; 2. crianças alfabetizadas; 3. adolescentes; 4. adultos de 20 a 40 anos; 5. adultos de 40 a 60 anos; 6 . terceira idade (de 60 a 80 anos); 7. quarta idade (acima de 80 anos).

** Trecho suprimido por permitir a identificação do monitor.

Observando as respostas dadas na Tabela 17, concluímos que os monitores concordam que as crianças precisam de um grupo separado daquele dos adultos, mas dentre os adultos muitos não veem a necessidade de separação. Precisamos pensar que o tipo de relação intergeracional que ocorre no IC possa envolver outras bases teóricas além daquelas que deram origem aos Programas Intergeracionais e trabalhar, também, com o fato de um grupo de língua estrangeira não "permitir" a interação intergeracional completa, envolvendo todas as faixas etárias (as crianças, por exemplo), mas que funciona bem quando estabelecido que as relações se darão entre adultos de diferentes gerações.

De qualquer maneira, apesar de não envolver todas as faixas etárias ou somente aquelas que não são economicamente ativas, o IC continua contribuindo 
da mesma forma para a aceitação e respeito ao outro pelo que ele é, ajudando a quebrar estereótipos e preconceitos social e historicamente construídos. Os próprios monitores apontam a troca de experiências e a convivência de diferentes faixas etárias como produtiva, interessante e enriquecedora.

Nas entrevistas, perguntamos se os monitores estavam preparados para lidar com a heterogeneidade dos grupos. M3e declara que o monitor tem que ter "jogo de cintura" para administrar os mais variados gostos da sala de aula ao escolher um material extra, por exemplo.

M3: O professor tem que ter um preparo. Um preparo bom porque dependendo de como ele consegue administrar a aula, isso pode ser positivo, mas pode ser negativo. Você me perguntou qual é a classe ideal ou o tipo de aluno ideal, me veio em mente isso do/o fato de você ter jovens e também senhores, porque você vê a troca de informações, mas depende muito da sala e de como você tá levando, porque isso pode ser estimulante como não. O jovem pode falar "ah, minha sala tem muito senhor e como eu não tô na mesma sintonia, então não gosto", mas outros gostam, então, depende, né?

M3e ressalta o papel do professor na administração da aula, declarando que a maneira como o professor lida com a heterogeneidade na sala de aula poder ter efeitos positivos ou negativos para o relacionamento dos alunos e o andamento do curso.

M2e coloca em questão o fato de na sua formação (e na dos monitores com a mesma formação) nunca ter sido levantada a questão da heterogeneidade etária em sala de aula. M5e declara que os monitores não estão preparados para lidar com a heterogeneidade dos grupos. E M4e acha que não existe um meio de se preparar para isso, que tudo depende de sentir o ritmo da sala e se adequar ao grupo que você tem. M1e declara: 
M1: Isso... Ai, é tão relativo, né, Lêe? [...] Não sei até que ponto a idade interfere positiva ou negativamente em alguma coisa perché com essa turma do nível 1 por exemplo, tem uma senhora de 61 que vai super bem, né, mas ao mesmo tempo já tive... já tive um aluno de 70 que era excelente também, muito bom. E já tive aluno de 40 que são essas incógnitas ${ }^{118}$, e já tive também alunos de 60 que também são desse grupo, incógnita que eu chamo, né? Então, eu vou falar por mim, assim, às vezes eu me sinto preparada, às vezes não. Eu não sei se é uma dificuldade minha e não sei se tem a ver com a idade ou se tem a ver com outros traços. Né?

Perguntamos, então, o que os monitores acham de trabalhar nesses grupos com grande diversidade etária. M4e e M5e mencionaram o fato de os alunos não se importarem com a mistura etária na sala de aula do IC:

M4: Eu acho muito bom. [...] Em relação à idade eu acho que não tem muito problema, assim, os alunos não veem muito problema. Pelo menos não que eu tenha sabido até hoje.

M5: [...] na verdade eu fui mudando minha opinião com a experiência lá em sala de aula. Porque só do meu ponto de vista de professor, eu diria que é complicado trabalhar com a heterogeneidade. Mas ouvindo os alunos e vendo o que acontece, é melhor... é mais interessante. Isso posso dizer, que ainda é fresco, né? Porque daqui dez anos eu vou ter muito claro na minha cabeça isso, que é mais interessante a heterogeneidade. [...]

M1e e M3e dizem que o bom entrosamento entre os alunos do grupo e a forma como o curso caminha depende mais dos alunos que fazem parte da sala do que do fato de ter ou não idades diferentes em uma mesma turma.

\subsection{A intergeracionalidade do Italiano no Campus}

Como vimos no começo deste capítulo, o público do Italiano no Campus está dividido de forma equilibrada entre as faixas etárias que o formam, com 
alunos de 16 a 78 anos. Perguntamos, então, a alunos e monitores sobre a divisão dos grupos por faixas etárias, a participação da terceira idade nos cursos de língua e a preferência por trabalhar ou não com determinados públicos.

Primeiramente, vejamos o que os monitores responderam no questionário sobre as faixas etárias com as quais normalmente trabalham e com as quais gostariam de trabalhar (Tabela 18):

Tabela 18: Você tem preferência em dar aula para alguma dessas faixas etárias*? (Q3:9)

\begin{tabular}{|c|c|c|}
\hline Monitor & Faixa(s) etária(s) & Justificativa \\
\hline 1 & $\begin{array}{l}\text { 4. adultos de } 20 \text { a } 40 \text { anos; } \\
\text { 5. adultos de } 40 \text { a } 60 \text { anos }\end{array}$ & $\begin{array}{l}\text { "Porque talvez seja o público que menos requer 'atenção especial'. } \\
\text { Eles aceitam mais o que o professor propõe. Os mais novos e os } \\
\text { mais velhos são mais contestadores. Entendo que, como a minha } \\
\text { proposta em sala de aula é fazer algo bem diferente do que vem } \\
\text { sendo feito, preferiria primeiro trabalhar com a faixa etária que } \\
\text { indiquei acima e depois, eventualmente, trabalhar com os outros } \\
\text { públicos." }\end{array}$ \\
\hline 2 & 4. adultos de 20 a 40 anos & $\begin{array}{l}\text { "Porque é mais fácil de se relacionar com alunos de sua mesma } \\
\text { faixa etária, o que talvez facilite a interação professor-aluno." }\end{array}$ \\
\hline 3 & 4. adultos de 20 a 40 anos & "Afinidade de interesses." \\
\hline 4 & 4. adultos de 20 a 40 anos & $\begin{array}{l}\text { "Porque, de modo geral, é mais fácil atender aos interesses de } \\
\text { aprendizagem dos alunos dessa faixa etária (a meu ver)." }\end{array}$ \\
\hline 5 & $\begin{array}{l}\text { 5. adultos de } 40 \text { a } 60 \text { anos; } \\
\text { 6. terceira idade (de } 60 \text { a } 80 \\
\text { anos) }\end{array}$ & "Público responsável e divertido." \\
\hline 6 & $\begin{array}{l}\text { 4. adultos de } 20 \text { a } 40 \text { anos; } \\
\text { 5. adultos de } 40 \text { a } 60 \text { anos; } \\
\text { 6. terceira idade (de } 60 \text { a } 80 \\
\text { anos) }\end{array}$ & $\begin{array}{l}\text { "Pessoas com conteúdo cultural mais estruturado e facilidade } \\
\text { pessoal para lidar com pessoas dessa faixa etária." }\end{array}$ \\
\hline
\end{tabular}

* Faixas etárias apresentadas: 1. crianças não alfabetizadas; 2. crianças alfabetizadas; 3. adolescentes; 4 . adultos de 20 a 40 anos; 5. adultos de 40 a 60 anos; 6. terceira idade (de 60 a 80 anos); 7. quarta idade (acima de 80 anos).

Podemos observar nas respostas da Tabela 18 que somente dois monitores indicam os idosos como um público com o qual preferem trabalhar. Algumas das alegações pela escolha da faixa de 20 a 40 anos são relacionadas à afinidade devido à proximidade etária entre monitor e aluno. Já os dois monitores que indicam o 
público idoso apontam a responsabilidade e a maturidade cultural como razões da escolha.

Nas entrevistas, também questionamos os monitores se preferem trabalhar com algum público específico (em faixas etárias). M1e e M4e disseram preferir trabalhar com um público de faixa etária aproximada à deles:

M1: Ah, prefiro ((risos)). Com certeza. É... se bem que, assim, não dá pra generalizar, porque eu já tive exceções, né? Mas acho que de um modo geral, EU acabo/me sinto melhor como professora, acabo tendo um relacionamento mais legal como professora mesmo - não pessoal... pessoal, com qualquer idade. Acho que entre 20 e 40-45, alguma coisa assim.

M4: Olha, eu:: eu gosto de dar aula pra pessoas:: mais ou menos na minha faixa etária. Porque eu acho que a comunicação se:: se faz de uma maneira mais tranquila... Então, por exemplo... - o policiamento é menor... quando o professor e a sala têm mais ou menos a mesma faixa etária. Mas como isso nunca aconteceu aqui ((risos)), então... eu acho que eu não tenho um público::: um público especial assim, porque/pelo qual eu me interessaria mais em dar aula. Acho que todos os grupos que eu dei aula foram bastante heterogêneos, assim, não tem uma idade específica, nem uma formação específica, nada muito regrado. E funciona, assim, nos cursos que eu dei, essa mistura funciona muito bem. [...]

M4e, apesar de dizer preferir um grupo com faixa etária próxima à sua, afirma que no IC um grupo desse tipo nunca aconteceu e, com isso, ele percebeu que a intergeracionalidade funciona bem em sala de aula. Já M5e prefere pensar com qual público não gostaria de trabalhar e declara não se sentir preparado a trabalhar com crianças e jovens no início da adolescência, e afirma não ter preferência por um público específico. M2e e M3e falam especificamente dos idosos. Vejamos, primeiramente, o depoimento de M3e:

M3: Olha, eu trabalhei bastante com senhores... É:: Foi uma surpresa, porque no início eu fiquei um pouco preocupada porque nas outras escolas era um público bem mais jovem. E eu fiquei preocupada, pensei: será que 
eu vou conseguir? Mas foi uma experiência muito boa porque você acaba aprendendo muito com eles também. Eles trazem muitos materiais extras, eles vão atrás, eles têm interesse é::... Além do fato de que tem uns que cozinham muito bem ((risos)), então, eles levavam uma receita, outros falavam "Ah, eu tenho uma receita, vou preparar um bolo" não sei o quê (incompreensível). Foi muito bom.

M3e ressalta o interesse dos alunos idosos no curso de língua. Como havíamos dito no capítulo dois, este é um dos estereótipos positivos sobre os alunos da terceira idade, eles geralmente se mostram mais interessados. A menção do fato de que eles levam pratos para as aulas (quitutes, muitas vezes da culinária italiana, com a finalidade de socializar o grupo, se socializar, trocar receitas etc) também ressalta um caráter socializador de alguns idosos que buscam em suas atividades extra uma forma de reinserção social e que acabam por conseguir, em alguns grupos, promover a interação em sala de aula e uma integração maior entre os alunos, transformando a classe em espaço também de lazer e prazer. Uma aluna, ao justificar por que acha que o relacionamento do grupo é bom, disse: " $A$ maior parte da minha turma foi de senhoras, o que tornou o relacionamento bom." (f47n5).

Destacamos o depoimento de M2e porque mostra como ele foi de um "pré-conceito" para uma nova visão dos idosos conforme sua experiência profissional aumentou:

M2: Olha, antigamente eu tinha um certo preconceito pra trabalhar com a terceira idade, mas eles se mostraram mais motivados de certa forma. Sem contar que é eles que me dão mais presentes. ((risos)) Não, não, isso aí não tinha que ser registrado, mas já ficou, né?

E: Eu apago depois na transcrição. ((ri))

M2: Obrigado, obrigado. É:: Mas antigamente eu tinha um PRÉ-conceito sim com o público de terceira idade. Porém isso depende muito de pessoa pra pessoa. Eu percebi muito que essa questão de sexo e idade ou até mesmo graduação depende muito. Às vezes você tem uma pessoa que ainda não é graduado você pensa "Ah, vai ter mais dificuldade", ao 
contrário, às vezes a pessoa tem uma certa aptidão, dom, não sei se posso dizer essas palavra, mas... ué... me ne frego.

E: E qual era o seu preconceito antes?

M2: Meu preconceito antes era acreditar que os grupos de terceira idade eram aquelas velhas idosas que não queriam fazer/frequentar, mas queriam encher o saco. Não. É assim, claro que poderia trabalhar melhor isso. Mas pelo fato de você acreditar que uma pessoa na terceira idade tenha mais, não mais, mas uma maior dificuldade em adquirir uma língua estrangeira porque segundo os/a linguística já está muito é::: fossilizado - fossilizado não, dá a ideia de morto/Já tá muito cristalizado a língua então para adquirir uma nova língua e traria muitos problemas. Ao contrário, depende muito de pessoa a pessoa.

Podemos perceber que M2e inicia sua carreira com a ideia preconcebida de que os idosos possuem maior dificuldade em adquirir/aprender uma língua estrangeira, uma visão generalizada e estereotipada, e que passa, com o exercício da profissão, a visualizar os idosos em sua individualidade, cada um com suas características, vendo que a dificuldade em aprender/adquirir uma LE varia de pessoa para pessoa.

Os estudos na área de aquisição/aprendizagem de LE ainda se baseiam muito nos estudos da área de a/a da língua materna por crianças. São ainda poucos os estudos que tratam dos processos de a/a de uma LE na velhice. Como afirma Meire Cachioni (2003), os estudos sobre os processos cognitivos dos idosos ainda são muito baseados na ideia de que a velhice é só declínio, pois tomam como fundamento uma visão biológica do envelhecimento humano. Os estudos que comprovam as poucas diferenças ou mesmo quando não há diferenças significativas entre os processos cognitivos de jovens e idosos ainda possuem baixo alcance, concentrando sua divulgação entre os pesquisadores com enfoque na Gerontologia. 
Embora muitos dos monitores não indiquem a terceira idade como o público com o qual preferem trabalhar, a maioria deles coloca a terceira idade como uma das faixas etárias "habituais" de seus alunos. Vejamos suas respostas na Tabela 19:

Tabela 19: Geralmente, qual a faixa etária* de seus alunos? (Q3:12)

\begin{tabular}{c|l}
\hline Monitor & \multicolumn{1}{c}{ Faixa(s) etária(s) } \\
\hline 1 & $\begin{array}{l}\text { 4. adultos de } 20 \text { a } 40 \text { anos; } 5 \text {. adultos de } 40 \text { a } 60 \text { anos; } \\
\text { 6. terceira idade (de } 60 \text { a } 80 \text { anos) }\end{array}$ \\
\hline 2 & $\begin{array}{l}\text { 4. adultos de } 20 \text { a } 40 \text { anos; } 5 . \text { adultos de } 40 \text { a } 60 \text { anos; } \\
\text { 6. terceira idade (de } 60 \text { a } 80 \text { anos) }\end{array}$ \\
\hline 3 & 4. adultos de 20 a 40 anos; 5. adultos de 40 a 60 anos; \\
\hline 4 & $\begin{array}{l}\text { 4. adultos de } 20 \text { a } 40 \text { anos; } 5 . \text { adultos de } 40 \text { a } 60 \text { anos; } \\
\text { 6. terceira idade (de } 60 \text { a } 80 \text { anos) }\end{array}$ \\
\hline 6 & 5. adultos de 40 a 60 anos; 6 . terceira idade (de 60 a 80 anos) \\
\hline & $\begin{array}{l}\text { 4. adultos de } 20 \text { a } 40 \text { anos; } 5 . \text { adultos de } 40 \text { a } 60 \text { anos; } \\
\text { 6. terceira idade (de } 60 \text { a } 80 \text { anos) }\end{array}$ \\
\hline
\end{tabular}

* Faixas etárias apresentadas: 1 . crianças não alfabetizadas; 2 . crianças alfabetizadas; 3. adolescentes; 4. adultos de 20 a 40 anos; 5 . adultos de 40 a 60 anos; 6 . terceira idade (de 60 a 80 anos); 7. quarta idade (acima de 80 anos).

Isso pode trazer implicações negativas em sala de aula caso a não preferência do monitor em trabalhar com o público idoso inclua estereótipos negativos e até mesmo preconceitos em relação aos idosos, influenciando o tratamento dispensado a eles em sala de aula. É importante lembrarmos de nossa discussão no capítulo dois sobre os estereótipos e o preconceito. Muitas vezes, a presença de um membro do grupo estereotipado (no caso, os idosos) basta para ativar o estereótipo e produzir um comportamento preconceituoso. A pessoa pode não ter consciência dessa ativação e, portanto, pode não controlá-la. Em sala de aula, por exemplo, essa ativação pode se manifestar na forma de impaciência quando algum aluno idoso se coloca em aula, ou com respostas bem menos explicadas para esclarecer uma dúvida, se esta parte de um idoso, por exemplo. 
Perguntamos aos monitores, ao fim da entrevista, se eles achavam que o público idoso era significativo no Italiano no Campus.

M1: É. Bastante. Tem alguns/eu não peguei, né,[*]mas já vi algumas turmas que tem aqui que praticamente é só terceira idade, né? É o contrário, né? As que eu peguei até agora, a maioria é jovem, mas tem turma aqui que, pelo que eu vi, que tem dez alunos, 6-7 de terceira idade.

M2: [...] Afinal eu diria que eles são quase 70\% do nosso público, se não fossem os alunos da terceira idade, acho que não haveria o IC pelo tamanho que ele é hoje, né? Com todos os monitores e todas as turmas existentes. [...]

M3: Tem. Tem sim. Foi uma surpresa. Foi uma surpresa, mas é... Eu gostei de trabalhar com eles, eu tive muita troca de experiência, não achei ruim, mas eu acho que o público da graduação deveria também frequentar mais.

M4: Eu diria hoje que é a maioria. Eu acho que é a maioria.

M5: É. É expressivo isso. Isso eu diria também categoricamente, é um público expressivo. Presente sim em TODAS as turmas, absolutamente todas e algumas, como eu disse, que eu tinha 7 alunos e 6 eram terceira idade, praticamente a totalidade. É que em turmas maiores isso dilui, né? [...]

Como podemos notar nos depoimentos acima, dois dos monitores (M2e e M4e) acham que o público idoso é maioria. Como vimos, a faixa etária de maior público no Italiano no Campus é a de 20 a 29 anos, sendo que os idosos correspondem a aproximadamente $25 \%$ do público do IC. O fato de algumas turmas terem a maioria dos alunos pertencentes à terceira idade pode ser a razão de M2e visualizar o público idoso como correspondendo a 70\% dos alunos do IC e de M4e os ver como maioria. Essa percepção de que eles são maioria também pode decorrer da relação que se tem sobre esse público, se ele for, de alguma forma, muito marcante para esses dois monitores em específico. 
Perguntamos se alguma vez, durante as reuniões com a coordenação, se discutiu essa grande presença idosa nos cursos do Italiano no Campus, e a resposta de todos os monitores entrevistados foi negativa.

Outra questão colocada aos monitores, no questionário geral, era a de qual público escolheriam para fazer um curso específico. As respostas podem ser conferidas na Tabela 20 abaixo:

Tabela 20: Se você tivesse que fazer um curso para uma faixa etária* específica, qual seria? (Q3:13)

\begin{tabular}{c|l|l}
\hline Monitor & \multicolumn{1}{|c|}{ Faixa(s) etária(s) } & \multicolumn{1}{c}{ Justificativa } \\
\hline 1 & $\begin{array}{l}\text { 4. adultos de } 20 \text { a } 40 \text { anos; } \\
\text { 5. adultos de } 40 \text { a } 60 \text { anos; }\end{array}$ & "Acredito que o que escrevi no item 9 responda a essa questão." \\
\hline 2 & 2. crianças alfabetizadas; & $\begin{array}{l}\text { "A capacidade de adquirir mais facilmente a língua estrangeira e o } \\
\text { desafio em 'prender a atenção' deles." }\end{array}$ \\
\hline 3 & $\begin{array}{l}\text { 4. adultos de } 20 \text { a } 40 \text { anos; } \\
\text { 5. adultos de } 40 \text { a } 60 \text { anos; }\end{array}$ & $\begin{array}{l}\text { "Adoro trabalhar com adultos. Geralmente são os mais } \\
\text { interessados." }\end{array}$ \\
\hline 5 & $\begin{array}{l}\text { 4. adultos de } 20 \text { a } 40 \text { anos; } \\
\text { 6. terceira idade (de } 60 \text { a } 80\end{array}$ & $\begin{array}{l}\text { "Prefiro trabalhar com adultos dessa idade, porque me identifico } \\
\text { mais com eles." }\end{array}$ \\
\hline 6 & $\begin{array}{l}\text { "Hána temas específicos a serem aborsação e opiniões. Eles são abertos a todas as atividades } \\
\text { (brincadeiras, músicas, leitura...) }\end{array}$ \\
\hline
\end{tabular}

* Faixas etárias apresentadas: 1 . crianças não alfabetizadas; 2 . crianças alfabetizadas; 3 . adolescentes; 4 . adultos de 20 a 40 anos; 5. adultos de 40 a 60 anos; 6 . terceira idade (de 60 a 80 anos); 7. quarta idade (acima de 80 anos).

Podemos notar que nesta questão retomamos o fato de que alguns monitores se sentem mais à vontade em trabalhar com alunos de faixas etárias próximas às suas, uma questão de identificação. M2q, por sua vez, cita a ideia de que as crianças aprendem mais facilmente uma língua estrangeira. Enquanto M5q, escolhendo alunos entre 40 e 80 anos, destaca o fato de alunos dessa idade estarem abertos a todos os tipos de atividade. Como vimos no capítulo dois, Pizzolatto (2008) destaca que alunos idosos costumam assumir uma postura de 
"nada a perder" na sala de aula, não temendo exposições diante dos outros alunos, o que facilita a interação entre todos da sala e acaba servindo de exemplo para os alunos de outras idades.

\section{Separação por faixas etárias}

Nossas últimas perguntas feitas aos monitores, tanto durante as entrevistas quanto nos questionários, se referiam à necessidade ou não, segundo eles, da divisão dos grupos do Italiano no Campus por faixas etárias. Em seguida confrontamos suas opiniões com aquelas dos estudantes.

TABELA 21: Você acha que os grupos deveriam ser divididos por faixa etária? (Q3:14)

\begin{tabular}{|c|c|c|}
\hline Monitor & Sim ou Não & Justificativa \\
\hline 1 & SIM & $\begin{array}{l}\text { "Acredito que crianças, adolescentes e pessoas com mais de } 80 \\
\text { anos tenham ritmos diferentes e demandem por atividades } \\
\text { específicas que deem conta dessas demandas. O professor } \\
\text { precisa ter formação específica para lidar bem com esses grupos } \\
\text { separadamente; mais formação ainda, se os alunos dessas faixas } \\
\text { etárias são colocados juntos na sala de aula." }\end{array}$ \\
\hline 2 & SIM & $\begin{array}{l}\text { "Não tão dividido como na questão anterior, mas entre dois } \\
\text { grupos: (3-12 anos) crianças e (12 a mais) adolescentes e } \\
\text { adultos, conforme resposta da questão } 11 . "\end{array}$ \\
\hline 3 & NÃO & "Pelo mencionado enriquecimento das diferentes idades." \\
\hline 4 & NÃO & $\begin{array}{l}\text { "Acho desnecessária essa divisão, porque as trocas de } \\
\text { experiências entre os alunos de diferentes idades costuma ser } \\
\text { algo muito positivo." }\end{array}$ \\
\hline 5 & NÃO & $\begin{array}{l}\text { "Apesar de, em alguns casos, ser interessante porque você atinge } \\
\text { (com a sua aula) o grupo por inteiro, essa homogeneidade pode } \\
\text { não ser útil para o aprendizado e faz com que o professor utilize } \\
\text { as mesmas formas de dar aula/aplicar atividades. Se o grupo é } \\
\text { heterogêneo o professor tenta alcançar os gostos, objetivos e } \\
\text { dificuldades de todos. Isso provoca o crescimento." }\end{array}$ \\
\hline 6 & NÃO & $\begin{array}{l}\text { "Um grupo composto de pessoas de diversas idades tende a } \\
\text { facilitar a troca de experiências, que contribui para a formação } \\
\text { do aluno." }\end{array}$ \\
\hline
\end{tabular}


Dos seis monitores, quatro responderam que não separariam os grupos por faixas etárias, e os dois outros monitores que responderam positivamente disseram que a afirmação se referia aos grupos de crianças e adolescentes por necessitarem de uma abordagem específica; e um deles indica também os idosos acima de 80 como faixa etária a ser separada das demais. Como pudemos ver, os monitores defendem o enriquecimento que acontece quando há o contato intergeracional. E é interessante destacarmos a resposta de M1q, na qual afirma que para lidar com a heterogeneidade na sala de aula a formação deve ser maior do que a habitual.

Nas entrevistas com os monitores perguntamos se eles separariam algum público do Italiano no Campus. As respostas foram negativas. Ressaltamos aquela dada por M1e e M4e:

M1: Ah, eu acho que não. Eu acho que não perché, como eu falei, né, não é a idade o problema, são outras coisas, né? então... Porque só podem ser outras coisas, mas se precisar - se eu já tive aluno de 70 que era excelente e aluno de 40 que tinha uma dificuldade de outro mundo, então não é idade. Tem alguns outros fatores - talvez, sei lá, o estilo de aprendizagem, ou não sei, a pessoa de repente não tem muita facilidade com língua... não sei, acho que não é a idade o problema, então não acho que deveria/não deveriam ser grupos separados por idade.

M4: Ahn... Eu acho que sim, caso tivesse, se a gente desse aula pra crianças. Assim, ou alfabetização ou crianças pequenininhas. Como nosso público são adultos, e adultos aí também vai de 20, 19 até 104, então não::: não tem por que muito separar.

Alguns alunos, respondendo à questão sobre a separação etária, deram uma resposta semelhante com a de M4e:

Acho que de 25 anos em diante não há problemas em misturar as idades. (f58n6)

Diferentemente das crianças e dos adolescentes, os adultos não precisam ser colocados em grupos diferentes de acordo com a faixa etária. (f37n2) 
Perguntamos também aos alunos se eles achavam que os grupos deveriam ter uma separação etária. O Gráfico 17 mostra a porcentagem dos que responderam afirmativa ou negativamente à pergunta.

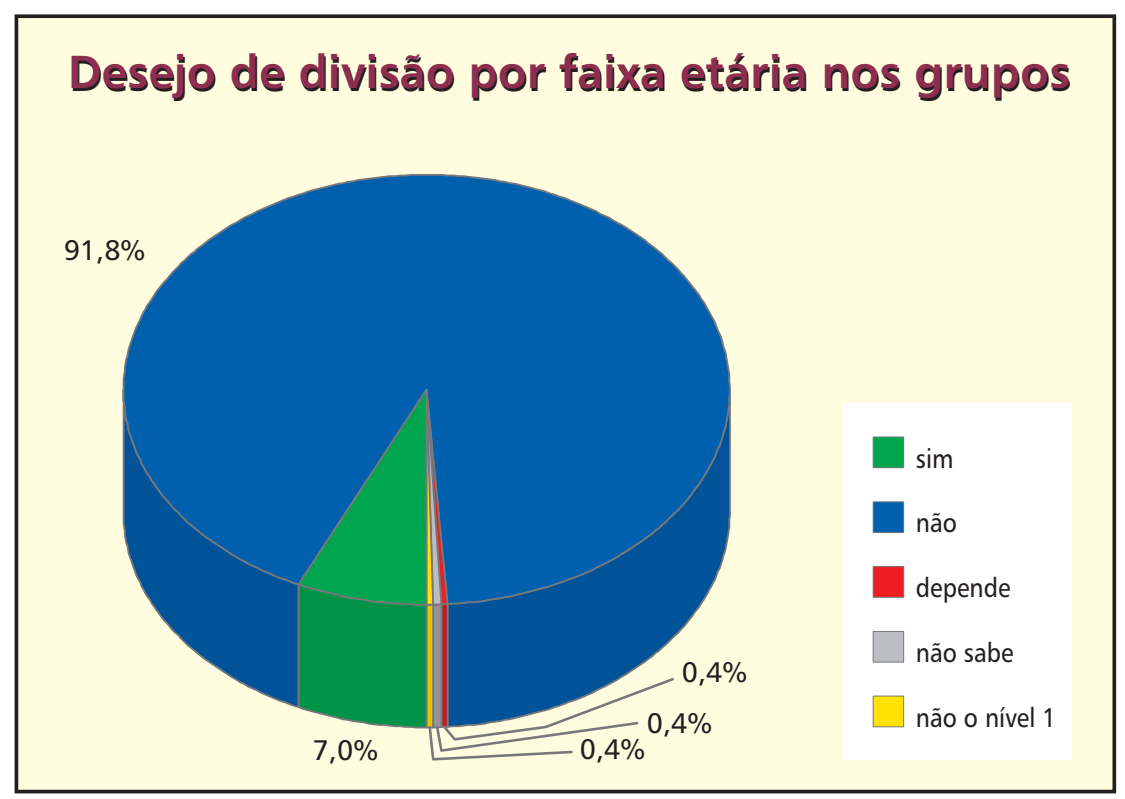

Gráfico 17 - Público geral que gostaria de separação por faixa etária

Como podemos ver no Gráfico 17, a maioria dos alunos, com 91,8\% das respostas obtidas, não quer a separação por faixa etária. A questão tinha as alternativas "Sim" e "Não" juntamente com um espaço para a justificativa. As respostas diferentes de "Sim" e "Não" não foram assinaladas, mas foram justificadas pelos alunos. Dentre as justificativas daqueles que dizem não achar que os grupos deveriam ser divididos por faixas etárias, selecionamos algumas mais significativas, as quais transcrevemos e comentamos a seguir.

- Justificativas que falam da necessidade da diferença na sala de aula Porque a diferença acrescenta, enriquece. (m24n1) A diferença é que faz o curso andar bem. (f29n6) 
O convívio com faixas etárias diferentes favorece o aprendizado do respeito às diferenças. (f48n8)

Acredito que a riqueza do conhecimento advém da diversidade e está em todos os seus aspectos. (m22n3)

Exatamente pela importância da troca cultural entre as faixas etárias. Acredito que todos possam aprender com essa experiência. (f23n4)

O aprendizado da língua é fundamental, mas a experiência compartilhada entre as diferentes pessoas é imprescindível. ( $f 27 n 2$ )

Obtivemos muitas justificativas que tratavam da necessidade e da importância da diferença ou do enriquecimento que ocorre em salas de aula onde há a diferença etária. Podemos notar que não há restrições de idade para tal declaração, sendo que a maioria das declarações selecionada foi feita por pessoas com idades entre 20 e 29 anos. Da seleção feita ressaltamos em negrito a declaração da aluna que declara que "[...] o aprendizado do respeito às diferenças" é um dos pontos positivos decorrente da convivência intergeracional. Justamente o que defendemos no terceiro capítulo deste trabalho, quando afirmamos que ambientes heterogêneos como o Italiano no Campus podem propiciar a quebra de estereótipos e preconceitos, ajudando no respeito às diferenças.

- Justificativas que apontavam a divisão etária como segregação e preconceito

Isso seria segregacionismo e as pessoas devem trocar experiências. (f47n5)

Discriminação sem razão. (søiøn7)

De forma nenhuma! Esse é um dos raros espaços sociais que encontro diversidade etária e de gênero. (f48n4)

Por que separar idade, sexo, cor? Se convive muito bem. (f76n1)

As gerações devem conviver em várias situações. (f61n6)

Dividir o grupo dessa forma é absurdo! (f22n1)

Temos que saber viver com todos. (sø41n1) 
Obtivemos algumas respostas até mesmo "exaltadas", considerando absurda a pergunta sobre se desejar ou não a divisão dos grupos em faixas etárias. Também aqui temos respostas selecionadas entre várias faixas etárias, mas achamos importante destacarmos uma delas, feita por uma aluna do nível 4, que declara que o IC "é um dos raros espaços sociais" em que ela encontra a heterogeneidade etária e de gênero. Como dissemos no terceiro capítulo, segundo Moragas (2004), com o enfoque organizacional pós Segunda Guerra Mundial, a sociedade ocidental passa a ser dividida por faixas etárias que cada vez mais segregam as gerações ao definir espaços sociais específicos para cada uma delas. O IC é rico e diversificado justamente por permitir em seus grupos o encontro das várias gerações, favorecendo o contato intergeracional que tem se perdido.

\section{- Justificativas que expressam a visão da diversidade na sala de aula}

Tendo os pré-requisitos para a participação, não vejo por que as exclusões. (m61n3)

Além do aprendizado da língua, há uma atualização dos modos de vida. (m65n1)

Pois as dificuldades, na maior parte das vezes, não estão relacionadas à idade. ( $f 25 n 1)$

Pois a idade não impede nada. (f27n2)

A mistura é muito boa, desde que haja interesse. (f43n2)

Acho que não atrapalha o andamento do curso a diferença de faixa etária. (f28n1)

O aprendizado me parece mais completo quando vejo que outro aluno mais velho raciocina de modo diverso. ( $f 26 n 1$ )

A mistura não compromete o andamento do curso. (f22n3)

Faixas etárias diferentes proporcionam maior aprendizado. (f63n1)

Faixas etárias diferentes proporcionam aulas mais dinâmicas. (f31n1)

Diferentes idades dão importância a diferentes assuntos e têm enfoques diferentes, enriquecendo, assim, as aulas. ( $f 26 n 3)$ 
Nesta seleção de justificativas podemos observar que os alunos consideram a mistura de faixas etárias na sala de aula enriquecedora e não a consideram um obstáculo para o curso. Ao contrário, declaram que a aula fica mais dinâmica, seu andamento não é prejudicado e até melhora o aprendizado.

\section{- Justificativas de alguns idosos}

Porque convém se conhecer a impressão dos mais jovens sobre os fatos da vida que para eles são novidade. (f61n3)

O convívio com os jovens é muito importante. (f67n3)

Ficaria muito monótono. A juventude sempre me revigora. (f66n2)

Cada faixa etária tem o que ensinar às demais. (f62n1)

Todos têm que assumir sua realidade. (m77n1)

Como podemos notar nos depoimentos selecionados, os idosos consideram positiva a convivência com os estudantes mais jovens, declarando que todas as faixas etárias têm algo a ensinar. Entendemos a última justificativa desta seleção, do aluno de 77 anos, considera como "assumir sua realidade", como o fato de todos se aceitarem como são, com a idade que possuem.

\section{- Algumas justificativas estereotipadas}

Porque se há somente adolescentes, tenho a impressão de o curso ficar bagunçado e se há somente terceira idade, ficar lento. (f22n2)

Se concentrar nos idosos o ritmo ficaria mais lento. (f62n4)

Não tem por que dividir, esta seria uma forma de segregá-los. (f19n1)

Não acho necessário, porque os mais velhos são mais dedicados, por terem muitas vezes mais tempo livre. (f29n1) 
Aqui temos novamente a questão da estereotipização de jovens e idosos, dessa vez na declaração de uma estudante de 22 anos, ao considerar que um grupo de adolescentes seria uma bagunça e se fosse um grupo só de idosos, seria lento. A estudante não fala de "jovens" quando vai se referir à bagunça, pois isso a incluiria. Fala, então, de adolescentes, uma faixa etária que praticamente não existe no Italiano no Campus. A segunda declaração é de uma idosa de 62 anos, na qual podemos vê-la assumindo o estereótipo e considerando um grupo só de idosos como naturalmente lentos.

Consideramos importante ressaltar as duas últimas declarações (que aparecem em negrito). Em nenhum momento do questionário nos referimos à terceira idade. No entanto, quando questionados sobre a divisão etária, essas duas declarações mostram que as alunas interpretaram nossa pergunta sobre a divisão dos grupos em faixas etárias como se estivéssemos nos referindo à separação específica dos idosos dos grupos. Elas não pensaram que a pergunta poderia se referir à separação da faixa etária delas. A primeira diz: que "esta seria uma forma de segregá-los". E nos perguntamos: Segregá-los quem? Por que a aluna não disse: NOS segregar? Provavelmente porque não se referia aos alunos de sua faixa etária. E como ela faz parte da faixa etária mais jovem do IC, podemos supor que ela se referia aos mais velhos. A segunda justificativa aponta diretamente os alunos mais velhos, como se tivéssemos questionado sobre eles: "Não acho necessário, porque os mais velhos são mais dedicados [...]". 
Dentre os 7\% dos alunos que disseram achar que os grupos deveriam ser divididos por faixas etárias, as justificativas (quando dadas) foram as seguintes ${ }^{119}$ :

1. Faria isso se houvesse pessoas com menos de 18 anos. (m32n1)

2. Os interesses são diferentes. (f42n6)

3. Acho que há interesses diversos em cada faixa etária. (m56n8)

4. Facilitaria as interações com colegas. (f19n1)

5. Os assuntos podem ser melhor explorados na conversação. (f53n6)

6. Cada um com sua cabę̧a. (f33n6)

7. Devido ao ritmo de aprendizado existente em cada faixa etária. (f30n3)

8. O ritmo, apesar de ser muito bom é diferente e nosso desempenho poderia ser maior (penso, talvez). (f25n2)

9. Apesar de me sentir bem, dividiria em função do ritmo que cada um tem. (f20n4)

10. O acompanhamento é diferente. (f23n3)

11. A princípio sim, pois muitas vezes o grupo da terceira idade apresenta maior dificuldade de aprendizado. (f33n8)

12. Às vezes atrapalha, quando os alunos são mais velhos (Terceira Idade) porque o ritmo de aprendizagem deles é mais lento. (f25n4)

13. Pois estudar com pessoas mais novas é ruim, muita dispersão, conversa. (f32n3)

14. Apesar da boa vontade de ambos, há diferença cultural e de hábitos. (f28n3)

A primeira justificativa se refere à separação de participantes com idades inferiores a 18 anos (é raro no IC estudantes com menos de 18 anos dada a

119 Numeramos as citações para ficar mais fácil referenciá-las no texto, já que não fizemos agrupamentos nesta parte. Transcrevemos todas as justificativas dadas por quem disse que gostaria que os grupos fossem separados por faixas etárias. Lembrando que alguns não justificaram sua escolha. 
exigência de Ensino Médio completo). A justificativa número 13 também fala de pessoas mais jovens, associando-as à falta de concentração durante as aulas, mas como não faz referência a nenhuma idade específica, pode ser associada à imagem estereotipada dos jovens.

As justificativas 2 e 3 se referem aos interesses dos alunos. Os dois alunos acham que há diferença de interesses e, portanto, as turmas devem ser separadas. Como vimos anteriormente neste mesmo capítulo, quando perguntamos aos alunos por que decidiram estudar italiano não vimos diferenças significativas nas respostas dadas por faixas etárias. O mesmo se aplica à questão referente aos assuntos que gostariam que fossem mais tratados em sala de aula. Esses índices podem mostrar que não há diferença relevante de interesses quanto ao curso que varie de idade para idade. Consideramos que, se os objetivos forem parecidos e os interesses no curso também, as diferentes opiniões contribuirão para um debate rico que, além de permitir a descoberta de outros pontos de vista sobre a mesma questão, também permitem uma prática única da língua estrangeira, pois o aluno se sentirá estimulado a mostrar a expor seu posicionamento sobre o tema e terá de fazê-lo em outra língua.

Nas respostas de 7 a 10 os alunos declaram que existem diferenças de ritmos, o que justificaria a divisão por faixas etárias. Interessante notarmos, entretanto, que na declaração 9 a aluna fala que dividiria em função do ritmo "que cada um tem". Vejamos, então, o gráfico que fala sobre o ritmo de aula. Lembrando que fizemos essa pergunta para verificar: se os idosos realmente fossem mais lentos, assinalariam a opção indicativa de que acham o curso rápido demais. Se os jovens são generalizadamente mais rápidos, eles assinalariam a resposta que indica que o curso, para eles, é lento. Observemos o Gráfico 18: 


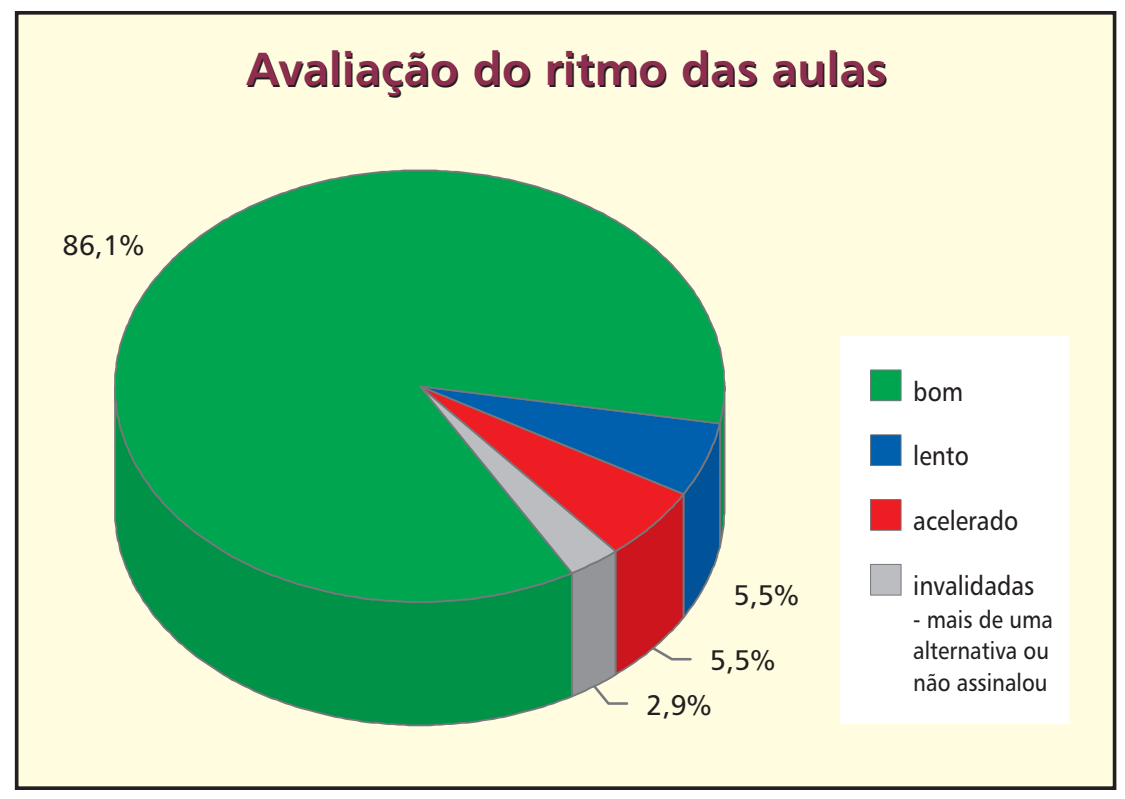

Gráfico 18 - Público geral: ritmo das aulas

Podemos observar no Gráfico 18 que apenas 5,5\% dos alunos declaram que o curso é lento e a mesma porcentagem declara que o curso é acelerado. Fizemos, então, um gráfico para visualizar essas escolhas por faixa etária. Das respostas válidas obtivemos o seguinte Gráfico 19:

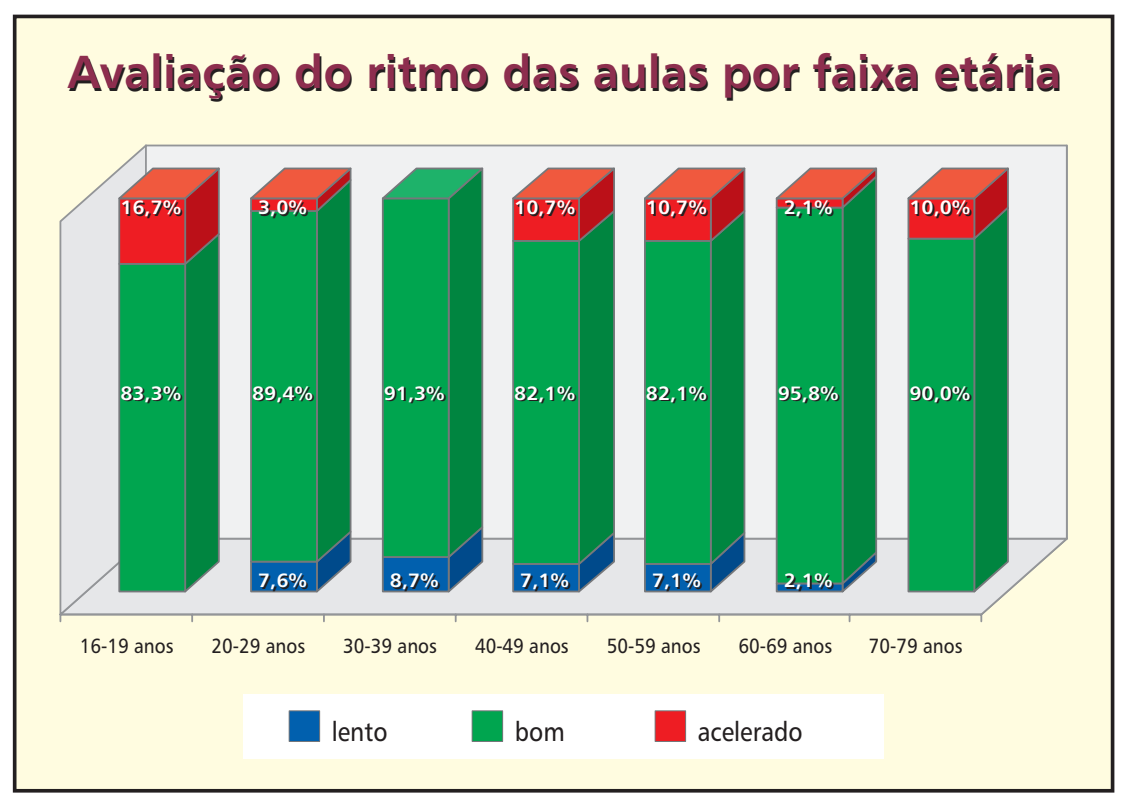

Gráfico 19 - Público geral: ritmo das aulas por faixa etária 
No Gráfico 19, podemos observar que em todas as faixas etárias a declaração de que o ritmo da aula é bom prevalece com larga folga. Não podemos afirmar que as faixas etárias mais jovens tendem a considerar o curso mais lento e nem que as faixas etárias mais velhas acham que o curso é mais acelerado. Temos, por exemplo, dentre os alunos de 20 a 19 anos, alunos que consideram o curso lento e aqueles que consideram o curso acelerado, enquanto que na faixa etária de 30 a 39 anos não há alunos que declarem achar o curso acelerado. O interessante é que na faixa etária mais jovem não há declarações de que o curso "é lento", mas há quem afirme que o curso "é acelerado".

Retomamos, portanto, a declaração de M1e, na qual afirma não ver a relação da idade com o andamento do curso e do grupo, considerando que está mais relacionado a estilos de aprendizagem ou facilidade com a língua do que com idade. E relata um caso que vivenciou no início de sua carreira lecionando italiano:

M1: [...] Quando eu comecei minha carreira, lá no minicurso, na Faculdade de Educação, você deve ter feito também. Tinha um aluno, que pelo jeito deu bastante trabalho aqui, o Aluno A ((risos)) que era ótimo, assim, o mais novo era o Aluno B que tinha 19 e o Aluno $A$ tinha 69. E o Aluno A era ótimo tanto quanto o Aluno $B$ que tinha 19. Não... o Aluno $B$ não tinha 19, tinha 21, mas tinha o Aluno C que tinha 19. Aluno $C$ tinha 19 e tinha uma dificuldade com o italiano, que era coisa de outro mundo, e o Aluno A, que tinha 69 ia super bem. E depois, pelo que eu soube, ele deu bastante trabalho aqui. ${ }^{120}$

E: É, mas era por causa de outra coisa...

M1: É, não era por causa de dificuldade de aprendizagem, né? Por isso que eu acho que não tem a ver com idade, né? [...] Então acho que é alguma coisa na pessoa, assim. O perfil de aprendizagem, estilo cognitivo, não sei. Mas não acho que é idade.

M1e complementa, dizendo que é um fator que varia de grupo para grupo. M4e faz a mesma associação: “[...] Então isso vai variar de sala pra sala. 
Tem sala de terceira idade que anda maravilhosamente bem e tem sala cheia de gente nova que é um desastre".

Vale ressaltarmos também que, na declaração 8, a aluna diz: "nosso desempenho poderia ser maior". Considerando que a pergunta feita se referia à separação por faixas etárias, entendemos que o uso do pronome "nosso" neste caso refere-se à faixa etária à qual ela pertence. Portanto, a aluna supõe que, se sua faixa etária tivesse um grupo só para ela, o desempenho seria maior, deixando transparecer sua opinião de que as outras faixas etárias são, de algum modo, inferiores. Associamos essa valorização do ingroup, que no caso se refere às pessoas pertencentes à mesma faixa etária da declarante, com a esterotipização do outgroup (como a declarante faz parte de uma das faixas etárias mais jovens do IC, supomos que ela esteja se referindo aos mais velhos). O outgroup é colocado, nesse caso, como uma "ameaça" ao bom desempenho do ingroup e classificado como inferior. No entanto, vimos no depoimento de M1e e M4e, que, segundo eles, a idade não é fator que determina o desempenho e ritmo do aluno em aula de língua estrangeira.

As justificativas 11 e 12 se referem diretamente aos idosos como mais lentos e com maiores dificuldades no curso de língua. Mais uma vez é importante notarmos que raramente os mais jovens se colocam na posição de grupo que será separado. Quando se fala em separação etária, aqueles que apontaram alguma faixa etária que gostariam que fosse separada colocam os idosos como grupo que deve ser segregado, e não apontam a própria faixa etária como grupo que devesse ser separado.

Destacamos em negrito a justificativa número 14 porque ela nos traz dois elementos interessantes para nossa discussão. O primeiro deles é que a aluna declara haver a "boa vontade de ambos", e nos perguntamos: ambos quem? Será que ela considera que existem apenas dois grupos participantes do Italiano no Campus? E se for, quais seriam eles? Os mais jovens e os mais velhos? Não existem várias faixas etárias? Mas o que mais nos chamou a atenção foi a aluna declarar 
que a justificativa da separação por faixas etárias é que "há diferença cultural e de hábitos", o que indica a vontade de se manter distante de cultura e hábitos que sejam diferentes dos seus, como se as diferenças não pudessem conviver e ser mutuamente respeitadas. Entendemos essa declaração como uma forma de intolerância com a diversidade e negação à possibilidade de entrar em contato com cultura e hábitos diferentes, o que nos faz questionar a razão de sua escolha em frequentar um curso de língua estrangeira, justamente uma disciplina que lida com cultura e hábitos diferentes e, por isso mesmo, é um ambiente ideal para incentivar o respeito à diferença.

A última pergunta relativa à idade dos alunos do grupo, no questionário geral, indagava se eles gostariam de um grupo só com a faixa etária deles. Como explicamos no quarto capítulo, se os alunos respondessem que queriam a divisão por faixas etárias, mas não quisessem um grupo só com pessoas de suas idades, poderíamos deduzir que há alguma faixa etária específica que eles não querem que faça parte de sua aula de LE, marcando ageism (preconceito etário). O Gráfico 20 mostra o porcentual de respostas positivas e negativas obtidas:

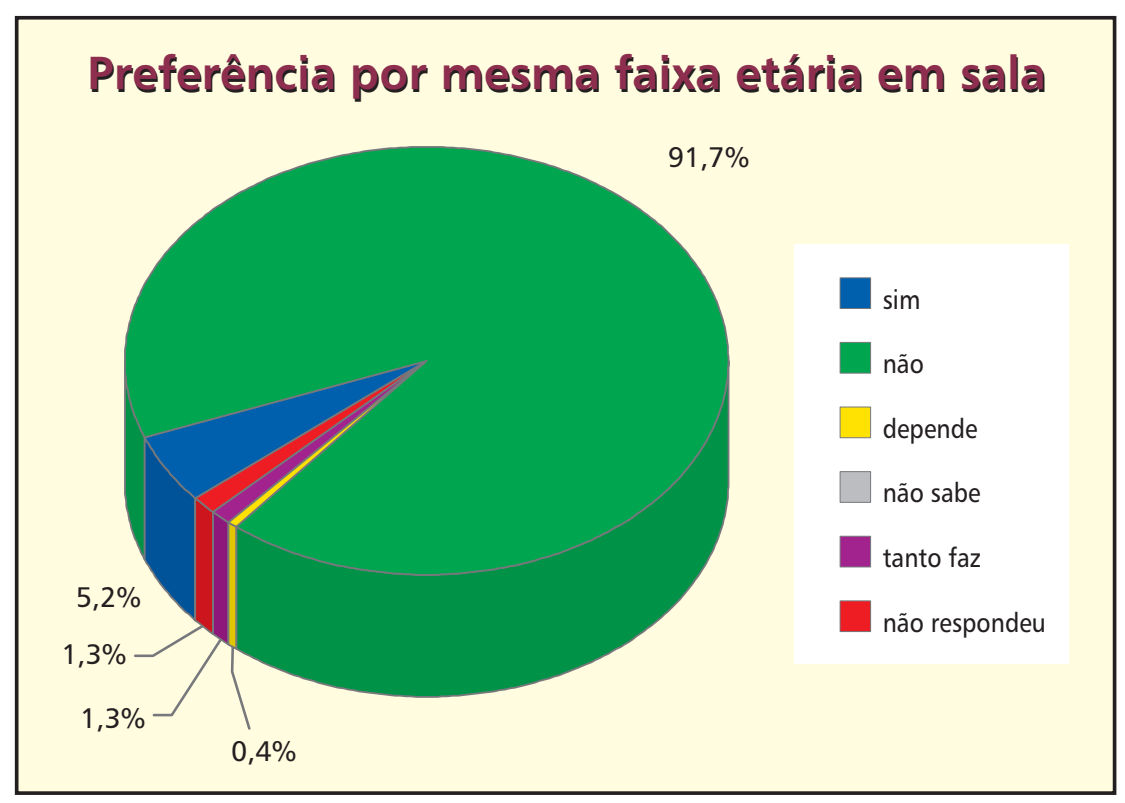

Gráfico 20 - Público geral que gostaria de um grupo só com sua faixa etária 
O número de pessoas que responde negativamente praticamente se mantém o mesmo (cai de 91,8\% para 91,7\%). Ou seja, os que disseram que não gostariam que os grupos fossem divididos por faixas etárias também disseram que não gostariam de grupos só com pessoas da sua idade.

Já o número de pessoas que respondem afirmativamente cai em relação aos dados do Gráfico 17, no qual o percentual de pessoas que gostariam de ver os grupos divididos por faixas etárias era de 7\%. Neste Gráfico 20, podemos ver que apenas 5,2\% gostariam de ter um grupo só com sua faixa etária.

As justificativas dadas foram muito similares àquelas apresentadas na pergunta anterior. Para aqueles que não gostariam de um grupo só com pessoas da mesma idade que a sua tiveram como justificativas mais dadas a de que "seria muito chato" um grupo etariamente homogêneo. As respostas mais significativas obtidas foram elencadas a seguir:

\section{- Depoimentos que indicam não conseguir ver como a segregação} ajudaria o curso

Acho que todos temos maturidade para respeitar o tempo de aprendizado de cada pessoa; além disso é muito bom conviver com pessoas diferentes. (f23n5)

O nível de conhecimento em italiano não seria definido pela idade e sim pelo interesse na língua. (f32n4)

Não acho que isso me faria aprender melhor ou mais. (f20n4)

Acho que o aprendizado independe da idade. (f25n3)

Isso não influi no aprendizado. (f56n1)

Além de limitar os assuntos $e$ as atividades, não acho que melhoraria o curso. (f23n5)

Isso limitaria as discussões do grupo. (m25n1)

Porque colocando pessoas de uma só faixa etária diminui muito o intercâmbio de informações. (m57n2)

Acho que temos troca de experiências em um grupo com pessoas de idades diferentes, o que enriquece muito o aprendizado e a cultura. (f37n2) 
Podemos observar que alguns alunos consideram que a aquisição/ aprendizagem de uma língua está relacionada ao interesse e não à idade, e não conseguem entender como um grupo etariamente homogêneo poderia ajudá-los nesse processo. Além disso, um dos fatores primordiais das relações intergeracionais está justamente na troca de informações, experiências, pontos de vista das diferentes gerações que enriquecem e são positivas a todos os participantes. Apesar da segregação etária que vivenciamos nos espaços sociais, temos que lidar com pessoas de todas as idades nas mais diversas situações da vida. Se instituirmos que a segregação deva existir, o diálogo, que já está se perdendo entre as gerações, acabará por se tornar ainda mais raro, aumentando o preconceito e a discriminação de uma geração em relação a outra. Nessa perspectiva, sofrerão mais justamente aqueles que são socialmente excluídos por não fazerem parte do que é valorizado pela nossa sociedade: a juventude.

\section{- Respostas que mostram indignação com a pergunta}

Não entendo o motivo dessa pergunta! Segregação! (sø41n1)

Pra quê? (m24n1)

Decidimos selecionar duas das respostas que mostram que o respondente não entende o motivo da pergunta porque elas indicam que essa possibilidade nem é considerada pelo estudante. A indignação com a questão, como no caso da primeira transcrita neste item, também mostra que o aluno acha absurdo que tenhamos considerado a hipótese de divisão etária para os grupos de língua.

Acreditamos que, assim como nos Programas Intergeracionais, a convivência de uma geração com a outra, quando bem coordenada e administrada para que ela se dê em cooperação e não em conflito, aumente a consciência sobre a importância das relações intergeracionais e, principalmente, sobre o respeito ao outro. Dessa forma, cada vez mais teríamos declarações como esta, por termos alunos sempre mais preparados a conviverem com a heterogeneidade e a tirar o 
melhor proveito das experiências e informações e toda uma série de fatores positivos que são propiciados pelo encontro dessas diferenças. Se nos limitamos a unir os "iguais", estaremos apenas contribuindo para manter uma atmosfera de segregação e de valorização do ingroup que, inevitavelmente, levará à desvalorização e discriminação do outgroup.

\section{- A valorização do jovem}

Quero a energia dos jovens, os seus pontos positivos. (f62n1)

Pessoas jovens nos alegram. (f78n5)

Por gostar de pessoas jovens ao redor. (f55n5)

Porque os jovens são mais curiosos e alegres. (f61n3)

Após uma certa idade, você só é convidado a hospitais e velórios. Quer maior falta de imaginação? E eu, sendo médico, só vêm falar de doença comigo. (m57n3)

O convívio com jovens é muito importante. (f67n3)

Estar com pessoas mais jovens nos rejuvenesce e "oxigena" nossas ideias. (f64n3)

Acho que a diferença etária traz experiências e anseios novos. (f62n3)

Estar estudando com alunos mais jovens é ótimo porque traz ideias novas. (f68n1)

Não é necessário. É bom conviver com mais jovens. (f52n1)

É muito divertido estar com os jovens e aprendemos sempre com eles. (f54n1)

A idade mínima dos depoentes selecionados aqui é de 52 anos. O que podemos observar nessas declarações é a valorização do jovem e de sua presença nos grupos. Os idosos, especialmente, falam dos jovens como portadores de alegria e de energia e que a convivência com eles renova suas ideias e seus anseios. Com essas declarações, podemos perceber que o contato com os jovens é benéfico para os alunos mais velhos. Entretanto, não colhemos depoimentos de jovens que se manifestem dessa forma em relação ao idoso. Não há respostas que valorizem a 
presença dos idosos na sala de aula ou mesmo que mostrem admiração por alguma característica que se suponha típica dos idosos. A afirmação que possivelmente mais se aproxima é feita por uma estudante de 22 anos, que declara que os mais velhos são mais tranquilos. (Esta resposta pode ser vista mais adiante.)

\section{- Depoimento de idosos ou quase idosos}

Tudo igual. (f62n2)

É chato ouvir os mesmos assuntos que habitualmente são falados por pessoas semelhantes. Somos muitas mulheres, professoras, aposentadas, muito igual. (f58n6)

Na verdade, não importa. Dos jovens vem a energia, dos mais velhos o companheirismo. (f60n4)

Não com pessoas só da minha idade, mas não gostaria de ser a única entre jovens. (f72n2)

Entretanto, não gostaria de ser a única idosa entre os jovens alunos. (f68n2)

Não gosto de me relacionar somente com pessoas idosas. (f69n3)

Não faria mais o curso (se fosse só com pessoas da minha idade). Prefiro estar com pessoas de todas as idades. (f60n4)

Gosto da variedade, e para mim, frequentemente, as pessoas de minha idade têm pouco em comum comigo. (f59n8)

No item anterior vimos que há uma valorização da presença jovem nos cursos, principalmente por parte dos idosos. Neste item podemos observar que os idosos não gostariam de estudar só com pessoas de sua faixa etária, sendo que uma das alunas declara que não faria mais o curso se houvesse essa divisão. É possível verificar também que duas das alunas afirmam que, apesar de não quererem um grupo só com pessoas de suas faixas etárias, elas não se sentiriam à vontade em um grupo no qual fossem as únicas idosas. 


\section{- Idosos que assumem uma posição estereotipada}

Seria uma coisa muito chata. Porque pessoas mais velhas geralmente são um pouco cansativas. Tem exceção. (f63n1)

As pessoas idosas são mais problemáticas. É melhor diluir os idosos em outras faixas etárias para não atrapalhar os colegas. (m77n1)

Nestes depoimentos acima, temos exemplos de idosos que colocam a si mesmos como pessoas cansativas e problemáticas. O aluno de 77 anos, inclusive, acha que os idosos atrapalham os colegas, mas que ao serem misturados com outras faixas etárias isso pode não ocorrer. Raramente vemos depoimentos de jovens que se colocam no lugar de grupo etário que pode ser problemático ou que possa atrapalhar o grupo.

\section{- Respostas que envolvem estereótipos e preconceitos}

Não necessariamente a mesma idade, mas poderia dividir a terceira idade de outras faixas etárias. (f30n3)

Porque as diferenças etárias enriquecem nosso convívio. Penso assim talvez porque nós temos no nosso grupo pessoas imaturas que necessitem de atenção diferenciada. (f54n2)

Porque pessoas da minha idade são desesperadas para aprender a falar, escrever e ler, já as mais velhas são mais tranquilas. (f22n2)

A maioria das pessoas com 19 anos não estariam tão interessadas a ponto de levar a aula a sério, o que tornaria o curso muito defasado. (f19n8)

Num grupo da minha idade não teríamos tanta chance de ouvir outras pessoas, com outras experiências de vida. (f21n7)

A primeira declaração é marcante para nós, pois a aluna destaca que não se importa com a mistura etária que existe nos grupos, mas que gostaria que a terceira idade fosse separada das outras faixas etárias, o que demonstra discriminação com os idosos ao colocá-los em um grupo separado dos demais. 
A segunda resposta demonstra o estereótipo relativo à imaturidade atribuída aos jovens. No entanto, a declaração não segue a linha de exclusão, mas sim de inclusão. Ou seja, a aluna considera que existem pessoas imaturas no grupo que talvez necessitem de atenção diferenciada, mas não declara que os colegas considerados por ela imaturos devam ser separados do restante do grupo. Ao contrário, diz que "as diferenças etárias enriquecem nosso convívio".

A terceira e a quarta justificativas transcritas acima são declarações de alunas jovens sobre sua própria faixa etária. A primeira delas é uma aluna de 22 anos, ela declara que pessoas de sua faixa etária esperam que os objetivos com a língua sejam alcançados de forma rápida, enquanto vê na figura dos mais velhos a tranquilidade em alcançar os mesmos objetivos. A outra aluna é uma estudante de 19 anos, ela vê os seus coetâneos como alunos que não estão interessados em levar o curso a sério, considerando que um grupo só com pessoas de sua faixa etária seria defasado. Essas duas declarações apontam para uma visão paradoxal do que seria uma turma só com a faixa etária das duas alunas (19-29 anos aproximadamente), já que uma diz que o curso seria "defasado", pois haveria pouco interesse, enquanto a outra aluna declara que os jovens têm muita pressa em aprender.

Perguntamos aos monitores, nas entrevistas, se alguma vez foi abordado o assunto terceira idade nas reuniões com a coordenação, dado que o público idoso é muito grande. As respostas foram negativas.

M5e diz que sempre que existe alguma reclamação sobre aluno idoso partindo dos monitores, ela é feita de forma "velada":

M5: O complicado disso é que é sempre velado, né? É sempre:.... é... Eu diria que sim, mas vou tá interpretando o que eles disseram, porque ninguém fala "não aguento mais aquela turma porque tem aquelas 3 velhas". Isso não acontece, mas assim, o pessoal reclama de... é que cai aquilo, né, "é a vida", "paciência". Não tem muito como evitar isso. O comentário cai pra esse lado. E fala-se sempre na chave cômica, né? Rindo da situação. "É, paciência"... Isso. Quando se fala do assunto de terceira 
idade, pra reclamar, sempre em tom de brincadeira, sempre a coisa virando riso, costuma tratar desse jeito do que tratar sério, como se fosse/falar sério fosse usar coisas politicamente incorretas.

Segundo o comentário feito por M5e, entendemos que o assunto "alunos idosos no IC" não foi abordado diretamente nem nas reuniões nem entre os colegas por um receio de que falar sobre o assunto seja politicamente incorreto. Comentar sobre idosos e situações que os envolvem em "tom de brincadeira" permite que seja mantida certa distância do assunto, pois, se indagados diretamente, poderão negar o preconceito dizendo que "estavam apenas brincando".

Com todos os pontos aqui expostos neste capítulo, pudemos ver que tanto alunos quanto monitores se colocam a favor da heterogeneidade na sala de aula, incluindo a etária. A divisão por faixas etárias é desejada por uma minoria dos alunos do Italiano no Campus. Nas declarações de monitores e alunos pudemos ver que muitos consideram a troca que existe em uma sala de aula intergeracional imprescindível. E a maioria relata o enriquecimento que a intergeracionalidade traz para a sala de aula, tanto no campo pessoal - troca de ideias, experiências, aprender a respeitar a diversidade - quanto no próprio processo de aquisição/aprendizagem de uma LE.

Antes de finalizarmos o capítulo, gostaríamos de reproduzir o depoimento de M5e sobre um grupo de terceira idade para o qual deu aula no início de sua carreira como professor:

\section{E: E como foi essa experiência?}

M5: Isso. Foi no $\left[{ }^{121}\right]$. Era muito no começo da minha.../eu tava bastante no começo. Bem, das diversas coisas que me vêm à mente, é que naquela época eu ainda tinha a dimensão de que ensinar língua era ensinar a frase. Bastava ensinar a conjugação verbal, as preposições, a pronúncia... E:: elas, porque eram só senhoras, eram duas turmas, gostavam muito. A 
coisa funcionava bastante. Uma característica minha, todos os alunos marcam isso, sempre marcam, dizem isso no final do semestre, é a paciência. Eu sou bastante paciente. Acho que isso é uma outra coisa que ia ao encontro das expectativas delas. Então, aquilo né?... Da aula clássica, aquela da frase, da gramática e ponto. "Essa é forma certa de montar a frase" e com bastante paciência, elas gostavam. O que ficava pra mim, sempre falando de diversos pontos de vista, o que ficava pra mim é que eu não queria fazer aquilo, não era o meu objetivo, porque o que acontece: os alunos da terceira idade, não... eles... tem aqueles poucos que têm um poder de processamento muito grande, e se divertem com isso, e querem isso, e sabe toda a matemática da língua. Mas em geral eles não estão preocupados com isso e eu acho bem mais interessante ((risos)) esse outro aspecto. No começo da minha carreira, o que eu queria era explicar as formas, e, né? Passar, que eles memorizassem rapidamente as formas regulares pra passar pras irregulares, e que avançassem na língua. Não tinha essa disposição, elas não tinham na terceira idade essa disposição. Isso me incomodava. E eu passei a achar que eu tava... -- é, isso eu também perdi com o tempo.-- Naquela época eu achava que eu tapeava, que era tudo enrolação. Eu tava ensinando coisa nenhuma a língua e::: mas depois eu entendi que não, que era a forma delas se apropriarem daquilo e que tava funcionando sim, era aula de língua sim. Diferente daquilo que eu imaginava como deveria ser. Ahn... Agora, no momento que eu estou, posso falar assim livremente ou falar mais especificamente dessa experiência lá?

\section{E: Pode!}

M5: Não, no momento que eu estou, então, agora eu estou pensando em atividades e pegar uma turma de terceira idade como lá do $\left[{ }^{122}\right]$ seria energia grande no sentido de preparar o material e entrar em outra sintonia. E é o que eu poderia fazer sim, com toda certeza, isso eu posso dizer. Se eu não tivesse essas ambições agora, desses materiais que estou preparando, dos textos que estou lendo sobre ensino de língua. Se eu não tivesse nessa sintonia, com prazer sim, eu daria aula.... Mesmo porque, falando de vários, vários aspectos mesmo, eu vejo que ali tem a possibilidade de ser bem remunerado, porque tem um público que vai pagar um valor mais alto e se estiver, fazer aulas bem feitas, não... geral.-- Agora voltando a falar ainda daquela experiência, a idade/que eu tenho sobre a terceira idade: eles não têm na cabeça quando acaba o curso. É um semestre depois do outro e eles vão fazendo, vão embora. É até bastante interessante pensar da questão do trabalho, do retorno financeiro, entre outras coisas. 
Não podemos esperar que todos os alunos tenham formas uniformes de aprender/adquirir uma língua estrangeira. Nem mesmo que os mecanismos, estratégias e seus estilos de aprendizagem sejam iguais. Podemos nos concentrar em tentar compreender a especificidade de cada um e ver os alunos não como um grupo homogêneo, mas respeitando sua heterogeneidade, ou seja, não esperar que todos se apropriem da língua da mesma forma, mas que se apropriem dela da forma como conseguem fazer melhor.

Os idosos, assim como qualquer outro grupo etário, não são um grupo homogêneo. Cada um possui um modo de internalizar a língua estrangeira. Uns mais rapidamente, outros mais lentamente, uns com mais facilidade para a gramática, outros com maior desenvoltura na conversação e assim por diante. O que não podemos, como professores, é ignorar as particularidades e estereotipar os alunos como uma massa homogênea que deve aprender/adquirir a LE de uma única maneira - que geralmente é aquela que o professor considera ideal -, muito menos tomar características negativas de um aluno e estendê-las a todos os outros que possuem idade aproximada à dele, ignorando comportamentos considerados negativos vindos de estudantes de outras faixas etárias e, por consequência, estimulando um ambiente desigual e preconceituoso.

Se os próprios alunos consideram a intergeracionalidade enriquecedora, cabe ao professor administrar essas relações intergeracionais de forma a se tirar o melhor proveito delas.

Encerramos com um trecho da obra de Silva (2008:101):

[...] talvez possamos dizer sobre a pedagogia aquilo que Maurice Blanchot (1969, p.115) disse sobre a fala e a palavra: fazer pedagogia significa "procurar acolher o outro como outro, o estrangeiro como estrangeiro; acolher outrem, pois, em sua irredutível diferença, em sua estrangeiridade infinita, uma estrangeiridade tal que apenas uma descontinuidade essencial pode conservar afirmação que lhe é própria". 


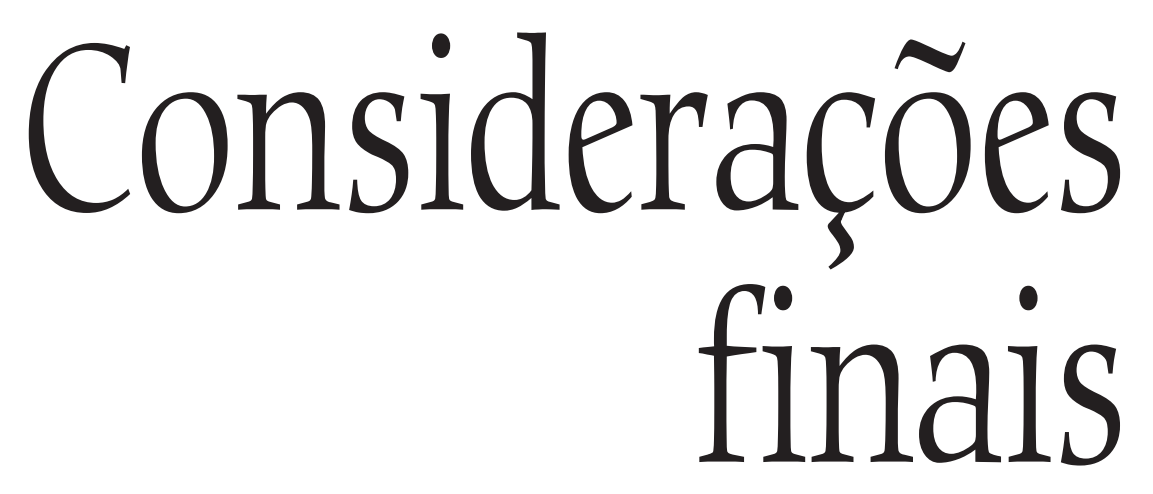


Não podemos ignorar o crescimento mundial da população idosa que ocorre ao mesmo tempo em que cresce a valorização do jovem e do novo. Esse novo desenho do perfil etário nos coloca diante de alguns desafios. O maior deles é o de oferecer ao idoso uma reinclusão social e um novo papel na sociedade, na qual ele deixe de ser visto sob o véu de preconceitos que existem hoje contra eles.

Os estudos envolvendo os idosos e o processo de aquisição/aprendizagem de uma língua estrangeira ainda são poucos. Alguns ainda calcados na ideia de que seu processo de a/a deve ser comparado à aquisição da língua materna como ocorre nas crianças, como se a experiência adquirida pela a/a de outras línguas e mesmo as características pessoais de aprendizagem não fossem significativas para que o processo de a/a da LE ocorresse.

Alguns estudos envolvendo idosos e seus processos cognitivos em ambientes educativos mostram que idosos possuem mecanismos de compensação para lidar com possíveis perdas e falhas e que utilizam sua experiência em aprendizagem para criar esquemas facilitadores do processo.

Com o aumento da população idosa, alguns conceitos e mitos - muitos baseados em estereótipos negativos sobre o envelhecimento e a velhice - precisam ser revistos para não perpetuarem ideias errôneas e preconceituosas em relação aos idosos, que estão cada vez mais frequentando cursos e outras atividades educativas. 
Como vimos no segundo capítulo, as pessoas passam boa parte de sua vida interiorizando os estereótipos culturais sobre a velhice e o processo de envelhecimento, e quando elas mesmas se tornam idosas, essas formas estereotipadas as levam a uma imagem negativa de seu próprio envelhecimento. Com isso, podem acabar incorporando os estereótipos e se comportando de acordo com eles.

É principalmente nesse sentido que ressaltamos a importância dos Programas Intergeracionais. Ao reunir diferentes gerações, oferecem um maior conhecimento de uma geração sobre a outra, aumentando o respeito e facilitando a quebra de estereótipos e preconceitos. Os PIs que envolvem crianças, jovens e idosos comprovadamente ajudam os participantes na dissolução de estereótipos (tanto dos jovens em relação aos idosos quanto o contrário). As pesquisas sobre esses programas mostraram que os jovens passam a ter uma relação melhor com os idosos que participam dos programas e também com todos os outros idosos.

O Italiano no Campus possui praticamente um quarto de seus alunos pertencentes à terceira idade. Modelos positivos de velhice ativa, exemplo de idosos que não viram a aposentadoria como a "morte" (Mito da Tríade) e a encararam como um momento de realização pessoal. E, como vimos no segundo capítulo, ter modelos positivos ajuda na quebra de estereótipos e preconceitos.

Consideramos importante que o Italiano no Campus reúna pessoas das faixas etárias intermediárias, aquelas consideradas adultas (da fase "ativa"), e adultos da terceira idade. A convivência pode auxiliar as pessoas das faixas intermediárias a encarar de forma mais positiva seu próprio envelhecimento, a quebrar estereótipos sobre a velhice e os idosos, o que proporcionará não só um melhor relacionamento entre as duas faixas, como também uma visão positiva da velhice, que se refletirá quando chegarem a essa fase da vida. 
As relações intergeracionais que ocorrem no Italiano no Campus não foram planejadas, elas ocorreram de forma espontânea, a intergeracionalidade não foi refletida, projetada. Ou seja, o IC não foi concebido para ser um Programa Intergeracional. Pensá-lo dessa forma poderia enriquecer ainda mais as trocas e os benefícios do contato.

Precisamos refletir sobre o papel central dos professores nas relações intergeracionais que ocorrem dentro da sala de aula. A relação entre os professores e instrutores do curso é fundamental para o bom resultado do programa. Como vimos no depoimento de M5e, os alunos podem ser influenciados pela forma como o professor trata outros alunos na sala de aula. Portanto, é importante que os professores reflitam sobre suas próprias crenças e questionem as identidades estabelecidas e as relações de poder em jogo na sua formação e papel social, a fim de poder, assim, construir um ambiente mais igualitário, no qual as relações intergeracionais se deem em forma de maior cooperação e menor conflito.

É importante que não se olhe para a inclusão do "diferente" como uma tentativa de apagar suas diferenças. Não é a tolerância que queremos estimular. O que defendemos é o respeito e a aceitação do outro como ele é, justamente na sua diferença. É necessário que se questione as relações de poder que o estabeleceram como "diferente". Afinal, quem estabeleceu "o normal", a norma? Por que é o idoso quem tem que se adaptar ao jovem? Por que é ele quem é considerado o "diferente"? Precisamos questionar quais relações fizeram com que os idosos passassem a ser vistos de forma negativamente marcada, estereotipada, na sociedade ocidental atual.

Como afirma Silva (2008), trata-se de explicar como as identidades são produzidas e envolvem relações de poder que definem, entre outros aspectos, o que fica dentro (ingroup) e o que fica fora (outgroup). O poder de estabelecer o "normal" e, consequentemente, estabelecer quem são os "diferentes". 
Consideramos importante que os professores, em sua formação docente, sejam preparados para a heterogeneidade, pois é fundamental que a questão da diferença seja discutida durante a formação dos futuros docentes. Não é uma questão de inclusão do diferente, do outro, obrigando-o a se adaptar ao restante do grupo e apagando suas diferenças com vistas a uma "uniformização". Trata-se de aceitar o outro justamente naquilo que ele é diferente, respeitá-lo por isso e, acima de tudo, questionar a sua posição como diferente. É ainda mais importante, para nós, que o professor se questione sobre suas crenças em relação ao processo de aquisição/aprendizagem no que diz respeito aos idosos. Estereótipos preconceituosos influenciam a forma como trata esses alunos em sala de aula. Vimos que M2e explica como foi de um "pré-conceito" sobre o processo de aquisição/aprendizagem dos idosos para outra concepção a partir de sua prática docente. Como pudemos observar, os monitores não relacionam a idade à forma como se dá o processo de a/a do italiano LE.

O professor de língua estrangeira também tem que estar ciente de seu papel como construtor de significados na sala de aula e mediador de outra cultura. Trabalhar com outra cultura, outra língua, é trabalhar com diferenças, com o outro. A forma como o professor se posiciona diante desse outro poderá ajudar a quebrar estereótipos ou reforçá-los e aumentar preconceitos.

O Italiano no Campus também é um espaço que serve de laboratório para a formação docente, isso reforça a importância de servir de espaço para que os monitores/professores reavaliem sua formação pedagógica, colocando novas questões a esses profissionais.

Boa parte dos estudos que abordam os idosos e o ensino de língua se concentra na área de inglês. Destacamos que o fato de a língua estrangeira que estudamos ser a italiana tem influências nesse contato intergeracional, pois, como vimos, quase um quarto dos estudantes de língua italiana escolheram o curso por serem descendentes de italianos, além disso, os monitores apontam que alunos de italiano são realmente interessados (por não ser uma língua exigida pelo mercado 
de trabalho: a procura pelos cursos de língua italiana geralmente ocorre pelo fator "interesse"). Alunos motivados e realmente interessados fazem a diferença nesse tipo de contato intergeracional, pois o objetivo é que importa: aprender a língua. A idade do aluno não é vista como fator o que marca o ritmo da aula, por exemplo. É o interesse que determina o andamento do curso. Se os objetivos e a relação com a língua estrangeira são muito diferentes, pode haver conflito.

Pudemos perceber, nos resultados obtidos com os estudantes do Italiano no Campus, que a maioria deles (mais de 90\%) prefere estudar em grupos intergeracionais. Os monitores também afirmaram não desejar que nenhuma faixa etária fosse separada do restante, a não ser os casos de crianças (alfabetizadas ou não) e pré-adolescentes, que, no processo de aquisição/aprendizagem de LE não poderiam ser unidos aos adultos. Grande parte das respostas obtidas mostra que os alunos consideram o contato intergeracional que ocorre no IC como enriquecedor para o curso.

São poucos os alunos que dizem ser contra os grupos intergeracionais. $O$ contato com as outras pessoas que são a favor e com um professor que se posiciona a favor dessa heterogeneidade, construindo um ambiente igualitário, no qual todos os alunos são tratados da mesma forma, pode fazer com que aqueles que são contra o caráter intergeracional do IC revejam suas crenças e possam mudar de opinião, deixando os estereótipos negativos de lado.

Registramos aqui nosso desejo de que, a partir deste trabalho, a atenção para a questão da heterogeneidade etária dos grupos do IC seja priorizada, considerando-se os benefícios que esses contatos intergeracionais podem trazer. E que se possa atentar, sobretudo, para uma preparação consciente dessa realidade intergeracional: preparação dos monitores, do curso, das aulas, das avaliações, das dinâmicas relacionais em sala de aula, da escolha e da elaboração de materiais 
didáticos para tirar melhor proveito desse ambiente. Sendo por si só um ambiente rico de trocas intergeracionais sem ter sido elaborado com esse fim, se ele for trabalhado com a finalidade de ser um Programa Intergeracional, elegendo como um de seus objetivos - além do ensino da língua - o contato intergeracional entre seus participantes, os benefícios observados poderão ser ainda maiores.

McCrea e Smith (1997b) ressaltam o papel fundamental da coordenação nesse tipo de relações, para cuidar da forma como o contato ocorre, certificando-se que ele ocorra por meio da cooperação e evitando o conflito. Também os professores, instrutores e monitores assumem um papel importante nessas relações, pois serão eles que estarão na sala de aula, lidando com esse contato, coordenando-o. Por isso, é fundamental que estejam preparados para a diversidade e que tenham, eles mesmos, quebrado estereótipos e preconceitos, principalmente aqueles que envolvem alunos e o processo de aquisição/aprendizagem de LE.

Deixamos em aberto questões que, a nosso ver, merecem aprofundamento:

- a relevância dos Programas Intergeracionais na sociedade em geral e não apenas pensadas para os cursos de língua estrangeira;

- a necessidade de se pensar em novas metodologias que lidem com as relações intergeracionais e que sejam voltadas para esse tipo de ambiente educacional;

- a importância de se incluir, já nos currículos de graduação e, principalmente, nas licenciaturas, a questão dos Programas Intergeracionais e da Pedagogia da Diferença;

- a inclusão pensada também na educação informal. 
Esperamos que a contribuição maior de nosso trabalho tenha sido a de voltar o olhar sobre as relações intergeracionais que existem em ambientes como o Italiano no Campus, mostrando que as aulas de língua estrangeira são ambientes que propiciam a aprendizagem ao longo de toda a vida e ainda contribuem para o melhor conhecimento, a aceitação e o respeito ao outro. O IC contribui para a reinserção do idoso na sociedade e ajuda a quebrar estereótipos e preconceitos sobre a velhice.

Os PIs podem, como resultados a longo prazo, não apenas quebrar estereótipos contra os idosos e o processo de envelhecimento, como também podem modificar toda uma cultura em relação à velhice, refletindo-se em adultos com uma concepção mais positiva e menos estereotipada dessa fase da vida e, consequentemente, mais ativos em grupos intergeracionais. 


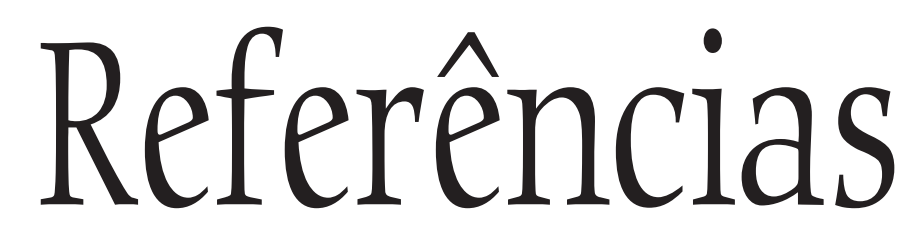

bibliográficas 
ALVES, Andréa Moraes. (2007). Os idosos, as redes de relações sociais e as reações familiares. In: NERI, Anita Liberalesso (org.). Idosos no Brasil : vivências, desafios e expectativas na terceira idade. São Paulo: Editora Fundação Perseu Abramo, Edições SESCSP. p. $125-140$.

ARIÈS, Philippe. (1981). Prefácio. In: História Social da criança e da família. Tradução: Dora Flaksman. Rio de Janeiro: Zahar Editores. $2^{\text {a }}$ ed. p. 9-27.

BEAUVOIR, Simone de. (1976a). A velhice : a realidade incômoda. São Paulo - Rio de Janeiro: Difel. Tradução: Heloysa de Lima Dantas. $2^{\text {a }}$ ed. v.1.

BEAUVOIR, Simone de. (1976b). A velhice : as relações com o mundo. São Paulo - Rio de Janeiro: Difel. Tradução: Heloysa de Lima Dantas. $2^{\text {a }}$ ed. v.2.

BELISÁRIO, Roberto. (2002). Mundo envelhecido, país envelhecido. Com Ciência (Revista Eletrônica de Jornalismo Científico), n 35, 10/09/2002. Disponível em:

<http://www.comciencia.br/reportagens/envelhecimento/texto/env16.htm>. Acesso em: 09/2006.

BENJAMIN, Walter. (1994). O narrador: considerações sobre a obra de Nikolai Leskov. In: BENJAMIN, Walter. Mágia e técnica, arte e política : ensaios sobre literatura e história da cultura. São Paulo: Brasiliense. (Obras escolhidas, v.1). p. 197-221.

BOBBIO, Norberto. (1991). L'età del tempo libero. In: URBANI, Giuliano et al. L'anziano attivo : proposte e riflessioni per la terza e la quarta età. Torino: Edizione della Fondazione Giovanni Agnelli. p.11-13.

BOBBIO, Norberto. (1997a). A mim mesmo. In: O tempo da memória : De senectude e outros escritos autobiolgráficos. Tradução: Daniela Versani. Rio de Janeiro: Campus. p. 314.

BOBBIO, Norberto. (1997b). De senectude. In: O tempo da memória : De senectude e outros escritos autobiolgráficos. Tradução: Daniela Versani. Rio de Janeiro: Campus. p. 1755.

BOSI, Ecléa. Um projeto feliz: apresentação do programa Universidade Aberta para a Terceira Idade da Universidade de São Paulo. Disponível em: <http://www.usp.br/prc/3idade/apresentacao.php>. Acesso em: 07/2006. 
BOSTRUM, Ann Kristin; HATTON-YEO, Alan; OHSAKO, Toshio; SAWANO, Yukiko. (2000). A general assessmentof IP initiatives in the countries involved. In: HATTON-YEO, Alan; OHSAKO, Toshio (eds.). Intergenerational programmes : public policy and implications. An international perspective. Paris: The UNESCO Institute for Education/ The Beth Johnson Foudation. p. 3-8. Disponível em: http://www.unesco.org/education/uie/pdf/intergen.pdf. Acesso em: 19/08/2010.

BRASIL. (2003). Lei $n^{0} 10.741$, de $1^{\circ}$ de outubro de 2003. Dispõe sobre o Estatuto do idoso. Presidência da República Federativa do Brasil, Casa Civil, Legislação. Disponível em: <https://www.planalto.gov.br/ccivil_03/Leis/2003/L10.741.htm>. Acesso em 04/2006.

BRASIL. (2007). Constituição da República dos Estados Unidos do Brasil (de 16 de julho de 1934). Presidência da República, Casa Civil, Subchefia para Assuntos Jurídicos. Disponível em: <http://www.planalto.gov.br/ccivil_03/Constituicao/Constituiçao34.htm>. Versão da página/última modificação do arquivo: 28 de setembro de 2007, às 09h07. Acesso em 16/04/2009.

CACHIONI, Meire. (2003). Crenças em relação à velhice. In: . Quem educa os idosos : um estudo sobre professores de Universidades Abertas da Terceira Idade. Campinas, SP: Alínea.129-153.

CACHIONI, Meire; NERI, Anita Liberalesso. (2004). Educação e velhice bem-sucedida no contexto das Universidades da Terceira Idade. In: NERI, Anita L.; YASSUDA, Mônica Sanches (orgs.); CACHIONI, Meire (colab.). Velhice bem-sucedida : aspectos afetivos e cognitivos. Campinas, SP: Papirus. (Vivaidade). $3^{\text {a }}$ ed. p. 29-50.

CANÔAS, Cilene Swain. (1985). A condição humana do velho. São Paulo : Cortez. $2^{\mathrm{a}}$ ed. 79 p.

CARVALHO, Cecília Barros; HORIGUELA, Maria de Lourdes Morales. (2007). Inserção social de idosos a partir da escolarização básica. In: BRUNS, Maria Alves de Toledo; DEL-MASO, Maria Candida Soares (orgs.). Envelhecimento humano : diferentes perspectivas. Campinas, SP: Alínea. p. 121-142.

CARVALHO, Maria Clotilde B. N. M. de. (2007). Grupo intergeracional: espaço de diálogo entre gerações. In: "O diálogo intergeracional entre idosos e crianças : projeto 'era uma vez... atividades intergeracionais". p. 52-69. Dissertação (Mestrado em Serviço Social). Pontifícia Universidade Católica do Rio de Janeiro, Rio de Janeiro. Disponível em: $<$ http://ww2.dbd.puc-rio.br/pergamum/tesesabertas/0410376_07_cap_04.pdf > . Acesso em: 27/07/2010.

CHAGAS, Anivaldo Tadeu Roston. (2000). O questionário na pesquisa científica. In: Administração Online : Prática-Pesquisa-Ensino, v.1, n.1. (janeiro/fevereiro/março). Disponível em: < http://www.fecap.br/adm_online/art11/anival.htm>. Acesso em: 29/04/2009. 
CUDDY, Amy J.; FISKE, Susan T. (2004). Doddering but dear: process, content, and function in stereotyping of older persons. In: NELSON, Todd D. (ed.). Ageism : stereotyping and prejudice against older persons. Massachusetts: The MIT Press. p. 3-26.

DEBERT, Grita Grin. (2004). Problema social e responsabilidade individual. In: DEBERT, Grita Grin. A reinvenção da velhice : socialização e processos de reprivatização do envelhecimento. São Paulo: Edusp; Fapesp. $1^{\mathrm{a}}$ ed. p. 195-231.

DELORS, Jacques. (1998). Prefácio. In: DELORS, Jacques et al. Educação : um tesouro a descobrir. Relatório para a Unesco da Comissão Internacional sobre Educação para o Século XXI. Tradução: José Carlos Eufrázio. São Paulo: Cortez; Unesco; MEC. p.11-32. Disponível em: <http://www.dominiopublico.gov.br/download/texto/ue000009.pdf>. Acesso em: 06/04/2009.

DELORS, Jacques et al. (1998a). Os quatro pilares da educação. In: Educação : um tesouro a descobrir . Relatório para a Unesco da Comissão Internacional sobre Educação para o Século XXI. Tradução: José Carlos Eufrázio. São Paulo: Cortez; Unesco; MEC. p.89-102. Disponível em <http://www.dominiopublico.gov.br/download/texto/ue000009.pdf>. Acesso em 06/04/2009.

DELORS, Jacques et al. (1998b). Educação ao longo de toda a vida. In: Educação : um tesouro a descobrir. Relatório para a Unesco da Comissão Internacional sobre Educação para o Século XXI. Tradução: José Carlos Eufrázio. São Paulo: Cortez; Unesco; MEC. p.103-117. Disponível em: <http://www.dominiopublico.gov.br/download/texto/ue000009.pdf>. Acesso em: 06/04/2009.

DEVINE, Patricia G. (1989). Stereotypes and Prejudice: their automatic and controlled components. Journal of Personality and Social Psychology, v.56, n.1, p.5-18. Disponível em: $<$ http://home.student.uu.se/t/thni9583/pp/8/devine.89.pdf>. Acesso em: 07/12/2009.

DOLL, Johannes. (2007). Educação, cultura e lazer: perspectivas de velhice bem-sucedida. In: NERI, Anita Liberalesso (org.). Idosos no Brasil : vivências, desafios e expectativas na terceira idade. São Paulo: Ed. Fundação Perseu Abramo, Edições SESC-SP. p. 109-124.

FALEIROS, Vicente de Paula. (2007). Cidadania : os idosos e a garantia de seus direitos. In: NERI, Anita Liberalesso (org.). Idosos no Brasil : vivências, desafios e expectativas na terceira idade. São Paulo: Ed. Fundação Perseu Abramo; Edições SESC-SP. p. 153-168.

FERRARA, Agnese. (2007). Chi parla un'altra lingua diventa un'altra persona. In: CHIUCHIÙ, Angelo; CHIUCHIÙ, Gaia. Avviamento alla lettura e alla composizione. Perugia: Guerra Edizioni. (Arte e Metodo).

FERRIGNO, José Carlos. (2003). Co-educação entre gerações. Petrópolis, RJ: Vozes; São Paulo: SESC. 233 p. 
FRANÇA, Lucia Helena; SOARES, Neusa Eiras. (1997). A importância das relações intergeracionais na quebra de preconceitos sobre a velhice. In: VERAS, Renato P. (org.). Terceira idade : desafios para o terceiro milênio. Rio de Janeiro: RelumeDumará/UnATI/UERJ. p. 143-169.

GIL, Antônio Carlos. (1991). A entrevista. In: . Métodos e técnicas de pesquisa social. São Paulo: Athas. $3^{\mathrm{a}}$ ed. p. 113-123.

GILLEARD, Chris; HIGGS, Paul. (2002). The third age: class, cohort or generation? Ageing \& Society, 22. Cambridge: Cambridge University Press. p. 369-382. Disponível em: $<$ http://journals.cambridge.org/action/displayFulltext? type $=1 \&$ fid $=116654 \& j i d=$ ASO\&volumeId $=22 \&$ issueId $=03 \&$ aid $=116653>$. Acesso em: $14 / 04 / 2010$.

GOFFMAN, Erving. (1982). Estigma : notas sobre a manipulação da identidade deteriorada. Tradução: Márcia Bandeira de Mello Leite Nunes. Revisão técnica: Gilberto Velho. Rio de Janeiro : Zahar Editores.

GOLDANI, Ana Maria. (2004). Relações intergeracionais e reconstrução do estado de bemestar. Por que se deve repensar essa relação para o Brasil?. In: CAMARANO, Ana Maria (org.). Os novos idosos brasileiros : Muito al.ém dos 60? Rio de Janeiro: Instituto de Pesquisa Econômica Avançada (IPEA). p. 111-250. Disponível em:

<http://www.ipea.gov.br/sites/000/2/livros/idososalem60/Arq_14_Cap_07.pdf>. Acesso em 14/04/2010.

GONÇALVES, Aurora Aparecida Fernandes; PASSOS, Andreza Garbeloti; CAMARGO, Isabel Cristina Ramos. (2007). Envelhecimento, trabalho e tempo livre : desmistificando essa relação. In: MATIAS, Maria Cristina Moreno; ABIB, José Antônio Damaso (orgs.). Sociedade em transformação : estudo das relações entre trabalho, saúde e subjetividade. Londrina, PR: EDUEL. p. 139-158.

GREENBERG, Jeff; SCHIMEL, Jeff; MARTENS, Andy. (2004). Ageism: denying the face of the future. In: NELSON, Todd D. (ed.). Ageism : stereotyping and prejudice against older persons. Massachusetts: The MIT Press. p. 27-48.

HALL, Stuart. (1997). Representation, meaning and language. In: HALL, Stuart (ed.) Representation : cultural representations and signifying practices. London: Sage Publications; The Open University. p. 15- 29.

HALL, Stuart. (1997b). A centralidade da cultura: notas sobre as revoluções culturais do nosso tempo. Educação \& Realidade, Porto Alegre, v. 22, n. 2, p.15-46, ju/dez. Tradução: Ricardo Uebel, maria Isabel Bujes, Marisa Vorraber Costa. Disponível em: < http://www.ufrgs.br/neccso/word/texto_stuart_centralidadecultura.doc $>$. Acesso em: 24/03/2010. 
HALL, Stuart. (1998). A identidade cultural na pós-modernidade. Tradução: Tomaz Tadeu da Silva, Guaraciara Lopes Louro. Rio de Janeiro: DP\&A. $2^{\text {a }}$ ed. 102 p.

HALL, Stuart. (2003a). O problema da ideologia: o marxismo sem garantias. In: . Da diáspora : identidades e mediações culturais. Organização: Liv Sovik. Tradução: Adelaine La Guardia Resende et al. Belo Horizonte: Editora UFMG. (Humanitas). p. 248-275.

HALL, Stuart. (2003b). A relevância de Gramsci para o estudo de reça e etnicidade. In: . Da diáspora : identidades e mediações culturais. Organização: Liv Sovik. Tradução: Adelaine La Guardia Resende et al. Belo Horizonte: Editora UFMG. (Humanitas). p. 276316.

HALL, Stuart. (2003c). Reflexões sobre o modelo de codificação/decodificação: uma entrevista com Stuart Hall. In: Da diáspora : identidades e mediações culturais. Organização: Liv Sovik. Tradução: Adelaine La Guardia Resende et al. Belo Horizonte: Editora UFMG. (Humanitas). p. 333-364.

HALL, Stuart. (2008). Quem precisa da identidade? In: SILVA, Tomaz Tadeu da (org.). Identidade e diferença : A perspectiva dos estudos culturais. Petrópolis, RJ: Vozes. 8a ed. p. 103-133.

HATTON-YEO, Alan; KLERQ, Jumbo; OHSAKO, Toshio; NEWMAN, Sally. (2000). Public policy and research recommendations: an international perspective. In: HATTON-YEO, Alan; OHSAKO, Toshio (eds.). Intergenerational programmes : public policy and implications. An international perspective. p. 9-17. Paris: The UNESCO Institute for Education/ The Beth Johnson Foudation. Disponível em:

<http://www.unesco.org/education/uie/pdf/intergen.pdf>. Acesso em: 19/08/2010.

IBGE. (2004). Projeção da população do Brasil por sexo e idade para o período : 1980-2050. Revisão 2004. Rio de Janeiro: Ministério do Planejamento, Orçamento e Gestão; Instituto Brasileiro de Geografia e Estatística; Diretoria de Pesquisas; Coordenação de População e Indicadores Sociais. Disponível em:

<http://www.ibge.gov.br/home/estatistica/populacao/estimativa2005/metodologia.pdf >. Acesso em: 09/2006.

IBGE. (2008). Projeção da População do Brasil por sexo e idade : 1980-2050. Revisão 2008. Rio de Janeiro: Ministério do Planejamento, Orçamento e Gestão; Instituto Brasileiro de Geografia e Estatística. (Estudos e Pesquisas, Informação Demográfica e Socioeconômica, 24). Disponível em:

<http://www.ibge.gov.br/home/estatistica/populacao/projecao_da_populacao/2008/pr ojecao.pdf>. Acesso em: 13/04/2009. 
IBGE. (2008). População brasileira envelhece em ritmo acelerado. Instituto Brasileiro de Geografia e Estatística, Notícias, 27/11/2008. Disponível em:

<http://www.ibge.gov.br/home/presidencia/noticias/noticia_visualiza.php? id_noticia $=1272 \&$ id_pagina $=1>$. Acesso em: 12/04/2009.

KITE, Mary E.; WAGNER, Lisa Smith. (2004). Attitudes toward older adults. In: NELSON, Todd D. (ed.). Ageism : stereotyping and prejudice against older persons. Massachusetts: The MIT Press. p. 129-162

KLEIMAN, Angela B. (1998). A construção de identidades na sala de aula : um enfoque interacional. In: SIGNORINI, Inês (org.). Lingua(gem) e identidade : elementos para uma discussão no campo aplicado. Campinas, SP: Mercado das Letras. (Letramento, Educação e Sociedade). p. 267-302.

KRAMSCH, Claire. (1998). Language and Culture. Oxford: Oxford University Press. 134 p. (Oxford Introductions to Language Study).

LEVY, Becca R.; BANAJI, Mahzarin R. (2004). Implicit ageism. In: NELSON, Todd D. (ed.). Ageism : stereotyping and prejudice agaist older persons. Massachusetts: The MIT Press. p. 49-76.

LEVY, Sheri R.; HUGHES, Julie Milligan. (2009). Development of racial and ethnic prejudice among children. In: NELSON, Todd D. (ed.). Handbook of prejudice, stereotyping, and discrimination. New York/Hove: Psychology Press. p. 23-42.

LIMA, Cristina Rodrigues. (2008). Programas intergeracionais : um estudo sobre as atividades que aproximam as diversas gerações. Campinas, SP: Alínea. (Velhice e Sociedade). 200 p.

LIMA, Maria Manuel, SIMÕES, Antônio; TAVARES, José. (1997). Percepção da capacidade para aprender ao longo do ciclo de vida: o caso dos adultos e dos idosos. Revista Portuguesa de Pedagogia, Ano XXXI (1, 2 e 3): 19-34. Disponível em:

<http://comodeantes.com/pdf/percepcao_da_capacidade.pdf>. Acesso em: 11/02/2010.

LOPES, Ruth Gelehrter da Costa. (2007). Imagem e auto-imagem: da homogeneidade da velhice para a heterogeneidade das vivências. In: NERI, Anita Liberalesso (org.). Idosos no Brasil : vivências, desafios e expectativas na terceira idade. São Paulo: Ed. Fundação Perseu Abramo, Edições SESC-SP. p. 141-152.

MAGALHÃES, Dirceu Nogueira. (1987). Introdução. In: . A invenção social da velhice. Rio de Janeiro: edição do autor. p. 13.

MAGRO, Viviane M. De Mendonça. (2003). Espelho em negativo: a idade do outro e a identidade etária. In: GUSMÃO, Neusa M. M. De (org.). Infância e velhice : pesquisa de idéias. Campinas, SP: Ed. Alínea. p. 33-46. 
MANNHEIM, Karl. (s/d). O problema das gerações. In: . Sociologia do conhecimento.

Tradução: Maria da Graça Barbedo. Porto: Rés-Editora. v. II. p.115-174.

MASCARELO, Andréia; MIORANDO, Gláucia Teresinha; PORTELA, Marilene Rodrigues. (2007). Presença masculina nos grupos de terceira idade: o que pensam homens e mulheres sobre a pouca adesão. In: SANTIN, J. R.; BETINELLI, L. A.; BENINCÁ, C. R. (orgs.).

Envelhecimento Humano : cuidado e cidadania. Passo Fundo, RS: Editora Universidade de Passo Fundo. p. 204-223.

MCCREA, James; SMITH, Thomas B. (1997a). Social issues addressed by intergenerational programs. In: NEWMAN, Sally et al. Intergenerational Programs : past, present and future. Washington, DC: Taylor \& Francis. p. 37-51.

MCCREA, James M.; SMITH, Thomas B. (1997b). Types and models of intergenerational programs. In: NEWMAN, Sally et al. Intergenerational Programs : past, present and future. Washington, DC: Taylor \& Francis. p. 81-114.

MINOIS, Georges. (1999). Introdução. In: Serafim Ferreira. Lisboa: Editorial Teorema. p. 11-19. . História da velhice no ocidente. Tradução:

MIRANDA, Danilo Santos de. (2006). Os dilemas da Quarta Idade. A Terceira Idade-SESC, n. 36, junho, Editorial. Disponível em:

$<$ http://www.sescsp.org.br/sesc/revistas/ti/index.cfm?

forget $=13 \&$ revista $=36 \&$ editorial $=1>$. Acesso em 02/05/2009.

MOITA LOPES, Luiz Paulo da. (1998). Discursos de identidade em sala de aula de leitura de L1: a consrução da diferença. In: SIGNORINI, Inês (org.). Lingua(gem) e identidade : elementos para uma discussão no campo aplicado. Campinas, SP: Mercado das Letras. (Letramento, Educação e Sociedade). p. 303-331.

MONTEPARE, Joann M.; ZEBROWITZ, Leslie A. (2004). A social-developmental view of ageism. In: NELSON, Todd D. (ed.). Ageism : stereotyping and prejudice against older persons. Massachusetts: The MIT Press. p. 77-125.

MORAGAS, Ricardo M. (2004). As relações intergeracionais nas sociedades contemporâneas. A terceira idade, v.15(29), janeiro. São Paulo: SESC/GETI. p. 7-27.

NELSON, Todd D. (2004). Preface. In: NELSON, Todd D. (ed.). Ageism : stereotyping and prejudice against older persons. Massachusetts: The MIT Press. p. IX-XIV.

NELSON, Todd D. (2009). Preface. In: NELSON, Todd D. (ed.). Handbook of prejudice, stereotyping, and discrimination. New York/Hove: Psychology Press. p. XIX-XXI.

NERI, Anita Liberalesso (org.). (2007). Idosos no Brasil : vivências, desafios e expectativas na terceira idade. São Paulo: Ed. Fundação Perseu Abramo; Edições SESC-SP. 288p. 
NERI, Anita Liberalesso. (2007a). Atitudes e preconceitos em relação à velhice. In: NERI, Anita Liberalesso (org.). Idosos no Brasil : vivências, desafios e expectativas na terceira idade. São Paulo: Ed. Fundação Perseu Abramo; Edições SESC-SP. p. 33-46.

NERI, Anita Liberalesso. (2007b). Feminização da velhice. In: NERI, Anita Liberalesso (org.). Idosos no Brasil : vivências, desafios e expectativas na terceira idade. São Paulo: Ed. Fundação Perseu Abramo, Edições SESC-SP. p. 47-64.

NERI, Marcelo Cortes. (2007). Renda, consumo, aposentadoria : evidências, atitudes e percepções. In: NERI, Anita Liberalesso (org.). Idosos no Brasil : vivências, desafios e expectativas na terceira idade. São Paulo: Ed. Fundação Perseu Abramo; Edições SESC-SP. p. 91-108.

NEWMAN, Sally. (1997a). Preface. In: NEWMAN, Sally et al. Intergenerational Programs : past, present and future. Washington, DC: Taylor \& Francis. p. XI-XV.

NEWMAN, Sally. (1997b). History and evolution of intergenerational programs. In: NEWMAN, Sally et al. Intergenerational Programs : past, present and future. Washington, DC: Taylor \& Francis. p. 55-79.

NEWMAN, Sally; SMITH, Thomas B. (1997). Developmental theories as the basis for Intergenerational Programs. In: NEWMAN, Sally et al. Intergenerational Programs : past, present and future. Washington, DC: Taylor \& Francis. p. 3-19.

ORLANDI, Eni Puccinelli. (1998). Identidade linguística escolar. In: SIGNORINI, Inês (org.). Lingua(gem) e identidade : elementos para uma discussão no campo aplicado. Campinas, SP: Mercado das Letras. (Letramento, Educação e Sociedade). p. 203-212.

PAIVA, Simone Borges; DEL-MASO, Maria Candida Soares. (2007). Envelhecimento humano : leitura e memória. In: BRUNS, Maria Alves de Toledo; DEL-MASO, Maria Candida Soares (orgs.). Envelhecimento humano : diferentes perspectivas. Campinas, SP: Alínea. p. 53-72.

PEIXOTO, Clarice. (1997). De volta às aulas ou de como ser estudante aos 60 anos. In: VERAS, Renato P. (org.). Terceira idade: desafios para o terceiro milênio. Rio de Janeiro: Relume-Dumará/UnATI/UERJ. p. 41-74.

PEREIRA, Marcos Emanuel. (2002). Psicologia social dos estereótipos. São Paulo: E.P.U. 202 p.

PIZZOLATTO, Carlos Eduardo. (2008). A sala de aula de língua estrangeira com adultos da terceira idade. In: ROCHA, Cláudia Hilsdorf; BASSO; Edcleia Aparecida (orgs.). Ensinar e aprender língua estrangeira nas diferentes idades : reflexões para professores e formadores. São Carlos: Editora Claraluz. p. 237-255. 
PRETI, Dino. (1991). A linguagem dos idosos : um estudo de análise da conversação. Apresentação: Luiz Antônio Marcuschi. São Paulo: Contexto. (Temas atuais). 126 p.

PRETI, Dino (org.). (2001). Normas para transcrição dos exemplos. In: Análise de textos orais. São Paulo: Humanitas FFLCH/USP. (Projetos Paralelos: v.1). 5ª ed. p. 11-12.

QUEIROZ, Maria Isaura Pereira de. (1991). Das entrevistas e da sua transcrição. In: Variações sobre a técnica do gravador no registro da informação viva. São Paulo: T. A. Queiroz. (Biblioteca básica de ciências sociais. Série 2. Textos; v.7). p. 81-90.

RAJAGOPALAN, Kanavillil. (1998). O conceito de identidade em linguística : é chegada a hora para uma reconsideração radical? Tradução de: Almiro Pisetta. In: Signorini, Inês (org.). Lingua(gem) e identidade : elementos para uma discussão no campo aplicado. Campinas, SP: Mercado das Letras. (Letramento, Educação e Sociedade). p.21-46.

REVUZ, Christine. (1998). A língua estrangeira entre o desejo de um outro lugar e o risco do exílio. Tradução: Silvana Serrani-Infante. In: SIGNORINI, Inês (org.). Lingua(gem) e identidade : elementos para uma discussão no campo aplicado. Campinas, SP: Mercado das Letras. (Letramento, Educação e Sociedade). p. 213-230.

ROSA, Maria Virgínia de F. P. Do Couto; ARNOLDI, Marlene Aparecida G. C. (2006). A entrevista na pesquisa qualitativa : mecanismo para validação dos resultados. Belo Horizonte: Autêntica. 112 p.

SANTELLANO, Maria Terezinha. (2009). Hábitos de consumo da terceira idade despertam interesse de empresas. Portal Terceira Idade, 06/04/2009. Disponível em:

<http://www.portalterceiraidade.com.br/horizontais/noticias_cidadao/index.htm>. Acesso em: 16/04/2009.

SANTOS, Geraldine Alves dos; LOPES, Andréa; NERI, Anita Liberalesso. (2007). Escolaridade, raça e etnia: elementos de exclusão social de idosos. In: NERI, Anita L.; YASSUDA, Mônica Sanches (orgs.); CACHIONI, Meire (colab.). Velhice bem-sucedida : aspectos afetivos e cognitivos. Campinas, SP: Papirus. (Vivaidade). $3^{\mathrm{a}}$ ed. p. 65-80.

SCHLEPPEGRELL, Mary. (1987). The older language learner. Eric Higher Education Digests, The National Teaching \& Learning Forum. Disponível em: http://www.ntlf.com/html/lib/bib/87-9dig.htm. Acesso: 10/02/2010.

SÉ, Elisandra Villela Gasparetto; QUEROZ, Nelma Caires; YASSUDA, Mônica Sanches. (2004). O envelhecimento do cérebro e a memória. In: NERI, Anita L.; YASSUDA, Mônica Sanches (orgs.); CACHIONI, Meire (colab.). Velhice bem-sucedida : aspectos afetivos e cognitivos. Campinas, SP: Papirus. (Vivaidade). $3^{\mathrm{a}}$ ed. p. 141-162. 
SENNETT, Richard. (2003). Deriva. In: . A corrosão do caráter : conseqüências pessoais do trabalho no novo capitalismo. Tradução: Marcos Santarrita. Rio de Janeiro; São Paulo: Record. $7^{\mathrm{a}}$ ed. p.13-34.

SILVA, Tomaz Tadeu da. (2008). A produção social da identidade e da diferença. In: SILVA, Tomaz Tadeu da (org.). Identidade e diferença : A perspectiva dos estudos culturais. Petrópolis, RJ:Vozes. $8^{\mathrm{a}}$ ed. p. 73-102.

STANGOR, Charles. (2009). The study of stereotyping, prejudice, and discrimination within Social Psychology: a quick history of the theory and research. In: NELSON, Todd D. (ed.). Handbook of prejudice, stereotyping, and discrimination. New York/Hove: Psychology Press. p.1-22.

STEPHAN, Walter G.; YBARRA, Oscar; MORRISON, Kimberly Rios. (2009). Intergroup threat theory. In: NELSON, Todd D. (ed.). Handbook of prejudice, stereotyping, and discrimination. New York/Hove: Psychology Press. p. 43-60

TAVARES, Carla Nunes Vieira. (2004). A (in)segurança na estrutura: uma reflexão sobre a relação sujeito-língua estrangeira. In: FERNANDES, Claudemar Alves [et al.], organizadores. Sujeito, identidade e memória. Urbelândia : EDUFU. p. 217-242. (Lingüística in focus).

URBANI, Giuliano. (1991). Introduzione. In: URBANI, Giuliano et al. L'Anziano Attivo: proposte e riflessioni per la terza e la quarta età. Torino: Edizioni della Fondazione Giovanni Agnelli. p.1-10.

VENTURI, Gustavo; BOKANY, Vilma. (2007). A velhice no Brasil : contrastes entre o vivido e o imaginado. In: NERI, Anita Liberalesso (org.). Idosos no Brasil : vivências, desafios e expectativas na terceira idade. São Paulo: Ed. Fundação Perseu Abramo, Edições SESC-SP. p. 21-32.

VERAS, Renato. (1997). Prefácio. In: VERAS, Renato P. (org.). Terceira idade: desafios para o terceiro milênio. Rio de Janeiro: Relume-Dumará/UnATI/UERJ. p. 7-11.

WARD, Christopher R. (1997). The context of intergenerational programs. In: NEWMAN, Sally et al. Intergenerational Programs : past, present and future. Washington, DC: Taylor \& Francis. p. 21-35.

WHITBOURNE, Susan Krauss; SNEED, Joel R. (2004). The paradox of well-being, identity processes, and stereotype threat: ageism and its potential relationships to the self in later life. In: NELSON, Todd D. (ed.). Ageism : stereotyping and prejudice against older persons. Massachusetts: The MIT Press. p. 247-273.

WOODWARD, Kathryn. (2008). Identidade e diferença: uma introdução teórica e conceitual. In: SILVA, Tomaz Tadeu da (org.). Identidade e diferença : A perspectiva dos estudos culturais. Petrópolis, RJ:Vozes. 8a ed. p. 7-72. 
Bibliografia
consultada 
AGUIAR, Maria Geralda G.; NASCIMENTO, Maria Ângela A. (2005). Saúde, doença e envelhecimento: representações sociais de um grupo de idosos da Universidade Aberta à Terceira Idade (UATI) - Feira de Santana - BA. Textos sobre envelhecimento, v.8, n.3, Rio de Janeiro. Disponível em: <http://www.unati.eurj.br/tse/scielo.php? script $=$ sci_arttext\&pid $=$ S1517-59282005000300004\&lng $=$ pt\&nrm $=$ iso $>$. Acesso em: 09/2006.

ARCANGELI, Massimo. (2007). Lingue centrali e lingue periferiche: accordi, compromessi, conflitti. In: . Lingua e identità. p.51-76.

ARCANGELI, Massimo. (2007). L'io è anche un altro. Lingue identitarie e identità linguistica. In: . Lingua e identità. p.97-134.

BACCIN, Paola G. (2003). Italianismos na terminologia gastronômica na cidade de São Paulo : um modelo de glossário. Tese (Doutorado) - Faculdade de Filosofia, Letras e Ciências Humanas, Universidade de São Paulo, São Paulo.

BITTENCOURT, Agueda Bernardete. (2004). Prefácio. In: GALLO, Sílvio; SOUZA, Regina Maria de. Educação do preconceito : ensaios sobre poder e resistência. Campinas, SP: Alínea. p. $5-8$.

BLIKSTEIN, Izidoro. (1995). Signo, significação e realidade. In: . Kaspar Hauser, ou a fabricação da realidade. São Paulo: Cultrix. 4a. ed. p. 19-20.

BOTELHO, Maria Izabel V.; COELHO, France Maria G.; SIQUEIRA, Renata Lopes. (2002). A velhice : algumas considerações teóricas conceituais. Ciência \& Saúde Coletiva, v. 7, n. 4, p. 899-906. Disponível em <http://www.scielo.br/pdf/csc/v7n4/14613.pdf>. Acesso em: $07 / 2006$.

CAMARANO, Ana Amélia. (2007). Instituições de longa permanência e outras modalidades de arranjos domiciliares para idosos. In: NERI, Anita Liberalesso (org.). Idosos no Brasil : vivências, desafios e expectativas na terceira idade. São Paulo: Ed. Fundação Perseu Abramo, Edições SESC-SP. p. 169-190.

CAPUANI, Gian Maria; PIANA, Giannino. (1991). L'anziano protagonista in uma società che cambia. In: URBANI, G. et al. L'anziano attivo : proposte e riflessioni per la terza e la quarta età. Torino: Edizione della Fondazione Giovanni Agnelli. p.15-23. 
CASUCCI, Maria Antonietta Aveni. (1991). Psicogerontologia: attualità e nuove prospettive. In: URBANI, G. et al. L'anziano attivo : proposte e riflessioni per la terza e la quarta età. Torino: Edizione della Fondazione Giovanni Agnelli. p. 53-69.

CATHERY-GOULART; Maria Teresa; PARENTE, Maria Alice de M.P. (2006). Leitura e escrita e o envelhecimento. In: PARENTE, Maria Alice de Mattos Pimenta [et al.]. Cognição e envelhecimento. Porto Alegre: Artmed. p. 191-202.

CELADA, Maria Teresa. (1999). Um equívoco histórico. In: INDURSKY, Freda; FERREIRA, Maria Cristina Leandro. Os múltiplos territórios da Análise do Discurso. Porto Alegre: Sagra Luzzatto. p. 301-320. (Ensaios, 12).

CELADA, Maria Teresa. (2004). "Lengua extranjera e subjetividad: apuntes sobre un proceso". In: Estudos Linguísticos XXXIII. Cd-rom. 51º Seminário do GEL. Taubaté: Unitau, maio de 2003.

CESAREO, Vincenzo. (1991). Anziani attivi: un possibile esempio di nuova centralità del sociale. In: URBANI, G. et al. L'anziano attivo : proposte e riflessioni per la terza e la quarta età. Torino: Edizione della Fondazione Giovanni Agnelli. p. 217-234.

CHNAIDERMAN, Miriam. (1998). Língua(s)-linguagem(ns)-identidade(s)-movimento(s) : uma abordagem psicanalítica. In: SIGNORINI, Inês (org.). Lingua(gem) e identidade : elementos para uma discussão no campo aplicado. Campinas, SP: Mercado das Letras. (Letramento, Educação e Sociedade). p. 47-68.

CIAMPA, Antonio da Costa. (1984). Identidade. In: LANE, Silvia T. M.; CODO, Wanderley (orgs.). Psicologia social : o homem em movimento. São Paulo : Brasiliense. 6 ${ }^{\mathrm{a}}$ ed. p. 58-75.

CORACINI, Maria José R. Faria. (2003). Língua estrangeira e língua materna : uma questão de sujeito e identidade. In: CORACINI, Maria José (org.). Identidade e discurso : (des) construindo subjetividades. Campinas, SP: Argos Editora Universitária. p. 139-160.

CORACINI, Maria José R. Faria. (2003b). A celebração do outro. In: CORACINI, Maria José (org.). Identidade e discurso : (des) construindo subjetividades. Campinas, SP: Argos Editora Universitária. p. 197-222.

CORACINI, Maria José R. Paiva. (2003c). As representações do saber científico na constituição da identidade do sujeito-professor e do discurso de sala de aula. In: CORACINI, Maria José (org.). Identidade e discurso : (des) construindo subjetividades. Campinas, SP: Argos Editora Universitária. p. 319-336.

CORDER, S. Pit. (1983). A role for the mother tongue. In: GASS, Susan; SELINKER, Larry (eds.). Language transfer in language learning. Rowley, Massachussetts: Newbury house Publishers. 
CUNHA, Raquel Vieira da. (1980). Educação permanente como perspectiva da integração social do idoso. In: Cadernos da Terceira Idade, nº 06. São Paulo: SESC. p. 7-8.

DEBERT, Grita Grin. (2004). Problema social e responsabilidade individual. In: DEBERT, Grita Grin. A reinvenção da velhice : socialização e processos de reprivatização do envelhecimento. São Paulo: Edusp; Fapesp. 1ª ed. p. 195-231.

DEL RÉ, Alessandra. (2006). A pesquisa em aquisição da linguagem: teoria e prática. In: DEL RÉ, Alessandra (org.). Aquisição da linguagem : uma abordagem psicolingüística. São Paulo : Contexto. p. 13-44.

DEUS, Suelma Inês Alves de; LOPES, Doraci. (2007). Negritude e envelhecimento. In: NERI, Anita Liberalesso (org.). Idosos no Brasil : vivências, desafios e expectativas na terceira idade. São Paulo: Ed. Fundação Perseu Abramo; Edições SESC-SP. p. 81-90.

DOLL, Johannes; PY, Ligia. (2007). O idoso na relação com a morte: aspectos éticos. In: NERI, Anita Liberalesso (org.). Qualidade de vida na velhice : enfoque multidisciplinar. Campinas, SP: Ed. Alínea. (Velhice e sociedade). p. 277-300.

DOMINGUES, José Maurício. (2002). Gerações, modernidade e subjetividade coletiva. Tempo social, São Paulo, v. 14, n. 1, Maio. Disponível em: <http://www.scielo.br/scielo.php? script $=$ sci_arttext\&pid $=$ S0103-20702002000100004\&lng $=$ en $\& n r m=i s o>$. Acesso em: $14 / 04 / 2010$.

DUARTE, Yeda Aparecida de Oliveira; LEBRÃO, Maria Lúcia. (2007). Saúde e independência: aspirações centrais para os idoso. Como estão sendo feitas? In: NERI, Anita Liberalesso (org.). Idosos no Brasil : vivências, desafios e expectativas na terceira idade. São Paulo: Ed. Fundação Perseu Abramo; Edições SESC-SP. p. 191-208.

ESCOSTEGUY, Ana Carolina. (2000). Estudos Culturais: uma introdução. In: SILVA, Tomaz Tadeu da (org.). O que é, afinal, Estudos Culturais? Tradução: Tomaz Tadeu da Silva. Belo Horizonte: Autêntica. 2a ed. (Estudos Culturais). p. 133-166.

EUFRÁSIO, Mario Antonio. (2006). Identidade, perspectivas teóricas e metodológicas. In: LUCENA, Célia Toledo; GUSMÃO, Neusa Maria Mendes (orgs.). Discutindo identidades. São Paulo : Humanitas/CERU. p. 15-16.

EWALD, Ariane P. (2005). Identidade e construção do sujeito numa era de incerteza. In: ZUGEIB NETO, Jamil (org.). Identidades e crises sociais na contemporaneidade. Curitiba: Ed. UFPR. p.215-232. (Pesquisa; n.107).

FONSECA, Rochele Paz; PARENTE, Maria Alice de M. P. (2006). "Compreensão da linguagem no envelhecimento". In: PARENTE, Maria Alice de Mattos Pimenta [et al.]. Cognição e envelhecimento. Porto Alegre: Artmed. p. 153-168. 
FONSECA, Rochele Paz; WAGNER, Gabriela Peretti; RINALDI, Juciclara; PARENTE, Maria Alice de M. P. (2007). O envelhecimento influencia as habilidades pragmáticas, léxicosemânticas e prosódicas do hemisfério direito? Estudos interdisciplinares sobre o envelhecimento, Porto Alegre, v. 12, p. 53-79. Disponível em: <http://www.seer.ufrgs.br/index.php/RevEnvelhecer/article/view/4979/2848.

FRANÇA, Lucia Helena; SOARES, Neusa Eiras. (1997). A importância das relações intergeracionais na quebra de preconceitos sobre a velhice. In: VERAS, Renato P. (org.). Terceira idade : desafios para o terceiro milênio. Rio de Janeiro: RelumeDumará/UnATI/UERJ. p. 143-169.

GIUST-DESPRAIRIES, Florence. (2005). A identidade como processo, entre ligação e desprendimento. In: ZUGUEIB NETO, Jamil (org.). Identidades e crises sociais na contemporaneidade. Curitiba: Editora UFPR. (Pesquisa, n. 107). p. 199-214.

GOMES, Christianne Luce. (2008). Lazer, trabalho e educação : relações históricas, questões contemporâneas. Belo Horizonte: Ed. UFMG. $2^{\text {a }}$ ed. rev. e ampl. 151 p. (Aprender).

GONZÁLES, Neide T. (1996). Lingüística e ensino de língua estrangeira: relações, nem sempre tão explicativas, entre a(s) teoria(s) e a(s) prática(s). ABRALIN, Boletim da Associação Brasileira de Lingüística, n.19, p. 187-196, Maceió, dez-1996.

GONZÁLES, Neide Maia. (2003). "Lugares de interpretação do fenômeno da aquisição de línguas estrangeiras". In: Estudos Linguísticos XXXIII. Campinas, SP: Unicamp. (publicado em CD-Rom.)

GRIGOLETTO, Marisa. (2003). "Representação, identidade e aprendizagem de língua estrangeira". In: CORACINI, Maria José (org.). Identidade e discurso : (des) construindo subjetividades. Campinas, SP: Argos Editora Universitária. p. 223-235.

GRIGOLETTO, Marisa. (2006). Leituras sobre a identidade: contingência, negatividade e invenção. In: MAGALHÃES, Izabel; CORACINI, Maria José; GRIGOLETTO, Margarida (org.). Práticas identitárias : língua e discurso. São Carlos: Claraluz. p. 15-26.

GUERRA, Paula Bierrenbach de Castro. (2002). Psicologia social dos estereótipos. PsicoUSF, Itatiba, v. 7, n. 2, dez. Disponível em: <http://pepsic.bvsalud.org/scielo.php? script $=$ sci_arttext\&pid $=$ S1413-82712002000200013\&lng $=$ pt\&nrm $=i s o>$. Acesso em: 08/06/2009.

GUSMÃO, Neusa Maria Mendes de. (2003). Infância e velhice: desafios da multiculturalidade. In: GUSMÃO, Neusa M. M. De (org.). Infância e velhice : pesquisa de idéias. Campinas, SP: Ed. Alínea. p. 15-32.

HADDAD, Eneida Gonçalves de Macedo. (1986). A ideologia da velhice. São Paulo: Cortez. $135 \mathrm{p}$. 
KRASHEN, Stephen D. (1982). Principles and practice in second language acquisition. New York: Pergamon Press. (Language Teaching Methodology Series). 202 p.

LABES, Emerson Moisés. (1998). Questionários. In: . Questionário : do planejamento à aplicação da pesquisa. São Bento do Sul, SC: Grifos Editora. p. 15-22. Parte 1.

LANE, Silvia T. M. (1984a). A Psicologia Social e uma nova concepção do homem para a Psicologia. In: LANE, Silvia T. M.; CODO, Wanderley (orgs.). Psicologia Social : o homem em movimento. São Paulo: Brasiliense. 6 ed. p.10-19.

LANE, Silvia T. M. (1984b). Linguagem, pensamento e representações sociais. In: LANE, Silvia T. M.; CODO, Wanderley (orgs.). Psicologia Social : o homem em movimento. São Paulo: Brasiliense. $6^{\mathrm{a}}$ ed. p. 32-39.

LANE, Silvia T. M.. (1984c). O processo grupal. In: LANE, Silvia T. M.; CODO, Wanderley (orgs.). Psicologia social : o homem em movimento. São Paulo : Brasiliense. 6a ed. p. 78-98.

LARSEN-FREEMAN, Diane. (1997). Chaos/Complexity Science and Second Language Acquisition. Applied Linguistics, vol. 18 - 2. Oxford University Press.

LIMA, Maria Manuel. (1997). "Considerações em torno do conceito de estereótipo: uma dupla abordagem". Revista da Universidade de Aveiro - Letras, 14. p. 169-181. Disponível em: <http://comodeantes.com/pdf/consideracoes_em_torno.pdf > . Acesso em: 11/02/2010.

LOPES, Andréa. (2006). Dependência, contratos sociais e qualidade de vida na velhice. In: VON SIMSOM, Olga R. De M.; NERI, Anita Liberalesso; CACHIONI, Meire (orgs.). As múltiplas faces da velhice no Brasil. Campinas, SP: Ed. Alínea. (Velhice e sociedade). $2^{\text {a }}$ ed. p. 129-140.

MABESA DO BRASIL. (s/d). Terceira Idade : um desafio para todos. Seção de artigos do site Mabesa do Brasil. Disponível em <http://www.mabesa.com.br/dicas_saude03.htm>. Acesso em 09/2006.

MANCUSO, Maria Inês R. (2006). Memória, representação e identidade. In: LUCENA, Célia Toledo; GUSMÃO, Neusa Maria Mendes (orgs.). Discutindo identidades. São Paulo : Humanitas/CERU. p. 57-74.

MARTINS, José de Souza. (2009). Culpados de velhice. Estadão, Suplementos, Aliás. Disponível em: <http://int.estadao.com.br/Multimidia/ShowImpressao.action? $\mathrm{xm} /$ Pathname $=$ not_sup420116,0.xml $>$. Acesso em: 12/2009.

MELO, Lélia Erbolato. (2005). Principais teorias/abordagens da aquisição de linguagem. In: MELO, Lélia Erbolato (org.). Tópicos de psicolingüística aplicada. São Paulo: Associação Editorial Humanitas. $3^{\text {a }}$ ed. p. 25-54. 
MEY, Jacob L. (1998). Etnia, identidade e língua. Tradução: Maria da Gloria Moraes. In: SIGNORINI, Inês (org.). Lingua(gem) e identidade : elementos para uma discussão no campo aplicado. Campinas, SP: Mercado das Letras. (Letramento, Educação e Sociedade). p. 69-88.

NERY, Marina. (2006). A nova velha geração. Desafios do desenvolvimento, ed. 32, junho. Brasília: Ipea. Disponível em:

<http://www.ipea.gov.br/desafios/edicoes/32/artigo44451-1.php>. Acesso em: 06/04/2009.

PACHECO, Jaime Lisandro. (2006). As Universidades Abertas à Terceira Idade como espaço de convivência entre gerações. In: VON SIMSOM, Olga R. De M.; NERI, Anita Liberalesso; CACHIONI, Meire (orgs.). As múltiplas faces da velhice no Brasil. Campinas, SP: Ed. Alínea. (Velhice e sociedade). $2^{\text {a }}$ ed. p. 223-250.

PETTER, Margarida. (2002). Linguagem, língua e linguuística. In: FIORIN, José Luiz (org.). Introdução à Linguística. São Paulo: Contexto, 11-24.

PICHIASSI, Mauro. (1999). Fondamenti di glottodidattica : temi e problemi della didattica linguistica. Perugia: Guerra Edizioni. (Studi sul linguaggio, sulla comunicazione e sull'apprendimento, 5).

PORTO, Mayla. (2002). A Política Nacional do Idoso: um Brasil para todas as idades. In: Com Ciência, Revista Eletrônica de Jornalismo Científico, n 35, 10/09/2002. Disponível em <http://www.comciencia.br/reportagens/envelhecimento/texto/env02.htm>. Acesso em 09/2006.

ROCHA-TRINDADE, Maria Beatriz. (2006). Recriação de identidades em contexto de migração. In: LUCENA, Célia Toledo; GUSMÃO, Neusa Maria Mendes (orgs.). Discutindo identidades. São Paulo: Humanitas/CERU. p.75-90.

SANTIN, Janaína Rigo; BETTINELLI, Luiz Antonio; BENINCÁ, Ciomara Ribeiro. (2007). Envelhecimento humano: cuidado e cidadania. In: SANTIN, Janaína Rigo; BETTINELLI, Luiz Antonio; BENINCÁ, Ciomara Ribeiro (orgs.). Envelhecimento humano : cuidado e cidadania. Passo Fundo, RS: Ed. Universidade de Passo Fundo. p. 11-20.

SANTOS, Raquel. (2002). A aquisição da linguagem. In: FIORIN, José Luiz (org.). Introdução à Linguística. São Paulo: Contexto. p. 211-226.

SAUSSURE, Ferdinand de. (1995). Curso de Lingüística Geral. Tradução: Antônio Chelini, José Paulo Paes, Izidoro Blikstein. São Paulo: Cultrix.

SELINKER, L. (1992). La interlengua. In: LICERAS, J. M. (org.). La adquisición de las lenguas extranjeras : hacia un modelo de análisis de la interlengua. Madrid: Visor. p.79-104. 
SERRANI-INFANTE, Silvana. (1997). Diversidade e alteridade na enunciação em línguas próximas. Revista Letras, 4, p. 11-17, Porto Alegre.

SERRANI-INFANTE, Silvana. (1998). Identidade e Segundas Línguas: as identificações no discurso. In: SIGNORINI, Inês (org.). Língua(gem) e identidade : elementos para uma discussão no campo aplicado. Campinas, SP: Fapesp; Mercado de Letras. p. 231-264.

SIGNORINI, Inês. (1998). "(Des)construindo bordas e fronteiras : letramento e identidade social". In: SIGNORINI, Inês (org.). Lingua(gem) e identidade : elementos para uma discussão no campo aplicado. Campinas, SP: Mercado das Letras. (Letramento, Educação e Sociedade). p. 139-172.

SIGNORINI, Inês. (1998b). "Figuras e modelos contemporâneos da subjetividade". In: SIGNORINI, Inês (org.). Lingua(gem) e identidade : elementos para uma discussão no campo aplicado. Campinas, SP: Mercado das Letras. (Letramento, Educação e Sociedade). p. 333380.

SIQUEIRA, Maria Eliane Catunda de. (2007). Velhice e políticas públicas. In: NERI, Anita Liberalesso (org.). Idosos no Brasil : vivências, desafios e expectativas na terceira idade. São Paulo: Ed. Fundação Perseu Abramo, Edições SESC-SP. p. 209-223.

TÍLIO, Rogério. (2009). Reflexões acerca do conceito de identidade. Revista eletrônica do Instituto de Humanidades, v. VIII, n. XXIX, abr-jun, p. 109-119. Disponível em: $<$ http:publicacoes.unigranrio.edu.br/index.php/reihm/article/view/596/539>. Acesso em: 21/01/2010.

VIERTLER, Renate B. (2006). Estudos sobre "identidade". In: LUCENA, Célia Toledo; GUSMÃO, Neusa Maria Mendes (orgs.). Discutindo identidades. São Paulo: Humanitas/CERU. p. 45-56. 
Anexos 


\section{Lista de anexos}

Anexo A - Página escaneada do livro Bar Italia:

anedotas sobre italianos

Anexo B - Modelo 1: questionário para estudantes do nível 1 do IC

Anexo C - Pesquisa com principiantes do IC: tabelas comparativas dos principais resultados gerais e por faixa etária

Anexo D - Modelo 2: questionário da pesquisa geral com estudantes do IC

Anexo E - Resultados da pesquisa geral do IC 269

Anexo F - Modelo 3: questionário geral para os monitores 281

Anexo G - Tabelas com as respostas dos monitores aos Questionário 3 que não entraram no capítulo 5

Anexo H - Modelo 3.1.: questionário específico para os monitores

Anexo I - Formulário de informação e compromisso para monitores entrevistados.

Anexo J - Modelo de roteiro de entrevista com os monitores.

Anexo K - Transcrição das entrevistas com os monitores 


\section{Anexo A - Página escaneada do livro Bar Italia: anedotas sobre italianos}

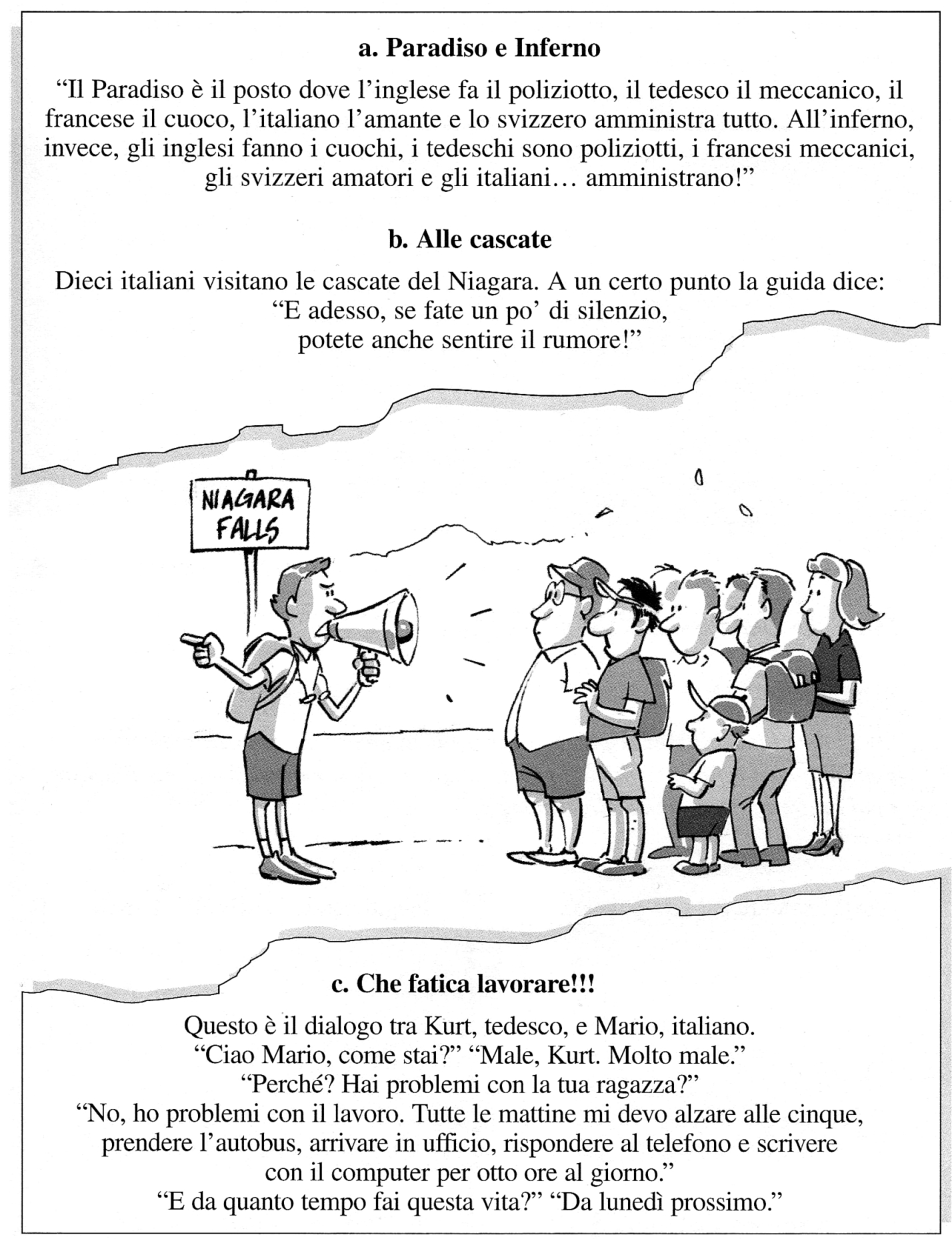

Retirada de DI FRANCESCO, A.; NADDEO, C.M. (2002). Bar Italia. Firenze: Alma Edizione, p. 9. 


\section{Anexo B - Modelo 1: questionário para estudantes do nível 1 do IC}

NOME (opcional):

IDADE: ___ anos SEXO: ( ) feminino ( ) masculino

Responda as questões de 1 a 4 com no mínimo 3 palavras e no máximo 5, sem refletir sobre elas. Escreva a primeira coisa que vier na sua cabeça.

1. Quando você pensa na Itália, quais são as palavras que te vêm em mente?

2. Quando você pensa no povo italiano, quais as palavras que vêm na tua mente com relação ao aspecto físico dos italianos?

3. E quanto aos aspectos psicológicos, com quais palavras você os definiria?

4. Por que decidiu estudar italiano?

5. você acha que aprender a língua italiana será:

( ) muito fácil ( ) fácil ( ) nem fácil nem difícil （ ) difícil （ ) muito difícil Justifique sua resposta: 
6. O que você acha que será o mais fácil do curso?

7. E o mais difícil?

8. Quais as suas expectativas em relação ao curso?

9. Quais elementos de língua e cultura italiana espera que sejam mais trabalhados? 


\section{Anexo C - Pesquisa com principiantes do IC: tabelas comparativas dos principais resultados gerais e por faixa etária}

Tabela C1: Quais palavras Ihe vêm à mente quando se fala em Itália? (Q1:1)

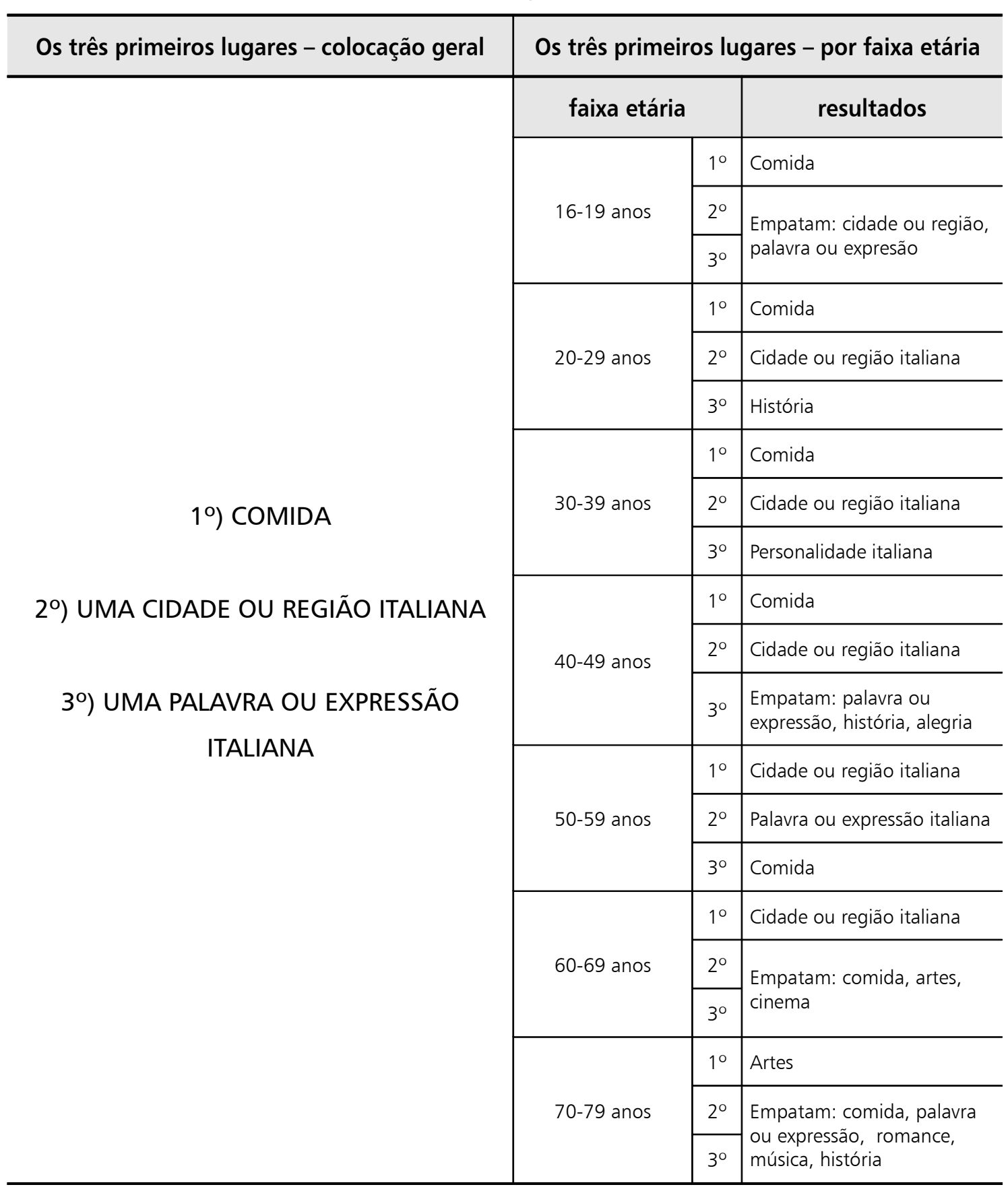


Tabela C2: Quais palavras lhe vêm à mente quando se fala em aspecto físico do povo italiano? (Q1:2)

\begin{tabular}{|c|c|c|c|}
\hline Os três primeiros lugares - colocação geral & \multicolumn{3}{|c|}{ Os três primeiros lugares - por faixa etária } \\
\hline \multirow[b]{9}{*}{$\left.1^{\circ}\right)$ BONITOS(AS)/BELOS(AS) } & \multicolumn{2}{|c|}{ faixa etária } & resultados \\
\hline & \multirow{2}{*}{$16-19$ anos } & $1^{\circ}$ & Empatam: Bonitos, Altos \\
\hline & & $2^{\circ}$ & Empatam: Loiros, Morenos \\
\hline & \multirow{3}{*}{$20-29$ anos } & $1^{\circ}$ & Altos \\
\hline & & $2^{\circ}$ & Bonitos \\
\hline & & $3^{\circ}$ & Empatam: Morenos, Brancos \\
\hline & \multirow{3}{*}{ 30-39 anos } & $1^{\circ}$ & Bonitos \\
\hline & & $2^{\circ}$ & Empatam: Altos, Morenos \\
\hline & & $3^{\circ}$ & $\begin{array}{l}\text { Empatam: Morenos, } \\
\text { Narigudos, Fortes/robustos }\end{array}$ \\
\hline \multirow[t]{2}{*}{$\left.2^{\circ}\right)$ ALTOS (AS) } & \multirow{3}{*}{ 40-49 anos } & $1^{\circ}$ & Bonitos \\
\hline & & $2^{\circ}$ & Empatam: Altos, Morenos \\
\hline \multirow[t]{8}{*}{ 3०) MORENOS(AS) } & & $3^{\circ}$ & $\begin{array}{l}\text { Empatam: Loiros, } \\
\text { Fortes/robustos }\end{array}$ \\
\hline & \multirow{3}{*}{$50-59$ anos } & $1^{\circ}$ & Bonitos \\
\hline & & $2^{\circ}$ & Altos \\
\hline & & $3^{\circ}$ & $\begin{array}{l}\text { Empatam: Morenos, } \\
\text { Fortes/robustos }\end{array}$ \\
\hline & $60-69$ anos & $1^{\circ}$ & $\begin{array}{l}\text { Empatam: Bonitos, } \\
\text { Morenos, Fortes/robustos }\end{array}$ \\
\hline & \multirow{3}{*}{ 70-79 anos } & $1^{\circ}$ & Bonitos \\
\hline & & $2^{\circ}$ & \multirow{2}{*}{$\begin{array}{l}\text { Empatam: Atraentes, } \\
\text { Mulheres feias }\end{array}$} \\
\hline & & $3^{\circ}$ & \\
\hline
\end{tabular}

Q1:3 Quais palavras the vêm à mente quando se fala em aspecto psicológico dos italianos? (Q1:3)

Os resultados desta questão não possuíam citações suficientes para uma divisão por faixas etárias. 
Tabela C3: Por que decidiu estudar italiano? (Q1:4)

\begin{tabular}{|c|c|c|c|}
\hline Os três primeiros lugares - colocação geral & \multicolumn{3}{|c|}{ Os três primeiros lugares - por faixa etária } \\
\hline \multirow{14}{*}{$\begin{array}{l}\text { 10) PORQUE É DESCENDENTE } \\
\text { DE ITALIANOS } \\
\left.2^{\circ}\right) \text { PORQUE ACHA A LÍNGUA BONITA }\end{array}$} & \multicolumn{2}{|c|}{ faixa etária } & resultados \\
\hline & 16-19 anos & $1^{\circ}$ & $\begin{array}{l}\text { Empatam: porque é } \\
\text { descendente de italianos, } \\
\text { porque acha a língua bonita }\end{array}$ \\
\hline & \multirow{3}{*}{$20-29$ anos } & $1^{\circ}$ & Porque acha a língua bonita \\
\hline & & $2^{\circ}$ & Porque é descendente \\
\hline & & $3^{\circ}$ & $\begin{array}{l}\text { Porque vai morar/estudar na } \\
\text { Itália }\end{array}$ \\
\hline & \multirow{2}{*}{ 30-39 anos } & 10 & Porque é descendente \\
\hline & & $2^{\circ}$ & Pela cultura italiana \\
\hline & \multirow{2}{*}{ 40-49 anos } & $1^{\circ}$ & $\begin{array}{l}\text { Porque é descendente de } \\
\text { italianos }\end{array}$ \\
\hline & & $2^{\circ}$ & $\begin{array}{l}\text { Porque vai/quer conhecer a } \\
\text { Itália }\end{array}$ \\
\hline & \multirow{3}{*}{$50-59$ anos } & $1^{\circ}$ & Porque é descendente \\
\hline & & $2^{\circ}$ & $\begin{array}{l}\text { Porque vai/quer conhecer a } \\
\text { Itália }\end{array}$ \\
\hline & & $3^{\circ}$ & Porque acha a língua bonita \\
\hline & $60-69$ anos & $1^{\circ}$ & $\begin{array}{l}\text { Empatam: porque é } \\
\text { descendente, Porque } \\
\text { vai/quer conhecer a Itália }\end{array}$ \\
\hline & 70-79 anos & $1^{\circ}$ & $\begin{array}{l}\text { Empatam: para falar mais } \\
\text { uma língua, para conservar } \\
\text { a memória }\end{array}$ \\
\hline
\end{tabular}


Tabela C4: Você acha que o curso de italiano será... * (Q1:5)

\begin{tabular}{|c|c|c|c|}
\hline Os três primeiros lugares - colocação geral & \multicolumn{3}{|c|}{ Os três primeiros lugares - por faixa etária } \\
\hline & \multicolumn{2}{|c|}{ Faixa etária } & resultados \\
\hline & \multirow{2}{*}{ 16-19 anos } & $1^{\circ}$ & $\begin{array}{l}\text { Nem fácil nem difícil } \\
(83,3 \%)\end{array}$ \\
\hline & & $2^{\circ}$ & Fácil $(16,7 \%)$ \\
\hline & \multirow{3}{*}{ 20-29 anos } & $1^{\circ}$ & Nem fácil nem difícil (52\%) \\
\hline & & $2^{\circ}$ & Fácil $(31,2 \%)$ \\
\hline & & $3^{\circ}$ & Difícil (16,8\%) \\
\hline & \multirow{3}{*}{ 30-39 anos } & $1^{\circ}$ & Nem fácil nem difícil (59\%) \\
\hline & & $2^{\circ}$ & Difícil (27,3\%) \\
\hline \multirow{11}{*}{$\begin{array}{l}\left.1^{\circ}\right) \text { NEM FÁCIL NEM DIFÍCIL } \\
\left.2^{\circ}\right) \text { DIFÍCIL } \\
\left.3^{\circ}\right) \text { FÁCIL }\end{array}$} & & $3^{\circ}$ & Fácil (9\%) \\
\hline & \multirow{2}{*}{ 40-49 anos } & $1^{\circ}$ & $\begin{array}{l}\text { Nem fácil nem difícil } \\
(62,5 \%)\end{array}$ \\
\hline & & $2^{\circ}$ & Difícil $(37,5 \%)$ \\
\hline & \multirow{4}{*}{ 50-59 anos } & $1^{\circ}$ & Nem fácil nem difícil (60\%) \\
\hline & & $2^{\circ}$ & Fácil (16\%) \\
\hline & & $3^{\circ}$ & Difícil (16\%) \\
\hline & & $4^{\circ}$ & Muito difícil (4\%) \\
\hline & \multirow{2}{*}{$60-69$ anos } & $1^{\circ}$ & Nem fácil nem difícil (70\%) \\
\hline & & $2^{\circ}$ & Difícil (30\%) \\
\hline & \multirow{2}{*}{ 70-79 anos } & $1^{\circ}$ & Nem fácil nem difícil (60\%) \\
\hline & & $2^{\circ}$ & Difícil (40\%) \\
\hline
\end{tabular}

* As alternativas eram: fácil, nem fácil nem difícil, difícil, muito difícil 
Tabela C5: 0 que acham que será o mais fácil do curso? (Q1:6)

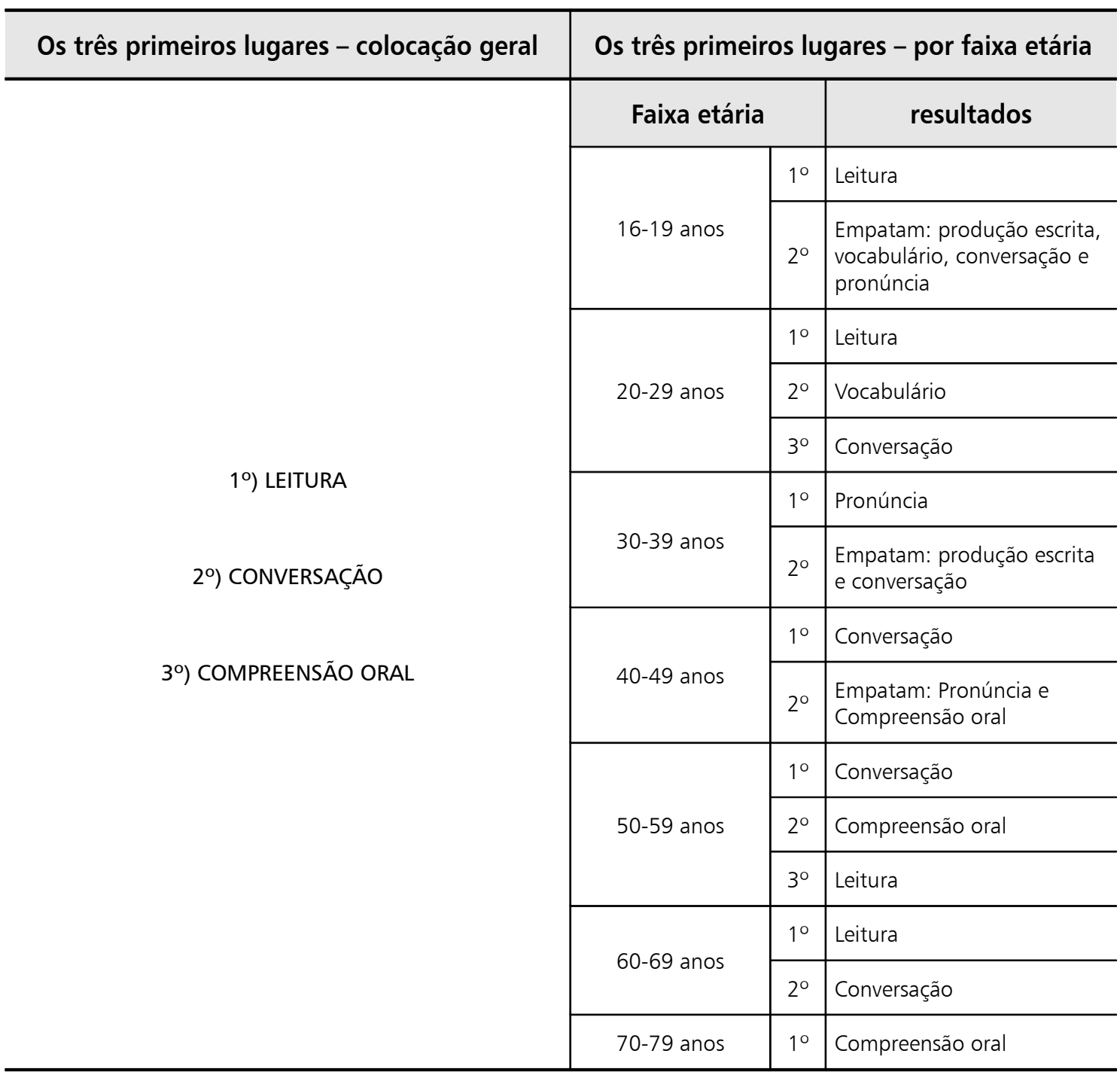


Tabela C6: O que acham que será o mais difícil do curso? (Q1:7)

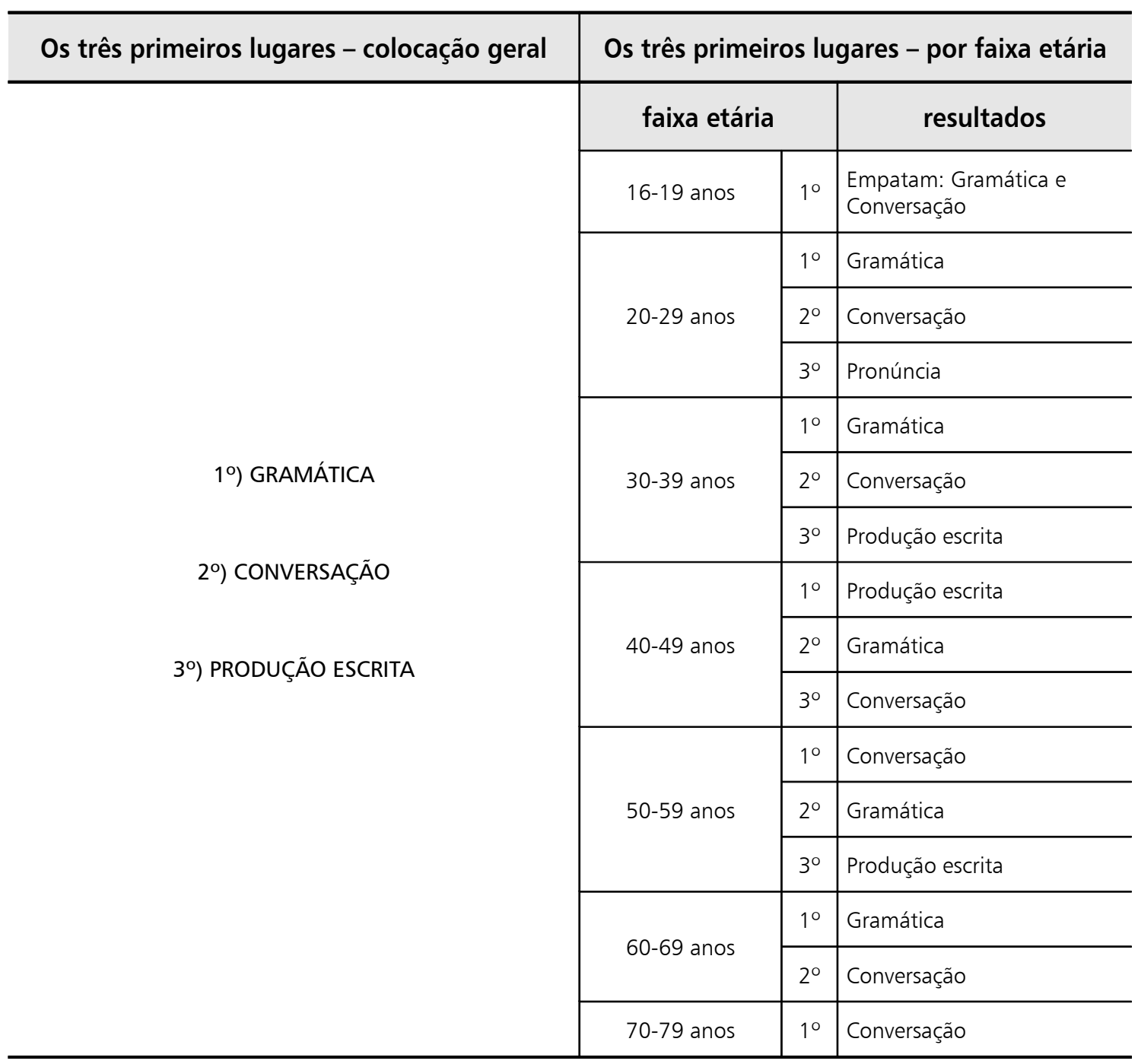


Tabela C7: O que espera conhecer no curso? (Q1:8)

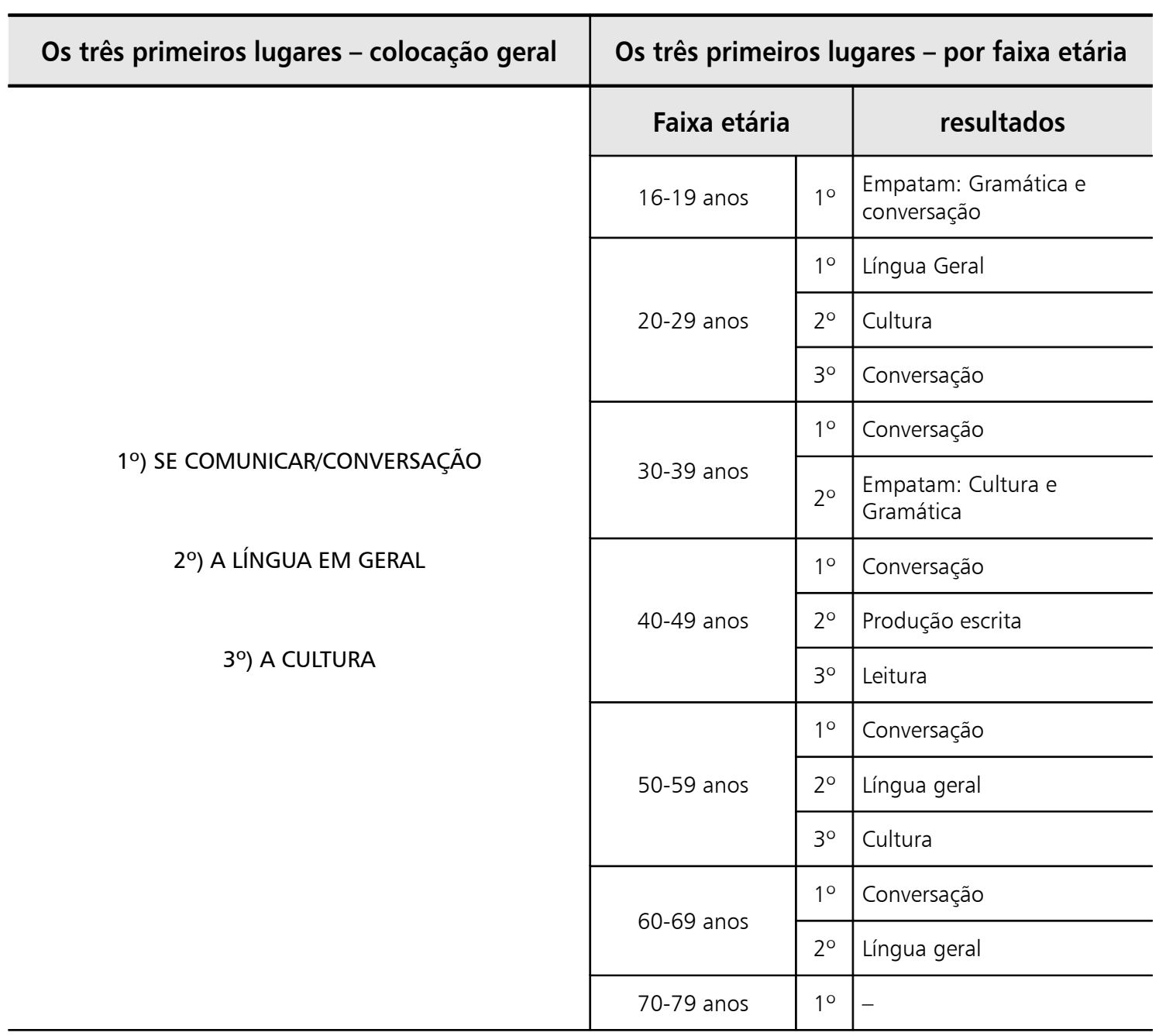


Tabela C8: Quais elementos você espera que sejam mais trabalhados? (Q1:1)

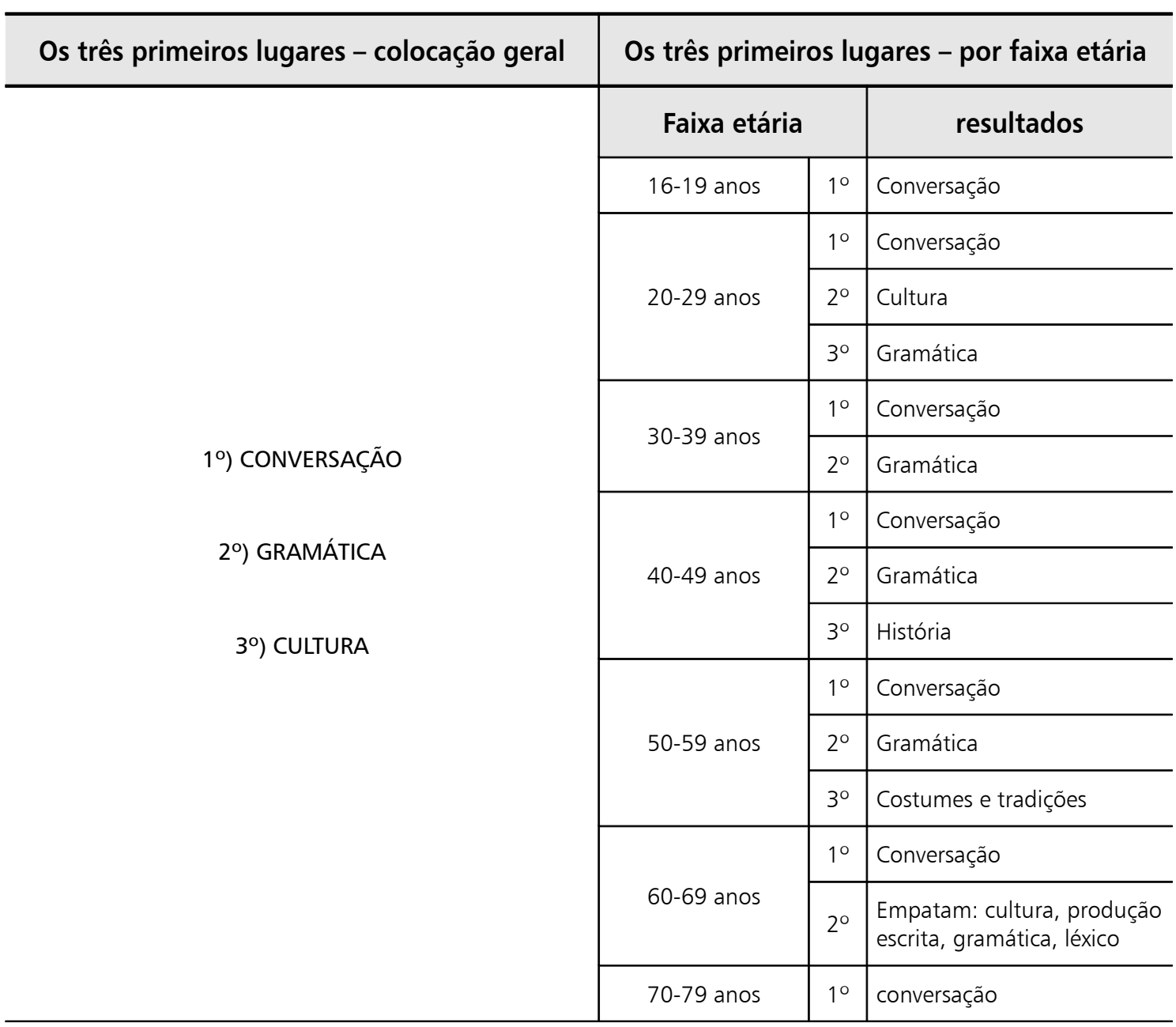




\section{Anexo D - Modelo 2: questionário da pesquisa geral com estudantes do IC}

\section{Questionário 2 (alunos IC)}

Idade: anos

Formação:
( ) Ensino médio completo
( ) superior completo
( ) mestrado completo
( ) doutorado completo

Sexo: ( ) feminino ( ) masculino

( ) superior em andamento

( ) mestrado em andamento

( ) doutorado em andamento

( ) outro:

Profissão atual:

1) O que te levou a fazer o curso de língua italiana?

2) O que te fez escolher o curso do Italiano no Campus ao invés de um em Instituto de Língua?

3) Você frequenta outros cursos "extra-curriculares" no momento? ( ) SIM, ( ) NÃO Se SIM, quantos?

4) Na sua opinião, qual o número ideal de estudantes por grupo? Por quê?

5) O que acha do ritmo das aulas?
( ) lento
( ) bom
( ) acelerado 
6) Acha que o ritmo deveria ser outro? ( ) Sim, ( ) Não

Justifique:

7) Com qual desses pontos você tem mais dificuldade:

( ) produção oral ( ) produção escrita ( ) leitura （ ) gramática

8) O que faria, ou gostaria que fosse feito, para melhorar isso?

9) Que assunto você gostaria que fosse mais trabalhado em sala de aula? (Exemplos: arte, culinária, música, filosofia, religião, esportes, cinema, gramática, história etc.)

10) Como é seu relacionamento com os colegas do grupo?
( ) ruim
( ) razoável ( ) bom
( ) muito bom
( ) ótimo

Explique sua resposta:

11) Como se sente estudando em um grupo com alunos de diferentes faixas etárias?

12) Você dividiria os grupos por faixas etárias? ( ) Sim, ( ) Não Justifique:

13) Você gostaria de ter um grupo só com pessoas da sua idade? ( ) Sim, ( ) Não Justifique: 
14) O curso tem atendido às suas expectativas? ( ) Sim, ( ) Em parte, ( ) Não Se pudesse mudar algo no curso, o que seria?

PIOGGIA DI PAROLE: Para cada ítem abaixo escreva de 3 a 5 palavras, das primeiras que te vierem à mente, sem refletir sobre elas, que te lembrem...

Itália:

italianos (fisicamente):

italianos (psicologicamente):

Muito obrigada pela sua participação!

\section{Arrivederci!}




\section{Anexo E - Resultados da pesquisa geral do IC}

\begin{tabular}{|l|c|c|c|c|c|c|c|c|c|}
\hline \multicolumn{10}{|c|}{ Todos Os ńvels } \\
\hline Faixas etárias pesquisadas & $\begin{array}{c}15-19 \\
\text { anos }\end{array}$ & $\begin{array}{c}20-29 \\
\text { anos }\end{array}$ & $\begin{array}{c}30-39 \\
\text { anos }\end{array}$ & $\begin{array}{c}40-49 \\
\text { anos }\end{array}$ & $\begin{array}{c}50-59 \\
\text { anos }\end{array}$ & $\begin{array}{c}60-69 \\
\text { anos }\end{array}$ & $\begin{array}{c}70-79 \\
\text { anos }\end{array}$ & $\begin{array}{c}\text { S/ } \\
\text { idade }\end{array}$ & $\begin{array}{c}\text { Total de } \\
\text { alunos }\end{array}$ \\
\hline Número de alunos & 6 & 68 & 27 & 28 & 42 & 49 & 10 & 7 & 237 \\
\hline
\end{tabular}

\begin{tabular}{|l|c|c|c|c|c|c|c|c|c|}
\hline sexo & & & & & & & & & Totais \\
\hline feminino & 6 & 47 & 20 & 22 & 36 & 40 & 9 & 4 & 184 \\
\hline masculino & & 21 & 7 & 5 & 6 & 8 & 1 & & 48 \\
\hline não assinalou uma alternativa & & & & 1 & & 1 & & 3 & 5 \\
\hline escolaridade & & & & & & & & & \\
\hline ensino médio incompleto & 1 & & & & & & & & 1 \\
\hline ensino médio completo & & & & 3 & 6 & 6 & 4 & 1 & 20 \\
\hline superior em andamento & 5 & 35 & 2 & & & & & & 42 \\
\hline superior completo & & 19 & 15 & 19 & 28 & 32 & 4 & 2 & 119 \\
\hline mestrado em andamento & & 9 & 1 & 1 & & 1 & & & 12 \\
\hline mestrado completo & & 2 & 4 & 1 & 3 & 7 & 2 & & 19 \\
\hline doutorado em andamento & & 3 & 2 & & 1 & & & & 6 \\
\hline doutorado completo & & & 3 & 3 & 3 & 3 & & 1 & 13 \\
\hline outro & & & & 1 & 1 & & & & 2 \\
\hline Não especificou & & & & & & & & 3 & 3 \\
\hline
\end{tabular}

\begin{tabular}{|c|c|c|c|c|c|c|c|c|c|}
\hline profissão atual & $\begin{array}{c}15-19 \\
\text { anos }\end{array}$ & $\begin{array}{c}20-29 \\
\text { anos }\end{array}$ & $\begin{array}{c}\text { 30-39 } \\
\text { anos }\end{array}$ & $\begin{array}{c}40-49 \\
\text { anos }\end{array}$ & $\begin{array}{c}50-59 \\
\text { anos }\end{array}$ & $\begin{array}{c}\text { 60-69 } \\
\text { anos }\end{array}$ & $\begin{array}{l}70-79 \\
\text { anos }\end{array}$ & $\begin{array}{c}\text { S/ } \\
\text { idade }\end{array}$ & $\begin{array}{c}\text { Total de } \\
\text { alunos }\end{array}$ \\
\hline administrador(a) de empresas & & & 1 & 2 & 1 & & & & 4 \\
\hline administrador(a) hospitalar & & & & & 1 & & & & 1 \\
\hline advogado/a & & & 3 & 1 & 3 & 3 & 1 & & 11 \\
\hline aeronauta & & & & & 1 & & & & 1 \\
\hline agente fiscal de rendas & & & & & & 1 & & & 1 \\
\hline analista contábil financeiro & & & & 1 & & & & & 1 \\
\hline analista de sistemas & & & 1 & 3 & 1 & & & & 5 \\
\hline analista de suporte & & 1 & & & & & & & 1 \\
\hline analista econômico financeiro & & & 1 & & & & & & 1 \\
\hline aposentado/a & & & & & 10 & 24 & 4 & & 38 \\
\hline área de construção civil & & & & & 1 & & & & 1 \\
\hline área financeira & & & & & & 1 & & & 1 \\
\hline arqueólogo/a & & & 1 & & & & & & 1 \\
\hline arquiteto/a & & & 1 & 1 & & & & & 2 \\
\hline artista plástico/a & & & & & & 1 & 1 & & 2 \\
\hline assistente comercial & & 1 & & & & & & & 1 \\
\hline ator/atriz & & & 1 & & & & & & 1 \\
\hline autônomo/a & & & & 1 & & & & & 1 \\
\hline auxiliar de classe & & 1 & & & & & & & 1 \\
\hline bailarino/a & & 1 & & & & & & & 1 \\
\hline bancária/o & & 2 & & & 1 & & & & 3 \\
\hline biólogo/a & & 3 & & & & & & & 3 \\
\hline biomédico/a & & & 1 & & & & & & 1 \\
\hline bioquímico/a & & & & & 1 & & & & 1 \\
\hline booker & & 1 & & & & & & & 1 \\
\hline
\end{tabular}




\begin{tabular}{|c|c|c|c|c|c|c|c|c|c|}
\hline profissão atual & $\begin{array}{c}15-19 \\
\text { anos }\end{array}$ & $\begin{array}{c}20-29 \\
\text { anos }\end{array}$ & $\begin{array}{c}30-39 \\
\text { anos }\end{array}$ & $\begin{array}{c}40-49 \\
\text { anos }\end{array}$ & $\begin{array}{c}\text { 50-59 } \\
\text { anos }\end{array}$ & $\begin{array}{c}\text { 60-69 } \\
\text { anos }\end{array}$ & $\begin{array}{c}70-79 \\
\text { anos }\end{array}$ & $\begin{array}{c}\text { S/ } \\
\text { idade }\end{array}$ & Totais \\
\hline cantor(a)/músico(ista) & & & 1 & & & & & & 1 \\
\hline comerciante & & 1 & & & & & & & 1 \\
\hline consultor & & 1 & & & & & & & 1 \\
\hline $\begin{array}{l}\text { consultor de engenharia de } \\
\text { saneamento ambiental }\end{array}$ & & & & & & 1 & & & 1 \\
\hline consultor(a) ambiental & & & & 1 & & & & & 1 \\
\hline contador(a) & & & & 1 & & & & & 1 \\
\hline coordenadora de compras & & 1 & & & & & & & 1 \\
\hline dentista & & 1 & & & & 1 & & & 2 \\
\hline desempregado & & & & 1 & & & & & 1 \\
\hline desenhista & & & 1 & & & & & & 1 \\
\hline designer & & & & 1 & & & & & 1 \\
\hline dona de casa & & & 1 & & 2 & & 1 & & 4 \\
\hline economista & & & & 1 & & 1 & & & 2 \\
\hline empresário/a & & & & & & & & 1 & 1 \\
\hline enfermeiro/a & & & & & & & & 1 & 1 \\
\hline engenheiro/a & & & 1 & 2 & 2 & 2 & & & 7 \\
\hline engenheiro/a mecânico/a & & & & & 1 & & & & 1 \\
\hline engenheiro/a químico/a & & & & & 1 & & & & 1 \\
\hline estagiário/a & & 3 & & 1 & & & & & 4 \\
\hline estatístico/a & & & & & 1 & & & & 1 \\
\hline esteticista & & & & 1 & & & & & 1 \\
\hline estudante & 6 & 22 & & & & & & & 28 \\
\hline fisioterapeuta & & & 2 & & & & & & 2 \\
\hline fotógrafo/a & & & & 1 & & & & & 1 \\
\hline funcionário público & & & & 1 & 1 & & & & 2 \\
\hline geógrafo/a & & & & & & 1 & & & 1 \\
\hline gerente de processamento de dados & & & 1 & & & & & & 1 \\
\hline gerente de projetos & & & & 1 & & & & & 1 \\
\hline ilustrador(a) & & 1 & & & & & & & 1 \\
\hline jornalista & & 3 & & & & & & & 3 \\
\hline médico/a & & & & & 1 & & & & 1 \\
\hline micro-empresário/a & & & & & 1 & & & & 1 \\
\hline modelista/estilista & & 1 & & & & & 1 & & 2 \\
\hline museólogo/a & & & & & & & 1 & & 1 \\
\hline musicista & & & 1 & & & & & 1 & 2 \\
\hline naturólogo/a & & 1 & & & & & & & 1 \\
\hline nutricionista & & & 1 & & & & & & 1 \\
\hline pedagogo/a & & & 1 & & & 1 & & & 2 \\
\hline pesquisador(a) & & & 1 & & & & & & 1 \\
\hline professor de língua estrangeira & & 4 & 1 & & & & & & 5 \\
\hline professor(a) & & 8 & 2 & 4 & 4 & 10 & & 1 & 29 \\
\hline professora universitária & & & 1 & & 2 & & & & 3 \\
\hline professora universitária aposentada & & & & & & & & 1 & 1 \\
\hline psicopedagogo/a & & & & & & 1 & & & 1 \\
\hline publicitário/a & & 1 & & & & & & & 1 \\
\hline químico/a & & 1 & & & & & & & 1 \\
\hline revisor(a) & & 1 & & & 1 & & & & 2 \\
\hline secretária/o & & & 1 & & 1 & & & & 2 \\
\hline
\end{tabular}




\begin{tabular}{|l|c|c|c|c|c|c|c|c|c|}
\hline profissão atual & $\begin{array}{c}\mathbf{1 5 - 1 9} \\
\text { anos }\end{array}$ & $\begin{array}{c}\mathbf{2 0 - 2 9} \\
\text { anos }\end{array}$ & $\begin{array}{c}\mathbf{3 0 - 3 9} \\
\text { anos }\end{array}$ & $\begin{array}{c}\mathbf{4 0 - 4 9} \\
\text { anos }\end{array}$ & $\begin{array}{c}\mathbf{5 0 - 5 9} \\
\text { anos }\end{array}$ & $\begin{array}{c}\mathbf{6 0 - 6 9} \\
\text { anos }\end{array}$ & $\begin{array}{c}\mathbf{7 0 - 7 9} \\
\text { anos }\end{array}$ & $\begin{array}{c}\text { S/ } \\
\text { idade }\end{array}$ & Totais* \\
\hline técnico/a de laboratório & & & & & 1 & & & & 1 \\
\hline tradutor(a) & & 2 & & 2 & & 1 & & & 5 \\
\hline turismólogo/a & & 1 & & & & & & & 1 \\
\hline veterinário & & 1 & & & & & & & 1 \\
\hline webdesigner & & 3 & 2 & 1 & 3 & & 1 & 2 & 12 \\
\hline não declarou & & & & & 1 & & & 1 \\
\hline *Uma pessoa declarou duas profissões & & & & & \\
\hline
\end{tabular}

\begin{tabular}{|c|c|c|c|c|c|c|c|c|c|}
\hline $\begin{array}{l}\text { 1) } 0 \text { que o/a levou a fazer o curso de } \\
\text { língua italiana? }\end{array}$ & $\begin{array}{l}15-19 \\
\text { anos }\end{array}$ & $\begin{array}{c}20-29 \\
\text { anos }\end{array}$ & $\begin{array}{l}30-39 \\
\text { anos }\end{array}$ & $\begin{array}{c}40-49 \\
\text { anos }\end{array}$ & $\begin{array}{c}50-59 \\
\text { anos }\end{array}$ & $\begin{array}{c}60-69 \\
\text { anos }\end{array}$ & $\begin{array}{l}70-79 \\
\text { anos }\end{array}$ & S/ & Totais \\
\hline "é o melhor para o meu futuro" & 1 & & & & & & & & 1 \\
\hline aprimorar a língua/conhecer melhor & & 1 & & 1 & 1 & 1 & & & 4 \\
\hline $\begin{array}{l}\text { bibliografia do mestrado/ doutorado } \\
\text { em italiano }\end{array}$ & & & 1 & 1 & & & & & 2 \\
\hline busca por atividade social & & & & 1 & 1 & & & & 2 \\
\hline Canta muita música italiana & & & 1 & & & & & 1 & 2 \\
\hline Convive com italianos & & & & & & & 1 & & 1 \\
\hline curiosidade (em conhecer a língua) & 1 & 3 & 1 & & & 1 & & & 6 \\
\hline $\begin{array}{l}\text { Cursa a graduação em italiano e faz IC } \\
\text { como suporte/ complemento }\end{array}$ & & 6 & 1 & & & & & & 7 \\
\hline estuda música & & 1 & & & & & & & 1 \\
\hline estudou em colégio italiano & & 1 & & & & & & & 1 \\
\hline Falar a língua dos antepassados (avós) & & & & 1 & 1 & 3 & & & 5 \\
\hline $\begin{array}{l}\text { Filhos estudam italiano e resolveu } \\
\text { estudar para ajudá-los }\end{array}$ & & & 1 & & & & & & 1 \\
\hline $\begin{array}{l}\text { Foi sorteado (bolsa) dentre outras } \\
\text { línguas/curso que estava disponível }\end{array}$ & & 1 & 1 & & & & & & 2 \\
\hline Gosta da língua/ Acha a língua bonita & 1 & 15 & 6 & 5 & 13 & 5 & & 3 & 48 \\
\hline Gosta da música italiana & 1 & & & 1 & & 1 & 1 & & 4 \\
\hline $\begin{array}{l}\text { Gosta da/tem interesse pela Itália, } \\
\text { da/pela cultura Italiana }\end{array}$ & & 9 & 4 & 5 & 2 & 5 & 4 & 1 & 30 \\
\hline Gosta dos filmes/cinema italianos & & 1 & & & & 1 & & & 2 \\
\hline Hobby/lazer & & 1 & & & & & 1 & & 2 \\
\hline incrementar o currículo & & 1 & & & & & & & 1 \\
\hline influência familiar & 1 & & & & & & & & 1 \\
\hline Interesse (pela língua) & & 3 & 1 & 1 & 1 & & & & 6 \\
\hline interesses acadêmicos & & 1 & & & & & & & 1 \\
\hline $\begin{array}{l}\text { maneira expressiva e gesticuladora da } \\
\text { cultura italiana }\end{array}$ & & 1 & & & & & & & 1 \\
\hline manter a fluência & & & & & 1 & & & & 1 \\
\hline necessidade & & 1 & & & & & & & 1 \\
\hline $\begin{array}{l}\text { necessidade de aprender uma língua } \\
\text { estrangeira (a mais) }\end{array}$ & & 2 & & & & & & & 2 \\
\hline orientador é italiano & & 1 & & & & & & & 1 \\
\hline $\begin{array}{l}\text { Para ativar/manter a memória/atividade } \\
\text { intelectual }\end{array}$ & & & & & 1 & & 1 & & 2 \\
\hline $\begin{array}{l}\text { Para conversar com a irmã, que estuda } \\
\text { italiano }\end{array}$ & & & & & & 1 & & & 1 \\
\hline $\begin{array}{l}\text { Para estudo/proficiência/ aumentar o } \\
\text { conhecimento }\end{array}$ & & 3 & 5 & 1 & & 2 & 1 & & 12 \\
\hline
\end{tabular}




\begin{tabular}{|c|c|c|c|c|c|c|c|c|c|}
\hline $\begin{array}{l}\text { 1) } 0 \text { que o/a levou a fazer o curso de } \\
\text { língua italiana? }\end{array}$ & $\begin{array}{l}15-19 \\
\text { anos }\end{array}$ & $\begin{array}{c}20-29 \\
\text { anos }\end{array}$ & $\begin{array}{l}30-39 \\
\text { anos }\end{array}$ & $\begin{array}{c}40-49 \\
\text { anos }\end{array}$ & $\begin{array}{c}50-59 \\
\text { anos }\end{array}$ & $\begin{array}{c}60-69 \\
\text { anos }\end{array}$ & $\begin{array}{c}70-79 \\
\text { anos }\end{array}$ & S/ & Totais \\
\hline $\begin{array}{l}\text { para ler literatura em italiano/pela } \\
\text { literatura italiana }\end{array}$ & & 3 & 1 & & & & & & 4 \\
\hline para ler textos de arte & & 1 & & & & & & & 1 \\
\hline $\begin{array}{l}\text { Para ler textos em italiano (jornais, } \\
\text { revistas etc) }\end{array}$ & & & & 1 & & & & & 1 \\
\hline Pesquisa sobre imigração & & & & & 1 & & & & 1 \\
\hline ponte com a língua francesa & & 1 & & & & & & & 1 \\
\hline Por causa do doutorado & & & 1 & & & & & & 1 \\
\hline Por causa do mestrado & & & 1 & 1 & & & & & 2 \\
\hline $\begin{array}{l}\text { Porque a família é de origem } \\
\text { italiana/dupla cidadania }\end{array}$ & 1 & 13 & 7 & 10 & 19 & 22 & 2 & 5 & 79 \\
\hline $\begin{array}{l}\text { Porque agora tem tempo para estudar } \\
\text { a língua/ Tempo livre }\end{array}$ & & & & & & 2 & & & 2 \\
\hline Prazer & & & & 1 & 1 & 1 & & & 3 \\
\hline Projeto de mestrado & & 1 & & & & & & & 1 \\
\hline $\begin{array}{l}\text { Razões profissionais/ necessidade } \\
\text { profissional }\end{array}$ & 1 & 3 & 2 & 2 & 3 & 2 & & & 13 \\
\hline $\begin{array}{l}\text { Recordar e exercitar a sua essência } \\
\text { cultural no Brasil }\end{array}$ & & & & 1 & & & & & 1 \\
\hline $\begin{array}{l}\text { Reestudar o italiano (aprendido há } \\
\text { muitos anos) }\end{array}$ & & & & & & 1 & & & 1 \\
\hline $\begin{array}{l}\text { Relembrar o que aprendeu na } \\
\text { graduação }\end{array}$ & & & & 1 & & & & & 1 \\
\hline se comunicar na Itália/Europa(1) & & 1 & 1 & 1 & 3 & & & & 6 \\
\hline $\begin{array}{l}\text { Tem amigos/parentes que moram na } \\
\text { Itália/só falam italiano }\end{array}$ & & & 2 & 2 & 3 & 1 & & & 8 \\
\hline ter acesso a uma cultura estrangeira & & & 1 & & & & & & 1 \\
\hline Usar o curso como terapia & & & & 1 & & & & & 1 \\
\hline Vai/quer morar/estudar na Itália & 1 & 5 & & 1 & 1 & & & & 8 \\
\hline $\begin{array}{l}\text { Viaja constantemente para a Itália } \\
\text { (todo ano) }\end{array}$ & & & & 2 & & & & & 2 \\
\hline $\begin{array}{l}\text { Viajará para a Itália/turismo/ quer } \\
\text { conhecer a Itália }\end{array}$ & & 5 & & 4 & 2 & 6 & & & 17 \\
\hline $\begin{array}{l}\text { Viajará para tirar a cidadania/para tirar } \\
\text { a cidadania }\end{array}$ & & & & 1 & & & & & 1 \\
\hline $\begin{array}{l}\text { Vontade de aprender uma nova } \\
\text { língua/Gosta de aprender línguas }\end{array}$ & & 5 & 3 & 2 & 2 & 5 & 1 & 1 & 19 \\
\hline $\begin{array}{l}\text { Vontade de estudar italiano e aprender } \\
\text { mais sobre a Itália }\end{array}$ & & 4 & 1 & & 1 & 1 & & & 7 \\
\hline Não respondeu & & 2 & & & 1 & 1 & & & 4 \\
\hline
\end{tabular}

\begin{tabular}{|l|c|c|c|c|c|c|c|c|c|}
\hline $\begin{array}{l}\text { 2) Porque o IC e não um } \\
\text { instituto de língua? }\end{array}$ & $\begin{array}{c}\mathbf{1 5 - 1 9} \\
\text { anos }\end{array}$ & $\begin{array}{c}\mathbf{2 0 - 2 9} \\
\text { anos }\end{array}$ & $\begin{array}{c}\mathbf{3 0 - 3 9} \\
\text { anos }\end{array}$ & $\begin{array}{c}\mathbf{4 0 - 4 9} \\
\text { anos }\end{array}$ & $\begin{array}{c}\mathbf{5 0 - 5 9} \\
\text { anos }\end{array}$ & $\begin{array}{c}\mathbf{6 0 - 6 9} \\
\text { anos }\end{array}$ & $\begin{array}{c}\mathbf{7 0 - 7 9} \\
\text { anos }\end{array}$ & $\begin{array}{c}\text { S/ } \\
\text { idade }\end{array}$ & Totais \\
\hline $\begin{array}{l}\text { "proposta de intercambiar c/ outras } \\
\text { unidades no campus cid. universitária" }\end{array}$ & & & & 1 & & & & & 1 \\
\hline a oportunidade & & & 1 & & & 1 & & & 2 \\
\hline acessível & & & & 2 & 2 & & & & 4 \\
\hline alto nível & & & & & & 2 & & & 2 \\
\hline ambiente universitário & & 3 & & & & & & & 3 \\
\hline comodidade & & & 1 & 1 & & & & & 2 \\
\hline $\begin{array}{l}\text { confiança na competência do professor } \\
\text { por ser a USP }\end{array}$ & & & & & & & 1 & 2 \\
\hline
\end{tabular}




\begin{tabular}{|c|c|c|c|c|c|c|c|c|c|}
\hline $\begin{array}{l}\text { 2) Porque o IC e não um } \\
\text { instituto de língua? }\end{array}$ & $\begin{array}{l}15-19 \\
\text { anos }\end{array}$ & $\begin{array}{c}20-29 \\
\text { anos }\end{array}$ & $\begin{array}{l}30-39 \\
\text { anos }\end{array}$ & $\begin{array}{c}40-49 \\
\text { anos }\end{array}$ & $\begin{array}{c}50-59 \\
\text { anos }\end{array}$ & $\begin{array}{c}60-69 \\
\text { anos }\end{array}$ & $\begin{array}{l}70-79 \\
\text { anos }\end{array}$ & S/ & Totais \\
\hline confiança na USP & & & & & & 2 & & & 2 \\
\hline confiança nos professores & & 1 & & & & & & & 1 \\
\hline convênio com o Estado & & 1 & & 2 & & & & & 3 \\
\hline costuma frequentar os cursos da USP & & & & 1 & & & & & 1 \\
\hline credibilidade & & & & & 1 & & & & 1 \\
\hline curiosidade & & & & 1 & 1 & & & & 2 \\
\hline curso bem estruturado & & & & & 1 & & & & 1 \\
\hline curso bem monitorado & & & & & & & 1 & & 1 \\
\hline curso muito acadêmico/sério & & 2 & & 2 & & & & & 4 \\
\hline Custo-benefício & & 1 & 1 & & 1 & & & & 3 \\
\hline $\begin{array}{l}\text { encontrou o curso na internet e se } \\
\text { interessou }\end{array}$ & & & 1 & & 1 & 1 & & & 3 \\
\hline gostou das aulas dos primeiros níveis & & 1 & & & & & & & 1 \\
\hline incentivo de parentes (que estudam) & & & & & & 1 & & & 1 \\
\hline $\begin{array}{l}\text { indicação (de amigos, colegas, ex- } \\
\text { monitores) }\end{array}$ & 1 & 5 & 2 & 4 & 6 & 4 & 1 & 1 & 24 \\
\hline $\begin{array}{l}\text { já fez outros cursos de idiomas "no } \\
\text { campus" e gostou }\end{array}$ & & & & 1 & & 6 & & 1 & 8 \\
\hline já tinha "ouvido falar" do curso & & 2 & & 1 & & & 1 & & 4 \\
\hline $\begin{array}{l}\text { já tinha feito o curso em instituto e } \\
\text { queria aprofundá-lo }\end{array}$ & & & & & 1 & & & & 1 \\
\hline localização & 3 & 18 & 7 & 8 & 12 & 16 & 3 & 1 & 68 \\
\hline mais completo/eficiente & & 1 & & & & & 1 & & 2 \\
\hline $\begin{array}{l}\text { mais interessante por reunir pessoas } \\
\text { várias }\end{array}$ & & & & & & 1 & & & 1 \\
\hline não pesquisou antes & & 1 & & & & & & & 1 \\
\hline nível dos professores & & & & 1 & & 1 & & & 2 \\
\hline nome (o curso "tem nome") & & & & & 1 & & & & 1 \\
\hline $\begin{array}{l}\text { O Italiano no Campus é um curso mais } \\
\text { dinâmico }\end{array}$ & & & 1 & & & & & & 1 \\
\hline $\begin{array}{l}\text { oportunidade de trocar experiência } \\
\text { com o pessoal da universidade }\end{array}$ & & & 1 & & & & & & 1 \\
\hline Pela facilidade (não especifica do que) & & 1 & & & & & & & 1 \\
\hline Pela formação dos professores & & & & 1 & & & 1 & & 2 \\
\hline $\begin{array}{l}\text { pelo fato de material didático e } \\
\text { método serem semelhantes aos de } \\
\text { Institutos }\end{array}$ & & & 1 & & & 1 & & & 2 \\
\hline $\begin{array}{l}\text { poder fazer o curso na hora do } \\
\text { almoço/os horários }\end{array}$ & & 3 & 2 & 3 & 3 & 2 & & & 13 \\
\hline por fazer a graduação & & & 1 & & & & & & 1 \\
\hline Por oferecer vagas gratuitas & & & & 1 & & 1 & 1 & & 3 \\
\hline $\begin{array}{l}\text { Por oferecer vagas gratuitas para a } \\
\text { terceira idade }\end{array}$ & & & & & & 1 & 1 & & 2 \\
\hline por ser na USP & & 2 & 2 & 2 & 1 & 2 & & & 9 \\
\hline $\begin{array}{l}\text { por ser o responsável pelo exame de } \\
\text { proficiência da faculdade de direito }\end{array}$ & & & 1 & & & & & & 1 \\
\hline $\begin{array}{l}\text { por ser parte do programa de } \\
\text { formação de alunos }\end{array}$ & & & & & 1 & & & & 1 \\
\hline $\begin{array}{l}\text { porque a formação dos professores é } \\
\text { superior a de outros cursos }\end{array}$ & & 1 & & & & & & & 1 \\
\hline
\end{tabular}




\begin{tabular}{|c|c|c|c|c|c|c|c|c|c|}
\hline $\begin{array}{l}\text { 2) Porque o IC e não um } \\
\text { instituto de língua? }\end{array}$ & $\begin{array}{l}15-19 \\
\text { anos }\end{array}$ & $\begin{array}{c}20-29 \\
\text { anos }\end{array}$ & $\begin{array}{l}30-39 \\
\text { anos }\end{array}$ & $\begin{array}{c}40-49 \\
\text { anos }\end{array}$ & $\begin{array}{c}50-59 \\
\text { anos }\end{array}$ & $\begin{array}{c}60-69 \\
\text { anos }\end{array}$ & $\begin{array}{l}70-79 \\
\text { anos }\end{array}$ & S/ & Totais \\
\hline $\begin{array}{l}\text { porque alguém da família estuda/é da } \\
\text { USP }\end{array}$ & & & & & 1 & 1 & 1 & 1 & 4 \\
\hline porque conseguiu bolsa & & & 1 & & & & & & 1 \\
\hline $\begin{array}{l}\text { porque estuda na USP/facilidade de já } \\
\text { estar na USP/trabalha na USP }\end{array}$ & 4 & 21 & 6 & 7 & 5 & 1 & & & 44 \\
\hline $\begin{array}{l}\text { porque os professores são estudantes } \\
\text { de pós da Instituição }\end{array}$ & & 1 & & & & & & & 1 \\
\hline $\begin{array}{l}\text { possibilidade de conviver com } \\
\text { estudantes da USP }\end{array}$ & & & & & & 1 & & & 1 \\
\hline preço & 3 & 42 & 9 & 15 & 12 & 14 & 5 & 2 & 102 \\
\hline preço acessível para a terceira idade & & & & & & 1 & & & 1 \\
\hline $\begin{array}{l}\text { preço porque faz a habilitação em } \\
\text { italiano }\end{array}$ & & 1 & & & & & & & 1 \\
\hline professores geralmente são ótimos & & 2 & & & 3 & 2 & & & 7 \\
\hline $\begin{array}{l}\text { prox. afetiva com a USP/FFLCH - foi } \\
\text { aluno/a, professor ou func. da USP }\end{array}$ & & 1 & & & 3 & 3 & & & 7 \\
\hline qualidade & 1 & 9 & 1 & 4 & 9 & 11 & 2 & 3 & 40 \\
\hline seriedade por ser em Universidade & & & & & 1 & 1 & 1 & & 3 \\
\hline $\begin{array}{l}\text { tempo de duração do curso em relação } \\
\text { a outros da USP }\end{array}$ & & 1 & & & & & & & 1 \\
\hline Não respondeu & & 2 & & 1 & & 1 & 1 & & 5 \\
\hline
\end{tabular}

\begin{tabular}{|l|c|c|c|c|c|c|c|c|c|}
\hline $\begin{array}{l}\text { 3) Frequenta outros cursos "extra- } \\
\text { curriculares" no momento? }\end{array}$ & $\begin{array}{c}\mathbf{1 5 - 1 9} \\
\text { anos }\end{array}$ & $\begin{array}{c}\mathbf{2 0 - 2 9} \\
\text { anos }\end{array}$ & $\begin{array}{c}\mathbf{3 0 - 3 9} \\
\text { anos }\end{array}$ & $\begin{array}{c}\mathbf{4 0 - 4 9} \\
\text { anos }\end{array}$ & $\begin{array}{c}\mathbf{5 0 - 5 9} \\
\text { anos }\end{array}$ & $\begin{array}{c}\mathbf{6 0 - 6 9} \\
\text { anos }\end{array}$ & $\begin{array}{c}\mathbf{7 0 - 7 9} \\
\text { anos }\end{array}$ & $\begin{array}{c}\text { S/ } \\
\text { idade }\end{array}$ & Totais \\
\hline Sim & 3 & 20 & 6 & 7 & 12 & 11 & 3 & 2 & 64 \\
\hline Não & 3 & 47 & 21 & 21 & 30 & 37 & 7 & 5 & 171 \\
\hline Quantos? & & & & & & & & & \\
\hline 1 & 2 & 14 & 5 & 5 & 10 & 9 & 2 & & 47 \\
\hline 2 & 1 & 4 & 1 & 1 & 2 & 1 & & 1 & 11 \\
\hline 3 ou mais & & 2 & & 1 & & 1 & 1 & & 5 \\
\hline Não especificou & & & & & & & & 1 & 1 \\
\hline
\end{tabular}

\begin{tabular}{|l|c|c|c|c|c|c|c|c|c|}
\hline $\begin{array}{l}\text { 4) Na sua opinião, qual o número } \\
\text { ideal de estudantes por grupo? }\end{array}$ & $\begin{array}{c}\mathbf{1 5 - 1 9} \\
\text { anos }\end{array}$ & $\begin{array}{c}\mathbf{2 0 - 2 9} \\
\text { anos }\end{array}$ & $\begin{array}{c}\mathbf{3 0 - 3 9} \\
\text { anos }\end{array}$ & $\begin{array}{c}\mathbf{4 0 - 4 9} \\
\text { anos }\end{array}$ & $\begin{array}{c}\mathbf{5 0 - 5 9} \\
\text { anos }\end{array}$ & $\begin{array}{c}\mathbf{6 0 - 6 9} \\
\text { anos }\end{array}$ & $\begin{array}{c}\mathbf{7 0 - 7 9} \\
\text { anos }\end{array}$ & $\begin{array}{c}\text { S/ } \\
\text { idade }\end{array}$ & Totais \\
\hline 5 & & 1 & & & & & & & 1 \\
\hline 7 & 1 & 2 & 2 & 1 & & & & & 6 \\
\hline 8 & & 7 & 1 & 4 & 5 & 4 & & 1 & 22 \\
\hline 10 & & 1 & 1 & & 2 & & 1 & & 5 \\
\hline 12 & & & & & & 1 & & & 1 \\
\hline 14 & & 5 & 3 & 2 & 1 & 8 & & 2 & 21 \\
\hline 15 & & & & & & 1 & & & 1 \\
\hline 18 & & 3 & 4 & 1 & 4 & 3 & & 1 & 16 \\
\hline 20 & & & 1 & & & & 2 & & 3 \\
\hline 25 & & 1 & & & & & & & 1 \\
\hline "Não importa" & & 1 & & 1 & & & & & 2 \\
\hline+ ou - 10 & & & & & & & & & 0 \\
\hline+ ou - 12 & 3 & 1 & 2 & 1 & 1 & 1 & & & 9 \\
\hline+ ou - 15 & & & & & & & & \\
\hline
\end{tabular}




\begin{tabular}{|c|c|c|c|c|c|c|c|c|c|}
\hline $\begin{array}{l}\text { 4) Na sua opinião, qual o número } \\
\text { ideal de estudantes por grupo? }\end{array}$ & $\begin{array}{l}15-19 \\
\text { anos }\end{array}$ & $\begin{array}{c}20-29 \\
\text { anos }\end{array}$ & $\begin{array}{l}30-39 \\
\text { anos }\end{array}$ & $\begin{array}{c}40-49 \\
\text { anos }\end{array}$ & $\begin{array}{c}50-59 \\
\text { anos }\end{array}$ & $\begin{array}{c}60-69 \\
\text { anos }\end{array}$ & $\begin{array}{l}\text { 70-79 } \\
\text { anos }\end{array}$ & $\begin{array}{c}\text { S/ } \\
\text { idade }\end{array}$ & Totais \\
\hline+ ou -20 & & 1 & & & 2 & 1 & & & 4 \\
\hline+ ou -25 & & 1 & & & & & & & 1 \\
\hline 6 ou $8 / 6$ a 8 & & & 1 & 1 & & & & & 2 \\
\hline 8 ou 10 & & 1 & & & & & & & 1 \\
\hline De 10 a 12 & & & & & & 2 & & 1 & 3 \\
\hline De 10 a 15 & & 6 & 2 & 3 & 2 & 7 & 2 & & 22 \\
\hline De 10 a 20 & & & & & & 1 & & & 1 \\
\hline De 12 a 18 & & 1 & & & & & & & 1 \\
\hline De 12 a 20 & & & & 1 & & & & & 1 \\
\hline De 15 a 18 & & & & & 1 & & & & 1 \\
\hline De 15 a 20 & 1 & 8 & 2 & & 5 & 2 & 2 & & 20 \\
\hline De 18 a 24 & & & & & 1 & & & & 1 \\
\hline De 20 a 25 & & 1 & & & 2 & 4 & & 1 & 8 \\
\hline De 25 a 30 & & & & 1 & & & & & 1 \\
\hline De 4 a 6 & & & 1 & & & & & & 1 \\
\hline De 5 a 10 & & 1 & 1 & & & & & & 2 \\
\hline De 5 a 7 & & 1 & & & & & & & 1 \\
\hline De 8 a 10 & & 1 & & & 1 & & & 1 & 3 \\
\hline Máximo 10 & & 11 & 1 & 1 & 4 & 2 & & & 19 \\
\hline Máximo 12 & & & & & & 2 & & & 2 \\
\hline Máximo 15 & 1 & 4 & 4 & 4 & 5 & 3 & 1 & & 22 \\
\hline Máximo 16 & & & & 1 & & & & & 1 \\
\hline Máximo 18 & & 1 & & & & 1 & & & 2 \\
\hline Máximo 20 & & 4 & 1 & 2 & 4 & 4 & & 1 & 16 \\
\hline Máximo 25 & & 1 & & & 1 & 2 & & & 4 \\
\hline Máximo 30 & & & & 1 & & & & & 1 \\
\hline Mínimo 25 & & & & & & & & & 0 \\
\hline não entendeu a pergunta... & & & & 1 & & & & & 1 \\
\hline Não especificou & & & & 2 & & & 1 & & 3 \\
\hline
\end{tabular}

\begin{tabular}{|l|c|c|c|c|c|c|c|c|c|}
\hline 5) O que acha do ritmo das aulas? & $\begin{array}{c}\mathbf{1 5 - 1 9} \\
\text { anos }\end{array}$ & $\begin{array}{c}\mathbf{2 0 - 2 9} \\
\text { anos }\end{array}$ & $\begin{array}{c}\mathbf{3 0 - 3 9} \\
\text { anos }\end{array}$ & $\begin{array}{c}\mathbf{4 0 - 4 9} \\
\text { anos }\end{array}$ & $\begin{array}{c}\mathbf{5 0 - 5 9} \\
\text { anos }\end{array}$ & $\begin{array}{c}\mathbf{6 0 - 6 9} \\
\text { anos }\end{array}$ & $\begin{array}{c}\mathbf{7 0 - 7 9} \\
\text { anos }\end{array}$ & $\begin{array}{c}\text { S/ } \\
\text { idade }\end{array}$ & Totais \\
\hline lento & 5 & 59 & 21 & 23 & 34 & 46 & 9 & 7 & 204 \\
\hline bom & 1 & 2 & & 3 & 5 & 1 & 1 & & 13 \\
\hline acelerado & & 2 & 4 & & & & & & 6 \\
\hline Invalidada (mais de uma opção) & & & & & & 1 & & & 1 \\
\hline Não marcou alternativa & & & & & & & & & 13 \\
\hline
\end{tabular}

\begin{tabular}{|l|c|c|c|c|c|c|c|c|c|}
\hline $\begin{array}{l}\text { 6) Acha que o ritmo deveria ser } \\
\text { outro? }\end{array}$ & $\begin{array}{c}\mathbf{1 5 - 1 9} \\
\text { anos }\end{array}$ & $\begin{array}{c}\mathbf{2 0 - 2 9} \\
\text { anos }\end{array}$ & $\begin{array}{c}\mathbf{3 0 - 3 9} \\
\text { anos }\end{array}$ & $\begin{array}{c}\mathbf{4 0 - 4 9} \\
\text { anos }\end{array}$ & $\begin{array}{c}\mathbf{5 0 - 5 9} \\
\text { anos }\end{array}$ & $\begin{array}{c}\mathbf{6 0 - 6 9} \\
\text { anos }\end{array}$ & $\begin{array}{c}\mathbf{7 0 - 7 9} \\
\text { anos }\end{array}$ & $\begin{array}{c}\text { S/ } \\
\text { idade }\end{array}$ & Totais \\
\hline Sim & & 16 & 5 & 5 & 8 & 2 & 1 & & 37 \\
\hline Não & 6 & 51 & 21 & 21 & 33 & 44 & 9 & 6 & 191 \\
\hline Não marcou alternativa & & 1 & 1 & 2 & 1 & 3 & & 1 & 9 \\
\hline
\end{tabular}




\begin{tabular}{|l|c|c|c|c|c|c|c|c|c|}
\hline $\begin{array}{l}\text { 7) Com qual desses pontos você tem } \\
\text { mais dificuldade? }\end{array}$ & $\begin{array}{c}\mathbf{1 5 - 1 9} \\
\text { anos }\end{array}$ & $\begin{array}{c}\mathbf{2 0 - 2 9} \\
\text { anos }\end{array}$ & $\begin{array}{c}\mathbf{3 0 - 3 9} \\
\text { anos }\end{array}$ & $\begin{array}{c}\mathbf{4 0 - 4 9} \\
\text { anos }\end{array}$ & $\begin{array}{c}\mathbf{5 0 - 5 9} \\
\text { anos }\end{array}$ & $\begin{array}{c}\mathbf{6 0 - 6 9} \\
\text { anos }\end{array}$ & $\begin{array}{c}\mathbf{7 0 - 7 9} \\
\text { anos }\end{array}$ & $\begin{array}{c}\text { S/ } \\
\text { idade }\end{array}$ & Totais \\
\hline produção oral & 3 & 44 & 14 & 20 & 24 & 36 & 7 & 4 & 151 \\
\hline produção escrita & & 2 & & 1 & 1 & 2 & & & 6 \\
\hline leitura & 1 & 14 & 6 & 6 & 13 & 14 & 2 & 2 & 58 \\
\hline gramática & & & 1 & & & & 1 & & 2 \\
\hline não assinalou nenhuma alternativa & & 1 & 1 & & & & & 2 \\
\hline $\begin{array}{l}\text { marcou todas as alternativas (ou mais } \\
\text { de 2) }\end{array}$ & & & & & & & & 2 \\
\hline
\end{tabular}

\begin{tabular}{|c|c|c|c|c|c|c|c|c|c|}
\hline $\begin{array}{l}\text { 8) } 0 \text { que faria, ou gostaria que fosse } \\
\text { feito, para melhorar isso? }\end{array}$ & $\begin{array}{l}15-19 \\
\text { anos }\end{array}$ & $\begin{array}{c}20-29 \\
\text { anos }\end{array}$ & $\begin{array}{l}30-39 \\
\text { anos }\end{array}$ & $\begin{array}{c}40-49 \\
\text { anos }\end{array}$ & $\begin{array}{c}50-59 \\
\text { anos }\end{array}$ & $\begin{array}{l}60-69 \\
\text { anos }\end{array}$ & $\begin{array}{l}\text { 70-79 } \\
\text { anos }\end{array}$ & $\begin{array}{c}\text { S/ } \\
\text { idade }\end{array}$ & Totais \\
\hline \multicolumn{10}{|l|}{ produção escrita } \\
\hline $\begin{array}{l}\text { Mais treino/ Mais exercícios/estudar } \\
\text { mais }\end{array}$ & & 2 & 2 & 2 & 4 & 1 & & & 11 \\
\hline aprimorar a conversação & & & & & & & & 1 & 1 \\
\hline $\begin{array}{l}\text { aulas reforçadas com memorização de } \\
\text { regras gramaticais }\end{array}$ & 1 & & & & & & & & 1 \\
\hline criação de textos, cartas/escrever mais & & 6 & 4 & 2 & 2 & 3 & & & 17 \\
\hline ler mais & & & & & 2 & & & & 2 \\
\hline mais aprofundamento gramatical & & & & & 1 & & & & 1 \\
\hline mais leitura & & 3 & & & & 1 & 1 & & 5 \\
\hline mais música & & & & & & & 1 & & 1 \\
\hline mais revisões de pontos gramaticais & & 1 & & & & & & & 1 \\
\hline $\begin{array}{l}\text { Mais tempo para exercícios/para } \\
\text { estudar }\end{array}$ & & 1 & & & 1 & 1 & & & 3 \\
\hline menos acelerado (ritmo das aulas) & & & & 1 & 1 & & & & 2 \\
\hline mudaria a metodologia do curso & 1 & & & & & & & & 1 \\
\hline reduzir o número de alunos & & & & & 1 & & & & 1 \\
\hline \multicolumn{10}{|l|}{ gramática } \\
\hline "mais gramática explícita" & & & 2 & & & & & & 2 \\
\hline dificuldade pessoal & & 1 & & & & & & & 1 \\
\hline $\begin{array}{l}\text { exercícios diferenciados (imagens, } \\
\text { multimídia etc) }\end{array}$ & & 1 & 1 & & & & & & 2 \\
\hline ler mais, estudar mais & & 5 & 1 & & 2 & 1 & & & 9 \\
\hline mais atividades dissertativas & & & & 1 & & & & & 1 \\
\hline mais exercício oral & & & & & 1 & 1 & 1 & & 3 \\
\hline mais exercícios & & & 1 & 1 & 1 & 2 & & & 5 \\
\hline mais exercícios escritos em sala & & & & & 1 & 1 & & & 2 \\
\hline $\begin{array}{l}\text { mais explicações sobre a estrutura } \\
\text { gramatical }\end{array}$ & & 1 & & & & & & & 1 \\
\hline $\begin{array}{l}\text { mais leituras e exercícios aplicados em } \\
\text { textos interessantes }\end{array}$ & & 1 & & & & & & & 1 \\
\hline mais tempo & 1 & 1 & & & 1 & & & & 3 \\
\hline $\begin{array}{l}\text { mais tempo de aula expositiva só para } \\
\text { gramática }\end{array}$ & & & & & 2 & & & & 2 \\
\hline material de apoio & & & & & 1 & & & 1 & 2 \\
\hline melhorar a didática & & & & & & 1 & & & 1 \\
\hline menos acelerado (aulas) & & & & 1 & 1 & & & & 2 \\
\hline $\begin{array}{l}\text { professores mais exigentes que } \\
\text { incentivassem mais os alunos }\end{array}$ & & 1 & 1 & & & & & & 2 \\
\hline reduzir o número de alunos & & & 1 & & 1 & & & & 2 \\
\hline
\end{tabular}




\begin{tabular}{|c|c|c|c|c|c|c|c|c|c|}
\hline $\begin{array}{l}\text { 8) O que faria, ou gostaria que fosse } \\
\text { feito, para melhorar isso? }\end{array}$ & $\begin{array}{l}15-19 \\
\text { anos }\end{array}$ & $\begin{array}{c}20-29 \\
\text { anos }\end{array}$ & $\begin{array}{l}30-39 \\
\text { anos }\end{array}$ & $\begin{array}{c}40-49 \\
\text { anos }\end{array}$ & $\begin{array}{c}50-59 \\
\text { anos }\end{array}$ & $\begin{array}{c}60-69 \\
\text { anos }\end{array}$ & $\begin{array}{c}70-79 \\
\text { anos }\end{array}$ & S/ & Totais \\
\hline \multicolumn{10}{|l|}{ produção oral } \\
\hline Depende de deixar a vergonha de lado & 1 & 2 & & & 2 & 2 & & & 7 \\
\hline $\begin{array}{l}10 \text { min./aula de conversação livre, s/ } \\
\text { preocupação c/ correções imediatas }\end{array}$ & & & & & & 1 & & & 1 \\
\hline aulas extra de conversação & & 1 & & 1 & & 1 & & & 3 \\
\hline cobraria mais entrega de atividades & & 1 & & & & & & & 1 \\
\hline conversas avaliadas de perto & & 2 & & & & & & & 2 \\
\hline curso específico de conversação & & 2 & 2 & 3 & 3 & 3 & 1 & & 14 \\
\hline Dificuldade natural & & 1 & 1 & & & & 1 & & 3 \\
\hline $\begin{array}{l}\text { dificuldade pessoal/ depende de } \\
\text { dedicação }\end{array}$ & & 5 & 2 & 2 & 4 & 2 & & & 15 \\
\hline discussão de temas com prep. prévia & & 2 & & & & & & & 2 \\
\hline discussão de temas sem prep. prévia & & & & & & & & & 0 \\
\hline ditados & & & & & 1 & & & & 1 \\
\hline elucidar a técnica para estudar mais & & & & & & 1 & & & 1 \\
\hline encenações/apresentações em grupo & & 1 & 2 & & & 2 & & & 5 \\
\hline $\begin{array}{l}\text { exercícios de leitura em voz alta para } \\
\text { treinar a pronúncia/fonética }\end{array}$ & & 3 & & & 2 & & & & 5 \\
\hline exercícios gramaticais supervisionados & & & & 1 & & & & & 1 \\
\hline $\begin{array}{l}\text { explorar mais conversação com temas } \\
\text { do cotidiano }\end{array}$ & & & & 2 & & & & & 2 \\
\hline laboratório & & 1 & & & & 1 & & & 2 \\
\hline mais atividades eficientes & & & & & & 1 & & & 1 \\
\hline mais correção & & 1 & & & & & & & 1 \\
\hline mais exercícios em dupla & & & & & & & & & 0 \\
\hline mais jogos & & 1 & & 1 & & & & & 2 \\
\hline mais leitura e interpretação & & & & & & 1 & & & 1 \\
\hline $\begin{array}{l}\text { mais oportunidades de conversação } \\
\text { com o prof., não só com colegas }\end{array}$ & & 1 & & 1 & & & & & 2 \\
\hline $\begin{array}{l}\text { Mais oportunidades de conversação na } \\
\text { sala de aula (c/ supervisão) }\end{array}$ & & 2 & 2 & 3 & & & & & 7 \\
\hline $\begin{array}{l}\text { mais perguntas do prof., obrigando o } \\
\text { aluno a falar/mais estímulo do prof. }\end{array}$ & & 1 & & 1 & & & & & 2 \\
\hline mais prática oral & & 11 & 1 & 3 & 7 & 8 & 3 & 1 & 34 \\
\hline $\begin{array}{l}\text { Mais tempo para exercícios/para } \\
\text { estudar }\end{array}$ & & 1 & 1 & & 1 & & & & 3 \\
\hline $\begin{array}{l}\text { Mais treino/Mais exercícios/estudar } \\
\text { mais }\end{array}$ & 1 & 2 & 1 & 1 & 1 & & & & 6 \\
\hline melhores aparelhos de áudio p/ ascolto & & 1 & & & & & & & 1 \\
\hline menos alunos & & 3 & & 1 & & 1 & & & 5 \\
\hline não fazer apresentações & & & & & & & & 1 & 1 \\
\hline $\begin{array}{l}\text { ouvir antes de falar/ascolto antes da } \\
\text { produção oral }\end{array}$ & & 1 & & & 1 & 2 & 1 & & 5 \\
\hline ter mais oportunidade de se expressar & & & & & 1 & 1 & & & 2 \\
\hline Treinar mais em casa & & 1 & 2 & & & & & & 3 \\
\hline $\begin{array}{l}\text { usar recursos multimídia: filmes, } \\
\text { canções etc. }\end{array}$ & & 2 & 1 & 2 & 1 & 1 & & 1 & 8 \\
\hline \multicolumn{10}{|l|}{ leitura } \\
\hline mais dedicação & & 1 & & & & & & & 1 \\
\hline $\begin{array}{l}\text { mais material extra (jornais, livros, } \\
\text { músicas) }\end{array}$ & & & & 1 & & & & & 1 \\
\hline
\end{tabular}




\begin{tabular}{|c|c|c|c|c|c|c|c|c|c|}
\hline $\begin{array}{l}\text { 9) Que assunto você gostaria que } \\
\text { fosse mais trabalhado em sala? }\end{array}$ & $\begin{array}{l}15-19 \\
\text { anos }\end{array}$ & $\begin{array}{c}20-29 \\
\text { anos }\end{array}$ & $\begin{array}{l}30-39 \\
\text { anos }\end{array}$ & $\begin{array}{c}40-49 \\
\text { anos }\end{array}$ & $\begin{array}{c}50-59 \\
\text { anos }\end{array}$ & $\begin{array}{l}60-69 \\
\text { anos }\end{array}$ & $\begin{array}{l}70-79 \\
\text { anos }\end{array}$ & $\begin{array}{c}\text { S/ } \\
\text { idade }\end{array}$ & Totais \\
\hline arquitetura & & 1 & & & & & & & 1 \\
\hline arte & 1 & 23 & 8 & 4 & 12 & 14 & 3 & 3 & 68 \\
\hline atualidades & & 1 & & 2 & & 2 & & & 5 \\
\hline $\begin{array}{l}\text { cantar na aula (música com letra - } \\
\text { fonética) }\end{array}$ & & & & & 1 & & & & 1 \\
\hline ciência & & 1 & & & & & & & 1 \\
\hline cinema & 3 & 32 & 13 & 5 & 10 & 12 & 3 & 1 & 79 \\
\hline conhecimentos gerais & & & & & 1 & & & & 1 \\
\hline costumes & & 2 & 1 & 1 & & & & & 4 \\
\hline cotidiano (temas do livro) & & 2 & & 1 & 1 & 1 & & & 5 \\
\hline culinária & & 5 & 6 & 4 & 7 & 6 & 1 & & 29 \\
\hline cultura & & 7 & 3 & & 2 & 1 & & & 13 \\
\hline esportes & 1 & 6 & 1 & & 1 & & & & 9 \\
\hline filosofia & & 1 & 3 & 3 & 1 & 2 & 1 & 1 & 12 \\
\hline geografia & & & 3 & & 1 & 1 & 1 & & 6 \\
\hline gramática & & 8 & 9 & 7 & 8 & 6 & 2 & 3 & 43 \\
\hline história & 4 & 27 & 10 & 8 & 12 & 21 & 4 & 3 & 89 \\
\hline leitura & & & & & 1 & & & & 1 \\
\hline literatura & & 6 & & & & 2 & & & 8 \\
\hline meio ambiente & & 1 & & & & & & & 1 \\
\hline mitologia & & 1 & 1 & & & & & & 2 \\
\hline moda & & 1 & & & & & & & 1 \\
\hline música & 3 & 35 & 13 & 10 & 14 & 13 & 4 & 3 & 95 \\
\hline política & & & & & & 1 & & & 1 \\
\hline produção oral & & & & 1 & 1 & & & & 2 \\
\hline profissões & & 1 & & & & & & & 1 \\
\hline temas específicos das pesquisas & & & & 1 & & & & & 1 \\
\hline textos de humanidades & & 1 & & & & & & & 1 \\
\hline todos/de tudo um pouco & & 6 & 3 & 6 & 10 & 7 & 1 & & 33 \\
\hline indiferente & & & & & 1 & & & & 1 \\
\hline $\begin{array}{l}\text { acha mais importante o uso da língua } \\
\text { do que os assuntos }\end{array}$ & & 1 & & & & & & & 1 \\
\hline
\end{tabular}

\begin{tabular}{|l|c|c|c|c|c|c|c|c|c|}
\hline $\begin{array}{l}\text { 10) Como é seu relacionamento com } \\
\text { os colegas do grupo? }\end{array}$ & $\begin{array}{c}\mathbf{1 5 - 1 9} \\
\text { anos }\end{array}$ & $\begin{array}{c}\mathbf{2 0 - 2 9} \\
\text { anos }\end{array}$ & $\begin{array}{c}\mathbf{3 0 - 3 9} \\
\text { anos }\end{array}$ & $\begin{array}{c}\mathbf{4 0 - 4 9} \\
\text { anos }\end{array}$ & $\begin{array}{c}\mathbf{5 0 - 5 9} \\
\text { anos }\end{array}$ & $\begin{array}{c}\mathbf{6 0 - 6 9} \\
\text { anos }\end{array}$ & $\begin{array}{c}\mathbf{7 0 - 7 9} \\
\text { anos }\end{array}$ & $\begin{array}{c}\text { S/ } \\
\text { idade }\end{array}$ & Totais \\
\hline ruim & & & & & & & & & 0 \\
\hline razoável & 4 & 28 & 14 & 9 & 19 & 20 & 3 & 1 & 98 \\
\hline bom & 2 & 17 & 9 & 10 & 13 & 15 & 2 & 2 & 70 \\
\hline muito bom & & 19 & 3 & 4 & 9 & 12 & 5 & 1 & 53 \\
\hline ótimo & & & & & & & & & 1 \\
\hline
\end{tabular}

\begin{tabular}{|l|c|c|c|c|c|c|c|c|c|}
\hline $\begin{array}{l}\text { 12) Você dividiria os grupos por } \\
\text { faixas etárias? }\end{array}$ & $\begin{array}{c}\mathbf{1 5 - 1 9} \\
\text { anos }\end{array}$ & $\begin{array}{c}\mathbf{2 0 - 2 9} \\
\text { anos }\end{array}$ & $\begin{array}{c}\mathbf{3 0 - 3 9} \\
\text { anos }\end{array}$ & $\begin{array}{c}\mathbf{4 0 - 4 9} \\
\text { anos }\end{array}$ & $\begin{array}{c}\mathbf{5 0 - 5 9} \\
\text { anos }\end{array}$ & $\begin{array}{c}\mathbf{6 0 - 6 9} \\
\text { anos }\end{array}$ & $\begin{array}{c}\mathbf{7 0 - 7 9} \\
\text { anos }\end{array}$ & $\begin{array}{c}\text { S/ } \\
\text { idade }\end{array}$ & Totais \\
\hline Sim & 1 & 5 & 4 & 1 & 4 & & & 1 & 16 \\
\hline Não & 5 & 62 & 23 & 23 & 37 & 48 & 10 & 4 & 212 \\
\hline Depende & & & & & 1 & & & & 1 \\
\hline Não sabe & & & & 1 & & & & & 1 \\
\hline Não o nível 1 & & 1 & & & & & & & 1 \\
\hline
\end{tabular}




\begin{tabular}{|l|c|c|c|c|c|c|c|c|c|}
\hline $\begin{array}{l}\text { 13) Você gostaria de ter um grupo } \\
\text { só com pessoas da sua idade? }\end{array}$ & $\begin{array}{c}\mathbf{1 5 - 1 9} \\
\text { anos }\end{array}$ & $\begin{array}{c}\mathbf{2 0 - 2 9} \\
\text { anos }\end{array}$ & $\begin{array}{c}\mathbf{3 0 - 3 9} \\
\text { anos }\end{array}$ & $\begin{array}{c}\mathbf{4 0 - 4 9} \\
\text { anos }\end{array}$ & $\begin{array}{c}\mathbf{5 0 - 5 9} \\
\text { anos }\end{array}$ & $\begin{array}{c}\mathbf{6 0 - 6 9} \\
\text { anos }\end{array}$ & $\begin{array}{c}\mathbf{7 0 - 7 9} \\
\text { anos }\end{array}$ & $\begin{array}{c}\text { S/ } \\
\text { idade }\end{array}$ & Totais \\
\hline Sim & 1 & 7 & & 2 & 1 & 1 & & & 12 \\
\hline Não & 5 & 57 & 27 & 23 & 39 & 47 & 8 & 4 & 210 \\
\hline Depende & & & & & & & & & 0 \\
\hline Não sabe & & 3 & & & & & & & 3 \\
\hline Tanto faz & & & & & 1 & & 1 & 1 & 3 \\
\hline Não escolheu nenhuma alternativa & & & & 1 & & & & 1 \\
\hline
\end{tabular}

\begin{tabular}{|c|c|c|c|c|c|c|c|c|c|}
\hline $\begin{array}{l}\text { 14) } 0 \text { curso tem atendido às suas } \\
\text { expectativas? }\end{array}$ & $\begin{array}{c}15-19 \\
\text { anos }\end{array}$ & $\begin{array}{c}20-29 \\
\text { anos }\end{array}$ & $\begin{array}{c}30-39 \\
\text { anos }\end{array}$ & $\begin{array}{c}40-49 \\
\text { anos }\end{array}$ & $\begin{array}{c}50-59 \\
\text { anos }\end{array}$ & $\begin{array}{l}\text { 60-69 } \\
\text { anos }\end{array}$ & $\begin{array}{l}70-79 \\
\text { anos }\end{array}$ & $\begin{array}{c}\text { S/ } \\
\text { idade }\end{array}$ & Totais \\
\hline Sim & 4 & 54 & 20 & 19 & 28 & 36 & 7 & 3 & 171 \\
\hline em parte & & 14 & 7 & 6 & 12 & 9 & 3 & 2 & 53 \\
\hline Não & 1 & & & & 1 & 1 & & & 3 \\
\hline Não selecionou uma alternativa & 1 & & & & 1 & 1 & & & 3 \\
\hline Não sabe & & & & & & 1 & & & 1 \\
\hline \multicolumn{10}{|l|}{$\begin{array}{l}\text { Se pudesse mudar algo no curso, o } \\
\text { que seria? }\end{array}$} \\
\hline "falta aprender o passado" & & & & & 1 & & & & 1 \\
\hline alguns professores & & 2 & & & & & & & 2 \\
\hline aulas com 2 horas & & & & & & & & & 0 \\
\hline aulas de manhã, 2 vezes por semana & & 2 & & & & & & & 2 \\
\hline aulas de 3 horas às sextas à noite & & & & & & 1 & & & 1 \\
\hline $\begin{array}{l}\text { aulas em sala de vídeo/trabalhar } \\
\text { filmes* }\end{array}$ & & & 1 & & & & & & 1 \\
\hline curso de cultura aos sábados & & 1 & & & & & & & 1 \\
\hline $\begin{array}{l}\text { diminuir o número de alunos nos níveis } \\
\text { iniciais }\end{array}$ & & & 1 & & & & & & 1 \\
\hline diminuir o ritmo das aulas & & & & & 1 & & & & 1 \\
\hline $\begin{array}{l}\text { elaboração de planejamento prévio das } \\
\text { aulas }\end{array}$ & & 1 & & & & & & & 1 \\
\hline falar mais de arte italiana & & 1 & & & 1 & & & & 2 \\
\hline $\begin{array}{l}\text { indicação de materiais que poderia ser } \\
\text { usados como auxiliares }\end{array}$ & & & & & & 1 & & & 1 \\
\hline ir além da teoria & & & & 1 & & & & & 1 \\
\hline $\begin{array}{l}\text { mais exercícios de compreensão oral } \\
\text { antes da produção oral }\end{array}$ & & & & & & & 1 & & 1 \\
\hline mais exercícios de gramática & & & 1 & & & & & & 1 \\
\hline maior oferta de horários & & 1 & 1 & & & & & & 2 \\
\hline maior tempo para leitura & & 3 & & & 1 & 1 & & & 5 \\
\hline mais ascolto & & & & & 1 & & & & 1 \\
\hline mais atividades extra-classe & & 1 & & 1 & 1 & & & & 3 \\
\hline mais atividades extra-curriculares & & 2 & & & & & & & 2 \\
\hline mais atividades diferentes do livro & & 5 & 1 & & 1 & 1 & & 1 & 9 \\
\hline mais atividades lúdicas & & & 1 & & & & & & 1 \\
\hline mais atividades orientadas & & & & & & 1 & & & 1 \\
\hline mais avaliação & & 1 & & & & & & & 1 \\
\hline mais conversação & & 5 & 2 & 2 & 9 & 6 & 3 & 2 & 29 \\
\hline mais conversação individual & & & & 1 & & & & & 1 \\
\hline mais culinária & & & & 1 & & & & & 1 \\
\hline mais dinamismo & & & 2 & & 1 & & & & 3 \\
\hline mais dramaticidade & & & 1 & & & & & & 1 \\
\hline
\end{tabular}




\begin{tabular}{|c|c|c|c|c|c|c|c|c|c|}
\hline $\begin{array}{l}\text { Se pudesse mudar algo no curso, o } \\
\text { que seria? }\end{array}$ & $\begin{array}{l}15-19 \\
\text { anos }\end{array}$ & $\begin{array}{c}20-29 \\
\text { anos }\end{array}$ & $\begin{array}{c}30-39 \\
\text { anos }\end{array}$ & $\begin{array}{c}40-49 \\
\text { anos }\end{array}$ & $\begin{array}{c}50-59 \\
\text { anos }\end{array}$ & $\begin{array}{l}60-69 \\
\text { anos }\end{array}$ & $\begin{array}{l}70-79 \\
\text { anos }\end{array}$ & $\begin{array}{c}\text { S/ } \\
\text { idade }\end{array}$ & Totais \\
\hline mais enfoque e cuidado na explicação & & 1 & & & & & & & 1 \\
\hline mais exercícios para casa & & 2 & & 1 & 1 & 1 & & & 5 \\
\hline $\begin{array}{l}\text { mais informalidade, sem perder a } \\
\text { seriedade }\end{array}$ & & & & & & 1 & & & 1 \\
\hline mais interatividade & & & 1 & & & & & & 1 \\
\hline mais leitura em voz alta & & & & & & 1 & & & 1 \\
\hline mais leituras curtas & & & & & & 1 & & & 1 \\
\hline mais lições em um nível & & & & & 1 & & & & 1 \\
\hline mais material didático & & & & & 1 & & & & 1 \\
\hline mais motivação para fazer exercícios & & 1 & & & & & & & 1 \\
\hline $\begin{array}{l}\text { mais produção escrita (como trabalho } \\
\text { de casa) }\end{array}$ & & & 1 & & 1 & 2 & & & 4 \\
\hline $\begin{array}{l}\text { mais revisão do que já foi visto em } \\
\text { módulos anteriores }\end{array}$ & 1 & & & & & & & & 1 \\
\hline $\begin{array}{l}\text { mais tempo p/ atividades extra (filme, } \\
\text { música etc)/mais filmes e músicas }\end{array}$ & 1 & 3 & & 2 & 3 & & & & 9 \\
\hline mais tempo para cada módulo & & & 1 & 1 & 3 & 2 & & & 7 \\
\hline mais tempo para tirar dúvidas & & & 1 & & & & & & 1 \\
\hline $\begin{array}{l}\text { manter o horário de uma vez por } \\
\text { semana (cursos de } 3 \text { horas) }\end{array}$ & & 1 & & & & & & & 1 \\
\hline $\begin{array}{l}\text { melhor aproveitamento do } \\
\text { tempo de aula }\end{array}$ & & & & & 1 & & & & 1 \\
\hline menos correria & & & & 1 & 1 & & & & 2 \\
\hline $\begin{array}{l}\text { monitorar mais o preparo dos prof.s, } \\
\text { alguns não se preparam p/ aulas }\end{array}$ & & 1 & & & & & & & 1 \\
\hline mudar abordagem/metodologia & 1 & 1 & & & & & & & 2 \\
\hline não controlar a frequência & & 1 & & & & & & & 1 \\
\hline o livro & & 1 & & 1 & & & & & 2 \\
\hline o horário & & 1 & & & & & & & 1 \\
\hline o número de alunos por grupo (menor) & 1 & 3 & & & & 1 & & & 5 \\
\hline $\begin{array}{l}\text { organização quanto aos professores } \\
\text { designados para cada turma }\end{array}$ & & 1 & & & & & & & 1 \\
\hline $\begin{array}{l}\text { parte da aula reservada só para } \\
\text { exposição gramatical e vocabulário }\end{array}$ & & & & & 1 & & & & 1 \\
\hline $\begin{array}{l}\text { possibilidade de manter o mesmo } \\
\text { professor em todos os módulos }\end{array}$ & & & 1 & 1 & & & & & 2 \\
\hline $\begin{array}{l}\text { professores mais exigentes (forçar } \\
\text { alunos a estudarem mais) }\end{array}$ & & & & 1 & & & & & 1 \\
\hline separaria as classes por faixas etárias & 1 & 2 & & & & & & & 3 \\
\hline temas mais atuais e cotidiano italiano & & 2 & & & & & & & 2 \\
\hline $\begin{array}{l}\text { ter um curso no período noturno ou no } \\
\text { sábado* }\end{array}$ & & 1 & 2 & & & & & & 3 \\
\hline trabalhar mais a gramática & 1 & 1 & 1 & 1 & & & & & 4 \\
\hline trabalhar mais temas culturais & & & 1 & & & & & & 1 \\
\hline uma música por aula & & & & & 1 & & & & 1 \\
\hline $\begin{array}{l}\text { usar mais recursos multimídia (músicas, } \\
\text { filmes, internet etc) }\end{array}$ & 1 & 4 & 2 & 2 & 3 & 1 & 1 & & 14 \\
\hline $\begin{array}{l}\text { usar outros prédios, manter as turmas } \\
\text { próximas }\end{array}$ & & 1 & & & & & & & 1 \\
\hline
\end{tabular}




\section{Anexo F - Modelo 3: questionário geral para os monitores}

\section{PERGUNTAS GERAIS}

Essas perguntas serão feitas somente uma vez e você não deve ter em mente nenhum grupo específico, mas sim levar em conta a sua experiência como professor(a) de italiano LE.

Qual a sua idade? anos Sexo: ( ) feminino

( ) masculino

Leciona italiano há quanto tempo?

1. Por que decidiu começar a estudar italiano?

2. E a escolha em ser professor(a) de italiano? Quais fatores te influenciaram?

3. Numa escala de 0 a 100\%, quanto você está satisfeito(a) profissionalmente?

4. O que, na sua profissão, te traz insatisfação?

5. Qual o número de alunos por grupo que você considera ideal? Justifique. 
6. Você acha que a divisão do conteúdo nos módulos (do Italiano no Campus) é adequada? ( ) SIM, ( ) Não. Justifique sua resposta.

7. Qual das habilidades abaixo você se sente mais à vontade para trabalhar?
( ) produção oral
( ) produção escrita
( ) leitura
( ) gramática

Por quê?

8. Se pudesse mudar algo no curso, o que seria?

9. Você tem preferência em dar aula para alguma dessas faixas etárias?
( ) crianças não-alfabetizadas
( ) crianças alfabetizadas
( ) adolescentes
( ) adultos de 20 a 40 anos
( ) adultos de 40 a 60 anos
( ) terceira idade (de 60 a 80 anos)
( ) quarta idade (acima de 80 anos)
Por quê?

10. O que acha dos grupos que misturam diversas faixas etárias, os ditos: grupos intergeracionais? 
11. Na sua opinião, alguma faixa etária não poderia ser "misturada"?

( ) crianças não-alfabetizadas

( ) crianças alfabetizadas

( ) adolescentes

( ) adultos de 20 a 40 anos

( ) adultos de 40 a 60 anos

( ) terceira idade (de 60 a 80 anos)

( ) quarta idade (acima de 80 anos)

Por quê?

12. Geralmente, qual a faixa etária de seus alunos?

( ) crianças não-alfabetizadas

( ) crianças alfabetizadas

( ) adolescentes

( ) adultos de 20 a 40 anos

( ) adultos de 40 a 60 anos

( ) terceira idade (de 60 a 80 anos)

( ) quarta idade (acima de 80 anos)

13. Se você tivesse que fazer um curso para uma faixa etária específica, qual seria?

( ) crianças não-alfabetizadas

( ) crianças alfabetizadas

( ) adolescentes

( ) adultos de 20 a 40 anos

( ) adultos de 40 a 60 anos

( ) terceira idade (de 60 a 80 anos)

( ) quarta idade (acima de 80 anos)

Explique sua escolha:

14. Você acha que os grupos deveriam ser divididos por faixa etária? ( ) Sim, ( ) Não Justifique: 


\section{Anexo G - Tabelas com as respostas dos monitores aos Questionário 3 que não entraram no capítulo 5}

Tabela G1: Qual o número de alunos por grupo que você considera ideal? Justifique. (Q3:5)

\begin{tabular}{c|c|l}
\hline Monitor & Número ideal/grupo & \multicolumn{1}{c}{ Justificativa } \\
\hline 1 & 15 alunos & $\begin{array}{l}\text { "Nem muito, nem pouco. Gosto muito de aplicar atividades que levem } \\
\text { os alunos a entrarem em contatos com os colegas de sala e a } \\
\text { aprenderem com eles. Gosto de mostrar aos alunos como eles podem } \\
\text { 'tirar proveito' da experiência dos colegas de sala. Meu foco é fazê-los } \\
\text { desenvolver a fluência verbal, e para tanto uso atividades em duplas } \\
\text { (que se alternam ao decorrer da aula) com muita frequência." }\end{array}$ \\
\hline 2 & Mínimo de 4, máximo de & $\begin{array}{l}\text { "Acredito que acima de 10 alunos o professor não consegue dar } \\
\text { atenção suficiente a todos no grupo e um mínimo de 4 para que haja } \\
\text { interação aluno-aluno, pois creio que a interação com seu mesmo nível } \\
\text { linguístico ajuda a desinibir a pessoa." }\end{array}$ \\
\hline 3 & Entre 5 e 10 alunos & $\begin{array}{l}\text { "Depende. Se o grupo é participativo, acredito que entre 5 e 10 alunos } \\
\text { possa ser o ideal." }\end{array}$ \\
\hline 5 & Mínimo de 4, máximo de & $\begin{array}{l}\text { "Com esse número de alunos, é possível fazer diversas atividades } \\
\text { individuais e em duplas/grupos e tentar acompanhar o processo de } \\
\text { aprendizagem de cada aluno." }\end{array}$ \\
\hline 5 & 10 alunos & $\begin{array}{l}\text { "Porque é possível fazer dinâmicas, atividades em grupos, promover } \\
\text { discussão a respeito de temas abordados." }\end{array}$ \\
\hline
\end{tabular}

Tabela G2: Se pudesse mudar algo no curso, o que seria? (Q3:8)

\begin{tabular}{c|l}
\hline Monitor & \multicolumn{1}{c}{ Resposta } \\
\hline 1 & $\begin{array}{l}\text { "A organização dos níveis por conteúdos gramaticais. Gostaria que os objetivos de cada nível fossem } \\
\text { pautados por habilidades a serem ensinadas e não por elementos gramaticais, que deveriam estar } \\
\text { subordinados àqueles objetivos. E que o livro adotado no curso contemplasse esse entendimento de } \\
\text { ensino de língua." }\end{array}$ \\
\hline 2 & $\begin{array}{l}\text { "A avaliação,acredito que apenas uma prova escrita e uma oral não sejam suficientes para avaliar um } \\
\text { aluno." }\end{array}$ \\
\hline 3 & $\begin{array}{l}\text { "Nada. Talvez a inclusão de mais uma avaliação no meio do curso. Apesar disso, considero a questão } \\
\text { da nota final pouco relevante." }\end{array}$ \\
\hline 5 & "No Italiano no Campus, eu reduziria o número de alunos por turma e adotaria outro livro didático." \\
\hline 6 & "O foco. Faria com que deixasse de ter um foco gramatical para um enfoque mais pragmático." \\
\hline
\end{tabular}




\section{Anexo H - Modelo 3.1.: questionário específico para os monitores}

\section{GRUPO}

1. Você acha que o ritmo das aulas neste grupo é:
( ) lento
( ) bom
( ) acelerado

Justifique:

2. Qual das competências abaixo você têm trabalhado mais com eles?

( ) produção oral ( ) produção escrita $\quad$ ( ) leitura ( ) gramática Por quê?

3. Com qual das competências abaixo você acha que os alunos deste grupo têm mais dificuldade?
( ) produção oral
( ) produção escrita
( ) leitura
( ) gramática

4. Você acha que a divisão do conteúdo neste módulo é adequada? ( ) Sim, ( ) Não Justifique:

5. Na sua opinião, como é o relacionamento entre os alunos deste grupo?

6. Qual você acha que é o assunto que eles mais gostam de falar? (arte, culinária, música, filosofia, religião, esportes, cinema, gramática, história etc.) 


\section{Anexo I - Formulário de informação e compromisso para monitores entrevistados}

\section{Formulário ao Participante}

A participação na entrevista é um convite e, como tal, pode ser aceito ou não.

O objetivo da entrevista é obter maiores informações sobre a interação entre os alunos do Italiano no Campus e seus monitores, bem como sobre a estrutura do curso, buscando verificar se existem dificuldades, diferenças de interesses e se algo deveria ser mudado na dinâmica dos grupos para que funcionassem melhor.

As entrevistas ocorrerão no prédio da Faculdade de Filosofia, Letras e Ciências Humanas da Universidade de São Paulo em salas que serão posteriormente informadas aos participantes da pesquisa, garantindo um ambiente tranqüilo para sua realização.

Trata-se de um encontro por participante, no qual a duração da entrevista não ultrapassará 1 (uma) hora. Será feita uma gravação em gravador de áudio, que gerará um arquivo mp3, de forma a poder armazená-lo em arquivo digital.

A entrevista será, posteriormente, transcrita e seus dados serão publicados garantindo ao entrevistado seu anonimato. Para que isso ocorra, utilizaremos nomes fictícios e os únicos dados reais do candidato que precisaremos manter durante a divulgação são idade e sexo, pois são importantes para a nossa pesquisa.

O participante é livre para se recusar a responder determinadas perguntas, bem como para abandonar a entrevista a qualquer momento, sem que haja penalidade ou perdas.

A participação de cada entrevistado/a é muito importante para nossa pesquisa, para que possamos obter dados mais fidedignos em relação ao curso de extensão de língua italiana: como os monitores sentem a relação entre os alunos e como se relacionam com esses alunos, quais materiais apresentados e se são satisfatórios, se proporiam alguma mudança na estrutura do curso etc. Espera-se, também, que os resultados da pesquisa possam contribuir, a posteriori, com o projeto Italiano no Campus.

Maiores esclarecimentos sobre os procedimentos da entrevista poderão ser fornecidos pessoalmente.

Agradeço desde já a atenção e colaboração.

Cordialmente, 


\section{Termo de Compromisso do Entrevistador}

O entrevistador se compromete a:

1. Fornecer as informações necessárias sobre os procedimentos e objetivos das entrevistas aos participantes, esclarecendo possíveis dúvidas que possam ter.

2. Não divulgar a identidade do entrevistado, utilizando nome fictício ou o termo "participante X" (onde X será substituído por um número) para a divulgação da entrevista.

2.1. Em caso de entrevista com coordenadores e/ou ex-coordenadores, será utilizado o termo "coordenação X" (onde X será substituído por um número).

3. Garantir o sigilo do arquivo de áudio, sendo que somente o entrevistador e o transcritor é que terão acesso a eles.

4. Não ultrapassar 1(uma) hora de entrevista, para que não haja desconforto nem cansaço por parte do participante.

5. Parar a entrevista, caso note desconforto por parte do entrevistado.

Eu, $R G n^{\circ}$ me comprometo a cumprir os dados acima mencionados na realização da entrevista e posterior tratamento e publicação dos dados.

São Paulo, de de 2009. 


\section{Termo de compromisso do participante}

O participante:

1. Aceita o convite para participar da entrevista e está ciente de que pode se recusar a fazê-la ou abandoná-la quando quiser.

2. Autoriza a divulgação e publicação da transcrição de sua entrevista, com sua identidade preservada, sob um nome fictício ou o termo "participante X" (onde X será substituído por um número).

2.1. Em caso de coordenação e/ou ex-coordenação, a transcrição receberá o nome de "coordenação X" (onde X será substituído por um número).

3. Autoriza a divulgação de sua idade e sexo.

4. Não se sentindo à vontade durante a entrevista, comunicará ao entrevistado que deseja não realizá-la ou fazê-la em outro momento.

$\mathrm{Eu}$, $R G n^{\circ}$

monitor(a)/ex-monitor(a) do Italiano no Campus, após ter sido informado(a) sobre os objetivos da pesquisa e como será conduzida, autorizo a entrevista e a publicação dos dados como acima estabelecidos.

São Paulo, de de 2009. 


\section{Anexo J - Modelo de roteiro de entrevista com os monitores}

\section{Perguntas aos monitores}

\section{SUA EXPERIÊNCIA DOCENTE}

1. Há quanto tempo você dá aulas de italiano?

2. Em quantos lugares já deu aula?

3. O que te traz mais prazer em ser professor de italiano?

4. O que te deixa insatisfeito?

5. Qual o número ideal de alunos por grupo, na sua opinião e por quê?

6. Como é, na sua opinião, o "aluno ideal"?

7. Com que tipo de aluno você acha que é mais difícil de trabalhar? (personalidade)

\section{ITALIANO NO CAMPUS}

8. E no Italiano no Campus, há quanto tempo trabalha?

9. O que você acha que diferencia o Italiano no campus de outros cursos de Italiano nos quais deu aula?

10. Você acha que a infra-estrutura é suficiente?

11. Você tem liberdade na escolha de materiais?

12. Quais materiais "extra" você leva para os alunos com mais freqüência?

13. Você está satisfeito com o livro didático adotado no curso?

14. Quantas e com qual freqüência são as reuniões entre monitores e coordenação?

15. Quais os assuntos mais tratados nas reuniões?

16. Houve alguma vez a sugestão de mudança do livro didático adotado?

17. A estrutura curricular do Italiano no Campus te satisfaz?

18. Na sua opinião, os alunos estão satisfeitos com o curso? 
19. O Italiano no Campus foi fundado com o objetivo de servir à comunidade USP, em primeiro lugar, e de se um laboratório para os estudantes de Pós em Língua e Literatura Italiana. Você acha que esses objetivos ainda se cumprem?

20. Quantos alunos você costuma ter por turma? (se o número for maior do que o indicado como ideal: você acha que prejudica a aula?)

21. Você gosta mais de dar aula para algum nível específico? Se sim, por quê?

22. E tem preferência por algum público?

23. Acha que, de alguma forma, o público freqüentador do Italiano no Campus é diferente daquele que freqüenta os cursos de italiano em outras instituições?

24. Como são as reuniões com a coordenação? Com qual freqüência elas ocorrem e quais são os assuntos discutidos?

25. Você acha que há um bom diálogo entre monitoria e coordenação?

\section{RELAÇÃO ENTRE ALUNOS/ ALUNOS-MONITORIA}

26. Como você percebe o relacionamento entre os alunos da turma?

27. Já teve que lidar com algum problema de relacionamento entre alunos?

28. E como você sente a relação dos alunos com você?

29. Alguma vez teve problemas com alunos no Italiano no Campus?

30. Durante as reuniões entre coordenação e monitoria, houve alguma questão levantada que dizia respeito aos alunos?

31. Alguma vez houve reclamações dos alunos à coordenação? Se sim: por quê?

32. Alguma vez os alunos reclamaram para você da coordenação?

33. Alguma vez um aluno (ou mais de um) reclamou para você dos colegas de grupo? Se sim, por quais razões?

34. Você acha que o Italiano no Campus é voltado para um perfil específico de alunos?

- Se SIM: Qual público? E de que forma as pessoas que não se encaixa nesse perfil conseguem levar o curso adiante?

- Se NÃO: Você acha que o Italiano no Campus está estruturado para a heterogeneidade do público que o frequenta? 
35. Há grande variedade grande de idades na sala de aula?

36. Os monitores do Italiano no Campus são preparados de alguma forma para a heterogeneidade dos grupos?

37. O que você acha de trabalhar com grupos de grande variedade etária? Alguma vez teve problemas?

38. Por você, deveria haver a separação de algum público dos grupos do italiano no Campus? (Turmas específicas, etc)

39. O que você acha da grande participação de alunos da pertencentes à chamada $3^{\text {a }}$ idade?

40. Você os separaria do restante do grupo? Por quê?

41. Alguma vez você presenciou a reclamação de colegas em relação aos alunos idosos? Se sim, por qual razão?

42. Alguma vez os alunos reclamaram dos companheiros idosos? Se sim, por qual razão?

43. A coordenação alguma vez já abordou o tema pelo fato do número de alunos idosos ser considerável?

44. Em alguma reunião já foi discutida a grande participação dos idosos nos cursos? 


\section{Anexo K - Transcrição das entrevistas com os monitores}

\section{Transcrição da entrevista com o Monitor 1}

$\left[{ }^{*}\right]$

E: Em quantos lugares diferentes você já deu aula?

M1: De italiano?

E: De italiano.

M1: Quatro.

E: E::: você - o que mais te traz satisfação no - em ser professora de italiano?

M1: Boa pergunta. ((risos)) Ah, eu gosto da língua, pra começar, né?. O que não acontece por exemplo com o inglês, que eu não suporto. Eu gosto da língua. Eu gosto de trabalhar COM os adultos, então, é... pelo que... pela minha pouca experiência [*], quem procura estudar italiano, estuda porque QUER, porque gosta. E trabalhar com gente que trabalha, que estuda porque quer mesmo, porque tem interesse, faz toda a diferença. Então acho que seria o interesse mesmo, dos alunos, além de... do fato de eu gostar mesmo da língua.

E: E o que te traz insatisfação?

M1: Como professora de italiano?... Insatisfação, acho que::: o que traz insatisfação pra qualquer professor, não só de italiano... ou seja, né, alguns... algumas coisas que acontecem por exemplo, é... você demorar um tempão para pesquisar um tema, para preparar uma atividade diferente, interessante e tem aluno que às vezes não faz, né? mas sempre são, graças a Deus, a minoria, né? Mas sempre tem assim um ou outro que às vezes não reconhece o seu trabalho ou até não o aluno, mas um coordenador, o dono da escola... Acho que isso deixa qualquer professor insatisfeito, né?

E: Na sua opinião, qual o número ideal de alunos por... por turma, de italiano?

M1: Isso... adulto? Qualquer outra idade?

E: Qualquer idade.

M1: Ah, pensando em adolescente ou adulto, no máximo 20. Mas o número ideal, eu diria, entre 10 e 15.

E: Qual é o perfil de aluno ideal, pra você?

M1: ((ri)) Aluno ideal... Ah, aluno ideal acho que é igual também pra praticamente todo mundo, e não só na área de italiano... Aquele aluno que estuda, que é interessado, que participa da aula, que faz todas as atividades que você propõe, que até, assim, contribui com sugestões pro seu trabalho também. Acho que esse.

E: E o aluno que é difícil de lidar? 
M1: Difícil de lidar?... Pra mim, pelo menos, são alunos que são incógnitas, pra mim. Que eu não consigo - eu tento descobrir o que fazer para ajudar aquele aluno, mas parece que de todas as formas que eu explico alguma coisa, né? Fazendo jogo, dando uma explicação tradicional, fazendo alguma atividade diferente, exercício, livro didático, a música, tem uns que parece que você não consegue atingir... E esses para mim, é difícil lidar, assim, são uma incógnita, né? Eu não sei até que ponto um professor pode ajudar um aluno que apresenta tanta dificuldade... né? E aí às vezes parece até/eu até me sinto meio incompetente, mas quando eu vejo que o resto da classe tá caminhando bem, aí eu penso: "Não, então não tá em mim o problema.". Mas aí você fica: "O que fazer, né, pra ajudar?" Pra ajudar essa pessoa que não vai pra frente, que não entende coisas que pros outros são simples e que pra mim também é simples. Acho que a dificuldade é essa.

E: Agora as questões são específicas sobre o Italiano no Campus, então pense só no Italiano no Campus.

M1: Tá.

E: É::... há quanto tempo você dá aula no Italiano no Campus?

\section{$\left[{ }^{*}\right]$}

E: E o que você acha que diferencia o IC dos outros lugares onde você deu aula de italiano?

M1: Eu acho que a coordenação mesmo do trabalho, perché os outros lugares que eu dei aula, se eu quisesse "brincar" de ser professora, fingir que tava dando aula, eu podia. Porque não tinha ninguém que controlasse isso. Agora aqui, não que tenha alguém que controle, né, porque não é que a coordenadora fique lá, vá lá na sala ver se a gente está trabalhando mesmo ou não. É que eu acho muito interessante isso de/essas reuniões mensais, né, que tem no IC. Dessas propostas de, por exemplo, como nós estamos fazendo agora, de refazer as provas::: Acho que a coordenação mesmo do trabalho, né? Que acabou que nos outros lugares que eu trabalhei não tinha.

E: E você acha que a infra-estrutura do IC é suficiente pra dar aula?

M1: Geral?

E: É.

M1: Não. Eu acho que não. Eu acho que, perché por exemplo, às vezes eu queria passar alguma coisa com filme e a gente não tem como usar, né? principalmente no sábado, não tem nada, né? Então você dá aula com giz, lousa, saliva ((risos)). Como dizem... E o rádio. Só, né?. Quando dá a gente traz algum jogo, né? [*], traz algum jogo, faz alguma brincadeira, traz alguma música. Mas aí é só isso, né? Talvez com outros recursos, a aula fosse até mais legal, tanto para nós quanto pros alunos, né?

E: E:: você tem liberdade na escolha dos materiais que você leva pra sala de aula?

M1: Ah, tirando o material didático que nós temos que usar, que é o Linea Diretta, né?... Sim, eu diria que sim.

E: E quais são os materiais que você gosta mais de levar? Ou que você leva com mais frequência. 
M1: Que eu levo com mais frequência são músicas mesmo. Eu gosto bastante de usar as músicas, alguns textos literários.. e:: e também, assim, história em quadrinhos. Aqui no IC, história em quadrinhos, por exemplo, eu não usei, mas fora daqui também já usei. Mas pensando só aqui, mais música mesmo e texto literário, acho que os principais.

\section{E: É:: Ah! Você tá satisfeita com o Linea Diretta?}

M1: Não. Eu não gosto muito do Linea Diretta.

E: Você sugeriria algum outro livro?

M1: Então, nas aulas particulares eu uso o Nuovo Progetto, que é o que usa aqui na graduação agora, né? Ele, a parte de ascolto do Linea Diretta eu acho muito boa, né, porque são mesmo parecidos os diálogos com diálogos autênticos. [*]... Mas fora isso, acho o Linea Diretta muito repetitivo:: acho confuso às vezes, então, eu, entre esses dois livros, eu prefiro o Nuovo Progetto mesmo.

E: Certo... Nas reuniões mensais com a coordenação, quais são os assuntos mais tratados?

M1: Mais tratados... ((ri)) Olha, faz tempo que a gente tá discutindo avaliação, né? Os critérios de avaliação oral, e, de produção oral e produção escrita e acho que nas duas ou três últimas foi só assim:: como que a gente tá refazendo as provas finais, né, as provas escritas... Então, acho que ultimamente são esses.

E: Em alguma dessas reuniões que você participou já houve a sugestão de troca de material didático?

M1: Não. Não.

E: E você acha que a estrutura curricular do IC te satisfaz?

M1: Ah, isso eu acredito que sim. Porque no fim, o currículo mesmo de italiano... acaba sendo parecido, pelo menos nos quatro lugares que trabalhei, com exceção da $\left[{ }^{1}\right]$, que... aquilo é uma aberração da natureza... ((entrevistadora ri)) você deve conhecer. Que é ridículo. Mas fora isso, acho que sim, né? Acho que o currículo acaba sendo parecido na maior parte dos lugares... então, pra mim tá bom.

E: Você acha que os alunos tão satisfeitos com o curso?

M1: Os que eu tive até agora... eu diria que sim. também não tive muitos, né? São três turmas por enquanto, mas eu diria que sim.

E: Você - Bom, o IC foi fundado com o objetivo de atender à comunidade USP em primeiro lugar, e em segundo lugar, de servir de laboratório pros alunos de Pós em Língua Italiana, você acha que esses objetivos eles ainda são os objetivos principais do IC?

M1: De atender à comunidade da USP acho que não. Perché a maioria dos alunos são de fora da USP, né? Pelo menos os que eu tive:: e tem sim alguns alunos daqui, né? da própria Letras ou de outros cursos da USP, mas a maioria não é daqui. A maioria é de

$1 \quad$ Nome de escola particular suprimido. 
outras faculdades ou até nem tá estudando, né? Já fez graduação ou pós, mas não é daqui. Então acho que não. Agora como, assim, pra nós, né? Que somos/que estamos fazendo a pós, eu acho que sim, perché, por exemplo, a minha pesquisa é [*]. E sempre que eu posso eu uso nas minhas aulas. Nunca pedi pra ninguém testar, né? por exemplo, mas acho que se eu pedisse pra qualquer um, né? pra qualquer um dos colegas, o Fulano, o Sicrano ${ }^{2}$, você, se ainda tivesse dando aula, acho que não teria nenhum problema em aplicar uma vez. Então eu acredito que sim, que esse objetivo sim, mas de atender à comunidade da USP acho que, assim, se transformou, né? o objetivo.

\section{E: Quantos alunos você costuma ter no IC por turma?}

M1: por turma?... deixa eu ver uma média... uns 20. 18, 20.

E: Você acha que esse número de alunos prejudica o andamento da aula ou não? Você teria menos (alunos por turma)?

M1: Eu acho, por exemplo, com a minha turma de nível 3 do semestre passado. Tinha 23 alunos. [*] Acho muito grande, pra fazer... porque alguns alunos, esses que pra mim são uma incógnita, né, têm mais dificuldade e outros, assim, são rápidos demais. Então esses que são rápidos ficavam entediados às vezes, porque eu tinha que repetir muitas vezes a mesma coisa. E mesmo repetindo muitas vezes a mesma coisa eles que são mais... é... "lentos", entre aspas, né? pra eles ainda não é suficiente. Então, esse semestre a turma foi menor, a mesma turma, nível quatro, eram 15. Então, até na avaliação que eles fazem no fim do curso eles colocavam que o número menos de alunos fez com que o andamento da aula fosse melhor e eu concordo com eles.

E: Você tem preferência por algum nível? Você GOSTA mais de dar aula para algum nível?

M1: Eu gosto, acho que dos principiantes, principalmente. Acho que até o nível 4 são os meus preferidos.

\section{E: Por alguma razão especial?}

M1: Ah, eu acho que quando eles tão começando a estudar italiano, acho que o encantamento ainda é maior. Então é como eu falei no começo, né? Trabalhar com interesse, com gente que tá a fim, faz toda a diferença, né? Acho que quando vai chegando nos níveis mais intermediário::, talvez ainda... aquele interesse ainda tá acesso. No final, tanto é que a gente vê que a turma se reduz bastante, né? As turmas vão se reduzindo. Às vezes o nível um começa com 20 e no nível 8 a mesma turma tá com, sei lá, 5, 7 alunos? E é a mesma turma. Então acho que talvez por isso. Acho eles mais animados, mais interessados, geralmente, até o nível 4.

E: Você prefere algum público pra dar aula? Se você tivesse que definir faixas etárias...

M1: Ah, prefiro ((risos)). Com certeza. É... se bem que, assim, não dá pra generalizar, porque eu já tive exceções, né? Mas acho que de um modo geral, EU acabo/me sinto melhor como professora, acabo tendo um relacionamento mais legal como professora mesmo - não pessoal... pessoal, com qualquer idade. Acho que entre 20 e 40-45, alguma coisa assim.

2 Nome dos outros monitores suprimidos. 
E: Você acha que o público que frequenta o IC é diferente dos dos outros lugares onde você deu aula?

M1: Não.

E: Não?

M1: Não acho. Dos que eu trabalhei, não. Ah, tirando os da $\left[^{3}\right]$, né? ((risos)) Tirando esses, eu diria que é igual, parecido.

E: Você acha que há um bom diálogo entre e monitoria e a coordenação?

M1: É... Como eu tô há pouco tempo, eu pelo menos, toda vez que eu precisei de alguma coisa, não tive problema. A coordenadora sempre foi muito disponível, então eu não tenho do que reclamar, né?

E: Certo... Agora da relação entre os alunos e você e os alunos... Como você percebe o relacionamento dos alunos com os próprios alunos? Você acha que há um entrosamento? Como que você vê?

M1: Mas de um modo geral?

E: Isso. De um modo geral.

M1: Então, eu acho que isso varia, né? de turma pra turma. Porque a minha turma de nível 1 desse semestre, por exemplo, eles são assim, muito unidos, né? se um falta o outro manda email falando o que que teve na aula. Eles se comunicam o tempo inteiro, e é brincando um com o outro o tempo inteiro, a aula é sempre assim. É bem divertida até. Já o nível 4 ... eles já são mais sérios, alguns não sabem - eles tão juntos desde o nível um - não sabem o nome de alguns colegas da sala, não tem nenhum, sabe, alunos brigando nada disso, mas eles não são tão entrosados quanto essa turma de nível 1, por exemplo.

E: E você já teve que lidar com algum probre/problema entre os alunos? No IC.

M1: Que tipo de problema?

E: De relacionamento, assim. Já houve discussões, assim...

M1: É... não. Já teve assim, por exemplo, um episódio, né? de algumas semanas atrás. Um aluno do nível 4, ele tinha pedido uma explicação, né? E eu comecei a explicar pra ele e ele, esse aluno sempre senta na frente, e tinha um outro aluno, esse aluno é um senhor, né? aí tinha um outro aluno atrás conversando - mas assim, como era bem início da aula e eles costumam chegar atrasados mesmo, eu sempre espero um pouquinho, né? E aí esse aluno, enquanto eu tava explicando pra ele, se irritou porque o outro tava conversando lá atrás com a colega, virou pra ele e começou a dar bronca. Aí ele falou assim... aí o outro, na boa, assim, falou: "Ah, tá, tá bom...". Ele começou a falar: "Fulano ${ }^{4}$, presta atenção. É importante o que ela tá falando aqui!". Aí a colega que tava conversando com ele até começou a rir, né? até eu olhei meio, né? Pensando: "Ué, eu não chamei a atenção, uma pessoa chamando", né? Mas fora isso, nunca presenciei nada assim de briga mesmo, né?

3 Nome da escola particular suprimido.

4 Nome do aluno suprimido. 
E: Certo... E a sua relação com os alunos, como você sente? Ela é boa?

M1: Ah, eu acho. Muito boa.

E: Alguma vez você teve algum problema com aluno de/do IC?

M1: Não, até agora... [*] Não. Até agora não. A gente sente, lógico, que tem alguns que gostam mais da gente, né? E outros que gostam menos. E fazem comparações com professores anteriores. Isso sempre acontece. Mas brigar, não. Tanto até que nessa avaliação que eles preenchem, né? no final de semestre, 5 todos me deram na parte de relacionamento com os alunos. Acho que nenhum deles tem o que reclamar, né? nesse sentido.

E: E durante as reuniões do IC. alguma vez se abordou um tema de aluno? Por exemplo, algum aluno que tava dando problema? Relacionamento entre a/os alunos, que atrapalhava a aula?

M1: Durante as reuniões?

E: É.

M1: Não. Durante as reuniões, não. Eu vim em todas que tiveram [*] e não, nenhuma vez.

E: Alguma vez houve reclamação dos alunos, na coordenação, sobre você? Já teve algum feedback desse tipo?

M1: Eu não.

E: E alguma vez algum aluno reclamou pra você da coordenação?

M1: Também não.

E: Só reclamação agora. ((entrevistada ri)). Alguma vez, algum aluno reclamou pra você de outro monitor?

M1: Ah, já.

E: E porque razão era a reclamação, você se lembra?

M1: Deixa eu ver se me lembro... Porque era uma pessoa que eu nem conheço, um monitor que não trabalha mais aqui. Conheço de nome só, nunca nem vi a pessoa... Deixa eu ver:... Uma aluna tinha reclamado acho que do dicionário que o professor, que o monitor tinha indicado falando que era bom:: e que não era. Mas essa aluna, pelo jeito não simpatizava muito com esse monitor. Né? o que acontece também, por exemplo - tem um do nível 4 esse, eu noto também o contrário, né, que esse mesmo monitor era muito querido por uma outra aluna que não gosta tanto de mim. Eu vejo pelo jeito que ela me olha, sabe? O santo não bate muito ((ri))... Então, assim, acho que é só isso, que eu me lembre. E uma outra vez, também, teve uma aluna que não tá, que fez o nível 3 só comigo, [*], que também reclamou de uma monitora, mas ela não explicou o porquê. Ela só, quer dizer, pelo menos pra mim não, talvez pros colegas ela tenha explicado. Só falou que tinha "professores péssimos". E se referiu a ela, mas não sei, aí também ficava chato perguntar porque que ela é péssima ((risos)) porque ia ficar parecendo que eu tava querendo fazer fofoca, sei lá, né?. 
E: É. - E alguma vez houve reclamação de outros colegas sobre algum aluno?

M1: Sobre algum aluno?... Que eu conheça?

E: Não. De modo geral.

M1: Ah, sim.

E: E qual que era a reclamação?

M1: A reclamação geralmente é que:: de dificuldade mesmo, de você explicar - ainda ontem eu tava falando disso com o [*], né, que tem alguns alunos que você explica cinquenta vezes a mesma coisa e você não sabe mais o que fazer. Eu mesma teve uma vez que uma aluna - e essa aluna é muito esforçada, e ficou com uma média boa, sabe, mas ela me fazia uma pergunta e eu explicava e explicava e explicava e aí ela: "ai, não tô entendendo nada!". Eu: "Não é possível, você tá no nível 4 e não tá entendendo nada?!". E aí ela: "Não, não tô entendendo nada!". Ai eu falei: "Mas bom, olha, não sei o que fazer com você perché eu já expliquei de todas as formas possíveis e aí os alunos começaram a tentar explicar para ela. E eu fiquei falando: "Gente, vocês tão entendendo? Acho que eu não sei explicar, não é possível." E os outros alunos falaram: "Não, a gente já entendeu." Então aí eles começaram a tentar explicar pra ela. Então, geralmente quando a gente comenta entre nós, é sobre esse tipo de problema mesmo. Pelo menos que eu tenha presenciado e participado, sempre assim.

E: Certo. É::: alguma vez, algum aluno reclamou pra você de outro aluno? De um colega de turma?

M1: Já, mas não de aluno que eu conhecesse. De alunos que fizeram outros níveis com eles mas não tava mais na turma.

E: E a reclamação, qual que era?

M1: Era de, por exemplo, sábado passado eles tavam falando de uma aluna que fez acho que o nível dois com eles que sempre interrompia o professor quando tava explicando, não parava de falar durante a aula e que só atrapalhava. Né? Geralmente são reclamações nesse sentido.

E: Você acha que o IC é voltado para um perfil específico de alunos?

M1: Não. Específico não. Acho que é bem abrangente.

E: E você acha que os monitores, eles tão preparados pra heterogeneidade dos grupos?

M1: Quanto à?...

E: Por exemplo, a diferença de idade. Que você tem alunos de 20 e de 60, 70.

M1: Isso... Ai, é tão relativo, né, Lê? Perché:: eu fico pensando nos meus... nos alunos que eu tenho aqui. Não sei até que ponto a idade interfere positiva ou negativamente em alguma coisa perché com essa turma do nível 1 por exemplo, tem uma senhora de 61 que vai super bem, né, mas ao mesmo tempo já tive... já tive um aluno de 70 que era excelente também, muito bom. E já tive aluno de 40 que são essas incógnitas, e já tive também alunos de 60 que também são desse grupo incógnita que eu chamo, né? Então, eu vou falar por mim, assim, às vezes eu me sinto preparada, às vezes não. Eu não sei se é uma dificuldade minha e não sei se tem a ver com a idade ou se tem a ver 
com outros traços. Né?

E: Você acha que, por exemplo, em termos de escolaridade, eles são um grupo parecido ((homogêneo))?

M1: Em termos de escolaridade acho que sim, perché a maioria deles, todos né? ou são graduandos, no mínimo. Alguns são pós-graduandos ou graduados, né? pósgraduados. Então, assim, todo mundo, eu não tive nenhum aluno que não tivesse pelo menos cursando, aqui né? O nível superior.

E: Certo. E o que você acha de trabalhar com esses grupos que tem uma grande variedade etária?

M1: Ai, que difícil. ((risos))

E: "Pergunta filosófica". Você sabe que você não é obrigada a responder nenhuma pergunta, né?

M1: Ah, não. Não teve nenhuma que me constrangesse até agora. Não - Assim acho difícil no sentido, como eu falei mesmo, que é relativo, né? Porque às vezes num grupo, né, é o que é legal. Fico contente de ver o meu grupo de nível um, eles são os meus xodós. ((ri)) Eles ficam, assim, saem juntos, pessoal de/ uma menina de vinte e uma de sessenta. Eu acho legal isso. Mas no do nível 4, por exemplo, quando era nível 3, já não tinha e não tem até agora esse entrosamento. Então não sei se é a idade que tem a ver, né? Não sei, pra mim é difícil responder. Não sei se eu consigo responder a pergunta... ((ri)) Eu acho que não, porque eu acho tão relativo né? Acho que depende de cada grupo.

E: Esse grupo de nível 3 que não tinha esse entrosamento, eles eram de sábado?

M1: Isso.

E: Você acha que deveria haver alguma separação no IC? De público?

M1: De idade?

E: É.

M1: Ah, eu acho que não. Eu acho que não perché, como eu falei, né, não é a idade o problema, são outras coisas, né? então... Porque só podem ser outras coisas, mas se precisar - se eu já tive aluno de 70 que era excelente e aluno de 40 que tinha uma dificuldade de outro mundo, então não é idade. Tem alguns outros fatores - talvez, sei lá, o estilo de aprendizagem, ou não sei, a pessoa de repente não tem muita facilidade com língua... não sei, acho que não é a idade o problema, então não acho que deveria/não deveriam ser grupos separados por idade.

E: E do que você viu do IC até agora, você acha que a participação da terceira idade é grande no IC?

M1: É. Bastante. Tem alguns/eu não peguei, né, como só tive três grupos até agora, mas já vi algumas turmas que tem aqui que praticamente é só terceira idade, né? É o contrário, né? As que eu peguei até agora, a maioria é jovem, mas tem turma aqui que, pelo que eu vi, que tem dez alunos, seis-sete de terceira idade.

E: E Alguma vez algum aluno reclamou pra você de algum colega idoso? 
M1: Não. Nenhum.

E: Eu perguntei se algum aluno reclamou, né? E algum colega, já reclamou pra você? Por ter aluno idoso?

M1: Já.

E: E qual foi a reclamação?

M1: Ah, a reclamação de "ah, é muito lento", "pessoa não entende", mas eu não sei se quando o comentário é esse, se é mesmo a idade, como eu falei, pra mim isso é um mistério, porque não entra na minha cabeça. Quando eu comecei minha carreira, lá no minicurso, na Faculdade de Educação, você deve ter feito também. Tinha um aluno, que pelo jeito deu bastante trabalho aqui, o Aluno A ((risos)) que era ótimo, assim, o mais novo era o Aluno B que tinha 19 e o Aluno A tinha 69. E o Aluno A era ótimo tanto quanto o Aluno B que tinha 19. Não... o Aluno B não tinha 19, tinha 21, mas tinha o Aluno $\mathrm{C}$ que tinha 19. Aluno $\mathrm{C}$ tinha 19 e tinha uma dificuldade com o italiano que era coisa de outro mundo, e o Aluno A, que tinha 69 ia super bem. E depois, pelo que eu soube, ele deu bastante trabalho aqui. ${ }^{5}$

E: É mais era por causa de outra coisa...

M1: É, não era por causa de dificuldade de aprendizagem, né? Por isso que eu acho que não tem a ver com idade, né? Até conheço pessoas - a diretora da escola onde eu trabalho de manhã, né, escola de educação infantil, é uma pessoa muito inteligente, é uma pessoa que é formada em pedagogia, letras, tem pós-graduação, né? especialização em psicopedagogia, e ela tem 40-45 anos e ela tem muita dificuldade com LÍNGUA ESTRANGEIRA. Então acho que é alguma coisa na pessoa, assim. O perfil de aprendizagem, estilo cognitivo, não sei. Mas não acho que é idade.

E: Alguma vez a coordenação, nessas reuniões, já falou desse grande público que o IC tem, de terceira idade?

M1: Não. Que eu tenha visto ou ouvido, não. 


\section{Transcrição da entrevista com Monitor 2}

\section{[*]}

E: Olha, algumas perguntas eu já fiz naquela folha, lembra? mas eu vou ter que repetir.

M2: Não se preocupa. É capaz até de eu responder coisas diferentes agora.

E: Ah, então, tá vendo... Já passou quase um semestre inteiro, né? Vamos lá. Há quanto tempo você dá aula de italiano?

E: E em quantos lugares diferentes você já deu aula?

M2: Putz! Essas escolas da vida, né? Então, deixa eu ver... Escola... um... dois... seis lugares.

\section{$\left[{ }^{*}\right]$}

E: É::... e o que te dá mais prazer em ser professor de italiano?

M2: De língua italiana o que me dá mais prazer é o fato de ensinar uma língua estrangeira, uma língua estrangeira que eu gosto muito. E poderia ser talvez francês ou mesmo espanhol, porque eu gosto muito das línguas neolatinas. Já, por exem/pra dar aula de inglês ou até mesmo minha língua materna, português, eu não me sinto muito à vontade. Ainda que talvez eu acredite que não domine completamente o italiano, mas ci provo.

E: E o que que te deixa insatisfeito?

M2: É:: Justamente essa questão da:: - que eu acredito que ainda não tenho uma competência linguística digamos suficiente às vezes até pra ministrar o curso DE uma língua específica, uma língua italiana. Umas coisas que me faltaram talvez na minha:: na minha formação... que eu tento correr atrás, né? ... Ah, claro, além do baixo salário.

E: Ah! Eu tava esperando ((risos)).

M2: ( ) BAIXÍSSIMO salário.

E: É:: Qual você acha que é o número ideal de alunos por sala de aula?

M2: Acredito que não mais do que 10.

E: Por quê?

M2: Porque a partir daí você:: não consegue ter, de certa forma - o professor de língua estrangeira, ele tem que ser, de certa forma, um professor particular em certas horas, principalmente porque a língua estrangeira, ela requer do aluno quatro competências, que é a produção oral e escrita e a competência ou compreensão oral e escrita. Diferente de outras disciplinas, por exemplo, que me vêem à cabeça, por exemplo, a matemática, o português ou história, no qual o aluno tem apenas que aprender aquelas fórmulas, métodos entre outras coisas e fica talvez mais fácil para 
ministrar em uma sala com um número maior de alunos. Porém, a partir do momento que você tem mais do que dez... sei lá, talvez estourando, 15 alunos, você já não consegue distinguir isso, porque sempre vai ter aquela ( ), o aluno às vezes que consegue:: ahn, digamos um avanço, um desenvolvimento mais rápido, se sente, digamos, prejudicados por aqueles outros que têm um desenvolvimento um pouco mais devagar. E aquele tem um desenvolvimento, uma capacidade de compreensão mais devagar se sentem prejudicados ou mesmo com vergonha em comparação àqueles que aprendem um pouco mais rápido.

E: E, na sua opinião, qual é o aluno ideal? Assim, aquele que te dá prazer de dar aula.

M2: Olha, o aluno ideal são aqueles motivados. Já é um bom avanço. Apesar que, por ser aula de italiano, e talvez aí até retome a primeira pergunta, uma das primeiras perguntas, o maior prazer de dar aula de língua italiana, é que geralmente aqueles que querem ter aula de língua italiana, geralmente são pessoas motivadas, que querem realmente ter aula. Diferente de inglês, que muitas vezes a pessoa é obrigada a aprender inglês, para o trabalho, por exemplo. E no italiano essas ocorrências são menores.

E: Em termos de personalidade de aluno, qual é o aluno mais difícil de trabalhar?

M2: O aluno mais difícil de trabalhar é o aluno inquieto, aquele que quer aprender tudo ao mesmo tempo. Esse, é o aluno, talvez mais difícil de trabalhar porque você tá tentando explicar uma coisa e ele já quer perguntar outra e é uma exceção da exceção da exceção. E às vezes você até tenta explicar pra ele algumas coisas, só que às vezes uma regrinha tá muito implícita ligada a outra e ele vai querer saber porque e você acaba perdendo o foco da::daquele tema, daquela aula, na tentativa do último aluno que impaciente quer aprender e os outros ficam até, digamos, não digo com raiva, mas fica quase que revoltado que você não explica pra ele. Você fala: "calma, calma, calma, você vai chegar lá." ((risos))

E: Se não atropela as coisas...

M2: É...

E: È verdade. - Agora, as perguntas são específicas sobre o IC. Há quanto tempo você dá aula no IC?

$[*]$

E: Ok. E você acha que o IC é diferente dos outros cursos onde você deu aula?

M2: Sim.

E: Em que sentido?

M2: Número de alunos...

E: É maior?

M2: Muito maior. Na maioria das escolas eu dava aula para alunos particulares, não eram particulares diretamente meus, mas ligados a escola, ou então no MÁXIMO 2-3 alunos. Uma vez só que foi uma sala com 4 alunos. 5. Que tinha uma que era... $\left.{ }^{6}\right] \ldots$

$6 \quad$ Nome de escola particular suprimido. 
((ri)) enfim. Em primeiro, o número de alunos. Aqui eu me deparei com uma... a primeira turma, o primeiro dia, 24 alunos olhando pra minha cara. ((ri)) Eu falei: "oi:: oi, gente...". Segunda coisa, metodologia. Aqui nós devemos, não que nas outras escolas não tenha isso, mas a gente deve seguir um programa em cima de um livro. As outras escolas adotam também um livro, só que é muito mais flexível. Aqui não. Você a cada semestre cumpre aquela meta. Mas do que isso porque você tem uma prova que é::.... esqueci a palavra... que é igual... uma prova uniforme para cada nível, então, você é obrigado a cumprir porque seu aluno vai ser avaliado por uma prova que não foi elaborada por você, então, consequentemente, você não pode dar mais aquele ponto que você quer trabalhar mais em sala, que você julgava que era necessário para aquele determinado nível, porque já existe uma coisa já prédeterminada, uma vez que são várias turmas, então - não que eu desqualifique ou critique isso, mas até pelo fato de serem várias turmas você tem que ter de alguma forma esse padrão, senão você não consegue.

E: Aproveitando o assunto, você acha que é justo ter só uma avaliação no final do curso? Você propõe outras avaliações ou não?

M2: Eu acabo não propondo outras avaliações porque eu tento cumprir o:: cronograma e tento dar coisas adicionais em cima disso para os alunos, então eu não acabo OS avaliando no meio do semestre. Ademais, seria uma questão também de tempo, uma perda de tempo, uma vez que eu não iria aproveitar essa avaliação para nota para eles. - Apesar que eu acredito que a nota muitas vezes, que nem sempre a nota acaba refletindo verdadeira:: desempenho do alunos. Muitas vezes eu tive que dar uma nota menor para alunos que eu vi que tinha melhor desenvolvimento, da mesma forma que me via obrigado a dar umas notas maiores para alunos que eu vi que não tinham o mesmo desenvolvimento/o mesmo desempenho, na verdade.

E: Você acha que a estrutura do IC/a infra-estrutura é suficiente?

M2: Não.

E: O que que falta?

M2: Recursos tecnológicos hoje em dia. Muitas vezes os alunos nos obrigam: "ah, mas você não traz texto de jornal", "ah, você não traz filme", "Ah, você não faz isso", "Ah, esse rádio é uma porcaria" ((risos)). Ponto. Aí você fala assim: "é, eu sei". Então a infra-estrutura é muito prejudicada nesse ponto. Talvez os alunos dos horários do almoço, da tarde, pessoal daqueles horários no qual o monitor tem o direito de usar as salas multi-mediais sejam um pouquinho mais sortudos por esse ponto, porque os outros alunos são obrigados a pedir pra vir outros horários para, por exemplo, colocar um filme pra eles assistirem, dar uma atividade extra. Então nesse ponto a infraestrutura é MUITO ruim. A... e infra-estrututa mesmo, olha, esse semestre os alunos colocaram naquela ficha de avaliação, a falta de ventilador na sala, e a gente lá começando a última semana que teve sol de 35, 40 graus, o sol bem na nossa cara, das duas às cinco da tarde, e a gente sem um ventilador na sala. E não tinha nenhuma outra sala que estivesse livre naquele horário pra dar aula. E os alunos fizeram prova, tiveram aula nessas condições. Isso prejudica muito.

E: Com certeza... Você tem liberdade pra escolher o material que você leva pra sala de aula?

M2: Total. 


\section{E: Total?}

M2: Total. Tanto é que ninguém sabe o material que eu levo pra sala de aula. ((ri))

E: E que tipo de material você leva com mais frequência? Extra.

M2: Música e texto da internet.

E: E você tá satisfeito com o livro adotado?

M2: Não.

E: Não? Você mudaria?

M2: Mudaria.

E: Você tem alguma sugestão?

M2: Progetto Italiano. O Nuovo Progetto Italiano.

E: Com quantas e com qual frequência é a sua reunião/a reunião dos monitores com a coordenação?

M2: Uma vez por semana...

E: Uma vez por semana?!

M2: Por mês.

E: Uma vez por mês... E nessas reuniões, quais são os assuntos mais tratados?

M2: Bem, no primeiro semestre discutimos...

E: O semestre inteiro?

M2: O semestre QUASE inteiro, sobre $i$ criteri descrittori para a avaliação das produções escritas. E neste segundo semestre, trabalhamos mais um pouquinho com isso... e agora a nossa luta ((risos)) é pela elaboração de uma segunda prova.

E: Uma segunda prova pra aplicar no meio do semestre?

M2: Não, pra aplicar no final do semestre. Pra gente ter uma Prova A e uma Prova B, entendeu? No primeiro semestre aquelas outras turmas já tem e no segundo as turmas farão as que estamos elaborando. E aí cada reunião é uma prova.

E: Ok. Alguma vez nessas reuniões houve a sugestão de mudança do livro didático?

M2: Não.

E: Nunca?

M2: Eu nem quis colocar o dedo nessa ferida.

E: A estrutura curricular do IC te satisfaz?

M2: Quanto à questão de número de horas, sim. talvez com o material utilizado, e 
com o programa que deve ser cumprido para cada nível, não. Acredito que a há níveis que poderiam ser melhores explorados se pensarmos toda a estrutura gramatical, apesar que este tipo de/não é muito o meu forte, e há níveis no qual o aluno está apenas iniciando, e você, e você é vomitado todo o Passato Prossimo sobre ele, o que assusta muito, você pode até ver, pelo menos eu percebi, altos níveis de defasagem, principalmente desses níveis. E há níveis que eu acredito que poderiam ser melhores aproveitados.

E: Entendi. - E na sua opinião, você acha que os alunos estão satisfeitos com o curso?

M2: No geral sim. No geral sim. Apesar dos pesares, sim. Se comparado, principalmente a outros cursos externos, sim.

E: É:: O IC foi fundado com o objetivo de servir à comunidade USP, em primeiro lugar, e em segundo lugar em ser um laboratório para os alunos de Pós. Você acha que ele ainda cumpre esses objetivos?

M2: O primeiro, sim. O segundo, justamente por nós termos de cumprir um programa, por nós termos que aplicar uma prova no final do semestre... Por exemplo, para a minha própria pesquisa o IC não serviria porque eu não poderia usar o IC pra fazer a minha pesquisa. [*]

$\left[{ }^{*}\right]$

E: Bom, quantos alunos você costuma ter por turma, no IC?

M2: Depende do nível. Níveis básicos chegam a ser 20 facilmente. Nível 2 já cai pra uns 15 daí vai aumentando o nível e vai diminuindo os alunos. Curso de cultura esse semestre foi 8 , por exemplo.

E: Nos níveis que tem um número maior do que dez alunos, você acha que o rendimento fica prejudicado?

M2: Fica. Até porque deveria ser ao contrário, porque nos níveis mais baixos você tá mais preocupado que o aluno adquira a fonética, você tá preocupado que o aluno comece a adquirir um pouquinho da sintaxe enquanto nos níveis mais altos nos quais você trabalha mais com estruturas ( ) essas coisas, nem tanto com a questão conversacional. Quer dizer, não que não tenha que trabalhar com a questão conversacional, mas que de certa forma você tava mais preocupado em dar o período hipotético, o imperativo, entre outras coisas, poderia se trabalhar com um número maior de alunos. E para as partes mais baixas nas quais você tem que fazer a diferença entre o $t i$, ci, di essas coisas um número maior de alunos acaba prejudicando.

E: E você prefere/tem preferência por algum nível? Você gosta mais de dar aula pra um nível?

M2: Eu gosto muito de trabalhar com os níveis iniciantes, ou seja, nível um, dois. Gostaria de trabalhar, que eu ainda não trabalhei, com os níveis 4, 5, pra trabalhar o imperativo. Fiz uma matéria aí que eu fiz uns materiais que gostaria de testar com eles. Talvez no próximo semestre eu consiga. E também cursos de cultura em que você trabalha com um certo tema o qual não é o::.... Não por ser um curso - quer dizer, é por ser um curso de cultura pelo fato de que você acaba elaborando o seu curso de cultura, então aí é o seu curso mesmo, né? Então você aplica o que você quer ensinar e aí é muito gratificante. Pelo menos eu tive um resultado muito positivo com os alunos. 
E: E tem algum nível que você não gostaria de dar aula?

M2: Não. Não especificamente. Pelo menos - TALVEZ quando eu desse aula para todos os níveis eu pudesse te responder melhor isso, mas como eu ainda não dei aula para todos os níveis até o momento...

((o outro gravador apita, pequena interrupção))

E: Bom, você tem preferência de trabalhar com algum público?

M2: Olha, antigamente eu tinha um certo preconceito pra trabalhar com a terceira idade, mas eles se mostraram mais motivados de certa forma. Sem contar que é eles que me dão mais presentes. ((risos)) Não, não, isso aí não tinha que ser registrado, mas já ficou, né?

E: Eu apago depois na transcrição. ((ri))

M2: Obrigado, obrigado. É:: Mas antigamente eu tinha um pré-conceito sim com o público de terceira idade. Porém isso depende muito de pessoa pra pessoa. Eu percebi muito que essa questão de sexo e idade ou até mesmo graduação depende muito. Às vezes você tem uma pessoa que ainda não é graduado você pensa "Ah, vai ter mais dificuldade", ao contrário, às vezes a pessoa tem uma certa aptidão, dom, não sei se posso dizer essas palavra, mas... ué... me ne frego.

\section{E: E qual era o seu preconceito antes?}

M2: Meu preconceito antes era acreditar que os grupos de terceira idade eram aquelas velhas idosas que não queriam fazer/frequentar, mas queriam encher o saco. Não. É assim, claro que poderia trabalhar melhor isso. Mas pelo fato de você acreditar que uma pessoa na terceira idade tenha mais, não mais mas uma maior dificuldade em adquirir uma língua estrangeira porque segundo os linguística já está muito é::: fossilizado - fossilizado não, dá a idéia de morto. Já tá muito cristalizado a língua então para adquirir uma nova língua e traria muitos problemas. Ao contrário, depende muito de pessoa a pessoa.

E: Você acha que o público que frequenta o IC ele é diferente dos das outras/dos outros lugares?

M2: Sim.

E: De que forma?

M2: Grau de instrução. Porque a maioria dos que vem aqui já estão ou na graduação, na USP mesmo, ou já são graduados. Ahn::: Também poder aquisitivo. Eu já dei aula pra alguns lugares em que o público tinha muito mais poder aquisitivo que os alunos do campus, ( ) executivos, ou então muito menos poder aquisitivo. Então eu diria que nós estamos trabalhando aqui com uma classe que:.... quase A, B. Então você vê ( ) eles tem maior experiência. Muitos já foram à Itália e por isso querem aprender italiano, ou então porque tem que ir para a Itália e por isso querem aprender italiano. Ou o público também... acho que talvez seja maior nisso mesmo. Pelo menos assim de imediato, brainstorming, não vem nada a mente, talvez se eu pensasse mais eu poderia achar outros pontos, mas essa é uma diferença.

E: É:: em relação. - Pergunta repetida. - Você acha, pensando nas reuniões com a coordenação, você acha que existe um bom diálogo entre a monitoria e a coordenação? 
M2: Sim... Mas, porém, contudo, todavia, entretanto, muitas vezes no::... Você nunca pode esquecer da questão hierárquica. Então, pelo menos eu como brasileiro, aí estou pensando nas questões pragmática, de cultura essas coisas, né? Eu às vezes, quando ela... Eu percebo às vezes que ela se evita a deixar uma brecha. Mas você não vai discutir com a sua chefe, né? Então você fica assim "ah, não, tá bom. Que seja assim."... às vezes até porque você ( ). Mas existe um diálogo sim, existe. Existe. A coordenação hoje é muito aberta. Quer dizer, hoje como se eu tivesse comparado com ontem, né? Mas a coordenação é sim, é aberta para sugestões e propostas.

E: Mas, intimida, digamos assim, de alguma forma? Você já deixou de falar coisas porque...

M2: Sim, sim, sim. Já deixei.

E: Agora falando dos alunos/ do relacionamento entre os alunos e tal. Como você percebe o relacionamento entre os alunos da turma? Pensando em um modo geral.

M2: Em um modo geral, geralmente é muito bom. Eu consigo pelo menos, pouco a pouco, até o final do semestre manter um relacionamento muito forte entre professor e aluno ( ) apesar que muitas vezes o uso disso não é saudável. Eu não vejo razões de não sê-lo. A não ser que a partir de algum momento um aluno aproveite dessa amizade, vai se interpolar e esquece no final das contas, perde o foco que no caso ele ia aprender a língua italiana etc. Mas de um modo geral é bom, muito saudável.

E: E o relacionamento de aluno com outro aluno?

M2: É complicado. Já vi situações assim, um tanto quanto inusitadas, em que os alunos começam a partir para a agressão verbal, claro, porque há alunos que, né? gostam de dar sua opinião, fala "ah, não, você tem razão quando fala disso tudo, que uma vez eu estive na Itália..." às vezes o aluno não fala nem tanto por querer se mostrar, mas claro que tem aluno que acaba interpretando isso como uma pessoa é::.... não ( ) uma pessoa que... ai, esqueci a palavra...

\section{E: Exibida?}

M2: Exibida. Exibicionista. E aí você, "Ah, cala a boca". Eu vivi situações assim que eu tava quase me sentindo aquele que/o mediador de um debate, que você tem que se interpor "ô, pessoas, vamos..." ((risos)) E como eu sou uma pessoa que tenho vergonha alheia muito fácil, fico vermelho muito facilmente, às vezes eu não consigo assim digamos - talvez até seja um defeito meu por ser professor, me impor mais, pra tentar manter, de certa forma, a ordem. "Ei, então, pessoal, sabe que ( )", né? Pra tentar mudar um pouco de assunto. Então a relação aluno-aluno de certa forma é boa, mas já vivi experiências assim um tanto quanto inusitadas.

E: E alguma vez teve algum problema de um aluno com você?

M2: Não, não que eu saiba. Pelo menos, se teve, nunca me expôs isso.

E: Durante as reuniões de coordenação, alguma vez já se levantou problemas com alunos? Já se falaram/já foi falado alguma vez de problemas com alunos?

M2: Durante, não. Não. Durante as reuniões, não. Às vezes por troca de email um ou outro caso aparece sim, mas durante a reunião, não.

E: E quando aparece é por quê? Assim, qual é o problema? 
M2: O último caso aconteceu recentemente. Uma aluna escreveu, pedindo a coordenação que eu continuasse sendo professor:: da turma dela. Porque agora já são, esse aqui seria o segundo semestre e como teoricamente::: tem uma questão de mudar de professor a cada dois semestres, essa aluna escreveu assim, quase que revoltada, querendo a minha permanência. Daí falei "fico muito agradecido pela sua atenção, mas infelizmente são ordens da coordenação". E ela escreveu pra coordenadora, e a coordenadora falou assim: "é, não porque você/esse pedido", como se eu fosse o culpado eu falei, "olha, desculpa, mas que bom que ( ) meu trabalho mas eu vou escrever a esses alunos" e escrevi realmente a esses alunos falando "olha, gente, desculpe, quem sabe no outro/no nível subsequente eu possa até voltar se vocês me idolatram como professor ((risos)). Mas, é assim. Mi dispiace.

E: Eram dois grupos iniciais, assim, nível 1 e nível 2?

M2: Isso. Dei nível 1 e nível 2. Foi a primeira turma que eu comecei com eles. E agora eles tão indo pro nível 3 e aí eu teria que/eu troquei de nível justamente por essa questão, né? de monitoria. E uma das aluna desse nível que agora é nível dois e tá indo pro nível 3 se manisfestou, escreveu a coordenação.

E: Alguma vez algum aluno foi reclamar na coordenação?

M2: Se foi não fiquei sabendo.

E: E alguma vez algum aluno reclamou pra você de algum outro aluno?

M2: Várias vezes.

E: Várias vezes? E qual era a reclamação?

M2: Essa questão do exibicionismo, que o aluno tá muito falante demais, que o aluno acaba prejudicando a concentração dos alunos... ahn::, em geral é isso.

E: Ahn... Alguma vez algum colega reclamou pra você de aluno?

M2: Reclamar, não. Mas ( ) fez comentários jocosos, que também nós fazemos, né? aquela conversa do café que você acaba falando sobre os seus alunos, né? "Ah, eu tenho uma aluna assim hahahahaá", mas reclamar de alunos assim, particularmente... - Minto, uma vez ocorreu de um monitor falar de uma aluna que se interpelava junto a ele falando que ela tentava responder pelo grupo, que não estava aprendendo nada e que na verdade era ela que não compreendia, que não seguia, enquanto o grupo estava indo muito bem, obrigado. E essa aluna, como querendo levantar um infante né? a bandeira "Ah, você não está sabendo explicar, não tá entendendo nada" sendo que era somente ela o problema ou que estava tendo problemas. ( ) tava tendo problemas também.

E: Entendi, aff que cruel... Ah, antes eu tenho uma outra... Alguma vez algum aluno reclamou pra você de outro monitor?

M2: Sim.

E: Por quê? Qual era a reclamação?

M2: Metodologia e didática desse professor.

E: Era muito... ultrapassada? Alguma coisa assim? 
M2: Digamos que não era nem ultrapassada. É que realmente não tinha. Falaram que... a pessoa não... não... Não é que não cumpria o programa, mas::: pulava exercício, não respondia as perguntas, tinha preguiça de escrever na lousa, essas coisas.

E: Você acha que o IC, ele é voltado pra algum perfil específico de alunos?

M2: De certa forma, sim. A partir do momento que você requer que sejam sempre alunos com ensino médio completo, você já está... não digo excluindo, mas administrando seu público alvo. Uma vez que você para você estar aqui dentro da cidade universitária, você também delimita a questão de uma pessoa que mora, sei lá, no Carrão só vir estudar aqui, caso ela não trabalhe ou estude aqui pela USP mesmo.

E: E você acha que as pessoas que de certa forma não se encaixam no perfil, então, do IC, elas não permanecem no curso?

M2: Depende muito da ( ) dessa pessoa, conheço essa senhora, por exemplo, que ela não se encaixa no perfil, primeiro por morar longe, segundo por não ser da USP, ahn:: mas que ela... por amor à língua ela persiste e vem e si sbriga mesmo, né? Ela tem muita força de vontade.

E: Você acha que há uma variedade muito grande de faixas etárias na sala de aula?

M2: Sim.

E: E você acha que os monitores do IC, eles estão preparados pra lidar com essa heterogeneidade?

M2: Não. Não pelo fato... pelos monitores do Campus em si. Mas eu acho que se forem principalmente como eu, que tive uma formação pela faculdade de educação, nós em nenhum momento trabalhamos com essa questão.

E: E você acha que trabalhar com esses grupos de...

M2: ...heterogêneos?

E: É. Alguma vez te trouxe alguma dificuldade?

M2: Especificamente pela questão da idade nem tanto. Pela heterogeneidade de::: de desempenho deles. Por um/ por alguns conseguirem captar ou:: adquirir mais fácil, absorver, compreender melhor de um tema e outros não, mas não necessariamente pela idade.

E: E o que você acha desses grupos heterogêneos? Você separaria algum público desse grupo/desses grupos? Ou você manteria da forma que está?

M2: Seria muito complicado de separá-los. Deveria fazer, por exemplo, teste de níveis para criar grupos, não... esqueci o nome... não é grupos de recuperação, mas seriam aqueles chamados grupos de baixo desempenho, grupos de REFORÇOS. Mas isso seria um trabalho e poderia até constranger os alunos de certa forma.

E: E o que você acha da grande participação dos alunos da terceira idade no IC?

M2: ( ) do Italiano no Campus, né? De certa forma. Afinal eu diria que eles são quase 70\% do nosso público, se não fossem os alunos da terceira idade, acho que não haveria o IC pelo tamanho que ele é hoje, né? Com todos os monitores e todas as turmas 
existentes. Então... são nossa grande terceira idade ou a melhor idade como/que nem as pessoas falam...

E: Muito bem. Você, alguma vez presenciou... uma reclamação dos seus colegas, dos outros monitores, a respeito dos alunos da terceira idade?

M2: Não. Um específico, mas não por ser da terceira idade, mas porque era um senhor digamos um tanto quanto chato. Que tá no IC há muito tempo.

E: E alguma vez os alunos reclamaram dos colegas da terceira idade?

M2: Não por ser especificamente da terceira idade.

E: Não por isso... - Você, então, não separaria a terceira idade do restante dos grupos?

M2: Não porque eu já tive experiências no qual havia aluno de terceira idade muito bons e outros com muita dificuldade.

E: A coordenação alguma vez já abordou esse tema terceira idade, por eles serem um público tão grande?

M2: Tsc-tsc ((som de negação)).

E: Então, assim, nas reuniões nunca foi discutida a participação deles, na verdade.

M2: Não. Nós nunca trabalhamos não só com a questão da terceira idade, mas com o nosso público alvo em si. Quais são, digamos, ahn:: os objetivos do nosso público alvo. 


\section{Transcrição da entrevista com Monitor 3}

\section{[*]}

E: E em quantos lugares você já deu aula?

M3: Eu dei aula... Pode falar o nome das escolas? Eu dei aula na $\left[^{7}\right]$ ahn... de italiano mesmo, em português eu dei em outras. E aqui no Italiano no Campus.

E: o que você tem mais prazer em ser professor de italiano? O que te traz mais prazer?

M3: Olha... aquilo que me levou a:: escolher ser professora de italiano primeiro interesse pela língua que eu tenho, a cultura em geral, mas o interesse que eu vejo também nos alunos, que eles não se vêem obrigados, eles mesmos escolhem pra aprender:: o idioma, então você vê que eles estão interessados, e isso... eu não consigo dar aula pra quem não tá interessado. Então por isso.

E: E o que te deixa insatisfeita?

M3: Insatisfeita, às vezes, no início, quando eu não tinha muito acesso assim à internet, era o material, que nós não conseguíamos encontrar, mas agora já com internet dá pra juntar bastante.

E: Qual o número ideal de alunos por sala?

M3: Difícil... ((risos)) Olha, ideal eu acho que 8 alunos já é um número bom pra você/você consegue trabalhar muito bem. Poucos alunos, menos do que oito, pra trabalhar em grupos assim não acho interessante. Então, um grupinho de oito a 15. Vinte já acho MUITO.

E: Muito. - E na sua opinião, qual que é o aluno ideal?

M3: Aluno ideal? Difícil essa daí também, hein! ((risos))

E: É uma pergunta filosófica! ((risos))

M3: Aluno ideal... Ah...

E: Um aluno que te dá prazer, assim... de ver na sala de aula

M3: Um aluno que realmente tem interesse. É sempre na mesma tecla, né? Esse é o ideal, que você vê que ele busca o conhecimento, que ele tá sempre... fala alguma coisa, dá uma brechinha ele diz que ele foi e pesquisou, e:.... você falou sobre um filme e ele foi lá e assistiu o filme, trouxe informações e::: esse é o aluno ideal, que vai atrás dessas informações ele mesmo.

E: E o aluno difícil de trabalhar?

M3: O aluno difícil... é aquele ((risos)) é aquele que, ele fica pondo várias vezes o professor à prova, fica colhendo palavrinhas em dicionário e fala "que que quer dizer tal coisa?" e, ou então aquele que... vai:: já teve informações, no passado e quer usar e

7 Dois nomes de escolas particulares foram suprimidos. 
não conseguiu, não sabe distinguir aquilo que é usado hoje e o que é uma palavra muito em desuso... Esse é um aluno difícil.

E: Agora em relação só ao IC. Há quanto tempo você deu aula no IC?

$[*]$

E: E você acha que o IC, ele é diferente dos outros cursos onde você deu aula?

M3: É. Bem diferente.

E: No quê?

M3: No sentido positivo ele é diferente porque nas outras escolas eu não tive um acompanhamento pedagógico com reuniões, ahn: com os colegas, com a coordenação. E no IC vão ter essas reuniões, é::: dá pra montar grupos entre os professores, os monitores e aprofundar questões importantes que nas outras escolas eu nunca via nada disso.

E: E você acha que a infra-estrutura do IC é suficiente?

M3: Uh-uh ((Som de negação seguida de risos)) Sempre batalhamos muito, né? A questão de salas, dos professores que podem tirar os monitores das salas, por exemplo, sala de vídeo, foi lá reservada e o professor que não reservou pode tirar os monitores... Então isso eu não acho muito legal, não.

E: E você tem liberdade, você tinha liberdade na escolha dos materiais didáticos?

M3: Sim. Sempre tive liberdade. Isso é bom.

E: E quais você gostava de levar ou quais/quais você levava com mais frequência?

M3: Eu sempre levei bastante músicas pros alunos, eles sempre demonstraram muito interesse. Tem aluno que têm uma memória boa com relação à música e filmes também são interessantes porque você quando ensina - não só deve ensinar competências linguísticas, mas outras também que um filme é:: o aluno consegue visualizar, perceber gestos e então é interessante usar esse tipo de recurso.

E: E aí tinha o problema da falta de vídeo, né?

M3: Ah, é. ((risos)) e o problema da falta de vídeo...

E: Certo... Quanto ao livro didático adotado, você estava satisfeita com ele?

M3: Olha, o Linea Diretta sempre foi, eu sempre usei esse no IC, eu estava satisfeita principalmente com o áudio dele, o ascolto, porque percebi que em alguns livros deixa muito a desejar. Eu acho bom porque eles sempre contextualizam, é::: algo que não é muito culto, o aluno - às vezes o aluno pode até reclamar que alguns são longos, os primeiros, mas depois são constantemente repetidos os trechos. Então eu sempre gostei. $\mathrm{Na}$ parte da gramática eu sempre precisava incrementar com algumas explicações, mas eu, com o Linea Diretta fiquei satisfeita, sim.

E: É:: Qual era a frequência das reuniões com a coordenação?

M3: Uma vez ao mês. Se não me engano! 


\section{E: E quanto/quais eram os assuntos mais tratados?}

M3: Ah, nós víamos muito em relação ao quadro de Riferimento, Quadro Comune di Riferimento, então sempre ficamos muito preocupados com a avaliação do aluno. E:: eu lembro que montávamos planilhas, pra saber qual era a competência, o que era uma competência linguística e, então foi ficando muito discutido tudo isso, que nas outras escolas nunca vi.

E: E em relação à avaliação, você acha que a avaliação dada pelo IC, uma só ao final do curso, ela é suficiente para avaliar o aluno?

M3: Olha, essa perguntinha! ((risos)) Ó, eu, ao longo do curso, eu sempre dei essa avaliação mesmo... Mas isso não quer dizer que o professor não possa ir aos poucos na questão de, o exemplo da/dos textos escritos, eu sempre passei bastante pros alunos, então é um modo d'eu avaliar. Eu mostrava pra eles e:: fazia a avaliação como no test finale e aí eles iam se acostumando ao modo de avaliar. Porque claro que uma avaliação só deixa o aluno preocupado porque ele fica: "Ah! Mas uma só!"... Eu não saberia, eu, na avaliação mesmo firme era uma, mas não quer dizer que eu só fazia essa avaliação. O aluno chegava um pouquinho mais tranquilo porque já sabia como que era o esquema da avaliação e como ele tava indo ao/ao longo do curso. Sempre mostrava: "ó, melhorar um pouco na coesione... que aumenta pontos e deixa o texto um pouquinho mais é... fluído, né, na leitura, então o aluno chegava um pouquinho mais tranquilo.

E: Então, você preparava o aluno pra prova.

M3: Eu preparava o aluno pra prova.

E: E você acha que o resultado final correspondia com aquilo que você sabia que o aluno era?

M3: Mais ou menos sim. Com essa preparação o aluno chegava mais tranquilo e eu não tinha surpresas, né? ao longo do... da correção do teste.

E: A estrutura curricular do IC... ela te satisfaz?

M3: A estrutura curricular?...

E: Você acha que é bem dividido?

M3: Você diz nas divisões conforme os níveis?

E: Isso.

M3: Ah, sim. É... porque bem ou mal. Nas reuniões eu percebi que foi uma divisão baseada no Quadro. E, mais ou menos com as unidades do Linea (Diretta) batiam, então... Não quer dizer que não vai ser revisto, porque eu lembro que o nível 5 você revê questões que são aprendidas no nível 2. Então essas questões curriculares você acaba revendo, então, eu fiquei satisfeita, sim, acho que tá certinho.

E: E você acha que os alunos estavam satisfeitos com o curso?

M3: Olha, alguns sim, ((risos)) outros... sempre tem uns que tão/tem que respeitar, né, o nível como uma pessoa... cada pessoa aprende num certo tempo então, alguns é... chegando no fim do curso, sentiam saudades já, sem ter terminado o curso no 
nível 8. "Ai, eu quero aprender mais, acho que tem que ter mais tempo"... Mas um... um aluno médio assim, no fim do curso ele consegue... dá pra ter... são oito níveis então... acho que tá bom, quatro anos.

E: Você acha que::: - Você acha, não. - O IC, ele foi fundado com o primeiro objetivo, atender a comunidade USP e o segundo objetivo era servir de laboratório pros estudantes de Pós. Você acha que esses objetivos ainda se cumprem ou não?

M3: Olha, se se cumprem?... Pensa bem nessa resposta... ((risos)) Porque para o... como laboratório para o monitor, é excelente e eu acho bacana isso que não tem divisão entre a pessoa que estuda língua ou literatura porque no fim é um estudante de italiano, então isso de deixar só para é... pessoas que fazem mestrado em língua não é correto, então, eu mesma da área de literatura, eu achei que foi muito bom pra mim... Eu, eu consegui aprofundar questões que, devido ao tempo estudando a literatura, eu tive que deixar de lado, mas com o IC eu pude aprofundar, então é... pro aluno é muito bom. Pra comunidade eu acho positivo, e:: mas vejo que não é só - são poucos os estudantes de Letras que eu vejo nos cursos. Vejo mais a comunidade fora da USP. Muitos senhores, aposentados, que não querem ficar só em casa, preferem aprofundar mais é:: também sobre a língua, coisas que eles sempre tiveram interesse, então não ficou só na comunidade. Coisa que poderia, a comunidade USP, poderia ser mais bem aproveitado pelos alunos de italiano mesmo, da graduação. São poucos.

E: É pouco divulgado...

M3: É pouco divulgado, sim, realmente.

E: Nossa, você tava falando, me veio uma pergunta mas ela foi embora...

M3: Ah, que bom! ((risos))

E: Não, você acha que:: - por exemplo, os alunos que trabalham com literatura e os que trabalham com alguma coisa específica da língua e queiram aplicar isso no IC, pra comprovar suas teorias, têm essa liberdade/de fazer isso?

M3: Tem. Tem sim. Tem os alunos... Nunca vi nenhum aluno que tenha se manifestado contra e sempre foi explicado "ó, vou"... - Eu mesma já participei de testes de outros alunos, mas sempre deixei claro que era para estudo e eles fizeram numa boa, sem reclamar, então pro aluno é uma oportunidade, é um laboratório realmente. Então eu acho positivo.

E: E há apoio da coordenação?

M3: Da coordenação? Humm... Olha, ah, creio que sim. Teve apoio sim, na época do... - eu passei por duas coordenações, nas duas eu vi apoio, não vi nada de contra, então, tudo bem.

E: Você costumava ter quantos alunos por turma no IC?

M3: Ah, 20. ((risos)) Vinte alunos, mas já tive também classes de oito. Que é um número bom. Mas tive classes que, devido a erros do computador, também extrapolou, não ficou só no 20. Ficou 20-22. E... é um número elevado. Se o professor souber trabalhar, em questão de grupos, você consegue fazer o aluno interagir bastante entre eles e sempre com técnicas, mas você percebe que eles ficam muito contentes, os ânimos já se:: aquecem e o barulho fica muito, eles acabam atrapalhando um pouco o colega do lado, então, por isso que eu acho que é um 
número é:: um pouco elevado, de 20. Mas um pouquinho menos, 15-16 estaria ótimo.

E: Você gosta de dar aula pra algum nível específico?

M3: Eu gosto muito do nível dois, porque eu acho que é um nível fundamental... é:: o aluno tem que ter uma boa base nesse nível porque ele tá aprendendo o Passato Prossimo e a estrutura desse tempo se repete mais pra frente em vários outros tempos... é:: o fato de ter um auxiliar, todo o/toda a estrutura do Passato, então, eu gosto bastante do nível dois.

E: E tem algum nível que você não gosta de dar aula?

M3: Nível que eu não gosto?... Eu dei bastante o nível 8, o último nível é:: não gosto por questão/ porque acaba o curso ((risos)). Então dá pra você ver que o aluno não tá, ele gostaria de ter mais, porque ele gostou da língua, etc. Mas um nível que eu não tenha gostado muito... talvez o... ah, eu não sei ((risos))... talvez o $5 \ldots$ Não, 5 não, é legal também... É o nível 6 que começa com o Imperativo? Porque eu nunca dei o nível $6 \ldots$

E: Que começa com o imperativo?

M3: É... O imperativo qual é o nível?...

E: É o quatro.

M3: Aqui no IC eu nunca dei o nível 4. Mas eu dei em outras escolas, mas eu não gosto muito, por mais que seja importante, que seja usado em vários... vários momentos, tal. Mas eu gosto mais do nível dois, assim. Não porque é um nível baixo, mas devido à importância do aluno ter uma boa base pra... pelo menos eu tive certeza de como foi passado... não que eu não confie nos outros ((risos)) mas eu gosto do nível dois.

E: Legal... Tem algum público com que você gosta de trabalhar mais? Uma faixa etária que te agrada mais?

M3: Olha, eu trabalhei bastante com senhores... É:: Foi uma surpresa, porque no início eu fiquei um pouco preocupada porque nas outras escolas era um público bem mais jovem. E eu fiquei preocupada, pensei: será que eu vou conseguir? Mas foi uma experiência muito boa porque você acaba aprendendo muito com eles também. Eles trazem muitos materiais extras, eles vão atrás, eles têm interesse é::... Além do fato de que tem uns que cozinham muito bem ((risos)), então, eles levavam uma receita, outros falavam "Ah, eu tenho uma receita, vou preparar um bolo" não sei o quê ( ). Foi muito bom.

E: Tem gente que fala: "ah, eu ganho muito presente!"

M3: Mas eu já ganhei muitas vezes ((risos)). Não. Presente não.

E: Presente não.

M3: Não. Mais pela troca mesmo.

E: Você acha que o público que frequenta o IC é diferente do dos outros lugares? 
M3: Sim. Ele é diferente. Ele é um pouco mais exigente também porque você vê que nos outros lugares às vezes a pessoa só tá fazendo porque talvez a empresa exigiu, é:: mas você vê que aqui na comunidade mesmo da USP os alunos estão interessados, quando eles fazem uma pergunta, é com propriedade, então é diferente.

E: Você acha que existe um bom diálogo entre a monitoria e a coordenação? ... Ou alguma vez você teve medo de propor alguma coisa?

M3: Hum... Bom, às vezes isso vai de características um pouco da pessoa. Eu sou uma pessoa sempre muito tímida, então, eu tentava me preparar ao máximo pras reuniões, assim eu chegava sabendo o assunto, ainda mais que tinham as pautas, que tinha um email que preparava: "ó, vai ser discutido tal argumento, tal coisa", então eu pesquisava pra chegar, senão eu sentiria um pouco talvez, não medo, mas eu ficaria mais quieta do que eu fiquei. É que eu me preparei, por isso eu não ficava tão quieta, senão eu ia ficar mudinha. ((risos))

E: Bom, na relação entre os alunos, agora. Como você percebe o relacionamento entre os alunos?

M3: Bom, de uma forma geral bom... Não sei se:.... Bom, acredito que com os outros monitores também, comentários, por mais que você não questione os alunos, você não deixe ir a conversa tão adiante por questões de ética, mas você sempre escuta comentários de alunos quando termina um nível e começa outro e o monitor é diferente. Então você, por mais que não queira, existe a comparação. Mas sempre foi pro lado positivo e:: eu escutei comentários muito bons de colegas também e a relação com os alunos sempre foi muito boa. É... já teve casos até de:: de fazer encontros entre os monitores e os alunos, una Festa Italiana, então, os alunos foram e eu achei que foi até/um relacionamento bom.

E: A relação de aluno com aluno também você acha...

M3: Aluno com aluno. Tem sempre umas panelinhas, né? Em todas as classe você vê que tem panelinha, mas é eu tive um nível, que eu peguei do nível um, um e o dois com eles e uma classe numerosa, essa de vinte alunos, mas eu fiquei contente porque eu vi que o/a relação entre eles mesmos era de alegria, entre eles, um na ponta conversava com o outro, mas sempre coisa pertinente à aula. Não é nada é:: que, ( ) disso de irritar o professor "ah, como assim? De um lado todos conversando?" Mas eu acho que em outras classes eu vi relacionamento bom entre alguns, troca de e-mails não faltava em/tá tendo um tipo de lição e na aula seguinte você via que o colega tinha passado pro aluno. Claro que sempre tem inimizades também. Você vê que um não suporta muito o outro. Isso fica um pouco complicado em::/pra trabalhar às vezes na interação troca entre os grupos, eu sempre fiz muito isso, que, ah, além de reuniões que a gente comentou antes também, infelizmente agora, fazíamos também muitas reuniões entre os colegas pra discutir conversação, pra trocarmos/trocas de materiais, de técnicas e aprendia técnicas de interação entre grupos, então se os alunos não se dão muito bem, quando eles estão nessa troca é um pouco complicado, mas você tem que deixar claro que ali é um exercício e::: amigos, amigos, mas... ou não amigos ((risos)) né? mas é hora de falar italiano, então, vamos conversar.

\section{E: E alguma vez algum aluno reclamou pra você de outro aluno?}

M3: De outro aluno?... Ah, sim. É... você também como professor precisa:: dar sempre a olhada na classe pra ir percebendo, um aluno que fala demais você vê já na cara dos outros a insatisfação porque tá interrompendo a aula, então, o professor tem também 
que ter o jogo de cintura de saber acalmar aquele aluno que quer falar muito e já teve aluno que veio reclamar, então eu tenho que tomar/ter uma postura ali pra tentar ter jogo de cintura dentro da aula. Acontece sim.

\section{E: E algum colega de trabalho já reclamou de aluno pra você?}

M3: Ah, sim! Também. ((risos)) Acontece. Tem alguns colegas... ((risos)) Mas isso também é positivo, porque no momento que ele tá ali falando, ele tá buscando uma ajuda de como melhorar a situação, então você precisa também dar conselhos: "Olha, faz isso, faz aquilo, ignorar não, mas..." ((risos)) Mas dá um - é bom, é troca, né? troca de experiências faz parte do trabalho.

E: Qual é reclamação mais feita por colegas?

M3: Por colegas?... ((risos)) Bom, de alunos que talvez que estava querendo por à prova o professor, é sempre aquele aluno que é o/é um dos piores alunos porque ele não tá interessado em aprender, mas em mostrar que ele é melhor do que o professor para os outros. Então, ele põe à prova constantemente e não que isso seja uma coisa tão ruim, porque dependendo - todos de um certo modo, quando fazem uma pergunta, quer a resposta satisfatória, né? Não é legal o tipo de aluno que quer por o professor lá embaixo. Então esse é o tipo de aluno que a reclamação de professor, pra mim, que teve em relação aos alunos, mais típica, mais frequente.

E: Em relação, assim... Nas reuniões com coordenação, já houve reclamação de aluno? Alguma vez chegou ao ponto de ir pra uma reunião?

M3: Ah, sim. Porque quando o aluno é:: - já teve casos assim, dois ou três casos assim, mas que ao meu ver, eram certos de ir pra coordenação mesmo pra poder ter um:: - sempre buscando como conseguir a saída da situação, como melhorar o comportamento, ahn:: sempre procurando conselhos. Teve sim, e achei que foi positivo.

E: É? Os dois casos eram de alunos que testavam o professor?

M3: É, é sempre o mesmo aluno. ((risos))

E: Ah, ok.

M3: Professores diferentes, mas sempre o mesmo aluno e você vê que chegou ao ponto de ir na coordenação pra poder ver o que que poderia ser feito.

E: Alguma vez houve reclamação sobre monitores para a coordenação?

M3: Não lembro, não. Não... Não. É, não. E quando é sobre monitores, já vi... - Bom, teve reclamação de alunos direta/não que foi levado à reunião, mas nessa conversa entre colegas, um acaba contando pro outro, fala "ah, fiquei sabendo que um aluno meu falou tal coisa e já escreveu direto pra coordenação ao invés de falar/tentar solucionar em classe", então, sempre trocas de informações entre os próprios colegas monitores, mas com o intuito de melhorar, nada de fofoca, isso eu nunca vi não.

E: E alguma vez já houve reclamação de alunos a respeito da coordenação?

M3: Sim, já. Já houve sim. É:: Principalmente em início - não sei se era inícios de cursos, mas não sei nem se é em relação a coordenação porque não chega muito... não sei se é poder dela, mas é sempre infra-estrutura, então não é tanto problema da 
coordenação, mas é... foi... os alunos sempre reclamaram disso: "Ah, eu escrevi pra coordenação porque eu acho um absurdo o fato de ter que sair da sala tal porque era de outro, e nós não tínhamos sala, porque minha sala era menor, blá blá blá" Mas isso não era problema da coordenação. Específico do modo como é coordenado o IC, não.

E: Alguma vez os alunos reclamaram pra você de outro monitor?

M3: De outro monitor?... Não.

\section{E: Não?}

M3: Não, não... Não me lembro de reclamar, não. Sempre... já foi comentado sobre outros monitores, mas é nada em questão negativa. Pelo menos não tô lembrada disso, não.

E: E você acha que o IC é feito pra um público específico?

M3: Não, não porque a::/os alunos que frequentam o curso são bem, são bem misturados. Você tem um pouco da comunidade USP, poucos, a meu ver, mas você tem alguns; você tem pai, filhos, é::que tão participando. Então, não.

E: E você acha que o IC, ele tá estruturado pra receber essa heterogeneidade no grupo?

M3: O professor tem que ter um preparo. Um preparo bom porque dependendo de como ele consegue administrar a aula, isso pode ser positivo, mas pode ser negativo. Você me perguntou qual é a classe ideal ou o tipo de aluno ideal, me veio em mente isso do/o fato de você ter jovens e também senhores, porque você vê a troca de informações, mas depende muito da sala e de como você tá levando porque isso pode ser estimulante como não. O jovem pode falar "ah, minha sala tem muito senhor e como eu não tô na mesma sintonia, então não gosto", mas outros gostam, então, depende, né?

E: Você acha que deveria haver um preparo dos monitores para lidar com esses grupos heterogêneos?

M3: É um preparo, mas também nem sei dizer como seria esse preparo, porque... ahn:: você tem que saber, você vai levar uma música é muito complicado nesse tipo de sala ((risos)) porque você vê senhores que falam sempre: "Ah, traz uma música do Peppino di Capri" ((risos)) e outros jovens que querem mais Tiziano Ferro, então, tem que saber lidar muito, não sei nem como seria o preparo. Tem que ter muito jogo de cintura.

E: Pra agradar gregos e troianos.

M3: Pra agradar gregos e troianos. ((ri))

E: Alguma vez você teve problemas com as salas por elas terem uma grande variedade de faixa etária.

M3: Não. Não. Eu tive uma sala muito particular... mas eu, conversando também com colegas que pegaram essa sala antes de mim, eles também confirmaram, era uma sala ahn... não tava nem tão assim heterogênea, de diferença entre os alunos, mas você via que os alunos não ligavam muito entre eles. Então por mais que você falasse, sempre teve a tal da festinha de conclusão do curso. Essa tal turma nunca quis fazer a festinha, então é esquisito, mas aconteceu. Mas ela ao longo da... no momento que era 
a aula, você fazia os grupos, um conversar com o outro, você via que a coisa ia, eles conversavam tudo, mas eles não ligavam. Era inútil. Com todos que eu perguntei aconteceu a mesma coisa. Era uma sala atípica. ((ri)) Muitas vezes acontece.

E: E o que você acha - Não... é:: Você acha que algum público que frequenta o IC, ele devia ser separado? deveria ter um curso específico pra eles?

M3: Ah, não. Aí já é... acho que não. Por exemplo, o de Terceira Idade é bom pra eles também ter o contato com os alunos jovens porque - muitos são até mais jovens do que os jovens ((ri)), entende? Nessa sala atípica, você via jovens que não tinham muita... tavam lá, mas... ainda mais no sábado de manhã, então tavam meio dormindo. Então você via o senhor que era muito mais alegre e deixava a sala um pouquinho melhor e se separasse... Não é legal. Acho que separar não faz bem não. E a mesma coisa, muitas reclamações de senhores que falaram que o teste final deveria ser diferenciado para o público de terceira idade porque já não tem muito que de ficar estudando, já tinham passado muito na vida por testes, não queriam mais testes, mas isso não. Acho que não é positivo. É um curso/não gosto dessa diferenciação, não.

E: Você acha que o IC tem um público muito grande de terceira idade?

M3: Tem. Tem sim. Foi uma surpresa. Foi uma surpresa, mas é... Eu gostei de trabalhar com eles, eu tive muita troca de experiência, não achei ruim, mas eu acho que o público da graduação deveria também frequentar mais.

E: E alguma vez algum colega reclamou dos alunos idosos?

M3: Dos alunos idosos?

E: Pelo fato deles serem idosos?

M3: Não, não. O que houve reclamação, mas nisso do aluno idoso não querer fazer o teste, então foi conversado e:: no caso foi trocado informação entre os monitores e realmente não tem isso de diferenciar. Mas não, reclamação por problema de aluno idoso, não.

E: E alguma vez houve uma reclamação feita pra você ou pra outros colegas, de alunos em relação aos colegas idosos?

M3: De alunos em relação a colegas? Não, também não. Você vê que:: pelo menos nas minhas salas, eu nunca vi isso não. Eu vi muito respeito dos alunos em relação aos colegas, os outros alunos idosos. Não vi nenhum tipo de reclamação, não.

E: A coordenação alguma vez, dado o número grande de terceira idade que participa do IC, alguma vez a coordenação já levantou esse assunto nas reuniões?

M3: Esse assunto de ter muito idosos?

E: É.

M3: Não.

E: Ou de falar da Terceira idade.

M3: Não, pelo que eu lembro, não. Nunca se tocou... Sempre foram tratados todos como iguais, né? 


\section{Transcrição da entrevista com Monitor 4}

\section{$\left[{ }^{*}\right]$}

E: Em quantos lugares diferentes você já deu aula de italiano?

M4: Acho que uns quatro... Quatro. quatro lugares.

E: E o que te traz mais prazer em ser professor de italiano?

M4: O fim do curso. ((risos)) Mas, calma, tem explicação. Principalmente pros níveis mais baixos, é quando vê que funcionou, que o curso funciona, assim. Alguém que chega e não sabe falar nada em italiano e no final do curso consegue manter uma conversação, já... ou ler ou ver um filme, alguma coisa, sozinho e isso... é o que... Óbvio, eu dependo dos alunos que me falem isso, mas quando eles falam é o que vale a pena.

E: E o que te traz mais insatisfação?

M4: Ah... eu acho que a::... o cansaço. Assim, não é fácil. Ainda mais como língua estrangeira, tem todo/toda essa... as pessoas já tem um - algumas tem bloqueios que tem passar; outras tem muita dificuldade em alguma coisa que tem, assim, que acaba vindo pra aula. Então... eu acho que, sem contar partes burocráticas e, sei lá, problemas com os alunos específicos... Acho que é mais essa parte do trabalho forçado, assim, é quase escravidão dar aula.

E: E, na sua opinião, qual é o perfil de aluno ideal?

M4: Eu acho que aquele que se interessa. Assim, o ideal do aluno é que se interesse e que corra atrás, sabe? Não fica ali na sala de aula com aquela cara de "Ah, meu Deus. Acaba, acaba.". Isso acaba sendo chato. O ideal é o aluno que... que realmente tem interesse, assim, que não seja forçado a aprender. Mas que tenha buscado o curso por gosto. Acho que isso que faz diferença.

E: E qual é o aluno difícil de lidar?

M4: Exatamente aquele que é obrigado. Que tá no curso porque precisa, ou porque deve, ou porque a mãe manda... Se bem que é difícil. Mas é aquele que não tem interesse na língua, acho que esse é o mais difícil pra gente dar aula porque é o aluno que ou atrapalha a aula ou que... é aquele aluno que você explica quinhentas e duas vezes e que não consegue entender, porque não tem... um pouco porque não tem vontade também. Acho que esse é o mais difícil pra dar aula.

E: E qual é, na sua opinião, o número ideal de alunos por turma?

M4: Eu gosto de trabalhar com grupos de 10 a 15, menos do que isso já é um problema gigante pra mim, eu não consigo trabalhar direito. E mais do que isso fica/assim, dá pra trabalhar mas é difícil de controlar. De 10 a 15 dá pra ter um jogo interessante.

E: Agora as perguntas são específicas do IC, tá? Só pensa no IC.

M4: Tá. 
E: Há quanto tempo você dá aula no IC?

\section{$\left[{ }^{*}\right]$}

E: E o que você acha que diferencia o IC dos outros cursos onde você deu aula?

M4: Ahn:: A primeira coisa é que é grupo. Eu dei aula em lugares onde::: era aula/as aulas eram meio que particulares, um aluno só, ou grupos que eles mesmos formavam de dois, três alunos. Que também é uma outra dificuldade que eu tenho, não consigo dar aula pra poucos alunos. Dois, três, é absurdamente pouco. E::.... de certa forma::, a maturidade dos alunos também, já trazem uma carga boa. Ou de outras línguas ou de experiências privadas. Que é difícil de:: de encontrar em outros lugares. Escola de língua italiana que chamam adolescentes também uma outra... caos... Então essa maturidade que é boa.

\section{E: E você acha que a infra-estrutura do IC é suficiente?}

M4: Em relação a sala, materiais, essas coisas? Não. Essa é a nossa grande briga, né?

E: O que que você sente mais falta?

M4: É... bom, isso não sou eu que digo, mas também os alunos, a privação de:: de aparelhos e audio/assim VISUAIS. Áudio... áudio tem. O problema são os vídeos, o visual, a parte visual que é inexistente, é impossível. Então tem sempre que adequar a aula a essa/a esse tipo de problema.

E: E você tem liberdade na escolha dos materiais que você leva?

M4: Sim. De materiais extra, sim. O livro, segue. Tem que seguir. Mas:: os materiais extra, sim. Sim. - Óbvio, tem que entrar em alguma coisa:: tem que ter uma relação com a matéria que tá sendo dada, mas em relação à escolha sim. Acredito que sim.

E: E quais materiais extra você prefere levar, ou você leva com mais frequência?

M4: Eu gosto muito de matéria de jornal... então, é:: eu uso sempre que posso, sempre que dá tempo também, né? ((ri)) Eu gosto bastante de textos:: de contos, literatura, mas uma literatura mais curta. Não livro, acho que acaba cansando demais. Mas contos também é uma coisa que me agrada.

E: E você tá satisfeito com o livro didático adotado?

M4: Ahn... Não é bom, mas também não é o pior. Assim, já trabalhei com livros muito piores, então... É::: eu acho que o Linea Diretta ele tem um:: ele... - como ele não é feito pro nosso público, então tem coisas muito supérfluas, ele tem coisas que não precisariam ser explicadas tão detalhadamente, que talvez pro público que ele foi::: que ele foi planejado, funcione bem. Pra gente tem algumas deficiências. Em relação a conteúdo, não/não existem muitas críticas. Tirando aquela coisa do senti, senti, senti, senti que me deixa louco ((risos)), parece que você está falando com um retardado, pedindo atenção toda a hora. E isso é uma coisa que acaba influenciando os alunos também, né? A gente vê, por exemplo, nos diálogos que eles têm que fazer, é um senti atrás do outro. Não tem como explicar pra eles que não pode falar daquele jeito. ((ri)) Então esse tipo de marcação que, pra mim, é completamente desnecessária. Em relação à divisão dos conteúdos... talvez a continuidade entre eles seja um problema... Aliás, a descontinuidade, porque uma coisa que você vê hoje, sei lá, no nível 3, não vai voltar nunca mais. Ou então, nível dois não vai voltar nunca mais ou 
vai voltar de outra forma, que vai... Então:::

E: Você sugeriria outro livro?

M4: Olha, eu sou um pouco contra livro didático. Então, não sei se eu sugeriria um outro pra substituir. O ideal é:: exatamente isso, trabalhar com o que tá no mundo, por isso que eu gosto de jornal. É uma coisa que tá ali, é feita todo dia, então não tem. - E dali dá pra puxar tudo. Eu já dei uma aula, por exemplo, pra nível 3, que eu consegui achar todas as matérias que... enfim, todos os conteúdos tratados no nível inteiro num artigo de jornal só. Então dá pra::... Dá pra trabalhar só com isso.

E: Você preferiria então, por exemplo que...

M4: Não tivesse livro.

E: Você pudesse adotar o material que você quisesse por aula.

M4: É um trabalho absurdo, né?

E: É... Mas...

M4: Por conveniência é bom ter um livro. Porque senão... Eu dou 7 cursos. Preparar material pra sete cursos são/é impossível. Não dá. Então, por conveniência, é bom ter um livro. O ideal, se a gente trabalhasse/só trabalhasse um curso é:: pra mim seria isso: preparar o próprio material de acordo com... - que também acarreta um monte de problemas, né? Mas enfim...

E: Quantas e com qual frequência são as reuniões com os monitores e a coordenação?

M4: São mensais, todos os meses.

E: E nessas reuniões quais os assuntos que são mais discutidos?

M4: Depende. Depende muito. Por exemplo, final de semestre... - Bom... ahn:: normalmente a pauta, ela se mantêm. Então a gente nunca consegue terminar um assunto em uma reunião. Tem os assuntos que demoram dois anos pra terminar. Então são dois anos falando da mesma coisa ((ri)). Reestruturação de prova, é::: reestruturação de conceitos pra avaliação... é:: Bom, do tempo que eu tô trabalhando aqui, basicamente foi isso. Entrei já no meio de uma discussão, que a gente terminou esse... o semestre passado, e agora a gente já entrou em outra que agora Deus sabe quando é que vai terminar. São problemas mas/na verdade não são problemas. São reestruturações do curso, são reflexões sobre o curso que a gente tem e tenta melhorar, da melhor forma possível.

E: E alguma vez nessas reuniões, alguém sugeriu a troca do livro didático?

M4: Que eu me lembre não. Pelo menos não oficialmente. Talvez entre conversa de monitores... eu acredito que seja um pouco de consenso entre os monitores, assim, o livro não é suficiente, não dá conta de tudo. Só que exatamente pela conveniência, o livro tá ali, então... A não ser que lancem um livro espetacular, feito para brasileiros, aí talvez a gente possa pensar em mudar o livro. Mas por enquanto, de propostas reais pra mudar ou pra cancelar o livro, nenhuma.

E: E você tá satisfeito com a estrutura curricular do IC? 
M4: Os conteúdos e as divisões... São... são divisões que me agradam. Tem algumas discrepâncias que... mas aí é físico do livro, o livro apresenta dessa forma. Não dá pra gente dar o capítulo 1 e depois ir pro 7 pra voltar pro $2 \ldots$ Então o livro já traz uma certa divisão que a gente segue e eu acho que essa divisão é:: adequada. Já dei aula em todos os níveis e:: e pelo que eu vi, a/os conteúdos são adequados pros níveis que a gente tem. O que eu não concordo, por exemplo, é o lugar onde tá o Condizionale. O Condizionale pra mim é coisa do primeiro semestre, que tinha que tá lá no começo ahn... extamente porque tá junto... bom, enfim, no quarto semestre acho que já não é uma boa colocação, do jeito que eu vejo. Ahn::... Que eu me lembre agora é o único conteúdo que eu acho que é muito deslocado dentro da organização do livro. Os outros não tem muito... muito problema, não.

\section{E: E você acha que os alunos tão satisfeitos com o curso?}

M4: Com o curso sim. Eu acho que eles gostam... aí tem aquela coisa, não sei se é porque eles gostam da língua, se eles gostam do professor, se eles gostam do livro, se eles gostam de matar tempo. Depende da/da motivação de cada um. Mas acredito que eles gostem bastante do curso em si. Que é uma coisa que de uma forma ou outra traz uma certa satisfação também pra eles, né? Parênteses: Essa é a vantagem do italiano, como eu vejo, que não é uma língua obrigatória, não é uma língua de comunicação mundial:: que nem o inglês ou o espanhol. Então quem vem fazer o curso é porque gosta. Então, exatamente por esse gosto que eles têm que eles continuam e gostam dos cursos e, não todos, obviamente, mas tem um número considerável que chega até o último nível. Eu acho que tudo isso tem que ser considerado.

E: O IC, ele foi fundado com como o primeiro objetivo atender à comunidade USP e o segundo, servir de laboratório pros alunos de pós. Você acha que esses objetivos, eles se mantêm?

M4: Ahn::.... Eu acredito que individualmente, sim. Atende à comunidade, perfeito. Realmente atende. Não só a comunidade USP, mas também se expandiu pra comunidade externa. Acho isso ótimo. E em relação à pesquisa... é::: pesquisa oficial praticamente não existe. Tanto que, assim, não tem publicação, não tem nada. Mas aí vai um pouco também da/do bom senso e da consciência de cada professor, né? De:: não como pesquisa formal, mas como um instrumento de reflexão do próprio trabalho. Pra mim, serve perfeitamente, assim, é um motivo super válido. Então, ainda que não hajam publicações, essa/essa/essa reflexão didática existe ou pode existir. É uma pena que não, não realmente não/ esse objetivo da pesquisa não seja levado a cabo, assim como pesquisa formal, porque o IC daria um ótimo corpus, com as situações extremas que a gente vive durante as aulas. Mas:: como pesquisa e reflexão individual funciona bem, assim, eu diria.

E: Quantos alunos você costuma ter por turma no IC?

M4: Depende muito do nível.

E: É?

M4: Depende muito.

E: Diminui?

M4: Quanto mais alto o nível, menor o número de alunos. Tenho um nível 1 com 25 e 
um nível 8 com 5. Acontecem algumas exceções. O nível 7 com 17 pessoas... Mas o número tende a cair conforme::/conforme o nível/conforme for aumentando o nível.

E: E você prefere dar aula pra algum nível específico?

M4: Eu prefiro 1 e 2.

E: Por quê?

M4: Aí é aquela satisfação pessoal mesmo. É uma coisa um pouco... é um ego um pouco exacerbado. E é o primeiro contato que eles têm realmente com a língua, então ali é o momento de explicar matematicamente o que que pode e o que não pode. Vado a fare é uma coisa que tem que trabalhar desde o primeiro nível e que, infelizmente ainda existem alunos no nível 8 que fazem isso. Então eu prefiro trabalhar com esses níveis, pra trabalhar com calma, trabalhar direitinho, dar uma base melhor, uma base mais sólida, pra evitar problemas maiores:: nos níveis mais altos. E::.... e também porque eu acho muito mais difícil dar aula pra nível 1 e nível 2 do que pra nível 8, por exemplo. Obviamente os conteúdos são mais elaborados, são mais:.... são mais difíceis, mas no nível 1 e no nível 2 é:: é um nulo total, eles não têm noção das coisas, então é um trabalho mais/mais forçado, é um trabalho mais braçal no nível 1. Eu acho que esses dois níveis são os melhores pra trabalhar.

E: E você prefere algum público específico? Adolescente...

M4: Olha, eu:: eu gosto de dar aula pra pessoas:: mais ou menos na minha faixa etária. Porque eu acho que a comunicação se:: se faz de uma maneira mais tranquila... Então, por exemplo... - o policiamento é menor... quando o professor e a sala tem mais ou menos a mesma faixa etária. Mas como isso nunca aconteceu aqui ((risos)), então... eu acho que eu não tenho um público::: um público especial assim, porque, pelo qual eu me interessaria mais em dar aula. Acho que todos os grupos que eu que eu dei aula foram bastante heterogêneos, assim, não tem uma idade específica, nem uma formação específica, nada muito regrado. E funciona, assim, nos cursos que eu dei, essa mistura funciona muito bem. Então, assim, não tem muito, muitas reclamações quanto a isso.

E: E você acha que o público frequentador do IC é diferente, por exemplo, dos outros lugares onde você deu aula?

M4: Bom, eu acho que sim. Eu acho que sim, porque, por exemplo, uma pessoa que procura uma aula particular através de um/através de uma escola, é uma pessoa que precisa de um::/de uma::.../de uma aprendizagem meio que relâmpago. Ou porque é uma pessoa que tá indo viajar amanhã e precisa saber tudo do italiano hoje, ou porque a:: é... o motivo maior era viagem. Ou sei lá, por conta do trabalho. Tá tendo uma fusão ou alguma coisa com uma empresa italiana e ele precisa se comunicar com alguém. Então são pessoas que querem aprender um vocabulário muito específico em um tempo muito curto. Assim, não é pra trabalhar a língua. É pra trabalhar a funcionalidade, assim, o que serve agora. E no IC, não. É um público que que quer aprender a língua como sistemas, com um funcionamento. Pra mim essa é a maior diferença entre os públicos. E na escola italiana mesmo são crianças que tão tendo os conteúdos mais variados como/em italiano. O italiano acaba sendo aprendido por tabela, não é a base. Então... a grande diferença, pra mim é essa. Entre o IC e essas escolas que oferecem o curso funcional de italiano.

E: E você::: Mudando, né, voltando pra coordenação: você acha que há um bom 
diálogo entre monitoria e coordenação no IC?

M4: Acredito que sim. Acredito que sim. A coordenação é bastante acessível. Então, ainda que não seja em horário de reunião, horário de reunião não dá... Mas qualquer problema que haja... é possível esse diálogo com a coordenação. Se não for a coordenadora que::/se a coordenadora não puder resolver no momento, te dá os instrumentos pra tentar resolver. Ou então passa também os problemas pra gente. Assim, um aluno escreve::, sei lá, pra secretaria, que manda pra coordenação, que volta pra gente.

((interrupção porque duas pessoas entraram na sala pra pedir informação))

M4: Que que eu tava falando mesmo?

E: Você tava falando da coordenação...

M4: Ah, sim, ah... Então esse diálogo acontece. Eu acho que funciona/funciona bem.

E: E, agora pensando nos alunos do IC. Como você vê o relacionamento entre eles? Você acha que geralmente os grupos são entrosados?

M4: Então, isso é uma coisa que eu falo sempre. Aluno é aluno e não importa a idade, então pode ser um grupo de senhoras e senhores de 102 anos, vai existir panelinha... Assim, conversam se respeitam, todos eles, mas sempre acaba acontecendo de:: juntar dois ou três ou quatro, e dois ou três ou quatro, dois ou três ou quatro e se formarem as panelinhas. Ahn::... O que não é ruim. Acredito que não seja ruim. As pessoas têm afinidades, maiores ou menores com os outros, então isso acaba::... é natural. Ahn::... Acontecem intriguinhas, óbvio. Uma pessoa fala uma coisa e a outra retruca. Ou então, é::... cochichinho... Sabe? Aquela coisa bem de adolescente mesmo... acontece. O que também é normal, assim, não é uma coisa que me preocupe muito.

E: Mas você já teve que lidar com algum problema de relacionamento entre alunos?

M4: Chamar a atenção, coisas do tipo?

E: Já teve discussão na sala de aula?

M4: Já.

E: Já?

M4: Já. Já aconteceu.

E: E qual que foi a razão, você lembra?

M4: Na verdade aconteceram duas vezes. No:::/a primeira vez foi exatamente isso. Eram panelinhas meio que rivais, assim, e:: ficava esse murmurinho, quando uma pessoa falava as outras ficavam ou, não sei se tirando sarro, não sei se comentando, não sei, mas ficava esse burburinho por trás. - Que acaba atrapalhando a aula, então, tem que chamar atenção e tudo o mais. E o outro caso foi de uma senhora que realmente atrapalhava a sala inteira. Assim:: ela, ela não... ela não conseguia se colocar no lugar de aluna e contestava tudo ou procurava explicações mais absurdas, comparando com o grego, com o latim, passando do grego e do latim até o português pra tentar explicar uma coisa do italiano. E os alunos acabaram ficando de::: ficando de saco cheio da aluna e meio que aconteceu uma revolta, assim, um "48" no meio da 
sala por conta dessa aluna que acabou depois tendo um problema comigo e desistiu da/do curso. E que nesse caso específico, os alunos tiravam sarro. Esses burburinhos viraram vozes altas de ter discussão na sala de aula mesmo. Que eu acho que acaba sendo um caso um pouco isolado. Que era essa aluna particular que conseguiu irritar um grupo inteiro. Inclusive eu, inclusive eu.

E: É? O que que aconteceu? Pode contar, faz parte da tua próxima pergunta: problemas com alunos.

M4: Problemas com alunos. Foi isso, assim, ela não conseguiu se colocar no lugar de aluno. Então tudo o que eu explicava, ela tentava/ela tentava colocar a explicação dela. ela era... - Assim, isso ela gritava aos sete ventos dentro da sala de aula, que ela era graduada, que ela tinha feito pós graduação há quarenta anos, que trabalhava na USP, que não sei o que... E que adorava falar da família, sabe? Encher a bola da família, dos filhos etc. Isso em sala de aula. E assim, eram discussões que não agregavam nada pra aula, assim, eram perguntas pra se fazer presente, pra tentar mostrar que:: que sabia ou mais do que eu ou mais do que os alunos e essas discussões, elas não levavam a lugar nenhum. Então chegou ao caso de eu ficar debatendo, EU e essa aluna debatendo durante meia hora em uma aula de uma hora e meia. Os alunos se entediam, é óbvio, porque isso não faz parte da aula e não, não interessa pra eles. Isso foi... - já tinha começado no nível 1, ela foi pro nível 2 e essa coisa continuou, continuou, continuou... até o momento que os alunos perderam, já tinham perdido a paciência e eu comecei a cortar quando ela fazia esse tipo de/de interferência... atendia celular na sala, sabe esse tipo de... é, problema de... - E um dia eu dei uma resposta atravessada. Aí, óbvio, os alunos começaram a tirar sarro, sabe aquela coisa? Ah, adolescente. Começaram a tirar sarro e ela, não sei se porque eles começaram a tirar sarro, se por conta mesmo da resposta, ela desceu pro inferno, ela começou a gritar na sala, fez escândalo, falou que ia reclamar na coordenação, que ia escrever carta pra não sei onde, falar com não sei quem, sabe? Tentando mostrar poder, aquela coisa. E::..... falava que eu não respeitava ela, não respeitava as opiniões dela, aí começou aquela coisa: "Mas você atende celular na sala de aula", sabe aquela coisa bem desagradável mesmo? E depois desse/dessa coisa, ela não voltou mais. Não... pro curso ela não voltou mais. Não sei se seguiu com outro professor, porque ela tava matriculada em outra turma e depois migrou pra minha de novo. Não sei se continuou com outro professor, se desistiu do IC... mas foi:: foi isso. E, tem problemas com alunos, assim, que... - porque eu tenho que levar essa coisa da pesquisa um pouco a sério, então eu tenho que experimentar na sala de aula, que não tem função nenhuma pra publicação nem nada. Talvez metodologias novas, métodos novos, ou coisas novas, que às vezes não funcionam, é obvio. A parte de::: de experimentação. E já aconteceu de, por exemplo, pra experimentar alguma coisa, eu pego um mês por exemplo, pra ver se a coisa funciona. E os alunos acabaram:: Assim, aconteceram duas vezes isso. Era um nível 5 e um nível 1 também. E uma aluna do nível 5 acabou se/se irritando, escreveu barbaridades, só que escreveu pro lugar errado, escreveu pra secretaria, que mandou pra coordenadora, que depois mandou pra mim. Mesma coisa no nível um também, que eu tava tentando... que foi meu primeiro grupo, aliás. Eu tava tentando desfazer uma/tava tentando uma:..... eu não lembro o que que era... eu acho que era trabalhar mais com... eu tava tentando trabalhar com:: baseado num texto durante um mês. E aí eu explicava a coisa no livro e não dava exercício. Mandava eles fazerem o exercício em casa e voltava pro texto. E aí também um aluno acabou se::: se irritando. O que eu achei mais incrível é que foi com um mês de aula e aí ele já escreveu barbaridades também pro lugar errado. É sempre esse problema, escreve pra secretaria que aí manda pra coordenação, depois me envia.

E: E as reclamações sempre sobre a sua metodologia, que você tava experimentando? 
M4: É, então, eles não sabiam que eu tava experimentando. Então eles falavam que não eu tinha metodologia, que eu não preparava a aula, que eu não dava exercício, que eu não usava o livro, que num::: num deixava eles falarem, assim, umas coisas absurdas. Já teve aluno, essa aluna do nível 5 também já, dentro dessa reclamações, falou que eu não sabia falar italiano, que eu tava:.... que não sabia porque que eu tava dando aula, esse tipo de coisa. Que aí também mostra, né, bem como as pessoas são. E... Acho que problemas com alunos são... Assim, eu não tenho problema com alunos, são os alunos que tem problema comigo. Eu não... assim, o aluno tá ali, ótimo. Não tá, também não::.... assim, eu não sou o interessado pro aluno tá ali. Acho que o aluno tem que se interessar pela aula, então, o que eu não deixo e não suporto é exatamente falta de respeito em relação à aula, em relação a mim e aos colegas. Mas o aluno estando ali ou não estando ali não é uma coisa que me preocupa demais. Me preocupa quando começa a faltar com respeito.

E: E alguma vez algum aluno reclamou pra você de outro colega? De outro aluno?

M4: Já. Já reclamou.

E: E a reclamação era por quê? Você lembra?

M4: Já aconteceu... Ahn:.... Não vou lembrar exatamente o que que ela falou. Foi um grupo de alunos que reclamaram de outro monitor, falando que ele não tinha, mesma coisa, que a metodologia não servia, que ele não conseguia controlar a sala e que acabava perdendo muito tempo. Ahn::... Mas foi a:: foi a única vez. O que acontece mais, que eu acho é o contrário, os alunos elogiarem outros professores pra você... Que também é uma forma de reclamar do seu trabalho. Então fala, sei lá, "Ai, eu adoro tal professor" ou "Eu acho esse professor super legal.". Que pra mim também não faz diferença nenhuma, porque cada um gosta do que gosta. Se não gosta sai. Simples assim. Então, eu acho que é o mais comum. Assim, eles usarem o nome de outros professores pra meio que reclamarem de você. Agora reclamar especificamente de um professor, isso aconteceu uma vez só.

\section{E: E algum professor já reclamou de aluno pra você?}

M4: Acaba acontecendo. Assim, por exemplo, esse/esses casos de alunos que reclamam dos professores, a gente acaba comentando. "Ah, tal aluno disse tal coisa." E todo mundo acaba tendo uma coisa, uma passagem parecida, ou que aconteceu alguma coisa não do mesmo teor, mas que lembra um pouco e acaba colocando na roda. Mas chegar e reclamar de um aluno específico... um... dois.

\section{E: E você saberia apontar uma reclamação frequente dos monitores?}

M4: Exatamente isso, os aluno se... determinados alunos tentam mostrar que sabem mais que o professor ou que::: tentam embaraçar o professor na frente da sala. Essa é... acho que essa:::/todo mundo já teve um. Então surge o assunto, todo mundo lembra de um aluno, ou lembra de uma vez que aconteceu com alguém e também acaba colocando na roda. E às vezes acaba citando o nome do aluno. Ou então, em divisão dos grupos, quando a gente se reúne pra dividir os grupos, quem vai dar determinado grupo, e vem a lista com o nome dos alunos. Aí todo mundo olha e "hum, esse aluno é problema." Aí já começa a contar porque que é problema, o que que acontece, como tem que lidar com o aluno. Que acaba sendo meio que um conselho, né? "Vai com calma com esse aí porque ele é assim mesmo" então... é isso.

E: Nas reuniões surge o assunto: relacionamento com os alunos? 
M4: Nas reuniões?... No café. Na reunião mesmo não. Não consi/não lembro de nenhuma vez.

E: E algum aluno já reclamou pra você da coordenação do IC?

M4: Já. Já. Quando teve a greve.

\section{E: E reclamou do fato do IC ter continuado?}

M4: Também, do IC ter continuado, porque era inacessível, a USP era inacessível e aí não tinha como continuarem as aulas e aí também teve essa última greve, por exemplo, que teve o confronto entre os alunos e::.... e a polícia. Eu tava dando aula no dia que aconteceu. Não liberei os alunos pra irem embora, exatamente porque a gente tava dentro da sala de aula, não ia botar ninguém pra fora no meio do tiroteio... E eu falei que ia manter a prova pra aula seguinte. Isso foi uma terça e a prova seria na quinta-feira. E aí os alunos reclamaram exatamente da atitude e também porque eu falei que... Bom, aí sempre entra a autoridade, né? A coordenação, não nos disse nada "tá parado ou não". Assim, aliás, o IC não pára porque é um curso pago e tudo o mais. Aí surgiram um pou/poucas reclamações sobre o fato de:: da coordenação não se manifestar. E foi sempre essa mesma aluna, sempre. Eu até relevo um pouco esse tipo de coisa, mas esse foi uma reclamação da coordenação. E agora que você falou, eu lembro que teve uma aluna que escreveu num formulário, falou alguma coisa da coordenação, que a coordenação era ausente::... que foi num desses casos que o aluno reclamou de mim e acabou recaindo pra... que a coordenação não:: não era presente, alguma coisa do tipo.

E: Você acha que o IC é voltado pra algum público específico?

M4: Não. Assim, tem o/o:.... um público específico muito amplo: quem terminou o terceiro colegial. Restringe, de uma certa forma, mas ainda é uma coisa muito ampla.

E: E você acha que os monitores do IC, eles tão preparados pra essa heterogeneidade que existe nos grupos?

M4: Eu acho que não tem muita preparação pra isso. Assim, é uma coisa que tá dada. A sala tá ali, são alunos então tem que dar aula pra:: tem que dar aula pra eles. Não acho que tenha que ter uma preparação especial para dar aula pra terceira idade, ou para jovens ou para... Você vai sentindo o ritmo da sala, que a sala dita e acaba se adequando àquilo que:: que a sala te apresenta. Então, isso vai variar de sala pra sala. Tem sala de terceira idade que anda maravilhosamente bem e tem sala cheia de gente nova que é um desastre.

E: E o que você acha de trabalhar com essas diferenças de idade?

M4: Eu acho muito bom. Assim, eu acho que agrega/primeiro agrega muito pros alunos tá em contato com esse:::... Esse semestre eu tava com uma sala que a mais nova tinha 19 e a mais velha, 62. E::... e o curso anda bem dessa forma, porque aí surge aquelas várias metodozinhos: bota um aluno bom com um que não é tão bom, bota alguém que tem mais dificuldade com alguém que tem mais facilidade. Isso acaba::... acaba sendo bom. Em relação à idade eu acho que não tem muito problema, assim, os alunos não vêem muito problema. Pelo menos não que eu tenha sabido até hoje.

E: E você separaria algum... algum público do IC? Você acha que algum mereceria uma turma específica? 
M4: Ahn... Eu acho que sim, caso tivesse, se a gente desse aula pra crianças. Assim, ou alfabetização ou crianças pequenininhas. Como nosso público são adultos, e adultos aí também vai de 20, 19 até 104 , então não::: não tem porque muito separar.

E: Você acha que a participação da terceira idade no IC é muito grande?

M4: Eu diria hoje que é a maioria. Eu acho que é a maioria.

E: E alguma vez você escutou reclamação de outros monitores sobre alunos da Terceira idade?

M4: Ahn:: Não por serem de terceira idade, mas reclamações que tinham a ver com outros problemas, que aí entra essa coisa de querer saber mais do que o professor. Talvez porque todos os professores são muito novos, assim, comparados com os aluno, todos nós somos muito novos... então alguns alunos tem esse problema de reconhecer a autoridade. Então eu que tenho 24 dando aula pra pessoas de 60-70 anos, alguns podem ter esse:: esse problema de ver autoridade numa pessoa muito mais nova. Que aí causam sempre essas mesmos problemas. Mas reclamando da terceira idade em si, especificamente, não.

E: E alunos reclamando de colegas idosos, alguma vez teve?

M4: Pra mim não. Pra mim nunca chegou esse... talvez entre eles, nesses cochichinhos, nesses... Pra mim, não.

E: E a coordenação alguma vez levantou essa grande participação da terceira idade nas reuniões?

M4: Não. Não que eu me lembre. Mas eu não me lembro de nenhuma vez surgir essa discussão. 


\section{Transcrição da entrevista com Monitor 5}

\section{$\left[{ }^{*}\right]$}

E: Em quantos lugares diferentes você já deu aula?

M5: Hum:: Foram vários, viu... A pergunta é mais pra quantificar?

E: É.

M5: Hum... Posso dizer com tranquilidade, por volta de quinze. Assim, respondendo rápido. Sim, eu diria isso, talvez um pouco menos... por volta de quinze. Várias escolas particulares, instituto... $\left[^{8}\right]$, vários lugares.

E: E o que te traz mais prazer em ser professor de italiano?

M5: Ah, o que eu gosto da profissão é que eu trabalho com o processo, e isso é o que me agrada bastante. Já pensei várias vezes em mudar de profissão, coisa de acho que três anos... Três anos. Faz três anos que eu decidi ser professor de italiano, antes eu dava aula, mas era só circunstancial, porque tinha demanda. Então antes eu pensava em seguir outra carreira, mesmo depois que eu decidi ser professor ainda passava pela minha cabeça outras profissões, mas o que me oferece a profissão de professor de italiano é trabalhar o processo, é lento e você vai construindo aos poucos. Isso é o que eu mais gosto. O que mais me dá prazer.

E: E o que não te dá prazer?

M5: Pergunta bem geral?

E: A-hã ((som afirmativo)).

M5: ((ri)) acho que é a... eu tô vivendo muito isso agora, né. Não é proporcional a quantidade de trabalho e a remuneração. Isso que é bastante... - Eu tô dando agora aulas particulares e tô feliz, recebendo uma remuneração maior. Mas a energia é muito, muito maior também, porque você vai entrando, vendo claramente a necessidade dos alunos nas aulas particulares e tentando dar conta dessa demanda, dessas demandas individuais. Embora eu esteja relativamente satisfeito com o que tô recebendo, ( ) muito mais, um trabalho muito sofisticado que eu tô fazendo... E, eu não sei se eu diminuo a sofisticação ((risos)), sem dúvida...

E: E, na sua opinião, qual o aluno ideal? O perfil de aluno ideal?

M5: Ah, isso também respondendo assim, sem processar muito, né? Aquele disposto. Aquele com disposição pra efetivamente jogar o jogo, dançar a dança. Esse que normalmente é o aluno ideal, que não tá refratário.

E: Então, e o aluno mais difícil de trabalhar?

M5: É::... por conseguinte, assim, exatamente o refratário... Seria isso, o refratário ou o que tá com outras propostas em sala de aula que não sejam aprender a língua. ((ruído))de alguma forma ( ) recentemente e o objetivo é aprender a língua. Tá por

8 Nome suprimido. 
algum outro motivo... são complicados de lidar com eles.

E: Qual é o número ideal de alunos, na sua opinião, por grupo?

M5: Pensando nas turmas? É, tudo respondendo assim, sem processar muito, uns $15 \ldots$ eu diria 15 na turma.

E: No máximo?

M5: É...

\section{E: Ou em média?}

M5: Em média. Eu colocaria desse jeito: $15 \mathrm{em}$ média. Talvez pensando pra responder um número máximo, eu diria 18. Mas 15 em média, pelo jeito como eu trabalho, pras dinâmicas funcionarem.

E: Agora pensando especificamente no IC, no seu trabalho no IC. Há quanto tempo você dá aula aqui?

\section{$\left[{ }^{*}\right]$}

E: Certo. E você acha que o IC, ele é diferente dos outros cursos de italiano onde você deu aula?

M5: Sim.

\section{E: De que forma?}

M5: Porque:: pelo público que aparece. A maioria das pessoas que estão aqui, elas têm um nível de escolaridade maior. E isso se reflete na sala de aula:: toda a dinâmica de trabalho. Essa, na minha opinião, é a principal característica que diferencia os alunos do IC para outras escolas. Eu estou trabalhando agora no Tatuapé, segundo semestre, isso fica BASTANTE claro. Porque lá uma turma com disposição mais pra aprender um curso mais voltado pra cultura outra quem tá querendo mais língua mesmo, aprender a gramática, nas duas turmas o nível de escolaridade é menor. Então isso tem implicações bem diferentes do que acontece aqui no IC.

\section{E: E você acha que a infra-estrutura é suficiente?}

M5: Não, longe, longe, muito longe de ser suficiente ((risos)), não. Não, não. Pra dar uma resposta precisa é insuficiente, em poucas palavras. Não. É totalmente inadequado.

E: Do que você sente mais falta?

M5: A sala de aula, né? Ela não tem preparação nenhuma multimídia, primeira coisa que vem em mente pra ser dito. Ahn:: E mesmo... algo/os problemas grosseiros, não? Como turmas grandes em salas pequenas, turmas pequenas em salas grandes, isso é... um dos problemas mais grosseiros. Mas seria essa questão da infra-estrutura. Que não podemos contar com isso. E mesmo nas salas multimídia, as poltronas, as cadeiras, são fixas. Então, mesmo que consigamos uma aula numa sala pra poder trabalhar, mas não tem como dispor de outra forma, os alunos já entendem que é uma coisa como palestra, indo pras salas multimídias. Então, não existe. Porque as salas multimídias são pra apresentações, não uma sala multimídia pra ensino de 
língua.

E: E você tem liberdade na escolha dos materiais que você leva pra sala de aula?

M5: É... eu diria que sim. Tem um livro adotado que tem que ser dado e seguido. Mas fora isso, não tem nenhum mecanismo, nada que eu vejo, que me impeça... Mesmo que eu poderia fazer, é que eu não faço isso muito, eu uso muito o livro em sala de aula, bastante o Linea Diretta aqui no IC. bastante mesmo. Mas eu poderia, com tranquilidade, usar na metade das aulas ou uma aula sim outra não, trazer outros materiais... Me sinto completamente livre.

E: E quais materiais extra você prefere levar ou leva com mais frequência?

M5: É... Eu procuro trazer os materiais autênticos. Durante um ano eu trabalhei muito com artigos de jornal. Os artigos online. E experimentei também fazer com que os alunos vissem os vídeos que ficam disponíveis. Sempre dos jornais, o Corriere, o Repubblica... dava atividades amarradas com os vídeos, mas não funcionava muito porque são trocadas constantemente e nem todos têm acesso à internet muito fácil... Mas seria isso, os jornais, que eu trabalhei bastante... ahn:.... é... tenho que pensar agora...

E: Música, filme, você costuma levar com frequência?

M5: Ah, perfeito, bem lembrado. Então, música eu trago porque os alunos pedem, porque eu mesmo não sou muito voltado pra ouvir música então tenho um repertório não muito grande. E dificilmente trabalho com música, mas os alunos vivem pedindo e eu dou um jeito de encontrar alguma música e trazer pra sala de aula. E dos filmes, assim, eu assisto muito e gostaria de trabalhar os filmes, mas trabalhar os filmes, mostrando cenas na sala de aula requer infra-estrutura... No segundo ano do IC eu tentei fazer isso com C'eravamo tanto amati. Trabalhei com cenas do filme e, mais uma vez foi muito trabalhoso: dificuldade de reservar a sala, também muito trabalhoso preparando o material. Então pouquíssimos. Filme, aquela experiência lá pontual. Música, de tanto em tanto, mas pouco.

\section{E: E com o livro didático, o Linea Diretta, você tá satisfeito?}

M5: Na verdade... a minha resposta... ah... eu acho que, por enquanto, do que tem no mercado, sim. É o melhor do que tem. Satisfeito, fechando assim, não:: é correto dizer. Eu trabalho com ele, mas eu procurei trabalhar agora com o Espresso... Estou vendo também que não tá funcionando como eu pensava que funcionaria e fico pensando em voltar pro Linea Diretta, eu entendia o Espresso como um material mais atualizado. Em alguns aspectos sim, em outros não. Eu acho que tendo que seguir um livro como base, eu ainda sim escolho o Linea Diretta. Ainda sim/ainda gosto dele. Mas a cada semestre que passa eu vejo mais problemas e mais defeitos no Linea Diretta. O que antes era só intuitivo, agora, nas matérias de pós, né? que estou fazendo, vou chegar a trabalhar com isso na monografia final, vendo um pouco das deficiências, mostrando o texto como pretexto, textos literários... Então, ele é menos sofrível, o Linea Diretta.

E: Certo. Quantas são e com qual frequência ocorrem as reuniões com a coordenação no IC?

M5: Reuniões, uma vez por mês, durante o período de aulas, né? Um semestre, são quatro meses de aula no semestre, são 4 reuniões, sempre no final do mês. 


\section{E: E quais os assuntos mais tratados nessas reuniões?}

M5: Pois é... Que fica:.... infelizmente o que acaba acontecendo... Recentemente eu vejo mais discussões didáticas, mas que não conseguem se concretizar. Então, antes, quando eu comecei [*], era praticamente só questões burocráticas. Hoje em dia, eu vejo mais questões didáticas, mas a coisa não se concretiza. Não... Se você me pergunta, né, qual é o tema, o tópico que está sendo discutido, então, sim, ao longo do semestre do IC, cada vez com mais frequência aparece o tópico didática. Mas se você me pergunta das discussões feitas efetivamente, conclusões a que foram chegadas, isso não::: não existe. Na verdade é mais um encontro pras pessoas se situarem, saber quem tá trabalhando no IC, pra gente, né? E discutir, mesmo questões burocráticas, muito gerais, nada mesmo amarrado com didática. É, isso é uma ( ) não existe amarração para nada nem quando se diz quanto às questões burocráticas, não são amarradas às questões didáticas. Porque nós poderíamos/é legitimo discutir questões burocráticas na hora ali, do lado das questões didáticas, desde que as burocráticas, como, por exemplo, o número máximo de alunos, isso é uma questão burocrática exigida pela secretaria... mas não. Não fica amarrado com nenhuma proposta pedagógica, didática.

E: E durante essas reuniões, alguma vez apareceu a sugestão de mudança de livro didático adotado?

M5: Assim, como ponto mesmo, como ponto da pauta, não. Isso não/nunca foi... É:: comentários de intervalo, ao final da reunião... mas efetivamente como "vamos discutir mudança de material", não.

E: A estrutura curricular do IC, ela te satisfaz? Você tá contente com ela ou não? A divisão em níveis...

M5: Não. Efetivamente não. Acho que é um modo bastante simplório e que é copiado do que já existe. Muito ainda calcado no senso comum. Deveria ser algo pensado, estruturado. Acredito que:: a divisão feita sobre cursos regulares, língua e cultura, de conversação, é um movimento na tentativa de reorganizar o::/essa estrutura curricular. Mas algo que não foi pensado, não foi discutido.

\section{E: E, na sua opinião, os alunos estão satisfeitos com essa estrutura ou não?}

M5: O aluno tem muita ilusão, né? De que fez o nível 1, 2, 3, 4, 5, 6 e chega no 8 e ele tá no nível 8 e acabou o curso de italiano. Mas se parar pra discutir com eles, eles vão apontar as carências. Acho que o problema maior é a acomodação, né? de ficar de um nível pro outro. E essa tentativa, né, que existem os cursos de conversação pra tentar dar conta da falta que eles apontavam... sempre apontavam, que faltava conversação em sala de aula. Ahn:: É, eles não se colocam muito quanto a sua insatisfação ou não. Acredito que se fosse perguntado isso a eles, eles apontariam os problemas. Não dizem se tão satisfeito não...

E: O IC foi fundado com o objetivo de servir a comunidade USP, em primeiro lugar. E depois, de servir como laboratório pras pesquisas de pós graduação em italiano. Você acha que esses objetivos eles ainda permanece?

M5: Não, absolutamente não. Isso não acontece e é uma pena. Eu gostaria muito, na verdade, se ficasse só dentro do/atendendo à comunidade, já seria esplendoroso, tem muito público. Se fosse só atendendo à comunidade, não? Alunos e funcionários, professores. Mas isso não acontece. Se perdeu, sim. 


\section{E: Quantos alunos você costuma ter por turma no IC?}

M5: Pensando no semestre passado. Tinha uma turma com 20, depois outra com $7 \ldots$ Outra mais ou menos com 15. Eu diria entre 10 e 15. Entre 10 e 15 alunos.

E: E você prefere dar aula pra algum nível específico? Você gosta mais de dar aula pra algum nível ou não?

M5: Sim, eu prefiro os níveis iniciais. Eu gosto mais.

\section{E: É? Por algum motivo específico?}

M5: Porque essa... da introdução dos alunos à língua, eu gosto bastante disso, essas primeiras noções... E também por não me sentir preparado o suficiente pra dar aula pros níveis mais avançados. Esses dois motivos: por gostar mesmo de introduzir os alunos à língua... e por não me sentir ainda suficientemente preparado pros níveis mais avançados.

E: Você prefere algum público? Alguma faixa etária, você gosta mais de trabalhar?

M5: Não. Eu diria::... É, eu sempre penso na negativa: eu não gostaria de trabalhar, não me sinto preparado pra trabalhar com crianças. Isso eu vejo... - E adolescentes, no começo da adolescência... não. Adolescentes já indo pra idade adulta, já terminando a adolescência tudo bem. Mas não teria uma preferência de público específico, MAS não... - E hoje em dia, no ponto em que cheguei, não aceitaria trabalhar com crianças ou adolescentes muito jovens.

E: E o público do IC, ele é muito diferente dos outros com os quais você trabalhou? De perfil... Você falou, né, da escolaridade... Você acha que em termos de idade, eles são muito diferentes?

M5: Isso... Não saberia dizer. Mas não. Não me vem à cabeça assim, nada marcado de diferença, não. Em relação ao perfil né? desses alunos e dos outros... Uma questão que eu vejo aqui mais é também o poder aquisitivo. Acaba concentrando mais, uma concentração maior/um número maior de pessoas com maior poder aquisitivo. Eu não via e não vejo ainda nos outros cursos, nos outros lugares onde dou aula, ou dei aula, pessoas que tivessem essa/que fossem com a frequência que os alunos daqui vão pra Itália. Ou que têm contato com italianos que vêm pra cá ou pessoas na família que vão pra Itália... Isso é::.... - Eles aqui no Italiano no Campus, por ter esse repertório, parecem que se sentem mais, têm mais claro que vão conseguir se apropriar da língua e usá-la. Em outros lugares ainda é muito pitoresco o italiano, uma coisa muito distante mesmo.

\section{E: E você acha que há um bom diálogo entre monitoria e coordenação?}

M5: No sentindo cortês da coisa, sim. No sentido, né? de que, se por acaso vai procurar, consegue se comunicar. Essa relação protocolar, assim, existe. Mas se é bom, no sentido de entendimento.. não. Isso não. Acessibilidade, sim. Indiscutivelmente. Agora de troca recíproca, de entendimento... um bom relacionamento, entendendo bom relacionamento como troca de idéias, expor aquilo que está se pensando, isso não.

E: Agora pensando a relação entre os alunos e os monitores só: Como você percebe a relação/o relacionamento entre os alunos da turma? Você acha que tem um bom relacionamento entre eles ou há alguma... 
M5: Acho que eu posso dizer, quase todas as turmas que eu peguei, né? não foram poucas [*], havia sim um um bom relacionamento... eu tava lá em cima, eu tava o tempo todo prestando atenção e quando eu começava a ver que desandava, eu me impunha, fazia alguma coisa pra que amenizasse. E eu vi com clareza nas turmas que eu deixei por conta própria, meio que desandava, eles vão se hostilizando, acontece isso.

E: E você já teve que lidar com algum problema de relacionamento entre os alunos?

M5: Hum:: Especificamente, com certeza, não. Mas... que eu já fiz, não. Explicitamente um problema mesmo nunca chegou a esse ponto entre os alunos. Comigo e com os alunos, sim. Mas entre os alunos, não. Mas o que já/ o que aconteceu mais de uma vez, foi eu tratar algum aluno de modo exemplar pra que os outros percebessem como tem que tratar aquele aluno, e eles começam a copiar. Assim... desse jeito assim, implícito. Por $\mathrm{N}$ motivos... pelo aluno ser... geralmente é por ser mais lento, por não conseguir acompanhar a turma. Mas também pelo aluno ser cri-qui/cri-cri também. E começar a apresentar problemas, a fazer perguntas demais e não aceitar nada explicado pela primeira vez, tem muito isso, né? Ficar pondo à prova. Faz isso comigo e faz isso com os colegas. Então, no meu comportamento mostro e eles passam a imitar.

E: Então você já teve problemas de relacionamento com os alunos?

M5: Sim.

E: De um modo geral, assim, qual era o problema principal? Por que que eles...

M5: Né?... Não sei se eu posso dizer problema com autoridade, de que eu representava a autoridade, desafiar a autoridade, não aceitavam minha autoridade. Não sei se eu poderia por nesses termos, pensando rápido assim, pra responder... Mas tive sim problemas. E .. é:: e voltaria àquilo que eu disse: não tá aceitando, o refratário, que tá sendo colocado. E não dá pra... fica difícil entender o motivo pelo qual... talvez por conta disso, de que eu represento autoridade, de ir contra a autoridade, de não aceitar os seus problemas de relacionamento. Não sei se eu respondi a sua pergunta.

E: Ã-ham. E você acha - Não, você acha não. - Durante as reuniões com a coordenação e a monitoria já foi levantado o relacionamento entre monitor e aluno? Algum problema já foi levado pra reunião?

M5: Sim. Isso já foi, mas nunca vira pauta de reunião. Nunca fala sobre isso. Fica tudo circunstancial. "Aconteceu". Geralmente quando acontece isso, alguém descreve um problema que teve com aluno... alguém diz que nunca teve problema com esse aluno ou outro diz que já teve também e depois faz algum comentário geral sobre como lidar com os alunos, mas tudo muito como se fosse um bate-papo. Tá rolando uma conversa, mas o assunto é logo terminado, concluído pra falar de alguma outra coisa que, aquilo sim seria, aquele outro assunto seria a pauta. Não, discutido efetivamente como um ponto da reunião, tsc, tsc ((Som de negação)).

\section{E: E alguma vez os alunos já reclamaram da coordenação pra você?}

M5: Isso não. Eles reclamam... da coordenação especificamente, não. Já reclamaram, sim, da falta de organização, daquilo que deveria ter sido feito e não foi... Na verdade, pontualmente reclamação de coordenação, não. Mas já reclamaram de outras coisas que a gente associa que competiria à coordenação fazer aquilo. Já se lamentaram uma 
vez assim: "Ah, antes a coordenadora vinha entregar os... passava nas salas entregando os diários e dando as boas-vindas. Não tem mais isso, é uma pena.".

E: E alguma vez os alunos reclamaram de você pra coordenação? Você já chegou a ter um feedback disso?

M5: De maneira direta, não. Mas teve comentários já... da coordenadora que fez entender que tinha/ que alguém tinha feito reclamação sobre mim. Mas com clareza "olha, alguns reclamaram de você", não, sim. Lembrando talvez, tem um caso clássico, que houve problema sim, mas não foi desse tipo. Que o aluno foi lá reclamar de mim pra coordenação. Na verdade, um mal-estar, um problema que houve e a coordenadora foi, de alguma forma, envolvida e se pronunciou sobre aquilo. E daí o aluno, explicitamente "se lamentou" do meu trabalho. Tô falando aqui e tô embaralhando com italiano. ((risos)) Mas fui claro?

E: A-hã. Alguma vez algum aluno reclamou pra você de outro aluno do grupo?

M5: Da turma?

E: É.

M5: Sim, sim.

E: E qual era a reclamação, você lembra?

M5: Não, isso, eu diria assim: não acompanhar a turma. Seria essa a idéia. Isso acontece com uma certa frequência, assim, de reclamar e quando reclama é nesse sentido: não tá acompanhando...

E: Certo. E você alguma vez já ouviu reclamação dos alunos sobre outros monitores?

M5: Sim. Isso com muita frequência.

E: E qual é a reclamação, geralmente?

M5: A primeira coisa, talvez porque eles estejam falando comigo, os alunos comentam muito que eu sou muito profissional e daí, com muita frequência eles falam isso: da falta de profissionalismo. Isso do jeito que eles falam mais doídos. Na verdade eles reclamam de vários colegas monitores, sobre vários aspectos diferentes, mas o mais frequente, aquilo que eles se mostram mais revoltados é a falta de profissionalismo, que eles dizem. Desde respeitar o horário da aula, não começar atrasado, não acabar a aula antes do horário... Esses aspectos. Até mesmo... ahn:..... expor de um jeito que não seria de um jeito de professor. Eles sentem isso: expôs o assunto, pediu matéria pra corrigir/pra fazer em casa e depois não lembra que pediu os exercícios pra fazer em casa, não corrige em sala de aula e já traz um outro assunto.

E: Entre os colegas monitores, você já escutou, já fez ou escutou, a reclamação de alunos? Se reclama de alunos entre os colegas?

M5: É:: Isso acontece, sim, mas é sempre naquela informalidade e é tudo como uma anedota.

E: Mas tem uma reclamação que ela é mais comum? Assim, um tipo de aluno que se reclama mais, digamos... 
M5: Compreendi... Compreendi... Não. Isso... Na verdade, isso é uma coisa que me incomoda, pra ser sincero, isso é uma coisa que me incomoda... Porque nós não temos espaço para falar da relação entre monitores e alunos e depois:: em conversas, né? Em tom de anedota que existem, sempre caem pr'uma "Ah, mas a vida é assim". Pra esse tom a conversa. Não no sentido de que "ah, existe esse problema mesmo, como você vai lidar com isso?". Não existe o espaço, não é tratado isso nas reuniões, e também os colegas acabam tendo essa postura de "ah, paciência, é um caso.". O que, na minha cabeça, se amarra totalmente com aquela idéia da falta de profissionalismo. No sentido de que a pessoa não ABRAÇA efetivamente aquilo que tá fazendo, a profissão, "estou aqui para ensinar, se tenho esses problemas aqui, tenho que analisar com calma o que tá acontecendo." Refletir comigo e eventualmente falar com colegas, pra encontrar uma solução. Mas não, fica alguma coisa do tipo: "ah, tá. tá acontecendo, mas é só um" e já troca o assunto. É só anedota.

E: E você acha que o IC é feito pra algum público específico?

M5: Hum:: Você quer dizer o que acontece na prática? Sem ser aquilo pra que ele foi criado...

E: É.

M5: Ah::: acho que ( ) acaba aparecendo ((risos)). Uma coisa alimenta a outra. Esse pessoal de diferentes faixas etárias, diferentes faixas etárias que tem um nível::... não só de escolaridade, mas também econômico, um tanto quanto alto, acima da média, digamos. E que espera ali um curso clássico... mais preocupado com o glamour de aprender italiano do que com o fato mesmo de::: assim, de educação: "Tô aqui pra verdadeiramente ampliar os horizontes, porque aprender uma outra língua enriquece." ... Isso é um discurso muito na boca de todo mundo: "Ah, tô aqui pra", né? "enriquecer o::... o meu conhecimento", uma relação de glamour, de vaidade com a língua. Eu acho que a forma como o trabalho é feito, como é tudo conduzido, isso vai atraindo mais gente desse tipo e, as pessoas que tem esse tipo de relação com a língua, permanecem. Entendem que tão no lugar certo. E pessoas, alunos que têm um outro objetivo, vão embora. E, por exemplo, pensando num público que existe, que são os universitários de diferentes institutos e faculdades, não só daqui da FFLCH ou só da Letras, mas que querem aprender a língua pra ir pra Itália, pra fazer um exame de língua, esses não têm lugar aqui. E eu vejo que os que estão frequentando tão fora do lugar, eles não conseguem e não vão conseguir chegar no objetivo deles. Não é. É pra se ter uma relação de:.... complicadíssima, complicadíssima com a universidade com esses cursos que tem por parte, com objetivo ser laboratório, mas é pra quem tem essa relação de vaidade, de grife com a língua. O curso é feito pra eles.

E: E nos seus grupos, nos que você já deu aula, tem uma grande variedade de faixa etária? Ou é mais ou menos homogêneo?

M5: É:: em algumas/algumas turmas que eu peguei, sim. Teve um semestre que eram 7 alunas, 6 da terceira idade e uma...ahn:.... E depois tem outras turmas, as turmas de nível 1, por exemplo, elas... Nível 1, nível 2 que são maiores, não? Não, não são homogêneas. Isso definitivamente. Como ponto de partida já, não são homogêneas.

E: Você acha que os monitores do IC estão preparados pra heterogeneidade dos grupos?

M5: Absolutamente. Não. Tsc-tsc. ((som de negação))

E: A coordenação oferece algum tipo de preparação pros monitores? 
M5: Não também. Posso ser, sem pestanejar, bem categórico: não.

E: E o que você acha de trabalhar com esses grupos de grande variedade etária?

M5: Ah::: veja, na verdade eu fui mudando minha opinião com a experiência lá em sala de aula. Porque só do meu ponto de vista de professor, eu diria que é complicado trabalhar com a heterogeneidade. Mas ouvindo os alunos e vendo o que acontece, é melhor... é mais interessante. Isso posso dizer, que ainda é fresco, né? Porque daqui dez anos eu vou ter muito claro na minha cabeça isso, que é mais interessante a heterogeneidade E tanto que o que eu penso agora é perfil diferente de curso, mas um curso como ele é pensado, com objetivo de curso. Sempre curso de língua, mas voltado mais pra um assunto... ou abordagem e daí quem quer se inscrever naquele curso, que se inscreva, independente da idade. Mas pra mim era muito forte na minha cabeça, muito forte, quando comecei aqui no IC com muita clareza. E se a pessoa quisesse estuda a língua italiana, se tem como objetivo aprender a língua, mas com mais informações culturais, imediatamente eu associava gente de terceira idade, aposentado. E se quer aprender a língua pra aprender bem a gramática, saber usar, precisão, é o pessoal jovem que tem esse objetivo. Hoje em dia, por conta da experiência prática, não. Eu não penso mais assim. Mas seria interessante ter aqui, falando por exemplo outra vez de currículo de IC, de grade... que houvesse ah:: cursos voltados pra cultura e outros voltados pra língua do cotidiano mais preciso, mas sempre com objetivo de ensinar língua, sem cair pra cultura, sem cair pra gramática em si mesma. E:: quem aparecesse aqui pra ter aula que escolhesse onde quer se inscrever. Então eu tenho, sim, 21 anos, mas quero aquele cultura, não quero essa precisão toda. Tenho que ir pra Itália, sim, tenho que fazer exame de língua, mas eu quero o curso que é voltado pra cultura, que eu vou me identificar mais. E tenho certeza, e posso até nominar ((risos)), não é o caso, muitos da terceira idade que se inscreveriam naquele outro curso preciso e com prazer acompanhariam o curso e fariam com prazer. Isso que é o mais interessante, né? falar do objetivo dos cursos e não já pondo como claro o objetivo do aluno a partir da idade dele.

E: Então, hoje, você separaria os grupos? Algum público? Alguma faixa etária, você separaria?

M5: Pensando, por exemplo, no IC, do nível 1 ao 8, sem ter objetivo nenhum especial do curso? Não. A resposta é não. Supondo, né? Abrir um nível um agora que esse nível 1 que é geral, que é tudo e que não é nada, porque não existe uma preparação específica, a gente parte sempre do senso comum, do sentido comum, né? do senso comum. Mas então abriria, por exemplo, 4 turmas, 2 pra uma faixa etária, 2 pra outra faixa etária?... Não.

E: E você já teve algum problema na sala de aula por causa dessa variedade de faixas etárias.

M5: Sim, sim. Sim.

E: E quais são os problemas mais comuns?

M5: Uma coisa que eu posso citar imediatamente, o pessoal de mais idade eles marcam que eles não gostam muito dessas metodologias modernas, e colocam tudo no mesmo balaio. E quando você faz alguma aula marcadamente diferente da tradicional, é comum eles se pronunciarem. Já vi tudo quanto é tipo de reação. Desde durante a aula, com um risinho discreto que, depois, eu perguntei sobre tal risinho até um senhor que atacou uma cadeira. ((risos)) 


\section{E: O quê?? ((risos))}

M5: Assim, de fato, de fato, tudo quanto é tipo de reação. Respostas atravessadas pra mim, Ahn:: comentários depois com outros colegas de alguma forma você ouve. Bateboca nunca aconteceu porque isso não é do meu/muito da minha índole fazer esse tipo de coisa, mas sim trocas de falas um pouco mais alteradas minha com algum aluno. Até esse extremo de um senhor - isso já era pro fim do semestre, ele já estava descontente, acho, com muito já do que acontecia de diferente daquilo que ele entendia de como deveria ser uma aula e dessa formação do semi-círculo. A gente tava nessa tentativa de formar o semi-círculo, mas já pro final do semestre, não era uma novidade. Ele não conseguindo... posicionar ali, queria tá fora do semi-círculo e ao mesmo tempo não queria tá explicitamente fora porque senão ficaria muito ridículo, não? Meio que dizendo que tá se enroscando com uma cadeira ele pegou a cadeira e jogou ela pra um canto.

E: Que horror...

M5: Continuei a aula ((risos))... Esse tipo de coisa.

E: Alguma vez você presenciou a reclamação de colegas sobre os alunos idosos?

M5: O complicado disso é que é sempre velado, né? É sempre:.... é... Eu diria que sim, mas vou tá interpretando o que eles disseram, porque ninguém fala "não aguento mais aquela turma porque tem aquelas 3 velhas". Isso não acontece, mas assim, o pessoal reclama de... é que cai aquilo, né, "é a vida", "paciência". Não tem muito como evitar isso. O comentário cai pra esse lado. E fala-se sempre na chave cômica, né? Rindo da situação. "É paciência"... Isso. Quando se fala do assunto de terceira idade, pra reclamar, sempre em tom de brincadeira, sempre a coisa virando riso, costuma tratar desse jeito do que tratar sério, como se fosse/falar sério fosse usar coisas politicamente incorretas.

E: E os alunos já reclamaram pra você de companheiros idosos na sala de aula? De colegas idosos?

M5: Sim. É, uma turma de nível dois, de sábado de manhã, [*]. E eles comentaram. E ali a turma se dividia em duas. Era complicado, sábado de manhã, eu já ia com muito sono pra aula, eu dormia pouco de sexta pra sábado, era complicado porque eu tava sem energia e deixava um pouco a coisa fluir de acordo com o ritmo deles. E foi isso, um pouco depois do final/um pouco depois do meio do curso, acabou a aula e quatro se aproximaram falando que tinha saído e, com muita delicadeza, eles disseram que eu sempre perguntava pra eles quanto ao ritmo das aulas e era o segundo semestre deles comigo. Disseram: "Ah, então, como você sempre perguntou desde o semestre passado, a gente queria dizer pra você que o ritmo não está bom e que a gente não quer ficar ensinando pra eles."

E: E a coordenação, alguma vez ela levantou o assunto terceira idade nas reuniões, já que o público de terceira idade no IC é cada vez maior, né?

M5: É. É expressivo isso. Isso eu diria também categoricamente, é um público expressivo. Presente sim em TODAS as turmas, absolutamente todas e algumas, como eu disse, que eu tinha 7 alunos e 6 eram terceira idade, praticamente a totalidade. É que em turmas maiores isso dilui, né? Não também. Não. Isso não foi... - tópicos foram avaliação, outros tópicos, mas não sobre isso. 
E: A minha lista de perguntas terminou, agora eu tenho duas perguntas específicas pra você. ((risos)) Veja bem, você falou no começo da entrevista, você já deu aula em cursos específicos pra terceira idade?

M5: Isso.

\section{E: E como foi essa experiência?}

M5: Isso. Foi no $\left[{ }^{9}\right]$. Era muito no começo da minha... eu tava bastante no começo. Bem, das diversas coisas que me vem à mente, é que naquela época eu ainda tinha a dimensão de que ensinar língua era ensinar a frase. Bastava ensinar a conjugação verbal, as preposições, a pronúncia... E: elas, porque eram só senhoras, eram duas turmas, gostavam muito. A coisa funcionava bastante. Uma característica minha, todos os alunos marcam isso, sempre marcam, dizem isso no final do semestre, é a paciência. Eu sou bastante paciente. Acho que isso é uma outra coisa que ia ao encontro das expectativas delas. Então, aquilo né?... Da aula clássica, aquela da frase, da gramática e ponto. "Essa é forma certa de montar a frase" e com bastante paciência, elas gostavam. O que ficava pra mim, sempre falando de diversos pontos de vista, o que ficava pra mim é que eu não queria fazer aquilo, não era o meu objetivo, porque o que acontece: os alunos da terceira idade, não... eles... tem aqueles poucos que tem um poder de processamento muito grande, e se divertem com isso, e querem isso, e sabe toda a matemática da língua. Mas em geral, eles não estão preocupados com isso e eu acho bem mais interessante ((risos)) esse outro aspecto. No começo da minha carreira, o que eu queria era explicar as formas, e, né? Passar, que eles memorizassem rapidamente as formas regulares pra passar pras irregulares, e que avançassem na língua. Não tinha essa disposição, elas não tinham na terceira idade essa disposição. Isso me incomodava. E eu passei a achar que eu tava... é, isso eu também perdi com o tempo. Naquela época eu achava que eu tapeava, que era tudo enrolação. Eu tava ensinando coisa nenhuma a língua e::: mas depois eu entendi que não, que era a forma delas se apropriarem daquilo e que tava funcionando sim, era aula de língua sim. Diferente daquilo que eu imaginava como deveria ser. Ahn... Agora, no momento que eu estou, posso falar assim livremente ou falar mais especificamente dessa experiência lá?

\section{E: Pode!}

M5: Não, no momento que eu estou, então, agora eu estou pensando em atividades e pegar uma turma de terceira idade como lá do $\left[{ }^{10}\right]$ seria energia grande no sentido de preparar o material e entrar em outra sintonia. E é o que eu poderia fazer sim, com toda certeza, isso eu posso dizer. Se eu não tivesse essas ambições agora, desses materiais que estou preparando, dos textos que estou lendo sobre ensino de língua. Se eu não tivesse nessa sintonia, com prazer sim, eu daria aula.... Mesmo porque, falando de vários, vários aspectos mesmo, eu vejo que ali tem a possibilidade de ser bem remunerado, porque tem um público que vai pagar um valor mais alto e se estiver, fazer aulas bem feitas, não... geral. Agora voltando a falar ainda daquela experiência, a idade que eu tenho sobre a terceira idade: eles não tem na cabeça quando acaba o curso. É um semestre depois do outro e eles vão fazendo, vão embora. É até bastante interessante pensar da questão do trabalho, do retorno financeiro, entre outras coisas. 